\title{
The Caribbean Community Preferential Trade Agreement
}

\author{
Citation for published version (APA):
}

Avila, G. T. (2019). The Caribbean Community Preferential Trade Agreement: Is there a legal obligation to create trade ? [Doctoral Thesis, Maastricht University]. Maastricht University.

https://doi.org/10.26481/dis.20190201ga

Document status and date:

Published: 01/01/2019

DOI:

10.26481/dis.20190201ga

Document Version:

Publisher's PDF, also known as Version of record

\section{Please check the document version of this publication:}

- A submitted manuscript is the version of the article upon submission and before peer-review. There can be important differences between the submitted version and the official published version of record.

People interested in the research are advised to contact the author for the final version of the publication, or visit the DOI to the publisher's website.

- The final author version and the galley proof are versions of the publication after peer review.

- The final published version features the final layout of the paper including the volume, issue and page numbers.

Link to publication

\footnotetext{
General rights rights.

- You may freely distribute the URL identifying the publication in the public portal. please follow below link for the End User Agreement:

www.umlib.nl/taverne-license

Take down policy

If you believe that this document breaches copyright please contact us at:

repository@maastrichtuniversity.nl

providing details and we will investigate your claim.
}

Copyright and moral rights for the publications made accessible in the public portal are retained by the authors and/or other copyright owners and it is a condition of accessing publications that users recognise and abide by the legal requirements associated with these

- Users may download and print one copy of any publication from the public portal for the purpose of private study or research.

- You may not further distribute the material or use it for any profit-making activity or commercial gain

If the publication is distributed under the terms of Article $25 \mathrm{fa}$ of the Dutch Copyright Act, indicated by the "Taverne" license above, 
Table of Contents

1. Introduction........................................................... 15

2. Relevance of Dissertation................................................... 19

3. Central Research Question and Subsidiary Research Questions.....................20

4. Organization of Dissertation, Methodology and Sources...........................22

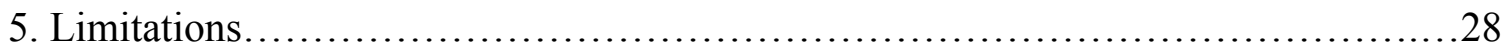

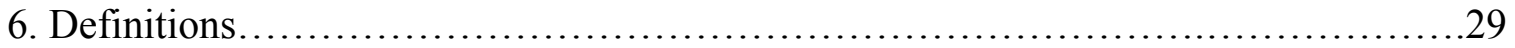

Chapter 1

Creation: The Birth of Preferential Trade Agreements

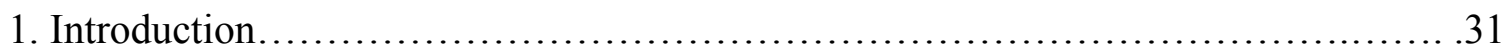

1.1 The Post-War Economic Environment.......................................33

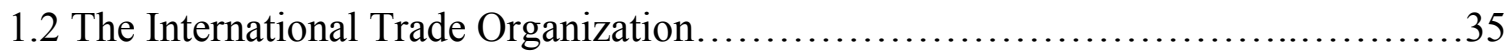

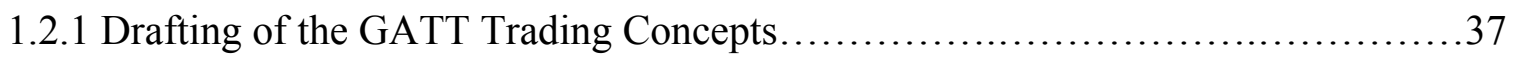

1.2.2 Permitted Preferences......................................................

1.3 The Treaty of Rome Establishing the European Economic Community..............41

1.4 The Treaty of Rome: Areas of Disagreement................................43

1.4.1 Subgroup A: Tariffs, Plan and Schedule...................................43

1.4.2 Subgroup B: Quantitative Restrictions (QRs)................................47

1.4.3 Subgroup C: Trade in Agricultural Products...............................48

1.4.4 Subgroup D: Association of Overseas Territories...........................50

1.5 The US Policy Position on the Treaty of Rome...............................52

1.6 Inconclusive Compatibility Report......................................53

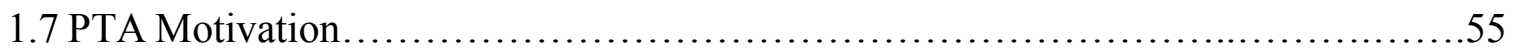

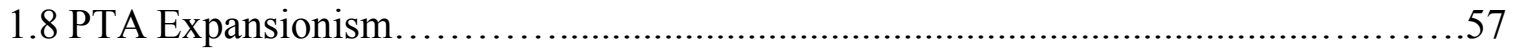

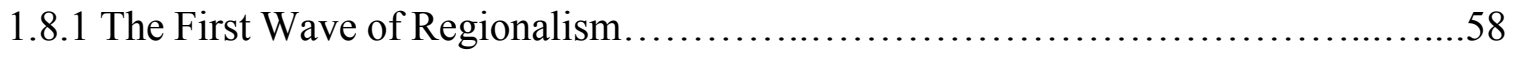

1.8.2 The Second Wave of Regionalism.......................................59

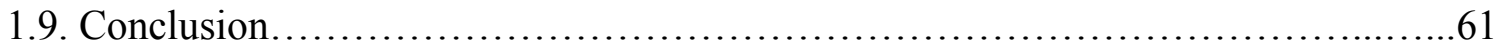


Chapter 2

Legal Design of Preferential Trade Agreements:

GATT Article XXIV and the Enabling Clause

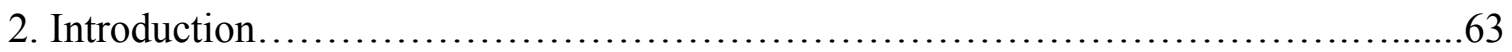

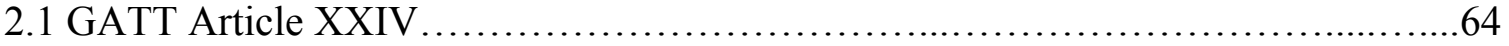

2.1.1 The Creation of Free Trade Areas and Customs Unions..............................67

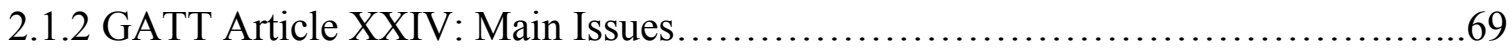

2.1.3 The Turkey-Textiles Case........................................................70

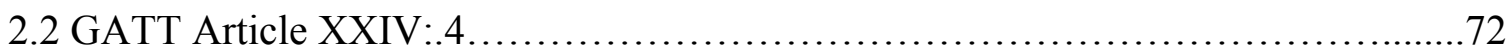

2.2.1 GATT Article XXIV:4: Clarified Concerns.......................................74

2.2.2 GATT Article XXIV:4: Unclarified Concerns.................................. 75

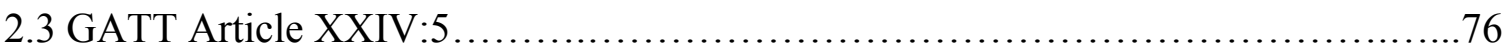

2.3.1 GATT Article XXIV: The Limited Justification for GATT Inconsistent

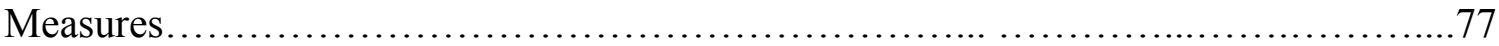

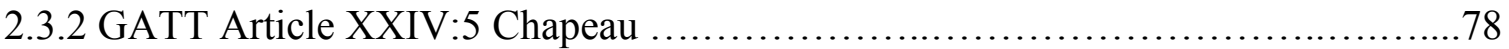

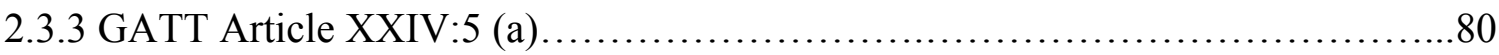

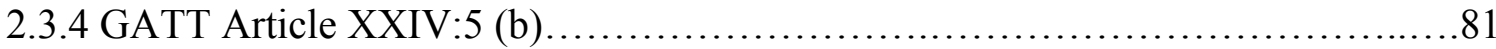

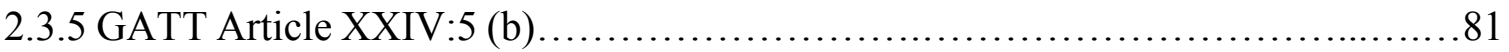

2.3.6 The Context and Object and Purpose of GATT Article XXIV:5(a) and (b)..........82

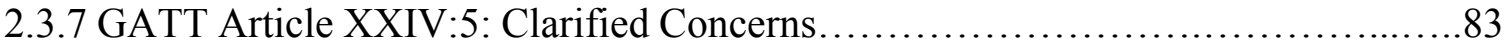

2.3.8 GATT Article XXIV:5: Unclarified Concerns.....................................84

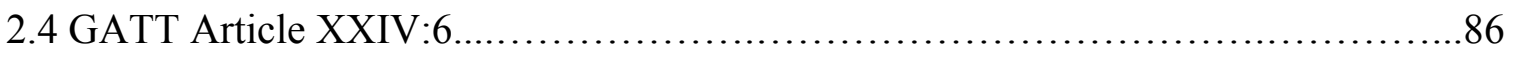

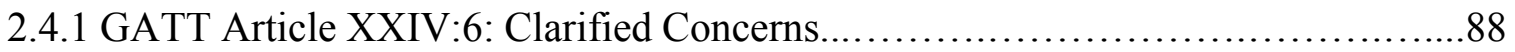

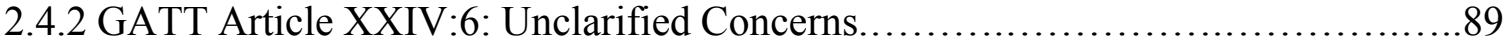

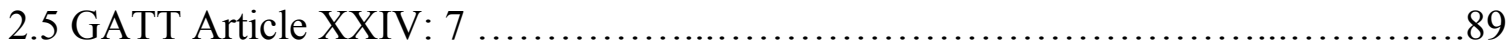

2.5.1 GATT Article XXIV:7: Clarified Concerns......................................91

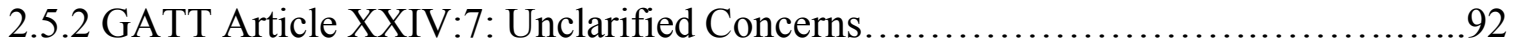

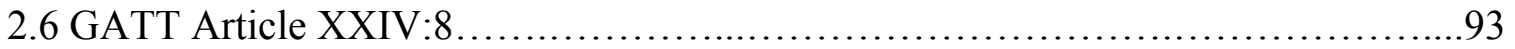

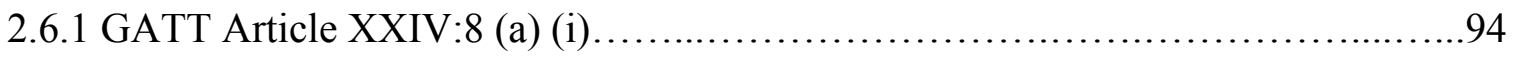

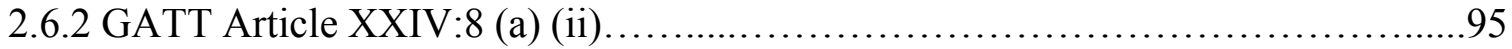

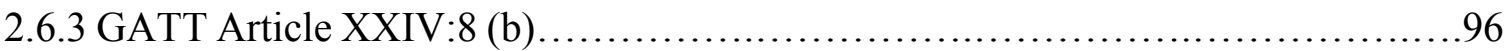


2.6.4 GATT Article XXIV:8: Clarified Concerns........................................ 97

2.6.5 GATT Article XXIV:8: Unclarified Concerns....................................97

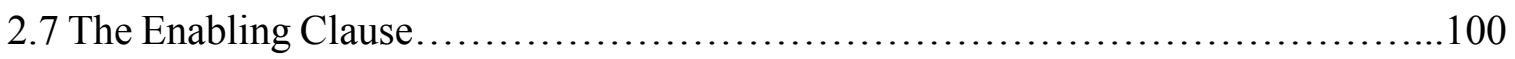

2.7.1 Paragraph 2 (c) of the Enabling Clause: .......................................101

2.7.2 The Context and Object and Purpose of Paragraph 2 (c) of the Enabling Clause:

2.7.3 Paragraph 2 (c) of the Enabling Clause: Clarified Concerns.......................104

2.7.4 Paragraph 2 (c) of the Enabling Clause: Unclarified Concerns.....................105

2.7.5 Paragraph 2 (c) of the Enabling Clause: Patterns of Use..........................106

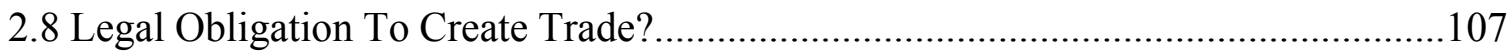

2.8.1 Legally Enforceable Provisions................................................. 108

2.8.2 GATT Article XXIV and Paragraph 2 (c) of the Enabling Clause..................110

2.8.3 Non-Enforceability of Trade Creation........................................111

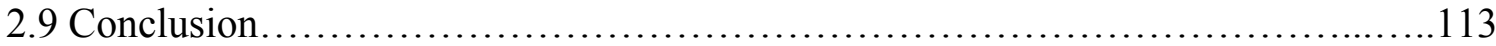

Chapter 3

Management: The Institutional Regulation of Preferential Trade Agreements

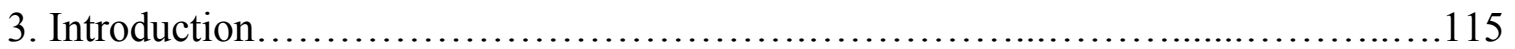

3.1 GATT Institutional Assessment - The Early Years..............................116

3.1.1 The South Africa-Southern Rhodesia Customs Union...........................117

3.1.2 The El Salvador-Nicaragua Free Trade Agreement...............................118

3.1.3 The Treaty of Rome Establishing the European Economic Community...........119

3.2 The Committee on Regional Trade Agreements....................................120

3.3 Regional Trade Agreement Transparency Mechanism............................122

3.3.1 The Background and Aim of the Regional Trade Agreement Transparency

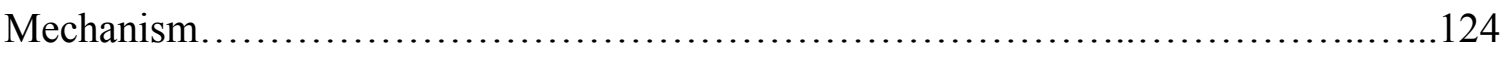

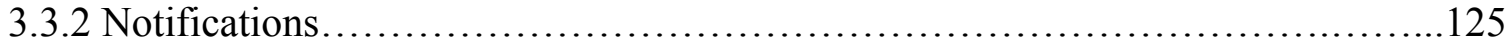

3.3.3 Preferential Trade Agreement Consideration.....................................127

3.3.4 Subsequent Notification................................................... 127

3.4 Institutional and Legal Review of the CARICOM Preferential Trade

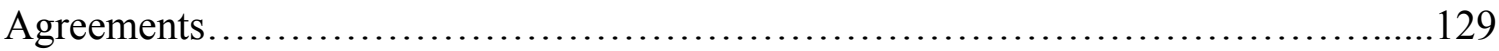


3.4.1 The Caribbean Free Trade Association (CARIFTA)..............................130

3.4.1.1 CARIFTA Analysis in Light of GATT Article XXIV:4 .......................130

3.4.1.2 CARIFTA Analysis in Light of GATT Article XXIV:5 ........................131

3.4.1.3 CARIFTA Analysis in Light of GATT Article XXIV:6 .......................133

3.4.1.4 CARIFTA Analysis in Light of GATT Article XXIV:7 ..........................134

3.4.1.5 CARIFTA Analysis in Light of GATT Article XXIV:8 .......................136

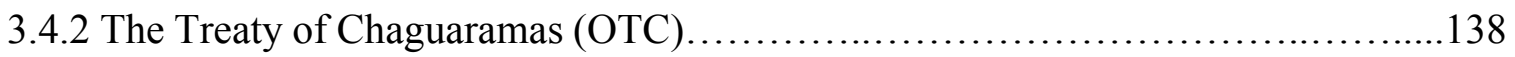

3.4.2.1 OTC Analysis in Light of GATT Article XXIV:4 ............................138

3.4.2.2 OTC Analysis in Light of GATT Article XXIV:5 ...............................139

3.4.2.3 OTC Analysis in Light of GATT Article XXIV:6............................. 140

3.4.2.4 OTC Analysis in Light of GATT Article XXIV:7 ...............................140

3.4.2.5 OTC Analysis in Light of GATT Article XXIV:8 ...............................141

3.4.3 The Revised Treaty of Chaguaramas (RTC) ...................................... 143

3.5 Reconciliation of the interrelationship between Preferential Trade Agreements and the

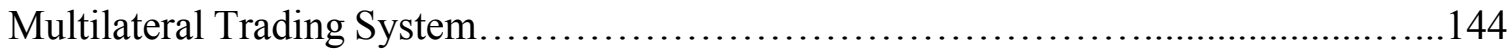

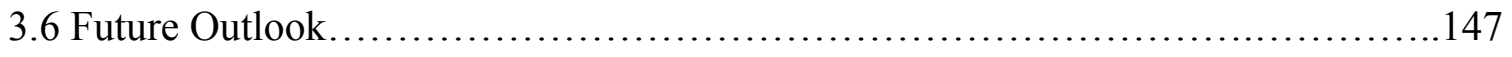

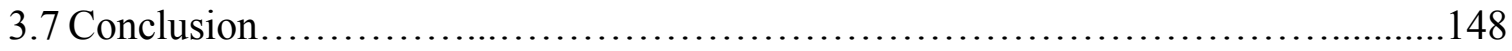

Chapter 4

The Evolution of Regional Integration in the Caribbean

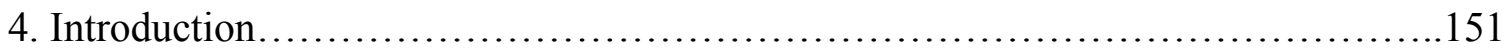

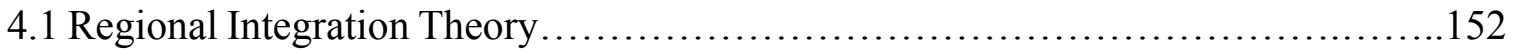

4.1.1 International Relations Analytical Frameworks on Regional Integration...........153

4.1.2 The Legacy of the Plantation Economy ........................................157

4.1.3 Introduction to Colonial Preferential Trade in the British Caribbean Region.......159

4.2 The British Caribbean Banana Trade.................................................160

4.2.1 The Early British Caribbean Banana Trade.......................................161

4.2.2 The Caribbean Banana Trade after the United Kingdom Accession to the European Economic Community .......................................................... 163

4.3 The Commonwealth Sugar Agreement...........................................164 
4.3.1 The Effect of the Imperial Preference System on the British Caribbean Sugar Industry..... .165

4.3.2 A Formalized Cycle of Economic Dependence...................................166

4.4 Phase 1: The West Indies Federation.................................................168

4.4.1 Demise of the West Indies Federation...........................................171

4.4.2 Points of Contrast with Regional Integration in West Africa........................173

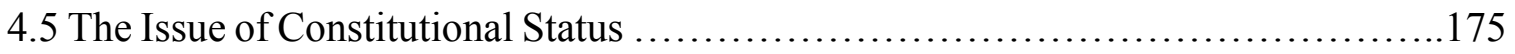

4.5.1 Decolonization in the British Caribbean........................................ 175

4.5.2 From Politics to Economics................................................. 180

4.6 Phase 2: The Caribbean Free Trade Association.......................................182

4.7 Phase 3: The Caribbean Community and Common Market............................184

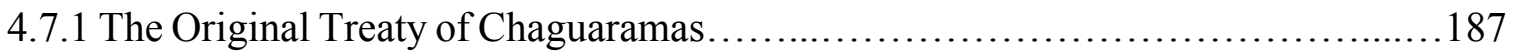

4.7.2 The Growth of PTAs in the American Hemisphere.................................189

4.8 Phase 4: The CARICOM Single Market and Economy...............................192

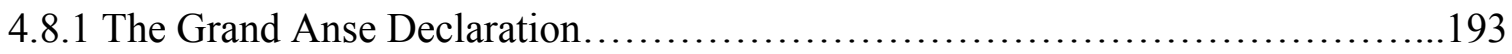

4.8.2 The CARICOM Single Market.................................................193

4.8.3 Future Outlook on Regional Integration in the Caribbean..........................195

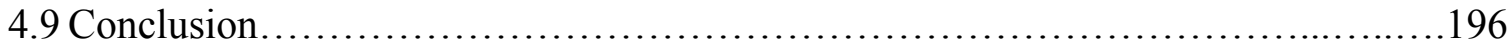

Chapter 5

CARICOM Intra-regional Trade

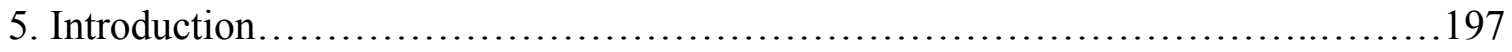

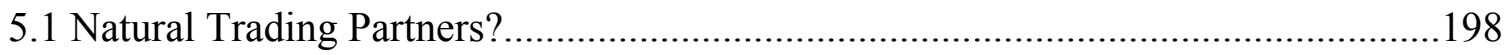

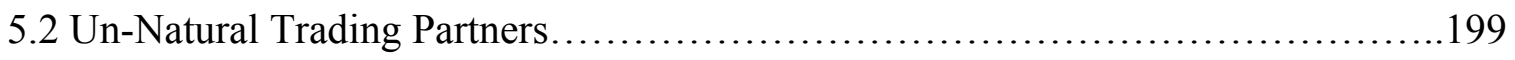

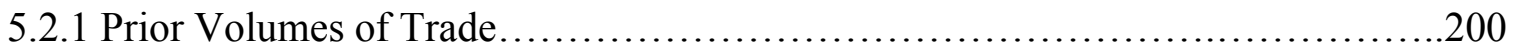

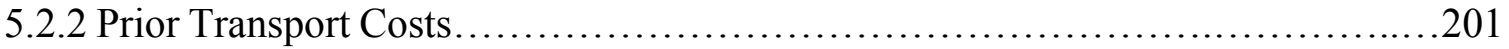

5.2.3 Complementarity vs. Competitiveness and Relative Levels of Economic

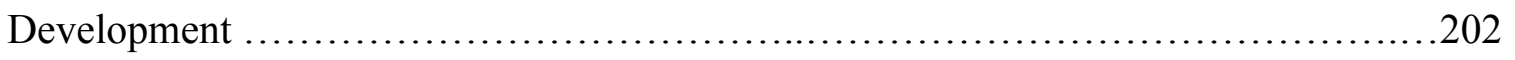

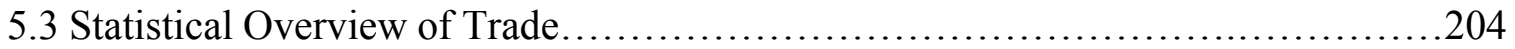

5.3.1 CARICOM MDCs and Intra-regional Trade: $1996-2010 \ldots \ldots \ldots \ldots \ldots \ldots \ldots \ldots \ldots . . .208$ 


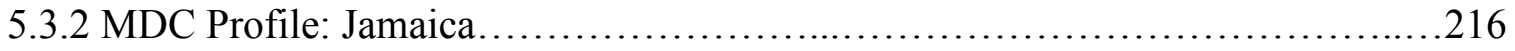

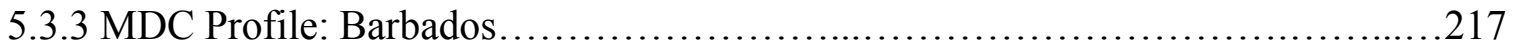

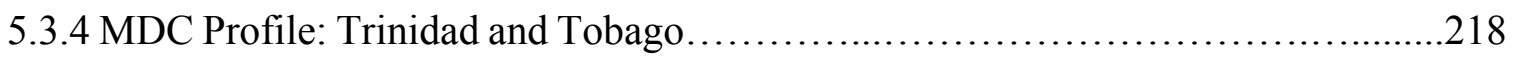

5.4 CARICOM LDCs \& Intra-regional Trade: 1996 - 2010 ...............................221

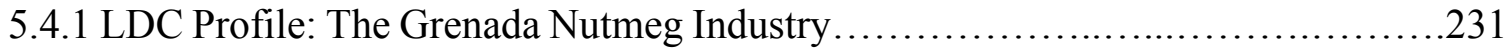

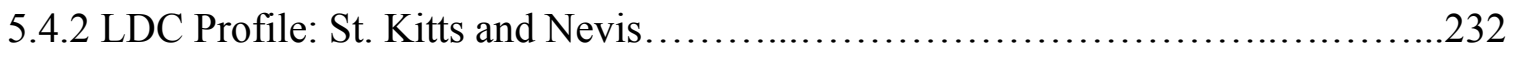

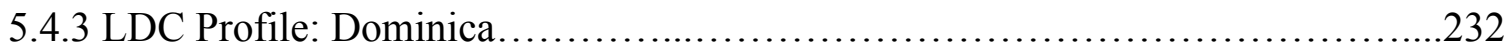

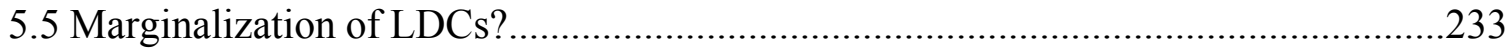

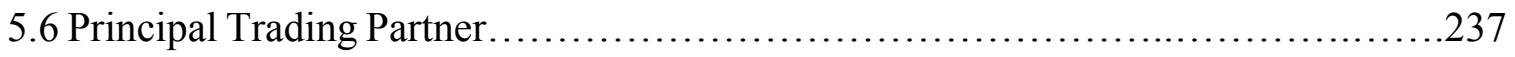

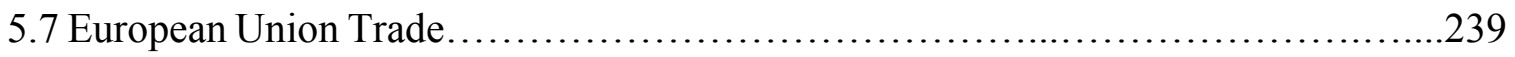

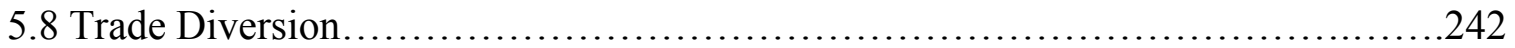

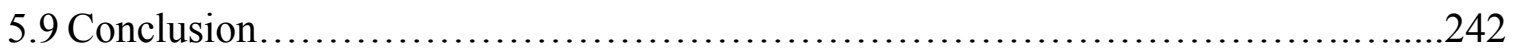

Chapter 6

Case Study on Belize

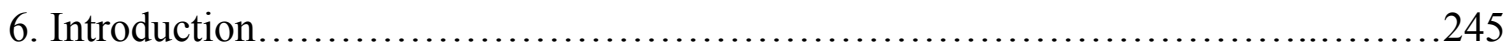

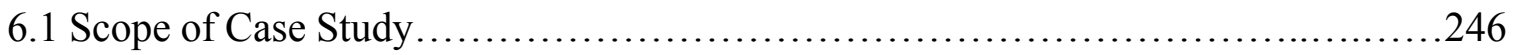

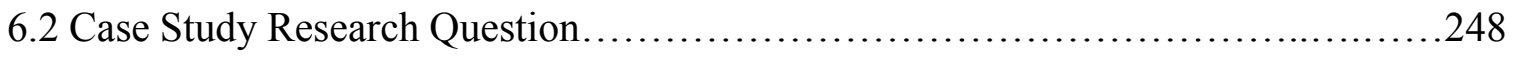

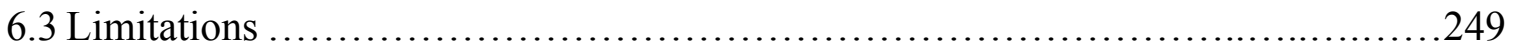

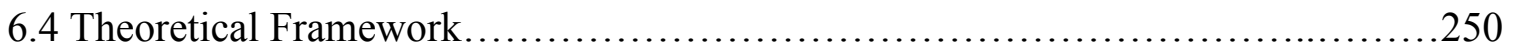

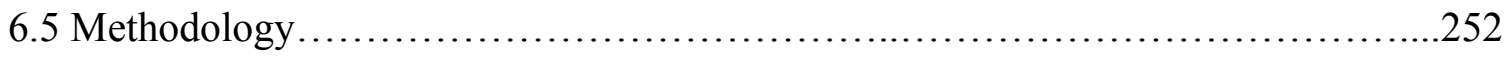

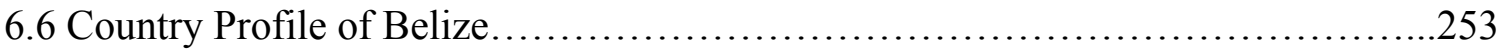

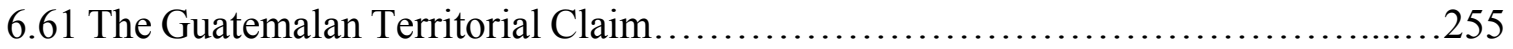

6.6.2 Guatemalan Efforts regarding the Territorial Claim.............................257

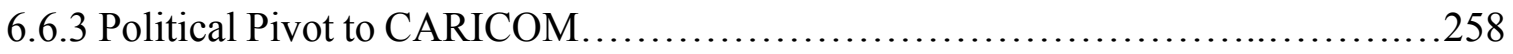

6.6.4 CARICOM and the International Community.................................260

6.6.5 The Question of Belize at the United Nations..................................260

6.7 Post Independence Level of Involvement in CARICOM............................262

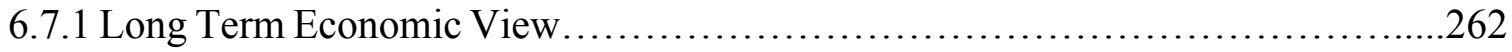

6.7.2 Social Attitudes towards CARICOM........................................264 


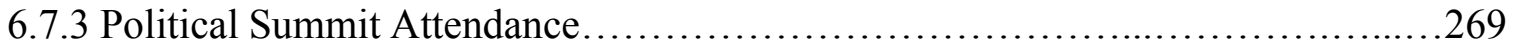

6.8 Importance Given to Foreign and International Trade Policy ........................274

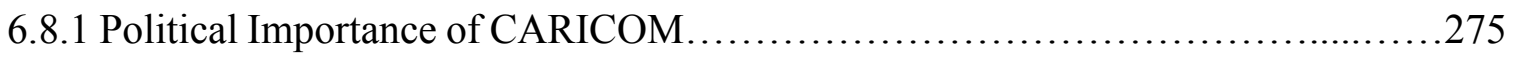

6.8.2 Statistical Picture of Intra-regional Trade ....................................277

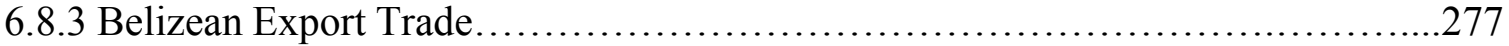

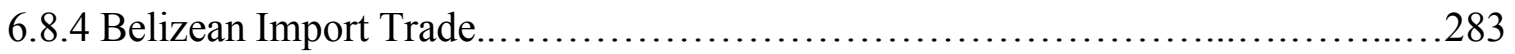

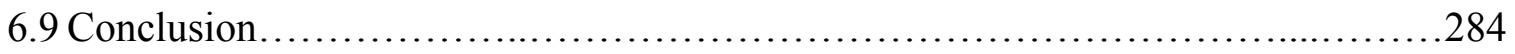

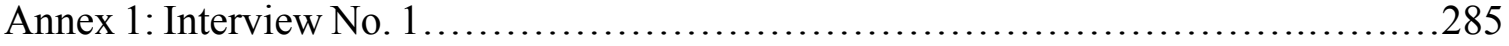

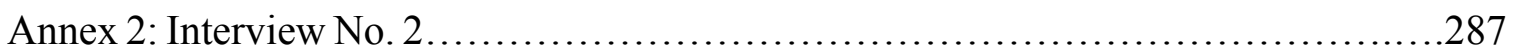

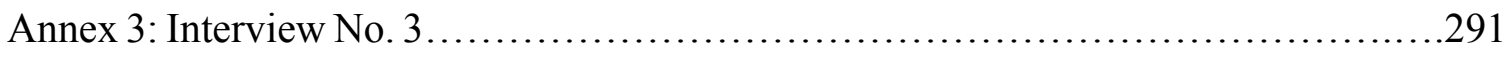

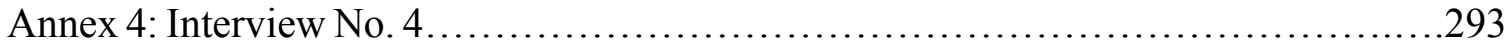

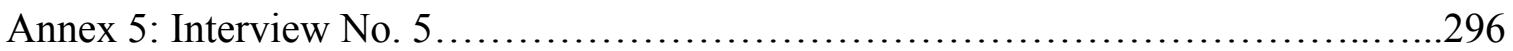

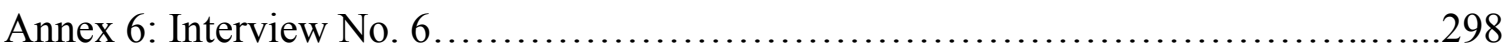

Annex 7: Statistical Institute of Belize: Belizean Exports by Destination: 2003-2014...300

Annex 8: Statistical Institute of Belize: Belizean Exports to CARICOM: 2003-2014 ...301

Annex 9: Statistical Institute of Belize: Belizean Imports by Origin: 2003-2014 .........302

\section{Chapter 7}

CARICOM: The External Dimension

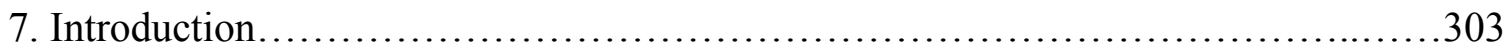

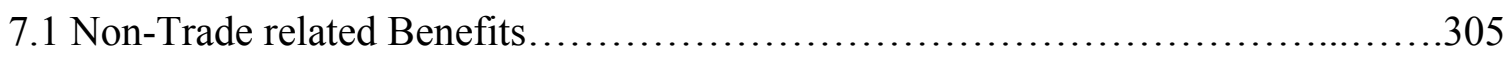

7.1.1 The Concept of Legal Competence........................................... 305

7.1.2 Legal Competence under the West Indies Federation and the Caribbean Free Trade

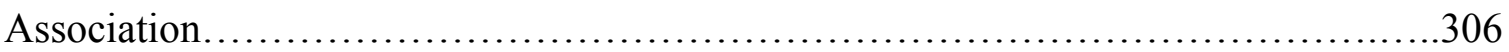

7.1.3 Legal Competence under the Original Treaty of Chaguaramas....................308

7.1.4 Legal Competence under the Revised Treaty of Chaguaramas.....................310

7.2 Institutional and Procedural Arrangements under the Federation and the Caribbean Free Trade Association.....................................................................

7.2.1 Institutional and Procedural Arrangements under the Original Treaty of Chaguaramas. 
7.2.1.1 The Standing Committee of Ministers of Foreign Affairs (SCMFA)............312

7.2.1.2 The Conference of Heads of Government (CHOG) .......................... 314

7.2.1.3 The Prime Ministerial Sub-Committee on External Relations (PMSCER) and the Caribbean Regional Negotiating Machinery (CRNM) ................................ 315

7.2.2 Institutional and Procedural Arrangements under the Revised Treaty of

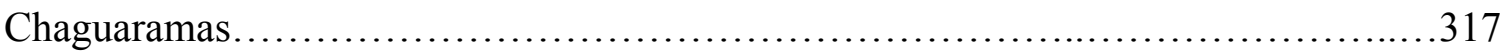

7.2.2.1 The Council for Trade and Economic Development (COTED).................318

7.2.2.2 The Council for Foreign and Community Relations (COFCOR)................318

7.2.2.3 Council for Trade and Economic Development and Council for Foreign and Community Relations Procedure............................................ 319

7.3 Substantive Areas of Coordination..........................................320

7.3.1 Coordinated Negotiation of the 1975 Lome Convention.......................321

7.4 CARICOM: Common Cooperation Platform............................... 322

7.4.1 Cooperation Agreement with Mexico......................................323

7.4.2 Cooperation Agreement with Canada...................................... 324

7.4.3 Other Common Cooperation Initiatives................................. 324

7.5 CARICOM: Interaction with other Regional Groupings.........................325

7.5.1 Regional Outreach to the Central American Integration System (SICA)...........325

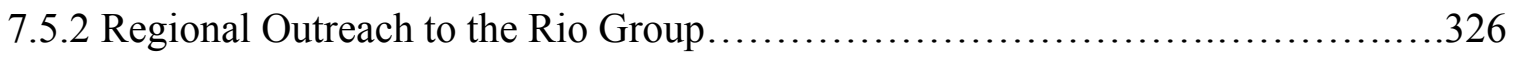

7.5.3 Regional Outreach to the Association of Caribbean States........................327

7.6 CARICOM: the Coordination of Common Policy Positions........................328

7.6.1 Diplomatic Support for Belize....................................... 328

7.6.2 Coordinated Voting at the United Nations.................................329

7.7 Foreign Policy Coordination: 2002 to Present.................................330

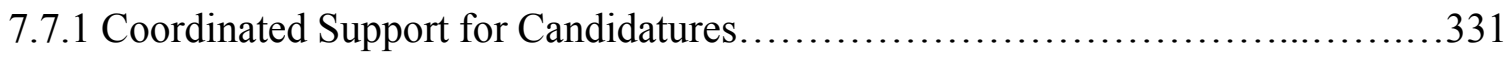

7.7.2 Coordination of Common Policy Positions.................................331

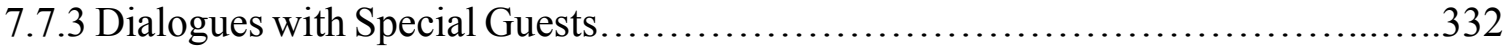

7.8 External Trade Coordination.......................................... 333

7.8.1 Coordinated Trade Relations with the United States and Canada.................334

7.8.2 The World Trade Organization Agenda.......................................335

7.8.3 The African Caribbean and Pacific Group of States.............................337 
Chapter 8

Conclusion and Recommendations

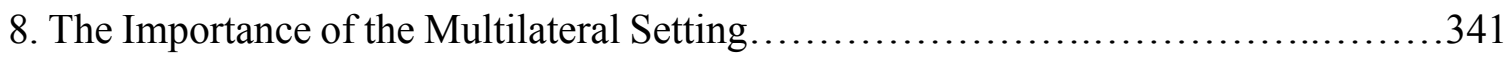

8.1 Multilateral Rules for Preferential Trade Agreements...........................343

8.2 The CARICOM Preferential Trade Agreement and GATT Article XXIV ............344

8.3 The Imprint of the Caribbean Colonial Paradigm...............................345

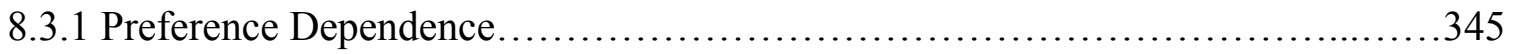

8.3.2 Lack of Product Diversification.............................................347

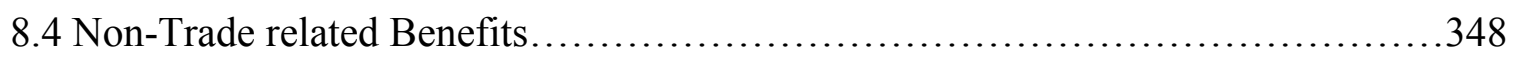

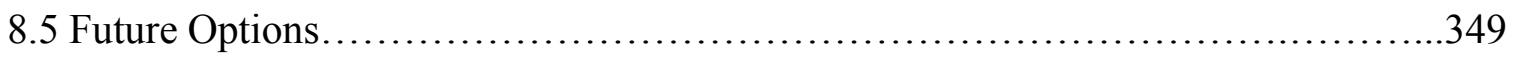

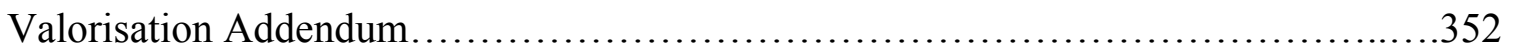

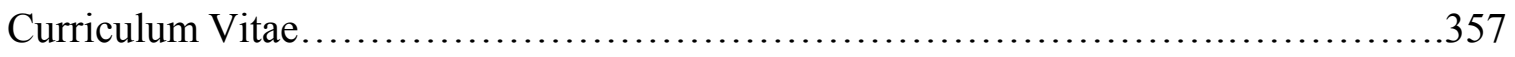




\section{List of Abbreviations}

$\mathrm{AB}$

ACS

ACP

AMP

ASEAN

BREXIT

CAP

CARIBCAN

CARICOM

CARIFTA

CBERA

CBI

CBTPA

CCJ

CCRS

CTD

CDB

CET

CHOG

CHOGM

COFCOR

COTED

CRNM

CRTA

CSA

CSME

DSU

EC
Appellate Body

Association of Caribbean States

African, Caribbean and Pacific States

Agricultural Marketing Protocol

Association

British Exit from the European Union

Common Agricultural Policy

Caribbean Canada Trade Agreement

Caribbean Community

Caribbean Free Trade Association

Caribbean Basin Economic Recovery Act

Caribbean Basin Initiative

Caribbean Basin Trade Partnership Act

Caribbean Court of Justice

Commonwealth Caribbean Regional Secretariat

Committee on Trade and Development

Caribbean Development Bank

Common External Tariff

Conference of Heads of Government

Commonwealth Heads of Government Meeting

Council for Foreign and Community Relations

Council for Trade and Economic Development

Caribbean Regional Negotiating Machinery

Committee for Regional Trade Agreements

Commonwealth Sugar Agreement

CARICOM Single Market and Economy

Dispute Settlement Understanding

European Community 


$\begin{array}{ll}\text { EC } \$ & \text { Eastern Caribbean Dollar } \\ \text { ECCAA } & \text { Eastern Caribbean Central Aviation Authority } \\ \text { ECCB } & \text { Eastern Caribbean Central Bank } \\ \text { ECCM } & \text { Eastern Caribbean Common Market } \\ \text { ECOWAS } & \text { Economic Community of West African States } \\ \text { ECS } & \text { Eastern Caribbean States } \\ \text { ECSC } & \text { European Coal and Steel Community } \\ \text { ECSC } & \text { Eastern Caribbean Supreme Court } \\ \text { EDF } & \text { European Development Fund } \\ \text { EEC } & \text { European Economic Community } \\ \text { EFTA } & \text { European Free Trade Association } \\ \text { EOI } & \text { End of Implementation } \\ \text { EU } & \text { European Union } \\ \text { FTAA } & \text { Free Trade Area of the Americas } \\ \text { FTA } & \text { Free Trade Agreement } \\ \text { GATT } & \text { General Agreement on Tariffs and Trade } \\ \text { GOB } & \text { Government of Belize } \\ \text { GRULAC } & \text { Group of Latin American and Caribbean States } \\ \text { GSP } & \text { Generalized System of Preferences } \\ \text { IBRD } & \text { International Bank of Reconstruction } \\ \text { ICJ } & \text { and Development } \\ \text { IDB } & \text { International Court of Justice } \\ \text { IICA } & \text { Inter-American Development Bank } \\ \text { IMF } & \text { Inter-American Institute for Cooperation } \\ \text { ITO } & \text { on Agriculture } \\ \text { LAFTA } & \text { International Monetary Fund } \\ \text { LDCs } & \text { International Trade Organization } \\ \text { MDCs } & \text { Latin American Free Trade Area } \\ \text { MERCOSUR } & \text { Least Developed Countries } \\ & \text { More Developed Countries } \\ & \text { Mercado Comun del Sur/Southern Common Market } \\ & \end{array}$




\begin{tabular}{|c|c|}
\hline MFN & Most Favored Nation \\
\hline MTS & Multilateral Trading System \\
\hline NAFTA & North American Free Trade Agreement \\
\hline NIDC & Net Importing Developing Country \\
\hline OAS & Organization of American States \\
\hline OECS & Organization of Eastern Caribbean States \\
\hline OTC & Original Treaty of Chaguaramas \\
\hline OTN & Office of Trade Negotiations \\
\hline PMSCER & $\begin{array}{l}\text { Prime Ministerial Sub-Committee } \\
\text { on External Relations }\end{array}$ \\
\hline PPA & Protocol of Provisional Application \\
\hline PTA & Preferential Trade Agreement \\
\hline QRs & Quantitative Restrictions \\
\hline RTA & Regional Trade Agreement \\
\hline \multirow[t]{2}{*}{ RTA TM } & Regional Trade Agreement \\
\hline & Transparency Mechanism \\
\hline RTAA & Reciprocal Trade Agreements Act \\
\hline RTB & Revised Treaty of Basseterre \\
\hline RTC & Revised Treaty of Chaguaramas \\
\hline \multirow[t]{2}{*}{ SCMFA } & Standing Committee of Ministers of \\
\hline & Foreign Affairs \\
\hline SDT & Special and Differential Treatment \\
\hline SIB & Statistical Institute of Belize \\
\hline SICA & Central American Integration System \\
\hline TTIP & Transatlantic Trade and Investment Partnership \\
\hline UK & United Kingdom \\
\hline UN & United Nations \\
\hline UNGA & United Nations General Assembly \\
\hline UNSC & United Nations Security Council \\
\hline US & United States \\
\hline USA & United States of America \\
\hline
\end{tabular}


USD

UWI

VCLT

WIAS

WTO
United States Dollars

University of West Indies

Vienna Convention on the Law of Treaties

West Indies Associated States

World Trade Organization 
The CARICOM Preferential Trade Agreement: Is there a legal obligation to create trade?

\section{Introduction}

This dissertation focuses on the circumstances that propelled the development of regional integration in the Caribbean and investigates how the British Caribbean colonial paradigm has impacted Caribbean Community (CARICOM) trade policy as well as the cultivation of trade creation within the CARICOM preferential trade agreement (PTA) and its compatibility with the World Trade Organization (WTO) legal provisions underpinning the establishment of PTAs for trade in goods. In this regard, it must be recalled that the British Caribbean colonial paradigm was rooted in the fact that modern day CARICOM Member States were formerly British Caribbean colonies. Most of these British Caribbean colonies constituted a part of the British Atlantic economy ${ }^{1}$ and were characterized by sugar plantations that used slave labor to produce sugar, which was subsequently exported to the United Kingdom (UK). ${ }^{2}$ In the aftermath of the abolition of slavery in 1834 , the UK was further tasked with ensuring that adequate conditions prevailed in the Caribbean region of its colonial empire. ${ }^{3}$ Nevertheless, the early twentieth century met the British Caribbean colonies in a condition whereby they remained challenged by a lack of socio-economic

\footnotetext{
${ }^{1}$ The term British Atlantic Economy describes the system whereby the economy of the United Kingdom was linked to and derived economic benefits from its slavery based sugar colonies in the Caribbean as well as the British colonies based in North America. N. Zahedieh, The Capital and The Colonies: London and The Atlantic Economy: 1660-1700 (Cambridge University Press, 2010), p. 260; J. Roberts, Slavery and The Enlightenment in The British Atlantic, 1750-1807 (Cambridge University Press, 2013), p. 13. See also (eds.) A.B. Leonard, D. Pretel, The Caribbean and the Atlantic World Economy: Circuits of Trade, Money and Knowledge, 1650-1914 (Palgrave McMillan, 2015).

${ }^{2}$ Haiti and Suriname are the only two current day CARICOM Member States that were not British Caribbean territories as they were respectively colonies of France and The Netherlands. Haiti joined CARICOM on $1^{\text {st }}$ July 2002 and Suriname joined CARICOM on $4^{\text {th }}$ July 1995. Thus, much of the initial analysis regarding the evolution of Caribbean regional integration, which occurred between the late 1950s and the early 1990s, does not pertain to these two CARICOM Member States.

${ }^{3}$ S. Carrington, The American Revolution and The British West Indies' Economy in (eds.) B. Solow, S. Engerman, British Capitalism and Caribbean Slavery: The Legacy of Eric Williams (Cambridge University Press, 2004), p. 135; C. Muellerleile, CARICOM Integration: Progress and Hurdles, A European View (Kingston Publishers Limited, Kingston, Jamaica, 1995), p. 9.
} 
development. ${ }^{4}$ Consequently, one of the forces underlying the early pivot to regional integration in the Caribbean was the improvement of the Caribbean economic condition. ${ }^{5}$

Although the UK government enacted various colonial policies aimed at improving socioeconomic conditions and spurring development, many of these policies served to further entrench the economic dependency of the British Caribbean colonies on the UK. ${ }^{6}$ This dissertation submits that the remnants of colonial policies from this chapter of Caribbean history continue to impact CARICOM trade policy, as the imprint of trade preferences for agricultural goods has contributed to an emphasis on an export oriented model for trade in agricultural goods. This export model can be traced back to the era of the British Atlantic economy and remains the policy choice of several CARICOM Member States despite less competitive, modern-day market conditions such as high labor costs, poor soil conditions and the absence of large-scale agro-processing plants. ${ }^{7}$ In addition to this, limited product diversification efforts have been undertaken despite the continuous clamor of economic policy advice against the maintenance of monoculture economies. ${ }^{8}$ Most of the CARICOM Member States remain net importing developing countries (NIDCs), which reinforces their overreliance on imports of basic consumer goods and the lack of manufacturing capacity. ${ }^{9}$

\footnotetext{
4 "In the early postwar years, Britain was unable to meet colonial demands for development expenditure and most West Indian colonies lacked economic resources necessary to satisfy mounting domestic demands for housing, education, health facilities and the like." A. Hinds, Sterling and Decolonization in the British Empire, 1945 - 1958, Social and Economic Studies, 1999, Vol. 48 (4), pp. 97-116, p. 103; D. O’Brien, CARICOM: Regional Integration in a Post-Colonial World, European Law Journal, 2011, Vol. 17(5), pp. 630-648, p. 633.

${ }^{5}$ S. Nicolls, A. Birchwood, P. Colthrust, E. Boodoo, The State of and Prospects for the Deepening and Widening of Caribbean Integration, The World Economy, 2000, Vol. 23(9), pp. 1161-1194, p. 1164.

${ }^{6}$ This included inter alia trade preferences for sugar and bananas as well as adjustments to the imperial preference system. A. Hinds, Sterling and Decolonization in the British Empire, 1945 - 1958, Social and Economic Studies, 1999, Vol. 48(4), pp. 97-116, p. 103.

${ }^{7}$ See M. Mlachila, P. Cashin, C. Haines, IMF Working Paper, Caribbean Bananas: The Macroeconomic Impact of Trade Preference Erosion (2010), p. 10; A. Payne, The End of Green Gold? Comparative Development Options and Strategies in the Eastern Caribbean Banana-Producing Islands, Studies in Comparative International Development, 2006, Vol. 41 (3), pp. 25-46, p. 26.

${ }^{8}$ See World Bank/Organization of American States, co-produced with the Governments of the CARIFORUM Countries, Poverty Reduction and Economic Management Sector Unit, Latin America and Caribbean Region, The Caribbean: Accelerating Trade Integration, Policy Options for Sustained Growth, Job Creation and Poverty Reduction (December 2008), p. 76, para. 4.45; H. Sandberg, J. Seale, T. Taylor, History, Regionalism and CARICOM Trade: A Gravity Model Analysis, Journal of Development Studies, 2006, Vol. 42 (5) pp. 795-811, p. 808.

${ }^{9}$ See Ibid, World Bank/Organization of American States, co-produced with the Governments of the CARIFORUM Countries, Poverty Reduction and Economic Management Sector Unit, Latin America and Caribbean Region, 2008, Introduction, p. 64, para. 4.5.
} 
The main effect of these CARICOM policy choices is that efforts to cultivate trade creation, which is one of the main ambitions of a PTA, continue to be hampered.

Since CARICOM is one of the oldest, continuous regional integration arrangements among developing countries, ${ }^{10}$ this dissertation provides fertile ground upon which claims regarding the long-term benefits of regional integration can be interrogated. In other words, this dissertation aims to inquire whether regional integration and its accompanying tradecreating institutions have assisted the small Caribbean developing countries with their overall development goals. Similarly, this dissertation aims to examine the impact of the British Caribbean colonial paradigm to determine its long-term effect on the development of CARICOM trade policy. Whereas other literature has addressed the nature of CARICOM relations with Europe and the development of the CARICOM single market, sparse attention has been paid to the legal underpinnings of regional integration in the Caribbean. ${ }^{11}$ The issue of whether the evolved legal competences have assisted the CARICOM Member States in countering the effects of the British Caribbean colonial paradigm and adjusting to the rules-based multilateral trading system (MTS) as well as changes in the wider international system also remains under-researched. ${ }^{12}$ This dissertation aims to analyze and clarify some of these issues, as current literature on regional integration in the Caribbean does not yet address the central research question posed in this dissertation.

\footnotetext{
${ }^{10}$ The process of regional integration in the Caribbean commenced in the mid 1960 s whereas a similar process commenced in Latin American in the late 1960s, which then stalled before continuing in the 1980s. Solid attempts at regional integration in Africa commenced in the 1990s.

${ }^{11}$ In this regard, H. Geiser, P. Alleyne, C. Garaj, Legal Problems of Caribbean Integration: A Study on the Legal Aspects of CARICOM (Institute of International Relations, St. Augustine, Trinidad and Tobago and A.W. Sijthoff International Publishing, Leiden, Netherlands, 1976) and more recently D. Berry, Caribbean Integration Law (Oxford University Press, 2014) stand apart as literature that has focused on the legal aspects of regional integration in the Caribbean.

${ }^{12}$ Most literature on regional integration in the Caribbean has utilized historical, political and economic prisms to view the process. See (eds) K. Hall, M. Chuck-A-Sang, The Integrationist: The CARICOM Single Market and Economy: Towards A Single Economic Space (Trafford Publishing, 2013), A. Payne, A Political History of CARICOM (Ian Randle Publishers, Kingston, Jamaica, 2008), E. Rose, Dependence and Socialism in the Modern Caribbean (Lexington Books Publishing, USA, 2002), C. Muellerleile, CARICOM Integration: Progress and Hurdles, A European View (Kingston Publishers Limited, Kingston, Jamaica, 1995), P. Clegg, The Caribbean Banana Trade: From Colonialism to Globalization (Palgrave MacMillan, UK, 2002).
} 
Three successive international treaties among the former British Caribbean colonies created three PTAs represented a regional application of the multilateral concept of a free trade area and subsequently, a customs union. PTAs are legally enshrined in the General Agreement on Tariffs and Trade (GATT) Article XXIV and the paragraph 2 (c) of the 1979 Decision on Differential and More Favorable Treatment, Reciprocity and Fuller Participation of Developing Countries (the Enabling Clause). ${ }^{13}$ Both legal provisions constitute an exception to the non-discrimination principle contained in GATT Article I, which is considered the cornerstone of the MTS given its underlying notion that global trade should be conducted under multilateral terms. ${ }^{14}$ From a trade policy perspective, PTAs are intended to foster trade creation whilst minimizing trade diversion for third parties. The requirements of both the aforementioned legal provisions aim to achieve this. ${ }^{15}$ In this regard, this dissertation also examines the compatibility of the CARICOM PTA with GATT Article XXIV, which was used to notify all three CARICOM PTAs. Since the aim of GATT Article XXIV is to foster trade creation, this dissertation dissects the ability of the CARICOM PTA to create trade and utilizes this ability as a benchmark to test compatibility with GATT Article XXIV. This benchmark represents a relevant concern given the original conception of the rules based MTS and its function to engender a nondiscriminatory environment for the regulation of international trade. In the absence of such

\footnotetext{
${ }^{13}$ See GATT Secretariat, Differential and More Favorable Treatment, Reciprocity and Fuller Participation of Developing Countries, Decision of 28 November 1979 (Geneva, 3 December 1979) [L4903].

${ }^{14}$ As the first legal provision of the GATT 1947, GATT Article I reflected the core belief of the GATT drafters, which sought to ensure that global trade be conducted under multilateral and non-discriminatory terms. See R. Herzstein, J. Whitlock, Regulating Regional Trade Agreements - A Legal Analysis in (eds) P. Macrory, A. Appleton, M. Plummer The World Trade Organization: Legal, Economic and Political Analysis, Volume II, (Springer Science and Business Media Inc, 2007), p. 221; Y. Lee, Reconciling RTAs with the WTO Multilateral Trading System: Case for a New Sunset Requirement on RTAs and Development Facilitation, Journal of World Trade, 2011, Vol. 45 (3), p. 629-651, p. 631.

${ }^{15}$ This raison d'etre is outlined in GATT Article XXIV: 4 and has been referenced as the underlying goal of PTAs irrespective of whether they were notified under GATT Article XXIV or the Enabling Clause. In support of the common goals of PTAs, irrespective of the legal provision used during notification, the WTO Panel Report on Brazil - Measures Affecting Imports of Retreaded Tyres case (Brazil Retreated Tyres) noted that although the MERCOSUR PTA was notified under the Enabling Clause, the PTA was also to be examined in light of GATT Article XXIV. "The terms of reference for the review of MERCOSUR, as contained in document WT/COMTD/5/Rev.1 of 25October 1995, are "to examine the Southern Common Market Agreement, (MERCOSUR) in the light of the relevant provisions of the Enabling Clause and of the GATT 1994, including Article XXIV [...]" See: WTO Panel Report on Brazil - Measures Affecting Imports of Retreaded Tyres (2007), para. 5.15, p. 116.
} 
an environment, concerns abound regarding the role of PTAs and whether they undermine the stability and coherence of the MTS. ${ }^{16}$

\section{Relevance of the Dissertation}

The 2016 decision of the UK to exit the European Union (EU) has shattered the assumption that regional integration is an inherently continuous and expansive process. The EU is viewed as the gold standard of regional integration initiatives and has inspired emulation by other regions including the Caribbean. ${ }^{17}$ In both the case of the EU and CARICOM, the gains of regional integration have been well touted and juxtaposed with the downsides of shared policy-making as well as the limitations on individual sovereignty and national interest. ${ }^{18}$ In light of the successes achieved by the EU, there was a tendency (until recent years) to present the aforementioned tradeoffs and burden-sharing endeavors as worthwhile. ${ }^{19}$ However, the question remains unanswered whether PTAs in the form of customs unions, which embody regional integration, have the wherewithal to achieve their lofty external policy ambitions without alienating the citizens of their constituent members on the domestic front, as seen with the UK. ${ }^{20}$

\footnotetext{
${ }^{16}$ One school of thought on PTAs maintains that they distort trade, segment markets, engender trade diversion, exclude small countries, increase trade negotiating costs and reduce political will for multilateral trade negotiations. See J. Bhagwati, Termites in the Trading System: How Preferential Agreements undermine Free Trade (Oxford University Press, 2008); J. Bhagwati, A. Krueger, Dangerous Drift to Preferential Trade Agreements (AEI Press, 1995); N. Limao, Preferential Trade Agreements as Stumbling Blocs for Multilateral Trade Liberalization: Evidence for the United States, American Economic Review, 2006, Vol. 96(3), pp. 896-914; Y. Lee, Reconciling RTAs with the WTO Multilateral Trading System: Case for a New Sunset Requirement on RTAs and Development Facilitation, Journal of World Trade, 2011, Vol. 45 (3), p. 629-651, p. 635; The Warwick Commission, The Multilateral Trade Regime: Which Way Forward? The Report of the First Warwick Commission (University of Warwick, 2007), p. 50; WTO Secretariat, World Trade Report 2003, Trade and Development (Geneva, 2003) p. 65.

17 O. Arthur, Caribbean Regionalism in the Context of Economic Challenges, Caribbean Journal of International Relations, 2014, Vol. 2(4), pp. 147-164, p. 152.

18 See World Bank/Organization of American States, co-produced with the Governments of the CARIFORUM Countries, Poverty Reduction and Economic Management Sector Unit, Latin America and Caribbean Region, The Caribbean: Accelerating Trade Integration, Policy Options for Sustained Growth, Job Creation and Poverty Reduction (December 2008), Chapter 2, p. 60.

19 J. Bhagwati, Regionalism and Multilateralism: An Overview in (eds) J. Bhagwati, P. Krishna, A. Panagariya, Trading Blocs: Alternative Approaches to Analyzing Preferential Trade Agreements (MIT Press, 1999), p. 9.

${ }^{20}$ A. Malamud, L. de Sousa, Regional Parliaments in Europe and Latin America: Between Empowerment and Irrelevance in (eds.) A. Ribeiro Hoffman, A. Van der Vleuten, Closing or Widening the Gap? Legitimacy and Democracy in Regional Integration Organizations, (Routledge, 2016), p. 89; W. Grenade, Paradoxes of Regionalism and Democracy: Brexit's Lessons for the Commonwealth, The Round Table, 2016, Vol. 105 (5), pp. 509-518, p. 510.
} 
This dissertation analyzes the evolution of regional integration in the Caribbean, which has been undertaken whilst resisting the embrace of supranationalism. The aforementioned progression is noteworthy for a developing country region with a strong colonial past. ${ }^{21}$ Since 1989, the CARICOM Single Market and Economy (CSME) has been pursued with a unified awareness of limited alternatives and the knowledge that the regional platform maximizes the ability to act on the international plane for the CARICOM Member States. ${ }^{22}$ The legal and institutional framework that has been established to facilitate the CSME is intended to serve for the longer term and should aid in adjusting to the myriad of changes that continue to characterize the wider international system. However, it is also questioned whether arguments regarding the importance of these legal and institutional structures have been ventilated on the domestic front of the CARICOM Member States to ensure a requisite level of awareness and coherence between the regional and domestic policy agendas.

\section{Central Research Question and Subsidiary Research Questions}

The principal inquiry of this dissertation is concerned with the CARICOM region and how various colonial era policies continue to influence the trajectory of its economic development. The central research question of this dissertation inquires: how does the British Caribbean colonial paradigm impact CARICOM trade policy, in particular the cultivation of trade creation within the CARICOM PTA, and its compatibility with the WTO legal provisions underpinning the establishment of PTAs for trade in goods? Additionally, this dissertation is aimed at answering four subsidiary research questions, which seek to examine the circumstances surrounding regional integration in the Caribbean, colonial trade policy and how the latter has affected the ability of the

\footnotetext{
${ }^{21}$ CARIFTA entered into force on $1^{\text {st }}$ May 1968 and although it was the $20^{\text {th }}$ PTA to be notified at the GATT Secretariat, there were only four other PTAs in existence among former colonial territories at that time: the South Africa - Southern Rhodesia Customs Union, the Ghana-Upper Volta Trade Agreement, the Equatorial Customs Union - Cameroon Association and the African Common Market. When compared to CARIFTA, most of these PTAs did not evolve beyond their then incarnation and many are no longer in force today.

${ }^{22}$ The July 1989 Grand Anse Declaration and the work programme for the advancement of the Caribbean integration movement emanated from the $10^{\text {th }}$ Meeting of the Heads of Government of CARICOM. It also represented the main intergovernmental decision to advance expeditiously towards the full establishment of a Caribbean customs union in the form of a single market and economy.
} 
CARICOM PTA to create trade. The four subsidiary research questions, as set out below, assist in answering the central research question.

Consequently, the CARICOM PTA is assessed in light of the WTO provisions that underpin the establishment of PTAs. Given the aforementioned, the first subsidiary research question seeks to ascertain whether GATT Article XXIV and the Enabling Clause constitute a legal obligation to create trade? It is submitted that both of these legal provisions aim to create a normative structure for the establishment of PTAs, which are formed with the expectation to create trade. But, can an expectation to create trade be equated with a legal obligation to create trade in order to benefit from these legal exceptions? In other words, is there (even) a legal obligation for the CARICOM PTA to result in trade creation? Both GATT Article XXIV and the Enabling Clause are examined with the aim of determining the relationship between the legal provisions and the concept of trade creation.

The second subsidiary research question asks why the CARICOM PTA has been unable to create significant intra-regional trade. The effect of non-reciprocal preferential trade policies on the CARICOM Member States is examined and mention is made of the respective preferential trade policies employed by the European Union, the United States and Canada. In this connection, the history of British Caribbean colonial trade preferences is noted as well as its evolution to European Economic Community (EEC) trade preferences in the aftermath of the UK accession to the EEC in 1973. It is inquired whether such trade policies skewed the direction of internal and external CARICOM trade flows. Also questioned is whether the LDC/MDC divide among the CARICOM Member States has affected the manner in which the intra-regional market is contextualized regarding the ability to produce and market tradable goods.

Despite the salience of GATT Article XXIV and paragraph 2 (c) of the Enabling Clause, this dissertation probes the wisdom of solely viewing the CARICOM PTA through the analytical prism of traditional trade gains. In this vein, the relevance of the third subsidiary research question is noted, as it inquires about the non-trade related benefits of the 
CARICOM PTA. Does the CARICOM PTA represent only a trade creation mechanism for its constituents? Or is the CARICOM platform also a successful bilateral and multilateral mechanism for engagement with external partners on the international plane?

Allied to this is the fourth subsidiary research question, which inquires whether it is likely that the CARICOM Member States will benefit from the CARICOM PTA in the future. It is recalled that the advent of regional integration in the Caribbean coincided with the commencement of decolonization in the Caribbean region of the British empire and has endured the ebbs and flows of the wider international system including the introduction of a rules based MTS and the far-reaching effects of globalization. Can the progress made thus far on regional integration in the Caribbean be considered seeds planted for the further growth of the CARICOM intra-regional trade arrangement? This dissertation seeks to answer these inquiries.

\section{Organization of Dissertation, Methodology and Sources}

This dissertation consists of four parts. Part 1 introduces the multilateral setting by outlining the WTO legal rules and procedures applicable to PTAs. In doing so, Part 1 establishes the multilateral underpinnings to which the CARICOM PTA must adhere. Part 2 and Part 3 of this dissertation examines a regional application of the WTO legal rules and procedures by investigating the CARICOM PTA. It probes how the British Caribbean colonial paradigm has impacted CARICOM trade policy with a particular focus on the cultivation of trade creation within the CARICOM PTA. Further to this, the compatibility of the CARICOM PTA with the WTO legal provisions underpinning the establishment of PTAs for trade in goods is assessed. The fundamental aim of both of these legal provisions is to foster trade creation and the CARICOM PTA is assessed in light of its ability to generate actual trade among its constituents.

Part 1 consists of 3 chapters. Chapter 1 utilizes explanatory legal research to outline the history of the GATT 1947 and doctrinal legal research to examine the drafting history of 
GATT Article XXIV. ${ }^{23}$ WTO law books and journals are used to: (a) assert the centrality of the multilateral principle, (b) shape the conceptual divide between preferential and multilateral trade and (c) demonstrate how preferential trade was seen as a threat to the MTS. ${ }^{24}$ Historical legal research is also used to contextualize the US view on preferential trade and its support for European regional integration. The Treaty of Rome establishing the European Economic Community (EEC) is then examined using secondary sources such as the GATT working party reports to highlight the concerns voiced about its legal compatibility with GATT Article XXIV ${ }^{25}$ Chapter 2 addresses the legal design of GATT Article XXIV and paragraph 2 (c) of the Enabling Clause by critically examining the legal provisions to understand: (a) what they aim to achieve and (b) whether they represent a legal obligation to create trade. Doctrinal legal analysis is used to address the aims, main requirements, use and systemic issues associated with both legal provisions. ${ }^{26}$ Primary sources such as the WTO legal texts, the rules of treaty interpretation of the Vienna Convention on the Law of Treaties (VCLT) and WTO jurisprudence relating to both GATT Article XXIV and the Enabling Clause are used. ${ }^{27}$ WTO law books assist with establishing

\footnotetext{
${ }^{23}$ See A. Porges, Guide to GATT Law and Practice: Analytical Index $\left(6^{\text {th }}\right.$ Edition, World Trade Organization, Geneva, 1995). Journal articles were also utilized to further contextualize the drafting history of GATT Article XXIV. See K. Chase, Multilateralism Compromised: The Mysterious Origins of GATT XXIV, World Trade Review, 2006, Vol. 5 (1), p. 1-30; K. Dam, Regional Economic Arrangements and The GATT: The Legacy of A Misconception, University of Chicago Law Review, 1963, Vol. 30 (4), pp. 615-665; F. Haight, Customs Union and Free Trade Areas under the GATT: A Reappraisal, Journal of World Trade Law, 1972, Vol. 6 (4), pp. 391-404.

${ }^{24}$ See M. Matsushita, T. Schoenbaum, P. Mavroidis, M. Hahn, The WTO: Law, Practice and Policy, Third Edition (Oxford University Press, 2015); J. Odell, B. Eichengreen, The United States, the ITO and the WTO: Exit Options, Agent Slack and Presidential Leadership in (ed) A. Krueger, The WTO as an International Organization (The University of Chicago Press, 1996; P. Van den Bossche, W. Zdouc, The Law and Policy of the World Trade Organization, Fourth Edition (Cambridge University Press, 2017); J. Jackson, The World Trading System: Law and Policy of International Economic Relations, Second Edition (MIT Press 1997); (eds) J. Bhagwati, P. Krishna, A. Panagariya, Trading Blocs: Alternative Approaches to Analyzing Preferential Trade Agreements (MIT Press, 1999).

${ }^{25}$ See GATT Secretariat, Treaty Establishing The European Economic Community, Report Submitted by the Committee on the Rome Treaty to the Contracting Parties on 29 November 1957 (Geneva, $20^{\text {th }}$ December 1957) [L/778].

${ }^{26}$ The customary rules of interpretation of international law outlined in Article 31 (1) of the Vienna Convention on the Law of Treaties (VCLT) are used to assess the state of play regarding the interpretation of these two legal provisions.

${ }^{27}$ See WTO Legal Texts (particularly the text of GATT Article XXIV); The Understanding on the Interpretation of Article XXIV of GATT 1994; See Appellate Body Report, Turkey - Restrictions on Imports of Textile and Clothing Products, WT/DS34/AB/R, adopted $19^{\text {th }}$ November 1999, DSR 1999:VI, 2345; Panel Report, Canada-Certain Measures Affecting the Automotive Industry, WT/DS139/AB/R/, WT/DS142/R, adopted $19^{\text {th }}$ June 2000, as modified by Appellate Body Report WT/DS139/AB/R, WT/DS/142/AB/R, DSR 2000:VII, 3043; Appellate Body Report, European Communities-Conditions for the Granting of Tariff Preferences to Developing Countries, WT/DS246/AB/R, adopted $20^{\text {th }}$ April 2004, DSR 2004:III, 925;
} 
an inter-relation between the systemic issues associated with GATT Article XXIV and the impairment of PTAs, as a WTO discipline. ${ }^{28}$

Chapter 3 considers the institutional treatment of PTAs with a descriptive assessment of the legal assessment process and the regulatory approach employed to manage PTAs. ${ }^{29}$ PTA surveillance and institutional management is relevant in determining whether PTAs serve to create trade and whether they function within the MTS as intended. WTO documentation and WTO law books are used to establish linkages between the systemic issues associated with GATT Article XXIV and (a) the previous inability to purposively monitor PTAs as well as (b) the PTA discipline being rooted on unstable ground. ${ }^{30} \mathrm{~A}$ historical assessment of institutional attempts to govern PTAs is undertaken and reference is made to the level of compliance achieved thus far. ${ }^{31}$ Chapter 3 also outlines the institutional and legal assessment undertaken for the CARICOM PTAs.

Appellate Body Report, Brazil - Measures Affecting Imports of Retreaded Tyres, Body, WT/DS332/AB/R, adopted $17^{\text {th }}$ December 2007, DSR 2007:IV, 1527; Appellate Body Report, Mexico - Tax Measures on Soft Drinks and Other Beverages, WT/DS308/AB/R adopted 24 March 2006, DSR 2006:I, 3; Appellate Body Report, United States - Definitive Safeguard Measures on Imports of Circular Welded Carbon Quality Line Pipe from Korea, WT/DS202/AB/R, adopted 8 March 2002, DSR 2002:IV, 1403.

28 See P. Mavroidis, The Regulation of International Trade, Volume I, GATT (MIT Press, 2016, (Eds) K. Bagwell, P. Mavroidis; Preferential Trade Agreements: A Law and Economics Analysis (Cambridge University Press, 2011); M. Trebilcock, R. Howse, A. Elliason, The Regulation of International Trade $4^{\text {th }}$ Edition (Routledge 2013); P. Mavroidis, If I Don't, Somebody Else Will (Or Won't): Testing the Compliance of Preferential Trade Agreements with Multilateral Rules, Journal of World Trade, 2006 (40) 1, pp. 187 214; T. Brink, Which WTO Rules Can a PTA Lawfully Breach? Completing the Analysis in Brazil - Tyres', Journal of World Trade 2010, Vol. 44(4), pp. 813 - 846.

${ }^{29}$ See R. Herzstein, J. Whitlock, Regulating Regional Trade Agreements - A Legal Analysis in (eds.) P. Macrory, A. Appleton, M. Plummer, The World Trade Organization: Legal, Economic and Political Analysis, Volume II (Springer, 2005); J. Pauwelyn, The Transformation of World Trade, Michigan Law Review, 2005, Vol. 104 (1), pp. 1-67; WTO Secretariat, Committee on Regional Trade Agreements, Decision of $6^{\text {th }}$ February 1996 (Geneva, $7^{\text {th }}$ February 1996)[WT/L/127]; F. Haight, Customs Union and Free Trade Areas under the GATT: A Reappraisal, Journal of World Trade Law, 1972, Vol. 6 (4), pp. 391-404.

${ }^{30}$ See J. Bhagwati, Termites in the Trading System: How Preferential Agreements undermine Free Trade (Oxford University Press, 2008); WTO Secretariat, World Trade Report 2003, Trade and Development (Geneva, 2003); The Warwick Commission, The Multilateral Trade Regime: Which Way Forward? The Report of the First Warwick Commission (University of Warwick, 2007); W. Davey, A Model Article XXIV: Are there Realistic Possibilities to Improve It? in (eds.) K. Bagwell, P. Mavroidis, Preferential Trade Agreements: A Law and Economics Analysis (Cambridge University Press, 2011); Report by the Consultative Board to the Director General Supachai Panitchpakdi, The Future of the WTO: Addressing Institutional Challenges in the New Millennium (The Sutherland Report) (WTO, 2004).

${ }^{31}$ See R. Fiorentino, J. Crawford, C. Toqueboeuf, The Landscape of RTAs and WTO Surveillance in (eds.) R. Baldwin, P. Low, Multilateralizing Regionalism: Challenges for the Global Trading System (Cambridge University Press, 2008); (ed.) R. Acharya, Regional Trade Agreements and the Multilateral Trading System (Cambridge University Press, 2016). 
Part 2 of the dissertation shifts the focus from the multilateral perspective on PTAs to the regional application of a PTA with a qualitative and quantitative assessment of the CARICOM PTA in pursuit of answering why the CARICOM PTA has been unable to create significant intra-regional trade, what are the non-trade related benefits of the CARICOM PTA and whether it is likely that CARICOM Member States will benefit from the PTA in the future. Part 2 consists of Chapter 4 and Chapter 5. Chapter 4 introduces the CARICOM PTA and uses explanatory legal research to outline the unfolding of regional integration in the Caribbean. Regional integration theory as well as the natural trading partner theory is used to contextualize the outcomes achieved. ${ }^{32}$ Historical legal research probes the origins and remnants of colonial trade policy. CARICOM Secretariat documentation as well as Caribbean history books are used to establish a linkage between colonial trade policy and the unaltered Caribbean economic structure. ${ }^{33}$ A correlation is established between (a) the provision of trade preferences, (b) the UK entry into the EEC as well as (c) the effects of increased globalization, and the progression of regional integration. ${ }^{34}$ WTO jurisprudence, journals and Caribbean history books are used to support this correlational analysis. ${ }^{35}$ Chapter 5 undertakes a quantitative assessment of the

\footnotetext{
${ }^{32}$ See P. Schmitter, Ernst B. Haas and the Legacy of Neofunctionalism, Journal for European Public Policy, 2005, Vol. 12(2), pp. 255-272, A. Moravcsik, F. Schinmelfennig, Liberal Intergovernmentalism in (eds.) T. Diez, A. Wiener, European Integration Theory (Oxford University Press, 2009); B. Rosamond, The Uniting of Europe and the foundation of EU Studies: Revisiting the Neofunctioalism of Ernst B. Haas, Journal for European Public Policy, 2005, Vol. 12(2), pp. 237-254; (eds.) C. Bickerton, D. Hodson, U. Puetter, The New Intergovernmentalism: States and Supranational Actors in the Post-Maastricht Era (Oxford University Press, 2015).

${ }^{33}$ See E. Wallace, The West Indies Federation: Decline and Fall, International Journal, 1962, Vol. 17 (3) pp. 269-288; K.M. Bennett, A Retrospective Look at the Role of Trade and Regional Integration in Caribbean Development, Social and Economic Studies, 1999, Vol. 48, No. 1(2), pp. 127-153, V. Bulmer-Thomas, The Economic History of the Caribbean since the Napoleonic Wars (Cambridge University Press, 2012); D. Berry, Caribbean Integration Law (Oxford University Press, 2014); H. Geiser, P. Alleyne, C. Garaj, Legal Problems of Caribbean Integration: A Study on the Legal Aspects of CARICOM (Institute of International Relations, St. Augustine, Trinidad and Tobago and A.W. Sijthoff International Publishing, Leiden, Netherlands, 1976).

${ }^{34}$ See M. Mlachila, P. Cashin, C. Haines, IMF Working Paper, Caribbean Bananas: The Macroeconomic Impact of Trade Preference Erosion (2010); D. Glickman, The British Imperial Preference System, Quarterly Journal of Economics, $1^{\text {st }}$ May 1947, p. 439-470; M. Moynagh, "The Negotiation of the Commonwealth Sugar Agreement: 1949-1951" Journal of Commonwealth and Comparative Politics, 1977, Vol. 15 (2), p.170-190; N. Piers Ludlow, Dealing with Britain: The Six and the First UK Application to the EEC (Cambridge University Press, 1997); J. Revauger, Regional Integration in the Commonwealth Caribbean and the Impact of the European Union, The Round Table, 2008, 97(399), p. 857-869.

${ }^{35}$ See GATT Panel Report, EEC-Member States' Import Regimes for Bananas, DS32/R, 3 June 1993, unadopted and GATT Panel Report, EEC-Import Regime for Bananas, DS38/R, 11 February 1994, unadopted. A. Hinds, Sterling and Decolonization in the British Empire, 1945-1958, Social and Economic Studies, 1999, Vol. 48 (4), p. 97-116; E. Rose, Dependence and Socialism in the Modern Caribbean
} 
CARICOM PTA by investigating the volume and pattern of its intra-regional trade flows. It illustrates, with data, the impact of the British Caribbean colonial paradigm on CARICOM economic production structures and highlights why the CARICOM PTA has been unable to generate significant intra-regional trade. CARICOM Statistics Unit trade data publications are used to conduct this analysis. ${ }^{36}$ WTO trade policy review reports are utilized to craft trading profiles of various CARICOM Member States and to underscore that the main trading partner of all the CARICOM PTA partners is a third country external to the PTA. ${ }^{37}$ Other economic literature underpins further explanatory research, which examines the divide between the CARICOM less developed countries (LDCs) and the CARICOM more developed countries (MDCs). ${ }^{38}$

Part 3 of the dissertation consists of chapters 6 and 7. Explanatory legal research is utilized in these chapters to illuminate the non-trade related benefits of the CARICOM PTA and advance the argument that despite the limited creation of intra-regional trade, other advantages are still derived from the PTA. Chapter 6 probes the motivation underlying the Belize policy decision to seek membership in the CARICOM PTA. ${ }^{39}$ Belize was one of the

(Lexington Books Publishing, USA, 2002); A. Payne, The Politics of the Caribbean Community: 1961 1979, Regional Integration amongst New States (Manchester University Press, 1980).

${ }^{36}$ See CARICOM's Trade: A Quick Reference to Some Summary Data, 1996 - 2001, Fourth Edition (Georgetown, Guyana, December 2005); CARICOM Statistical Unit, CARICOM's Trade: A Quick Reference to Some Summary Data, 2005 - 2010 (Georgetown, Guyana, 2013).

${ }^{37}$ See Office of the United States Trade Representative, $10^{\text {th }}$ Report to United States Congress on the Operation of the Caribbean Basin Economic Recovery Act (Washington D.C. USA, $31^{\text {st }}$ December 2013); Office of the United States Trade Representative, $11^{\text {th }}$ Report to United States Congress on the Operation of the Caribbean Basin Economic Recovery Act (Washington D.C. USA, 30 ${ }^{\text {th }}$ December 2015); WTO Secretariat, Trade Policy Review of Trinidad and Tobago 2012, Report by the Secretariat (Geneva, $1^{\text {st }}$ February 2012) [WT/TPR/S/260]; WTO Secretariat, Trade Policy Review of Barbados 2014, Report by the Secretariat (Geneva, 16 ${ }^{\text {th }}$ December 2014) [WT/TPR/6/308]; WTO Secretariat, Trade Policy Review of Barbados 2014, Report by the Secretariat (Geneva, 30 ${ }^{\text {th }}$ March 2015) [WT/TPR/6/308/Rev. 1]; WTO Secretariat, Trade Policy Review of Jamaica 2010, Report by the Secretariat (Geneva, 22 ${ }^{\text {nd }}$ February 2011) [WT/TPR/G/242/Rev.1]; WTO Secretariat, Trade Policy Review of the OECS- WTO Members, Report by the Secretariat (Geneva, $18^{\text {th }}$ September 2014) [WT/TPR/G/299/Rev.1].

${ }^{38}$ Caribbean Development Bank (CDB) annual economic reviews, Inter-American Bank (IDB) private sector assessment reports, International Monetary Fund (IMF) regional reports, sector specific development strategies for St. Kitts and Nevis and Grenada, World Bank/Organization of American States (OAS) regional reports, Caribbean Court of Justice (original jurisdiction) jurisprudence and Commonwealth Secretariat reports.

${ }^{39}$ See Ibid, M. Schiff, L. Winters, 2003; R. Baldwin, A Domino Theory of Regionalism in (eds) J. Bhagwati, P. Krishna, A. Panagariya, Trading Blocs: Alternative Approaches to Analyzing Preferential Trade Agreements (MIT Press, 1999); E. Mansfield, H. Milner, The New Wave of Regionalism, International Organization, 1999, Vol. 53 (3), pp.589-627, p. 602. 
last CARICOM Member States to attain independence and is the only CARICOM member state outside of an intra-CARICOM coalition. ${ }^{40}$ Information derived from secondary sources such as Belizean history books, Caribbean history books and journals are used to establish a causal link between (a) underlying political motivations and (b) the non-trade related benefits to be derived from the CARICOM PTA, and the decision to join the CARICOM PTA. ${ }^{41}$ Explorative legal research is undertaken to investigate whether PTA involvement has fostered greater interaction between Belize and its regional partners. ${ }^{42}$

Chapter 7 undertakes an analytical assessment of the external dimension of the CARICOM PTA and the non-trade related benefits derived therefrom. The treaties establishing the three phases of regional integration in the Caribbean are examined to gain insights into how various legal competences evolved in tandem with changes in the world economy. ${ }^{43}$ The two 'community' entities, endowed with juridical personality, are critically examined by analyzing the degree to which they have been able (a) to facilitate the expansion of relations with third states and international organizations, and (b) to further treaty making activities. $^{44}$ These aspects are benchmarked according to the volume and depth of

\footnotetext{
${ }^{40}$ All of the other LDCs are members of the OECS and the CARICOM MDCs tend have to shared interests in the wider CARICOM decision-making process.

${ }^{41}$ V. Bulmer-Thomas, The Economic History of the Caribbean since the Napoleonic Wars (Cambridge University Press, 2012); I. Griffith, The Quest for Security in the Caribbean: Problems and Promises in Subordinate States (Routledge, 2015); E. Lauterpacht, S. Schwebel, S. Rosenne, F. Orrego Vicuna, Government of Belize Legal Opinion on Guatemala's Territorial Claim to Belize (November 2001); A. Shoman, Belize's Independence and Decolonization in Latin America: Guatemala, Britain and the UN (Palgrave MacMillan 2010); A. Shoman, A History of Belize in 13 Chapters, $2^{\text {nd }}$ Edition (Angelus Press, Belize, 2011); A. Payne, A Political History of CARICOM (Ian Randle Publishers, 2008); P. Thomson, Belize: A Concise History (Macmillan Publishers Limited, 2004; R. Willard, "How to get less than you bargain for: Adjudicating the Guatemala - Belize territorial dispute at the ICJ" Emory International Law Review, 2009, Vol. 23, pp. 739 - 782; K. Wiegand, "Nationalist Discourse and Domestic Incentives to prevent settlement of the Territorial Dispute between Guatemala and Belize" Nationalism and Ethnic Politics, 2005 Vol. 11(3) pp. 349-383.

${ }^{42}$ Insights into how CARICOM membership has impacted Belize is ascertained from information received through 6 interviews, which were conducted in 2013 with persons representing public and private sector interests in Belize. This information is used to: (a) reinforce the aforementioned factor that political motives underpinned involvement in the CARICOM PTA, (b) emphasize the non-trade related benefits that were derived and (c) assert that more proactive engagement is required by Belize to capitalize on the opportunities afforded by the CARICOM PTA.

${ }^{43}$ See H. Geiser, P. Alleyne, C. Garaj, Legal Problems of Caribbean Integration: A Study on the Legal Aspects of CARICOM (Institute of International Relations, St. Augustine, Trinidad and Tobago and A.W. Sijthoff International Publishing, Leiden, Netherlands, 1976); A. Payne, A Political History of CARICOM (Ian Randle Publishers, Kingston, Jamaica, 2008).

${ }^{44}$ See K.O. Hall, B. Blake, "The Emergence of the African, Caribbean and Pacific Group of States: An Aspect of African and Caribbean International Cooperation" African Studies Review, 1979, Vol. 22(2) p. 111-125;
} 
initiatives undertaken during the respective time periods. CARICOM Secretariat communiqués and press releases are used to demonstrate the deepening and widening of the CARICOM regional integration agenda and the possible future benefits from the CARICOM PTA are speculated upon. ${ }^{45}$ Part 4 addresses the conclusions and recommendations of the dissertation. The conclusion of this dissertation reiterates that the Caribbean conception of sovereignty was linked with the pursuit of independence. With the subsequent achievement of independence, it was assumed that the post-colonial Caribbean nation state could pursue its own (economic) development path unencumbered by external powers. However, developments within the GATT/WTO framework and the legacy of colonial trade policy changed the assumed effect of sovereignty for Caribbean nation states. The changing nature of the international system has resulted in a paradigm shift for the CARICOM Member States whereby the interdependence of the regional grouping platform provided by the CARICOM PTA has gained more prominence in the conduct of their engagement with the MTS and the wider international system.

\section{Limitations}

The starting point for the examination of regional integration in the Caribbean that is utilized by this dissertation is 1958 . References are made to the years preceding 1958 in an effort to contextualize conditions, which existed in the British Caribbean territories that served to prompt the initial pursuit of regional integration. The dissertation then traces developments from this time period to 2006 when the RTC entered into force and the CARICOM Single Market (CSM) was established.

Furthermore, a historical assessment of British trade policy towards the British Caribbean territories is undertaken and the framework regarding the provision of trade preferences is outlined. In this context, the starting point of examination is the immediate aftermath of

E. Laurent, The Integrationist: Understanding International Trade - A CARICOM Perspective (Ian Randle Publishers, Kingston, Jamaica, 2007); J. Braveboy-Wagner, Small States in Global Affairs: The Foreign Policies of the Caribbean Community (CARICOM) (Palgrave MacMillan, 2008).

${ }^{45}$ See Commonwealth Caribbean/CARICOM Secretariat Communiques issued at the conclusion of the Conference of Heads of Government of the Commonwealth Caribbean/CARICOM for the years spanning 1963 to 2016. 
the First World War. Thus, this dissertation does not address $19^{\text {th }}$ Century British trade policy towards the Caribbean.

In addressing the trade creation question, which forms part of the main inquiry of this dissertation, the analysis provided is solely from a trade in goods perspective. The main reason for this revolves around the fact that the first two Caribbean PTAs only provided coverage for trade in goods. Coverage for trade in services commenced with the third Caribbean PTA and thus, much of the historical, policy and trade data analysis provided precedes this stage of Caribbean regional integration.

\section{Definitions}

Since this dissertation pertains to the Caribbean region, several historical facts assist in understanding some of the terminologies employed. Most of the present-day CARICOM Member States are former British colonies and hence, the terminology "British Caribbean territories" is extensively used in this dissertation. This terminology is also meant to refer to the Caribbean geographical region of the then British Empire and to differentiate these territories from the French, Spanish and Dutch Caribbean territories. On a related note, Haiti and Suriname are two present day CARICOM Member States that were respectively French and Dutch colonial territories. Much of the historical analysis provided in the dissertation does not pertain to these two CARICOM Member States as Suriname joined CARICOM in 1995 and Haiti joined in 2002. It is also instructive to note that since the British Caribbean territories were granted independence at different times, they held varying constitutional statuses throughout the various time periods referenced. Thus, the term "then independent Caribbean countries" is also used in certain sections of this dissertation.

With respect to the trade preferences accorded to Caribbean commodities, it is important to highlight that the bilateral trade preferences, referred to as "colonial trade preferences" or "imperial trade preferences", in the dissertation, were accorded by the UK government to its British Caribbean territories. These trade preferences differ from those accorded post1975 after the entry of the UK into the EEC. The first Lome Convention was signed in 
1975 and thereafter, the British Caribbean territories (and then independent Caribbean countries) were granted "EEC trade preferences".

Where the use of the term "CARICOM" is concerned, it should be noted that it applies post-1973 after the signing of the (original) Treaty of Chaguaramas (OTC), which created the Caribbean Community including the Caribbean Common Market. Thus, the dissertation refers to CARIFTA (1965) as the first Caribbean PTA and refers to the fact that there have been three Caribbean PTAs. The term "CARICOM PTA" can be used to refer to the second and third Caribbean PTA. 


\section{Chapter 1}

Creation: The Birth of Preferential Trade Agreements

\section{Introduction}

Chapter 1 is aimed at introducing the concept of preferential trade agreements (PTAs) and outlines how legal coverage for such agreements originated in the General Agreement on Tariffs and Trade (GATT) $1947 .{ }^{46}$ In outlining the origins of PTAs, the drafting history of both the GATT 1947 and GATT Article XXIV is examined to assert the vision of GATT drafters regarding the centrality of multilateral trade in the multilateral trading system (MTS). ${ }^{47}$ Chapter 1 also provides a foundation upon which this dissertation subsequently examines the Caribbean Community (CARICOM) PTA. The WTO legal provisions that underpin the establishment of PTAs are GATT Article XXIV and paragraph 2 (c) of the 1979 Decision on Differential and More Favorable Treatment, Reciprocity and Fuller Participation of Developing Countries (the Enabling Clause). ${ }^{48}$ Both legal provisions constitute an exception to the most favored nation (MFN) principle contained in GATT Article I, which is considered the cardinal principle of the rules-based MTS that commenced in $1948 .{ }^{49}$ Insights obtained from explanatory legal research demonstrate how the protectionist trade era of the 1930s and the Second World War informed the policy thinking on international economic relations and influenced the crafting of the GATT 1947 as well as GATT Article XXIV. ${ }^{50}$

\footnotetext{
${ }^{46}$ General Agreement on Tariffs and Trade 1947, 55 UNTS 194 (adopted $30^{\text {th }}$ October 1947, provisional application $1^{\text {st }}$ January 1948).

${ }^{47}$ A note on terminology: This dissertation employs the use of the term preferential trade agreement (PTA) as it accounts for the cross-regional nature of many trade arrangements notified under GATT Article XXIV. This stands in contrast to the term regional trade agreement (RTA), which places emphasis on trade arrangements that are regional in nature.

${ }^{48}$ See GATT Secretariat, Differential and More Favorable Treatment, Reciprocity and Fuller Participation of Developing Countries, Decision of 28 November 1979 (Geneva, 3 December 1979) [L4903].

${ }^{49}$ The rules based MTS replaced a power-based system of trade whereby political and diplomatic vagaries determined international trade relations. This paradigm was characterized by initiatives such as the British imperial preference system and the various US bilateral trade agreements. See J. Pauwelyn, The Transformation of World Trade, Michigan Law Review, 2005, Vol. 104 (1), pp. 1 - 67, p. 3.

${ }^{50}$ See M. Matsushita, T. Schoenbaum, P. Mavroidis, M. Hahn, The WTO: Law, Practice and Policy, Third Edition (Oxford University Press, 2015); J. Odell, B. Eichengreen, The United States, the ITO and the WTO: Exit Options, Agent Slack and Presidential Leadership in (ed) A. Krueger, The WTO as an International Organization (The University of Chicago Press, 1996); P. Van den Bossche, W. Zdouc, The Law and Policy of the World Trade Organization, Fourth Edition (Cambridge University Press, 2017); J. Jackson, The World Trading System: Law and Policy of International Economic Relations, Second Edition (MIT Press 1997);
} 
In asserting the centrality of the MFN principle, Chapter 1 utilizes WTO law books and journals to explore the conceptual divide between multilateral and preferential liberalization of tariffs in the regulation of international trade, which was displayed during the drafting of the GATT 1947. ${ }^{51}$ The Treaty of Rome establishing the European Economic Community (EEC) held great significance in this conceptual divide, as it employed the use of a PTA to assist in the economic reconstruction of Europe. ${ }^{52}$ The United States (US), then a committed critic of preferential trade, was heavily invested in the European integration project since it aligned with broader US policy on Europe. Therefore, the US contextualized the Treaty of Rome in political terms given the implications for the then future of Europe. ${ }^{53}$ As the third PTA to be notified at the GATT Secretariat and examined by a GATT working party, the Treaty of Rome illustrated an important attribute regarding PTAs: they are often allied with non-trade related motives. ${ }^{54}$ Chapters 6,7 and 8 of this dissertation serve to highlight some of the non-trade related benefits associated with PTAs. Further to this, the GATT working party's legal assessment of the Treaty of Rome is investigated and the design flaws encountered are noted. It is argued that the inability to substantively address these flaws contributed to the systemic impairment of the PTA discipline. The proliferation of PTAs is outlined and mention is made of its impact on the interrelationship between PTAs and the MTS. The aforementioned is important given the standstill in policy developments relating to PTAs.

(eds) J. Bhagwati, P. Krishna, A. Panagariya, Trading Blocs: Alternative Approaches to Analyzing Preferential Trade Agreements (MIT Press, 1999).

51 "The General Agreement has two grand designs: that free trade be promoted through multilateral tariff negotiation and that discrimination be eliminated by means of the most favored nation principle. For the draftsmen of the General Agreement, customs unions and free trade areas produced a conflict between those goals." K. Dam, Regional Economic Arrangements and The GATT: The Legacy of A Misconception, University of Chicago Law Review, 1963, Vol. 30 (4), p. 615-665, p. 622; J. Bhagwati, Regionalism and Multilateralism: An Overview in ibid, (eds) J. Bhagwati, P. Krishna, A. Panagariya, 1999, p. 3.

52 See Treaty Establishing the European Economic Community 1957, 298 UNTS 11 (adopted 25 ${ }^{\text {th }}$ March 1957, in force $1^{\text {st }}$ January 1958). See also GATT Secretariat, European Economic Community, Official Transmission to the GATT (Geneva, 24 ${ }^{\text {th }}$ April 1957) [L/626].

${ }^{53}$ One of the primary aims of the Treaty of Rome was to solidify the notion of peace in Europe and commit its signatories to do their utmost to prevent the reoccurrence of war on the European continent.

${ }^{54}$ F. Haight, Customs Union and Free Trade Areas under the GATT: A Reappraisal, Journal of World Trade Law, 1972, Vol. 6 (4), pp. 391-404, p. 393. 


\subsection{The Post-War Economic Environment}

The origins of PTAs were closely linked with the origins of the GATT 1947 as the dichotomy between preferential trade and multilateral trade was an early preoccupation for the drafters of the GATT $1947 .{ }^{55}$ PTAs evolved in tandem with the MTS and can be traced back to the post-war reconstruction period when the global economy was characterized by a retreat from the economic protectionism of the 1930s. The US Tariff Act of 1930 (Smooth-Hawley Act) remains a hallmark from this era of global economic history. ${ }^{56}$ The harmful effects of the Smooth-Hawley Act led the US Congress to a policy shift that resulted in the congressional approval of the 1934 Reciprocal Trade Agreements Act (RTAA) whereby MFN treatment was granted under bilateral trade agreements. ${ }^{57}$ This initiative was met with limited success, as it was largely unable to reverse the prevailing protectionist trend. ${ }^{58}$ It is important to recall that many countries had enacted high retaliatory tariffs in the aftermath of the Smooth-Hawley Act and any attempts to overturn these policies, which were underpinned by domestic legislation, proved a lengthy challenge. ${ }^{59}$ The aforementioned experience colored the view of policymakers regarding

\footnotetext{
${ }^{55}$ Article 32 of the Vienna Convention on the Law of Treaties (VCLT) addresses the issue of supplementary means of interpretation and notes that recourse may be had to the preparatory work of a treaty or the circumstances of its conclusion to confirm or determine further meaning and interpretation of a treaty. In this vein, certain aspects of the negotiating history of the GATT 1947 and the 1948 Havana Charter on an International Trade Organization are referenced.

${ }^{56}$ The Smoot-Hawley Act resulted in the increase of hundreds of US import duties and tainted US trade relations with other countries by ushering in a period of economic isolationism and retaliatory measures. It also contributed to a contraction in the volumes of global trade and its enduring influence on the global economy required decades of work and negotiations to dismantle. D. Irvin, Peddling Protectionism: SmoothHawley and The Great Depression (Princeton University Press, 2011), p. 101; B. Hoekman, M. Kostecki, The Political Economy of the World Trading System, Third Edition (Oxford University Press, 2009), p. 478; K. Bagwell, R. Staiger, The Economics of the World Trading System (MIT Press, 2002), p. 44.

${ }^{57}$ The RTAA was signed on $12^{\text {th }}$ June 1934 and authorized the negotiation of bilateral trade agreements between the US and other countries based on reciprocal tariff reductions. It also empowered the Office of the US President (as opposed to the US Congress) to negotiate and conclude these agreements. Akin to the present-day Trade Promotion Authority, the RTAA was granted on a temporary basis and was subject to renewal after 3 years. Trade agreements concluded in this manner were intended to enter into force through the use of executive agreements instead of treaties, which would ordinarily require US Senate approval. Between 1934 and 1939, 22 tariff reducing agreements were negotiated under the RTAA authority. See M. Hiscox, The Magic Bullet? The RTAA, Institutional Reform and Trade Liberalization, International Organization, 1999, 53 (4), pp. 669 - 690, p. 671; Ibid, B. Hoekman, M. Kostecki, 2009, p. 478.

58 "The RTAA, however, was met with a lot of skepticism in some quarters. The prevailing view at the time [...] was that trade protectionism protected US jobs. RTAA was thus portrayed as a mere temporary measure, and not as a permanent feature in the US legal arsenal." See P. Mavroidis, Trade in Goods, Second Edition (Oxford University Press, 2012), p. 5; See also M. Matsushita, T. Schoenbaum, P. Mavroidis, M. Hahn, The WTO: Law, Practice and Policy, Third Edition (Oxford University Press, 2015), p. 6.

${ }^{59}$ As a consequence of the RTAA, the US signed a reciprocal trade agreement with the UK in 1938; however, it achieved poor results due to the fact that the UK had already implemented the imperial preference system,
} 
the adverse effects of protectionism and resulted in a theoretical embrace for shared international economic regimes regulated by shared international institutions. ${ }^{60}$

Furthermore, the 1941 Atlantic Charter Statement that was released by the UK and the US as a joint declaration of their wartime aims reflected some of these sentiments and served to outline US President Franklin Roosevelt's vision for a post-war global environment characterized by inter alia peaceful relations among states, the abandonment of the use of force, democratically elected governments and improved trade relations. ${ }^{61}$ Similar sentiments were echoed in Article VII of the 1942 Anglo-American Mutual Aid Agreement whereby both the UK and US stated their common goal of pursuing the promotion of mutually advantageous economic relations between them and the improvement of global economic relations. ${ }^{62}$ In iterating the latter, Article VII called for 'agreed action' by both parties on the best means of attaining the establishment of domestic and international measures to improve trade, production and employment. The eventual plan would be open to the participation of other countries and focus on inter alia the elimination of all forms of discriminatory treatment in international commerce and the reduction of tariffs and other trade barriers as well as the economic objectives summarized in the Atlantic Charter Statement. $^{63}$

which skewed its trade towards the Commonwealth of Nations. See Ibid, P. Mavroidis, 2012, p. 3. See also J. Jackson, Sovereignty, The WTO and Changing Fundamentals of International Law (Cambridge University Press, 2006), p. 92; B. Ruddy, The Critical Success of the WTO: Trade Policies of the Current Economic Crisis, Journal of International Economic Law, 2010, Vol. 13(2), pp. 475-495, p. 476.

${ }^{60}$ Such thinking would set the stage for the eventual emergence of the Bretton Woods system.

${ }^{61}$ The Atlantic Charter Statement was issued on $14^{\text {th }}$ August 1941. With respect to improved relations, its fifth point called for the "fullest collaboration between all nations in the economic field, with the object of securing, for all, improved labor standards, economic advancement and social security."

${ }^{62}$ The Anglo-American Mutual Aid Agreement was signed on $28^{\text {th }}$ February 1942.

${ }^{63}$ Article 7 of the Anglo-American Mutual Aid Agreement stated "In the final determination of the benefits to be provided to the United States of America by the Government of the United Kingdom in return for aid furnished under the Act of Congress of March 11, 1941, the terms and conditions thereof shall be such as not to burden commerce between the two countries, but to promote mutually advantageous economic relations between them and the betterment of world-wide economic relations. To that end, they shall include provision for agreed action by the United States of America and the United Kingdom, open to participation by all other countries of like mind, directed to the expansion, by appropriate international and domestic measures, of production, employment, and the exchange and consumption of goods, which are the material foundations of the liberty and welfare of all peoples; to the elimination of all forms of discriminatory treatment in international commerce, and to the reduction of tariffs and other trade barriers; and in general, to the attainment of all the economic objectives set forth in the Joint Declaration made on August 121941 by the President of the United States of America and the Prime Minister of the United Kingdom. At an early convenient date, conversations shall be begun between the two governments with a view to determining, in 
Subsequently, the 1944 Bretton Woods Conference established the International Monetary Fund (IMF) and the International Bank for Reconstruction and Development (IBRD/World Bank) by drafting and adopting their Articles of Agreement. ${ }^{64}$ It is notable that the Bretton Woods Conference was guided by the belief that multilateral institutions could establish global standards for the post-war international economic system and thereby avoid a repeat of the economic failures witnessed with the Great Depression and the protectionist era of the 1930s. ${ }^{65}$ In this vein, policymakers had also noted that economic factors contributed to the rise of political radicalism in Europe and festered alongside other social ills that resulted in the Second World War. ${ }^{66}$ The notion of a shared international institution to coordinate the negotiation of multilateral tariff reductions and the administration of the MTS was agreed at the Bretton Woods Conference, however, finer details were to be tackled at a later point in time. ${ }^{67}$

\subsection{The International Trade Organization}

In the aftermath of the Second World War, the main impediment to international trade was the presence of high tariffs and thus, tariff reduction was the main form of multilateral trade liberalization sought, as trade barriers behind the border were not yet deemed a major concern. ${ }^{68}$ Attempts were made to create an international trade organization that would

\footnotetext{
the light of governing economic conditions, the best means of attaining the above-stated objectives by their own agreed action and of seeking the agreed action of other like-minded governments."

${ }^{64}$ The IMF and IBRD Articles of Agreement entered into force on $27^{\text {th }}$ December 1945. World Bank operations commenced on $25^{\text {th }}$ June 1946. The organization's initial mandate was to provided reconstruction capital for countries whose economies had been negatively affected by the Second World War. Subsequently, a redefined focus led to the mandate of providing development capital to developing countries. IMF operations commenced on $1^{\text {st }}$ March 1947. The organization was charged with maintaining exchange rate stability as well as assisting countries facing balance of payment crises by accessing special IMF drawing rights instead of resorting to trade restrictions. See M. Trebilcock, R. Howse, A. Elliason, The Regulation of International Trade, Fourth Edition, (Routeledge, 2013), p. 23.

${ }^{65}$ P. Mavroidis, Trade in Goods, Second Edition (Oxford University Press, 2012), p. 2; Y. Lee, Reclaiming Development in the World Trading System, Second Edition (Cambridge University Press, 2016), p. 7.

${ }^{66}$ See K. Kennedy, GATT 1994 in (eds) P. Macrory, A. Appleton, M. Plummer The World Trade Organization: Legal, Economic and Political Analysis, Volume II, (Springer Science and Business Media Inc, 2007), p. 91; T. Oppermann, On the Present International Economic Order: Basic Values and Shortcomings in (eds.) T. Oppermann, E. Petersmann, Reforming the International Economic Order (Dunker and Humblot, 1987), p.187.

${ }^{67}$ M. Matsushita, T. Schoenbaum, P. Mavroidis, M. Hahn, The WTO: Law, Practice and Policy, Third Edition (Oxford University Press, 2015), p. 27; L. Winters, What Can European Experience Teach Developing Countries About Integration?, The World Economy, 1997, Vol. 20 (7), p. 889-912, p. 890.

${ }^{68}$ J. Jackson, Sovereignty, The WTO and Changing Fundamentals of International Law (Cambridge University Press, 2006), p. 93.
} 
complement the existing Bretton Woods institutions. Multilateral negotiations commenced with the aim to draft an initial schedule of tariff reductions that would become known as the GATT 1947 and efforts were also undertaken to craft the International Trade Organization (ITO) Charter, which was intended to outline the permanent institutional base for the MTS. ${ }^{69}$ By 1947, the preparatory committee was able to finalize the GATT text, which was characterized by four foundational principles: generalized MFN treatment with exceptions only for longstanding preferences, no increases in existing preferences, a commitment to negotiate reductions in existing tariffs barriers and a ban on using quantitative restrictions except under exceptional conditions. $^{70}$

The ITO Charter, however, was not concluded until 1948 and this resulted in a change from the initial plan to attach the GATT text to the ITO Charter. The concern at the time was ensuring the prompt entry into force of the GATT 1947, as there was apprehension that the agreed, confidential tariff concessions could become public knowledge and influence global trade patterns. ${ }^{71}$ Consequently, it was agreed that the GATT Protocol of Provisional Application (PPA) would be signed no later than $15^{\text {th }}$ November 1947 and it eventually entered into force on $1^{\text {st }}$ January $1948 .^{72}$ This mechanism was utilized as a second-best policy option and the general intention was that the GATT 1947 would be fully (as opposed to provisionally) adopted alongside the ITO Charter. ${ }^{73}$ Later, the ITO Charter failed to enter into force as the US President Harry Truman abandoned his efforts to gain congressional

\footnotetext{
6923 countries participated in these negotiations: Australia, Belgium, Brazil, Burma (Myanmar), Canada, Ceylon (Sri Lanka), Chile, China, Cuba, Czechoslovakia, France, India, Lebanon, Luxembourg, The Netherlands, New Zealand, Norway, Pakistan, South Africa, Southern Rhodesia (Zimbabwe), Syria, United Kingdom and the United States.

${ }^{70}$ J. Odell, B. Eichengreen, The United States, the ITO and the WTO: Exit Options, Agent Slack and Presidential Leadership in (ed) A. Krueger, The WTO as an International Organization (The University of Chicago Press, 1996), p. 184-185.

71 J. Jackson, The World Trading System: Law and Policy of International Economic Relations, Second Edition (MIT Press, 1997), p. 39.

${ }^{72}$ Although the PPA became effective on $1^{\text {st }}$ January 1948, it was signed by 8 of the 23 contracting parties on $30^{\text {th }}$ October 1947: Australia, Belgium, Canada, France, Luxembourg, The Netherlands, United Kingdom and the United States. The other contracting parties subsequently signed and in order to avert any constitutional issues with parliamentary approval in certain countries, the PPA specifically provided for an existing legislation exception, whereby it was only required to be applied to the extent of inconsistency with existing legislation. P. Van den Bossche, W. Zdouc, The Law and Policy of the World Trade Organization, Fourth Edition (Cambridge University Press, 2017), p. 83.

${ }^{73}$ M. Matsushita, T. Schoenbaum, P. Mavroidis, M. Hahn, The WTO: Law, Practice and Policy, Third Edition (Oxford University Press, 2015), p. 2.
} 
approval for it. ${ }^{74}$ Given the domestic opposition, the US opted against presenting the ITO Charter for ratification. The domino effect of this led other countries to abandon ratification of the ITO Charter and the GATT 1947 continued its provisional existence for almost half a century. $^{75}$

\subsubsection{Drafting of the GATT Trading Concepts}

The draft text of the GATT 1947 was closely linked with a 1946 US State Department policy document entitled the Suggested Charter for an International Trade Organization of the United Nations (Suggested Charter). ${ }^{76}$ These negotiations were infused with an economic policy thinking centered on the MFN principle and the reverence accorded thereto was rooted in the notion that freer trade would be mutually advantageous for economic and security reasons in the long term. ${ }^{77}$ In this vein, a linkage has also been established between discriminatory trade policies and the deterioration of political and economic relations between countries. ${ }^{78}$ Further to this, it was noted that consideration for developing countries was lacking and a uniform policy approach to all trading partners was employed. ${ }^{79}$ Draft Article 1 of the Suggested Charter proposed an unconditional adherence to the MFN principle, which reflected the US view that non-discrimination should be the

\footnotetext{
${ }^{74}$ J. Jackson, Sovereignty, The WTO and Changing Fundamentals of International Law (Cambridge University Press, 2006), p. 94.

75 "While the GATT was directly based on a chapter of the ITO Charter concerned with tariff cuts, its implementation did not require new authorization in US Law. Presidents could implement tariff cuts under the authority of the RTAA (and similar subsequent legislation.) The GATT, although designed to be part of the charter, was thus available as an alternative to the ITO as a whole.” J. Odell, B. Eichengreen, The United States, the ITO and the WTO: Exit Options, Agent Slack and Presidential Leadership in (ed) A. Krueger, The WTO as an International Organization (The University of Chicago Press, 1996), p. 186.

${ }^{76}$ R. Hudec, Developing Countries in the GATT Legal System (Cambridge University Press, 2011), p. 28; K. Chase, Multilateralism Compromised: The Mysterious Origins of GATT XXIV, World Trade Review, 2006, Vol. 5 (1), p. 1-30, p. 4; Y. Devuyst, GATT Customs Union Provisions and the Uruguay Round: The European Community Experience, Journal of World Trade, 1992, Vol. 26(1), p. 15-34, p. 18.

${ }^{77}$ The then US Secretary of State, Cordel Hull, was a known champion of free trade and a proponent of the Wilsonian view that free trade promoted peace and prosperity. B. Hoekman, M. Kostecki, The Political Economy of the World Trading System, Third Edition (Oxford University Press, 2009), p. 27; T. Zeiler, Free Trade, Free World: The Advent of the GATT (University of North Carolina Press, 1999), p. 7.

${ }^{78}$ See P. Van den Bossche, W. Zdouc, The Law and Policy of the World Trade Organization, Fourth Edition (Cambridge University Press, 2017), p. 24.

${ }^{79}$ GATT 1947 did not recognize the special needs of developing countries despite the fact that 11 of the 23 original contracting parties were developing countries: Brazil, Burma (Myanmar), Ceylon (Sri Lanka), Chile, Cuba, China, India, Lebanon, Pakistan, Southern Rhodesia (Zimbabwe) and Syria. See B. Hoekman, M. Kostecki, The Political Economy of the World Trading System, Third Edition (Oxford University Press, 2009), p. 536; R. Hudec, Developing Countries in the GATT Legal System (Cambridge University Press, 2011), p. 28.
} 
foundational principle of the MTS. ${ }^{80}$ Given the lessons learnt from the protectionist era of the 1930s, the US favored multilateral rules-based trade and rejected the concept of preferential trade. At the time, this was most successfully embodied in the British imperial preference system. ${ }^{81}$ The US made overtures for the reversal of this preference system during the Second World War as US President Franklin Roosevelt and other US political actors referenced the incompatible nature of a preferential approach to trade policy with multilateralism on several occasions. ${ }^{82}$ Such was the US preoccupation with the British imperial preference system that it was even suggested that the United Kingdom (UK) dismantle it as compensation for US assistance given through the Lend Lease program. ${ }^{83}$

Nevertheless, the UK did its utmost to preserve the British imperial preference system due to the central economic role it played by providing foreign markets for UK exports. ${ }^{84}$ The accommodation of the UK interest is reflected in GATT Article I: 2 (a), which provides a limited exception for preferences between two or more territories listed in Annex A of the GATT $1947 .{ }^{85}$ Even though the battle over the principles underpinning preferential trade

\footnotetext{
80 "Examination of the pre-GATT history suggests the US drive to gain international acceptance for the unconditional MFN principle was based in large part on US suspicion of discriminatory trading blocs, such as the Commonwealth System of trade preferences." R. Herzstein, J. Whitlock, Regulating Regional Trade Agreements - A Legal Analysis in (eds) P. Macrory, A. Appleton, M. Plummer The World Trade Organization: Legal, Economic and Political Analysis, Volume II, (Springer Science and Business Media Inc, 2007), p. 221; M. Trebilcock, R. Howse, A. Elliason, The Regulation of International Trade, Fourth Edition, (Routeledge, 2013), p. 56.

${ }^{81}$ The Sterling Area was informally established as a trading bloc in 1931 after the UK abandoned the Gold Standard. Members of the British Empire agreed to peg their currencies to the Pound Sterling and held their official external reserves largely in Sterling assets. Lower tariffs were enacted on goods produced within the British Empire whilst goods produced outside of the British Empire were levied with a higher tariff. See A. Hinds, Sterling and Decolonization in the British Empire, 1945 - 1958, Social and Economic Studies, 1999, Vol. 48 (4), pp. 97-116, p. 97.

${ }^{82}$ K. Burk, American Foreign Economic Policy and Lend Lease in (eds) A. Lane, H. Temperly, The Rise and Fall of The Grand Alliance 1941-1945 (Macmillan Press, 1995), p. 46.

${ }^{83}$ Ibid, K. Burk, 1995, p. 54.

${ }^{84}$ During these post-war negotiations, the UK was skeptical about the principle of non-discrimination embodied in the MFN clause. It also favored the imperial preference system because it provided a measure of protection for its overseas colonies and dominions. J. Bhagwati, Termites in the Trading System: How Preferential Agreements Undermine Free Trade (Oxford University Press, 2008), p. 2; R. Hudec, Developing Countries in the GATT Legal System (Cambridge University Press, 2011), p. 29.

85 "The British had established an extensive set of imperial preferences starting with the Ottawa Conference in 1932. Trade with the Commonwealth and Empire accounted for nearly half of the United Kingdom's merchandise trade in the second half of the forties. If Britain failed to obtain acceptable terms in the ITO negotiations, it could credibly threaten to walk away and fall back on trade with the Commonwealth. The British, dead set against liberalization, obtained a GATT clause that grandfathered pre-World War II preferences allowing Britain to hold out against their removal." J. Odell, B. Eichengreen, The United States,
} 
was played out between the US and the UK, other countries were able to benefit from the hard won textual accommodation secured by the UK. GATT Article I: 2 (b) permitted France, Belgium and The Netherlands to retain a similar preferential arrangement with their dependent territories and colonies. ${ }^{86}$

\subsubsection{Permitted Preferences}

Despite the US aversion to preferential trade, another legal exception to the nondiscrimination principle was allowed in the Suggested Charter and this provision was specific to newly established PTAs. Draft Article 33 of the Suggested Charter allowed for the formation of customs territories under strict circumstances and was able to survive several revised drafts of the Suggested Charter. ${ }^{87}$ It was eventually renamed Draft Article 42 and made reference to customs unions and free trade areas (FTAs) as well as interim agreements leading to their formation. This legal provision would become known as GATT Article XXIV. It is useful to articulate the policy rationale underpinning the legal exceptions that permitted preferential trade. With respect to the inclusion of GATT Article I: 2 (b), which grandfathered rights pertaining to existing preferential trade arrangements, it should be noted that the drafting of the GATT 1947 occurred alongside the penultimate stage of colonialism and despite its imminent end, European powers had received crucial assistance from colonial manpower during the Second World War. Thus, a sense of paternalism towards colonial and dependent territories remained and most importantly, these territories represented export markets for the imperial metropoles. ${ }^{88}$ It has also been argued that the drafters of the GATT had to be mindful of negotiating countries that were already members of existing customs unions. ${ }^{89}$ Although the GATT 1947 crafted the

the ITO and the WTO: Exit Options, Agent Slack and Presidential Leadership in (ed) A. Krueger, The WTO
as an International Organization (The University of Chicago Press, 1996), p. 193.
${ }^{86}$ The then dependent territories and colonies of France, Belgium and The Netherlands are listed in Annex
B and Annex C of GATT Article I.
${ }^{87}$ K. Chase, Multilateralism Compromised: The Mysterious Origins of GATT XXIV, World Trade Review,
2006 , Vol. 5 (1), pp. 1-30, p. 4 .
${ }^{88}$ The compromise to permit the continuation of preferential trade aided in reinforcing existing colonial
(economic) ties between the European powers and their extended network of colonies around the world. See
R. Hudec, Developing Countries in the GATT Legal System (Cambridge University Press, 2011), p. 29; M.
Schiff, L. Winters, Regional Integration and Development (World Bank/Oxford University Press, 2003), p.
5 .
${ }^{89}$ Syria and Lebanon were members of the Lebano- Syrian Customs Union, which was established around
1944 . Legal accommodation for this is reflected in the final text of GATT Article I: 2(d). Belgium, The 
concept of PTAs in the form of FTAs and customs union, the concept of customs unions predated the GATT $1947 . .^{90}$

On the issue of GATT Article XXIV, which represented a compromise allowing for the establishment of new PTAs, it was argued that the legal provision would provide a framework to enable the post-war reconstruction of Europe. ${ }^{91}$ It has been submitted that the US accepted the flexibility granted in the legal provision for new PTAs because it yielded to the view that deeper European integration might occur with the establishment of a European PTA. ${ }^{92}$ Unbeknownst to wider audiences, the US had negotiated an FTA with Canada and it was imperative for the US that the global trade rules legally accommodate the concept of an FTA. ${ }^{93}$ The US-Canada FTA was never signed or approved, but the negotiated GATT legal provision covering customs unions and FTAs remained and formed the basis upon which GATT Article XXIV was shaped. ${ }^{94}$

In addition to GATT Article XXIV, paragraph 2 (c) of the 1979 Enabling Clause provides a legal basis for the formation of PTAs and reflects efforts to cultivate inclusiveness within

Netherlands and Luxembourg were members of the Benelux Economic Union, which was created on $5^{\text {th }}$ September 1944 with the signing of the London Customs Convention. The London Customs Convention was ratified in 1947 and entered into force in 1948. Legal accommodation for the Benelux Economic Union is reflected in the final text of GATT Article I: 2(b). See O. Cattaneo, The Political Economy of PTAs in (eds.) S. Lester, B. Mercurio, L. Bartels, Bilateral and Regional Trade Agreements: Commentary and Analysis, Second Edition (Cambridge University Press, 2015), p. 31; A. Krueger, Are PTAs Trade-liberalizing or Protectionist?, Journal of Economic Perspectives, 1999, Vol. 13(4), pp. 105-124, p. 106.

${ }^{90}$ See L. Winters, What Can European Experience Teach Developing Countries About Integration?, The World Economy, 1997, Vol. 20 (7), pp. 889-912, p. 890.

91 “[...] After Secretary of State George C. Marshall's famous "Marshall Plan" speech on 5 June 1947, the unification of Western Europe became one of Washington's central foreign policy goals. As a result, banning customs unions became inconceivable since they were regarded as an adequate means to obtain European integration." Y. Devuyst, GATT Customs Union Provisions and the Uruguay Round: The European Community Experience, Journal of World Trade, 1992, Vol. 26(1), pp. 15-34, p. 19; F. Haight, Customs Union and Free Trade Areas under the GATT: A Reappraisal, Journal of World Trade Law, 1972, Vol. 6 (4), pp. 391-404, p. 392.

92 A. Porges, Guide to GATT Law and Practice: Analytical Index, $6^{\text {th }}$ Edition, (World Trade Organization, Geneva, 1995), p. 825.

${ }^{93}$ K. Chase, Multilateralism Compromised: The Mysterious Origins of GATT XXIV, World Trade Review, 2006, Vol. 5 (1), pp. 1-30, p. 12; A. Krueger, Are PTAs Trade-liberalizing or Protectionist?, Journal of Economic Perspectives, 1999, Vol. 13(4), pp. 105-124, p. 106.

94 "In March 1948, the two nations concluded a secret draft protocol eliminating most tariffs and quotas bilaterally, but this was ultimately rejected by the Canadians." See R. Baldwin, The Causes of Regionalism, The World Economy, 1997, Vol. 20 (7), pp. 865-888, p. 869; M. Smith, The Free Trade Agreement in Context: A Canadian Perspective in (eds) J. Schott, M. Smith, The Canada-United States Free Trade Agreement: The Global Impact (Institute for International Economics, 1988), p. 39. 
the MTS as the concerns of developing countries were often overlooked during the early GATT years. Since the Enabling Clause debuted 32 years after the GATT 1947, only a cursory mention of its impact on the PTA landscape is made in Chapter 1. The legal provision is thoroughly addressed in Chapter 2 of this dissertation. As noted earlier, the GATT 1947 was drafted during a period of world history when European imperialism was drawing to a close, but many developing countries were still colonies of the European imperial powers. ${ }^{95}$ The textual accommodation displayed in the GATT 1947 is a possible reflection of the prevailing thinking at the time and might explain why the developing country perspective was not considered. The protracted exchange between the US and the UK over the British imperial preference system, suggests an acknowledgment of the impact of colonialism on global trade and the trading interests of the European imperial powers.

\subsection{The Treaty of Rome Establishing the European Economic Community}

One of the principal aims of Chapter 1 is to outline the development of PTAs alongside that of the MTS. From 1947 to 1956, GATT Article XXIV was minimally used as only two PTAs were notified using the legal provision. ${ }^{96}$ The Treaty of Rome Establishing the European Economic Community (1957) was the third PTA to be notified under GATT Article XXIV in 1958. The coverage of the Treaty of Rome included the freedom of movement of the four factors of economic production as well as other GATT agenda issues. ${ }^{97}$ Despite being recognized in GATT parlance as a PTA, the Treaty of Rome was

\footnotetext{
${ }^{95}$ The drafting history of GATT Article XXIV: 1 concedes to this fact as the wording was changed from "customs territories of the members" to "metropolitan customs territories of the members and to any other customs territories in respect of which this charter has been accepted..." in order to avoid the impression that the customs territories of colonies constituted part of the customs territory of the metropolitan state. See A. Porges, Guide to GATT Law and Practice: Analytical Index $6^{\text {th }}$ Edition, (World Trade Organization, Geneva, 1995), p. 795.

${ }^{96}$ The South Africa-Southern Rhodesia Agreement was notified as an interim agreement for the formation of customs union and was signed on $6^{\text {th }}$ December 1948. It entered into force on $1^{\text {st }}$ April 1949. See GATT Secretariat, Report of Working Party 4 on South Africa - Southern Rhodesia Customs Union (Geneva, $14^{\text {th }}$ May 1949) [GATT/CP.3/24]. The El Salvador-Nicaragua Agreement was notified under GATT Article XXIV as a Free Trade Area and was signed on $9^{\text {th }}$ March 1951. It entered into force on $21^{\text {st }}$ August 1951. See GATT Secretariat, Item 23: Nicaragua - El Salvador Free Trade Area, Note by the Executive Secretary (Geneva, 22 ${ }^{\text {nd }}$ October 1951) [GATT/CP.6/24/Add 1]. It is asserted that the minimal use of GATT Article XXIV was in keeping with the original vision of how the MTS was meant to function. The general intention was that global trade would be regulated on an MFN basis and historical records note that the drafters of the GATT 1947 did not envision the extensive use of GATT Article XXIV. See Ibid, A. Porges, 1995, p. 858.

${ }^{97}$ L. Winters, What Can European Experience Teach Developing Countries About Integration?, The World Economy, 1997, Vol. 20 (7), pp. 889-912, p. 892.
} 
also a political project aimed at reconstructing Europe. Its preamble referred to a determination "to lay the foundation of an ever closer union among the peoples of Europe", which emphasized its socio-political importance. Thus, the Treaty of Rome was aimed at utilizing the understandings of common market policies to eliminate divisions and avert the reoccurrence of war on the European continent. It is submitted that these political considerations played a crucial role in how the legal compatibility of the Treaty of Rome with GATT Article XXIV was contextualized by the US. ${ }^{98}$

The GATT legal compatibility examination of the Treaty of Rome represented a test case for the interrelationship of the non-discrimination principle, which underpinned multilateral trade, and that of selective discrimination, which underpinned preferential trade. Many observers considered the Treaty of Rome to be an emblematic representation of the disregard that could be given to the well-touted mantra of multilateralism and its inconclusive passage through the GATT legal compatibility examination signaled that trade liberalization would be permitted to occur in Europe (initially) on a preferential basis instead of a multilateral basis. ${ }^{99}$ The ensuing debate over the interpretational difficulties that emerged from the legal examination of the Treaty of Rome exposed the design flaws of GATT Article XXIV and had serious implications on the interpretation of GATT Article XXIV for over half a century. ${ }^{100}$

\footnotetext{
98 “[...] The United States, long suspicious of discriminatory trade arrangements, restrained itself from resorting to [GATT] Article XXIV. The formation of the European Community in 1958 marked a partial watershed. The United States put its shoulder to the wheel and saw the Common Market through, negotiating around the different hoops of Article XXIV, emasculating the Article somewhat so as to seek GATT approval of an imperfect union (especially in regard to discriminatory preferences for the eighteen ex-colonies in Africa that the Europeans insisted on retaining, requiring therefore a waiver of GATT rules), all in the cause of what it saw as a politically beneficial union of the original six nations that formed the Community." J. Bhagwati, P. Krishna, A. Panagariya, Regionalism and Multilateralism: An Overview in (eds) J. Bhagwati, P. Krishna, A. Panagariya, Trading Blocs: Alternative Approaches to Analyzing Preferential Trade Agreements (MIT Press, 1999), p. 9.

${ }^{99}$ R. Fiorentino, J. Crawford, C. Toqueboeuf, The Landscape of Regional Trade Agreements in (eds) R. Baldwin, P. Low, Multilateralizing Regionalism: Challenges for the Global Trading System (Cambridge University Press, 2008), p. 55; Ibid, J. Bhagwati in (eds) J. Bhagwati, P. Krishna, A. Panagariya, 1999, p. 9; F. Haight, Customs Union and Free Trade Areas under the GATT: A Reappraisal, Journal of World Trade Law, 1972, Vol. 6 (4), pp. 391-404, p. 398.

100 "If a single adjective were to be chosen to describe Article XXIV, that adjective would be "deceptive". First, the standards established are deceptively concrete and precise; any attempt to apply the standards to a specific situation reveals ambiguities, which [...] go to the heart of the matter. Second, while the rule appears to be carefully conceived, the principles enunciated make little economic sense." K. Dam, Regional
} 


\subsection{The Treaty of Rome: Areas of Disagreement}

The legal assessment of the Treaty of Rome resulted in several unresolved issues of concern. ${ }^{101}$ Many of these concerns pertained to inter alia the implementation of the proposed common agricultural policy (CAP), the proposed association with overseas territories and the textual interpretation of GATT Article XXIV. It is worth noting that the textual ambiguities highlighted in 1958 still remain, as many issues are still unclear to date. In order to undertake the legal assessment, the GATT Contracting Parties established a committee on the Treaty of Rome. Subsequently, four Subgroups were established to analyze different aspects of the Treaty of Rome: (i) tariffs, plan and schedule, (ii) quantitative restrictions (QRs), (iii) trade in agricultural goods and (iv) association with overseas territories. None of these Subgroups were able to produce any conclusive findings for various reasons and many of the unresolved issues are now considered as part of the systemic concerns associated with GATT Article XXIV. ${ }^{102}$ These issues have arisen in subsequent GATT or World Trade Organization (WTO) working party legal compatibility examinations for other PTAs.

\subsubsection{Subgroup A: Tariffs, Plan and Schedule ${ }^{103}$}

Subgroup A encountered interpretational difficulties regarding the relationship between GATT Article XXIV:4 and GATT Article XXIV:5 to 9. It is noted that the relationship between these subsections of GATT Article XXIV is still considered a systemic issue. ${ }^{104}$

Economic Arrangements and The GATT: The Legacy of A Misconception, University of Chicago Law Review, 1963, Vol. 30 (4), pp. 615-665, p. 619.

101 "The contracting parties first dealt with the EEC Treaty at the GATT's eleventh Session in late 1956, when the Community was still in the negotiating stages. Between the eleventh and twelfth Sessions, an intersessional committee was appointed by the contracting parties to meet at Geneva with the express purpose of exploring the European Economic Community Agreement. As a result of the preparatory work completed at this conference, the contracting parties launched into a full scale discussion of legal compatibility at the GATT's twelfth Session.” J. Allen, The European Common Market and the GATT: A Study in Compatibility, Law and Contemporary Problems, 1961, Vol. 26 (3), pp. 559 - 571, p. 561.

${ }^{102}$ See GATT Secretariat, Treaty Establishing The European Economic Community, Report Submitted by the Committee on the Rome Treaty to the Contracting Parties on 29 November 1957 (Geneva, 20 ${ }^{\text {th }}$ December 1957) [L/778] p. 1.

${ }^{103}$ Subgroup A on Plan and Schedule and Tariffs was chaired by Austria. The other members of Subgroup A were: Canada, Chile, Cuba, Czechoslovakia, India, Japan, Norway, Sweden, United Kingdom and the United States. Subgroup A also included two of the six EEC Member States. See GATT Secretariat, Committee on the Treaty of Rome, Sub-Groups appointed on 7 November 1957 (Geneva, 9 ${ }^{\text {th }}$ November 1957) [W.12/21] p. 2.

${ }^{104}$ See WTO Secretariat, Synopsis of "Systemic" Issues related to Regional Trade Agreements (Geneva, $2^{\text {nd }}$ March 2000) [WT/REG/W/37], p. 15, para. 34. 
The EEC view was that these provisions were to be interpreted interdependently due to the usage of the word "accordingly" in GATT Article XXIV:5, which states:

"Accordingly, the provisions of this Agreement shall not prevent, as between the territories of contracting parties, the formation of a customs union or of a free-trade area or the adoption of an interim agreement necessary for the formation of a customs union or of a free-trade area; Provided that:

(a) with respect to a customs union, or an interim agreement leading to a formation of a customs union, the duties and other regulations of commerce imposed at the institution of any such union or interim agreement in respect of trade with contracting parties not parties to such union or agreement shall not on the whole be higher or more restrictive than the general incidence of the duties and regulations of commerce applicable in the constituent territories prior to the formation of such union or the adoption of such interim agreement, as the case may be;

(b) with respect to a free-trade area, or an interim agreement leading to the formation of a free-trade area, the duties and other regulations of commerce maintained in each of the constituent territories and applicable at the formation of such free-trade area or the adoption of such interim agreement to the trade of contracting parties not included in such area or not parties to such agreement shall not be higher or more restrictive than the corresponding duties and other regulations of commerce existing in the same constituent territories prior to the formation of the free-trade area, or interim agreement as the case may be; and

(c) any interim agreement referred to in subparagraphs (a) and (b) shall include a plan and schedule for the formation of such a customs union or of such a free-trade area within a reasonable length of time.". 105

\footnotetext{
${ }^{105}$ See GATT Secretariat, Treaty Establishing The European Economic Community, Report Submitted by the Committee on the Rome Treaty to the Contracting Parties on 29 November 1957 (Geneva, $20^{\text {th }}$ December 1957) [L/778], p. 3, para. 2.
} 
As a consequence of this, the EEC argued that so long as a customs union satisfied the requirements of GATT Article XXIV:5 to 9, it would automatically satisfy the requirements of GATT Article XXIV:4. It should be noted that GATT Article XXIV: 8 states:

For the purposes of this Agreement:

(a) A customs union shall be understood to mean the substitution of a single customs territory for two or more customs territories, so that

(i) duties and other restrictive regulations of commerce (except, where necessary, those permitted under Articles XI, XII, XIII, XIV, XV and XX) are eliminated with respect to substantially all the trade between the constituent territories of the union or at least with respect to substantially all the trade in products originating in such territories, and,

(ii) subject to the provisions of paragraph 9, substantially the same duties and other regulations of commerce are applied by each of the members of the union to the trade of territories not included in the union;

(b) A free-trade area shall be understood to mean a group of two or more customs territories in which the duties and other restrictive regulations of commerce (except, where necessary, those permitted under Articles XI, XII, XIII, XIV, XV and XX) are eliminated on substantially all the trade between the constituent territories in products originating in such territories.

And, GATT Article XXIV: 9 states:

The preferences referred to in paragraph 2 of Article I shall not be affected by the formation of a customs union or of a free-trade area but may be eliminated or adjusted by means of negotiations with contracting parties affected. This procedure of negotiations with affected contracting parties shall, in particular, apply to the elimination of preferences required to conform with the provisions of paragraph $8(a)(i)$ and paragraph 8 (b). 
Some members of Subgroup A maintained a different interpretation of these provisions noting that they were not interdependent. ${ }^{106}$ They was argued that GATT Article XXIV: 4 established basic GATT principles regarding trade creation as well as the avoidance of trade diversion and these principles were viewed as being applicable to all PTAs notified under the legal provision. ${ }^{107}$ GATT Article XXIV:4 states:

"The contracting parties recognize the desirability of increasing freedom of trade by the development, through voluntary agreements, of closer integration between the economies of the countries parties to such agreements. They also recognize that the purpose of a customs union or of a free-trade area should be to facilitate trade between the constituent territories and not to raise barriers to the trade of other contracting parties with such territories."

The EEC common external tariff (CET), whereby the same external duties were to be applied to third countries, was another source of contention. ${ }^{108}$ Since the rates of duty to be applied were as yet unknown, it was difficult to determine the consistency of the CET with GATT Article XXIV:5(a), which requires that the duties and other regulations of commerce imposed shall not on the whole be higher or more restrictive than the general incidence of those applicable prior to the formation of the PTA. ${ }^{109}$ The overall concern was that the EEC application of the CET on $1^{\text {st }}$ January 1958 as a simple, un-weighted arithmetic average of tariffs could possibly lead to tariff increases for many imports

\footnotetext{
${ }^{106}$ See Ibid, GATT Secretariat, 1957, p. 3, para. 2.

${ }^{107}$ See Ibid, GATT Secretariat, 1957, p. 4, para. 3.

${ }^{108}$ The EEC CET is provided for under Article 18 of the Treaty of Rome, which states "Member States hereby declare their willingness to contribute to the development of international commerce and the reduction of barriers to trade by entering into reciprocal and mutually advantageous arrangements directed to the reduction of customs duties below the general level which they could claim as a result of the establishment of a customs union between themselves."

Furthermore, Article 19(1) of the Treaty of Rome addresses the formulation of the CET and states "Under the conditions and within the limits laid down below, the duties under the common customs tariff shall be at the level of the arithmetical average of the duties applied in the four customs territories covered by the Community".

109 " [...] Contracting Parties were not in a position to judge the consistency of the EEC external tariff with the General Agreement, because the common level of duties had not yet been published." J. Allen, The European Common Market and the GATT: A Study in Compatibility, Law and Contemporary Problems, 1961, Vol. 26 (3), pp. $559-571$, p. 561.
} 
destined for the European common market. ${ }^{110}$ Due to the lack of clarity on this issue as well as others, Subgroup A was unable to arrive at a solid conclusion on the issues within its remit.

\subsubsection{Subgroup B: Quantitative Restrictions (QRs) ${ }^{111}$}

One of the main concerns for Subgroup B was the permitted use of QRs under the Treaty of Rome especially in circumstances not justified by the balance of payment position of a given EEC Member State. It was admitted that this would no longer merit concern once the EEC Member States held foreign exchange reserves in common. ${ }^{112}$ The EEC emphasized its view of GATT Article XXIV:5 and outlined that it understood the provision to mean that it was allowed to deviate from other GATT provisions if these provisions presented an obstacle to the formation of the customs union. ${ }^{113}$ The EEC further explained that the elimination of QRs was understood to only be required in an intra-customs union context and not with third countries. Definitional issues also arose regarding the actual meaning of "substantially the same duties and other regulations of commerce" and "other regulations of commerce" as outlined in GATT Article XXIV:8(a)(ii). ${ }^{114}$ It was also unclear whether this wording was meant to include QRs. ${ }^{115}$

As far as the EEC was concerned, GATT Article XXIV:5(a) defined the scope of the common regulations of commerce by stating that they must not on the whole be more restrictive than those applicable prior to the formation of the customs union and implicitly

\footnotetext{
${ }^{110}$ See GATT Secretariat, Treaty Establishing The European Economic Community, Report Submitted by the Committee on the Rome Treaty to the Contracting Parties on 29 November 1957 (Geneva, $20^{\text {th }}$ December 1957) [L/778], p. 4, para. 6.

${ }^{111}$ The chair of Subgroup B on QRs was Cuba. The other members of Subgroup B were: Australia, Brazil, Burma, Canada, Japan, Peru, United Kingdom and the United States. Subgroup B also included two of the six EEC Member States. See GATT Secretariat, Committee on the Treaty of Rome, Sub-Groups appointed on 7 November 1957 (Geneva, $9^{\text {th }}$ November 1957) [W.12/21], p. 2.

${ }^{112}$ See GATT Secretariat, Treaty Establishing The European Economic Community, Report Submitted by the Committee on the Rome Treaty to the Contracting Parties on 29 November 1957 (Geneva, $20^{\text {th }}$ December 1957) [L/778], p. 9, para. 2.

${ }^{113}$ See Ibid, GATT Secretariat, 1957, p. 9, para. 3.

${ }^{114}$ The ambiguity associated with the definition of these terms is still considered a systemic issue regarding GATT Article XXIV. See WTO Secretariat, Synopsis of "Systemic" Issues related to Regional Trade Agreements (Geneva, $2^{\text {nd }}$ March 2000) [WT/REG/W/37], p. 17, para. 46.

${ }^{115}$ See GATT Secretariat, Treaty Establishing The European Economic Community, Report Submitted by the Committee on the Rome Treaty to the Contracting Parties on 29 November 1957 (Geneva, $20^{\text {th }}$ December 1957) [L/778], p. 9, para. 3.
} 
provides the customs union members with the right to apply restrictive measures other than those which they would have applied had the customs union not been established. ${ }^{116}$ The CET was adopted pursuant to GATT Article XXIV:8(a)(ii) and consequently, the EEC considered quantitative import restrictions to be permissible. ${ }^{117}$ Most of the members of Subgroup B disagreed with this view ${ }^{118}$ and interpreted the GATT 1947 to mean that countries entering a customs union would continue to be bound by GATT Article XI and other legal provisions, which provide certain exceptions to the use of QRs. ${ }^{119}$ Due to a difference of opinions on this matter, and others, Subgroup B was also unable to reach a conclusive determination on issues within its remit.

\subsubsection{Subgroup C: Trade in Agricultural Products ${ }^{120}$}

Many members of Subgroup $C$ were concerned about the manner in which the EEC agricultural plan would unfold due to inter alia the lack of a precise plan outlining how the agricultural provisions would apply to the trade of third countries, how the intracommunity removal of barriers to trade would operate and the amount of discretion that would be given to the EEC common institution (The European Commission). ${ }^{121}$ The details provided regarding these matters were vague and lacking; thus, members of Subgroup C were unable to form conclusions about them. It was also stated that the transitional nature of some of the arrangements failed to provide a clear overview of how the overall policy on the regulation of agriculture would operate. The EEC stated that the GATT 1947 provisions did not preclude contracting parties from joining common institutions and

\footnotetext{
${ }^{116}$ See Ibid, GATT Secretariat, 1957, p. 10, para. 3.

${ }^{117}$ See Ibid, GATT Secretariat, 1957, p. 10, para. 3.

118 This matter is still considered a systemic issue regarding GATT Article XXIV. See WTO Secretariat, Synopsis of "Systemic" Issues related to Regional Trade Agreements (Geneva, $2^{\text {nd }}$ March 2000) [WT/REG/W/37], p. 17, para. 38.

${ }^{119}$ See GATT Secretariat, Treaty Establishing The European Economic Community, Report Submitted by the Committee on the Rome Treaty to the Contracting Parties on 29 November 1957 (Geneva, $20^{\text {th }}$ December 1957) [L/778], p. 10, para. 4.

${ }^{120}$ The chairman of Subgroup C on Trade in Agricultural Products was Pakistan. The other members of Subgroup C were: Australia, Cuba, Denmark, Indonesia, New Zealand, South Africa, Turkey, United Kingdom, United States and Uruguay. Subgroup C also included two of the six EEC Member States. See GATT Secretariat, Committee on the Treaty of Rome, Sub-Groups appointed on 7 November 1957 (Geneva, $9^{\text {th }}$ November 1957) [W.12/21], p. 2.

${ }^{121}$ See GATT Secretariat, Treaty Establishing the European Economic Community, Report Submitted by the Committee on the Rome Treaty to the Contracting Parties on 29 November 1957 (Geneva, $20^{\text {th }}$ December 1957) [L/778], p. 19, para. 14.
} 
interventions against such an intention could only be made if the implementing measure was contrary to the GATT 1947. As far as the EEC was concerned, the legal provisions relating to agriculture were in accordance with GATT Article XXIV. ${ }^{122}$ Some members of Subgroup $C$ highlighted that even though the EEC position considered the agriculture provisions to be consistent with GATT Article XXIV, this did not mean that the EEC was at the liberty to construct their agriculture policy irrespective of the international commitments of Member States as outlined in Article $234^{123}$ of the Treaty of Rome. ${ }^{124}$

Some members of Subgroup C advised that a regular and appropriate mechanism should be established to track the unfolding of the overall EEC agricultural policy. ${ }^{125}$ The EEC countered this suggestion by stating that it was an unwarranted approach for them to be required to supply information on agriculture measures, as there was no specific legal commitment to this effect. Further, the EEC considered Article $229^{126}$ of the Treaty of Rome to be a sufficient basis for any liaison that might be necessary. ${ }^{127}$ It was noted that many important questions still remained unresolved and Subgroup $\mathrm{C}$ was unable to determine whether the agriculture provisions or the implementation thereof would be

\footnotetext{
${ }^{122}$ See Ibid, GATT Secretariat, 1957, p. 14, para. 2.

${ }^{123}$ Article 234 of the Treaty of Rome states that "The rights and obligations resulting from conventions concluded prior to the entry into force of this Treaty between one or more Member States, on the one hand, and one or more third countries, on the other hand, shall not be affected by the provisions of this Treaty.

In so far as such conventions are not compatible with this Treaty, the Member State or States concerned shall take all appropriate steps to eliminate any incompatibility found to exist. Member States shall, if necessary, assist each other in order to achieve this purpose and shall, where appropriate, adopt a common attitude.
}

Member States shall, in the application of the conventions referred to in the first paragraph, take due account of the fact that the advantages granted under this Treaty by each Member State form an integral part of the establishment of the Community and are therefore inseparably linked with the creation of common institutions, the conferring of competences upon such institutions and the granting of the same advantages by all other Member States."

${ }^{124}$ See GATT Secretariat, Treaty Establishing The European Economic Community, Report Submitted by the Committee on the Rome Treaty to the Contracting Parties on 29 November 1957 (Geneva, 20 ${ }^{\text {th }}$ December 1957) [L/778], p. 14, para. 2.

125 See Ibid, GATT Secretariat, 1957, p. 17, para. 8.

126 Article 229 of the Treaty of Rome states that "The Commission shall be responsible for ensuring all suitable contacts with the organs of the United Nations, of their Specialized Agencies and of the General Agreement on Tariffs and Trade. The Commission shall also ensure appropriate contacts with all international organizations."

${ }^{127}$ See GATT Secretariat, Treaty Establishing The European Economic Community, Report Submitted by the Committee on the Rome Treaty to the Contracting Parties on 29 November 1957 (Geneva, 20 ${ }^{\text {th }}$ December 1957) [L/778], p. 19, para. 17. 
consistent with the GATT 1947. A concluding remark of the report of Subgroup C stated "The majority of members of the subgroup considered, moreover, that the particular measures envisaged under the Treaty [of Rome] carried a strong presumption of increased external barriers and a substitution of new internal barriers in place of existing tariffs and other measures". 128

\subsubsection{Subgroup D: Association of Overseas Territories ${ }^{129}$}

Subgroup D examined the legal provisions regarding the association of the EEC with its overseas territories, which was provided for in Article 131 of the Treaty of Rome. ${ }^{130}$ Numerous concerns were raised regarding the association as the arrangement entailed the preferential access of developing country exports to the proposed EEC internal market. ${ }^{131}$ It is imperative to state that the EEC labeled this initiative as an "association" and the term "free trade area" was not used in its description. Despite this, the report of Subgroup D stated "The fact that the Treaty did not call the Association a "Free Trade Area" in no way altered the nature or legal structure of the Association." 132 Furthermore, the contours of the proposed association did not satisfy the GATT Article XXIV requirements to establish an FTA, as the associated territories would not be required to eliminate their high duties on exports to the EEC and they would be empowered to levy duties on EEC imports according to their fiscal requirements or the needs of their economic development. The provisions for

\footnotetext{
${ }^{128}$ See Ibid, GATT Secretariat, 1957, p. 19, para. 14.

${ }^{129}$ The chairman of Subgroup D on Association of Overseas Territories was Sweden. The other members of Subgroup D were: Brazil, Ceylon, Dominican Republic, Ghana, Greece, India, Pakistan, Rhodesia and Nyasaland, United Kingdom and the United States. Subgroup D also included two of the six EEC Member States. See GATT Secretariat, Committee on the Treaty of Rome, Sub-Groups appointed on 7 November 1957 (Geneva, $9^{\text {th }}$ November 1957) [W.12/21], p. 2.

${ }^{130}$ Article 131 of the Treaty of Rome provides for the Association with Overseas Territories and states "The Member States hereby agree to bring into association with the Community the non-European countries and territories which have special relations with Belgium, France, Italy and the Netherlands. These countries and territories, hereinafter referred to as "the countries and territories", are listed in Annex IV to this Treaty. The purpose of this association shall be to promote the economic and social development of the countries and territories and to establish close economic relations between them and the Community as a whole. In conformity with the principles stated in the Preamble to this Treaty, this association shall in the first place permit the furthering of the interests and prosperity of the inhabitants of these countries and territories in such a manner as to lead them to the economic, social and cultural development, which they expect."

${ }^{131}$ See A. Yusuf, Legal Aspects of Trade Preferences for Developing States: A Study in the influence of development needs on the evolution of International Law (Martinus Nijhoff Publishers, 1982), p. 54.

${ }^{132}$ See GATT Secretariat, Treaty Establishing the European Economic Community, Report Submitted by the Committee on the Rome Treaty to the Contracting Parties on 29 November 1957 (Geneva, 20 ${ }^{\text {th }}$ December 1957) [L/778], p. 27, para. 24.
} 
the proposed association also lacked reference to the elimination of QRs on EEC imports and the elimination of duties on substantially all trade. ${ }^{133}$ Consequently, many members of Subgroup D noted that "the language structure, references and technique are those of an extension of preferences". 134

Some members of Subgroup D viewed the proposed association as closely resembling an FTA and argued that the same group of countries should not simultaneously belong to a customs union among themselves and an FTA-like association with other territories. ${ }^{135}$ It was stated that whilst on one hand GATT Article XXIV:5(a) required that "duties previously applied by countries participating in a customs union not be higher or more restrictive than the general incidence of duties in force before the establishment of a customs union", the imposition of a CET (a necessary requirement for a customs union) might lead to an increase in customs duties under certain conditions. GATT Article XXIV:5(b), which was applicable to FTAs, required that "duties not be greater than those previously applied" to be maintained in respect of third countries. Thus, the formation of the EEC as a customs union with a CET could require the increase of certain customs duties, which would be higher than those previously in force and contradict the requirements of GATT Article XXIV: 5 (b) if the EEC were to form an FTA-like association with its overseas territories. ${ }^{136}$ Some members of Subgroup D viewed the inconsistency between these two legal provisions as supporting evidence that the drafters of GATT Article XXIV did not envision their simultaneous use. ${ }^{137}$

The EEC argued that its association with the overseas territories fell within the purview of GATT Article XXIV and that if the drafters of GATT Article XXIV had not intended the

\footnotetext{
${ }^{133}$ See Ibid, GATT Secretariat, 1957, p. 24, para. 15.

${ }^{134}$ See Ibid, GATT Secretariat, 1957, p. 23, para. 10; “[...] no section of the Treaty establishing the European Economic Community has caused greater concern than this one. Not only does this section appear plainly incompatible with GATT provisions with respect to preferences not accorded nonmembers, but the unparalleled opportunity for trade diversion, especially at the expense of the newly developed countries, makes this system a primary target for regulation and control by the contracting parties." J. Allen, The European Common Market and the GATT: A Study in Compatibility, Law and Contemporary Problems, 1961, Vol. 26 (3), pp. 559 - 571, p. 569.

${ }^{135}$ See Ibid, GATT Secretariat, 1957, p. 21, para. 2.

${ }^{136}$ See Ibid, GATT Secretariat, 1957, p. 21, para. 3.

${ }^{137}$ See Ibid, GATT Secretariat, 1957, p. 21, para. 4.
} 
simultaneous use of Article XXIV:5(a) and (b), they would have explicitly provided for this in a legal provision. ${ }^{138}$ The EEC pointed out that the staggered establishment of its customs union and its association with overseas territories, could traverse the legal concerns outlined above. Most of the members of Subgroup D were also concerned about the level of asymmetry between the industrialized EEC Member States and their overseas territories. ${ }^{139}$ It was questioned whether the concept of an FTA-like association could satisfy such divergent interests. ${ }^{140}$ Further, it was mentioned that the drafters of the GATT did not envision the legal exceptions allowing for derogations from MFN-based trade would be used in a manner that would cover nearly a quarter of global trade. ${ }^{141}$ Due to these differences of opinion, Subgroup D was unable to arrive at a conclusive decision on the issues within its remit.

\subsection{The US Policy Position on the Treaty of Rome}

Despite the aforementioned concerns regarding the legal compatibility of the Treaty of Rome with GATT Article XXIV, the US still supported the endeavor as it possessed a strong interest in the reconstruction of Europe after the Second World War. The emergence of the European integration project aligned with US aims for a peaceful Europe and simultaneously countered the Soviet threat. ${ }^{142}$ At the time, the US was an ardent defender of multilateralism and lending its support to the Treaty of Rome, a preferential trading arrangement in need of GATT legal legitimacy, seemed inconsistent. ${ }^{143}$ The US policy stance on this matter was not necessarily a reflection of diplomatic altruism, but rather one

\footnotetext{
${ }^{138}$ See Ibid, GATT Secretariat, 1957, p. 22, para. 5.

${ }^{139}$ Most of the overseas territories were characterized by low levels of economic development and had export strategies, which focused mainly on raw materials.

${ }^{140}$ See GATT Secretariat, Treaty Establishing the European Economic Community, Report Submitted by the Committee on the Rome Treaty to the Contracting Parties on 29 November 1957 (Geneva, $20^{\text {th }}$ December 1957) [L/778], p. 23, para. 10.

${ }^{141}$ See Ibid, GATT Secretariat, 1957, p. 23, para. 10.

${ }^{142}$ One of the main US initiatives that assisted with the economic reconstruction of Europe after the Second World War was the 1948 Marshall Plan. It administered 13 Billion USD to 16 European countries between 1948 and 1952. The plan was intimately linked with international trade and required aid recipients to cooperate for the establishment of a strong production effort, expansion of foreign trade, the creation and maintenance of international financial stability and the development of economic cooperation including...the progressive elimination of trade barriers. See also A. Krueger, Are PTAs Trade-liberalizing or Protectionist?, Journal of Economic Perspectives, 1999, Vol. 13(4), pp. 105-124, p. 107.

${ }^{143}$ The then US Administration, led by President Dwight D. Eisenhower, voiced its political support for the Treaty of Rome notwithstanding the areas of economic concern outlined by other GATT contracting parties such as the UK, Canada, New Zealand and Australia.
} 
of self-serving rationalization based on the belief that further economic stability in Europe would lead to further engagement in the MTS. ${ }^{144}$ This overarching policy thinking could not afford to fail due to 'legal technicalities'. ${ }^{145}$

\subsection{Inconclusive Compatibility Report}

To fully appreciate the importance of the GATT legal assessment of the Treaty of Rome, it is useful to outline the GATT institutional framework for the examination of PTAs, as it then existed. As the third PTA notified under GATT Article XXIV, only two legal compatibility examinations preceded the Treaty of Rome and much of the legal review practice developed after 1958. The use of confidential ad hoc working parties was the main mechanism employed to assess the legal consistency of PTAs with GATT Article XXIV. Upon the signing of a PTA, signatories were required to notify the PTA to the GATT Council, which then mandated a working party to examine the PTA and invited all GATT Contracting Parties to submit questions outlining any concerns regarding the PTA. ${ }^{146}$ Subsequently, the working party would draft a compendium of collected questions and the replies issued by the PTA signatories. The examination report would eventually be submitted to the GATT Council for adoption. A practice developed whereby GATT

\footnotetext{
${ }^{144}$ The cornerstone of US foreign policy in Europe, which embodied in the 1948 Marshall Plan, emphasized "the restoration or maintenance in European countries of principles of individual liberty, free institutions and genuine independence rests largely upon the establishment of sound economic conditions, stable international economic relationships and the achievement by the countries of Europe of a healthy economy independent of extraordinary outside assistance." Title I of the Economic Cooperation Act of 1948 of the US Congress, Section 102(a). The Economic Cooperation Act authorized the funding of the Marshall Plan, which was to be administered by the Economic Cooperation Administration.

145 "If the GATT were too juridical in its appraisal and too demanding in it requirements, the [European Economic] Community could conceivably find it more profitable to withdraw from the organization altogether. The US has NATO to bear in mind; the political and strategic interest in a stable and prosperous Europe, able to take its place as a full partner of the West in the continuing struggle with the Communist bloc, more than compensates for any slight amount of discrimination or technical inconsistency with the GATT. A subsidiary interest, all too often forgotten, is that at long last France and Germany, who thrice in ninety years have involved Europe and the world in turmoil, are finally united in the eminently constructive pursuit of restoring Europe to its rightful place in the power constellation of nations." J. Allen, The European Common Market and the GATT: A Study in Compatibility, Law and Contemporary Problems, 1961, Vol. 26 (3), pp. $559-571$, p. 571.

${ }^{146}$ GATT working party procedural rules and examination process were determined on an individual basis. This lack of consistency resulted in varied rules of procedure and varied final reports, as there was no standard format for the substantive content of these reports. R. Herzstein, J. Whitlock, Regulating Regional Trade Agreements - A Legal Analysis in (eds) P. Macrory, A. Appleton, M. Plummer, The World Trade Organization: Legal, Economic and Political Analysis, Volume II, (Springer Science and Business Media Inc, 2007), p. 228.
} 
working parties were required to reach consensus that a PTA was legally compatible with GATT Article XXIV. ${ }^{147}$ This would be followed by a compatibility declaration stated in the final report.

The respective GATT working party subgroups were unable to reach a definitive finding regarding the legal compatibility of the Treaty of Rome with GATT Article XXIV. However, it did not issue a statement of incompatibility either. Instead, the final report on the Treaty of Rome stated that "there were a number of important matters on which there was not at this time sufficient information...to complete the examination of the Rome Treaty...this examination and the discussion of the legal questions involved in it could not be usefully pursued at the present time." The further examination of the Treaty of Rome was not addressed again and the default policy position was to monitor the development of the EEC with the understanding that any complications would be pragmatically resolved on an ad hoc basis. ${ }^{148}$ This inconclusive approach to the legal examination process would turn out to be the first of many such instances and it is argued that this was the genesis of some of the ambiguity surrounding the interpretation of GATT Article XXIV. ${ }^{149}$

\footnotetext{
${ }^{147}$ See D. Steger, The Culture of the WTO: Why it needs to change, Journal of International Economic Law, 2007, Vol. 10 (3), pp. 483-495, p. 488.

148 "As a matter of fact, since the contracting parties have never officially formulated agreed conclusions as to the EEC's conformity with Article XXIV, the EEC's legal status within the GATT has never been settled in a definitive way." Y. Devuyst, GATT Customs Union Provisions and the Uruguay Round: The European Community Experience, Journal of World Trade, 1992, Vol. 26(1), pp. 15-34, p. 22.

149 "At a very early stage, i.e. especially in the period of 1949-1960, GATT failed to create a body of case law in which the requirements of Article XXIV were enforced, which means it failed to disapprove of agreements which did not comply with Article XXIV. This made it very difficult to condemn any regional arrangement which was examined later and posed the same legal questions." J. Huber, The Practice of GATT in examining regional arrangements under Article XXIV, Journal of Common Market Studies, 1981, Vol. 19(3), pp. 281-298, p. 296.
} 


\subsection{PTA Motivation}

There are various underlying reasons associated with a policy decision to seek membership in a PTA. Oftentimes, this has been linked to non-trade related goals. ${ }^{150}$ The Treaty of Rome was allied with the non-trade related goal of fomenting greater social and political cohesion in Europe. ${ }^{151}$ And, it is well accepted that the motivation behind the establishment of the European Coal and Steel Community (ECSC) was the prevention of the reoccurrence of war in Europe. ${ }^{152}$ The geopolitical relations underpinning many PTAs demonstrate that economic efficiency is not the sole consideration. Moreover, a dichotomy has been observed in the way that developed and developing countries utilize PTAs to advance their foreign (economic) policy ambitions. Developed countries have used PTAs to forge their geopolitical alliances irrespective of the trade flow between the constituent members and some of these agreements have been asymmetrical. ${ }^{153}$ It is also argued that developed countries have pursued PTAs because it is a less complicated alternative when compared to multilateral negotiations. ${ }^{154}$ The US was previously a committed multilateralist and was not involved in many PTAs before 2000; however, PTAs are now a prominent feature in US commercial trade policy. ${ }^{155}$

\footnotetext{
${ }^{150}$ Non-trade related goals are goals other than the traditional trade gain. In this regard, stated PTA motivations include the promotion of democracy and human rights, regional cooperation and coordination and involvement as a defensive necessity against economic isolation. M. Schiff, L. Winters, Regional Integration and Development (World Bank/Oxford University Press, 2003), p. 9; K. Chase, Trading Blocs: States, Firms and Regions in the World Economy (University of Michigan Press, 2005), p.18; T. Carpenter, A Historical Perspective on Regionalism in (eds) R. Baldwin, P. Low, Multilateralizing Regionalism: Challenges for the Global Trading System (Cambridge University Press, 2008), p. 13; J. Chauffour, J. Maur, Beyond Market Access in (eds.) J. Chauffour, J. Maur, Preferential Trade Agreement Policies for Development: A Handbook (World Bank, 2011), p. 25; R. Fernandez, J. Portes, Returns to Regionalism: An Analysis of Non-Traditional Gains from Regional Trade Agreements, World Bank Economic Review, 1998, Vol. 12(2), pp. 197-220.

${ }^{151}$ Ibid, R. Fernandez, J. Portes, 1998, p. 208.

${ }^{152}$ The preamble to the 1951 Treaty of Paris, which established the ECSC, makes clear mention that it was aimed at "creating a deeper Community among peoples long divided by bloody conflict."

${ }^{153}$ The 1985 US-Israel FTA was based on a geopolitical alliance and served to underscore the special relationship between the two countries. See H. Rosen, Free Trade Agreements as Foreign Policy Tools: The US-Israel and US-Jordan FTAs in (ed.) J. Schott, Free Trade Agreements: US Strategies and Priorities (Institute for International Economics, 2003), p. 58.

154 "The stark contrast between the ease of regional liberalization and the glacial GATT talks does not reflect a GATT failure: GATT Rounds have always been protracted, have always been slow, and have always been difficult." R. Baldwin, A Domino Theory of Regionalism in (eds) J. Bhagwati, P. Krishna, A. Panagariya, Trading Blocs: Alternative Approaches to Analyzing Preferential Trade Agreements (MIT Press, 1999), p. 487.

${ }^{155}$ Schiff and Winters have argued that the US volte-face on RTAs was rooted in its frustration with the glacial pace of the multilateral negotiating process. M. Schiff, L. Winters, Regional Integration and Development (World Bank/Oxford University Press, 2003), p. 9.
} 
The gaining of multilateral bargaining power is a factor that has also spurred both developed and developing countries to participate in PTAs. ${ }^{156}$ In the case of developing countries, PTAs have been used to lock in domestic policy reforms thereby making policy reversals difficult to undertake by subsequent governments as was seen with the Mexican pursuit of the North American Free Trade Agreement (NAFTA). ${ }^{157}$ After the fall of communism in Eastern Europe, the transitional economies utilized PTA rules to attain EU candidate country status, which sent credible signals by locking in domestic policy reforms during the establishment of their market economies. ${ }^{158}$ It is submitted that trade linkages engendered by PTAs serve to increase the cost of conflict and by extension, PTAs possess the ability to result in the improvement of border cooperation. ${ }^{159}$ This was demonstrated with Mercado Común del Sur (MERCOSUR), which was created with the partial aim to bolster political stability in the then recently restored democracies of Brazil and Argentina. ${ }^{160}$ The entry of Portugal, Spain and Greece into the EEC in the 1980 s was also motivated by the aim of consolidating democracy in the aftermath of dictatorships. ${ }^{161}$ Developing countries also seek PTAs because of their desire to maintain sovereignty by pooling it with countries of a similar profile particularly in areas of economic governance where they might be considered too small to act alone. ${ }^{162}$ This was seen with the former British Caribbean territories and their pursuit of regional integration, which commenced with the Caribbean Free Trade Association (CARIFTA) in 1968. ${ }^{163}$

\footnotetext{
${ }^{156}$ WTO Secretariat, World Trade Report 2011 (Geneva, 2011), p. 97; R. Fernandez, J. Portes, Returns to Regionalism: An Analysis of Non-Traditional Gains from Regional Trade Agreements, World Bank Economic Review, 1998, Vol. 12(2), pp. 197-220, p. 211.

${ }^{157}$ R. Baldwin, A Domino Theory of Regionalism in (eds) J. Bhagwati, P. Krishna, A. Panagariya, Trading Blocs: Alternative Approaches to Analyzing Preferential Trade Agreements (MIT Press, 1999), p. 483.

${ }^{158}$ WTO Secretariat, World Trade Report 2011 (Geneva, 2011), p. 96; E. Mansfield, H. Milner, The New Wave of Regionalism, International Organization, 1999, Vol. 53 (3), pp.589-627, p. 600.

${ }^{159}$ R. Fernandez, J. Portes, Returns to Regionalism: An Analysis of Non-Traditional Gains from Regional Trade Agreements, World Bank Economic Review, 1998, Vol. 12(2), pp. 197-220, p. 208.

${ }^{160}$ M. Schiff, Multilateral Trade Liberalization and Political Disintegration, Implication for the Evolution of Free Trade Areas and Customs Unions (World Bank Development Research Group, Trade, 2000), p. 10.

${ }^{161}$ E. Mansfield, H. Milner, The New Wave of Regionalism, International Organization, 1999, Vol. 53 (3), pp.589-627, p. 606.

${ }_{162}$ M. Schiff, L. Winters, Regional Integration and Development (World Bank/Oxford University Press, 2003), p. 6.

${ }^{163}$ See Chapter 4, Section 4.1 entitled Regional Integration Theory and Section 4.6 entitled Phase 2: The Caribbean Free Trade Association.
} 


\subsection{PTA Expansionism}

The development of PTAs in the MTS has featured ebbs and flows that have resulted in an overall exponential growth. Whether in the shallow form of a simple tariff reducing FTA or the deeper form of a customs union with a CET, the growth of PTAs has meant that all WTO members are now parties to PTAs. ${ }^{164}$ It has also been argued that the survival and ensuing success of the EEC contributed to the initial growth spurt of PTAs. ${ }^{165}$ Consequently, GATT Article XXIV is now in frequent use as most PTAs have utilized it for notification purposes. ${ }^{166}$ This can be contrasted with the two PTAs, which were notified under GATT Article XXIV in the first decade of the legal provision's existence. ${ }^{167}$ It is also important to note that from 1958 to 2006, most PTAs were still institutionally assessed using respective GATT and WTO working parties that were tasked with ascertaining whether the notified PTA was legally compatible with the legal provision under which it was notified. Given the interpretational divide on GATT Article XXIV, the majority of these PTAs completed their institutional assessment without a formal declaration being made regarding their legal compatibility. ${ }^{168}$ Post-2006, the institutional assessment of PTAs is addressed by the Regional Trade Agreement Transparency Mechanism (RTA TM), which is addressed in Chapter 3 of this dissertation.

The exponential growth of PTAs has impacted the MTS because as previously noted, GATT Article XXIV was intended as a legal exception and GATT drafters did not envision its extensive use. The crafting of a rules-based MTS was meant to engender a nondiscriminatory environment for the regulation of international trade. Therefore, concerns have been raised about whether the stability and coherence of multilateralism has been

\footnotetext{
164 Previously, Mongolia was the only WTO Member that was not party to a PTA. However, the JapanMongolia FTA was signed on $10^{\text {th }}$ February 2015 and notified at the WTO Secretariat under GATT Article XXIV. The FTA entered into force on $7^{\text {th }}$ June 2016.

165 J. Bhagwati, Regionalism and Multilateralism: An Overview in (eds) J. Bhagwati, P. Krishna, A. Panagariya, Trading Blocs: Alternative Approaches to Analyzing Preferential Trade Agreements (MIT Press, 1999), p. 9.

${ }^{166}$ As of 2017, 654 PTA notifications have been received at the WTO Secretariat. Most of these PTAs have been notified using GATT Article XXIV.

${ }^{167}$ The Interim Agreement for a Customs Union between the Union of South Africa and Southern Rhodesia (1949) and The Free Trade Treaty between the Republics of Nicaragua and El Salvador (1951).

168 This matter is further addressed in Chapter 2 of this dissertation.
} 
undermined. ${ }^{169}$ It remains to be seen whether PTAs embody as useful supplement to multilateral trade or whether they are an alternative thereto. It is argued that PTAs slow multilateral liberalization because domestic groups may be largely satisfied with the exclusivity of PTA trade concessions and oppose the multilateral extension of concessions. ${ }^{170}$ It is also thought that PTAs perpetuate inefficient resource allocation as the costs of negotiating at the PTA level could detract from the overall efforts required for negotiating at the multilateral level. ${ }^{171}$ Nevertheless, over half of global trade is now conducted under preferential terms and there are no signs that this trend will abate. ${ }^{172} \mathrm{~A}$ disconcerting issue for multilateralism is that the legal rules governing PTAs have been left in limbo for decades. It must be conceded, however, that efforts have been undertaken to improve on this state of affairs, especially through the establishment of the RTA TM.

\subsubsection{The First Wave of Regionalism ${ }^{173}$}

During the first decade after the creation of the GATT 1947, there was minimal usage of GATT Article XXIV to notify PTAs, however, its usage increased significantly between 1960 and the late 1970s. Most of these PTAs were of the shallow variety and were basic FTAs consisting of simple tariff reduction schemes located within a geographically defined area. ${ }^{174}$ Early PTAs were signed between countries with comparable levels of economic

\footnotetext{
169 "The increasing number of regional arrangements may also represent a threat to multilateral liberalization. Preferential agreements can distort trade flows and for this reason may be regarded as an inferior option compared to coordinated multilateral liberalization... The question, then, is one of balance. Regional arrangements can be destructive of more desirable multilateral outcomes, but they can also supplement and build upon multilateralism in positive ways." See WTO Secretariat, World Trade Report 2003, Trade and Development (Geneva, 2003), p. 65.

${ }^{170}$ W. Davey, A Model Article XXIV: Are there Realistic Possibilities to Improve It? in (eds.) K. Bagwell, P. Mavroidis, Preferential Trade Agreements: A Law and Economics Analysis (Cambridge University Press, 2011), p. 246.

${ }^{171}$ See The Warwick Commission, The Multilateral Trade Regime: Which Way Forward? The Report of the First Warwick Commission (University of Warwick, 2007), p. 50; A. Krueger, Are PTAs Trade-liberalizing or Protectionist?, Journal of Economic Perspectives, 1999, Vol. 13(4), pp. 105-124, p. 119.

172 "In 2014, almost half of world trade was taking place between countries that had signed a PTA and almost one third was regulated by deep trade agreements." See UNCTAD Secretariat, Key Statistics and Trends in Trade Policy: Preferential Trade Agreements (Geneva, 2015) [UNCTAD/DITC/TAB/2015/2], p. 14; Report by the Consultative Board to the Director General Supachai Panitchpakdi, The Future of the WTO: Addressing Institutional Challenges in the New Millennium (The Sutherland Report) (WTO, 2004), p. 79.

${ }^{173}$ This phrase was first coined by J. Bhagwati.

${ }^{174}$ The EEC, which was established in 1958, was the exception to the shallow variety of FTAs as it sought to create a customs union and efforts were made from the very beginning to address issues such as the establishment of the CET, which is considered an element of deep integration. Other examples of early PTAs include the Central American Free Trade Area (1959), the European Free Trade Area (1960), the Latin
} 
development and thus, the PTA landscape was characterized by North-North PTAs such as the EEC and European Free Trade Association (EFTA) or South-South PTAs such as Latin American Free Trade Area (LAFTA) and CARIFTA. Many of the South-South PTAs followed a closed regionalism philosophy whereby import substitution policies and high external trade barriers were commonplace in an attempt to further economic development through industrialization. ${ }^{175}$ Allied to this notion was the fact that developing countries sought to limit their economic and political dependence on certain developed countries and emphasis was placed on the need to minimize imports as well as maximize the development of local industries. An exception to the aforementioned PTA pattern was the trade agreements concluded by the EEC with their former and existing colonies. These PTAs featured non-reciprocal systems of preferences and were notified to the GATT Secretariat under GATT Article XXIV. ${ }^{176}$

\subsubsection{The Second Wave of Regionalism ${ }^{177}$}

The second period that featured a marked increase in the formation of PTAs started in the late 1980s leading into the early 1990s. One of the catalysts for the increased growth of PTAs during this time was the volte-face by the US regarding its involvement with preferential trade. ${ }^{178}$ The 1985 Israel-US FTA was the first PTA negotiated by the US and was subsequently followed by the 1989 Canada-US FTA. ${ }^{179}$ The US also committed itself

\footnotetext{
American Free Trade Area (1961), the Central American Common Market (1961), the New Zealand/Australia Free Trade Area (1966), the United Kingdom/Ireland Free Trade Area (1966) and the Agreement establishing the Caribbean Free Trade Association (1968).

175 M. Schiff, L. Winters, Regional Integration and Development (World Bank/Oxford University Press, 2003), p. 5.

${ }^{176}$ Examples of these PTAs include the Convention of Association between the EEC and the African and Malagasy States Associated with that community (Yaounde I) ( ${ }^{\text {st }}$ January 1964), Association between the EEC and certain non-European Countries and Territories maintaining special relations with France and the Netherlands (EEC-PTOM I) $\left(1^{\text {st }}\right.$ June 1964, Agreement establishing an Association between the EEC and the United Republic of Tanzania, the Republic of Uganda and the Republic of Kenya (Arusha II Agreement) ( $1^{\text {st }}$ January 1971), EEC-PTOM II (1 $1^{\text {st }}$ January 1971), Yaounde II (1 ${ }^{\text {st }}$ January 1971), ACP - EEC First Convention of Lome ( $1^{\text {st }}$ April 1976).

${ }^{177}$ This phrase was also coined by J. Bhagwati, as a sequel to First Regionalism.

178 "The "conversion" of the US from a strong backer of multilateralism to an avid participant in regional schemes has been a driving force [in the growth of PTAs.]" R. Baldwin, A Domino Theory of Regionalism in (eds) J. Bhagwati, P. Krishna, A. Panagariya, Trading Blocs: Alternative Approaches to Analyzing Preferential Trade Agreements (MIT Press, 1999), p. 479; A. Krueger, Are PTAs Trade-liberalizing or Protectionist?, Journal of Economic Perspectives, 1999, Vol. 13(4), pp. 105-124, p. 108.

179 The Agreement on the establishment of a free trade area between the Government of the United States of America and the Government of Israel (Israel-US FTA) entered into force on $19^{\text {th }}$ August 1985 and was
} 
to granting non-reciprocal trade preferences to developing countries when it concluded the 1984 United States Caribbean Basin Economic Recovery Act (US-Caribbean CBERA). ${ }^{180}$

Another factor that contributed to the growth of PTAs during this period was the end of the Cold War. In late 1989, the fall of the Berlin Wall occurred and eventually the communist regimes of Eastern Europe collapsed. By 1990, all of the Eastern European countries gained democratically elected governments seeking further integration into the regional European economy. Consequently, the early 1990s were characterized by a spate of interim agreements on trade and trade-related matters between the EEC and individual postcommunist countries. ${ }^{181}$ Furthermore, the demise of the Soviet Union in late 1991 contributed to the growth of PTAs as 15 separate countries emerged after the Soviet Union disintegrated and all of them required adjustments from their previously centralized economic systems. Many of the post-Soviet republics utilized PTAs as a first step in integrating their economies into regional European economy. ${ }^{182}$

In the American hemisphere, the 1994 NAFTA represented a progressive change to the previous PTA paradigm as it linked a developing country economy (Mexico) with that of two advanced, developed country economies (United States and Canada) in an attempt to bolster the economic development of all three economies involved. ${ }^{183}$ Subsequent to this, a gradual shift occurred whereby PTAs adopted a more interventionist character and sought

\footnotetext{
notified at the GATT Secretariat under GATT Article XXIV. The Canada- US FTA entered into force on $1^{\text {st }}$ January 1989 and was notified at the GATT Secretariat under GATT Article XXIV.

${ }^{180}$ The US-Caribbean CBERA entered into force on $1^{\text {st }}$ January 1984 and required the legal cover of a waiver under GATT Article 1: 1.

${ }^{181}$ Such agreements were concluded with: The Czech and Slovak Federal Republic $\left(1^{\text {st }}\right.$ March 1992), Hungary ( $1^{\text {st }}$ March 1992), Poland ( $1^{\text {st }}$ March 1992), Romania ( $1^{\text {st }}$ May 1993) and Bulgaria (31 $1^{\text {st }}$ December 1993). In addition to this, the EFTA grouping signed individual PTAs with the Czech and Slovak Federal Republic ( $1^{\text {st }}$ July 1992), Romania ( $1^{\text {st }}$ May 1993), Bulgaria ( $1^{\text {st }}$ May 1993$)$, Hungary $\left(1^{\text {st }}\right.$ October 1993$)$ and Poland $\left(15^{\text {th }}\right.$ November 1993). All of these PTAs were notified at the GATT Secretariat under GATT Article XXIV.

${ }^{182}$ Examples of such PTAs include: The Latvia-Norway FTA and Lithuania-Norway FTA (both: $16^{\text {th }}$ June 1992), Estonia-Sweden FTA, Latvia-Sweden FTA, Lithuania-Sweden FTA (all: $1^{\text {st }}$ July 1992), EstoniaSwitzerland FTA, Latvia-Switzerland FTA, Lithuania-Switzerland FTA (all: $1^{\text {st }}$ April 1993) All of these PTAs were notified at the GATT Secretariat under GATT Article XXIV.

${ }^{183}$ Regional Integration: Observed Trade and Other Economic Effects (OECD 2001), p. 6; A. Krueger, Are PTAs Trade-liberalizing or Protectionist?, Journal of Economic Perspectives, 1999, Vol. 13(4), pp. 105-124, p. 108 .
} 
to optimize geographical locations based on low labor costs. ${ }^{184}$ The import substitution emphasis that had characterized many of the early PTAs was abandoned because it was largely unsuccessful at engineering economic development.

The post-Uruguay Round period of the mid 1990s heralded the rise of North-South and cross-regional PTAs as well as a growing acceptance of the notion that non-reciprocal, preferential trade was untenable. This resulted in the replacement of some of the nonreciprocal systems of preferences with reciprocal trade regimes. ${ }^{185}$ These changes introduced a trend whereby countries with asymmetrical levels of development were treated as equal trading partners and the coverage of PTAs were also extended to include trade in services as well as other policy areas that were outside of the scope of the WTO. Many have attributed the ambitious expansion in the scope and coverage of PTAs to the paucity of advancements in multilateral trade negotiations. ${ }^{186}$

\subsection{Conclusion}

Chapter 1 provides a foundational understanding on PTAs and addresses the emergence of the legal concept for such agreements during the drafting of the GATT 1947. It therefore outlines GATT Article XXIV, which was the first legal provision to underpin the establishment of PTAs within the MTS as well as the manner in which GATT drafters envisioned its use. The GATT legal examination of the Treaty of Rome is highlighted and identified as a source of numerous systemic issues still associated with GATT Article XXIV. Other subsequent developments such as the increased use of PTAs as well as the motives that have spurred their growth demonstrate the dynamic role that PTAs have played in the MTS since 1947. Most importantly, Chapter 1 provides the introductory basis

\footnotetext{
${ }^{184}$ M. Schiff, L. Winters, Regional Integration and Development (World Bank/Oxford University Press, 2003), p. 5.

${ }^{185}$ As a result of this, the ACP-EEC Fourth Convention of Lome $\left(1^{\text {st }}\right.$ September 1991$)$ required the legal cover of a waiver under GATT Article 1: 1. It should be noted that the first three Conventions of Lome were notified under GATT Article XXIV and did not require such a waiver.

186 “... Regional integration has prospered as an alternative to multilateralism since the multilateral trade negotiations have become too cumbersome to deal with today's complex trade issues." R. Baldwin, A Domino Theory of Regionalism in (eds) J. Bhagwati, P. Krishna, A. Panagariya, Trading Blocs: Alternative Approaches to Analyzing Preferential Trade Agreements (MIT Press, 1999), p. 479; A. Krueger, Are PTAs Trade-liberalizing or Protectionist?, Journal of Economic Perspectives, 1999, Vol. 13(4), pp. 105-124, p. 119.
} 
upon which this dissertation will further examine PTAs as a legal discipline within the WTO architecture and the regional application of this discipline in the CARICOM PTA. 


\section{Chapter 2 \\ Legal Design of Preferential Trade Agreements: \\ GATT Article XXIV and The Enabling Clause}

\section{Introduction}

Chapter 2 is aimed at outlining and analyzing the two World Trade Organization (WTO) legal provisions that underpin the establishment of preferential trade agreements (PTAs) for trade in goods: General Agreement on Tariffs and Trade (GATT) Article XXIV and paragraph 2 (c) of the 1979 GATT Decision on Differential and More Favorable Treatment (the Enabling Clause). ${ }^{187}$ GATT and WTO Secretariat documentation, WTO legal texts, WTO law books and journals are used to undertake the doctrinal legal analysis of these two legal provisions. ${ }^{188}$ Furthermore, the aims, purpose, main requirements and usage of GATT Article XXIV and paragraph 2 (c) of the Enabling Clause are assessed. The rules of interpretation of public international law outlined in the Vienna Convention on the Law of Treaties (VCLT) are used to assist in this analysis. ${ }^{189}$ WTO jurisprudence is also used to illuminate how the WTO Appellate Body (AB) has chosen to interpret the text, context and object and purpose of these legal provisions. ${ }^{190}$ The associated, systemic issues and the various attempts to clarify GATT Article XXIV and the Enabling Clause are also noted.

\footnotetext{
${ }^{187}$ See GATT Secretariat, Differential and More Favorable Treatment, Reciprocity and Fuller Participation of Developing Countries, Decision of 28 November 1979 (Geneva, 3 December 1979) [L4903]. Article 2(c) of the Enabling Clause states: "Regional or global arrangements entered into amongst less-developed contracting parties for the mutual reduction or elimination of tariffs and, in accordance with criteria or conditions which may be prescribed by the CONTRACTING PARTIES, for the mutual reduction or elimination of non-tariff measures, on products imported from one another".

${ }^{188}$ See WTO Legal Texts (particularly the text of GATT Article XXIV); The Understanding on the Interpretation of Article XXIV of GATT 1994. See P. Mavroidis, The Regulation of International Trade, Volume I, GATT (MIT Press, 2016, (Eds) K. Bagwell, P. Mavroidis; Preferential Trade Agreements: A Law and Economics Analysis (Cambridge University Press, 2011); M. Trebilcock, R. Howse, A. Elliason, The Regulation of International Trade $4^{\text {th }}$ Edition (Routledge 2013); P. Mavroidis, If I Don't, Somebody Else Will (Or Won't): Testing the Compliance of Preferential Trade Agreements with Multilateral Rules, Journal of World Trade, 2006 (40) 1, pp. 187 -214; T. Brink, Which WTO Rules Can a PTA Lawfully Breach? Completing the Analysis in Brazil - Tyres', Journal of World Trade 2010, Vol. 44(4), pp. 813 - 846.

${ }^{189}$ See Vienna Convention on the Law of Treaties, 1969, 1155 UNTS 331 (adopted 23 ${ }^{\text {rd }}$ May 1969, in force $27^{\text {th }}$ January 1980 ).

${ }^{190}$ See Appellate Body Report, Turkey - Restrictions on Imports of Textile and Clothing Products, WT/DS34/AB/R, adopted $19^{\text {th }}$ November 1999, DSR 1999:VI, 2345; Panel Report, Canada-Certain Measures Affecting the Automotive Industry, WT/DS139/AB/R/, WT/DS142/R, adopted $19^{\text {th }}$ June 2000 , as modified by Appellate Body Report WT/DS139/AB/R, WT/DS/142/AB/R, DSR 2000:VII, 3043; Appellate Body Report, European Communities-Conditions for the Granting of Tariff Preferences to Developing Countries, WT/DS246/AB/R, adopted $20^{\text {th }}$ April 2004, DSR 2004:III, 925; Appellate Body Report, Brazil Measures Affecting Imports of Retreaded Tyres, Body, WT/DS332/AB/R, adopted $17^{\text {th }}$ December 2007, DSR 2007:IV, 1527.
} 
Lastly, in addressing both legal provisions, Chapter 2 seeks to ascertain whether they constitute a legal obligation to create trade. This particular point is noteworthy, as further chapters of this dissertation will demonstrate that the CARICOM PTA has been criticized for not creating trade. In this regard, further chapters will enquire whether there is a legal obligation to create trade within the CARICOM PTA and whether the failure to do so impairs any benefits accruing under the WTO Agreement.

\subsection{GATT Article XXIV}

GATT Article XXIV was the first legal provision to underpin the establishment of PTAs within the multilateral trading system (MTS). Its origins are closely linked with the drafting of the GATT 1947 and the drafting history of GATT Article XXIV is addressed in Chapter 1 of this dissertation. ${ }^{191}$ Nevertheless, it is useful to reiterate that the GATT 1947 was predicated on the understanding that global trade would be conducted in a nondiscriminatory trading environment. ${ }^{192}$ This dissertation, therefore, argues that the object and purpose of the GATT 1947 envisioned the full liberalization or freeing of global trade. ${ }^{193}$ It is submitted that this object and purpose remains the same for the present day GATT 1994. In this vein, it is noted that although inherently discriminatory in nature, PTAs were initially contextualized by GATT drafters in light of their building-block function and their ability to facilitate a general movement towards global free trade. ${ }^{194}$ This sentiment is echoed in the preamble to the Understanding on the Interpretation of Article XXIV of the GATT 1994, which states "Recognizing the contribution to the expansion of world trade that may be made by closer integration between the economies of the parties to such

\footnotetext{
${ }^{191}$ See Chapter 1, Section 1.2.2 entitled Permitted Preferences.

192 The Preamble to the GATT 1947 states "Being desirous of contributing to these objectives by entering into reciprocal and mutually advantageous arrangements directed to the substantial reduction of tariffs and other barriers to trade and to the elimination of discriminatory treatment in international commerce,".

${ }^{193}$ See "[...] The fundamental justification for the free trade position [...] is that the most efficient allocation of resources for the world as a whole will be achieved by the elimination of tariffs and other arbitrary barriers to trade." See K. Dam, Regional Economic Arrangements and The GATT: The Legacy of A Misconception, University of Chicago Law Review, 1963, Vol. 30 (4), pp. 615-665, p. 623.

194 See K. Dam, Regional Integration Arrangements and The GATT: The Legacy of A Misconception, University of Chicago Law Review, 1963, Vol. 30 (4), pp.615-665, p. 622; J. Crawford, C. Lim, Cast Light and Evil Will Go Away: The Transparency Mechanism for Regulating Regional Trade Agreements, Three Years After, Journal of World Trade, 2011, Vol. 45(2), pp. 375-400, p. 377; O. Cattaneo, The Political Economy of PTAs in (eds.) S. Lester, B. Mercurio, L. Bartels, Bilateral and Regional Trade Agreements: Commentary and Analysis, Volume 1, Second Edition (Cambridge University Press, 2015), p. 31.
} 
agreements". Similarly, it is asserted that PTAs assist in achieving one of the broad objectives of the WTO Agreement, which is focused on expanding the production of and trade in goods. ${ }^{195}$

The formation requirements outlined in GATT Article XXIV are aimed at the full liberalization of trade within a free trade area (FTA) or a customs union and this is reflected in the requirement that substantially all trade be 'freed' of tariffs. Still, interpretative complications have arisen due to the wording used to capture the general object and purpose of GATT Article XXIV. Many issues including inter alia the meaning of the terms "not to raise barriers to trade" in GATT Article XXIV:4, "other regulations of commerce" in GATT Article XXIV:5 and "substantially all trade" in GATT Article XXIV:8 remain unclear. ${ }^{196}$ The legal provision has been the subject of substantial debate and disagreement within the GATT and WTO membership for decades due to its ambiguous wording. ${ }^{197}$ Chapter 1 of this dissertation addressed some of the ambiguity associated with GATT Article XXIV that arose during the GATT working party examination of the Treaty of Rome, which established the European Economic Community (EEC). Subsequent sections of Chapter 2 will delve deeper into issues upon which clarifications have been provided as well as issues that remain unclarified to date.

It is useful to highlight that the debate and disagreement on GATT Article XXIV has contributed to the ineffectual enforcement of legal rules relating to PTAs. This resulted in

\footnotetext{
195 See Preamble to the WTO Agreement

196 "With a text which uses such vague phrases as ""substantially all the trade" and "reasonable length of time" and without assistance from the records for assessing "'substantial" or "reasonable" it is not surprising that there has been Pack of agreement on the meaning of Article XXIV. No other critically important provisions of the GATT leave such difficult tasks of interpretation to the judgment of the Contracting Parties. Nevertheless, it is regrettable, looking back in sadness, that governments did not make a greater effort to interpret and implement the provisions in a manner which would preserve integrity and order in their trading relationships". See F. Haight, Customs Union and Free Trade Areas under the GATT: A Reappraisal, Journal of World Trade Law, 1972, Vol. 6 (4), pp. 391-404, p. 397.

197 See K. Dam, Regional Economic Arrangements and The GATT: The Legacy of A Misconception, University of Chicago Law Review, 1963, Vol. 30 (4), pp. 615-665, p. 619; Ibid, F. Haight, 1972, p. 397; J. Jackson, Jurisprudence of the GATT and WTO: Insights on Treaty Law and Economic Relations (Cambridge University Press, 2000), p. 104; J. Bhagwati, Termites in the Trading System: How Preferential Agreements undermine Free Trade (Oxford University Press, 2008) p. 28; J. Crawford, C. Lim, Cast Light and Evil Will Go Away: The Transparency Mechanism for Regulating Regional Trade Agreements, Three Years After, Journal of World Trade, 2011, Vol. 45(2), pp. 375-400, p. 378.
} 
few PTAs being pronounced as legally consistent with GATT Article XXIV. Added to this complexity is the fact that none of the PTAs examined by GATT and WTO working parties were declared inconsistent with GATT Article XXIV. ${ }^{198}$ It is noteworthy that the second CARICOM PTA created by the Treaty of Chaguaramas (1974), which is part of the focus of this dissertation, was one of the few PTAs to be pronounced as legally consistent with GATT Article XXIV. Chapter 3 of this dissertation will examine the Aricle XXIV consistency of the three successive CARICOM PTAs and assess the institutional review process that was undertaken when these PTAs were notified at the GATT and WTO Secretariats.

The ambiguity associated with GATT Article XXIV has also contributed to political sensitivity in judicially addressing this provision. ${ }^{199}$ It is noted that the WTO dispute settlement system has been empowered to review PTAs. ${ }^{200}$ The AB reinforced that GATT Article XXIV is justiciable in its report in Turkey - Restrictions on Imports of Textile and Clothing Products (Turkey-Textiles). ${ }^{201}$ Several other WTO dispute settlement cases have

\footnotetext{
198 "On only five occasions has consensus been reached, the working party or CRTA in each case finding the notified PTA to be consistent with [GATT] Article XXIV". M. Trebilcock, R. Howse, A. Elliason, The Regulation of International Trade $4^{\text {th }}$ Edition (Routledge 2013), p. 100. See also Ibid, J. Jackson, 2000, p. 109; R. Herzstein, J. Whitlock, Regulating Regional Trade Agreements: A Legal Analysis in (eds.) P. Macrory, A. Appleton, M. Plummer, The World Trade Organization: Legal, Economic and Political Analysis, Volume II (Springer, 2007), p. 245. See institutional assessment of PTAs in Chapter 3.

${ }^{199}$ During the GATT years, only 3 Panels were established to examine GATT Article XXIV consistency. Of these three, the work of one Panel was suspended and the reports of the other two Panels were not adopted. In both GATT Panel Report, European Community-Tariff Treatment on Imports of Citrus Products from certain countries in the Mediterranean Region, L/5776, $7^{\text {th }}$ February 1985, unadopted, and GATT Panel Report, EEC-Import Regime for Bananas, DS38/R, $11^{\text {th }}$ February 1994, unadopted, the overall consistency of the PTA at issue was not examined and emphasis was solely placed on the measures at issue. See P. Mavroidis, If I Don't, Somebody Else Will (Or Won't): Testing the Compliance of Preferential Trade Agreements with Multilateral Rules, Journal of World Trade, 2006 (40) 1, pp. 187 -214, p. 205; M. Trebilcock, Advanced Introduction to International Trade Law (Edward Elgar Publishing, 2015), p. 52.

${ }^{200}$ Paragraph 12 of the 1994 Understanding on the Interpretation of Article XXIV of the GATT states "The provisions of Articles XXII and XXIII of GATT 1994 as elaborated and applied by the Dispute Settlement Understanding may be invoked with respect to any matters arising from the application of those provisions of Article XXIV relating to customs unions, free-trade areas or interim agreements leading to the formation of a customs union or free-trade area".

${ }^{201}$ At the Panel stage of Turkey-Textiles, it was stated that "it is arguable" whether Panels have jurisdiction to assess the overall compatibility of a customs union with the requirements of GATT Article XXIV. At the appellate stage, however, the $\mathrm{AB}$ made reference to one of its previous rulings whereby it had pronounced that Panels do, in fact, have the competence to review such matters and left no doubt that it held a different view from the Panel on the matter of the examination of GATT Article XXIV. See Appellate Body Report, Turkey - Restrictions on Imports of Textile and Clothing Products, WT/DS34/AB/R, adopted $19^{\text {th }}$ November 1999, DSR 1999:VI, 2345, p. 17.
} 
indirectly addressed aspects of GATT Article XXIV and the resulting case law, which has utilized the customary rules of interpretation of public international law, has clarified certain issues regarding Article XXIV. Still, some observers have argued that there has been judicial avoidance in addressing GATT Article XXIV within the WTO dispute settlement system. ${ }^{202}$ The few WTO dispute settlement cases that have scrutinized aspects of GATT Article XXIV have employed the use of judicial economy and have avoided examining the overall legal compatibility of the PTA in question by limiting the legal examination to the particular PTA measure at issue. ${ }^{203}$ Thus, the ambiguity associated with GATT Article XXIV remains and PTAs are still seen as being based on ill-defined legal grounds. $^{204}$

\subsubsection{The Creation of Free Trade Areas and Customs Unions}

It is instructive to outline that GATT Article XXIV and paragraph 2 (c) of the Enabling Clause aim to create PTAs in the form of FTAs and customs unions. As previously noted in section 2.1 of this chapter, the economic policy rationale for allowing the first GATT

\footnotetext{
202 "Complainants with strong trade interests and many PTAs may be reticent to have GATT Article XXIV adjudicated upon because it might provide clarifications which are contrary to their interests." T. Brink, Which WTO Rules Can a PTA Lawfully Breach? Completing the Analysis in Brazil - Tyres', Journal of World Trade 2010, Vol. 44(4), pp. 813 - 846, p. 819; P. Mavroidis, If I Don't, Somebody Else Will (Or Won't): Testing the Compliance of Preferential Trade Agreements with Multilateral Rules, Journal of World Trade, 2006 (40) 1, pp. 187 -214, p. 187; J. Pauwelyn, The Puzzle of WTO Safeguards and Regional Trade Agreements, Journal of International Economic Law, 2004, Vol. 7(1), pp. 109-142, p. 121; L. Bartels, WTO Dispute Settlement Practice on Article XXIV of the GATT in (eds) F. Ortino, E. Petersmann, The WTO Dispute Settlement System: 1995 - 2003 (Kluwer Law International, 2004), p. 271; J. Jackson, The Jurisprudence of the GATT and WTO: Insights on Treaty Law and Economic Relations (Cambridge University Press, 2000), p. 65.

${ }^{203}$ Several Panels and the AB have simply assumed that the PTAs under scrutiny were compatible with GATT Article XXIV as was seen in Turkey-Textiles. "To a large extent, WTO members have learned to live in a world where PTAs will not be challenged and, by now, they might rationally be expecting to receive a no challenge status when they enter into PTAs." Ibid, P. Mavroidis, 2006, p. 209. See Appellate Body Report, Brazil - Measures Affecting Imports of Retreaded Tyres, Body, WT/DS332/AB/R, adopted $17^{\text {th }}$ December 2007, DSR 2007:IV, 1527, p. 100; Appellate Body Report, Mexico - Tax Measures on Soft Drinks and Other Beverages, WT/DS308/AB/R, adopted $24^{\text {th }}$ March 2006, DSR 2006:I, 3, p. 23.

204 "The Panel considered that, in effect, the CONTRACTING PARTIES had withheld judgment at that time as to the conformity of the [preferential trade] agreements with the requirements of Article XXIV. The agreements had not been disapproved, nor had they been approved. The Panel found therefore that the question of the conformity of the agreements with the requirements of Article XXIV and their legal status remained open." See GATT Panel Report, European Community-Tariff Treatment on Imports of Citrus Products from certain countries in the Mediterranean Region, L/5776, $7^{\text {th }}$ February 1985, unadopted, p. 77. See also J. H. Mathis, The Legalization of GATT Article XXIV - Can Foes become Friends? in (eds.) K. Bagwell, P. Mavroidis, Preferential Trade Agreements: A Law and Economic Analysis (Cambridge University Press, 2001), p. 36; M. Trebilcock, Advanced Introduction to International Trade Law (Edward Elgar Publishing, 2015), p. 46.
} 
legal provision underpinning the establishment of PTAs was based on the understanding that PTAs could contribute to the growth of global trade. ${ }^{205}$ Political considerations related to the maintenance of colonial ties between European imperialist countries and their dominions also provided further justification for such a GATT legal provision. ${ }^{206}$ PTAs that are customs unions maintain a common external tariff (CET) on trade with the rest of the world. This legally distorts multilateral trade as preferential treatment is extended among PTA partners at the expense of non-extension to third countries. ${ }^{207}$ As a consequence of this, protection is provided to producers from PTA partners within an enlarged internal market where internally produced goods are given national treatment, whilst third countries do not share this privilege. ${ }^{208}$ PTAs that are FTAs do not feature a CET, as FTA partners maintain separate external tariffs on trade with the rest of the world. A rules of origin regime is used to enforce preferential trade among the FTA partners. ${ }^{209}$ This legally distorts multilateral trade due to the select inclusion of certain sectors of trade in the coverage of a given FTA. ${ }^{210}$

\footnotetext{
${ }^{205}$ See K. Dam, Regional Economic Arrangements and The GATT: The Legacy of A Misconception, University of Chicago Law Review, 1963, Vol. 30 (4), pp. 615-665, p. 622; J. Crawford, C. Lim, Cast Light and Evil Will Go Away: The Transparency Mechanism for Regulating Regional Trade Agreements, Three Years After, Journal of World Trade, 2011, Vol. 45(2), pp. 375-400, p. 377; O. Cattaneo, The Political Economy of PTAs in (eds.) S. Lester, B. Mercurio, L. Bartels, Bilateral and Regional Trade Agreements: Commentary and Analysis, Volume 1, Second Edition (Cambridge University Press, 2015), p. 31.

${ }^{206}$ See Chapter 1, Section 1.2.2 entitled Permitted Preferences; See also S. Cone, The Promotion of Free Trade Areas Viewed in Terms of Most-Favored-Nation Treatment and "Imperial Preference", Michigan Journal of International Law, 2005, Vol. 26(2), pp. 563-585, p.570.

207 "[A Customs Union] combines elements of freer trade with elements of greater protection. While it provides freedom to trade between the participating countries, it also provides more protection for producers inside the customs union area against competition from outside the area, since the protected market available to these producers is enlarged by the creation of a protected position in the markets of other countries partner to the union in addition to their protected position in their domestic market." H. Johnson, The Economic Theory of Customs Union in (eds) J. Bhagwati, P. Krishna, A. Panagariya, Trading Blocs: Alternative Approaches to Analyzing Preferential Trade Agreements (MIT Press, 1999), p. 127; L. A. Winters, Preferential Trade Agreements: Friend or Foe? in (eds.) K. Bagwell, P. Mavroidis, Preferential Trade Agreements: A Law and Economic Analysis (Cambridge University Press, 2001), p. 11.

${ }^{208}$ Ibid, H. Johnson in (eds) J. Bhagwati, P. Krishna, A. Panagariya, 1999, p. 127.

${ }^{209}$ L. A. Winters, Preferential Trade Agreements: Friend or Foe? in (eds.) K. Bagwell, P. Mavroidis, Preferential Trade Agreements: A Law and Economic Analysis (Cambridge University Press, 2001), p. 12.

${ }^{210}$ W. James, Rules of Origin and Rules of Preference and the World Trade Organization: The Challenge to Global Trade Liberalization in (eds.) P. Macrory, A. Appleton, M. Plummer, The World Trade Organization: Legal, Economic and Political Analysis, Volume II (Springer, 2007), p. 280.
} 


\subsubsection{GATT Article XXIV: Main Issues}

The following sections of this dissertation will (a) examine the main formation requirements outlined in GATT Article XXIV and (b) discuss the issues upon which clarifications have been provided as well as issues that remain unclarified to date. This examination will utilize the rules of interpretation of public international law that are outlined in Article 31 and 32 of the VCLT. ${ }^{211}$ Furthermore, the following sections addressing GATT Article XXIV will demonstrate how the AB has chosen to apply the customary rules of international law in interpreting GATT Article XXIV in WTO case law. A proviso applies to the discussion and analysis of GATT Article XXIV herein, as consideration is given to the various unresolved definitional issues. The select interpretative differences mentioned in this section are addressed in the context of existing WTO Member discussions and currently held interpretations of GATT Article XXIV. The existing ambiguity does not affect the central aim of this dissertation. Moreover, the focus of these sections of the dissertation is on the preamble and operative elements contained in GATT Article XXIV:4 to $8 .^{212}$ Various attempts have been made to provide clarity on the

${ }^{211}$ Article 31 of the VCLT states:

"1. A treaty shall be interpreted in good faith in accordance with the ordinary meaning to be given to the terms of the treaty in their context and in the light of its object and purpose.

2. The context for the purpose of the interpretation of a treaty shall comprise, in addition to the text, including its preamble and annexes:

(a) any agreement relating to the treaty which was made between all the parties in connection with the conclusion of the treaty;

(b) any instrument which was made by one or more parties in connection with the conclusion of the treaty and accepted by the other parties as an instrument related to the treaty.

3. There shall be taken into account, together with the context:

(a) any subsequent agreement between the parties regarding the interpretation of the treaty or the application of its provisions;

(b) any subsequent practice in the application of the treaty which establishes the agreement of the parties regarding its interpretation;

(c) any relevant rules of international law applicable in the relations between the parties.

4. A special meaning shall be given to a term if it is established that the parties so intended".

Article 32 of the VCLT states:

"Recourse may be had to supplementary means of interpretation, including the preparatory work of treaty and the circumstances of its conclusion, in order to confirm the meaning resulting from the application of article 31 , or to determine the meaning when the interpretation according to article 31 :

(a) leaves the meaning ambiguous or obscure; or

(b) leads to a result which is manifestly absurd or unreasonable."

${ }^{212}$ GATT Article XXIV: 1 to 3 and 9 to 12 will not be examined as these subsections are considered noncontentious elements that serve to further contextualize GATT Article XXIV: 4 to 8 . 
ambiguities associated with GATT Article XXIV. ${ }^{213}$ The Understanding on the Interpretation of Article XXIV of GATT 1994, which was adopted during the Uruguay Round of Multilateral Negotiations, represented an amendment to GATT Article XXIV that sought to clarify some of the contentious elements of the legal provision. ${ }^{214}$

\subsubsection{The Turkey-Textiles Case}

As noted above, WTO jurisprudence has served to clarify certain elements of GATT Article XXIV. ${ }^{215}$ In this regard, the leading case on GATT Article XXIV requires mention. The AB Report in Turkey - Textiles is viewed as an authority on various aspects of GATT Article XXIV. This case pertained to the commercial policy on textiles that Turkey implemented due to its formation of a customs union with the European Communities (EC). Turkey imposed quantitative restrictions (QRs) on 19 categories of textiles and clothing imports from India and argued in its defence that the measure was justified under GATT Article XXIV. Turkey argued that the formation requirements of GATT Article XXIV:8 (a) (i) mandated the application of the same regulations of commerce (including QRs), which its customs union partner applied to third countries. Turkey argued that the EC applies a similar policy to India. At the Panel stage, the measure was found inconsistent with GATT Articles XI ${ }^{216}$ and XIII ${ }^{217}$ and prohibited by Article 2.4 of the Agreement on Textiles and Clothing (ATC). ${ }^{218}$ The Panel explained that there were alternative options available to Turkey with respect to the formation requirements outlined in GATT Article XXIV: 8 (a). As such, the adoption of QRs was not necessary to the formation of the customs union. The Panel Report in Turkey - Textiles noted:

\footnotetext{
${ }^{213}$ Many of these ambiguities date back to the 1957 GATT working party examination of the Treaty of Rome. See GATT Secretariat, Contracting Parties Twelfth Session, Committee on Treaty of Rome (Geneva, $20^{\text {th }}$ December 1957) [L/778].

${ }^{214}$ The Understanding on GATT Article XXIV is meant to be read in tandem with GATT Article XXIV. It has provided clarity on several issues including inter alia that PTAs must comply with paragraphs 5,6,7, and 8 of GATT Article XXIV, that GATT Article XXIV is justiciable, that a reasonable length of time referenced in GATT Article XXIV: 5(c) should not exceed 10 years.

${ }^{215}$ When compared to other areas of WTO law, there has been limited case law on GATT Article XXIV. It has been argued that perhaps this is reflective of a general unwillingness to judicially enforce GATT Article XXIV. P. Mavroidis, If I Don't, Somebody Else Will (Or Won't): Testing the Compliance of Preferential Trade Agreements with Multilateral Rules, Journal of World Trade, 2006 (40) 1, pp. 187 -214, p. 187.

${ }^{216}$ GATT Article XI provides for a prohibition on quantitative restrictions.

${ }^{217}$ GATT Article XIII provides for the non-discriminatory administration of quantitative restrictions.

${ }^{218}$ Article 2.4 of the ATC provides for a prohibition on new restrictions relating to the Agreement.
} 
"With regard to the specific relationship between, in the case before us, Article XXIV and Articles XI and XIII (and Article 2.4 of the ATC), we consider that the wording of Article XXIV does not authorize a departure from the obligations contained in Articles XI and XIII of GATT and Article 2.4 of the ATC. We consider that it is possible and even necessary in order to avoid a conclusion that would lead to politically and economically absurd results, to interpret the provisions of Article XXIV in such a way as to avoid conflicts with the prescriptions of Article XI and XIII of the GATT and Article 2.4 of the ATC. [...] As we have noted, Paragraphs 5 and 8 of Article XXIV provide parameters for the establishment and assessment of a customs union, but in doing so allow flexibility in the choice of measures to be put in place on the formation of a customs union. [...] These provisions do not, however, address any specific measures that may or may not be adopted on the formation of a customs union and importantly they do not authorize violations of Articles XI and XIII, and Article 2.4 of the ATC. [...] We draw the conclusion that even on the occasion of the formation of a customs union, Members cannot impose otherwise incompatible quantitative restrictions. ${ }^{, 219}$

At the appellate stage, the AB agreed with the Panel that QRs were not justifiable using the GATT Article XXIV exception. The AB explained that GATT Article XXIV: 8 (a) (i) provides WTO Members with a limited degree of flexibility in their common commercial policy when they are in the process of forming a customs union. It was explained that this flexibility could have been utilized to address any possible concerns regarding trade diversion. The AB Report in Turkey - Textiles noted:

"We agree with the Panel that had Turkey not adopted the same quantitative restrictions that are applied by the European Communities, this would not have prevented Turkey and the European Communities from meeting the requirements of sub-paragraph 8(a)(i) of Article XXIV, and consequently from forming a customs union. We recall our conclusion that the terms of sub-paragraph $8(a)(i)$ offer some - though limited - flexibility of constituent members of a customs union when available to Turkey and the European

219 Appellate Body Report, Turkey - Restrictions on Imports of Textile and Clothing Products, WT/DS34/AB/R, adopted 19 ${ }^{\text {th }}$ November 1999, DSR 1999:VI, 2345, p. 146. 
Communities to prevent any possible diversion of trade, while at the same time meeting the requirements of sub-sub- paragraph 8(a)(i). For Example, Turkey could adopt rules of origin for textiles and clothing products that would allow the European Communities to distinguish between those textile and clothing products originating in Turkey, which would enjoy free access to the European Communities under the terms of the customs union, and those textile and clothing products originating in third countries, including India. In fact, we note that Turkey and the European Communities themselves appear to have recognized that rules of origin could be applied to deal with any possible trade diversion. Article 12(3) of Decision 1/95 of the EC-Turkey Association Council, which sets out the rules for implementing the final phase of the customs union between Turkey and the European Communities, specifically provides for the origin would have been a reasonable alternative until the quantitative restrictions applied by the European Communities are required to be terminated under the provisions of the ATC. Yet no use was made of this possibility to avoid trade diversion. Turkey preferred instead to introduce the quantitative restrictions at issue. ${ }^{220}$

In addition to the aforementioned, the $\mathrm{AB}$ Report in Turkey - Textiles outlined the judicial interpretation of inter alia the primary purpose of GATT Article XXIV, its internal requirement, its external requirement as well as the other related subsections of this provision. The clarity provided has assisted the WTO membership in understanding the text, context and object and purpose of Article XXIV. The findings of the AB will be referenced throughout the next sections of this dissertation.

\subsection{GATT Article XXIV:4}

GATT Article XXIV:4 states:

"The contracting parties [WTO Members] recognize the desirability of increasing freedom of trade by the development, through voluntary agreements, of closer integration between the economies of the countries parties to such agreements. They also recognize that the purpose of a customs union or of a free trade area should be to facilitate trade between the

\footnotetext{
${ }^{220}$ See Ibid, Appellate Body Report, 1999, p. 18.
} 
constituent territories and not raise barriers to the trade of other contracting parties with such territories."

This subsection of GATT Article XXIV refers to the development of "voluntary agreements of closer integration between the economies of countries parties to such agreements". In doing so, the ordinary meaning of the words give recognition to WTO Members that are desirous of pursuing closer economic integration with each other through the use of PTAs. ${ }^{221}$ The wording of GATT Article XXIV:4 notes the purpose of a PTA as being "to facilitate trade" between its constituents. The wording then adds the qualification whilst "not raising the barriers to trade" of third countries. This restrictive qualifier makes it clear that the text of GATT Article XXIV must be contextualized. The desirability to create PTAs must be undertaken alongside an awareness of trade diversion, which is a natural byproduct of the inherent discrimination that accompanies the selective nature of preferential trade liberalization. ${ }^{222}$ Thus, an effort must be made to minimize trade diversion. $^{223}$ The AB has contextualized the wording of GATT Article XXIV in a similar vein by stating in Turkey - Textiles: "[The] objective demands that a balance be struck by the constituent members of a customs union. A customs union should facilitate trade within the customs union, but it should not do so in a way that raises barriers to trade with third countries", 224

It is submitted that GATT Article XXIV:4 captures the primary ambition of the entire legal provision (GATT Article XXIV), as it outlines that the creation of PTAs entails the granting of preferential trade concessions to select partners by eliminating internal trade

\footnotetext{
${ }^{221}$ G. Marceau, C. Reiman, When and How is a Regional Trade Agreement compatible with the WTO?, Legal Issues of Economic Integration, 2001, Vol. 28(3), pp. 297-336, p. 309.

${ }^{222}$ Ibid, G. Marceau, C. Reiman, 2001, p. 309; N. Lockhart, A. Mitchell, Regional Trade Agreements under GATT 1994 in (ed.) A. Mitchell, Challenges and Prospects for the WTO (Cameron May, 2005), p. 219.

${ }^{223}$ The qualified nature of the ambition to create PTAs is further reflected in the Preamble to the Understanding on the Interpretation of Article XXIV of GATT 1994, which states "Reaffirming that the purpose of such agreements should be to facilitate trade between the constituent territories and not to raise barriers to the trade of other Members with such territories; and that in their formation or enlargement the parties to them should to the greatest possible extent avoid creating adverse effects on the trade of other Members;"

${ }^{224}$ See Appellate Body Report, Turkey - Restrictions on Imports of Textile and Clothing Products, WT/DS34/AB/R, adopted 19 $9^{\text {th }}$ November 1999, DSR 1999:VI, 2345, p. 15.
} 
barriers whilst discriminating against third countries by introducing external trade barriers. $^{225}$ The letter and spirit of GATT Article XXIV:4 cautions that this primary ambition of creating trade must be pursued in a balanced way. The wording of Article XXIV is focused on ventilating the qualified purpose of a PTA and does not impose a legal obligation of any kind on WTO Members. It is, therefore, asserted that GATT Article XXIV:4 does not impose a legal obligation on WTO Members to create trade.

\subsubsection{GATT Article XXIV:4: Clarified Concerns}

This section of Chapter 2 addresses certain aspects of GATT Article XXIV:4 upon which further clarity has been provided. In this regard, the AB Report in Turkey - Textiles has provided interpretational guidance on the meaning and function of GATT Article XXIV:4. It is important to note that both GATT Contracting Parties and WTO Members have long been divided on the interpretation of certain aspects of GATT Article XXIV:4. One issue of contention was whether GATT Article XXIV:4 contains any additional requirements to those specified in GATT Article XXIV:5 to $8 .{ }^{226}$ The AB has explained that GATT Article XXIV:4 constitutes an important element of the context of the chapeau of GATT Article $\mathrm{XXIV:5}$ as it contains "purposive...language, [which] does not set forth a separate obligation itself but, rather, sets forth the overriding and pervasive purpose for GATT Article XXIV, which is manifested in operative language in the specific obligations that are found elsewhere in GATT Article XXIV', ${ }^{227}$

\footnotetext{
${ }^{225}$ S. Cone, The Promotion of Free Trade Areas Viewed in Terms of Most-Favored-Nation Treatment and "Imperial Preference", Michigan Journal of International Law, 2005, Vol. 26(2), pp. 563-585, p. 567.

${ }^{226}$ The relationship between GATT Article XXIV: 4 and GATT Article XXIV: 5 to 8 was initially raised in the 1957 GATT working party examination of the Treaty of Rome. Undoubtedly, this issue provides an illustration of the stagnation of policy developments related to GATT Article XXIV and demonstrates that it has taken several decades to obtain clarity on this particular aspect of the legal provision. Where WTO member positions on this matter is concerned, the EC holds the view that GATT Article XXIV: 4 is not merely an introductory provision and it outlines additional requirements to those in GATT Article XXIV: 5 to 8. See WTO Secretariat, Fourteenth Session of the CRTA (Geneva, $24^{\text {th }}$ November 1997) [WT/REG/M/14] p. 5. New Zealand and Japan also share the EC view on this matter. See WTO Secretariat, Synopsis of "Systemic" Issues related to Regional Trade Agreements, Note by Secretariat (Geneva, $2^{\text {nd }}$ March 2000) [WT/REG/W/37], p. 15. On the contrary, Argentina, Brazil, Canada and the US consider GATT Article XXIV: 4 to be introductory in nature. See Ibid, WTO Secretariat, 2000, p. 16.

${ }^{227}$ See Appellate Body Report, Turkey - Restrictions on Imports of Textile and Clothing Products, WT/DS34/AB/R, adopted 19 ${ }^{\text {th }}$ November 1999, DSR 1999:VI, 2345, p. 15.
} 
By doing so, the AB clarified and confirmed that GATT Article XXIV:4 is, in fact, an introductory provision that does not contain any additional requirements with which WTO Members have to comply. This subsection of GATT Article XXIV serves the important function of outlining the primary ambition of the legal provision. The AB also reaffirmed that the main formation requirements of GATT Article XXIV are contained in GATT Article XXIV:5 to 8. This issue was initially affirmed by Paragraph 1 of the Understanding on the Interpretation of Article XXIV of the GATT 1994, which stated "Customs unions, free-trade areas, and interim agreements leading to the formation of a customs union or free-trade area, to be consistent with Article XXIV, must satisfy, inter alia, the provisions of paragraphs 5, 6, 7 and 8 of that Article". 228

\subsubsection{GATT Article XXIV:4: Unclarified Concerns}

This section of Chapter 2 addresses certain aspects of GATT Article XXIV:4 upon which further clarity has yet to be provided. In this regard, WTO Members have held divided opinions on the use of the phrase "not to raise barriers to trade", which has been contrasted with the requirements outlined in GATT Article XXIV:5. WTO Members, such as the EC, are of the view that GATT Article XXIV:4 refers to the fact that the net effect of trade barriers on third countries must be considered. This view is based on the understanding that an increase in the overall level of barriers is prohibited; however, it is also noted that there is no specific legal obligation prohibiting the raising of trade barriers. ${ }^{229}$ Other WTO Members view the use of this phrase in GATT Article XXIV:4 as a broader statement to guard against the raising of overall as well as new trade barriers against third countries. ${ }^{230}$ It is noted that the preambular language of the Understanding on the Interpretation of Article XXIV of the GATT 1994 explains that the formation and enlargement of PTAs should "to the greatest possible extent avoid creating adverse effects on the trade of other

\footnotetext{
228 The issue of whether notified PTAs are legally consistent with GATT Article XXIV is now in abeyance as the adoption of the 2006 Regional Trade Agreement Transparency Mechanism has led (temporarily) to less emphasis being placed on this examination. Since 2006, the examination process for PTAs no longer employs the use of working parties to assess such matters.

${ }_{229}$ Argentina, The EC and Turkey share this view. See WTO Secretariat, Synopsis of "Systemic" Issues related to Regional Trade Agreements, Note by Secretariat (Geneva, ${ }^{\text {nd }}$ March 2000) [WT/REG/W/37], p. 16.

${ }^{230}$ Australia holds this view. See Ibid, WTO Secretariat, 2000, p.16.
} 
members". ${ }^{231}$ Despite the use of this amendment to GATT Article XXIV, clarity has not been achieved on this matter because the aforementioned interpretative division between WTO Members remains. Further to this, WTO case law has not addressed this particular matter. It, therefore, remains an unclarified issue related to GATT Article XXIV: 4.

\subsection{GATT Article XXIV:5}

\section{GATT Article XXIV: 5 states}

"Accordingly, the provisions of this Agreement shall not prevent, as between the territories of contracting parties, the formation of a customs union or of a free-trade area or the adoption of an interim agreement necessary for the formation of a customs union or of a free-trade area; Provided that:

(a) with respect to a customs union, or an interim agreement leading to a formation of a customs union, the duties and other regulations of commerce imposed at the institution of any such union or interim agreement in respect of trade with contracting parties not parties to such union or agreement shall not on the whole be higher or more restrictive than the general incidence of the duties and regulations of commerce applicable in the constituent territories prior to the formation of such union or the adoption of such interim agreement, as the case may be;

(b) with respect to a free-trade area, or an interim agreement leading to the formation of a free-trade area, the duties and other regulations of commerce maintained in each of the constituent territories and applicable at the formation of such free-trade area or the adoption of such interim agreement to the trade of contracting parties not included in such area or not parties to such agreement shall not be higher or more restrictive than the corresponding duties and other regulations of commerce existing in the same constituent territories prior to the formation of the free-trade area, or interim agreement as the case may be; and

(c) any interim agreement referred to in subparagraphs (a) and (b) shall include a plan and schedule for the formation of such a customs union or of such a free-trade area within a reasonable length of time."

\footnotetext{
${ }^{231}$ See Preamble to The Understanding on the Interpretation of Article XXIV of the GATT 1994.
} 
GATT Article XXIV:5 is commonly referred to as the external requirement of GATT Article XXIV, as this subsection addresses the external barrier to trade with third countries that must be introduced to create a customs union. It also imposes an obligation with respect to the formation of FTAs whereby the duties and other regulations of commerce applied by FTA constituents to third countries should not be higher or more restrictive than those existing prior to the formation of the FTA. The ordinary meaning of the words of the chapeau of GATT Article XXIV:5 states that the provisions of the GATT 1994 "shall not prevent" WTO Members from creating PTAs in the form of customs unions and FTAs. It can, therefore, be discerned that the overall functioning of the GATT 1994 should not restrict the creation of PTAs. ${ }^{232}$

\subsubsection{GATT Article XXIV:5: The Limited Justification for GATT Inconsistent Measures}

In Turkey-Textiles, the AB interpreted the ordinary meaning of "shall not prevent" to mean that "the provisions of GATT 1994 shall not make impossible the formation of a customs union". The AB further explained that as a consequence of this, GATT Article XXIV “may be invoked as a possible defence" for a measure that would otherwise be deemed GATT inconsistent. ${ }^{233}$ The $\mathrm{AB}$ outlined that two conditions must be satisfied in order to avail of this limited justification: firstly, the measure at issue must be introduced upon the formation of a customs union that fully meets the requirements of GATT Article XXIV:5 (a) and GATT Article XXIV:8(a), and secondly, the formation of the customs union in question would have been prevented without the introduction of the inconsistent measure (the necessity test). ${ }^{234}$

In Canada-Certain Measures Affecting the Automotive Industry (Canada-Autos), the panel in that case added to the aforementioned Turkey-Textiles requirements by stating that the measure being used as a limited justification must be granted to all PTA partners and

\footnotetext{
${ }^{232}$ See Appellate Body Report, Turkey - Restrictions on Imports of Textile and Clothing Products, WT/DS34/AB/R, adopted $19^{\text {th }}$ November 1999, DSR 1999:VI, 2345, p. 11.

${ }^{233}$ See Ibid, Appellate Body Report, 1999, p. 11.

${ }^{234}$ See Ibid, Appellate Body Report, 1999, p. 16.
} 
conversely, this measure should not be extended to non-PTA partners. ${ }^{235}$ It was explained that the Canadian measure of an import duty exemption for specified commercial vehicles by certain manufacturers was inconsistent with GATT Article I:1 because it not only failed the necessity test as outlined in the Turkey-Textiles, but the measure was not granted to all NAFTA manufacturers and was also extended to manufacturers from non-NAFTA countries. $^{236}$

\subsubsection{GATT Article XXIV:5 Chapeau}

The AB interpretation of GATT Article XXIV:5 chapeau in Turkey-Textiles highlighted that reference must be made to GATT Article XXIV:8 (a) (i), which provides a definition for a customs union. ${ }^{237}$ Thus, the ordinary wording of GATT Article XXIV:5 chapeau indicates that WTO Members shall not be prevented from creating customs unions and FTAs as per the definitions contained respectively in GATT Article XXIV:8 (a) (i) and GATT Article XXIV:8 (b). GATT Article XXIV:5 chapeau concludes with "provided that" before introducing the substantive subsections of the legal provision. The inclusion of "provided that" adds context to the meaning of the chapeau and highlights that the creation of PTAs is not to be generally restricted. The AB Report in Turkey-Textiles has interpreted the phrase "provided that" to be "an essential element of the chapeau" as it introduces the fact that preferential trade liberalization should be permitted on the qualification that GATT Article XXIV:5 (a) and (b) are satisfied. ${ }^{238}$ The AB has also clarified that GATT

\footnotetext{
${ }^{235}$ The Panel Report from this case stated "In our view, Article XXIV clearly cannot justify a measure which grants WTO-inconsistent duty-free treatment to products originating in third countries not parties to a customs union or a free trade agreement." See Panel Report, Canada-Certain Measures Affecting the Automotive Industry, WT/DS139/AB/R/, WT/DS142/R, adopted $19^{\text {th }}$ June 2000 , as modified by Appellate Body Report WT/DS139/AB/R, WT/DS/142/AB/R, DSR 2000:VII, 3043, p. 366.

236 "While in view of the particular foreign affiliation of these manufacturers, the exemption will mainly benefit products of the United States and Mexico, products of certain producers in these countries who have no relationship with such manufacturers are unlikely to benefit from the exemption. Thus, in practice the import duty exemption does not apply to some products that would be entitled to duty-free treatment if such treatment were dependent solely on the fact that the products originated in the United States or Mexico. We thus do not believe that the import duty exemption is properly characterized as a measure, which provides for duty-free treatment of imports of products of parties to a free-trade area". See Ibid, Panel Report, 2000, p. 366.

${ }^{237}$ See Appellate Body Report, Turkey - Restrictions on Imports of Textile and Clothing Products, WT/DS34/AB/R, adopted $19^{\text {th }}$ November 1999, DSR 1999:VI, 2345, p. 11.

${ }^{238}$ See Ibid, Appellate Body Report, 1999, p. 13.

G. Marceau, C. Reiman, When and How is a Regional Trade Agreement compatible with the WTO?, Legal Issues of Economic Integration, 2001, Vol. 28(3), pp. 297-336, p. 310; L. Bartels, "Interim Agreements" under Article XXIV GATT, World Trade Review, 2009, Vol. 8(2), pp. 339-350, p. 340.
} 
Article XXIV:5 chapeau "cannot be interpreted correctly without constant reference to [the] purpose [outlined in GATT Article XXIV:4]". 239

It is submitted that the object and purpose of GATT Article XXIV:5 chapeau is related to the wider object and purpose of the WTO Agreement, which is to create trade and thereby assist in the movement towards global free trade. ${ }^{240}$ This task was intended to be undertaken in a non-discriminatory, multilateral environment generally governed by GATT Article I, which enshrines the MFN clause. ${ }^{241}$ GATT Article XXIV, however, represents an exception to GATT Article I and enables WTO Members to create trade via preferential liberalization. Consequently, the object of GATT Article XXIV:5 chapeau speaks to the balancing act that must be performed between the MFN clause, long considered the cornerstone of the MTS, and the exclusive nature of preferential trade liberalization reflected in GATT Article XXIV. ${ }^{242}$

A similar understanding of this balancing act is captured in the preamble to the Understanding on the Interpretation of Article XXIV of the GATT 1994, which states "Reaffirming that the purpose of such [preferential trade] agreements should be to facilitate trade between the constituent territories and not to raise barriers to the trade of other Members with such territories; and that in their formation or enlargement the parties to them should to the greatest possible extent avoid creating adverse effects on the trade of other Members". In this vein, it is again recalled that GATT Article XXIV:4 makes a direct

${ }^{239}$ See Appellate Body Report, Turkey - Restrictions on Imports of Textile and Clothing Products, WT/DS34/AB/R, adopted $19^{\text {th }}$ November 1999, DSR 1999:VI, 2345, p. 15.

${ }^{240}$ A similar view is expressed in the preamble to the WTO Agreement, which states "Recognizing that their relations in the field of trade and economic endeavor should be conducted with a view to raising the standards of living, ensuring full employment and a large and steadily growing volume of real income and effective demand, and expanding the production of trade in goods and services [...]"

${ }^{241}$ N. Lockhart, A. Mitchell, Regional Trade Agreements under GATT 1994 in (ed.) A. Mitchell, Challenges and Prospects for the WTO (Cameron May, 2005), p. 219. See also Preamble to the WTO Agreement, which states: "Being desirous of contributing to these objectives by entering into reciprocal and mutually advantageous arrangements directed to the substantial reduction of tariffs and other barriers to trade and to the elimination of discriminatory treatment in international trade relations,"

${ }^{242}$ G. Marceau, C. Reiman, When and How is a Regional Trade Agreement compatible with the WTO?, Legal Issues of Economic Integration, 2001, Vol. 28(3), pp. 297-336, p. 315; R. Howse, Regulatory Cooperation, Regional Trade Agreements and World Trade Law: Conflict or Complementarity?, Law and Contemporary Problems, 2015, Vol. 78 (4), pp. 137-151, p. 142; M. Trebilcock, R. Howse, A. Elliason, The Regulation of International Trade $4^{\text {th }}$ Edition (Routledge 2013), p. 107. 
reference in its wording to the balancing act of facilitating trade between PTA constituents whilst not raising the barriers to trade for third countries. In Turkey-Textiles, the AB has interpreted GATT Article XXIV:4 as "[setting] forth the overriding and pervasive purpose for Article XXIV, which is manifested in the operative language in specific obligations that are found elsewhere in Article XXIV, ${ }^{243}$ Thus, it is submitted that the balancing act outlined in GATT Article XXIV:4 provides the pervasive purpose on which the object and purpose of GATT Article XXIV:5 chapeau can be contextualized.

\subsubsection{GATT Article XXIV:5 (a)}

The text of GATT Article XXIV:5 (a) refers to the creation of PTAs that are "customs unions" or "interim agreements leading" thereto. The ordinary meaning of the words utilized explains that GATT Article XXIV can be used to create these two instruments, which lead to PTAs. GATT Article XXIV:5 (a) also mentions that "duties and other regulations of commerce" introduced upon the formation of a customs union or interim agreements leading thereto are applicable to the trade of third countries and should not be "on the whole higher or more restrictive" than the "general incidence" of that which existed prior to the creation of a customs union or an interim agreement leading thereto. Broadly speaking, this paragraph refers to the external PTA trade barrier that must be created for trade with third countries and adds the conditionality that such a barrier should not restrict trade by imposing higher duties and other regulations of commerce. On this point, the AB agreed with the initial comments provided by the Panel in Turkey-Textiles whereby it was submitted that GATT Article XXIV:5 (a) constitutes "an economic test for assessing whether a specific customs union is compatible with Article XXIV', ${ }^{244}$ This view is based on the fact that overall effect of the abovementioned (newly created) external PTA trade barrier, consisting of measures and policies, should not be more trade restrictive. ${ }^{245}$

\footnotetext{
${ }^{243}$ See Appellate Body Report, Turkey - Restrictions on Imports of Textile and Clothing Products, WT/DS34/AB/R, adopted $19^{\text {th }}$ November 1999, DSR 1999:VI, 2345, p. 15.

${ }^{244}$ See Ibid, Appellate Body Report, 1999, p. 15.

${ }^{245}$ See Ibid, Appellate Body Report, 1999, p. 15.
} 


\subsubsection{GATT Article XXIV:5 (b)}

The text of GATT Article XXIV:5 (b) refers to the creation of PTAs that are "FTAs" or “interim agreements leading” thereto. Again, the ordinary meaning of the words utilized explains that GATT Article XXIV can be used to create these two instruments, which lead to PTAs. GATT Article XXIV:5 (b) also references that "duties and other regulations of commerce" maintained (separately) by each FTA partner and applicable to the trade of third countries should not be "higher or more restrictive" than those which existed prior to the creation of the FTA or its interim agreement. Broadly speaking, this paragraph refers to the external barrier to trade with third countries created by FTAs, which use rules of origin to assist with selective external trade. Consequently, FTA partners still maintain individual duties and other regulations of commerce (measures), as they do not share a common external regime. Again, it is stated that the external barrier created by the FTA should not restrict trade by imposing higher duties and other regulations of commerce. Therefore, the individual measures of the various FTA constituents must be assessed to ensure against this. ${ }^{246}$

\subsubsection{GATT Article XXIV:5 (c)}

The text of GATT Article XXIV:5 (c) refers to the fact that interim agreements leading to PTAs require that " $a$ plan and schedule for the[ir] formation" be submitted within a "reasonable period of time". The ordinary meaning of this wording refers to the nature of interim agreements, as they are yet to be finalized per se. Such interim agreements are necessary and useful as they provide WTO Members with a timeframe in which to establish their PTAs. It must be noted that the implementation of a PTA is not a swift process, but rather a phased process where WTO Members require time to implement the legal and administrative measures that will result in creation of a finalized PTA. Nevertheless, the MTS can ill afford to have incomplete PTAs, as this could result in inconsistency and complications. The requirement that interim agreements provide a plan and schedule with a timeline for finalization provides the WTO membership with greater transparency and

\footnotetext{
${ }^{246}$ M. Trebilcock, Advanced Introduction to International Trade Law (Edward Elgar Publishing, 2015), p.
} 47. 
policy coherence within the MTS. ${ }^{247}$ It should be noted that GATT Article XXIV:5 (c) is related to GATT Article XXIV:7 (b), which is addressed in subsequent section of Chapter 2. Both of these provisions refer to the WTO review mechanism for PTAs and illustrate that WTO working parties (consisting of WTO Members) have the ability to make recommendations in the event that a submitted plan and schedule for an interim agreement is unlikely to result in the formation of a PTA within the time period specified or if an unreasonable period of time for formation has been proposed. ${ }^{248}$ It is submitted that the object of GATT Article XXIV:5 (c) is to enhance transparency by requiring that WTO Members share information regarding the formation of their PTAs.

\subsubsection{The Context and Object and Purpose of GATT Article XXIV:5 (a) and (b)}

It must be stated that the object and purpose of both GATT Article XXIV:5 (a) and (b) is related, as both subsections of this provision are concerned with the external effect that a creation of a PTA might present to the trade of third countries. ${ }^{249}$ Hence, these subsections serve a preemptive purpose with respect to any possible detrimental effects that might arise in the MTS as a result of preferential trade liberalization. It is surmised that, if, "duties and other regulations of commerce" are, in fact, higher than prior to the establishment of a PTA, this might pose a trade diverting effect on the trade of third countries. And in this vein, the context of XXIV:5 chapeau is referenced as it cautions against institutional permission or approval being given to PTAs that are likely to cause detrimental effects within the MTS. Thus, GATT Article XXIV:5 chapeau provides the conditional introduction that the GATT 1994 should only allow for the creation of PTAs that meet the conditions outlined in GATT Article XXIV:5 (a) and (b). ${ }^{250}$ In Turkey-Textiles, the AB

\footnotetext{
247 "It is not the intention of the Contracting Parties to permit GATT Article XXIV to serve as a backdoor route to preferential trade arrangements not constituting full fledged customs unions or FTAs". K. Dam, Regional Economic Arrangements and The GATT: The Legacy of A Misconception, University of Chicago Law Review, 1963, Vol. 30 (4), pp. 615-665, p. 618. "[The inclusion of GATT Article XXIV:5 (c)] would ensure [against] very long undefined periods of interim agreements". See J. Bhagwati, Termites in the Trading System: How Preferential Agreements Undermine Free Trade (Oxford University Press, 2008), p. 21.

${ }^{248}$ L. Bartels, "Interim Agreements" under Article XXIV GATT, World Trade Review, 2009, Vol. 8(2), pp. 339-350, p. 341.

${ }^{249}$ R. Howse, Regulatory Cooperation, Regional Trade Agreements and World Trade Law: Conflict or Complementarity?, Law and Contemporary Problems, 2015, Vol. 78 (4), pp. 137-151, p. 142.

${ }^{250} \mathrm{~S}$. Cone, The Promotion of Free Trade Areas Viewed in Terms of Most-Favored-Nation Treatment and "Imperial Preference", Michigan Journal of International Law, 2005, Vol. 26(2), pp. 563-585, p. 566.
} 
asserted this when it stated that GATT Article XXIV can only be invoked as a justification for a measure that is inconsistent with certain GATT provisions if the measure is introduced "upon the formation of a customs union which meets the requirement in sub-paragraph 5 (a) of Article XXIV...". ${ }^{251}$ Thus, it can be discerned that customs unions must meet the requirements of GATT Article XXIV:5 (a) and by extension, FTAs must meet the requirements of GATT Article XXIV:5 (b). It is, therefore, asserted that GATT Article XXIV: 5 imposes a legal obligation on WTO members to comply with its specified framework in order to create balanced PTAs, which are not inconsistent with the underlying goal of GATT Article I. GATT Article XXIV:5 does not impose a legal obligation on WTO Members to create trade.

\subsubsection{GATT Article XXIV:5: Clarified Concerns}

This section of Chapter 2 addresses certain aspects of GATT Article XXIV:5 upon which further clarity has been provided. The Understanding on the Interpretation of Article XXIV of the GATT 1994 has provided clarification on GATT Article XXIV:5 and in doing so, has contributed to greater understanding on what this subsection of the legal provision aims to achieve. With respect to GATT Article XXIV:5 (a), it has been explained that prior "general incidence of duties and other regulations of commerce" of the constituents to a customs union (or interim agreement leading thereto) referenced are to be based on the overall assessment of weighted average tariff rates and the applied rate ${ }^{252}$ of customs duties collected. ${ }^{253}$ The AB reaffirmed this understanding in Turkey - Textiles. ${ }^{254}$

With respect to GATT Article XXIV:5 (c), it has been explained that the "reasonable amount of time" that is permissible regarding the transition from an interim agreement leading to the establishment of a PTA to a fully established PTA should only exceed ten

\footnotetext{
${ }^{251}$ See Appellate Body Report, Turkey - Restrictions on Imports of Textile and Clothing Products, WT/DS34/AB/R, adopted $19^{\text {th }}$ November 1999, DSR 1999:VI, 2345, p. 14.

${ }^{252}$ The distinction between bound and applied rates of duty stems from the practice that WTO Members commit to bind their tariff rates at a certain level (the bound rate), however, the actual rate of application can be performed at a lower level (the applied rate). These rates tend to be the same in developed countries; however, developing countries tend to use their bound rates of duty as a tariff ceiling with the lower applied rate of duty.

${ }^{253}$ See paragraph 2 of the Understanding on the Interpretation of Article XXIV of the GATT 1994.

${ }^{254}$ See Appellate Body Report, Turkey - Restrictions on Imports of Textile and Clothing Products, WT/DS34/AB/R, adopted 19 $9^{\text {th }}$ November 1999, DSR 1999:VI, 2345, p. 14.
} 
years in exceptional circumstances. ${ }^{255}$ Clarification was also provided on the scope of authority, possessed by the WTO review mechanism for PTAs (via WTO working parties), to address interim agreements leading to the establishment of a PTA. The Understanding on the Interpretation of GATT Article XXIV of the GATT 1994 explained that WTO working parties have the scope of authority to make recommendations (via its working party report) regarding the proposed timeframe for completion of a PTA as well as formation measures required for the completion of a PTA. ${ }^{256}$ It is noteworthy that the Understanding on the Interpretation of Article XXIV of the GATT 1994 empowered WTO working parties with the authority to recommend (via its working party report) a plan and schedule for PTAs that were non-compliant with the requested GATT Article XXIV:7 (a) plan and schedule. In such cases, it has been explained that the parties to a PTA, notified without a plan and schedule, would be required to modify their PTA according to the WTO working party report recommendation. In the event that the WTO working party report recommendation is not adopted, the parties would not be permitted to maintain or enter their PTA into force. ${ }^{257}$

\subsubsection{XXIV:5 Unclarified Concerns}

This section of Chapter 2 addresses certain aspects of GATT Article XXIV:5 upon which further clarity has yet to be provided. Although the AB clarified certain aspects of GATT Article XXIV:5 chapeau in Turkey-Textiles, WTO Members are still divided on its meaning and whether GATT Article XXIV represents a derogation from only GATT Article I or from all other GATT provisions. ${ }^{258}$ Many WTO Members hold the view that legal cover should not be provided for measures, which would otherwise be legally inconsistent with the WTO Agreement simply because they have been implemented in the context of PTA formation. These WTO members argue that GATT Article XXIV does not provide WTO members who enter PTAs with the right to violation various GATT legal provisions. ${ }^{259}$

\footnotetext{
${ }^{255}$ See paragraph 3 of the Understanding on the Interpretation of Article XXIV of the GATT 1994.

${ }^{256}$ See paragraph 8 of the Understanding on the Interpretation of Article XXIV of the GATT 1994.

${ }^{257}$ See paragraph 10 of the Understanding on the Interpretation of Article XXIV of the GATT 1994.

${ }^{258}$ See WTO Secretariat, Fourteenth Session of the CRTA (Geneva, 24 ${ }^{\text {th }}$ November 1997) [WT/REG/M/14] p. 4 ; WTO Secretariat, Fifteenth Session of the CRTA (Geneva, $13^{\text {th }}$ January 1998), p. 19.

${ }^{259}$ Korea, India, Hong Kong China and Japan among others hold the view that GATT Article XXIV should be a derogation of only GATT Article I. See WTO Secretariat, Synopsis of "Systemic" Issues related to Regional Trade Agreements, Note by Secretariat (Geneva, $2^{\text {nd }}$ March 2000) [WT/REG/W/37], p. 12.
} 
Other WTO members consider GATT Article XXIV a derogation from numerous GATT provisions due to the usage of the phrase 'the provisions of this Agreement shall not prevent' in the first sentence of GATT Article XXIV: 5. These WTO members argue that GATT Article XXIV does not define the number of provisions from which derogations are allowed. ${ }^{260}$ It has also been argued that international law on multilateral treaties allows for a subset of parties to a wider multilateral agreement to form a subsequent agreement among themselves provided that it does not diminish the rights of third parties to the initial wider agreement. $^{261}$ It is admitted that this would result in varied rights and obligations among the parties. In the context of PTAs, this argument would allow WTO members to join PTAs so long as it does not modify the rights of WTO members that are third parties to the PTA and signatories to the wider WTO Agreement. ${ }^{262}$ Although a substantive interpretation on the entirety of this matter has yet to be achieved, the AB clarified in Peru-Additional Duty on Imports of Certain Agricultural Product (Peru-Agricultural Products) that FTA constituents do, in fact, modify as between themselves their WTO rights and obligations. ${ }^{263}$

Moreover, the term "other regulations of commerce" referenced in GATT Article XXIV:5 (a) and (b) has been the source of divided opinions for WTO Members, as they have maintained different understandings of this term. ${ }^{264}$ Even the wording that surrounds the aforementioned term has led to disagreement among WTO Members. GATT Article XXIV:5 (a) makes reference to duties and other regulations of commerce "imposed" by a PTA shall not be higher than that which was "applicable" prior to the formation of the PTA. In contrast, GATT Article XXIV:5 (b) refers to duties and other regulations of commerce "maintained" in the PTA partner countries and "applicable" at the formation of

\footnotetext{
${ }^{260}$ In this vein, the EC is a prominent proponent of the view that GATT Article XXIV should represent a derogation from other GATT provisions in addition to GATT Article I. See Ibid, WTO Secretariat, 2000, p. 12 .

${ }^{261}$ Ibid, WTO Secretariat, 2000, p. 12.

${ }^{262}$ Ibid, WTO Secretariat, 2000, p. 12.

263 See Appellate Body Report, Peru-Additional Duty on Imports of Certain Agricultural Products, WT/DS/457/AB/R and Add 1, adopted $31^{\text {st }}$ July 2015, p. 38.

${ }^{264}$ One of the main sticking points in this regard is whether this definition includes safeguards and antidumping measures.
} 
the PTA. ${ }^{265}$ It is noted that paragraph 2 of the Understanding on the Interpretation of Article XXIV of the GATT 1994 clarifies certain aspects of the legal provision pertaining to the duties and charges referenced under GATT Article XXIV: 5, however, it does not provide a definition for "other regulations of commerce".

On the matter of GATT Article XXIV:5 (a), the AB explained in Turkey - Textiles that this subsection is aimed at ensuring that the effects of the resulting PTA trade measures and policies shall not be overall more trade restrictive than the previously existing separate trade measures and policies of the respective PTA partners. ${ }^{266}$ The AB agreed with the Panel that this in effect serves as an economic test of assessing the compatibility of the PTA with GATT Article XXIV. ${ }^{267}$ WTO Members have been divided on exactly how this overall economic test should be applied.

\subsection{GATT Article XXIV: 6:}

GATT Article XXIV: 6 states:

"If, in fulfilling the requirements of subparagraph 5 (a), a contracting party proposes to increase any rate of duty inconsistently with the provisions of Article II, the procedure set forth in Article XXVIII shall apply. In providing for compensatory adjustment, due account shall be taken of the compensation already afforded by the reduction brought about in the corresponding duty of the other constituents of the union."

GATT Article XXIV:6 addresses the issue of compensatory adjustment in the event that it is required as a result of the creation of a PTA. The ordinary meaning of the wording of

\footnotetext{
${ }^{265}$ The EC holds the view that this wording refers to bound rates of duty. See WTO Secretariat, Synopsis of "Systemic" Issues related to Regional Trade Agreements, Note by Secretariat (Geneva, $2^{\text {nd }}$ March 2000) [WT/REG/W/37], p. 17.

${ }^{266}$ See Appellate Body Report, Turkey - Restrictions on Imports of Textile and Clothing Products, WT/DS34/AB/R, adopted 19 $9^{\text {th }}$ November 1999, DSR 1999:VI, 2345, p. 15.

${ }^{267}$ See Ibid, Appellate Body Report, 1999, p. 15.

Although there still remains an interpretational divide on this issue, (as previously mentioned, the EC holds the view that these duties are a reference to bound duties) it is argued that the status quo has had limited effect on the use of GATT Article XXIV. To date, working party examinations have not noted that any PTAs have failed the economic means test outlined in GATT Article XXIV: 5 or stated that a notified PTA plan is unlikely to result in the formation of a PTA as per GATT Article XXIV: 7(b). Perhaps, this is reflective of guarded approach to analyzing GATT Article XXIV.
} 
this subsection commences with the phrase "If, in fulfilling the requirements of subparagraph 5 (a)", which affirms that GATT Article XXIV:6 is referring to WTO Members that are in the process of creating the external barrier to trade with third countries that customs unions or interim agreements leading thereto require. It is recalled that this external trade barrier must not impose "duties and other regulations of commerce" that are, "on the whole higher or more restrictive" than the "general incidence" of that which existed prior to the formation of a customs union or an interim agreement leading thereto. ${ }^{268}$ GATT Article XXIV:6 further states that "if" a WTO Member "proposes to increase any rate of duty inconsistently with the provisions of Article II' as a result of the creation of the external barrier to trade with third countries, this proposal will trigger the procedure outlined in GATT Article XXVIII, which outlines the GATT procedure for the modification of tariff schedules. The use of the word "if" implies that not all WTO Members, that are in the process of fulfilling the requirements of GATT Article XXIV:5 (a), might need to avail of this subsection of the legal provision.

GATT Article XXIV:6 further contextualizes this requirement, in the event that it is needed, by stating that "due account shall be taken of the compensation already afforded by the reduction brought about in the corresponding duty of the other constituents of the union." This qualification makes known that consideration will be given the overall effect of the tariff adjustments regarding GATT Article II made by other constituents of the customs union that is in the process of being created. It is noted that in the process of creating the external barrier to trade with third countries, a customs union must create a CET. This requires that a tariffs adjustment exercise be undertaken to align member tariffs to a common (external) level. Such an exercise might require some members to increase their tariffs and other members to decrease their tariffs. The aforementioned sentence of GATT Article XXIV:6 notes that consideration will be given to this particular aspect: the

\footnotetext{
${ }^{268}$ Again, it must be recalled that the qualification outlined in GATT Article XXIV:5 chapeau only allows the GATT 1994 to permit the formation of PTAs which meet the aforementioned requirements. The main thrust of the qualification in GATT Article XXIV:5 chapeau is to assist in preventing the establishment of PTAs that could produce detrimental effects to the wider MTS.
} 
members that might be required to decrease their tariffs in the tariff adjustment exercise regarding GATT Article II.

The wording of GATT Article XXIV:6 also highlights its object and purpose as being that of compensatory adjustment. It is submitted that the aim of compensatory adjustment is an attempt to restore some semblance of balance to the MTS given the discriminatory nature of PTAs and their possible detrimental effects on the trade of third countries. It is, therefore, asserted that GATT Article XXIV:6 imposes a legal obligation on WTO Members to engage in a compensatory adjustment exercise in the event of duty increases related to GATT Article II are required when the obligation in GATT Article XXIV:5 (a) is being fulfilled. GATT Article XXIV:6 does not impose a legal obligation on WTO Members to create trade.

\subsubsection{GATT Article XXIV:6: Clarified Concerns}

This section of Chapter 2 addresses certain aspects of GATT Article XXIV:6 upon which further clarity has been provided. The Understanding on the Interpretation of Article XXIV of the GATT 1994 sought to clarify certain aspects of GATT Article XXIV:6 and in doing so, explained that the compensatory adjustment process applies to bound rates of duty, which PTA parties are intent upon increasing. It further outlined that the compensation adjustment process could entail compensation through the reduction of duties on a different tariff line in the event that common agreement cannot be reached on the initial tariff line that was the target of the adjustment process. ${ }^{269}$ Moreover, it has also been highlighted that the GATT 1994 does not require that a WTO member, who is intent on joining a customs union or an interim agreement leading thereto, to compensate its constituents in event that it has to reduce it duties when undertaking the duty adjustment process to establish a common external tariff. ${ }^{270}$

\footnotetext{
${ }^{269}$ See paragraph 5 of the Understanding on the Interpretation of Article XXIV of the GATT 1994.

${ }^{270}$ See paragraph 6 of the Understanding on the Interpretation of Article XXIV of the GATT 1994.
} 


\subsubsection{GATT Article XXIV:6: Unclarified Concerns}

This section of Chapter 2 addresses aspects of GATT Article XXIV:6 upon which further clarity has yet to be provided. Many WTO members remain divided on the issue of the timing related to GATT Article XXIV:6. It remains unclear precisely when compensatory negotiations should occur. Paragraph 4 of the Understanding on the Interpretation of Article XXIV of GATT 1994 has stated that such negotiations should commence before concessions are modified or withdrawn upon the formation of a customs union. ${ }^{271}$ Nevertheless, mixed opinions still abound on this matter, as some WTO Members consider that compensatory negotiations should occur after the conclusion of negotiations on the formation of a customs union. This view cites the difficulty involved in finalizing compensation before the customs union is finalized. ${ }^{272}$ Other WTO Members hold the view that compensatory negotiations should occur before any tariff concession is withdrawn especially given that some transition periods can be lengthy. ${ }^{273}$

\subsection{GATT Article XXIV:7}

GATT Article XXIV:7 states:

“(a) Any contracting party deciding to enter into a customs union or free-trade area, or an interim agreement leading to the formation of such a union or area, shall promptly notify the CONTRACTING PARTIES and shall make available to them such information regarding the proposed union or area as will enable them to make such reports and recommendations to contracting parties as they may deem appropriate.

(b) If, after having studied the plan and schedule included in an interim agreement referred to in paragraph 5 in consultation with the parties to that agreement and taking due account of the information made available in accordance with the provisions of subparagraph (a),

\footnotetext{
${ }^{271}$ Paragraph 4 of The Understanding on GATT Article XXIV states "Paragraph 6 of Article XXIV establishes the procedure to be followed when a Member forming a customs union proposes to increase a bound rate of duty. In this regard Members reaffirm that the procedure set forth in Article XXVIII, as elaborated in the guidelines adopted on 10 November 1980 (BISD 27S/26-28) and in the Understanding on the Interpretation of Article XXVIII of GATT 1994, must be commenced before tariff concessions are modified or withdrawn upon the formation of a customs union or an interim agreement leading to the formation of a customs union."

${ }^{272}$ See WTO Secretariat, Synopsis of "Systemic" Issues related to Regional Trade Agreements, Note by Secretariat (Geneva, $2^{\text {nd }}$ March 2000) [WT/REG/W/37], p. 29.

${ }^{273}$ See Ibid, WTO Secretariat, 2000, p. 29.
} 
the CONTRACTING PARTIES find that such agreement is not likely to result in the formation of a customs union or of a free-trade area within the period contemplated by the parties to the agreement or that such period is not a reasonable one, the CONTRACTING PARTIES shall make recommendations to the parties to the agreement. The parties shall not maintain or put into force, as the case may be, such agreement if they are not prepared to modify it in accordance with these recommendations.

(c) Any substantial change in the plan or schedule referred to in paragraph 5 (c) shall be communicated to the CONTRACTING PARTIES, which may request the contracting parties concerned to consult with them if the change seems likely to jeopardize or delay unduly the formation of the customs union or of the free-trade area."

GATT Article XXIV:7 is known as the notification requirement of GATT Article XXIV, as the wording contained in GATT Article XXIV:7 (a) requires that WTO Members "shall promptly notify" information regarding their PTA that is under negotiation. The ordinary meaning of the words of GATT Article XXIV:7 affirms that a procedural notification requirement is contained therein, as the direction is given that WTO Members "shall notify" their PTA to other WTO Members via the WTO Secretariat and "shall make available information" on their PTA. GATT Article XXIV:7 (b) assists in contextualizing how this subsection of GATT Article XXIV is intended to function. Reference is made to the WTO review mechanism for PTAs, as it is outlined that WTO Members are required to "[study] the plan and schedule" of a notified PTA. Furthermore, the WTO Members are required to assess if the plan and schedule notified is "likely to result in the formation of a customs union or of a free-trade area within the period contemplated by the parties to the agreement or that such period is not a reasonable one”. GATT Article XXIV:7 (c) is related to GATT Article XXIV:5(a), as both provisions require that information on a PTA plan and schedule be submitted to the WTO Secretariat. WTO Members must also notify any substantial modifications made to their PTA. This requirement is necessary in the event that "the change seems likely to jeopardize or delay unduly the formation" of the PTA.

By fulfilling all of the aforementioned notification requirements, WTO Members assist in the achievement of the main object and purpose of GATT Article XXIV:7: the 
enhancement of transparency. Further confirmation on the matter of enhancing transparency is reflected as Article XXIV:7 states that by providing information on a PTA, WTO Members "will enable [Contracting Parties] to make [...] reports and recommendations [...] as they may deem appropriate." The importance of enhanced transparency is also echoed in the preamble to the Understanding on the Interpretation of Article XXIV of the GATT 1994, which states "Convinced also of the need to reinforce the effectiveness of the role of the Council for Trade in Goods in reviewing agreements notified under Article XXIV, by clarifying the criteria and procedures for the assessment of new or enlarged agreements, and improving the transparency of all Article XXIV agreements". In this vein, it is submitted that GATT Article XXIV:7 is intended to serve as a monitoring mechanism ventilating relevant information regarding the formation of PTAs within the MTS. GATT Article XXIV:7 operates in tandem with the WTO review mechanism for PTAs (via working parties) to assist with transparency concerns and to ensure that viable PTAs are established within the MTS. ${ }^{274}$ The information obtained as a result of compliance with GATT Article XXIV:7 can also assist in determining the overall impact of PTAs on the growth and regulation of global trade. It is, therefore, asserted that GATT Article XXIV:7 imposes a legal obligation on WTO Members to comply with its various procedural notification requirements for information on PTAs. GATT Article XXIV:7 does not impose a legal obligation on WTO Members to create trade.

\subsubsection{GATT Article XXIV:7: Clarified Concerns}

This section of Chapter 2 addresses certain aspects of GATT Article XXIV:7 upon which further clarity has been provided. It should be noted that GATT Article XXIV:7 can be considered the original attempt to inject transparency into the PTA formation framework and reflects the fact that transparency has long been an institutional concern for the

\footnotetext{
${ }^{274}$ It should be noted that the institutional regulation of PTAs was characterized by policy stagnation for many decades due to the interpretative divide on the meaning of GATT Article XXIV. Consequently, the ability of GATT Contracting Parties/WTO Members (via working groups) to assess the viability of proposed PTAs was severely handicapped. It was only in rare instances that GATT Article XXIV compatibility was declared and all other PTAs were not declared incompatible with GATT Article XXIV. See P. Mavroidis, The Regulation of International Trade, Volume I, GATT (MIT Press, 2016), p. 302; G. Marceau, C. Reiman, When and How is a Regional Trade Agreement compatible with the WTO?, Legal Issues of Economic Integration, 2001, Vol. 28(3), pp. 297-336, p. 311; N. Lockhart, A. Mitchell, Regional Trade Agreements under GATT 1994 in (ed.) A. Mitchell, Challenges and Prospects for the WTO (Cameron May, 2005), p. 220. See also Chapter 3, Section 3.2 entitled The Committee on Regional Trade Agreements.
} 
regulation of PTAs. The Understanding on the Interpretation of Article XXIV of the GATT 1994 has clarified that all notifications under GATT Article XXIV:7 (a) are to be examined by a working party (consisting of WTO Members) in light of the relevant provisions of the GATT 1994 and paragraph 1 of the Understanding on the Interpretation of Article XXIV of the GATT 1994. ${ }^{275}$ In addition to this, it was explained that WTO Members are expected to notify any significant changes and/or developments to their PTA as they occur. ${ }^{276}$ On a related note, it should be mentioned that the Regional Trade Agreement Transparency Mechanism of 2006 contains several (separate and additional) requirements for PTA notification and this is bolstered by precise language regarding when notifications are required. $^{277}$ These requirements serve a similar purpose of ventilating information regarding the PTA landscape of the MTS. It is notable, however, that WTO Members have not maintained a stellar notification record even in the period after the adoption of new rules on PTA notifications. ${ }^{278}$

\subsubsection{GATT Article XXIV:7: Unclarified Concerns}

This section of Chapter 2 addresses certain aspects of GATT Article XXIV:7 upon which further clarity has yet to be provided. In this regard, it is highlighted that some WTO Members consider GATT Article XXIV: 7 to be an imprecise requirement and they consider its wording to be unclear regarding exactly when the notification should occur. Some WTO members consider the wording "shall promptly notify" to reflect that notification should occur before the entry into force of the PTA ${ }^{279}$, whilst other WTO Members consider this an impracticality because of the nature and context of last minute concessions involved in negotiations. ${ }^{280}$ In addition to this, interpretative division also

\footnotetext{
${ }^{275}$ See paragraph 7 of the Understanding on the Interpretation of Article XXIV of the GATT 1994.

${ }^{276}$ See paragraph 7 of the Understanding on the Interpretation of Article XXIV of the GATT 1994.

277 See Chapter 3, Section 3.3 entitled Regional Trade Agreement Transparency Mechanism.

${ }^{278}$ See Chapter 3, Section 3.3.2 entitled Notifications.

${ }^{279}$ Hong Kong China, Japan and Korea among others share this view. See WTO Secretariat, Synopsis of "Systemic" Issues related to Regional Trade Agreements, Note by Secretariat (Geneva, $2^{\text {nd }}$ March 2000) [WT/REG/W/37], p. 8.

${ }^{280}$ Norway and Canada support the view that notification should occur after the entry into force of the RTA. See Ibid, WTO Secretariat, 2000, p. 8.
} 
exists regarding whether the "information regarding the proposed union or area" requested in GATT Article XXIV: 7 (a) should be qualitative or quantitative in nature. ${ }^{281}$

\subsection{GATT Article XXIV:8}

GATT Article XXIV:8 states:

"For the purposes of this Agreement:

(a) A customs union shall be understood to mean the substitution of a single customs territory for two or more customs territories, so that

(i) duties and other restrictive regulations of commerce (except, where necessary, those permitted under Articles XI, XII, XIII, XIV, XV and XX) are eliminated with respect to substantially all the trade between the constituent territories of the union or at least with respect to substantially all the trade in products originating in such territories, and,

(ii) subject to the provisions of paragraph 9, substantially the same duties and other regulations of commerce are applied by each of the members of the union to the trade of territories not included in the union;

(b) A free-trade area shall be understood to mean a group of two or more customs territories in which the duties and other restrictive regulations of commerce (except, where necessary, those permitted under Articles XI, XII, XIII, XIV, XV and XX) are eliminated on substantially all the trade between the constituent territories in products originating in such territories."

GATT Article XXIV:8 is commonly referred to as the internal requirement of GATT Article XXIV. This subsection addresses the formation requirements that form the very core of the legal provision, as emphasis is placed on the elimination of trade barriers that should result in increased trade creation. The ordinary meaning of the words of GATT Article XXIV:8 (a) introduce the GATT definition of a customs union as being "the

\footnotetext{
${ }^{281}$ Canada holds the view that full disclosure of quantitative information is required to understand how the economies of the PTA partners function after the establishment of the PTA and that such disclosure aids in assessing conformity with WTO rules. See Ibid, WTO Secretariat, 2000, p. 10.
} 
substitution of a single customs territory for two or more customs territories". It can be discerned from these words that the creation of a customs union involves transitioning from one country with a single external customs arrangement (of duties and other regulations of commerce) to an enlarged internal market, consisting of two or more countries that utilize a single external customs arrangement.

\subsubsection{GATT Article XXIV:8 (a) (i)}

GATT Article XXIV:8 (a) (i) explains that "duties and other restrictive regulations of commerce" should be eliminated on "substantially all trade" between the constituents of a customs union or at least on "substantially all the trade in products" from the constituents of a customs union. The ordinary meaning of these words refers to the process of creating a customs union whereby the internal barriers to trade are removed between and among the constituents and tariffs are liberalized on substantially all trade in order to create an enlarged internal market. The implementation of these measures is intended to stimulate trade creation between the customs union constituents. The AB stated in Turkey-Textiles that GATT Article XXIV:8 (a) (i) "establishes the standard for the internal trade between constituent members in order to satisfy the definition of a customs union". ${ }^{282}$

The contents of GATT Article XXIV:8 (a) (i) is commonly referred to as the SAT (substantially all trade) requirement and is contextualized by the qualification of "(except, where necessary, those permitted under Articles XI, XII, XIII, XV and XX)". It is understood that the duties and other restrictive regulations of commerce that relate to these provisions of the GATT 1994 need not be eliminated in the context of this subsection of GATT Article XXIV. The AB explained in Turkey-Textiles that the maintenance of these respective provisions offers customs union constituents "some flexibility" when liberalizing their internal trade regime. ${ }^{283}$ Further to this, the $\mathrm{AB}$ cautioned that the aforementioned flexibility "is limited by the requirement that duties and other restrictive regulations of commerce be eliminated with respect to substantially all internal trade". ${ }^{284}$ The $\mathrm{AB}$ also

\footnotetext{
${ }^{282}$ See Appellate Body Report, Turkey - Restrictions on Imports of Textile and Clothing Products, WT/DS34/AB/R, adopted $19^{\text {th }}$ November 1999, DSR 1999:VI, 2345, p. 12.

${ }^{283}$ See Ibid, Appellate Body Report, 1999, p. 12.

${ }^{284}$ See Ibid, Appellate Body Report, 1999, p. 12.
} 
explained that "substantially all trade" is not "all the trade" and that "substantially all trade" is considered "something considerably more than merely some of the trade" ${ }^{285}$ It is submitted that the object and purpose of GATT Article XXIV:8 (a) (i) is to provide a definition of the term 'customs union' within the context of the WTO Agreement and, by extension, to announce to WTO Members that are desirous of creating a customs union the necessary requirements which need to be fulfilled. This object and purpose was affirmed by the AB in Turkey-Textiles in the context of its legal interpretation of GATT Article XXIV:5 Chapeau when it was stated "It follows necessarily that the text of the chapeau of paragraph 5 of Article XXIV cannot be interpreted without reference to the definition of a "customs union". This definition is found in paragraph 8 (a) of Article XXIV, which states..."286

\subsubsection{GATT Article XXIV:8 (a) (ii)}

GATT Article XXIV:8 (a) (ii) refers to "substantially the same duties and other regulations of commerce" that should be applied by "each of the members of the union to the trade of territories not included in the union". This wording explains that customs union constituents should apply a common external trade arrangement to the trade of third countries. In Turkey-Textiles, the $\mathrm{AB}$ clarified that this subsection only requires that "substantially the same", not "the same" duties and other regulations of commerce be applied to third countries. It was further explained that the term "substantially the same" provided "a certain degree of [limited] "flexibility" to customs union constituents and that "substantially" qualifies the word "the same". Therefore, in our view, something closely approximating "sameness" is required by Article XXIV:8(a)(ii)". ${ }^{287}$ The position has been advanced that liberalization measures that pose less disadvantages to third countries should be adopted. $^{288}$

\footnotetext{
${ }^{285}$ See Ibid, Appellate Body Report, 1999, p. 12.

${ }^{286}$ See Ibid, Appellate Body Report, 1999, p. 11.

${ }^{287}$ See Ibid, Appellate Body Report, 1999, p. 13.

${ }^{288}$ A. Von Bogdandy, T. Makatsch, Collission, Co-existence or Cooperation? Prospects for the Relationship between World Trade Organization and European Union Law in G. De Burca, J. Scott, The EU and the WTO: Legal and Constitutional Issues (Hart Publishing, 2001), p. 139.
} 
Additionally, the requirements of GATT Article XXIV:8 (a) (ii) must be contextualized as the substance of the subsection is qualified by the introductory phrase "subject to the provisions of paragraph 9 [of GATT Article XXIV]". It is noted that GATT Article XXIV:9 makes reference to GATT Article I: 2, which served to maintain certain trade preferences that existed at the time that the GATT 1947 was signed. ${ }^{289}$ These preferences can be eliminated or adjusted through negotiations with the affected WTO members. It is submitted that the object and purpose of GATT Article XXIV:8 (a) (ii) is to reinforce that customs union constituents must apply a common external regime to their trade with third countries whilst being mindful of the preferences outlined in GATT Article I: 2.

\subsubsection{GATT Article XXIV:8(b)}

GATT Article XXIV:8 (b) explains that an FTA is defined as a group of two or more countries where "the duties and other restrictive regulations of commerce (except, where necessary, those permitted under Articles XI, XII, XIII, XIV, XV and XX) are eliminated on substantially all trade" between such countries on "the products originating in" such countries. The ordinary meaning of the words explains that in order to create an FTA, two or more countries must eliminate the duties and other restrictive regulations of commerce on "substantially all trade" between themselves on their products. Again, these formation requirements are qualified as GATT Article XXIV:8 (b) states "(except, where necessary, those permitted under Articles XI, XII, XIII, XIV, XV and XX)". In view of the AB interpretation of the exceptions permitted in GATT Article XXIV:8 (a) (i), it is understood that the duties and other restrictive regulations of commerce that relate to these provisions of the GATT 1994 need not be eliminated. It is assumed that the maintenance of these respective provisions allows FTA constituents "some flexibility" when liberalizing their internal trade regime. It is submitted that the object of GATT Article XXIV:8 (b) is to provide a definition of the term 'FTA' within the context of the WTO Agreement and by

\footnotetext{
${ }^{289}$ For example, GATT Article I:2 (b) permitted Imperial European Countries such as the United Kingdom, The Netherlands, France and Belgium to retain their preferential trade arrangements with their dependent territories and colonies. Since 1947, most of these territories have attained independence and trade with their former colonial power is no longer governed by GATT Article I:2 (b). In many cases, WTO-consistent PTAs, governed by GATT Article XXIV, have been signed.
} 
extension, announce to WTO Members that are desirous of establishing an FTA the necessary requirements which need to be fulfilled.

It is clear that GATT Article XXIV:8 is aimed at ventilating the formation requirements that WTO Members must undertake in the event that they decide to establish a PTA either in the form of an FTA or a customs union. In both instances, "substantially all trade" between the respective constituents must be freed of restrictions. This sentiment is echoed in the preamble to the Understanding on the Interpretation of Article XXIV of the GATT 1994, which states "Recognizing also that such contribution is increased if the elimination between the constituent territories of duties and other restrictive regulations of commerce extends to all trade, and diminished if any major sector of trade is excluded." It is, therefore, asserted that GATT Article XXIV:8 imposes a legal obligation on WTO Members to comply with its formation requirements should they be desirous of creating an FTA or a customs union. Article XXIV:8 does not impose a legal obligation on WTO Members to create trade.

\subsubsection{GATT Article XXIV:8: Clarified Concerns}

This section of Chapter 2 addresses certain aspects of GATT Article XXIV:8 upon which further clarity has been provided. It is generally recognized that GATT Article XXIV:8 provides the GATT definition of a 'customs union' and an 'FTA'. As previously noted above, the AB affirmed this in Turkey-Textiles when it interpreted GATT Article XXIV:5 chapeau by stating "It follows necessarily that the text of the chapeau of paragraph 5 of Article XXIV cannot be interpreted without reference to the definition of a "customs union". This definition is found in paragraph 8 (a) of Article XXIV, which states...",290

\subsubsection{GATT Article XXIV:8: Unclarified Concerns}

This section of Chapter 2 addresses certain aspects of GATT Article XXIV:8 upon which further clarity has yet to be provided. Both the meaning of "other restrictive regulations of commerce" and "substantially all trade" remain undefined. The lack of clarity regarding

\footnotetext{
${ }^{290}$ See Appellate Body Report, Turkey - Restrictions on Imports of Textile and Clothing Products, WT/DS34/AB/R, adopted 19 $9^{\text {th }}$ November 1999, DSR 1999:VI, 2345, p. 11.
} 
these terms applies to their usage in GATT Article XXIV: 8(a)(i) and GATT Article XXIV:8(b). ${ }^{291}$ As noted above in the legal analysis on GATT Article XXIV:8, the preamble to the Understanding on the Interpretation of Article XXIV of the GATT 1994 makes mention that the gains from greater integration are reduced if any major section of trade is excluded from the elimination of internal trade barriers, but it omits a precise definition of the term "substantially all trade".

The AB noted in Turkey-Textiles that the definition of "substantially all trade" has been a longstanding issue of ambiguity as "Neither GATT Contracting Parties nor the WTO Members have ever reach an agreement on the interpretation of the term "substantially" in this provision". ${ }^{292}$ The AB further explained "substantially all trade" differs from "all the trade" and that "substantially all trade" is "something considerably more than merely some of the trade". ${ }^{293}$ Nevertheless, the AB did not provide a precise definition of the term and WTO members remain divided as to whether a qualitative approach or a quantitative approach should be employed when determining the meaning of "substantially all trade". 294

Another issue requiring clarity relates to the list of permitted exceptions contained in GATT Article XXIV:8. WTO Members are unclear on the scope of these permitted exceptions and whether these legal provisions are the only exceptions allowed to WTO Members. ${ }^{295}$ Generally speaking, WTO Members are divided on whether the list of

\footnotetext{
${ }^{291}$ It is notable that the GATT working party, which examined the Caribbean Free Trade Association (CARIFTA) in 1971 stated that "CARIFTA was already a free trade area in which substantially all trade ... was liberalized". At the time, over $90 \%$ of trade between the PTA partners had been liberalized, but to date the meaning of the term still remains undefined. GATT Secretariat, Report of the Working Party on the Caribbean Free Trade Agreement (Geneva, $29^{\text {th }}$ September 1971) [L/3584], p. 2, para. 7.

${ }^{292}$ See Appellate Body Report, Turkey - Restrictions on Imports of Textile and Clothing Products, WT/DS34/AB/R, adopted $19^{\text {th }}$ November 1999, DSR 1999:VI, 2345, p. 12.

${ }^{293}$ See Ibid, Appellate Body Report, 1999, p. 12.

${ }^{294}$ See WTO Secretariat, Synopsis of "Systemic" Issues related to Regional Trade Agreements, Note by Secretariat (Geneva, ${ }^{\text {nd }}$ March 2000) [WT/REG/W/37], p. 21. See also R. Herzstein, J. Whitlock, Regulating Regional Trade Agreements: A Legal Analysis in (eds.) P. Macrory, A. Appleton, M. Plummer, The World Trade Organization: Legal, Economic and Political Analysis, Volume II (Springer, 2007), p. 227.

${ }^{295}$ See Ibid, WTO Secretariat, 2000, p. 22; A. Von Bogdandy, T. Makatsch, Collission, Co-existence or Cooperation? Prospects for the Relationship between World Trade Organization and European Union Law in G. De Burca, J. Scott, The EU and the WTO: Legal and Constitutional Issues (Hart Publishing, 2001), p. 139.
} 
permitted exceptions is exhaustive or illustrative. ${ }^{296}$ Additionally, the requirement in GATT Article XXIV:8 (a) (ii) that customs union members apply "substantially the same duties and other regulations of commerce" to third countries has been the subject of divided opinion. Some WTO Members interpret this wording to mean that total harmonization of the external trade regime of a customs union is not required. ${ }^{297}$ Given this understanding, some WTO Members argue that such harmonization can occur to the benefit of the customs unions members whilst disadvantaging third countries. ${ }^{298}$

The preceding sections of this dissertation attempt to outline some of the areas of ambiguity regarding GATT Article XXIV. It, by no means, attempts to delve exhaustively into all of the systemic concerns and ambiguities associated with this provision. WTO Members remain divided on these and other issues pertaining to GATT Article XXIV. Consequently, this state of affairs has stalled the development of rules and disciplines relating to PTAs. Nevertheless, WTO Members remain committed to negotiations aimed at clarifying and improving the discipline on PTAs. ${ }^{299}$ Any possible clarifications should hopefully assist in identifying the systemic role that PTAs can play in achieving the aims of the WTO Agreement.

It is also notable that the preceding sections of this dissertation argued that GATT Article XXIV does not impose a legal obligation on WTO Members to create trade. This argument is of relevance to further chapters of this dissertation, which will demonstrate that the CARICOM PTA has not created significant trade among its constituents. Although the lack of trade creation could not have been predicted, the CARICOM PTA was one of the few PTAs that were deemed legally compatible with GATT Article XXIV. Later sections and chapters of this dissertation will enquire whether there are any legal options are available

\footnotetext{
${ }^{296}$ M. Trebilcock, R. Howse, A. Elliason, The Regulation of International Trade $4^{\text {th }}$ Edition (Routledge 2013), p. 117.

${ }^{297}$ See WTO Secretariat, Synopsis of "Systemic" Issues related to Regional Trade Agreements, Note by Secretariat (Geneva, $2^{\text {nd }}$ March 2000) [WT/REG/W/37], p. 24.

${ }^{298}$ See Ibid, WTO Secretariat, 2000, p. 26.

${ }^{299}$ See Paragraph 29 of the Doha Ministerial Declaration which states: "We also agree to negotiations aimed at clarifying and improving disciplines and procedures under the existing WTO provisions applying to regional trade agreements. The negotiations shall take into account the development aspects of regional trade agreements."
} 
to address the lack of trade creation in a PTA in light of the argument that GATT Article XXIV does not impose a legal obligation to create trade.

\subsection{The Enabling Clause}

Paragraphs 1 and 2 (c) of the Enabling Clause state:

"1. Notwithstanding the provisions of Article I of the General Agreement, contracting parties [WTO Members] may accord differential and more favourable treatment to developing countries, without according such treatment to other contracting parties.

\section{The provisions of paragraph 1 apply to the following:}

(c) Regional or global arrangements entered into amongst less-developed contracting parties [WTO Members] for the mutual reduction or elimination of tariffs and, in accordance with criteria or conditions which may be prescribed by the CONTRACTING PARTIES [WTO Members], for the mutual reduction or elimination of non-tariff measures, on products imported from one another;"

The 1979 Enabling Clause was one of the key decisions resulting from the Tokyo Round of negotiations and remains one of the foremost illustrations of special and differential treatment (SDT) within the WTO legal architecture. ${ }^{300}$ The Enabling Clause formalized the

\footnotetext{
${ }^{300}$ The concept of SDT revolved around the belief that a different approach was required in addressing trade rules for developing countries because the economics of trade liberalization were inapplicable to them. Thus, reciprocity in trade concessions was an unsound policy for developing country trade given their supply side constraints, limited market size and their globally inconsequential volume of trade. The GATT 1947 did not recognize the special needs of developing countries despite the fact that 11 of the 23 original contracting parties were developing countries and this resulted in developing countries participating in the MTS as equal partners adhering to uniform rules with developed countries from 1948 until the clamor for asymmetrical treatment yielded some results. See P. Conconi, C. Perroni, Special and Differential Treatment of Developing Countries in the WTO, World Trade Review, 2015, Vol. 14(1) pp. 67 - 86, p. 71; Report by the Consultative Board to the Director General Supachai Panitchpakdi, The Future of the WTO: Addressing Institutional Challenges in the New Millennium (The Sutherland Report) WTO 2004, p. 24, para. 90; R. Wilkinson, J. Scott, Developing Country participation in the GATT: A Reassessment, World Trade Review, 2008, Vol. 7(3) pp. 473-510, p. 479; R. Hudec, Developing Countries in the GATT Legal System (Cambridge University Press, 2011), p. 41.
} 
1971 waiver for the generalized system of preferences (GSP) scheme. ${ }^{301}$ It is also one of the "other decisions of the contracting parties" referred to in paragraph 1(b) (iv) of the GATT 1994, which incorporates by reference the GATT 1947 as well as other decisions of the GATT Contracting Parties into the WTO Agreement. ${ }^{302}$ It must also be added that the Enabling Clause reflects one of the broad objectives of the WTO Agreement, which recognizes "the need for positive efforts designed to ensure that developing countries and especially the least developed among them, secure a share in the growth of international trade commensurate with the needs of their economic development" ${ }^{303}$ This understanding was affirmed by the $\mathrm{AB}$ in European Communities - Conditions for the Granting of Tariff Preferences to Developing Countries (EC-Tariff Preferences) where it was stated "We understand, therefore, that the Enabling Clause is among the 'positive efforts' called for in the Preamble to the WTO Agreement to be taken developed-country Members to enhance the 'economic development' of developing-country Members". ${ }^{304}$

\subsubsection{Paragraph 2 (c) of the Enabling Clause}

Paragraph 2 (c) of the Enabling Clause refers to the establishment of "regional or global arrangements amongst less-developed Contracting Parties [WTO Members]". The ordinary meaning of the wording affirms that "regional or global arrangements" can be

\footnotetext{
${ }^{301}$ In 1971, GATT contracting parties agreed to a legal waiver whereby goods originating from developing countries were afforded preferential treatment under a generalized system of preferences (GSP) for 10 years, which was subject to further renewal. This essentially legalized (another) deviation from the MFN principle and signified a fundamental shift in one of the central tenets underpinning the MTS. The theoretical acceptance that preferences could act as a tool to assist with trade creation for developing countries did not only swim against the tide of the multilateral principle, but it also required developed countries to adapt their commercial trade policy to suit this new philosophy. Such policies have since been labeled as a mixed success and it remains arguable whether developing countries derived any meaningful benefit. See J. Jackson, Jurisprudence of the GATT and WTO: Insights on Treaty Law and Economic Relations (Cambridge University Press, 2000), p. 65; L. Bartels, The WTO Enabling Clause and Positive Conditionality in the European Community's GSP Program, Journal of International Economic Law, 2003, Vol. 6(2), pp. 507532, p. 511; Ibid, Report by the Consultative Board to the Director General Supachai Panitchpakdi, 2004, p. 25, para. 99.

${ }^{302}$ See Paragraph 2(a) of the Enabling Clause. See Appellate Body Report, European CommunitiesConditions for the Granting of Tariff Preferences to Developing Countries, WT/DS246/AB/R, adopted $20^{\text {th }}$ April 2004, DSR 2004:III, 925, p. 35. The Enabling Clause is considered one of the "other decisions of the contracting parties to GATT 1947" mentioned in paragraph 1 (b) (iv) of Annex 1 A, which has been incorporated into the WTO Agreement.

${ }^{303}$ See Preamble to the WTO Agreement

${ }^{304}$ See Appellate Body Report, European Communities-Conditions for the Granting of Tariff Preferences to Developing Countries, WT/DS246/AB/R, adopted $20^{\text {th }}$ April 2004, DSR 2004:III, 925, p. 37.
} 
created using this legal provision. These arrangements should be aimed at "the mutual reduction and elimination of tariffs as well as non-tariff measures on products". Although paragraph 2 (c) of the Enabling Clause does not refer to 'customs unions' and 'FTAs', it is asserted that in the context of the WTO legal architecture, regional arrangements aimed at the mutual reduction and elimination of tariff and non-tariff measures on trade in goods are, in fact, PTAs. Additionally, it is submitted that by 1979 when the Enabling Clause was introduced, GATT Article XXIV (of 1947) had already been in operation for several decades and had established some semblance of the WTO review mechanism for PTAs using ad hoc working parties consisting of select GATT Contracting Parties. It is further submitted that the wording regarding "criteria or conditions, which may be prescribed by the Contracting Parties" refers to the procedures used by the WTO review mechanism for PTAs.

It is important to highlight that the ordinary meaning of the words of paragraph 1 of the Enabling Clause states "notwithstanding the provisions of Article 1 of the General Agreement', which is interpreted to mean 'despite the provisions of Article I'. It is notable that to date, GATT Article XXIV is the only other WTO legal provision that links the establishment of a "regional arrangement" for trade in goods with an exception to GATT Article I, which contains the MFN clause. It can, thus, be discerned that paragraph 2 (c) of the Enabling Clause is intended to function as an exception to only GATT Article I. Therefore, there is no need for clarity regarding whether paragraph 2 (c) of the Enabling Clause allows for a deviation from other GATT legal provisions.

The $\mathrm{AB}$ affirmed in EC-Tariff Preferences that "The Enabling Clause operates as an “exception" to [GATT] Article I: 1". ${ }^{305}$ Consequently, both paragraph 2 (c) of the Enabling Clause as well as GATT Article XXIV allow for WTO Members that are PTA constituents to provide preferential treatment to a select group of other WTO Members whilst not extending this treatment "immediately and unconditionally" to the wider WTO membership. In EC-Tariff Preferences, the AB agreed with the Panel and interpreted the word "notwithstanding" in the abovementioned sentence to mean "in spite of, without

${ }^{305}$ See Ibid, Appellate Body Report, 2004, p. 36. 
regard to or prevention by" ${ }^{306}$ Paragraph 1 of the Enabling Clause was thereby clarified to mean that "differential and more favorable treatment" can be given to developing countries "in spite of" GATT Article I:1. ${ }^{307}$ It is submitted that paragraph 2 (c) of the Enabling Clause is a developing country specific legal provision that can be used to legally underpin PTAs for trade in goods. As a consequence of this, it constitutes a second legal avenue that underpins the establishment of PTAs within the WTO legal architecture.

2.7.2 The Context and Object and Purpose of Paragraph 2 (c) of the Enabling Clause The wording of paragraph 2 (c) of the Enabling Clause refers to the creation of "regional or global arrangements amongst less-developed Contracting Parties [WTO Members]" with the qualification that this task must be undertaken "notwithstanding the provisions of Article 1 of the General Agreement" and "in accordance with criteria and conditions which may be prescribed by Contracting Parties". Therefore, a balancing act must be performed whereby the preferential liberalization of trade in goods is undertaken, whilst being mindful of GATT Article I, which enshrines the MFN clause. Contextually speaking, emphasis is placed on the critical importance of the multilateral approach to trade liberalization notwithstanding the fact that this preferential legal carve-out is meant to assist developing countries with the establishment of PTAs. This sentiment is further bolstered by paragraph 3(a) of the Enabling Clause, which states:

"Any differential and more favourable treatment provided under this clause:

(a) shall be designed to facilitate and promote the trade of developing countries and not to raise barriers to or create undue difficulties for the trade of any other contracting parties [WTO Members];

(b) shall not constitute an impediment to the reduction or elimination of tariffs and other restrictions to trade on a most-favoured-nation basis;"

Similar to GATT Article XXIV, it is submitted that the object of paragraph 2 (c) of the Enabling Clause is to create trade among developing countries and, in doing so, contribute

\footnotetext{
${ }^{306}$ See Ibid, Appellate Body Report, 2004, p. 35.

${ }^{307}$ See Ibid, Appellate Body Report, 2004, p. 35.
} 
to the wider movement towards global free trade. However, it is noted that the text of the legal provision is broadly worded and does not refer to a specific modality that should be utilized to create PTAs. The main requirement stated in paragraph 2 (c) of the Enabling Clause relates to a broad framework, which requires that PTAs should be aimed at the "mutual reduction or elimination of tariffs" and should be created in "accordance with criteria or conditions which may be prescribed by Contracting Parties [WTO Members]". ${ }^{308}$ There is no wording which outlines precisely how to undertake this task. ${ }^{309}$ It is, therefore, asserted that paragraph 2 (c) of the Enabling Clause imposes a legal obligation on WTO Members, which are developing countries and desirous of establishing a PTA among themselves, to comply with its broadly worded formation requirements for PTAs. Paragraph 2 (c) of the Enabling Clause does not impose a legal obligation on WTO Members to create trade.

\subsubsection{Paragraph 2 (c) of the Enabling Clause: Clarified Concerns}

This section of Chapter 2 addresses certain aspects of paragraph 2 (c) of the Enabling Clause upon which further clarity has been provided. It must be admitted that there are limited areas where the WTO membership share a common understanding on this legal provision. It has been argued that the broad wording "regional or global arrangements amongst less-developed Contracting Parties [WTO Members]" reflects an admission that customs unions cannot be established by paragraph 2 (c) of the Enabling Clause due to the fact the legal provision does not require the "substantially all trade" requirement outlined

\footnotetext{
${ }^{308}$ It is noted that the Enabling Clause contains a notification requirement whereby developing countries are required to notify (previously the GATT Secretariat) the WTO Secretariat about a PTA under formation and supply appropriate information about the PTA. See Paragraph 4(a) of the Enabling Clause, which states "Any contracting party [WTO Member] taking action to introduce an arrangement pursuant to paragraphs 1, 2 and 3 above or subsequently taking action to introduce modification or withdrawal of the differential and more favourable treatment so provided shall: (a) notify the CONTRACTING PARTIES [WTO Members] and furnish them with all the information they may deem appropriate relating to such action;"

309 Additionally, it is noted that the rules pertaining to the Regional Trade Agreement Transparency Mechanism (RTA TM) apply to PTAs notified under paragraph 2 (c) of the Enabling Clause and the Committee on Trade and Development (CTD) has been entrusted with the responsibility for conducting such reviews. See WTO Secretariat, Transparency Mechanism for Regional Trade Agreements, Decision of 14 December 2006 (Geneva, 18 ${ }^{\text {th }}$ December 2006) [WT/L/671]. Section C, Paragraph 7(a) of the RTA TM provides that developing country RTAs are given a 20 weeks timeframe for data submission (whereas developed countries have a timeframe of 10 weeks) after the date of RTA notification. Section F of the RTA TM also provides that developing and least developed countries shall be provided with technical assistance to aid in implementing the transparency mechanism especially where the preparation of RTA-related data and other information to be submitted to the WTO is concerned.
} 
in GATT Article XXIV: $8 .{ }^{310}$ A related argument states that paragraph 2 (c) of the Enabling Clause is unable to establish a customs union as this could entail the creation of measures that are inconsistent with various GATT legal provisions, not solely GATT Article I. As has been previously noted, paragraph 2 (c) of the Enabling Clause represents solely a deviation from GATT Article I. Furthermore, paragraph 2 (c) of the Enabling Clause requires that WTO Members undertake "the mutual reduction or elimination of tariffs". It has been noted that this formation requirement differs from and does not require the elimination of duties and other restrictive regulations of commerce on substantially all trade. ${ }^{311}$ Lastly, although the wording used in paragraph 2 (c) of the Enabling Clause refers to less developed countries, this aspect of the legal provision has generally been interpreted to apply to all developing countries.

\subsubsection{Paragraph 2 (c) of the Enabling Clause: Unclarified Concerns}

This section of Chapter 2 addresses certain aspects of paragraph 2 (c) of the Enabling Clause upon which further clarity has yet to be provided. There has been contention in reconciling PTAs created under paragraph 2 (c) of the Enabling Clause with their wider placement within the MTS. ${ }^{312}$ It was noted earlier in this chapter that PTAs were accepted within the initial GATT legal architecture due to the fact that they were viewed as "halfway

\footnotetext{
${ }^{310}$ In this regard, it is noted that the AB confirmed in Turkey-Textiles that GATT Article XXIV:8 (a) (ii) provides the definition of a customs union and as per this definition, a customs union requires the elimination of duties and other restrictive regulations of commerce on substantially all trade between the constituents involved. If an interim agreement leading to the establishment of a customs union that is notified under paragraph 2 (c) of the Enabling Clause results solely in a reduction of duties and other restrictive regulations of commerce and not an elimination thereon on substantially all trade, such an interim agreement cannot lead to a customs union as per the definition outlined in GATT Article XXIV:8(a)(ii).See J. Jackson, The World Trading System: Law and Policy of International Economic Relations, Second Edition (MIT Press, 1997), p. 172. In this regard, it is noted that the WTO working party, which examined MERCOSUR undertook its examination in light of the relevant provisions of the Enabling Clause and the GATT 1994 including GATT Article XXIV.

${ }^{311}$ See J. Bum Kim, Dual WTO Notifications of RTAs with Non-Reciprocal Trade liberalization, Journal of International Economic Law, 2012, Vol. 15 (2), pp. 647-672, p. 655.

312 "The notification of RTAs under the Enabling Clause has been described as a systemic issue, but no substantive debate has taken place on it. Broader issues surrounding this particular question appear to be related both to the relationship between disciplines under the Enabling Clause and GATT Article XXIV, and to the adequacy of WTO surveillance of RTAs among developing countries." See WTO Secretariat, Synopsis of "Systemic" Issues related to Regional Trade Agreements, Note by Secretariat (Geneva, $2{ }^{\text {nd }}$ March 2000) [WT/REG/W/37], p. 14.
} 
houses on the road to non-discriminatory and freer trade". ${ }^{313}$ Inherent in this understanding of PTAs was that these "halfway houses" would result in the elimination of tariffs on substantially all trade. Despite the interpretational divide on GATT Article XXIV, it is understood that its formation requirements are aimed at achieving the aforementioned. Many have submitted that the same cannot be said of the Enabling Clause. It has also been argued that the Enabling Clause is flawed due to inter alia its vague language, its unspecified detailed formation requirements and its unspecified timeframe for completion of tariff reduction efforts. ${ }^{314}$ Moreover, the self-selection basis on which developing country status is determined can invite complications with respect to emerging economy developing countries and their involvement with PTAs notified using paragraph 2 (c) of the Enabling Clause. ${ }^{315}$

\subsubsection{Paragraph 2 (c) of the Enabling Clause: Pattern of Use}

Several developing countries have utilized paragraph 2 (c) of the Enabling Clause to notify PTAs. Mercado Comun del Sur (MERCOSUR), the Andean Community and the Economic Community of West African States (ECOWAS) were notified under the Enabling Clause. ${ }^{316}$ Further to this, paragraph 2 (c) of the Enabling Clause has been used to legally underpin many bilateral FTAs formed in Asia. ${ }^{317}$ Paragraph 2 (c) of the Enabling Clause

\footnotetext{
${ }^{313}$ See K. Dam, Regional Economic Arrangements and The GATT: The Legacy of A Misconception, University of Chicago Law Review, 1963, Vol. 30 (4), pp. 615-665, p. 615.

314 J. Bhagwati, Termites in the Trading System: How Preferential Agreements undermine Free Trade (Oxford University Press, 2008), p. 27; P. Mavroidis, The Regulation of International Trade: GATT, Volume I (MIT Press, 2016), p. 250; See J. Ravenhill, Regional Trade Agreements in (ed.) J. Ravenhill, Global Political Economy, Third Edition (Oxford University Press, 2011), p. 205; M. Matsushita, T. Schoenbaum, P. Mavroidis, M. Hahn, The WTO: Law, Practice and Policy, Third Edition (Oxford University Press, 2015), p. 708.

${ }^{315}$ In this regard, the European Communities-Conditions for the Granting of Tariff Preferences to Developing Countries case addressed the issue of the variation in treatment accorded to developing countries under paragraph 2 (a) of the Enabling Clause. However, this was in the context of extra preferences granted under the EU GSP program to select developing countries whilst another country was excluded. See L. Bartels, The WTO Enabling Clause and Positive Conditionality in the European Community's GSP Program, Journal of International Economic Law, 2003, Vol. 6 (2), pp. 507-532. See also Ibid, P. Mavroidis, 2016, p. 250; Ibid, J. Bhagwati, 2008, p. 27; R. Acharya, Regional Trade Agreements: Recent Developments in (ed.) R. Acharya, Regional Trade Agreements and the Multilateral Trading System (Cambridge University Press, 2016) p. 2.

${ }^{316}$ To date, 42 PTAs have been notified using the Enabling Clause. Author's own compilation of statistics based on information retrieved from www.wto.org.

${ }^{317}$ S. Hamanaka, Asian Free Trade Agreements and WTO Compatibility (World Scientific, 2014), p. 94.
} 
remains the lesser-used provision to notify PTAs. ${ }^{318}$ Perhaps this is reflective of the asymmetrical nature that many PTAs now feature, as many developed countries have pursued PTAs with developing countries as a part of their commercial policy. ${ }^{319}$ By 1979 when the Enabling Clause was introduced, a substantial number of PTAs were already in existence, having been notified under GATT Article XXIV ${ }^{320}$ It should also be mentioned that the CARICOM PTA, which is the focus of this dissertation, is a developing country exclusive PTA. Its creation, however, predated the 1979 Enabling Clause and was therefore notified under GATT Article XXIV in 1974. Consequently, most of its trade liberalization was undertaken pursuant to GATT Article XXIV:8 and its "substantially all trade" requirement.

\subsection{Legal Obligation to create trade?}

This section of the dissertation will examine the argument that the legal provisions underpinning PTAs for trade in goods do not amount to a legal obligation to create trade. This is a relevant enquiry given the previously mentioned goals of the WTO Agreement and the fact that trade liberalization was originally envisioned within a multilateral, nondiscriminatory environment. It is useful to know whether it is legally justifiable to permit PTAs, which have failed to create significant trade, to persist within the MTS. In other words, is it legally acceptable for the MTS to accommodate PTAs that have the ability to distort multilateral trade if these PTAs fail to create trade? Both the purpose of GATT Article XXIV and paragraph 2 (c) of the Enabling Clause is intertwined with the concept of trade creation. Thus, it might be purposively construed that WTO Members are obligated to create trade within their PTAs in order to justify usage of these legal provisions. This

\footnotetext{
${ }^{318}$ During the GATT era (1947 to 1994), 98 PTAs were notified under GATT Article XXIV and 11 PTAs were notified by developing countries under the Enabling Clause. See T.N. Srinivasan, Nondiscrimination in the GATT/WTO: Was There Anything There to Begin with and is There Anything Left? World Trade Review, 2005, Vol. 4, pp. 69-95, p. 81; M. Trebilcock, Advanced Introduction to International Trade Law (Edward Elgar Publishing, 2015), p. 44.

${ }^{319}$ See J. Bum Kim, Dual WTO Notifications of RTAs with Non-Reciprocal Trade liberalization, Journal of International Economic Law, 2012, Vol. 15 (2), pp. 647-672, p. 649. See also Chapter 1, Section 1.8 entitled PTA Expansionism.

${ }^{320}$ By 1979 , there were already 60 PTAs notified under GATT Article XXIV. Author's own compilation of statistics based on Table 2A.1 Regional Trading Arrangements Notified to the GATT/WTO, 1949-1995 in J. Bhagwati, A. Panagariya, Preferential Trading Areas and Multilateralism - Strangers, Friends, or Foes? in (eds.) J. Bhagwati, P. Krishna, A. Panagariya, Trading Blocs: Alternative Approaches to Analyzing Preferential Trade Agreements (MIT Press, 1999), p. 80.
} 
trend of thought would even appear logical given the much-emphasized inherently discriminatory nature of PTAs and the detrimental effects that they can cause to the MTS. Previous sections of Chapter 2 of this dissertation have demonstrated that a strict textual analysis of both legal provisions elucidate that they are not positive legal obligations that require trade creation. Rather, these legal provisions outline how newly formed GATT inconsistent measures are justifiable by their respective formation requirements for creating PTAs for trade in goods. ${ }^{321}$ Given their notification requirements, it is argued that GATT Article XXIV and The Enabling Clause also serve to register PTAs within the WTO legal architecture and thereby assist with the enhancement of transparency.

\subsubsection{Legally Enforceable Provisions}

The WTO Agreement is an international treaty governed by international law and based on rights as well as obligations. Furthermore, the WTO Agreement prevails over national law as per the principle of pacta sunt servanda. As a corollary to this, a WTO Member may not use its national laws as a justification for failing to act on its international legal obligations. $^{322}$ Consequently, WTO Members are required to remedy measures, which are found to be inconsistent with WTO obligations. ${ }^{323}$ In light of the foregoing, it must be enquired: what exactly constitutes a WTO legal obligation? The WTO Agreement is considered a reciprocal and mutually advantageous arrangement aimed at achieving certain objectives. It, therefore, imposes on WTO Members a basic obligation to perform or abstain from certain actions.

\footnotetext{
321 "Essentially Article XXIV GATT imposes three obligations on WTO members wishing to enter a PTA: (i) an obligation to notify the PTA (procedural requirement). [...] (ii) an obligation to liberalize among constituents of the PTA substantially all trade (substantive requirement); and (iii) an obligation not to raise the overall level of protection and make access of products of third parties not participating in the PTA more onerous (substantive obligation)." P. Mavroidis, Do not ask too many questions: The institutional arrangement for accommodating Regional Integration within the WTO in (eds.) E. Kwan Choi, J. Hartigan, Handbook of International Trade: Economic and Legal Analyses of Trade Policy and Institutions, Volume II (Blackwell Publishing, 2004), p. 244.

${ }^{322}$ See Article 26 and Article 27 of the VCLT. See also Ibid, J. Trachtman, 2007, p. 146.

323 "WTO-inconsistent measures and practices under national law have to be brought in compliance with WTO obligations within a reasonable period of time. In most cases, this can only be achieved by removal of the measures concerned." T. Cottier, K. Nadakavukaren, The Relationship between WTO Law, National and Regional Law, Journal of International Economic Law, 1998, Vol. 1(1), pp. 83 -122, p. 85.
} 
WTO legal obligations can be divided into negative legal obligations and positive legal obligations. ${ }^{324}$ A negative legal obligation imposes a legal responsibility against the commission of certain acts. In the event that the specified acts are still committed, negative legal obligations can be enforced. As a consequence of this, these types of provisions are considered enforceable legal obligations. For example, GATT Article III: ${ }^{325}$ is a negative legal obligation whereby WTO Members should not apply internal taxation measures that amount to protection for domestic products and in the avoidance thereof, WTO Members ensure that all products are given national treatment. Conversely, positive legal obligations impose a right of specific performance. For example, GATT Article II:1 (a) ${ }^{326}$ imposes a positive legal obligation that WTO Members accord the commerce of other WTO Members treatment no less favorable than that provided for in the appropriate schedule annexed to the WTO Agreement. It is consequently understood that WTO Members must accord treatment of a specific nature to the trade in goods of other WTO Members. Both of these provisions can be violated, per se, if WTO Members fail to perform or abstain from the standard of treatment outlined. Thus, they are considered an enforceable legal obligation and the dispute settlement system can be used to address the impairment and nullification of benefits arising from any inconsistencies with the legal provision. ${ }^{327}$

\footnotetext{
${ }^{324}$ A negative legal obligation imposes on a state the responsibility against the commission of certain acts and a positive legal obligation imposes on a state a right to perform an act and essentially amounts to a prescriptive norm.

${ }^{325}$ GATT Article III:1 states: "The contracting parties recognize that internal taxes and other internal charges, and laws, regulations and requirements affecting the internal sale, offering for sale, purchase, transportation, distribution or use of products, and internal quantitative regulations requiring the mixture, processing or use of products in specified amounts or proportions, should not be applied to imported or domestic products so as to afford protection to domestic production."

${ }^{326}$ GATT Article II:1 (a) states: " Each contracting party shall accord to the commerce of the other contracting parties treatment no less favourable than that provided for in the appropriate Part of the appropriate Schedule annexed to this Agreement."

${ }^{327}$ See Article 1 of the DSU, which states "[...] The rules and procedures of this Understanding shall also apply to consultations and the settlement of disputes between Members concerning their rights and obligations under the provisions of the Agreement establishing the World Trade Organization and of this Understanding taken in isolation or in combination with any other covered agreement." See also J. Trachtman, The WTO Cathedral, Stanford Journal of International Law, 2007, Vol. 43, pp. 127-167, p. 131.
} 


\subsubsection{GATT Article XXIV and Paragraph 2 (c) of the Enabling Clause}

As noted earlier in this dissertation, the object and purpose of the WTO Agreement is to create trade and thereby assist in the movement towards global free trade. ${ }^{328}$ Similar sentiments are echoed in the preamble to the WTO Agreement. ${ }^{329}$ This dissertation submits that although PTAs amount to an exclusive trading arrangement among a narrower and identifiable group of WTO Members, PTAs still assist in the (gradual) movement towards global free trade. The function played by both GATT Article XXIV and paragraph 2 (c) of the Enabling Clause demonstrates that their formation requirements outline normative frameworks, which are aimed at creating trade. ${ }^{330}$ Chapter 2 of this dissertation argues that these frameworks must comply with the requirements of GATT Article XXIV or paragraph 2 (c) of the Enabling Clause. The actual ability of this framework to create trade is the ultimate ambition envisioned, but it is not a legal obligation. Therefore, these legal provisions cannot be violated by failing to create trade. ${ }^{331}$

It is important to note that the external requirement outlined in GATT Article XXIV:5 is considered crucial to the trade pact among the narrow and identifiable trade partners of a PTA. Nevertheless, this particular requirement is aimed at the protection of the wider WTO membership, not party to the PTA, and by extension the general stability of the MTS. ${ }^{332}$

\footnotetext{
328 "The object of WTO obligations is trade. Trade is and remains a bilateral occurrence. Goods or services from one country are being exported or transferred to one other country. The rights and obligations negotiated in the WTO are aimed at ensuring market access for a given product from member A into the market of member B." J. Pauwelyn, A Typology of Multilateral Treaty Obligations: Are WTO Obligations Bilateral or Collective in Nature? European Journal of International Law, 2003,Vol. 14(5), pp. 907-951, p. 930.

${ }^{329}$ The preamble to the WTO Agreement states "Recognizing that their relations in the field of trade and economic endeavor should be conducted with a view to raising the standards of living, ensuring full employment and a large and steadily growing volume of real income and effective demand, and expanding the production of trade in goods and services..."

${ }^{330}$ Given the ambiguity surrounding GATT Article XXIV, even the normative structure of creating PTAs has been in dispute and this has resulted in the lack of an authoritative interpretation of the legal provision.

${ }^{331}$ It is noteworthy that GATT Article XXIV: 7(b) provides a legal avenue whereby WTO Members can halt a proposed plan for the establishment of a PTA if they are of the view that it would be difficult for the PTA to materialize in the given timeframe. However, this provision has never been used.

${ }^{332}$ GATT Article XXIV: 5 states: Accordingly, the provisions of this Agreement shall not prevent, as between the territories of contracting parties, the formation of a customs union or of a free-trade area or the adoption of an interim agreement necessary for the formation of a customs union or of a free-trade area; Provided that:

(a) with respect to a customs union, or an interim agreement leading to a formation of a customs union, the duties and other regulations of commerce imposed at the institution of any such union or interim agreement in respect of trade with contracting parties not parties to such union or agreement shall not on the whole be higher or more restrictive than the general incidence of the duties and regulations of commerce applicable in
} 
The collective nature of GATT Article XXIV:5 demonstrates a legal obligation owed (by PTA constituents) to all WTO Members not raise barriers to trade and to balance the effects of PTAs within the MTS, whilst simultaneously contributing to the growth of global free trade.

\subsubsection{Non-enforceability of Trade Creation}

As noted throughout Chapter 2, the broad objectives of the WTO Agreement include inter alia raising the standing of living, ensuring full employment and expanding the production of and trade in goods and services. ${ }^{333}$ In this regard, the WTO dispute settlement system operates under a rules-based framework to assist in the safeguarding of the rights and obligations related to these broad objectives. ${ }^{334}$ In order to initiate the WTO dispute settlement system, a situation must exist whereby a benefit accruing to a WTO Member, either directly or indirectly under the covered agreements, is being impaired by a measure undertaken by another WTO Member. ${ }^{335}$ Given the aforementioned, it is submitted that it would be challenging to enforce the lack of trade creation in a PTA.

the constituent territories prior to the formation of such union or the adoption of such interim agreement, as the case may be;

(b) with respect to a free-trade area, or an interim agreement leading to the formation of a free-trade area, the duties and other regulations of commerce maintained in each of the constituent territories and applicable at the formation of such free-trade area or the adoption of such interim agreement to the trade of contracting parties not included in such area or not parties to such agreement shall not be higher or more restrictive than the corresponding duties and other regulations of commerce existing in the same constituent territories prior to the formation of the free-trade area, or interim agreement as the case may be; and

$(c)$ any interim agreement referred to in subparagraphs $(a)$ and $(b)$ shall include a plan and schedule for the formation of such a customs union or of such a free-trade area within a reasonable length of time.

${ }_{333}^{333}$ See Preamble to the WTO Agreement.

${ }^{334}$ See GATT Article XXIII: 1 which states

"If any contracting party [WTO Member] should consider that any benefit accruing to it directly or indirectly under this Agreement is being nullified or impaired or that the attainment of any objective of the Agreement is being impeded as the result of

(a) the failure of another contacting party [WTO Member] to carry out its obligations under this Agreement, or

(b) the application by another contracting party[WTO Member] of any measure, whether or not it conflicts with the provisions of this Agreement, or

(c) the existence of any other situation,

the contracting party [WTO Member] may, with a view to the satisfactory adjustment of the matter, make written representations or proposals to the other contracting party or parties [WTO Members] which it considers to be concerned. Any contracting party [WTO Member] thus approached shall give sympathetic consideration to the representations or proposals made to it."

335 Article 3 (3) of the DSU refers to "The prompt settlement of situations in which a Member considers that any benefits accruing to it directly or indirectly under the covered agreements are being impaired by measures taken by another Member is essential to the effective functioning of the WTO and the maintenance of a proper balance between the rights and obligations of Members". 
The failure to create trade under GATT Article XXIV and paragraph 2 (c) of the Enabling Clause does not constitute: (i) an infringement of a legal obligation or right assumed under the covered agreements; (ii) a nullification or impairment of a benefit accruing under the covered agreements; (iii) a presumption of breach of rules; (iv) an adverse impact on other WTO Members or (v) a complaint with a rebuttable charge. ${ }^{336}$ It is asserted that the ordinary meaning of the wording contained in GATT Article XXIV and paragraph 2 (c) of the Enabling Clause does not extend to a legal obligation to create trade. The legal obligation assumed under these legal provisions extend solely to compliance with the stated formation requirements, which are aimed at creating trade. This interpretation is supported by the initial approach taken by the GATT and WTO working parties (which consisted of GATT Contracting Parties and WTO Members) to legally examine PTAs. ${ }^{337}$ Despite being mired in disagreement, the previous GATT and WTO working party exercise was aimed at determining compliance with the respective legal provisions of GATT Article XXIV and paragraph 2 (c) of the Enabling Clause. Hence, this process was aimed at ensuring that the legal obligation to implement the formation requirements had been undertaken. ${ }^{338}$

In light of the above, the failure to create trade would not form a basis for a request for consultations or the subsequent establishment of a WTO panel, as there is no benefit accruing from the covered agreements that has been impaired by the measures of another WTO Member or the existence of a situation that nullifies or impairs a benefit. ${ }^{339}$ Clearly

\footnotetext{
${ }^{336}$ See Article 3 (8) of the DSU, which states "In cases where there is an infringement of the obligations assumed under a covered agreement, the action is considered prima facie to constitute a case of nullification and impairment. This means that there is normally a presumption that a breach of the rules has an adverse impact on other Member parties to that covered agreement, and in such cases, it shall be up to the Member against whom the complaint has been brought to rebut the charge."

${ }^{337}$ See R. Herzstein, J. Whitlock, Regulating Regional Trade Agreements - A Legal Analysis in (eds.) P. Macrory, A. Appleton, M. Plummer, The World Trade Organization: Legal, Economic and Political Analysis, Volume II (Springer, 2005), p. 228. See also Chapter 3, Section 3.1 GATT Institutional Assessment: The Early Years and Section 3.2 The CRTA

338 "The Working Party agreed that, based on the documentation provided by the Parties to the Agreement, the Customs Union Agreement between the Czech Republic and the Slovak Republic was consistent with the provisions of Article XXIV of the General Agreement." See GATT Secretariat, Working Party Report on the Customs Union between The Czech Republic and the Slovak Republic (Geneva, 15 ${ }^{\text {th }}$ July 1994) [L/7501] p. 3.

${ }^{339}$ See Article 4 (2) of the DSU, which states: "Each Member undertakes to accord sympathetic consideration of and afford adequate opportunity for consultation regarding any representations made by another Member concerning measures affecting the operation of any covered agreement taken within the territory of the former."
} 
then, there would also be no nullification and impairment of a benefit or presumption of a breach of WTO rules. It is important to reiterate that trade creation is the foremost aim of forming a PTA, which is reflected in GATT Article XXIV:4. ${ }^{340}$ This overriding purpose, however, cannot be conflated with a legal obligation to the same effect. Any adverse impact that might affect a WTO Member due to the failure to create trade within a PTA would not amount to an impaired benefit. Indeed, this argument is reinforced by the fact that the few GATT and WTO dispute settlement cases that have addressed PTAs have not questioned the issue of trade creation.

\subsection{Conclusion}

Chapter 2 asserts that GATT Article XXIV and paragraph 2 (c) of the Enabling Clause, which underpin the establishment of PTAs for trade in goods, do not contain a legal obligation to create trade. In the international legal context, these legal provisions are constituent parts of the WTO Agreement, which has been described as a reciprocal and mutually advantageous arrangement. Thus, the WTO Agreement obliges WTO Members to perform or abstain from certain actions as a basic duty. Although there is no basic duty to participate in a PTA, should a WTO Member decide to do so, the text of both GATT Article XXIV and paragraph 2 (c) of the Enabling Clause provide a prescriptive approach as to how a PTA should be created. Both legal provisions serve to textually outline the formation requirements for creating PTAs. These formation requirements are aimed at creating trade, however, there is no legal obligation per se to create trade. This assertion is relevant to the various enquiries of this dissertation, as further chapters will examine the extent to which the CARICOM PTA meets the formation requirements outlined in GATT Article XXIV. It will also be demonstrated that the CARICOM PTA has been plagued by an inability to create trade. Nevertheless, no benefits accruing to other WTO Members have been impaired and the existence of a PTA that has not created significant trade is unlikely to result in the initiation of the WTO dispute settlement system. It is submitted that GATT Article XXIV and paragraph 2 (c) of the Enabling Clause were created in different eras

\footnotetext{
${ }^{340}$ The AB explained in the Turkey-Textiles case that the provisions of GATT Article XXIV is to be interpreted by constant reference to the purpose outlined in GATT Article XXIV: 4. See WTO Secretariat, Turkey - Restrictions on Imports of Textile and Clothing Products, Report of the Appellate Body (Geneva, $22^{\text {nd }}$ October 1999) [WT/DS34/AB/R], p. 15.
} 
within the wider evolution of the MTS. Despite this, they both share the same primary ambition in that they outline requirements with which WTO Members must comply in order to create a PTA. As noted throughout Chapter 2, both legal provisions suffer from the affliction of being plagued with ambiguities. These ambiguities have not affected their usage as the formation and notification of PTAs have continued. Attempts to address these ambiguities also continue. 


\section{Chapter 3}

Management: The Institutional Regulation of Preferential Trade Agreements

\section{Introduction}

Chapter 3 is aimed at examining the institutional management of preferential trade agreements (PTAs) and outlines the processes by which PTAs for trade in goods have been procedurally assessed by working parties of both the General Agreement on Tariffs and Trade (GATT) and World Trade Organization (WTO) Secretariats. It also addresses the treatment of PTAs as a legal discipline within the GATT and WTO legal architecture. In undertaking this examination, a historical assessment of the institutional approach employed to PTAs is outlined by reference to GATT working party reports and subsequent procedural decisions that have affected the governance of this area of the WTO legal architecture.

Previously, the main thrust of the PTA legal assessment process was centered on ensuring compatibility with either GATT Article XXIV or paragraph 2 (c) of the 1979 GATT Decision on Differential and More Favorable Treatment (the Enabling Clause). ${ }^{341}$ This legal compliance was equated with the understanding that a PTA would have the ability to create trade whilst minimizing the effects of trade diversion. The aforementioned historical assessment that is undertaken assists in establishing a causal link between the stymieing of the legal assessment process and the systemic issues associated with GATT Article XXIV. Consequently, most of the legal compatibility assessments undertaken ended on inconclusive terms. ${ }^{342}$

The legal scrutiny of PTAs has been guided by the requirements outlined in GATT Article XXIV: 4 and the core aim has been to determine if barriers to trade with third countries

\footnotetext{
${ }^{341}$ See GATT Secretariat, Differential and More Favorable Treatment, Reciprocity and Fuller Participation of Developing Countries, Decision of 28 November 1979 (Geneva, 3 December 1979) [L4903].

${ }^{342}$ Since the establishment of the Regional Trade Agreement Transparency Mechanism (RTA TM) in 2006, the main focus of the procedural assessment process has shifted, as it no longer rests on legal compatibility and an attempt is made to focus on an ex post facto analysis of whether a PTA has achieved trade creation. See WTO Secretariat, Transparency Mechanism for Regional Trade Agreements, Decision of 14 December 2006 (Geneva, $18^{\text {th }}$ December 2006) [WT/L/671].
} 
have been created as well as whether conditions conductive to trade creation have been engendered. ${ }^{343}$ WTO documentation and WTO law books are used to highlight that the institutional surveillance mechanism has not functioned as intended and has resulted in stalled policy improvements as well as a suboptimal status quo regarding PTAs. ${ }^{344}$ This factor coupled with the unanticipated extensive use of GATT Article XXIV has fostered an environment whereby a significant proportion of global trade is conducted under preferential terms. ${ }^{345}$ It is noted that MFN-based trade was the original vision of the GATT drafters. With this, the question of whether the rise of preferential trade serves to augment the policy goals of the multilateral trading system (MTS) or undermines them remains unanswered. Chapter 3 also addresses the institutional and legal examination of the Caribbean Community (CARICOM) PTAs, which are the main focus of Part 2 and 3 of this dissertation.

\subsection{GATT Institutional Assessment - The Early Years}

The main purpose of the GATT institutional assessment was to examine a notified PTA to ascertain whether the formation requirements outlined in GATT Article XXIV were undertaken. ${ }^{346}$ This exercise was conducted with a view to establishing whether it was likely that a PTA would result in trade creation whilst limiting the discriminatory effects that could result in trade divergence. As noted earlier, the initial emphasis of this procedural exercise was on legal compatibility with GATT Article XXIV, as it was assumed that PTAs, which passed this test could engender trade creating conditions. During the GATT

\footnotetext{
${ }^{343}$ GATT Article XXIV: 4 states: The contracting parties recognize the desirability of increasing freedom of trade by the development, through voluntary agreements, of closer integration between the economies of the countries parties to such agreements. They also recognize that the purpose of a customs union or of a freetrade area should be to facilitate trade between the constituent territories and not to raise barriers to the trade of other contracting parties with such territories.

${ }^{344}$ See R. Herzstein, J. Whitlock, Regulating Regional Trade Agreements - A Legal Analysis in (eds.) P. Macrory, A. Appleton, M. Plummer, The World Trade Organization: Legal, Economic and Political Analysis, Volume II (Springer, 2005); J. Pauwelyn, The Transformation of World Trade, Michigan Law Review, 2005, Vol. 104 (1), pp. 1-67; WTO Secretariat, Committee on Regional Trade Agreements, Decision of $6^{\text {th }}$ February 1996 (Geneva, $7^{\text {th }}$ February 1996)[WT/L/127]; F. Haight, Customs Union and Free Trade Areas under the GATT: A Reappraisal, Journal of World Trade Law, 1972, Vol. 6 (4), pp. 391-404.

345 "In 2014, almost half of world trade was taking place between countries that had signed a PTA and almost one third was regulated by deep trade agreements." See UNCTAD Secretariat, Key Statistics and Trends in Trade Policy: Preferential Trade Agreements (Geneva, 2015) [UNCTAD/DITC/TAB/2015/2], p. 14.

${ }^{346}$ See R. Herzstein, J. Whitlock, Regulating Regional Trade Agreements - A Legal Analysis in (eds.) P. Macrory, A. Appleton, M. Plummer, The World Trade Organization: Legal, Economic and Political Analysis, Volume II (Springer, 2005), p. 228.
} 
era, confidential ad hoc working parties were used to assess the legal compatibility of PTAs with GATT Article XXIV and after 1979, with paragraph 2 (c) of the Enabling Clause. ${ }^{347}$ The first terms of reference for the examination of a PTA were those of the ad hoc working party examining the South Africa-Southern Rhodesia Customs Union, which stated that the working party intended "to examine the Agreement for the re-establishment of a customs union between South Africa and Southern Rhodesia, in light of the provisions of Article XXIV and taking account of the remarks made during the discussions and of the statements by the representatives of South Africa and Southern Rhodesia, and to submit a report and recommendations to the Contracting Parties. $" 348$

\subsubsection{The South Africa-Southern Rhodesia Customs Union}

The South Africa-Southern Rhodesia Customs Union was the first PTA that was notified to the GATT Secretariat in $1949 .{ }^{349}$ Thereafter, the legal compatibility examination commenced and the GATT Council mandated the establishment of a working party to examine its provisions. All GATT Contracting Parties were invited to submit questions outlining any possible concerns. The GATT Secretariat drafted a compendium of collected questions and the replies issued by the PTA signatories. Subsequently, a working party report consisting of an examination of the PTA in light of GATT Article XXIV as well as the aforementioned compendium of questions and replies was submitted by the GATT working party to the GATT Council for adoption. On the issue of future institutional assessments, the GATT working party report from the South Africa-Southern Rhodesia customs union stated that a case-by-case approach would be employed. ${ }^{350}$ It was explained that each PTA should be considered on its own merits and that one particular PTA

\footnotetext{
347 The GATT era was the 47-year period spanning 1947 to 1994.

${ }^{348}$ See GATT Secretariat, Working Party 4 on the South Africa - Southern Rhodesia Customs Union Terms of Reference (Geneva, 26 ${ }^{\text {th }}$ April 1949) [GATT/CP.3/WP.4/1].

${ }^{349}$ See GATT Secretariat, Interim Agreement for a Customs Union between the Union of South Africa and Southern Rhodesia (Geneva, 10 ${ }^{\text {th }}$ March 1949) [GATT/CP.3/9]. The agreement entered into force on $1^{\text {st }}$ April 1949.

350 "The terms of reference might include an examination of the procedure to be established for the implementation of Article XXIV. The working party discussed this question and reached the conclusion that consideration by the contracting parties of proposals for customs unions would have to be based on the circumstances and conditions of each proposal and, therefore, no general procedures can be established beyond those provided in the article itself." See GATT Secretariat, Report of Working Party 4 on South Africa - Southern Rhodesia Customs Union (Geneva, 14 ${ }^{\text {th }}$ May 1949) [GATT/CP.3/24], p. 8, para. 7.
} 
examination could not establish a precedent because all PTAs had different characteristics. $^{351}$ It is notable, however, that from the first PTA notified at the GATT Secretariat, the letter of GATT Article XXIV was not strictly adhered to, as both South Africa and Southern Rhodesia failed to submit a plan and schedule for their PTA to the GATT Contracting Parties. ${ }^{352}$ Despite this, the PTA was still given legal approval. ${ }^{353}$

\subsubsection{The El Salvador - Nicaragua Free Trade Agreement (FTA)}

The El Salvador - Nicaragua FTA was the second PTA that was notified to the GATT Secretariat in 1951. The process of examination replicated that which was previously applied to the South Africa - Southern Rhodesia Customs Union as the GATT Council also mandated the establishment of a GATT working party to examine the provisions of the PTA. In this regard, several complexities arose due to the fact that El Salvador was not a GATT Contracting Party. ${ }^{354}$ Thus, the provisions of GATT Article XXIV:10 were employed. ${ }^{355}$ It is notable that the El Salvador - Nicaragua FTA still permitted the imposition of quantitative restrictions (QRs) on intra-FTA trade under certain circumstances despite the requirements of GATT Article XXIV:8 (b), which outlined that such 'restrictive regulations of commerce' be eliminated. Nevertheless, Contracting Parties

\footnotetext{
351 "[...] to establish precedents was clearly against the spirit of Article XXIV...Precedents were created in law only if identical circumstances were applicable." See GATT Secretariat, Third Session of the Contracting Parties, Summary Record of the Thirteenth Meeting (Geneva, $18^{\text {th }}$ May 1949) [GATT/CP.3/SR.13], p.7.

352 "The first experience in the application of Article XXIV was in 1949 when the Contracting Parties (at their third session in Annecy) examined the Customs Union Agreement between South Africa and Southern Rhodesia. The two partners did not wait for this examination before making the Agreement effective. Nor did they provide a plan and schedule, saying they would be unable to do so until the Agreement had been in operation for five years. Without a plan and schedule the Contracting Parties could not judge the reasonableness of the proposed ten-year transitional period nor could they judge whether the proposed union between two states at rather different stages of economic development was likely to be carried to completion." F. Haight, Customs Union and Free Trade Areas under the GATT: A Reappraisal, Journal of World Trade Law, 1972, Vol. 6 (4), pp. 391-404, p. 397; K. Dam, Regional Economic Arrangements and The GATT: The Legacy of A Misconception, University of Chicago Law Review, 1963, Vol. 30 (4), pp. 615-665, p. 636.

353 "The Contracting Parties declare that the Governments of the Union of South Africa and Southern Rhodesia are entitled to claim benefits of the provisions of Article XXIV of the General Agreement on Tariffs and Trade relating to the formation of customs union;" See GATT Secretariat, Working Party 4 on the South Africa - Southern Rhodesia Customs Union Terms of Reference (Geneva, 26 ${ }^{\text {th }}$ April 1949) [GATT/CP.3/WP.4/1], p. 9.

${ }^{354}$ El Salvador became a GATT Contracting Party on $22^{\text {nd }}$ May 1991.

355 "As El Salvador is not a Contracting Party to the General Agreement, the Treaty is not covered by the provisions of paragraph 5 which apply only to the formation of a free trade area between contracting parties, and a specific decision of the Contracting Parties under paragraph 10 of Article XXIV will be required..." See GATT Secretariat, Item 23: Nicaragua - El Salvador Free Trade Area, Note by the Executive Secretary (Geneva, 22 ${ }^{\text {nd }}$ October 1951) [GATT/CP.6/24/Add 1], p. 2, para. 5.
} 
granted legal approval to the PTA under the understanding that they retained the right to review their decision if the PTA was not functioning as an FTA in the sense of GATT Article XXIV. ${ }^{356}$ Again, it is highlighted that disregard was shown to the letter of GATT Article XXIV.

\subsubsection{The Treaty of Rome Establishing the European Economic Community}

As noted in Chapter 1 of this dissertation, the Treaty of Rome was the third PTA that was notified to the GATT Secretariat in $1957 .{ }^{357}$ Its working party's examination was inconclusive, as agreement could not be reached on the legal compatibility of the Treaty of Rome with the GATT 1947. It is noted that the GATT working party allowed certain flexibilities regarding the compliance with the letter of GATT Article XXIV. The legal scrutiny of the first three PTAs that were notified to the GATT Secretariat failed to establish a solid procedural pattern and this has contributed to some of the systemic issues now associated with GATT Article XXIV. All subsequent GATT working party procedural rules and examination processes were determined on an individual basis. This lack of consistency resulted in varied rules of procedure and varied final reports. There was no standard format for the stylistic and substantive content of these reports. ${ }^{358}$ A practice emerged whereby the final decision regarding the legal compatibility of a PTA evolved into a consensus-based decision followed by a compatibility declaration stated in the final report. $^{359}$

\footnotetext{
${ }^{356}$ K. Dam, Regional Economic Arrangements and The GATT: The Legacy of A Misconception, University of Chicago Law Review, 1963, Vol. 30 (4), pp. 615-665, p. 637.

${ }^{357}$ See Treaty Establishing the European Economic Community 1957 (adopted $25^{\text {th }}$ March 1957, in force $1^{\text {st }}$ January 1958) 298 UNTS 11. See also GATT Secretariat, European Economic Community, Official Transmission to the GATT (Geneva, 24 $4^{\text {th }}$ April 1957) [L/626].

${ }^{358}$ R. Herzstein, J. Whitlock, Regulating Regional Trade Agreements: A Legal Analysis in (eds.) P. Macrory, A. Appleton, M. Plummer, The World Trade Organization: Legal, Economic and Political Analysis, Volume II (Springer, 2007), p. 228.

359 GATT Article XXV provided for decision-making by majority vote, however, decision-making by consensus developed as a practice in the 1960s. The US and Japan were keen supporters of this type of decision-making, which subsequently became a recognized rule in Article IX of the Marrakesh Agreement. See D. Steger, The Culture of the WTO: Why it needs to change, Journal of International Economic Law, 2007, Vol. 10 (3), pp. 483-495, p. 488.
} 


\subsection{The Committee on Regional Trade Agreements (CRTA)}

The establishment of the CRTA in 1996 streamlined the use of ad hoc working parties as the permanent forum was mandated to examine PTAs notified under GATT Article XXIV and, upon request, PTAs notified under GATS Article V. ${ }^{360}$ PTAs notified under paragraph 2 (c) of the Enabling Clause were not mandated, however, such PTAs were notified to the Committee on Trade and Development (CTD). The CRTA was also tasked with (a) considering how the required reporting on the operation of PTAs should be undertaken, (b) making appropriate recommendations to this effect, (c) developing procedures to improve the PTA examination process, (d) considering the systemic implications of the interrelationship between PTAs and the MTS and (e) making appropriate recommendations to the WTO General Council. ${ }^{361}$ The CRTA addressed some of its mandate by appointing the WTO working parties, which examine the various PTAs that have been notified to the WTO Secretariat. In addition to this, the CRTA improved the procedural approach to examining PTAs as well as the PTA notification process by initiating the use of standard formats for information on PTAs that cover trade in goods and services. ${ }^{362}$ Prior to 2006, the CRTA also created a reporting requirement that WTO Members should submit biennial reports on their PTAs. ${ }^{363}$ It is noted that the CRTA conducted in-depth discussions regarding the systemic issues pertaining to PTAs and assisted in the ventilation of such issues. $^{364}$

Despite this mandate, the CRTA was unable to reach a consensus opinion on the legal compatibility of most notified PTAs due to the ambiguities and interpretative differences regarding GATT Article XXIV, as discussed in Chapter 2. Thus, the systemic issues

\footnotetext{
${ }^{360}$ See WTO Secretariat, Committee on Regional Trade Agreements, Decision of $6{ }^{\text {th }}$ February 1996 (Geneva, $7^{\text {th }}$ February 1996)[WT/L/127], p. 1, para. 1.

${ }^{361}$ The CRTA mandate has been revised as a result of the establishment of the RTA TM in 2006. The RTA TM is addressed in section 3.3 of this dissertation.

${ }^{362}$ See WTO Secretariat, Committee on Regional Trade Agreements, Guidelines on Procedures to Improve and Facilitate The Examination Process (Geneva, $6^{\text {th }}$ May 1996)[WT/REG/E/15], See WTO Secretariat, Committee on Regional Trade Agreements, Standard Format for Information on Regional Trade Agreements (Geneva, 15 ${ }^{\text {th }}$ August 1996)[WT/REG/W/6], See WTO Secretariat, Committee on Regional Trade Agreements, Standard Format for Information on Economic Integration Agreements on Services (Geneva, $6^{\text {th }}$ May 1997)[WT/REG/W/14].

${ }^{363}$ This practice has been discontinued since the implementation of the RTA TM.

${ }^{364}$ See WTO Secretariat, Synopsis of "Systemic" Issues related to Regional Trade Agreements, Note by Secretariat (Geneva, $2^{\text {nd }}$ March 2000) [WT/REG/W/37].
} 
associated with GATT Article XXIV obstructed the procedural mechanism that was intended to examine notified PTAs. ${ }^{365}$ As a consequence of this, there was no way to verify whether PTAs had achieved their stated goals. Between 1996 and 2006, the relevant WTO Council would adopt terms of reference for the examination of a given PTA and refer the examination process to the CRTA. ${ }^{366}$ The CRTA would then establish a WTO working party to examine the PTA in question and this working party would convene an oralquestion-and-reply session with WTO Members. Upon conclusion of the examination process, the CRTA was required to approve the report and submit it back to the referring Council, which would either adopt the report or make appropriate recommendations. ${ }^{367}$ The use of consensus-based decision-making in the WTO enabled many Members to block PTA compatibility declarations based on their own self-interest. ${ }^{368}$ Consequently, legal compatibility examinations would conclude with an inconclusive statement regarding the compatibility of a PTA with GATT Article XXIV. ${ }^{369}$ The final examination report would indicate that some Members considered the agreement compatible with GATT Article XXIV whilst other Members considered the opposite to be the case. ${ }^{370}$

\footnotetext{
365 J. Crawford, C. Lim, Cast Light and Evil Will Go Away: The Transparency Mechanism for Regulating Regional Trade Agreements, Three Years After, Journal of World Trade, 2011, Vol. 45(2), pp. 375-400, p. 386.

${ }^{366}$ The Council for Trade in Goods (CTG) in the case of PTAs for trade in goods, Council for Trade in Services (CTS) in the case of PTAs for trade in services or the Council for Trade and Development (CTD) in the case of PTAs among developing countries. PTA examinations were based on information provided by the PTA parties.

${ }^{367}$ R. Herzstein, J. Whitlock, Regulating Regional Trade Agreements: A Legal Analysis in (eds.) P. Macrory, A. Appleton, M. Plummer, The World Trade Organization: Legal, Economic and Political Analysis, Volume II (Springer, 2007), p. 228.

${ }^{368}$ In the early GATT years, both voting and consensus-based decision-making were used. However, the practice of consensus-based decision-making eventually became an informal rule whereby prior agreement was reached and formal meetings served to confirm a given decision. It has been argued that consensus based decision making provided GATT Contracting Parties and WTO Members with the ability to have their voices heard irrespective of their size and status. During the GATT years, it also provided a voice to provisional or de facto GATT contracting parties and it has been submitted that it provided the entire membership with the ability to veto decisions. See J. Pauwelyn, The Transformation of World Trade, Michigan Law Review, 2005, Vol. 104 (1), pp. 1 - 67, p. 21.

${ }^{369}$ It is important to note that some PTAs notified under paragraph 2 (c) of the Enabling Clause are examined in light of the GATT 1994, which includes GATT Article XXIV. An illustration of this approach to examining PTAs was seen when the Committee for Trade and Development adopted the terms of reference for the GATT working party for MERCOSUR, which stated "to examine the Southern Common Market Agreement (MERCOSUR) in light of the relevant provisions of the Enabling Clause and of the General Agreement, including Article XXIV and to transmit a report and recommendations to the Committee for submission to the Contracting Parties [...]" See GATT Secretariat, Draft Note on Proceedings of the SeventyFourth Session (Geneva, 23rd June 1993) [Spec (93) 21], p. 2.

370 The GATT working party report of the Czech Republic - Slovak Republic customs union was one of the few PTAs to receive full legal compatibility with GATT Article XXIV. Its working party report stated "The
} 


\subsection{Regional Trade Agreements Transparency Mechanism (RTA TM)}

Since the establishment of the GATT Secretariat, several attempts have been made to institutionally review and substantively regulate the discipline of PTAs. Confidential ad hoc GATT working parties were used for PTA examination from 1949 to 1994 and, in 1996, the establishment of the CRTA provided a permanent forum for examining PTAs. ${ }^{371}$ These mechanisms were unable to institutionally review PTAs in an effective manner and this structural failure was symptomatic of deeper systemic issues. ${ }^{372}$ The need for RTA TM arose from the imprecise nature of the wording (and subsequent inoperability) of GATT Article XXIV:7, which is considered the original notification requirement provision on PTAs. It is noted that the additional notification requirements outlined in the RTA TM is intended to inform WTO Members precisely when and how they should notify the WTO Secretariat of information regarding their PTAs.

The interpretative differences on the meaning of GATT Article XXIV that were noted in Chapter 2 have served as a chief distraction in the assessment of PTAs and have contributed to a paralysis of PTA regulation and management. Between the establishment of the CRTA in 1996 and the adoption of the RTA TM in 2006, the CRTA completed factual examinations of 66 PTAs: 45 of which covered PTAs for trade in goods and 21 of which covered PTAs for trade in services. ${ }^{373}$ During this time, the various working parties were

Working Party agreed that, based on the documentation provided by the Parties to the Agreement, the Customs Union Agreement between the Czech Republic and the Slovak Republic was consistent with the provisions of Article XXIV of the General Agreement." See GATT Secretariat, Working Party Report on the Customs Union between The Czech Republic and the Slovak Republic (Geneva, 15 ${ }^{\text {th }}$ July 1994) [L/7501], p. 3, para.17.

${ }^{371}$ Paragraph 7 of The 1994 Understanding on GATT Article XXIV formalized the working party process: "All notifications made under paragraph 7(a) of Article XXIV shall be examined by a working party in light of the relevant provisions of GATT 1994 and of paragraph 1 of this Understanding. The working party shall submit a report to the Council for Trade in Goods on its findings in this regard. The Council for Trade in Goods may make such recommendations to Members as it deems appropriate."

372 "It was not just the widespread intellectual failure to understand the critical distinction between freeing trade in discriminatory and non-discriminatory ways that facilitated the spread of PTAs over time. The rot also set in because the relatively stringent requirements, originally built into Article XXIV as preconditions that had to be satisfied before this exception to MFN could be utilized, were progressively reduced to near irrelevance." J. Bhagwati, Termites in the Trading System: How Preferential Agreements undermine Free Trade (Oxford University Press, 2008), p. 19; R. Herzstein, J. Whitlock, Regulating Regional Trade Agreements: A Legal Analysis in (eds.) P. Macrory, A. Appleton, M. Plummer, The World Trade Organization: Legal, Economic and Political Analysis, Volume II (Springer, 2007), p. 241.

${ }^{373}$ WTO Secretariat, WTO Analytical Index: Guide to WTO Law and Practice, Third Edition, Volume 1, (Cambridge University Press, 2012), paragraph 1023. 
unable to reach agreement on the legal compatibility of most PTAs and unable to discern whether these PTAs had achieved their stated goals. This state of affairs served as a catalyst for improvements to the manner in which the WTO institutionally reviewed PTAs. ${ }^{374}$

Since 2006, the RTA TM has been used to examine PTAs and the mechanism represents a temporary departure from the debate over the ambiguities associated with GATT Article XXIV. Emphasis is now placed on the WTO Secretariat being given a transparent picture of the existing PTA landscape along with specific requirements that are aimed at understanding whether PTA trade creation goals were achieved. Although the clarity sought by the debate on the ambiguities associated with GATT Article XXIV is important in the holistic functioning of PTAs, the fact remains that these ambiguities contributed to the ineffective regulation of PTAs. ${ }^{375}$ The foregoing statement is not intended to understate the modest developments relating to PTAs that have been made since 1947: (i) The 1979 Enabling Clause was designed to allow developing countries and least developed countries to form legally permissible RTAs whilst discriminating between developed, developing and least developed trading partners. The measure was considered an early form of special and differential treatment and sought to provide inclusivity for disadvantaged countries by relaxing the legal requirements for the formation of RTAs, (ii) The 1994 Understanding on GATT Article XXIV also sought and provided some clarifications for ambiguities associated with GATT Article XXIV, (iii) The establishment of the CRTA in 1996 led to a formalization of the system of ad hoc working parties, which examined the legal compatibility of RTAs. This measure provided more predictability and structure to the manner in which RTAs were institutionally addressed at the WTO, (iv) The 1999 issuance of the Appellate Body Report on the Turkey-Textiles case also provided clarifications on some of the other ambiguities associated with GATT Article XXIV. Nevertheless, the rules and disciplines relating to PTAs are considered a neglected area of WTO legal

\footnotetext{
${ }^{374}$ J. Crawford, C. Lim, Cast Light and Evil Will Go Away: The Transparency Mechanism for Regulating Regional Trade Agreements, Three Years After, Journal of World Trade, 2011, Vol. 45(2), pp. 375-400, p. 386.

${ }^{375}$ It is worthwhile to reiterate that GATT Article XXIV encountered its first substantive challenge during the working party examination of the Treaty of Rome in 1958. It is argued that the legal provision has since remained in a precarious state. Other aspects of the GATT legal architecture have evolved, yet the disciplines regarding PTAs have remained at a standstill.
} 
architecture. $^{376}$ The exponential increase in PTAs was allowed to proceed without the formulation of clear legal rules, which demonstrates that there was no aggressive pursuit of solutions to end the PTA regulation impasse. ${ }^{377}$

\subsubsection{The Background and Aim of the Regional Trade Agreement Transparency} Mechanism

The origins of the RTA TM lie in Paragraph 29 of the Doha Ministerial Declaration, which called upon WTO Members to clarify and improve the disciplines relating to PTAs. ${ }^{378}$ To this end, the WTO General Council adopted the RTA TM on 14 December 2006. This mechanism is applicable to all PTAs covering both goods and/or services that have been notified to the WTO Secretariat under GATT Article XXIV, paragraph 2 (c) of the Enabling Clause or GATS Article V. ${ }^{379}$ The aim of the RTA TM is to enhance transparency in the institutional scrutiny of PTAs and includes the specific obligation that WTO Members provide the WTO Secretariat with detailed information about a PTA within specific time limits.

The WTO Secretariat is at the center of affairs as a neutral party that formulates a factual report based on information submitted by the PTA parties. Paragraph 7 (b) of the RTA TM requires that the WTO Secretariat prepare a factual presentation in consultation with the PTA parties, which then serves as the basis for the examination. ${ }^{380}$ The RTA TM continues

\footnotetext{
376 "The GATT/WTO membership has almost never agreed that a PTA presented for examination is in conformity with the rules, nor insisted on any modification to bring an agreement into conformity. This created a major hole in the multilateral system of trade disciplines. It is the result of willful neglect on the part of the membership, reflecting in no small part the comfort of mutual indulgence." See The Warwick Commission, The Multilateral Trade Regime: Which Way Forward? The Report of the First Warwick Commission (University of Warwick, 2007), p. 51.

${ }^{377}$ E. Mansfield, E. Reinhardt, Multilateral Determinants of Regionalism: The Effects of GATT/WTO on the formation of Preferential Trade Agreements, International Organization, 2003, Vol. 57(4), pp. 829-862, p. 833.

${ }^{378}$ Paragraph 29 of the Doha Ministerial Declaration states "We also agree to negotiations aimed at clarifying and improving disciplines and procedures under the existing WTO provisions applying to regional trade agreements. The negotiations shall take into account the developmental aspects of regional trade agreements."

${ }^{379}$ PTAs that have been notified under GATT Article XXIV and GATS Article V fall under the remit of the CRTA, which is responsible for implementing the RTA TM in these instances. PTAs notified under the Enabling Clause fall under the remit of the CTD, which convenes in a dedicated session to implement the RTA TM in such instances. See Paragraph 18 of the RTA Transparency Mechanism.

380 Many factual presentations so far have entailed a description of the trade environment, the main characteristics of the PTA and its impact on market access for the PTA parties. See R. Fiorentino, J. Crawford,
} 
to be applied on a provisional basis and is applicable to all PTAs, including those already in force. ${ }^{381}$ Moreover, it is noted that the RTA TM is subject to review and modification. ${ }^{382}$

\subsubsection{Notifications}

The first RTA TM notification requirement is an early announcement request whereby WTO Members that intend to form a PTA should notify the WTO Secretariat that they intend to commence such negotiations. ${ }^{383}$ Newly signed PTAs should also be notified to the WTO Secretariat by the submission of inter alia the official name of the PTA, its text, scope, date of signature and any foreseen timetable of entry into force or provisional application. ${ }^{384}$ It is important to note that the RTA TM early announcement is a separate obligation from the notification requirement under GATT Article XXIV:7 (a) and it represents a clear and precise legal request that WTO Members notify their intention to negotiate a PTA.

This first RTA TM notification requirement has seen some compliance as 38 RTAs were 'early announced' to the WTO Secretariat since December 2016. ${ }^{385}$ Prior to this, 28 RTAs had been 'early announced' during the period of October 2011 and May 2015. Of these 28 early announcements, 9 were for newly signed RTAs and 19 were for RTAs under negotiation. However, only 3 of these agreements were subsequently notified under GATT Article XXIV and 6 were notified under both GATT Article XXIV and GATS Article V. ${ }^{386}$ Perhaps the latter is indicative of the fact that WTO Members are still unclear about the need to notify their PTAs as per the original procedural requirements of the legal provisions that underpin the establishment of PTAs. Nevertheless, such statistics demonstrate that

C. Toqueboeuf, The Landscape of RTAs and WTO Surveillance in (eds) R. Baldwin, P. Low, Multilateralizing Regionalism: Challenges for the Global Trading System (Cambridge University Press, 2008), p. 60.

${ }^{381}$ See Paragraph 22 of the RTA Transparency Mechanism.

${ }^{382}$ See Paragraph 23 of the RTA Transparency Mechanism.

${ }^{383}$ See Paragraph 1(a) of the RTA Transparency Mechanism.

${ }^{384}$ See Paragraph 1(a) and (b) of the RTA Transparency Mechanism.

${ }^{385}$ WTO Secretariat, Committee on Regional Trade Agreements $83^{\text {rd }}$ Session, Note on the Meeting of $7^{\text {th }}-8^{\text {th }}$ November 2016 (Geneva, $7^{\text {th }}$ December 2016) [WT/REG/M/83], p. 2.

${ }^{386}$ WTO Secretariat, WTO Analytical Index: Guide to WTO Law and Practice, Supplement covering New Developments in WTO Law and Practice October 2011 - June 2015 (Geneva, 2015), p. 111, para. 443. 
WTO Members do not maintain a good record of compliance with their procedural obligations under GATT Article XXIV and GATS Article V.

The second RTA TM notification requirement states that a PTA should be notified as soon as possible, but no later than its ratification or application. This notification should occur before the application of preferential treatment between the parties and should indicate under which WTO legal provision the PTA is being notified. ${ }^{387}$ The two separate notification provisions indicate two distinct timeframes that are intended to provide clarity on when the respective notifications are required. It is submitted that both notification provisions represent an attempt to bridge the interpretative differences on the issue of PTA notifications. ${ }^{388}$ Despite the improved clarity regarding PTA notification requirements, there remains some resistance on the part of WTO Members to properly notify their PTAs. Whilst few justifications have been provided for this, it is clear that the peer pressure approach enlisted by some members of the CRTA has not been effective. ${ }^{389}$ The WTO Secretariat maintains a list of non-notified PTAs that have appeared in factual presentations pursuant to the requirements of the RTA TM. ${ }^{390}$ In the absence of proper notifications, vital information is withheld from both the WTO Secretariat and other WTO Members. ${ }^{391}$ It is noted that the transparent exchange of information on PTAs assists in the regulation of preferential trade within the MTS and provides general awareness about preferential tariffs that are being applied among a subset of the WTO membership.

\footnotetext{
${ }^{387}$ See Paragraph 3 and 4 of the RTA Transparency Mechanism.

${ }^{388}$ Previously, WTO Members held different opinions about the meaning of "notify promptly" contained in GATT Article XXIV: 7 (a). Some WTO Members had interpreted the wording to mean that a PTA should be notified before its entry into force, whereas others held the view that this lacked practicality and that a PTA should only be notified after it had entered into force. See Chapter 2, Section 2.5.2 entitled GATT Article XXIV:7 Unclarfied Concerns.

${ }^{389}$ M. Shaefer, Ensuring that Regional Trade Agreements Complement the WTO System: US Unilateralism a Supplement for WTO Initiatives? in (eds.) W. Davey, J. Jackson, The Future of International Economic Law (Oxford University Press, 2008, p. 158.

390 As of October 2017, the WTO Secretariat estimates that there are 69 PTAs that have not been notified. Most of these PTAs cover the regions of Africa, Asia and Latin America. See WTO Secretariat, CRTA: List of RTAs, which have appeared in factual presentations (issued up to $27^{\text {th }}$ October 2017) and have not yet been notified to the WTO. (Geneva, 30 ${ }^{\text {th }}$ October 2017) [WT/REG/W/122].

${ }^{391}$ See WTO Secretariat, Committee on Regional Trade Agreements $73^{\text {rd }}$ Session, Note on Meeting of $23^{\text {rd }}$ June 2014 (Geneva, 28 ${ }^{\text {th }}$ July 2014) [WT/REG/M/73] p. 3, para. 2.7.
} 


\subsubsection{Preferential Trade Agreement Consideration}

The RTA TM states that the consideration of a notified PTA shall be normally concluded in a period not exceeding one year after the date of notification. A precise timetable for the consideration of the PTA is formulated in consultation with the parties at the time of notification. ${ }^{392}$ Parties are also required to submit data about the PTA to the WTO Secretariat as soon as possible and this time period should not exceed 10 weeks, or 20 weeks in the case of PTAs involving only developing countries, after the date of notification of the agreement. ${ }^{393}$ One formal meeting of the CRTA, or the CTD in the event of a PTA notified under paragraph 2 (c) of the Enabling Clause, is held to consider each notified PTA. ${ }^{394}$ All other exchange of information occurs in written form and this includes the WTO factual presentation on the PTA under consideration. All questions and comments from other WTO Members must be in written form and must be transmitted to the parties through the WTO Secretariat in advance of the CRTA meeting. Furthermore, all questions and replies should be distributed in written form to all WTO Members in advance of the CRTA meeting.

\subsubsection{Subsequent Notification}

The RTA TM stipulates that subsequent notification and reporting should be undertaken in the event that there are changes, which affect the implementation of a PTA. ${ }^{395}$ Parties are required to submit a short written report on the realization of (the originally notified) liberalization commitments at the end of the PTA implementation period. ${ }^{396}$ This aspect of the RTA TM represents a new school of thought on PTA transparency, as it is aimed at ascertaining information about a PTA after the formal examination process is completed. It seeks an understanding of whether a PTA has accomplished its stated goals and allows for changes in trade patterns to be noted. It is, therefore, asserted that compliance with this requirement provides the WTO Secretariat with a more accurate overview of preferential trade trends. This factor was not addressed under the previous examination process. There

\footnotetext{
${ }^{392}$ See Paragraph 6 of the RTA Transparency Mechanism

${ }^{393}$ See Paragraph 8 of the RTA Transparency Mechanism

${ }^{394}$ See Paragraph 11 of the RTA Transparency Mechanism

395 See Paragraph 14 of the RTA Transparency Mechanism

${ }^{396}$ See Paragraph 15 of the RTA Transparency Mechanism
} 
has been some degree of compliance with the first part of the aforementioned requirement as changes to 12 PTAs, which have been notified under the GATT Article XXIV were reported to the WTO Secretariat during the period of October 2011 to May 2015. During this time period, changes to 1 PTA, which was notified under both GATT Article XXIV and GATS Article V was also notified to the WTO Secretariat. ${ }^{397}$

It is noted that the subsequent notification requirement pursuant to paragraph 15 of the RTA TM, which stipulates the submission of an end of implementation report (EOI Report), has seen a low level of compliance. The first EOI report was submitted by a WTO Member in 2014. ${ }^{398}$ As of the end of 2017, ten EOI reports have been submitted. ${ }^{399}$ However, general compliance has not been forthcoming because as of 13 February 2017, EOI reports for 136 RTAs were still outstanding. ${ }^{400}$ WTO Members have been invited to submit their EOI reports and to request any assistance, which they might require from the WTO Secretariat in order to formulate such reports. Currently, the CRTA maintains an updated list of PTAs subject to end of implementation reports, which are (over) due. ${ }^{401}$ Admittedly, there is a concern that trade information 'exposed' as a result of cooperation with the WTO Secretariat in the context of the RTA TM could be used as evidence in trade disputes. In order to allay such fears, it has been expressly stated that trade information ventilated in the context of the RTA TM cannot be used as a basis for future disputes. ${ }^{402}$

It is submitted that the latter aspect of the RTA TM as well as its low level of compliance reflects that there is a divide between the WTO Secretariat and the WTO membership on the matter of transparency. Although increased transparency regarding the regulation of

\footnotetext{
${ }^{397}$ WTO Secretariat, WTO Analytical Index: Guide to WTO Law and Practice, Supplement covering New Developments in WTO Law and Practice October 2011 - June 2015 (Geneva, 2015), p. 111, para. 444.

${ }^{398}$ The EU-Chile Association Agreement implementation report was submitted on 6 November 2014. See WTO Secretariat, EU-Chile Implementation Report - Joint Submission by the Parties on the Trade Pillar of the EU-Chile Association Agreement (Geneva, $6^{\text {th }}$ November 2014) [WT/REG/164/R/1].

${ }^{399}$ EOI reports for the following PTAs were submitted to the WTO Secretariat: Ukraine-Azerbaijan, UkraineTajikistan, Ukraine-Kazakhstan, Ukraine-Armenia, Ukraine-Montenegro, EU-Jordan, EU-Montenegro and EU-South Africa. See WTO Secretariat, Committee on Regional Trade Agreements-Regional Trade Agreements Subject To Implementation Reports, Updated as of $13^{\text {th }}$ February 2017 (Geneva, $20^{\text {th }}$ February 2017) [WT/REG/W/113], p. 1.

${ }^{400}$ See Ibid, WTO Secretariat, 2017, p. 1 - p. 2.

${ }^{401}$ See Ibid, WTO Secretariat, 2017, p. 1 - p. 2.

${ }^{402}$ Paragraph 10 of the RTA Transparency Mechanism.
} 
PTAs can translate to progress in improving various areas of policy, ${ }^{403}$ many WTO Members are more concerned with their self-preservation and have adopted a lax approach to transparency irrespective of the systemic effect that this can present to the MTS. Many WTO Members are simply unprepared to reveal delicate information regarding their PTAs and it appears that there is little that the WTO Secretariat can undertake to compel change in this regard. Many WTO Members remain unwilling to provide information on their PTAs due to 'dispute settlement awareness' and other untold complications that might arise from the ventilation of information. ${ }^{404}$ It is plausible that some WTO Members are simply indifferent to the concept of transparency. Conversely, others might consider it in their systemic interest to notify information about their PTAs and as such, they do so. Thus, the enforcement of the RTA TM remains a work in progress. The larger systemic concern is how can PTA trade creation be assessed, if transparent monitoring of PTAs presents a challenge for the WTO membership. ${ }^{405}$ From a multilateral perspective, it is also useful for all WTO Members to know when and where preferential tariffs are being applied.

\subsection{Institutional and Legal Review of the CARICOM Preferential Trade Agreements}

This section of the dissertation examines the GATT working party examination process of the three Caribbean PTAs. The wider focus of this dissertation concentrates on the CARICOM PTA, as chapters 4, 5 and 7 highlight various perspectives on regional integration in the Caribbean. In light of this, it is useful to examine how the various incarnations of the CARICOM PTA were institutionally and legally assessed. The CARICOM Member States have utilized three PTAs, which have been notified under

\footnotetext{
${ }^{403}$ See The Warwick Commission, The Multilateral Trade Regime: Which Way Forward? The Report of the First Warwick Commission (University of Warwick, 2007), p. 52.

${ }^{404} \mathrm{M}$. Shaefer, Ensuring that Regional Trade Agreements Complement the WTO System: US Unilateralism a Supplement for WTO Initiatives? in (eds.) W. Davey, J. Jackson, The Future of International Economic Law (Oxford University Press, 2008, p. 156.

${ }^{405}$ This concern is reflected in Paragraph 28 of the 2015 Nairobi Ministerial Declaration, which states "We reaffirm the need to ensure that Regional Trade Agreements (RTAs) remain complementary to, not a substitute for, the multilateral trading system. In this regard, we instruct the Committee on Regional Trade Agreements (CRTA) to discuss the systemic implications of RTAs for the multilateral trading system and their relationship with WTO rules. With a view to enhancing transparency in, and understanding of, RTAs and their effects, we agree to work towards the transformation of the current provisional Transparency Mechanism into a permanent mechanism in accordance with the General Council Decision of 14 December 2006, without prejudice to questions related to notification requirements." See WTO Secretariat, Nairobi Ministerial Declaration, Adopted on $19^{\text {th }}$ December 2015 (Nairobi, 2015) [WT/MIN(15)/DEC].
} 
GATT Article XXIV, to advance the process of regional integration and to pursue the gradual establishment of the CARICOM single market of today: The Caribbean Free Trade Association (CARIFTA), the Original Treaty of Chaguaramas (OTC) and Revised Treaty of Chaguaramas (RTC).

\subsubsection{The Caribbean Free Trade Association (CARIFTA)}

CARIFTA was established by the Dickenson Bay Agreement in 1968 and was the first Caribbean PTA that was notified to the GATT Secretariat under GATT Article XXIV. ${ }^{406}$ The main objective of CARIFTA was to fulfill the common determination of its signatories, which was aimed at the full employment of the peoples of the Caribbean region and their improved living standards. ${ }^{407}$ This section of Chapter 3 will examine CARIFTA in light of the requirements of GATT Article XXIV:4 to 8 and also provide commentary on the issues ventilated during the GATT working party examination of CARIFTA.

\subsubsection{CARIFTA Analysis in Light of GATT Article XXIV:4}

GATT Article XXIV:4 states:

"The contracting parties recognize the desirability of increasing freedom of trade by the development, through voluntary agreements, of closer integration between the economies of the countries parties to such agreements. They also recognize that the purpose of a customs union or of a free trade area should be to facilitate trade between the constituent territories and not raise barriers to the trade of other contracting parties with such territories."

As noted in Chapter 2 of this dissertation, GATT Article XXIV:4 is an introductory provision that outlines the purpose of a PTA and does not set forth an obligation. Therefore,

\footnotetext{
406 See Dickenson Bay Agreement establishing the Caribbean Free Trade Association (adopted $15^{\text {th }}$ December 1965, in force $1^{\text {st }}$ May 1968) 772 UNTS 3; See GATT Secretariat, Caribbean Free Trade Agreement, Notification Pursuant to Article XXIV: 7(a) (Geneva, 22 ${ }^{\text {nd }}$ October 1968) [L/3074].

${ }^{407}$ It should be noted that these were two key issues of concern that the British Caribbean territories had with the UK government and these issues formed part of the displeasure with the status quo that led many British Caribbean territories to press for independence. See Caribbean displeasure with the UK government in Chapter 4, Section 4.4 entitled Phase 1: The West Indies Federation; See also The preamble to the Dickenson Bay Agreement Establishing CARIFTA, which states "Sharing a common determination to fulfill within the shortest possible time the hopes and aspirations of their peoples of other Caribbean countries for full employment and improved living standards."
} 
there is no legal requirement contained in this subsection of the legal provision that CARIFTA was required to meet.

\subsubsection{CARIFTA Analysis in Light of GATT Article XXIV:5}

GATT Article XXIV: 5 states

"Accordingly, the provisions of this Agreement shall not prevent, as between the territories of contracting parties, the formation of a customs union or of a free-trade area or the adoption of an interim agreement necessary for the formation of a customs union or of a free-trade area; Provided that:

(a) with respect to a customs union, or an interim agreement leading to a formation of a customs union, the duties and other regulations of commerce imposed at the institution of any such union or interim agreement in respect of trade with contracting parties not parties to such union or agreement shall not on the whole be higher or more restrictive than the general incidence of the duties and regulations of commerce applicable in the constituent territories prior to the formation of such union or the adoption of such interim agreement, as the case may be;

(b) with respect to a free-trade area, or an interim agreement leading to the formation of a free-trade area, the duties and other regulations of commerce maintained in each of the constituent territories and applicable at the formation of such free-trade area or the adoption of such interim agreement to the trade of contracting parties not included in such area or not parties to such agreement shall not be higher or more restrictive than the corresponding duties and other regulations of commerce existing in the same constituent territories prior to the formation of the free-trade area, or interim agreement as the case may be; and

(c) any interim agreement referred to in subparagraphs (a) and (b) shall include a plan and schedule for the formation of such a customs union or of such a free-trade area within a reasonable length of time."

It must be recalled that CARIFTA was an FTA and as such, GATT Article XXIV:5 (b) was applicable to its formation. This subsection of GATT Article XXIV is focused on the fact that the respective individual external barriers to trade with third countries must not be 
higher or more restrictive than that which existed prior to the establishment of the FTA. In this regard, it is noted that the economies of the CARIFTA Members were heavily dependent on a small basket of agricultural products. Manufacturing was a less prominent sector for these economies and only provided 15\% contribution to GDP for the most advanced territory within the grouping and a mere $2 \%$ contribution to GDP for the least advanced territory within the grouping. ${ }^{408}$ The overreliance on trade in agricultural products and relative absence of a manufacturing sector was more acute in the lesserdeveloped Caribbean territories. As such, the application of the agricultural marketing protocol (AMP) was mainly for the benefit of the lesser-developed Caribbean territories. ${ }^{409}$ The AMP provided for the orderly marketing of agricultural products by establishing a restrictive regime on imports from third countries for specified products until the intraCARIFTA surpluses had been used. ${ }^{410}$

The AMP was a source of contention during the GATT working party examination and was cited as a source of possible inconsistency with GATT Article XXIV:5 (b). ${ }^{411}$ The CARIFTA Members considered the AMP to be justified due to the fact that it recognized the ability of the more-developed Caribbean territories to benefit immediately from the liberalization of trade due to their 'more mature' manufacturing sector. ${ }^{412}$ The drafters of CARIFTA considered that the lesser-developed territories possessed weaker manufacturing sectors and stronger agricultural sectors. Thus, they would not benefit immediately from trade liberalization and it was surmised that they had a greater need for the expansion of agricultural exports in the regional market. ${ }^{413}$ Consequently, the lesser-

\footnotetext{
${ }^{408}$ See GATT Secretariat, Report of the Working Party on the Caribbean Free Trade Agreement (Geneva, $29^{\text {th }}$ September 1971) [L/3584], p.1, para. 3 .

409 The Preamble to CARIFTA stated "Mindful of the different levels of development attained by the Caribbean territories [...]".

${ }^{410}$ The list of exceptions to liberalization included 22 items, which represented $1 \%$ of intra-CARIFTA trade. For the first three years of CARIFTA, each territory was allowed to import up to $30 \%$ of any commodity on the list of exceptions from third countries without prior permission from the CARIFTA Secretariat. See GATT Secretariat, Report of the Working Party on the Caribbean Free Trade Agreement (Geneva, $29^{\text {th }}$ September 1971) [L/3584], p.1, para. 4.

${ }^{411}$ See GATT Secretariat, Report of the Working Party on the Caribbean Free Trade Agreement (Geneva, $29^{\text {th }}$ September 1971) [L/3584], p. 2, para. 8.

${ }_{412}$ GATT Secretariat, Caribbean Free Trade Agreement, Questions and Replies (Geneva, $23^{\text {rd }}$ July 1971) [L/3547], p. 2.

${ }^{413}$ See GATT Secretariat, Report of the Working Party on the Caribbean Free Trade Agreement (Geneva, $29^{\text {th }}$ September 1971) [L/3584], p. 3, para. 11.
} 
developed territories were given this priority by the Caribbean Council of Ministers. ${ }^{414}$ In defence of the AMP, it was explained that there was no intention to raise new barriers to trade with third countries and that Caribbean territories would address any problems that arose in connection with its operation. ${ }^{415}$

In addition to this, Article 5 of CARIFTA provided for a regime pertaining to the area of origin for tariff treatment of products. Article 5 (c) of CARIFTA referenced a Basic Materials List (BML) that listed many input materials that were not produced within the CARIFTA territories, but deemed to be of regional origin for value-added criterion. 'CARIFTA origin' was conferred upon any product that utilized input materials from the BML. This area of origin regime also represented an attempt to assist the weak manufacturing industries of the CARIFTA territories. ${ }^{416}$

With respect to the requirements of GATT Article XXIV:5 (c), the submission of CARIFTA to the GATT Secretariat included a plan and schedule, which identified specific timeframes for the implementation of certain commitments related to the formation of the FTA ${ }^{417}$ In addition to this, it is noted that by 1971 when the GATT working party examined CARIFTA, the FTA had already been in operation since $1968 .^{418}$

\subsubsection{CARIFTA Analysis in Light of GATT Article XXIV:6}

GATT Article XXIV: 6 states:

"If, in fulfilling the requirements of subparagraph 5 (a), a contracting party proposes to increase any rate of duty inconsistently with the provisions of Article II, the procedure set forth in Article XXVIII shall apply. In providing for compensatory adjustment, due account shall be taken of the compensation already afforded by the reduction brought about in the corresponding duty of the other constituents of the union."

\footnotetext{
${ }^{414}$ See Ibid, GATT Secretariat, 1971, p. 3, para. 11.

415 See Ibid, GATT Secretariat, 1971, p. 4, para. 13.

${ }^{416}$ E. Rose, Dependence and Socialism in the Modern Caribbean (Lexington Books Publishing, USA, 2002), p. 98; T. Heron, The New Political Economy of the US-Caribbean Relations (Routledge, 2004), p. 42.

${ }^{417}$ See Annex A, B and D in GATT Secretariat, Caribbean Free Trade Agreement, Notification Pursuant to Article XXIV: 7(a) (Geneva, 22 ${ }^{\text {nd }}$ October 1968) [L/3074].

${ }^{418}$ See GATT Secretariat, Report of the Working Party on the Caribbean Free Trade Agreement (Geneva, $29^{\text {th }}$ September 1971) [L/3584], p.1, para. 4.
} 
This subsection of GATT Article XXIV was not applicable to CARIFTA due to the fact that the agreement created an FTA and this legal provision is applicable to PTAs that are customs unions.

\subsubsection{CARIFTA Analysis in Light of GATT Article XXIV:7}

GATT Article XXIV:7 states:

“(a) Any contracting party deciding to enter into a customs union or free-trade area, or an interim agreement leading to the formation of such a union or area, shall promptly notify the CONTRACTING PARTIES and shall make available to them such information regarding the proposed union or area as will enable them to make such reports and recommendations to contracting parties as they may deem appropriate.

(b) If, after having studied the plan and schedule included in an interim agreement referred to in paragraph 5 in consultation with the parties to that agreement and taking due account of the information made available in accordance with the provisions of subparagraph (a), the CONTRACTING PARTIES find that such agreement is not likely to result in the formation of a customs union or of a free-trade area within the period contemplated by the parties to the agreement or that such period is not a reasonable one, the CONTRACTING PARTIES shall make recommendations to the parties to the agreement. The parties shall not maintain or put into force, as the case may be, such agreement if they are not prepared to modify it in accordance with these recommendations.

(c) Any substantial change in the plan or schedule referred to in paragraph 5 (c) shall be communicated to the CONTRACTING PARTIES, which may request the contracting parties concerned to consult with them if the change seems likely to jeopardize or delay unduly the formation of the customs union or of the free-trade area."

CARIFTA was notified at the GATT Secretariat pursuant to GATT Article XXIV:7 (a). ${ }^{419}$ In this regard, it is noted that CARIFTA was adopted on 15 December 1965 and entered

\footnotetext{
${ }^{419}$ See GATT Secretariat, Caribbean Free Trade Agreement, Notification Pursuant to Article XXIV: 7(a) (Geneva, 22 ${ }^{\text {nd }}$ October 1968) [L/3074].
} 
into force on 1 May 1968. Thereafter, CARIFTA was notified at the GATT Secretariat on 22 October 1968: five months after its entry into force. By fulfilling this notification requirement, the CARIFTA Members enabled the GATT Secretariat institutional review process to commence. In 1971, a GATT working party was established to examine CARIFTA in light of the GATT $1947^{420}$ and GATT Contracting Parties were also requested to submit any questions or concerns that they might have regarding the notified agreement. ${ }^{421}$ GATT Secretariat documentation has demonstrated that the CARIFTA Members were forthcoming in ventilating the necessary details regarding the agreement and replied to various concerns held by several GATT Contracting Parties. ${ }^{422}$

With respect to GATT Article XXIV:7 (b), it is noted that CARIFTA was already a functioning FTA by the time that the GATT Contracting Parties conducted their working party examination of the agreement. CARIFTA was not an interim agreement leading to the establishment of an FTA and as such, this provision was not applicable to it. ${ }^{423}$ Where GATT Article XXIV:7 (c) is concerned, it is again reiterated that CARIFTA was a functioning FTA by the time of the GATT working party examination of 1971. As such, there could not have been changes to jeopardize or delay the formation of the FTA. Although some aspects of CARIFTA involved timeframes that were not yet completed, this dissertation submits that it is unlikely that any substantial change was made to the agreement. The GATT working party examination of the agreement occurred in 1971 and by 1973 , the second phase of regional integration in the Caribbean had commenced with

\footnotetext{
420 "The Chairman said that the establishment of a working party met with general approval, the following terms of reference should be appropriate: To examine, in the light of the relevant provisions of the General Agreement, the Caribbean Free Trade Agreement and to report to the Contracting Parties." See GATT Secretariat, Contracting Parties $25^{\text {th }}$ Session, Summary Record of the Seventh Meeting (Geneva, $12^{\text {th }}$ December 1968) [SR.25/7] p. 118.

421 "The Chairman further suggested that to expedite the examination of the Agreement, Contracting Parties wishing to ask question concerning its interpretation or implementation should submit them in writing to the Secretariat; a questionnaire would be prepared by the Secretariat for submission to the member states. The questions and answers would be distributed and the working party would then be convened." See Ibid, GATT Secretariat, 1968, p.118; See also GATT Secretariat, Caribbean Free Trade Agreement, Questions and Replies (Geneva, 23 ${ }^{\text {rd }}$ July 1971) [L/3547].

${ }^{422}$ Further to this, the CARIFTA representative affirmed during the Questions and Replies session that CARIFTA members were prepared to submit reports to the GATT Contracting Parties as per the requirements of GATT Article XXIV:7. See Ibid, GATT Secretariat, 1971, p. 4.

${ }^{423}$ During the Questions and Replies on CARIFTA, it was affirmed that the agreement establishes an FTA and that it is not considered an interim agreement leading to an FTA. See Ibid, GATT Secretariat, 1971, p.1.
} 
the adoption and entry into force of the OTC. The OTC itself was notified to the GATT Secretariat as a successor agreement to CARIFTA.

\subsubsection{CARIFTA Analysis in Light of GATT Article XXIV:8}

GATT Article XXIV:8 states:

"For the purposes of this Agreement:

(b) A customs union shall be understood to mean the substitution of a single customs territory for two or more customs territories, so that

(i) duties and other restrictive regulations of commerce (except, where necessary, those permitted under Articles XI, XII, XIII, XIV, XV and XX) are eliminated with respect to substantially all the trade between the constituent territories of the union or at least with respect to substantially all the trade in products originating in such territories, and,

(ii) subject to the provisions of paragraph 9, substantially the same duties and other regulations of commerce are applied by each of the members of the union to the trade of territories not included in the union;

(b) A free-trade area shall be understood to mean a group of two or more customs territories in which the duties and other restrictive regulations of commerce (except, where necessary, those permitted under Articles XI, XII, XIII, XIV, XV and XX) are eliminated on substantially all the trade between the constituent territories in products originating in such territories."

It is noted that GATT Article XXIV:8 (b) outlines the internal requirement for the establishment of FTAs. This subsection requires FTA constituents to eliminate duties and other restrictive regulations of commerce on substantially all trade in order to create the (internal) economic area where free trade will be conducted. In this regard, CARIFTA liberalized over $90 \%$ of trade between its constituents. ${ }^{424}$ Annex B of CARIFTA outlined the immediate removal of import duties on certain products for the more-developed

\footnotetext{
${ }^{424}$ See GATT Secretariat, Report of the Working Party on the Caribbean Free Trade Agreement (Geneva, $29^{\text {th }}$ September 1971) [L/3584], p. 2, para. 5.
} 
Caribbean territories, whilst allowing the lesser-developed territories to progressively reduce of their import duties on the same specified products in order to allow for their gradual adjustment to competition within the new internal economic area. ${ }^{425}$ Annex D of CARIFTA highlighted import duties that represented an important source of revenue and outlined their gradual reduction in a manner, which would allow the various domestic industries to adjust to competition. ${ }^{426}$ The GATT working party report on CARIFTA refers to the fact that the establishment of the FTA had "resulted in the dismantling of import duties and import restrictions on substantially all trade between member territories" ${ }^{427}$ Further to this, the GATT working party report confirmed that "CARIFTA was already a free-trade area in which substantially all trade among member territories was liberalized". ${ }^{428}$

Lastly, the GATT working party report explained that where the compatibility of CARIFTA with GATT Article XXIV was concerned "the Agreement provided for the establishment of a free trade area within the meaning of Article XXIV:8 (b)". ${ }^{429}$ Despite this, concerns were noted regarding the overall compatibility of CARIFTA with the GATT $1947 .^{430}$ The main issue was the possible effects of the AMP and it was argued that the AMP might be inconsistent with GATT Articles XXIV: 4, XXIV: 5(b), XI and XIII. ${ }^{431}$ Notwithstanding this, the AMP was not a major hindrance to the legal compatibility assessment of CARIFTA. It is posited that this may have been indicative of the circumstances that were already present regarding the institutional treatment of PTAs notified under GATT Article XXIV. By 1971, there was already an awareness regarding the inoperability of the legal rules contained in GATT Article XXIV. Thus, it was unlikely

${ }^{425}$ GATT Secretariat, Caribbean Free Trade Agreement, Questions and Replies (Geneva, 23 ${ }^{\text {rd }}$ July 1971) [L/3547], p. 2.

${ }^{426}$ See Ibid, GATT Secretariat, 1971, p. 3.

${ }^{427}$ See GATT Secretariat, Report of the Working Party on the Caribbean Free Trade Agreement (Geneva, $29^{\text {th }}$ September 1971) [L/3584], p. 2, para. 5.

${ }^{428}$ See Ibid, GATT Secretariat, 1971, p. 2, para. 7.

${ }^{429}$ See Ibid, GATT Secretariat, 1971, p. 4, para. 13.

${ }^{430}$ It must be recalled that the GATT working party was required to "examine [CARFITA] in the light of the relevant provisions of the General Agreement... and report to the Contracting Parties." Thus, some of the contentious issues raised did not only pertain to GATT Article XXIV, but also other provisions of the General Agreement. See Ibid, GATT Secretariat, 1971, p. 1, para. 1.

${ }^{431}$ It was suggested that other less restrictive mechanisms could be used to promote agriculture such as improved marketing and agricultural research. See Ibid, GATT Secretariat, 1971, p. 2, para. 8. 
that a PTA would be declared fully consistent with GATT Article XXIV. ${ }^{432}$

\subsubsection{The Original Treaty of Chaguaramas (OTC)}

The OTC was the second Caribbean PTA notified at the GATT Secretariat under GATT Article XXIV. ${ }^{433}$ As the hallmark of the second phase of regional integration in the Caribbean, the OTC built upon the foundation laid by CARIFTA $^{434}$ and its main provisions addressed inter alia trade liberalization, the rights of establishment between Member States, the coordination of economic and foreign policies ${ }^{435}$ and special measures for the lesser developed territories within the regional grouping. ${ }^{436}$ This section of Chapter 3 will examine the OTC in light of the provision of GATT Article XXIV: 4 to 8 and also provide commentary on the issues ventilated during the GATT working party examination of OTC.

\subsubsection{OTC Analysis in Light of GATT Article XXIV:4}

The full text of GATT Article XXIV:4 is noted in section 3.4.1.1 of this chapter. As previously mentioned, GATT Article XXIV:4 is an introductory provision that outlines the purpose of a PTA and does not set forth an obligation. Therefore, there is no legal requirement contained in this subsection of the legal provision that the OTC was required

\footnotetext{
432 "In retrospect, the inconclusive nature of deliberations on the establishment of the Treaty of Rome came to symbolize a continuing de facto recognition of the inoperability of the conditions contained in GATT Article XXIV. The subsequent examination of customs unions and free trade areas notified to the GATT did not yield any clearer assessments of full consistency with the rules." See R. Fiorentino, J. Crawford, C. Toqueboeuf, The Landscape of RTAs and WTO Surveillance in (eds) R. Baldwin, P. Low, Multilateralizing Regionalism: Challenges for the Global Trading System (Cambridge University Press, 2008), p. 55.

${ }^{433}$ The 1973 Treaty of Chaguaramas is oftentimes referred to as the Original Treaty of Chaguaramas (OTC) due to its subsequent revision. The OTC was also known as the Caribbean Community and Common Market Agreement. See The Treaty of Chaguaramas (adopted $4^{\text {th }}$ July 1973, in force $1^{\text {st }}$ August 1973) 946 UNTS 17; See GATT Secretariat, Treaty Establishing the Caribbean Community (Geneva, $14^{\text {th }}$ October 1974) [L/4083]. ${ }^{434}$ The preamble to the OTC states "Conscious that [...] objectives can most rapidly be attained by the optimum utilization of available human and natural resources of the region; by accelerated, coordinated and sustained economic development, particularly through the exercise of permanent sovereignty over their natural resources $[\ldots]$ ".

${ }^{435}$ Article 4 (a) of the OTC refers to the economic integration of the Member States by the establishment of a common market regime and Article 4 (b) refers to the coordination of the foreign policies of Member States. ${ }^{436}$ It must be recalled that the OTC created the Caribbean Community and the Caribbean Common Market. The Common Market Annex of the OTC included a special regime for the CARICOM LDCs, which consisted of various measures including inter alia a provision allowing LDCs to suspend common market tariff treatment on imports on the grounds of industrial development promotion (Article 56 of the Common Market Annex, a provision facilitating mechanisms to promote investment flows to LDCs (Article 59 of the Common Market Annex) and a provision providing additional special arrangements to assist Belize with participation in the common market (Article 61 of the Common Market Annex).
} 
to meet.

\subsubsection{OTC Analysis in Light of GATT Article XXIV:5}

GATT Article XXIV: 5 states

"Accordingly, the provisions of this Agreement shall not prevent, as between the territories of contracting parties, the formation of a customs union or of a free-trade area or the adoption of an interim agreement necessary for the formation of a customs union or of a free-trade area; Provided that:

(a) with respect to a customs union, or an interim agreement leading to a formation of a customs union, the duties and other regulations of commerce imposed at the institution of any such union or interim agreement in respect of trade with contracting parties not parties to such union or agreement shall not on the whole be higher or more restrictive than the general incidence of the duties and regulations of commerce applicable in the constituent territories prior to the formation of such union or the adoption of such interim agreement, as the case may be; [...]

(c) any interim agreement referred to in subparagraphs (a) and (b) shall include a plan and schedule for the formation of such a customs union or of such a free-trade area within a reasonable length of time."

It is noted that GATT Article XXIV:5 (a) was applicable to the OTC, as the treaty established an interim agreement leading to a customs union. ${ }^{437}$ Again, it must be recalled that this subsection of GATT Article XXIV is aimed at establishing the external barrier that customs unions must impose on trade with third countries. Several GATT Contracting Parties opined that the OTC might not fully satisfy the requirements of GATT Article XXIV: 5(a) because of the previously noted AMP and its discrimination against third

\footnotetext{
437 "The member states are of the view that the Agreement constitutes an interim agreement for the formation of a customs union within the meaning of Article XXIV: 5 of the GATT." See GATT Secretariat, Treaty establishing the Caribbean Community and Common Market, Questions and Replies (Geneva, $21^{\text {st }}$ June 1976) [L/4361], p.1.
} 
country suppliers. ${ }^{438}$ The same justification that was offered during the CARIFTA working party examination was restated during the OTC working party examination. ${ }^{439}$ The CARIFTA representative explained that the trade effect of the AMP had not resulted in discrimination against third countries and on the contrary, products listed on the AMP exception list had seen an increase in trade rising from \$27 million Eastern Caribbean Dollars to $\$ 57$ million Eastern Caribbean Dollars. ${ }^{440}$ It was submitted that the AMP was in place since the CARIFTA era and the value of exports affected by the mechanism was 1.2 per cent of the total intra-regional trade. It was also argued that legal compatibility with GATT Article XXIV was to be judged in terms of the liberalization of a substantial portion of intra-regional trade and this had occurred. ${ }^{441}$ Hence, the GATT working party concluded that the AMP did not pose a problem to the final confirmation of the OTC.

\subsubsection{OTC Analysis in Light of GATT Article XXIV:6}

The full text of GATT Article XXIV:6 is noted in section 3.4.1.3. In this regard, it should be highlighted that although GATT Article XXIV:5 (a) was applicable to the OTC, the GATT documentation examined for the GATT working party examination of the OTC did not encounter any evidence that the CARICOM Member States utilized GATT Article XXIV:6 during their tariff adjustment exercise to implement the CARICOM common external regime.

\subsubsection{OTC Analysis in Light of GATT Article XXIV:7}

The full text of GATT Article XXIV:7 is noted in section 3.4.1.4. The OTC was notified at the GATT Secretariat pursuant to GATT Article XXIV:7 (a). It is also noted that the OTC was adopted on 4 July 1973 and entered into force on 1 August 1973. Thereafter, the treaty was notified at the GATT Secretariat on 14 October $1974 .{ }^{442}$ By fulfilling this notification requirement, the CARICOM Member States enabled the GATT Secretariat

\footnotetext{
${ }^{438}$ See Ibid, GATT Secretariat, 1977, p. 3, para. 11.

${ }^{439}$ This justification is outlined in Section 3.4.1.2 entitled CARIFTA Analysis in light of GATT Article XXIV:5.

${ }^{440}$ GATT Secretariat, Report of the Working Party on the Caribbean Community and Common Market (Geneva, $2^{\text {nd }}$ February 1977) [L/4470], p. 4, para. 11.

${ }^{441}$ See Ibid, GATT Secretariat, 1977, p. 4, para. 11.

${ }^{442}$ See GATT Secretariat, Treaty Establishing the Caribbean Community (Geneva, $14^{\text {th }}$ October 1974) [L/4083].
} 
institutional review process of the OTC to commence. Subsequent to its notification, a GATT working party was established to examine the agreement in light of the GATT $1947^{443}$ and GATT Contracting Parties were requested to submit any questions or concerns that they might have regarding the notified agreement. ${ }^{444}$ GATT Secretariat documentation has, again, demonstrated that the CARICOM Member States were forthcoming in ventilating the necessary details regarding the agreement and replied to various concerns held by several GATT Contracting Parties. ${ }^{445}$

With respect to GATT Article XXIV:7 (b), which addresses the likelihood that a submitted plan and schedule will not result in the establishment of a PTA within a specified period of time, it is unlikely that this subsection of GATT Article XXIV was used in relation to the OTC. As noted several times during the GATT working party examination, the OTC built upon the existing infrastructure from the CARIFTA era of regional integration in the Caribbean. As a consequence of this, many elements common to an FTA were already present in the CARICOM 'internal economic area' prior to any attempt to comply with the internal and external requirements of GATT Article XXIV pertaining to customs unions. In addition to this, many elements of a customs union, such as the CET, were already partially implemented by the time that the GATT working party examination occurred. With respect to GATT Article XXIV:7 (c), the CARICOM Member States indicated their intent to submit any future substantial changes to their customs union.

\subsubsection{OTC Analysis in light of GATT Article XXIV:8}

GATT Article XXIV:8 states:

"For the purposes of this Agreement:

(a) A customs union shall be understood to mean the substitution of a single customs territory for two or more customs territories, so that

\footnotetext{
443 "The working party was established by the GATT Council at its meeting on $21^{\text {st }}$ October 1974 to examine, in the light of the relevant provisions of the General Agreement, the provisions of the Treaty establishing the Caribbean Community and Common Market and to report to the Council." See GATT Secretariat, Report of the Working Party on the Caribbean Community and Common Market (Geneva, $2^{\text {nd }}$ February 1977) [L/4470], p. 1, para. 1.

${ }^{444}$ See GATT Secretariat, Treaty establishing the Caribbean Community and Common Market, Questions and Replies (Geneva, 21 ${ }^{\text {st }}$ June 1976) [L/4361].

${ }^{445}$ See Ibid, GATT Secretariat, 1976.
} 
(i) duties and other restrictive regulations of commerce (except, where necessary, those permitted under Articles XI, XII, XIII, XIV, XV and XX) are eliminated with respect to substantially all the trade between the constituent territories of the union or at least with respect to substantially all the trade in products originating in such territories, and,

(ii) subject to the provisions of paragraph 9, substantially the same duties and other regulations of commerce are applied by each of the members of the union to the trade of territories not included in the union; [...]"

Since the OTC was an interim agreement leading to the establishment of a customs union, GATT Article XXIV:8 (a) (i) and (ii) were applicable to its formation. Again, it is noted that these subsections of GATT Article XXIV relate to the enlarged internal market created by the constituents who are intent on forming a customs union. GATT Article XXIV:8 (a) (i) required that duties and other regulations of commerce be eliminated on substantially all trade. In this regard, it is submitted that CARIFTA had already eliminated over $90 \%$ of all such duties and other regulations of commerce. Consequently, several GATT Contracting Parties noted that the OTC, as the successor to CARIFTA, was already consistent with GATT Article XXIV. It was also concluded that the provisions of the OTC were not more trade restrictive than those, which existed formerly under CARIFTA. ${ }^{446}$

With respect to GATT Article XXIV:8 (a) (ii), which requires that substantially the same duties and other regulations of commerce be applied to third countries, it is noted that CARICOM Member States had already commenced the implementation of their common external regime. It was submitted that by the time of the GATT working party examination of the OTC, the CARICOM common external tariff (CET) was fully implemented by the four more-developed Member States and the lesser-developed Member States were in the process of adopting it. ${ }^{447}$ The more-developed Member States that had high tariffs in place were required to accept a substantial reduction in many individual tariffs in order to

\footnotetext{
${ }^{446}$ See GATT Secretariat, Report of the Working Party on the Caribbean Community and Common Market (Geneva, $2^{\text {nd }}$ February 1977) [L/4470], p. 2, para. 7.

447 GATT Secretariat, Report of the Working Party on the Caribbean Community and Common Market (Geneva, $2^{\text {nd }}$ February 1977) [L/4470], p. 2, para. 5.
} 
establish average tariff rates. Consequently, the total import duties collected in 1974 were lower than previously recorded levels. These reductions were necessary to ensure that the CET was consistent with the requirements of GATT Article XXIV:5 (a). ${ }^{448}$ Despite the lack of full adoption by all Member States, it was reported that the CET was already being applied to a majority of imports into the common market from third countries. ${ }^{449}$ As a consequence of the abovementioned analysis of the OTC and GATT Article XXIV, the GATT working party declared the OTC to be legally compatible with GATT Article XXIV. $^{450}$

\subsubsection{The Revised Treaty of Chaguaramas (RTC)}

The RTC was the third notified Caribbean PTA and the first to be notified to the WTO Secretariat after the WTO's establishment in $1995 .{ }^{451}$ It introduced coverage for trade in services into the Caribbean regional integration landscape and accordingly, it was also notified to the WTO Secretariat under GATS Article V:7 (a). The notification of the 1973 OTC under GATT Article XXIV remains on file at the WTO Secretariat, as the RTC was not notified or examined in relation to this legal provision. It is submitted that this is possibly based on the fact that the RTC did not introduce any substantially different concepts regarding trade in goods. As the most mature regime within the CARICOM PTA, trade in goods has been legally examined both in the context of CARIFTA and the OTC. Both GATT working parties had attested that substantially all trade had been liberalized among the CARICOM Member States. As such, the revised text of the RTC was shared with the WTO Secretariat. ${ }^{452}$ In light of the foregoing, the RTC was examined by the CRTA

\footnotetext{
${ }^{448}$ See Ibid, GATT Secretariat, 1977, p. 2, para. 8.

${ }^{449}$ See Ibid, GATT Secretariat, 1977, p. 2, para. 5.

450 "It was generally agreed that the Caribbean Common Market constituted an interim agreement leading to the establishment of a customs union and as such, was consistent with the provisions of Article XXIV of the General Agreement.” See Ibid, GATT Secretariat, 1977, p. 5, para. 13.

${ }^{451}$ See Revised Treaty of Chaguaramas Establishing The Caribbean Community Including The CARICOM Single Market and Economy (adopted 5 July 2001, in force 1 January 2006) 2259 UNTS 293; WTO Secretariat, Notification pursuant to Article V: 7(a) of the General Agreement on Trade in Services (Geneva, $19^{\text {th }}$ February 2003) [S/C/N/229].

452 See WTO Secretariat, Caribbean Community and Common Market, Text of the Revised Treaty (Geneva, $8^{\text {th }}$ July 2003) [WT/REG155/1].
} 
solely from a trade in services perspective. ${ }^{453}$ The main import of the RTC was that it introduced measures to encourage the further movement of the factors of production, it provided coverage for trade in services and provided for the rights of establishment for businesses. ${ }^{454}$ These elements were considered critical aspects for the proposed CARICOM Single Market and Economy (CSME) and the 1973 OTC was revised to give effect to new components of the regional arrangement. ${ }^{455}$ Much of the other examination details pertain to Caribbean trade in services, which is outside the purview of this dissertation.

3.5 Reconciliation of the interrelationship between Preferential Trade Agreements and the Multilateral Trading System

The role of preferential trade in the MTS remains a source of legitimate concern given that the MTS was designed with the understanding that global trade would be transacted under non-discriminatory terms. ${ }^{456}$ The centrality of the MFN principle in Article 1 of the GATT 1947 underscores this understanding. ${ }^{457}$ Nevertheless, the GATT 1947 grandfathered rights for existing preferential arrangements in GATT Article 1:2 (b) and provided legal coverage for the establishment of new preferential arrangements in GATT Article XXIV. ${ }^{458}$ The aforementioned legal framework was hinged on the assumption that there would be limited use of GATT Article XXIV, as it was generally understood that the discriminatory

\footnotetext{
${ }^{453}$ The RTC was the first Caribbean PTA to be examined by the WTO Secretariat, as the other Caribbean PTAs were examined by the GATT Secretariat. See WTO Secretariat, Examination of the Caribbean Community and Common Market, Services (Geneva, $19^{\text {th }}$ November 2004) [WT/REG155/M/1].

${ }^{454}$ See Ibid, WTO Secretariat, 2004, p. 2, para. 5.

${ }^{455}$ It was explained that the services sector was of critical importance to the Caribbean regional economy as tourism, financial services and related services categories accounted for 75 per cent of CARICOM GDP. See Ibid, WTO Secretariat, Examination of the Caribbean Community and Common Market, Services (Geneva, $19^{\text {th }}$ November 2004) [WT/REG155/M/1], p. 2, para. 5.

456 The preamble to the WTO Agreement states "Being desirous of contributing to these objectives by entering into reciprocal and mutually advantageous arrangements directed to the substantial reduction of tariffs and other barriers to trade and to the elimination of discriminatory treatment in international trade relations."

457 "The MFN rule quickly gained preeminence in the aftermath of World War II and was considered by many as a key element in building a post war architecture that minimized the risk of war. By the time that the GATT was founded by 1947, the Contracting Parties agreed to put the MFN rule first and foremost among all rules of the GATT System.” R. Herzstein, J. Whitlock, Regulating Regional Trade Agreements: A Legal Analysis in (eds.) P. Macrory, A. Appleton, M. Plummer, The World Trade Organization: Legal, Economic and Political Analysis, Volume II (Springer, 2007), p.221.

${ }^{458}$ And, subsequently in paragraph 2 (c) of the Enabling Clause.
} 
application of tariffs and regulatory barriers would undermine the MFN principle. ${ }^{459}$ As noted in Chapter 1, the early GATT years were characterized by the limited use of PTAs. The subsequent unprecedented levels of PTA use by GATT Contracting Parties including several of the major trading economies, however, has served to distort trade patterns and perpetuate exclusivity among PTA partners. ${ }^{460}$

The establishment of the WTO in 1995 coincided with a sharp rise in the use of PTAs by several countries that had previously concentrated their efforts on multilateral trade. ${ }^{461}$ Since 1995, there has been an average of 25 PTAs notified each year and this can be contrasted with the GATT years where on average 3 PTAs were notified each year. ${ }^{462}$ Despite advocating an early message to the contrary ${ }^{463}$, the WTO Secretariat has described the proliferation of PTAs as a threat to multilateralism. ${ }^{464}$ Nevertheless, the use of PTAs has continuously increased and the existing ambiguities regarding GATT Article XXIV have not deterred WTO Members from participating in PTAs. The increase in PTA notifications at the WTO Secretariat supports the conclusion that many WTO Members

\footnotetext{
${ }^{459}$ See J. Odell, B. Eichengreen, The United States, the ITO and the WTO: Exit Options, Agent Slack and Presidential Leadership in (ed) A. Krueger, The WTO as an International Organization (The University of Chicago Press, 1996), p. 184-185.

${ }^{460}$ It has been asserted that the rise in PTA use, particularly by the major trading economies, constitutes a major threat to the MTS. See R. Baldwin, The Causes of Regionalism, The World Economy, 1997, Vol. 20 (7), pp. 865-888, p. 876.

${ }^{461}$ Namely the United States, Japan and Korea. See W. Davey, A Model Article XXIV: Are there Realistic Possibilities to Improve It? in (eds.) K. Bagwell, P. Mavroidis, Preferential Trade Agreements: A Law and Economics Analysis (Cambridge University Press, 2011), p. 236; Y. Lee, Reconciling RTAs with the WTO Multilateral Trading System: Case for a New Sunset Requirement on RTAs and Development Facilitation, Journal of World Trade, 2011, Vol. 45 (3), pp. 629-651, p. 636.

${ }^{462}$ R. Acharya, Regional Trade Agreements: Recent Developments in (ed.) R. Acharya, Regional Trade Agreements and the Multilateral Trading System (Cambridge University Press, 2016), p. 5.

463 "The regional and multilateral integration initiatives are complements rather than alternatives in the pursuit of open trade." See WTO Secretariat, WTO Press Release, No evidence of Polarization of World Trade among three "blocs" and no clash between world and regional trade systems - says new WTO Report, (Geneva, 18 ${ }^{\text {th }}$ April 1995) [Press/10].

464 “The increasing number of regional arrangements may also represent a threat to multilateral liberalization. Preferential agreements can distort trade flows and for this reason may be regarded as an inferior option compared to coordinated multilateral liberalization... The question, then, is one of balance. Regional arrangements can be destructive of more desirable multilateral outcomes, but they can also supplement and build upon multilateralism in positive ways." See WTO Secretariat, World Trade Report 2003, Trade and Development (Geneva, 2003), p. 65.
} 
still consider it worthwhile to attempt trade creation in the context of exclusive preferential arrangements. ${ }^{465}$

This state of affairs competes directly with one of the core aims of the MTS, which is to create a non-discriminatory global trading environment. Although there is a high degree of discrimination in the MTS due to the use of PTAs, it still remains to be seen if their true impact hinders or fosters multilateral trade. Cogent arguments abound on both sides of the divide as it has been proffered that PTAs possess many positives such as the ability to provide refuge for coalitions of the willing who want to pursue broader and deeper trade relations than that afforded by multilateralism. ${ }^{466}$ Others have cited that PTAs have the ability to spur the multilateral agenda forward and NAFTA as well as the EEC have been offered as credible examples of this argument. It is also claimed that PTAs present the international system with a win-win game set because not only is trade creation achieved, but many noble non-trade related motivations are assured, namely: policy reform, poverty alleviation and anti-corruption initiatives. ${ }^{467}$

On the other side of the divide, PTA detractors speak to the 'corrosive impact' that PTAs have on international trade relations. ${ }^{468}$ This school of thought maintains that PTAs distort trade and segment markets, which in turn leads to trade diversion. It is also argued that PTAs result in the exclusion of small countries because their limited market size is considered unattractive. Thus, PTAs engender unfairness for small, vulnerable countries. ${ }^{469}$ Furthermore, resource allocation issues have ensued for countries wishing to

\footnotetext{
${ }^{465}$ Since the implementation of the RTA TM in 2006, 143 PTAs have been considered under the mechanism. See WTO Secretariat, Recent Developments in Regional Trade Agreements (July - December 2016), (Geneva, December, 2016) [INT/SUB/RTA/153], p. 3.

${ }^{466}$ Report by the Consultative Board to the Director General Supachai Panitchpakdi, The Future of the WTO: Addressing Institutional Challenges in the New Millennium (The Sutherland Report) (WTO, 2004), p. 19, para. 61.

${ }^{467}$ Ibid, Report by the Consultative Board to the Director General Supachai Panitchpakdi, 2004, p. 20, para. 63; Y. Lee, Reconciling RTAs with the WTO Multilateral Trading System: Case for a New Sunset Requirement on RTAs and Development Facilitation, Journal of World Trade, 2011, Vol. 45 (3), pp. 629651, p. 638.

${ }^{468}$ The Warwick Commission, The Multilateral Trade Regime: Which Way Forward? The Report of the First Warwick Commission (University of Warwick, 2007), p. 49.

${ }^{469}$ J. Bhagwai and N. Limao have written extensively on the negative impact that PTAs have had on the MTS. See J. Bhagwati, Termites in the Trading System: How Preferential Agreements undermine Free Trade (Oxford University Press, 2008); J. Bhagwati, A. Krueger, Dangerous Drift to Preferential Trade Agreements
} 
utilize PTAs as a part of their commercial policy, whilst still participating in multilateral negotiations. ${ }^{470}$ The resource costs of negotiating at both the preferential and multilateral levels have brought additional financial strain on many countries and in itself constitute a threat to multilateralism. ${ }^{471}$ Another undesirable effect of PTA growth has been the diminution of the political will required for multilateral negotiations due to involvement in extensive negotiations at the PTA level. ${ }^{472}$ Despite the foregoing dichotomy of arguments, the true economic effect of PTAs on the MTS remains unknown and it is impossible to assess how global trade markets would have evolved in their absence. ${ }^{473}$

\subsection{Future Outlook}

In an ideal world, the prescriptive solution for the regulation of PTAs would entail the meaningful revision GATT Article XXIV:5 and XXIV:8 as well as the implementation of an institutional framework aimed at managing the expansion of PTAs. The incorporation of a monitoring mechanism to identify the undesirable effects of PTAs on the MTS would also be beneficial for the WTO Secretariat, which is currently faced with a lackluster approach to transparency on the part of WTO Members. This is highly unlikely given the realities and politics of the member-driven WTO. ${ }^{474}$ PTAs will continue to be a salient feature of the MTS and it is hoped that the interrelationship between the two entities can be improved upon. In this vein, the establishment of the RTA TM is a step in the right

(AEI Press, 1995); N. Limao, Preferential Trade Agreements as Stumbling Blocs for Multilateral Trade Liberalization: Evidence for the United States, American Economic Review, 2006, Vol. 96(3), pp. 896-914.

${ }^{470}$ Y. Lee, Reconciling RTAs with the WTO Multilateral Trading System: Case for a New Sunset Requirement on RTAs and Development Facilitation, Journal of World Trade, 2011, Vol. 45 (3), pp. 629651, p. 635; A. Krueger, Are PTAs Trade-liberalizing or Protectionist?, Journal of Economic Perspectives, 1999, Vol. 13(4), pp. 105-124, p. 119.

${ }^{471}$ See The Warwick Commission, The Multilateral Trade Regime: Which Way Forward? The Report of the First Warwick Commission (University of Warwick, 2007), p. 50.

${ }^{472}$ See WTO Secretariat, World Trade Report 2003, Trade and Development (Geneva, 2003), p. 65.

473 See W. Davey, A Model Article XXIV: Are there Realistic Possibilities to Improve It? in (eds.) K. Bagwell, P. Mavroidis, Preferential Trade Agreements: A Law and Economics Analysis (Cambridge University Press, 2011), p. 244.

${ }^{474}$ An illustration of such politics was recently seen during CRTA discussions regarding the transformation of the RTA TM into a more permanent mechanism.

"[The Chairman's] first impression was that there was a clear prioritization among [WTO] Members with hardly any believing that it was a priority to turn the provisional Transparency Mechanism into a permanent one. There had been one or two exceptions, but in general that was not the priority. There were concerns that new negotiations about the Transparency Mechanism would open up areas that had been agreed before and would be difficult to renegotiate." WTO Secretariat, Committee on Regional Trade Agreements $81^{\text {st }}$ Session, Note on the Meeting of $27^{\text {th }}$ June 2016 (Geneva, 12 $2^{\text {th }}$ July 2016) [WT/REG/M/81], p. 7, para. 1.45. 
direction. However, the mere establishment of the RTA TM is in itself an admission of the untamable nature of the behemoth into which PTAs have evolved. The intensity and coverage of the new wave of PTAs tend to be efficiently focused on certain policy areas including inter alia investment and competition issues. ${ }^{475}$ Consequently, this dissertation argues that it would be a herculean task to implement any major substantive change to PTA legal rules because such changes are likely to be opposed by WTO Members mainly for reasons related to self-preservation regarding their involvement with PTAs. ${ }^{476}$

Although the proliferation and regulation of PTAs has been suboptimal, this dissertation argues that the actual tipping point of the interrelationship between PTAs and the MTS is imminent. The current systemic impasse has oftentimes been diagnosed as requiring a prescription that includes clarifying and improving disciplines and procedures. ${ }^{477}$ As of 2014, a considerable proportion of global trade is transacted under preferential terms and this proportion is likely to increase if, and when, the major trading economies form a PTA among themselves. ${ }^{478}$ In this regard, the EU-Japan FTA is noted. ${ }^{479}$ The systemic effect that PTAs of such magnitude could have on the MTS may turn the tide in an untold manner.

\footnotetext{
${ }^{475}$ R. Acharya, Regional Trade Agreements: Recent Developments in (ed.) R. Acharya, Regional Trade Agreements and the Multilateral Trading System (Cambridge University Press, 2016), p. 1; Y. Lee, Reconciling RTAs with the WTO Multilateral Trading System: Case for a New Sunset Requirement on RTAs and Development Facilitation, Journal of World Trade, 2011, Vol. 45 (3), pp. 629-651, p. 631.

${ }^{476}$ It is submitted that this factor contributed to the paucity of advancements to resolve the interpretational difficulties of GATT Article XXIV, which have plagued PTAs for almost sixty years.

${ }^{477}$ Paragraph 29 of the 2001 Doha Ministerial Declaration states "We also agree to negotiations aimed at clarifying and improving disciplines and procedures under the existing WTO provisions applying to regional trade agreements. The negotiations shall take into account the developmental aspects of regional trade agreements."

478 "In 2014, almost half of world trade was taking place between countries that had signed a PTA and almost one third was regulated by deep trade agreements." See UNCTAD Secretariat, Key Statistics and Trends in Trade Policy: Preferential Trade Agreements (Geneva, 2015) [UNCTAD/DITC/TAB/2015/2] p. 14; See also The Warwick Commission, The Multilateral Trade Regime: Which Way Forward? The Report of the First Warwick Commission (University of Warwick, 2007), p. 53.

${ }^{479}$ The EU-Japan FTA was early announced at the WTO Secretariat on $15^{\text {th }}$ April 2013. As of $8^{\text {th }}$ December 2017, the EU-Japan Economic Partnership Agreement was finalized; however, it has not yet been notified at the WTO Secretariat.
} 


\subsection{Conclusion}

Chapter 3 provides an overview of attempts to manage PTAs despite the systemic issues surrounding GATT Article XXIV. Increased transparency and appropriate surveillance mechanisms are necessary elements in the overall task of exploring whether PTAs actually create trade. Considerable challenges have been involved with the process of institutionally and legally addressing PTAs. Nevertheless, it is imperative that this legal discipline be properly situated within the WTO architecture. It is only through monitoring, regulating and managing PTAs that a transparent flow of information can be provided to ascertain whether PTAs have achieved their outlined goals and enhanced the welfare of the countries that participate in them. In this regard, it is asserted any progress achieved is dependent on the will of WTO Members and their willingness to comply with the RTA TM, which is the principal initiative that has been advanced to address many of the aforementioned concerns. 


\section{Chapter 4}

The Evolution of Regional Integration in the Caribbean

\section{Introduction}

Chapter 4 is the first chapter of Part II of this dissertation and it shifts the focus of the dissertation from the multilateral sphere to regional sphere. It introduces regional integration theory as well as several of the international relations analytical frameworks that have sought to theorize regional integration outcomes. ${ }^{480}$ These theoretical insights are used to contextualize the unfolding of regional integration in the Caribbean Community (CARICOM) region, which commenced in 1956. In addition to this, Chapter 4 questions the aims and motivations underpinning the pursuit of regional integration in the Caribbean. Caribbean history books and CARICOM Secretariat documents are utilized to undertake a historical assessment of British Caribbean colonial paradigm as well as the colonial trade policy emanating therefrom. Both of these factors influenced the economic development trajectory of the Caribbean region as well as the progression of regional integration in the Caribbean. ${ }^{481}$

The catalytic effect of several global events including inter alia the growth and expansion of PTAs in Europe, North America and South America ${ }^{482}$ is analyzed in order to contextualize the four phases of regional integration in the Caribbean: the West Indies Federation, the Caribbean Free Trade Association (CARIFTA), the Caribbean Community

\footnotetext{
${ }^{480}$ See P. Schmitter, Ernst B. Haas and the Legacy of Neofunctionalism, Journal for European Public Policy, 2005, Vol. 12(2), pp. 255-272; B. Rosamond, The Uniting of Europe and the foundation of EU Studies: Revisiting the Neofunctioalism of Ernst B. Haas, Journal for European Public Policy, 2005, Vol. 12(2), pp. 237-254; (eds.) C. Bickerton, D. Hodson, U. Puetter, The New Intergovernmentalism: States and Supranational Actors in the Post-Maastricht Era (Oxford University Press, 2015).

${ }^{481}$ See E. Wallace, The West Indies Federation: Decline and Fall, International Journal, 1962, Vol. 17 (3) pp. 269-288; K.M. Bennett, A Retrospective Look at the Role of Trade and Regional Integration in Caribbean Development, Social and Economic Studies, 1999, Vol. 48, No. 1(2), pp. 127-153, V. Bulmer-Thomas, The Economic History of the Caribbean since the Napoleonic Wars (Cambridge University Press, 2012); D. Berry, Caribbean Integration Law (Oxford University Press, 2014); H. Geiser, P. Alleyne, C. Garaj, Legal Problems of Caribbean Integration: A Study on the Legal Aspects of CARICOM (Institute of International Relations, St. Augustine, Trinidad and Tobago and A.W. Sijthoff International Publishing, Leiden, Netherlands, 1976).

${ }^{482}$ The UK accession to the European Economic Community (EEC), the subsequent deepening of European integration through the adoption of the European Single Market, the birth of the North American Free Trade Agreement (NAFTA), the further consolidation of South American regional integration and successive rounds of GATT negotiations all served as a clarion call for the Caribbean region to galvanize its efforts regarding the regulation of its international trade policy. See Ibid, K.M. Bennett, 1999, p. 140.
} 
and Common Market (CARICOM) and the CARICOM Single Market (CSM). The narrative provided herein also outlines how key aspects of colonial trade policy, which preceded the process of regional integration, has impacted the Caribbean economic structure and the cultivation of trade creation within the CARICOM preferential trade agreement (PTA).

\subsection{Regional Integration Theory}

Regional integration is concerned with the "voluntary interaction of autonomous nation states in a multidimensional relationship characterized by the pooling of sovereignty across a range of policy areas in order to perform particular tasks". ${ }^{483}$ Consequently, regional integration theory focuses on core assumptions regarding the most optimal way to achieve certain dominant goals. It also looks at the underlying forces that shape the development of this form of cooperation and the instruments available to operationalize cooperation. ${ }^{484}$ The growth of regional integration theory in the mid $20^{\text {th }}$ century was aimed at deciphering an adequate form of political organization given the structural changes in the international system and the prevailing perception that the dominance of the nation state system was weakening. ${ }^{485}$

The expansion of regional integration is related to the increased use of PTAs in the multilateral trading system (MTS), as several PTAs are customs union that possess several of the deeper aspects of regional integration that are mentioned below. ${ }^{486}$ In this regard, the unfolding of regional integration in Europe constituted a template from which many

\footnotetext{
${ }^{483}$ N. Slocum, L. Van Langenhove, The Meaning of Regional Integration: Introducing Positioning Theory in Regional Integration Studies, Journal of European Integration, 2004, Vol. 26(3), pp. 227-252, p. 227.

${ }^{484}$ W. Mattli, The Logic of Regional Integration: Europe and Beyond (Cambridge University Press, 1999), p. 3; T. Diez, N. Tocci, G. Faleg, E. Scherwitz, Promoting Regional Integration and Transforming Conflicts? in (eds.) T. Diez, N. Tocci, The EU, Promoting Regional Integration and Conflict Resolution (Palgrave Macmillan, 2017), p. 4.

${ }^{485}$ C. Parsons, Showing Ideas as Causes: The Origins of the European Union, International Organization, 2002, Vol. 56 (1), pp. 47-84, p. 58; P. Lindseth, Power and Legitimacy: Reconciling Europe and The Nation State (Oxford University Press, 2010), p. 62.

${ }^{486}$ The concept of a regional integration arrangement being intertwined with a PTA was also a preoccupation of the drafters of the General Agreement on Tariffs and Trade (GATT) 1947. See R. Hudec, Developing Countries in the GATT Legal System (Cambridge University Press, 2011), p. 29; M. Schiff, L. Winters, Regional Integration and Development (World Bank/Oxford University Press, 2003), p. 5; Y. Devuyst, GATT Customs Union Provisions and the Uruguay Round: The European Community Experience, Journal of World Trade, 1992, Vol. 26(1), pp. 15-34, p. 19.
} 
notions were conceived for the spread of regional integration arrangements via PTAs that are customs union in West Africa, the Caribbean and South America. Several international relations analytical frameworks have sought to theorize regional integration and their core assumptions have been visible in the evolution of regional integration in different regions of the world. Hence, these international relations analytical frameworks are helpful in analyzing the various hurdles and successes encountered. ${ }^{487}$

\subsubsection{International Relations Analytical Frameworks on Regional Integration}

The modern concept of regional integration in Europe gained greater currency in the aftermath of the Second World War. It is noted that the main conceptual driver for this was the avoidance of conflict as well as the promotion of peace. ${ }^{488}$ The analytical framework of functionalism influenced various views and efforts advocated by Jean Monnet, an early architect of European integration. ${ }^{489}$ This resulted in an integrated approach to security within Europe and led to the establishment of the European Coal and Steel Community

\footnotetext{
${ }^{487}$ The analytical frameworks on regional integration originated in the aftermath of the signing of the Treaty of Rome in 1957 and sought to describe, explain and predict regional integration outcomes at a time when the certainty of peace in Europe was not an absolute given. See P. Schmitter, Ernst B. Haas and the Legacy of Neofunctionalism, Journal for European Public Policy, 2005, Vol. 12(2), pp. 255-272, B. Rosamond, The Uniting of Europe and the foundation of EU Studies: Revisiting the Neofunctioalism of Ernst B. Haas, Journal for European Public Policy, 2005, Vol. 12(2), pp. 237-254.

${ }^{488}$ There have been various attempts at regional integration prior to the post Second World War integration of Europe. It is notable that Belgium, The Netherlands and Luxembourg were members of the Benelux Economic Union, which was created on $5^{\text {th }}$ September 1944 with the signing of the London Customs Convention. The London Customs Convention was ratified in 1947 and entered into force in 1948. See O. Cattaneo, The Political Economy of PTAs in (eds.) S. Lester, B. Mercurio, L. Bartels, Bilateral and Regional Trade Agreements: Commentary and Analysis, Second Edition (Cambridge University Press, 2015), p. 31; A. Krueger, Are PTAs Trade-liberalizing or Protectionist?, Journal of Economic Perspectives, 1999, Vol. 13(4), pp. 105-124, p. 106.

${ }^{489}$ Functionalism, advanced by David Mitrany in 1943, is regarded as the precursor to regional integration theory. This analytical framework offered assumptions about international integration aimed at greater economic, social and political cohesion. It was also concerned with the most optimal manner to organize policy tasks via an international orientation. Its dominant goal was the avoidance of conflict and the promotion of peace. See D. Mitrany, A Working Peace System: An Argument for the Functional Development of International Organization (Oxford University Press, 1943). See also W. Mattli, The Logic of Regional Integration: Europe and Beyond (Cambridge University Press, 1999), p. 21; J. Cooper, Organizing for Peace: Science, Politic and Conflict in the Functional Approach in (eds.) L. Ashworth, D. Long, New Perspectives on International Functionalism (MacMillan Press, 1999), p. 28.
} 
(ECSC) ${ }^{490}$ It is notable that the dominant functionalist goal of promoting peace is reflected in the preamble of the Treaty of Paris (1951), which established the ECSC. ${ }^{491}$

In addition to this, the Treaty of Rome establishing the European Economic Community (1958) represented a milestone in the furtherance of regional integration. ${ }^{492}$ It was aimed at establishing a common market and a customs union among the original six Member States of the European Economic Community (EEC). ${ }^{493}$ Neofunctionalism, an analytical framework on regional integration, was reflected in several aspects of European integration including the creation of the European Commission, which remains the main (supranational) institution operationalizing cooperation among the now European Union (EU) Member States. ${ }^{494}$ This de-emphasis of the nation state in achieving dominant goals relating to regional integration reflects a neofunctionalist core assumption. ${ }^{495}$ Several other

${ }^{490}$ Functionalism advocated that its policy goals were to be achieved through the establishment of a supranational (international) authority staffed by transnational technical elites. Nation states would transfer 'slices' of their sovereignty to the supranational authority and initially focus on 'low politics' technical cooperation policy areas with the hope of raising confidence in the process. Eventually, the process would shift to 'high politics' political cooperation policy areas. See D. Mitrany, The Functional Approach to World Organization, 1948, International Affairs, Vol. 24 (3), pp. 350-363, p. 358; O. Rosenboim, The Emergence of Globalism: Visions of World Order in Britain and The US, 1939-1950 (Princeton University Press, 2017), p. 34; P. Lindseth, Power and Legitimacy: Reconciling Europe and The Nation State (Oxford University Press, 2010), p. 96; M. Burgess, Federalism and Federation in (ed.) M. Cini, European Union Politics, Second Edition (Oxford University Press, 2007), p. 89.

${ }^{491}$ See Treaty Establishing the European Coal and Steel Community 1951 (adopted $18^{\text {th }}$ April 1951, in force 23 July 1952, expired 23 July 2002) 261 UNTS 140. The Preamble of the Treaty of Paris (1951) states: "CONSIDERING that world peace may be safeguarded only by creative efforts equal to the dangers which menace it; CONVINCED that the contribution, which an organized and vital Europe can bring to civilization is indispensable to the maintenance of peaceful relations;"

${ }^{492}$ See Treaty Establishing the European Economic Community 1957 (adopted $25^{\text {th }}$ March 1957, in force $1^{\text {st }}$ January 1958) 298 UNTS 11. See also GATT Secretariat, European Economic Community, Official Transmission to the GATT (Geneva, $24^{\text {th }}$ April 1957) [L/626].

${ }^{493}$ This reflected a core neofunctional belief that the liberalization of factors of production through regional integration could improve relations among the European nation states, which had endured two World Wars. P. Schmitter, Ernst B. Haas and the Legacy of Neofunctionalism, Journal for European Public Policy, 2005, Vol. 12(2), pp. 255-272, p. 256; C. Holbraad, Internationalism and Nationalism in European Political Thought (Palgrave Macmillan, 2003), p. 49.

${ }^{494}$ Neofunctionalism, advanced by Ernst Haas in 1958, focused on the successful integration of nation states on a regional level through the creation of a supranational organization. Additionally, regional interest associations/social movements were to be used to advance integration with the aim of securing maximum welfare. See E. Haas, The Uniting of Europe: Political, Social and Economic Forces (Stanford University Press, 1958). See also J. Wunderlich, Regionalism, Globalization and the International Order: Europe and Southeast Asia (Ashgate, 2007), p. 14; B. Rosamond, The Uniting of Europe and the foundation of EU Studies: Revisiting the Neofunctioalism of Ernst B. Haas, Journal for European Public Policy, 2005, Vol. 12(2), pp. 237-254, p. 240.

${ }^{495}$ The neofunctionalist logic gave primacy to the technical governance of core areas that would lead to economic integration. Emphasis was placed on the role of regional bureaucrats to manage the process of 
neofunctionalist core assumptions characterized the unfolding of regional integration in Europe, as many functional policy spillovers occurred whereby the regional integration agenda expanded beyond the initial set of policy issues. This resulted in increased automaticity in the integration process. This has contributed to a deeper intensity of the regional integration agenda. ${ }^{496}$

Another analytical framework on regional integration, which was unseen in Europe, is intergovernmentalism. Advanced by Stanley Hoffmann in the mid-1960s, it utilized the realist analysis of interstate bargaining and reflected the realist notion that nation states are rational, self-interested actors focused on their survival as well as their economic growth. ${ }^{497}$ It challenged the neofunctionalist core assumptions on the automaticity of the integration process and the de-emphasis in the role of the nation state. ${ }^{498}$ Visible in the unfolding of regional integration in South America and the Caribbean, intergovernmentalism eschewed supranationalism and instead placed primacy on the concept of sovereignty. ${ }^{499}$ It asserted that the nation state should be the central actor to shape regional integration according to its own goals. This has been seen with the Southern Common Market (MERCOSUR) and CARICOM. ${ }^{500}$ In both of these regional integration processes, the Heads of Government of the respective Member States constitute the supreme decision-making bodies, which

sovereignty pooling. Neofunctionalism considered the nation state important only for the initial establishment of a regional supranational organization. Thereafter, nation states do not control the resulting direction and pace of the regional integration process. See J. Wunderlich, Regionalism, Globalization and the International Order: Europe and Southeast Asia (Ashgate, 2007), p. 14; P. Schmitter, Ernst B. Haas and the Legacy of Neofunctionalism, Journal for European Public Policy, 2005, Vol. 12(2), pp. 255-272, p. 257.

${ }^{496}$ P. Schmitter, Ernst B. Haas and the Legacy of Neofunctionalism, Journal for European Public Policy, 2005, Vol. 12(2), pp. 255-272, p. 257.

${ }^{497}$ M. Cini, Intergovernmentalism in (ed.) M. Cini, European Union Politics, Second Edition (Oxford University Press, 2007), p. 101; (ed.) M. O'Neill, The Politics of European Integration, A Reader (Routledge, 2005), p. 56.

${ }^{498}$ C. Bickerton, D. Hodson, U. Puetter, The New Intergovernmentalism and the Study of European Integration in (eds.) C. Bickerton, D. Hodson, U. Puetter, The New Intergovernmentalism: States and Supranatioanal Actors in the Post-Maastricht Era (Oxford University Press, 2015), p. 17; C. Stoby-Jensen, Neofunctionalism in (ed.) M. Cini, European Union Politics, Second Edition (Oxford University Press, 2007), p. 89.

${ }^{499}$ See A. Stone Sweet, W. Sandholtz, European Integration and Supranational Governance, Journal of European Public Policy, 1997, Vol. 4(3), pp. 297-317, p. 298.

${ }^{500}$ See Treaty Establishing a Common Market between The Argentine Republic, The Federal Republic of Brazil, The Republic of Paraguay and the Eastern Republic of Uruguay (adopted $26^{\text {th }}$ March 1991, in force $29^{\text {th }}$ November 1991) 2140 UNTS 319. The Treaty was notified under the Enabling Clause at the GATT Secretariat on $17^{\text {th }}$ February 1991. See GATT Secretariat, Southern Common Market (MERCOSUR), (Geneva, $9^{\text {th }}$ July 1992) [L/7044]. 
utilize interstate bargaining to further the regional integration agenda. ${ }^{501}$ Therefore, the starting point of regional integration has been based on political motives related to the nation state, not technocratic motives related to a supranational institution. ${ }^{502}$ However, it must be stated that the delineation between 'high politics' and 'low politics' issues on the regional integration agenda has not been as clear-cut in regions outside of Europe.

Generally speaking, it is noted that countries have pivoted to regional integration when they possess common interest in achieving certain dominant goals. The aforementioned international relations analytical frameworks have sought to assist the manner in which the stated common goals have been achieved. Hence, regional integration has been viewed and utilized as a broad mechanism to achieve and eventually expand upon common goals. In Europe, this was visible with the common goal of economically reconstructing both the continent and a durable peace in the aftermath of the Second World War. In the British Caribbean, this was visible with the common goal of safeguarding the region's economic and geopolitical interests given the common historical experience of British colonialism. ${ }^{503}$ In South America, this was visible with the common goal of rebuilding political and economic stability in the aftermath of military dictatorships. ${ }^{504}$ Conversely, it is noted that regional integration is slow to progress in a meaningful way in regions such as West Africa when countries are not sufficiently committed to the stated common goal for various reasons including inter alia slow implementation of agreed decisions and international conflict. $^{505}$

\footnotetext{
${ }^{501}$ Interstate bargaining utilizes a convergence of policy preferences. Distinctions are made between issues classified as 'low politics' and 'high politics'. Intergovernmentalism contends that this process will enable integration on 'low politics' issues; however, nation states will challenge further 'intrusive' integration on 'high politics' issues that might affect sovereignty. See R. Ginsberg, Demystifying the European Union: The Enduring Logic of Regional Integration (Rowman and Littlefield Publishers, 2007), p. 70; W. Mattli, The Logic of Regional Integration: Europe and Beyond (Cambridge University Press, 1999), p. 19.

${ }_{502}$ M. Cini, Intergovernmentalism in (ed.) M. Cini, European Union Politics, Second Edition (Oxford University Press, 2007), p. 104; (ed.) M. O'Neill, The Politics of European Integration, A Reader (Routledge, 2005), p. 56; C. Bickerton, D. Hodson, U. Puetter, The New Intergovernmentalism and the Study of European Integration in (eds.) C. Bickerton, D. Hodson, U. Puetter, The New Intergovernmentalism: States and Supranatioanal Actors in the Post-Maastricht Era (Oxford University Press, 2015), p. 15.

${ }^{503}$ See Section 4.5.2 entitled From Politics to Economics.

${ }^{504}$ See Section 4.7.2 entitled The Growth of PTAs in the American Hemisphere.

${ }^{505}$ See Section 4.4.2 entitled Points of Contrast with Regional Integration in West Africa.
} 


\subsubsection{The Legacy of the Plantation Economy}

This section of Chapter 4 will address a key aspect of the historical origin of the British Caribbean region: the plantation economy. ${ }^{506}$ Many of the socio-economic conditions that prevailed in the British Caribbean at the beginning of the twentieth century such as poor living conditions, lack of economic development and the low priority status for the UK colonial government are traceable to the plantation economy. It is also submitted that many of the aforementioned conditions contributed to the pivot to regional integration. As later sections of Chapter 4 will demonstrate, the initial Caribbean leaning to regional integration was interlinked with the achievement of self-governance. Self-governance was seen as a medium for the eventual attainment of independence, which would then enable the British Caribbean territories to determine their own development path and increase their likelihood of tackling the various socio-economic ills that plagued Caribbean societies.

The starting point for any analysis of regional integration in the Caribbean must entail an overview of the economic, political and social history of the British Caribbean. This is intertwined with the British Caribbean colonial paradigm, which was characterized by the concept of the plantation economy whereby tropical commodities, including sugar, were grown in an agricultural system geared for export production. It is irrefutable that the British Caribbean territories entered the global economy as overseas colonial possessions that utilized slave labor to bolster the profitability of the sugar trade for the United Kingdom (UK). The stagnating effects of this particular circumstance have influenced the policy thinking regarding regional integration in the Caribbean. The monoculture strategy

\footnotetext{
506 "The theory of Plantation Economy asserted the specificity of the Caribbean experience. It was one of the earliest attempts to understand the Caribbean economy within its own terms, rather than within the framework of a pre-ordained paradigm of Metropolitan provenance. It is heterodox rather than orthodox, eclectic rather than ideological, and Caribbean-centered rather than Eurocentric. And it provides an historical perspective on the relationship of Caribbean countries to globalization that is highly relevant to the challenges now facing policy-makers in the region. The theory is not, except in a very limited sense, about plantations and agriculture. The term 'Plantation Economy' is used as a means of characterizing how the typical Caribbean economy works, by reference to its historical origins. The theory aims to explain why Caribbean economies undergo alternating cycles of 'boom' and 'bust', why periods of boom are not self-sustaining, and why adjustment during the bust does not free the economy from dependence on the 'plantation sector'-broadly defined as that which is foreign-owned and export-oriented. It is, in a sense, a theory of permanent dependence: of growth without development, of adjustment without structural change, of diversification without transformation. "N. Girvan, Plantation Economy in the Age of Globalization, Foreword (eds) L. Best, K. Levitt, Essays on The Theory of Plantation Economy (University of West Indies Press, 2009), p. 2.
} 
of the plantation system inhibited the growth of diversified economies and altered the economic trajectory of the Caribbean region. ${ }^{507}$ The development of the Caribbean banana trade in the late 1800s provided some economic relief from the waning fortunes of the sugar trade. However, the sugar trade had a long and prosperous era in the economic history of the Caribbean and the economic efficiency achieved through the use of slave labor was of little moral concern to most of those involved with the sugar trade. ${ }^{508}$

It is submitted that the colonial era of British Caribbean economic history initiated a cycle of functional dependence on export markets, which relegated domestic consumption to a secondary concern. ${ }^{509}$ The eventual collapse of the plantation system, which was attributed to the abolition of slavery as well as the growth of the European beet sugar industry, left the British Caribbean monoculture economies facing economic decline. ${ }^{510}$ In the aftermath of the abolition of slavery, alternative labour arrangements such as indentured servants from India were introduced to the British Caribbean; however, the lack of agricultural diversification remained and has manifested itself as a persistent challenge for CARICOM economies even today. ${ }^{511}$ As a consequence of the aforementioned, it has been posited that

\footnotetext{
507 "The life of the Caribbean residents has been determined by external economic interests since European colonization. Only since World War II have independence and self determination been won..." C. Muellerleile, CARICOM Integration: Progress and Hurdles, A European View (Kingston Publishers Limited, Kingston, Jamaica, 1995), p. 9.

508 "At the beginning of the $19^{\text {th }}$ Century, there was no aspect of trade policy more controversial than trade in slaves. However, the slave trade was not just an issue of commercial policy. It was a crucial component of the Caribbean labor market and at the same time, slaves represented one of the most important assets in the process of capital accumulation." V. Bulmer-Thomas, The Economic History of the Caribbean since the Napoleonic Wars (Cambridge University Press, 2012), p. 41. "For almost a century, sugar production had been the cornerstone of the economies of the West Indian and Caribbean colonies... unfortunately, very low prices during most of the time since the beginning of the Twentieth Century kept the workers in perpetual poverty and precluded investment in the modernization of [sugar] production." A. Viton, The International Sugar Agreements: Promise and Reality (Purdue University Press, 2004), p. 6.

509 "In the case of the Caribbean colonies, mercantilism required that all their exports be sold directly to the imperial power in Europe or to the 'mother' country's colonies in the Americas. Imports were expected to come either directly from the imperial power or to be supplied by colonies in the Americas." Ibid, V. BulmerThomas, 2012, p. 36.

510 "Historically, most of the CARICOM economies were founded on sugar plantations, slavery and slave trading, the latter of which are now accepted as two of the most fundamental violations of the rules of international law, breaching jus cogens obligations. The horrors of the institution of slavery [...] left a deep and permanent imprint upon the peoples and countries of the region." D. Berry, Caribbean Integration Law (Oxford University Press, 2014), p. 17.

511 "What is perhaps even more disturbing is the fact that, taken as a group, the Caribbean has underperformed and even regressed in the specific areas which have been chosen as being of greatest strategic importance to its progress and development. It has also underperformed relative to the broader global group of small island economies on almost every major determinant of competitiveness." O. Arthur, Caribbean Regionalism in the
} 
the root cause of several ills that have plagued the Caribbean economic structure and have inhibited the growth of intra-regional trade can be traced to the colonial plantation economy as well as the reluctance to diversify agricultural production.

\subsubsection{Introduction to Colonial Preferential Trade in the British Caribbean Region}

The early 1900s marked the advent of UK trade preferences for British Caribbean commodities such as bananas and sugar. ${ }^{512}$ The provision of trade preferences assists in contextualizing the pre- and post-independence Caribbean economic experience, as they enabled two key agricultural industries to thrive when market conditions and economic efficiency would have dictated otherwise. It is also noteworthy that UK trade preferences enabled a continued emphasis on export-led agricultural production as opposed to the stimulation of other export capacities that could have catered to the intra-regional trade market. It is submitted that early UK colonial trade preferences skewed the British Caribbean agriculture industry towards a certain direction of production, which eventually inhibited the growth of intra-regional trade upon the creation of the first Caribbean PTA.

The following two sections of Chapter 4 provide a background to the British Caribbean narrative of trade preferences for sugar and bananas. These sections explain how UK trade preferences preceded any notions of regional integration or independence. They also demonstrate how the economic viability of British Caribbean economies was externally hinged on the UK economy. In order to protect the two agricultural industries that constituted their economic lifeline, the British Caribbean territories pivoted to regional integration and sought to capitalize on the increased bargaining power therein to safeguard the provision of their trade preferences initially granted by the UK and subsequently granted by the EEC/EU after UK accession to the regional bloc.

Context of Economic Challenges, Caribbean Journal of International Relations, 2014, Vol. 2(4), pp. 147164, p. 148.

512 These trade preferences represented an early form of the imperial preference system, which was formalized in 1932. 


\subsection{The British Caribbean Banana Trade}

This section of Chapter 4 outlines the contours of the early British Caribbean banana trade and illustrates how colonial banana trade preferences, in the form of duty free import privileges and guaranteed import quotas, preceded the grant of independence and economically tied the British Caribbean territories to the UK. ${ }^{513}$ The lasting imprint of this type of colonial trade policy was visible upon the eventual grant of independence to the British Caribbean territories. Minimal changes were noted to this trade relationship. Furthermore, trade preferences were strengthened in the post-independence period of Caribbean history. ${ }^{514}$ It is pertinent to note that informal banana trade preferences commenced in the early 1900s and this timeline can be contrasted with the era of Caribbean decolonization, which commenced in the 1960s. Similarly, material efforts regarding Caribbean regional integration commenced in the 1960s. Thus, this dissertation argues that the desire to maintain these trade preferences acted as one of the early dominant economic goals of regional integration in the Caribbean. The aforementioned desire also advanced the development of the Caribbean PTA by reinforcing the geopolitical realization that acting as a regional grouping on the international plane was the most optimal mode of interaction with the UK and eventually, the EEC. ${ }^{515}$

\footnotetext{
513 "Bananas have played a significant role, second only to sugar among the export crops, in the economic history of the Caribbean. Indeed, the growth of exports of bananas is in many ways tied to the demise of the sugar sector. First in Jamaica and then in the Windward Islands, bananas were introduced as a replacement crop when profits from sugar exports decreased." R. Anderson, T. Taylor, T. Josling, The Caribbean and the Banana Trade in (eds) T. E Josling, T. G. Taylor, Banana Wars: The Anatomy of a Trade Dispute (CABI Publishing, UK, 2003), p. 123.

514 "The UK governed the Windward Islands and Jamaica and the nature of the [...] relationship within the banana trade was underpinned by that dynamic. Further, even when [these territories] gained their independence, the legacy of colonial rule continued to be an important factor in defining the nature of the relationship between the actors involved in the UK banana trade. P. Clegg, The Caribbean Banana Trade: From Colonialism to Globalization (Palgrave MacMillan, 2002), p. 2.

515 “"Early thinking on the issue of economic integration emphasized the role it could play in helping to relieve the constraints on economic activity imposed by the small size of individual countries. However, it was always recognized that the creation of a regional market would not be sufficient to permit establishment of the range of activities necessary to provide employment for the large labour force in the region. Economic integration could play a role in helping to secure access to external markets, since acting jointly in pursuit of a common goal would allow for more effective bargaining than would be the case if the countries negotiated individually." See K.M. Bennett, A Retrospective Look at the Role of Trade and Regional Integration in Caribbean Development, Social and Economic Studies, 1999, Vol. 48, No. 1(2), pp. 127 - 153, p. 128.
} 


\subsubsection{The Early British Caribbean Banana Trade}

British involvement in the Caribbean banana trade commenced in the late 1800s when Jamaica started exporting bananas to the UK. This was seen as a positive step in binding the British Empire by strengthening colonial economic links and increasing banana consumption patterns in the UK. ${ }^{516}$ The introduction of refrigerated shipping capabilities assisted the trade in bananas by allowing the fragile fruit to arrive at distant foreign markets in a relatively acceptable condition. In the early 1900s, Jamaican bananas benefitted from informal preferential arrangements as a result of Jamaica being a part of the British Empire. ${ }^{517}$ The 1932 British Empire Economic Conference formally established the imperial preference system and sought to use trade policy as a tool to bolster the sterling trading area. ${ }^{518}$ The 1932 Import Duties Act ended the British commitment to free trade by enacting at $10 \%$ tariff on manufactured imports. However, there were exemptions that included raw materials, foodstuff and products produced elsewhere in the British Empire. This tariff was increased to $20 \%$ and by 1935 , the tariff had reached $50 \%$ for certain products. ${ }^{519}$ The imperial preference system was beneficial to Jamaican bananas, which were considered foodstuff produced in the British Empire and thus duty free.

The UK became the largest export market for Jamaican bananas. This effectively established a monopoly on the UK market as it accounted for $87 \%$ market share in the early 1940 s, which had increased from the $40 \%$ market share that existed in the $1920 \mathrm{~s} .{ }^{520}$ The Jamaican banana trade was suspended during the Second World War due to shipping disruption as well as the requisition of boats for the war effort. It was also noted that the

\footnotetext{
${ }^{516}$ Prior to this, banana imports to the UK were mostly of the Cavendish variety from the Canary Islands. Jamaican bananas were of the Gros Michel variety and were larger in size. G. Myers, Banana Wars - The Price of Free Trade: A Caribbean Perspective (Zed Books, London, 2004), p. 8.

517 "In the early 1900s, British colonial policies transformed Jamaica - previously a minor source of US and European bananas - into the major supplier of bananas to Britain, the largest market in Europe. Small scale Jamaican producers were encouraged to grow bananas for export to Britain, where they were guaranteed a market." L. Raynolds, The Global Banana Trade in (eds.) S. Striffler, M. Moberg, Banana Wars: Power, Production and History in the Americas (Duke University Press, 2003), p. 27.

${ }^{518}$ The Sterling Area was informally established as a trading bloc in 1931 after the UK abandoned the Gold Standard. All of its members agreed to peg their currencies to the Pound Sterling and held their official external reserves largely in Sterling assets. A. Hinds, Sterling and Decolonization in the British Empire, 1945 - 1958, Social and Economic Studies, 1999, Vol. 48 (4), pp. 97-116, p. 97.

${ }^{519}$ R. Pope, The British Economy since 1914: A study in Decline? (Routledge, 1998), p. 36.

${ }^{520}$ G. Myers, Banana Wars - The Price of Free Trade: A Caribbean Perspective (Zed Books, London, 2004), p. 15 .
} 
fruit was deemed too perishable to transport and by the time trade resumed after the war, the industry was weakened due to the wartime interruption of trade, increased instances of Panama disease ${ }^{521}$ and the growth of the Latin American banana trade. ${ }^{522}$ The UK government was mindful of the socioeconomic conditions in its British Caribbean territories and encouraged the expansion of banana production in the Windward Islands of St. Lucia, Dominica, Grenada and St. Vincent and the Grenadines, which all started exporting bananas to the UK in $1953 .{ }^{523}$ In order to assist the growth of their banana industries, the UK guaranteed these territories a token annual quota of 4,000 tons. ${ }^{524}$

Despite the exponential growth of the Windward Island banana exports, the British Caribbean banana trade was economically inefficient when compared to the Latin American banana trade, which was characterized by large-scale plantations owned by US multinational corporations. ${ }^{525}$ Latin American banana production was more economically efficient due to richer soil, technology intensive methods, higher yields, lower wages and lower shipping costs. In the absence of UK colonial trade preferences, the Caribbean

\footnotetext{
${ }^{521}$ Panama disease, also known as banana wilt, is a plant disease caused by a fungus that attacks the roots of a banana plant. This disease is resistant to chemicals and was responsible for the decimation of the Central American banana industry in the 1950s.

${ }^{522}$ In the 1950s, Jamaica produced 150,000 tons of bananas per year. This can be contrasted with pre-war figures to illustrate the decline in production, which continued throughout the 1960s and 1970s. By 1975, Jamaica was producing 70,000 tons of bananas for the UK market. Many have attributed this decline to the political and economic problems, which afflicted the Jamaica economy during this period. Additionally, the 1973 rise in oil prices increased shipping costs. R. Potter, D. Barker, D. Conway, T. Klak, The Contemporary Caribbean (Pearson, 2004), p. 118.

523 "The Report on Marketing and Preparing for the Market of Foodstuffs produced in Overseas Territories issued by the Imperial Economic Committee encouraged banana production in the Windward Islands as a means of breaking the United Fruit company's monopoly in the UK banana market." See R. Anderson, T. Taylor, T. Josling, The Caribbean and the Banana Trade in (eds.) T. E Josling, T. G. Taylor, Banana Wars: The Anatomy of a Trade Dispute (CABI Publishing, UK, 2003), p. 125.

${ }^{524}$ One of the main reasons for the protective approach to Caribbean bananas was the UK motivation to advance the economic development of the Caribbean territories. Prior to the banana trade, a high level of poverty and poor social conditions existed. The proceeds of the banana trade aided in easing this state of affairs and some degree of economic development flourished. G. Myers, Banana Wars - The Price of Free Trade: A Caribbean Perspective (Zed Books, London, 2004), p. 3. See also Ibid, R. Anderson, T. Taylor, T. Josling, in (eds.) T. E Josling, T. G. Taylor, 2003, p. 126.

${ }_{525}$ A variety of factors including size, scale and climate as well as higher wages led to a situation where Caribbean banana planters achieved a smaller yield when compared to their Latin American competitors. Caribbean banana production was the result of independent, small farms located on poorly irrigated, steep land in a geographical region more prone to climactic shocks such as hurricanes and droughts. It also involved more labor-intensive methods and higher shipping costs, as four port calls were involved in shipping Windward Islands bananas to the UK. Ibid, G. Myers, 2004, p. 21; A. Payne, The End of Green Gold? Comparative Development Options and Strategies in the Eastern Caribbean Banana-Producing Islands, Studies in Comparative International Development, 2006, Vol. 41 (3), pp. 25-46, p. 26.
} 
banana trade would have been unprofitable. ${ }^{526}$ Further increases to the British import tariff on bananas from non-sterling sources effectively reserved the UK market for banana imports from Jamaica, the British Cameroons ${ }^{527}$ and the Windward Islands. ${ }^{528}$

4.2.2 The Caribbean Banana Trade after the United Kingdom accession to the European Economic Community

Upon accession to the EEC in 1973, the UK was required to adopt the European common external tariff (CET) and extend duty-free import privileges to bananas from former and existing European colonies and associated territories. Consequently, Caribbean bananas faced some competition in the European market but were still not competing with Latin American bananas on the EEC market. The status of preferential trade with the Commonwealth territories was a concern for both the UK and the British Caribbean territories that was eventually remedied with the 1975 Lome Convention, which established both a banana and sugar protocol. ${ }^{529}$

The establishment of the European Single Market in 1993, however, changed the EU banana import regime that had previously permitted the fragmentation of imports. ${ }^{530}$ The previous national import regimes restricted banana imports through the use of quantitative restrictions and licensing requirements. This essentially amounted to a situation where EC Members were allowed to reserve their domestic market for bananas of their preferred

\footnotetext{
${ }^{526}$ It has been sufficiently noted that banana production in the Windward Islands was economically inefficient. Due in large part to the availability of preferences, many marginal farmers pursued banana cultivation and consequently, any reduction in the level of preferences would have decimated the industry because production costs exceeded international prices. See M. Mlachila, P. Cashin, C. Haines, IMF Working Paper, Caribbean Bananas: The Macroeconomic Impact of Trade Preference Erosion (2010), p. 10.

${ }^{527}$ In 1961, the British Cameroons joined the French Cameroons and left the British Commonwealth. Thus, they forfeited the duty free entry of their bananas to the UK market and only bananas from Jamaica and the Windward Islands remained.

${ }^{528}$ It should be noted that during this time the UK banana regime attracted scrutiny and was criticized for its protectionist approach, which disadvantaged Latin American banana producers.

${ }_{529}$ The Lome Convention (Lome I Agreement: 1975 - 1980) was signed between 46 ACP countries and 9 EEC Member States. It provided aid for a 5-year period and guaranteed a non-reciprocal trade arrangement. Separate protocols on sugar and bananas were also agreed upon whereby ACP producers were guaranteed prices above the world market price. Part of the rationale for such preferences revolved around the legacy of colonialism and a sense of duty to assist with the further economic development of the ACP territories.

${ }^{530}$ Prior to 1993, EU members maintained distinct policies for banana imports, including preferential regimes for Member States' overseas departments and former colonies. See M. Mlachila, P. Cashin, C. Haines, IMF Working Paper, Caribbean Bananas: The Macroeconomic Impact of Trade Preference Erosion (2010), p. 4.
} 
choice including, in some cases, traditional ACP bananas. The single community-wide market for bananas amounted to single regime common to all EC Members. ${ }^{531}$ The new banana regime consisted of several regulations including inter alia a set tariff free quota for $\mathrm{ACP}^{532}$ bananas at a level not less than the amounts traditionally supplied. ${ }^{533}$ It also levied a tariff on imported Latin American bananas up to a fixed quota at a specified duty per ton and imposed a tariff per ton on imports above that level. One of the factors that influenced the abovementioned changes to the EEC import regime for bananas were the un-adopted General Agreement on Tariffs and Trade (GATT) Panel reports, which highlighted that the EEC banana import regime discriminated against non-ACP suppliers. ${ }^{534}$

\subsection{The Commonwealth Sugar Agreement}

As previously noted, the British Caribbean sugar trade benefitted from trade preferences in the pre-independence period of Caribbean history and these trade preferences continued in the post-independence period. Similar to banana trade preferences, sugar trade preferences preceded any notions on regional integration in the Caribbean. British Caribbean sugar cultivation can be traced back to the 1700s and the commodity has held great economic significance for the economies of the British Caribbean territories ever since. This section of Chapter 4 frames the British Caribbean sugar trading landscape prior to the UK accession to the EEC when UK colonial trade preferences were the main form of trade assistance granted to the British Caribbean sugar industry. It is submitted that these trade preferences colored the Caribbean view of relations with the UK and any perceived threats thereto influenced the British Caribbean territories to geopolitically contextualize regional

\footnotetext{
${ }^{531}$ P. Sutton, The Banana Regime of the European Union, the Caribbean and Latin America, Journal of InterAmerican Studies and World Affairs, 1997, Vol. 39 (2), pp. 5-36, p. 11.

${ }^{532}$ The 1975 Georgetown Agreement created the ACP group of countries and essentially extended a Yaoundé type association to the commonwealth territories as a result of the UK accession to the EEC.

533 "As a result [of the EU banana import regime], the price of bananas in the EU averaged some 80 per cent more than the world (free market) price." See M. Mlachila, P. Cashin, C. Haines, IMF Working Paper, Caribbean Bananas: The Macroeconomic Impact of Trade Preference Erosion (2010), p. 5; A. Payne, The End of Green Gold? Comparative Development Options and Strategies in the Eastern Caribbean BananaProducing Islands, Studies in Comparative International Development, 2006, Vol. 41 (3), pp. 25-46, p. 26. ${ }^{534}$ See GATT Panel Report, EEC-Member States' Import Regimes for Bananas, DS32/R, $3^{\text {rd }}$ June 1993 , unadopted and GATT Panel Report, EEC-Import Regime for Bananas, DS38/R, $11^{\text {th }}$ February 1994, unadopted. These legal rulings, although unadopted, effectively started the dismantling of the EC import regime for Bananas. This section of the dissertation will not delve into these legal cases as they are outside the scope of the key area of concern regarding the early establishment of trade preferences for Caribbean bananas.
} 
integration as a coping mechanism in an increasingly globalized world. Thus, the preservation of trade preferences for the British Caribbean sugar industry also acted as a dominant economic goal in the early development of regional integration in the Caribbean.

\subsubsection{The Effect of the Imperial Preference System on the British Caribbean Sugar Industry} The end of the First World War resulted in a shift in British trade ideology, which was previously centered on free trade. The new trade ideology manifested itself in the imperial preference system, which linked the economy of the British Empire to the pound sterling in the aftermath of the gold standard collapse, thereby creating a sterling trading area. ${ }^{535}$ Part of the justification for the policy shift revolved around the British wartime experience with the vulnerability of its food supply. ${ }^{536}$ By 1919 , the British tariff system was amended to reflect the new preferential tariff for imports from the British Empire and there was also a reduction in the rate of tariffs on sugar produced in the British Empire.

Furthermore, several measures favorable to Empire-produced sugar exports were implemented such as the 1928 tariff amendments, which decreased tariffs on raw sugar and increased tariffs on refined sugar. ${ }^{537}$ In 1934, the level of preference given to British Caribbean sugar was widened in comparison to those given to other sugar produced in other parts of the British Empire. ${ }^{538}$ It is important to recall that British Caribbean sugar exports to the UK had continued in the aftermath of the abolition of slavery and the efforts of the (British) West Indian planters aided in the continued preferential treatment, which was given to the commodity. ${ }^{539}$

\footnotetext{
${ }^{535}$ See imperial preference system in Chapter 1, Section 1.2.1 entitled Drafting of the GATT Trading Concepts. See also D. Glickman, The British Imperial Preference System, Quarterly Journal of Economics, $1^{\text {st }}$ May 1947, pp. $439-470$, p. 441.

536 "When war was declared by the UK on $4^{\text {th }}$ August 1914 , it was expected to last only a few months. As it became clear that this would not be the case, the British view of the world started to change. The UK, dependent on food imports from non-empire sources, had become vulnerable to hostilities in Europe. Free trade, questioned by Joseph Chamberlain since the 1890s and under attack from the Conservative Party when they went into opposition in 1905, came to an end with the introduction of the McKenna duties in the 1915 budget." V. Bulmer-Thomas, The Economic History of the Caribbean since the Napoleonic Wars (Cambridge University Press, 2012), p. 215.

${ }_{537}$ Ibid, V. Bulmer-Thomas, 2012, p. 216.

${ }^{538}$ Ibid, V. Bulmer-Thomas, 2012, p. 216.

${ }^{539}$ B. Richardson, Sugar: Refined Power in a Global Regime (Palgrave Macmillan, 2009), p.6.
} 
Commencing in 1944, the UK government entered into an informal year-to-year arrangement whereby it guaranteed the purchase of all exportable sugar from within the British Empire including the British Caribbean territories. ${ }^{540}$ This arrangement endured until it was eventually formalized in the Commonwealth Sugar Agreement (CSA), which was signed on 21 December $1951 .^{541}$ The initial duration of the CSA was for eight years and the agreement committed the UK to purchase specific quantities of raw sugar at an annually negotiated quota price, which exceeded the world market price. Other quantities of sugar would be purchased at the world market price then imported into the UK under the lower imperial preference tariff. In keeping with the previously noted rationale for the UK shift to preferential trade, the main aims of the CSA were to safeguard the UK supply of raw sugar, bolster the sterling trading area and to assist with the economic development of the colonial territories within the British Empire. ${ }^{542}$ Another underlying factor of this arrangement was that the First World War decimated the European (beet) sugar industry and the UK was keen to find an alternate source for its sugar supply. ${ }^{543}$

\subsubsection{A Formalized Cycle of Economic Dependence}

The CSA provided obvious economic benefits for the sugar exporting territories and it is estimated that in 1963, trade in sugar accounted for $80 \%$ of the export earnings of the

\footnotetext{
${ }^{540}$ D. Jones, The Commonwealth Sugar Agreement and the European Economic Community, Bulletin of the Oxford University Institute of Economics and Statistics, $1^{\text {st }}$ August 1967, pp. 211 - 232, p. 213.

${ }^{541}$ The sugar producing Commonwealth members from which the UK committed to purchase sugar were: Australia, South Africa, the British West Indies (British Caribbean territories), Mauritius, Fiji, the East African Countries and British Honduras (Belize).

542 " [...] It was hoped that the [CSA] would promote economic development in the colonies concerned by providing an assured market for their products and the same time alleviate Britain's acute shortage by encouraging an expansion of sterling supplies to meet her import requirements." M. Moynagh, "The Negotiation of the Commonwealth Sugar Agreement: 1949 - 1951" Journal of Commonwealth and Comparative Politics, 1977, Vol. 15 (2), pp. 170 - 190, p. 170.

543 "The outbreak of the First World War was to cause deep changes in the functioning of the sugar industry in Europe as a whole and more especially in Great Britain: the beet fields of France and Belgium themselves were the theatre of the conflict, [...] With its traditional suppliers now in the enemy camp and with the disappearance of the privileged London-Hamburg link, Great Britain itself, the major consumer market, had to look to the international (or Imperial) market for supplies to satisfy one of the highest rates of consumption in the world." P. Chalmin, The Making of a Sugar Giant: Tate \& Lyle, 1859 - 1989 (Harwood Academic Publishers, Chur, Switzerland, 1990), p. 115.
} 
Lesser Antilles ${ }^{544}$ and 30\% of the export earnings of Jamaica. ${ }^{545}$ Thus, the CSA resulted in assured trade gains for the British Caribbean sugar producing territories and also formalized a cycle of economic dependence. The preservation of these trade preferences would condition Caribbean policy thinking over the course of its regional integration journey. Since the latter was a dominant economic goal for the British Caribbean territories, any externality that threatened the provision of these trade preferences raised alarm and inadvertently spurred the evolution of regional integration in the Caribbean. ${ }^{546}$ As will be further explained in Chapter 4, one such externality was the UK entry into the EEC in 1973. Prior to this, the UK had undertaken two failed attempts to join the EEC and one of the main issues of contention regarding the UK entry into the EEC was the UK sugar policy, which stood at a variance from the self-sufficiency approach to sugar that was employed by the EEC at that time. ${ }^{547}$

As previously mentioned, the informal trade preferences for sugar commenced in 1944 and were formalized in 1951. Hence, they preceded the first phase of Caribbean regional integration, which commenced in $1956 .{ }^{548}$ Where the formal cultivation of Caribbean intraregional trade is concerned, such efforts commenced with the entry into force of CARIFTA (the second phase of Caribbean regional integration) in 1968. This was twenty-four years

\footnotetext{
${ }^{544}$ The term Lesser Antilles is used to describe a group of 20 Caribbean islands of various European colonial heritages. The British Caribbean territories which were a part of this grouping and are now CARICOM Member States are: Antigua and Barbuda, Barbados, Dominica, Grenada, St. Kitts and Nevis, St. Lucia, St. Vincent and the Grenadines and Trinidad and Tobago.

${ }^{545}$ P. Chalmin, The Making of a Sugar Giant: Tate \& Lyle, 1859 - 1989 (Harwood Academic Publishers, Chur, Switzerland, 1990), p. 238.

${ }^{546}$ British Caribbean sugar was purchased at a price in excess of the world market price and this provided great benefit to the British Caribbean territories. However, it established a trade pattern whereby the sugar trade and assured trade gains were understood to be synonymous. These preferences first received through the CSA evolved over the years and developed into a prism through which the Caribbean territories viewed many global policy developments.

547 "The sugar policy of the EEC aims at slightly more that one hundred percent self sufficiency and in recent years this has often been achieved. If the United Kingdom were to join, there seems little doubt that the present EEC producing area plus the United Kingdom's own beet sugar industry would rapidly be able to achieve self sufficiency and there is little doubt that the admission of commonwealth sugar to this market will be vigorously opposed by beet sugar producers in the present EEC." D. Jones, The Commonwealth Sugar Agreement and the European Economic Community, Bulletin of the Oxford University Institute of Economics and Statistics, $1^{\text {st }}$ August 1967, pp. $211-232$, p. 212.

${ }^{548}$ By the time that The West Indies Federation was created in 1956, the CSA had been in formal operation for five years. The CSA also preceded the other incarnations of Caribbean regional integration such as CARIFTA, CARICOM and the CSME.
} 
after to commencement of preference enabled export-led sugar production in 1944. Thus, the main emphasis of British Caribbean sugar production was fixed on the aforementioned export-oriented paradigm. In this regard, it should be noted that the UK continued to utilize the CSA until 1974, when the Lome Convention was negotiated and finalized. Thereafter, the Sugar Protocol annexed to the Lome Convention governed the trade assistance between the EEC (with the UK as a member) and the independent sugar producing Caribbean territories. $^{549}$

\subsection{Phase 1: The West Indies Federation ${ }^{550}$}

The first attempt at regional integration in the Caribbean occurred with the establishment of the West Indies Federation (the Federation) in 1956. The historical backdrop of the Federation was characterized by anti-imperialism and increased nationalism whereby colonialism was viewed as an anachronistic approach to rule and, in the aftermath of the Second World War, colonial powers were encouraged to pursue decolonization. ${ }^{551}$ Several British colonies were granted their independence commencing in $1947^{552}$ and thereafter, British Caribbean political leaders sought to capitalize on the decolonization movement by pressing for initial self-government and eventually for full independence. ${ }^{553}$ At the time,

\footnotetext{
${ }^{549}$ The Sugar Protocol that was annexed to the Lome Convention provided non-reciprocal, preferential treatment to ACP sugar exports. Under Lome I, seven CARICOM Member States benefitted from this arrangement: Barbados, Belize, Guyana, Jamaica, St. Kitts-Nevis-Anguilla,Suriname and Trinidad and Tobago. Lome I operated in a two-tiered manner: firstly, it bound the then EEC to purchase a specific amount of sugar at a guaranteed preferential price during a transition phase from 1 February 1975 to 30 June 1975. Thereafter, the Sugar Protocol had an indefinite duration. Secondly, the then EEC guaranteed that it would purchase and import country specific quotas of raw sugar each year at an agreed floor price. See T. Koch, The Sugar Protocol: An Appraisal, Intereconomics, Vol. 24(6), pp.293-297, p. 294.

${ }^{550}$ The West Indies Federation consisted of 10 British Caribbean colonies namely: Antigua and Barbuda, Barbados, Dominica, Grenada, Jamaica, Montserrat, St Kitts-Nevis-Anguilla, Saint Lucia, Saint Vincent and Trinidad and Tobago. The grouping was created with the passage of the 1956 British Caribbean Federation Act in the United Kingdom Parliament and was formally established on 22nd April 1958. The general intention was that the West Indies Federation would eventually transition into an independent federal state.

551 "In view of the anti-colonial trends in the world and the growing number of sovereign states following World War II, [...] colonial character was no longer tenable." C. Muellerleile, CARICOM Integration: Progress and Hurdles, A European View (Kingston Publishers Limited, Kingston, Jamaica, 1995), p. 27; D. Benn, The Caribbean: An Intellectual History 1774- 2003 (Ian Randle Publishers, 2004), p. 85. Additionally in 1960, the United Nations encouraged colonial powers to end colonialism in all of its manifestations. See United Nations Secretariat, Declaration on the Granting of Independence to Colonial Countries and Peoples, UNGA Resolution 1514 (XV) (New York, 14 ${ }^{\text {th }}$ December 1960) [A/RES/1514(XV).

${ }^{552}$ India and Pakistan had received their independence in 1947 and decolonization had spread to the British sub-Sahara African colonies. In 1957, Ghana gained its independence, as did Cyprus in 1960.

553 " $[. .$.$] All ten territories decided to participate in the federal experiment, primarily because it provided a$ means for greater independence from British colonial authorities. In fact, Caribbean leaders appear to have
} 
the British Caribbean territories were plagued with poor living and working conditions ${ }^{554}$ and many Caribbean political leaders considered themselves sufficiently capable to govern their own affairs, as had been done in India and the British African colonies before the formal grant of independence. ${ }^{555}$ As a consequence of the aforementioned, Chapter 4 argues that the improvement of the socio-economic conditions and the further economic development of the British Caribbean territories as well as the maintenance of colonial trade preferences served as a dominant goals of this early attempt at regional integration in the Caribbean.

The prevailing British Caribbean view was that their small economies represented an inhibiting factor to further industrial development. The fact that the British Caribbean economies were mainly primary product producers also made the prospect of further economic development a challenge. Furthermore, most of the British Caribbean territories retained the same colonial, agricultural production structure and despite their quest for independence, most remained economically dependent on the UK. Nine of the British Caribbean territories, which formed the ten-member Federation, were recipients of trade preferences under the previously mentioned CSA. ${ }^{556}$ Therefore, colonial trade policy economically supported their main agricultural industries.

taken the pragmatic view that the federation would either itself provide for greater independence or serve as the impetus for independence if it failed." D. Berry, Caribbean Integration Law (Oxford University Press, 2014), p. 19; D. Benn, The Caribbean: An Intellectual History 1774- 2003 (Ian Randle Publishers, 2004), p. 79.

554 "In the early postwar years, Britain was unable to meet colonial demands for development expenditure and most West Indian colonies lacked economic resources necessary to satisfy mounting domestic demands for housing, education, health facilities and the like." A. Hinds, Sterling and Decolonization in the British Empire, 1945 - 1958, Social and Economic Studies, 1999, Vol. 48 (4), pp. 97-116, p. 103; D. O’Brien, CARICOM: Regional Integration in a Post-Colonial World, European Law Journal, 2011, Vol. 17(5), pp. 630-648, p. 633.

${ }^{555}$ Many Caribbean theorists regard this to be the golden era of pioneers in Caribbean political leadership such as Sir Grantley Adams (Barbados), Dr. Eric Williams (Trinidad and Tobago) and Mr. Norman Manley (Jamaica).

556 "Beneath the clamour for self-government and independence, farmers sought assurances that Britain would continue to guarantee the region's main agricultural exports preferential access to its market in the post-colonial era." A. Hinds, Sterling and Decolonization in the British Empire, 1945 - 1958, Social and Economic Studies, 1999, Vol. 48 (4), pp. 97-116, p. 115. 
The UK was not entirely opposed to the idea of the Federation as it was viewed as a cost effective way to administrate the Caribbean region of the British Empire ${ }^{557}$ and relieve the UK of its colonial responsibilities. ${ }^{558}$ However, the financial viability of the British Caribbean territories was a major concern for the UK in their contemplations regarding the grant of independence. There was a subtle understanding that the Federation represented the only viable channel through which independence would be granted as the individual British Caribbean territories were too small to achieve financial sustainability as independent states. ${ }^{559}$ Thus, the initial concept of regional integration in the Caribbean was viewed as a political medium through which independence could be attained. ${ }^{560}$ The establishment of a Caribbean PTA was not a factor for consideration since the aim was to create a single federation of states.

Upon its establishment, the Federation was plagued with difficulties regarding the overall vision of regional integration. ${ }^{561}$ The more developed territories such as Jamaica and Trinidad and Tobago were concerned about the burden sharing required in a grouping with

\footnotetext{
557 "The British Government tried to grant its Caribbean colonies independence as one unit, if possible, thereby obviating individual negotiations and financial settlements. The Federation of the West Indies, which it initiated, could not stop the growing nationalism of the territories or the particularism motivated by political power." C. Muellerleile, CARICOM Integration: Progress and Hurdles, A European View (Kingston Publishers Limited, Kingston, Jamaica, 1995), p. 20.

558 "The most important early attempt at regional integration began after the end of the Second World War, again at the initiatives of the British colonial authorities. The British called a conference at Montego Bay in 1947 of all of its Caribbean territories to explore the possibility of regional federalism. This drive was motivated by self-interest, since the war had weakened the UK and its colonies were increasingly seen as burdensome.” D. Berry, Caribbean Integration Law (Oxford University Press, 2014), p. 18; A. Payne, The Rise and Fall of Caribbean Regionalism, Journal of Common Market Studies, 1981, Vol. 19(3), pp. 255-280, p. 275.

559 "The British Caribbean dependencies [...] were for the most part liabilities demanding self-government and political independence from Britain, even though guaranteed access to British markets was necessary for their survival in the post-colonial era." A. Hinds, Sterling and Decolonization in the British Empire, 1945 1958, Social and Economic Studies, 1999, Vol. 48 (4), pp. 97-116, p. 116; G. Atkinson, Economic Integration in the Caribbean Community: A Problem of Institutional Adjustment, Journal of Economic Issues, 1982, Vol. 16 (2), pp. 507-513, p. 507.

${ }^{560}$ See A. Payne, The Rise and Fall of Caribbean Regionalism, Journal of Common Market Studies, 1981, Vol. 19(3), pp. 255-280, p. 256.

561 "Despite an awareness of the need to deal with the spectre of dependency in the region, the West Indies Federation, from its inception, did not display an significant capacity to transform this perception into policy and reality since none of its members were independent states during this period. Their goal within the federation was to deal with the problem of external control and the attainment of independence." E. Rose, Dependence and Socialism in the Modern Caribbean (Lexington Books Publishing, USA, 2002), p. 96; D. Benn, The Caribbean: An Intellectual History 1774- 2003 (Ian Randle Publishers, 2004), p. 86.
} 
the lesser-developed territories and whether this could hinder their overall development. ${ }^{562}$ The free movement of people was a contentious issue, as the larger territories feared that an influx of economic migrants could place a strain on their already limited social services. Regional wrangling over the intended location of the Federal capital occurred and the issue of funding the Federation resulted in friction among territories. ${ }^{563}$ The Federation featured a weak federal structure as the colonies lacked a single customs union and functioned as separate economies with separate tariffs. The initial federal budget consisted of grants from the UK alongside contributions from the territories. Jamaica and Trinidad and Tobago alone contributed $85 \%$ of the revenue to the federal budget, which added to already existing tensions. $^{564}$

\subsubsection{Demise of the West Indies Federation}

Jamaica withdrew from the Federation in 1961 mainly because of its desire for individual national independence. ${ }^{565}$ Subsequent to this, the Federation was legally dissolved by a legislative act in the UK parliament in $1962 .{ }^{566}$ Several factors have been attributed for the failure of the Federation including inter alia the lack of local support, competing insular nationalism, the weakness of the federal government, prohibitions on federal taxation and freedom of movement. ${ }^{567}$ It must be recalled that the British Caribbean territories were not

\footnotetext{
562 " [...] under the original [West Indies Federation] constitution, residual powers remained with the units, while Federal Parliament received very limited jurisdiction, with no authority to tax. Its annual budget was approximately one-tenth the size of Trinidad's or Jamaica's. As the larger territories refused to yield the powers they cherished most, there was no common coinage or postage, and no provision for a customs union or free migration from one island to another." See E. Wallace, The West Indies Federation: Decline and Fall, International Journal, 1962, Vol. 17 (3) pp. 269 - 288, p. 271.

563 “Jamaicans were disgruntled that the federation's cabinet was eventually seated in Port of Spain, the capital of Trinidad and Tobago." E. Rose, Dependence and Socialism in the Modern Caribbean (Lexington Books Publishing, USA, 2002), p. 96.

564 "Concerns were expressed about the level of contribution to the Federation by certain member states, with Jamaica and Trinidad and Tobago being dissatisfied with having to contribute together more than three quarters of the budget.” D. Berry, Caribbean Integration Law (Oxford University Press, 2014), p. 20.

565 "In a national referendum held in September 1961, Jamaicans voted against further membership in the federation and instead for independence. Among the many reasons were the alienation of the vast majority of Jamaicans from the negotiation process which allowed the opposition to suggest that Jamaica was being forced by the British to shoulder the financial burden of the smaller Caribbean states and that the benefits derived from its newfound wealth (bauxite and tourism) would be diverted away from the Jamaican masses to subsidize the poorer islands." E. Rose, Dependence and Socialism in the Modern Caribbean (Lexington Books Publishing, USA, 2002), p. 96.

566 The West Indies Act 1962 legally dissolved the West Indies Federation.

567 " [...] in tackling the problem of regional political association first, the federation erred in that it ignored the lessons of history, which suggest that the chances of successful integration in a community are enhanced
} 
autonomous nation states at this stage of their regional integration journey. Hence, it is challenging to apply theories advocated by the various international relations analytical frameworks to this attempt at regional integration. Although some of the aforementioned factors such as the lack of local support and competing insular nationalism have been visible in the unfolding of regional integration in Europe, this has been related to the (neofunctionalist) diminution in the role of the nation state in the regional integration process. In the case of the British Caribbean territories, they were yet to attain independence. This fact also renders it challenging to label policy issues as being either 'high politics' or 'low politics'. There is a limited frame of reference from which to assess policy issues when certain powers and duties were still held by the UK government. ${ }^{568}$

Consequently, decolonization played a central role in both the birth and demise of the Federation. The desire for self-government had been a crucial motivation in galvanizing the regional integration effort. However, the grouping splintered due to the political nature of its existence and its focus on the political concerns of the territories. ${ }^{569}$ The aspiration for individual national independence on the part of larger territories particularly Jamaica and Trinidad and Tobago shaped their approach to the Federation. ${ }^{570}$ Jamaica was granted independence on 6 August 1962 and Trinidad and Tobago was granted independence on 31 August 1962. Thus, the first attempt at regional integration in the Caribbean was viewed primarily as a political means of achieving an end: the attainment of sovereign

when its economic interests are established ahead of time. The collapse of the federation, however, increased awareness on the part of the four largest Caribbean countries of the need to develop a viable regional economic union to improve intraregional trade and to stimulate economic growth in order to minimize the prospects of the external dependence and improve the overall well-being of the Caribbean people." E. Rose, Dependence and Socialism in the Modern Caribbean (Lexington Books Publishing, USA, 2002), p. 97.

${ }^{568}$ See Section 4.5.1 entitled Decolonization in the British Caribbean.

569 "Perhaps the most important factor in the failure of the West Indies Federation was its colonial origin and nature. The Federation was from the start a colonial project. It did not bring significantly greater independence for its ten territorial units and was institutionally and financially controlled by Britain." D. Berry, Caribbean Integration Law (Oxford University Press, 2014), p. 20.

570 "Rigid nationalism with all symbols and attributes such as flags, national anthems, National Heroes, Days of Remembrance and currencies followed colonialism - despite their common historical legacy and sociocultural background. It appeared as if the new wielders of power in the Caribbean countries wanted to enjoy the advantages of closer regional cooperation but without surrendering their own personal gains from sovereignty, power, status, position [...]" C. Muellerleile, CARICOM Integration: Progress and Hurdles, A European View (Kingston Publishers Limited, Kingston, Jamaica, 1995), p. 20. 
independence. The establishment of a preferential trade arrangement was not considered at the time. ${ }^{571}$

\subsubsection{Points of Contrast with Regional Integration in West Africa}

The origins of regional integration in the Caribbean differed from regional integration in other former colonial regions such as Africa. Regional integration in West Africa materialized much later than in the British Caribbean, as the Treaty of Lagos that established the Economic Community of West African States (ECOWAS) was signed in 1975. ${ }^{572}$ Nevertheless, it shared a similar goal to that of regional integration in the Caribbean and it sought to promote cooperation as well as integration among the West African states. ${ }^{573}$ One important point of differentiation between West Africa and the Caribbean is that all of the countries involved with ECOWAS were independent states when they commenced attempts at regional integration. Hence, regional integration was not intended as a path to independence.

Another point of differentiation between West Africa and the Caribbean relates to geographical boundaries. Most of the Caribbean territories that sought integration are islands and the definition of their territorial borders has not presented political or economic concerns. ${ }^{574}$ It is imperative to note that West Africa consists of several traditional tribal settlements sharing the same language, religion and cultural traits, which were disintegrated by colonial mapmaking. ${ }^{575}$ The imposition of such borders has been viewed

\footnotetext{
571 "The collapse of the West Indies Federation of 1958 to 1962 led to a change in thinking in the integration movement. After 1962, the integrationists sought to achieve political integration by means of economic cooperation (forms follows fact). This was a contrast to 'fact follows form' the predominant view in the 1940s and 1950s whereby the West Indian small states should first become a political unit, after which cooperation in all fields would follow almost automatically." Ibid, C. Muellerleile, 1995, p. 29.

572 See Treaty of the Economic Community of West African States (adopted $28^{\text {th }}$ May 1975, in force $20^{\text {th }}$ June 1975) 1010 UNTS 17. At the time, the dominant goal underlying the regional integration of the 15 West African Member States was the promotion of cooperation and economic integration among themselves.

${ }^{573}$ The Member States of ECOWAS are: Benin, Burkina Faso, Cape Verde, Ghana, Gambia, Guinea, GuineaBissau, Ivory Coast, Liberia, Mali, Niger, Nigeria, Senegal, Sierra Leone and Togo. It should be noted that Cape Verde joined ECOWAS in 1977 and Mauritania opted to withdraw from ECOWAS in 2000.

${ }^{574}$ In this vein, the territorial disputes between Belize and Guatemala as well as Guyana and Venezuela are noted. It is submitted that these territorial disputes have not contributed to the type of conflict experienced in West Africa.

575 "The French and British colonized most of the [West African] region in the nineteenth century, dividing it linguistically, economically and politically into one large country, Nigeria, and 14 small fiefdoms. These boundaries did not reflect the strong cultural traditions of the Igbo, Hausa, Asante, Wolof and other peoples.
} 
in some quarters as an artificial byproduct of colonialism, which has contributed to setbacks regarding international security and economic development. ${ }^{576}$ Further to this, many ECOWAS Member States have experienced a long history of social, economic and political ills including civil wars. ${ }^{577}$ It is submitted that these characteristics of the ECOWAS region may have contributed to the later development and stagnation of attempts at regional integration. Consequently, the regional integration agenda has not been advanced and policy 'spillovers' have not occurred.

Despite this, the ECOWAS Member States have endeavored to deepen the regional integration process by signing a successor treaty and the stated dominant goal has now evolved to the creation of an economic and monetary union of West Africa. ${ }^{578}$ In order to achieve this, there has been an admission on the part of ECOWAS Member States that more 'slices' of sovereignty must be transferred to the community realm. This understanding might have been influenced by the slow implementation of the ECOWAS FTA work program. ${ }^{579}$ In 1993 when the ECOWAS Revised Treaty was signed, ECOWAS

Thus, the legitimacy of these states was undermined from the outset, leaving divided populations to see any competition for power as a zero sum game and enabling elites to exploit identity divisions for personal gain." See S. Kaplan, West African Integration: A New Development Paradigm? The Washington Quarterly, 2006, Vol. 29 (4), pp. $81-97$, p.83.

${ }^{576}$ One of the underlying forces shaping cooperation in West Africa has considered regional integration as a re-integration of these settlements. Regional integration was viewed as possessing the ability to renew harmony and re-strengthen relations that once existed among the pre-colonial African empires

577 "West Africa, the 15 countries stretching from Senegal to Nigeria that are members of ECOWAS, has been racked by some of the worst problems facing the developing world: pervasive intergroup conflict, corrupt officials suffocating vacuous institutions, a dearth of skilled workers made worse by a prolific brain drain, poor investment climates and the AIDS epidemic.” See Ibid, S. Kaplan, 2006, p. 83.

578 The ECOWAS Revised Treaty was signed on $24^{\text {th }}$ July 1993 and entered into force on the same date. It was notified at the WTO Secretariat in 2005 under The Enabling Clause. See WTO Secretariat, ECOWAS Revised Treaty, Notification from Parties to the Agreement (Geneva, $26^{\text {th }}$ September 2005) [WT/COMTD/N/21]. It should be noted that many non-trade related policy issues were added to the scope of the ECOWAS work program such as the protection of human rights, regional security and good governance. See K. Alter, L. Helfer, J. McAllister, A New Human Rights Court for West Africa: The ECOWAS Community Court of Justice, American Journal of International Law, 2013, Vol. 107, pp. 737779, p. 743.

${ }^{579}$ United Nations Economic Commission for Africa/Economic Community of West African States, An Assessment of Progress towards Regional Integration in the Economic Community of West African States (May, 2015) [ECA-WA/NREC/2015/03], p. 88. 
was still in the process of implementing its FTA and, to date, ECOWAS remains an FTA having not yet progressed into a customs union. ${ }^{580}$

It remains rather challenging to apply the various international relations analytical frameworks to regional integration in West Africa. This is mainly attributable to the lack of actual regional integration. As noted above, ECOWAS is still an FTA and none of the key elements of a customs union have been implemented. Nevertheless, the ECOWAS Revised Treaty provides for supranational concepts such as the principle of subsidiarity and the direct effect of ECOWAS Community law. Many of the institutional and policy structures advocated by the ECOWAS Revised Treaty have utilized 'labels' similar to those seen in regional integration in Europe. The ECOWAS Executive Secretariat has been transformed into an ECOWAS Commission, which is intended to function as a supranational institution directing the unfolding of regional integration in West Africa. The post of Executive Secretary has been transformed into that of a Commission President. In addition to this, there is a Vice President and thirteen Commissioners for various policy areas. ${ }^{581}$ It is clear that attempts to introduce and expand upon regional integration in West Africa have not achieved the level of success seen in the Caribbean. CARICOM has advanced beyond the stage of an FTA and now exists as a single market with plans to establish a single economy. Although the institutional framework to actualize regional integration in West Africa has been improved upon, the expansive liberalization of intraregional trade has yet to occur. Implementation deficits, political instability and conflict have been noted as possible reasons for the slow unfolding of regional integration.

\footnotetext{
580 January 2006 marked the implementation of the ECOWAS common external tariff (CET) among its Member States. See Ibid, United Nations Economic Commission for Africa/Economic Community of West African States, 2015, p. 90.

${ }^{581}$ This arrangement provides each ECOWAS member state with one senior post within the Commission. Additional institutions such as the Parliament of the Community, the Community Court of Justice and the Economic and Social Council have also been established.
} 


\subsection{The Issue of Constitutional Status}

This section of Chapter 4 addresses the constitutional status of the British Caribbean territories in the aftermath of the Federation. As previously noted, the main aim of the Federation was to secure a common mechanism through which the ten British Caribbean territories could attain firstly, self-government and secondly, political independence from the UK. ${ }^{582}$ Although the British Caribbean Federation Act of 1956 gave birth to the Federation, the legislation was passed in the UK Parliament and this reinforced the fact that under international law, all ten British Caribbean territories were UK colonies. ${ }^{583}$ The Federation itself was formed in 1958 and, consequently, certain powers and duties were conferred upon the Federal government by the UK government. ${ }^{584}$ Upon the failure of the Federation to progress in unifying its constituents, it was also dissolved by an Act of the UK Parliament, the West Indies Act of 1962. In this context, it should be noted that two years prior to the dissolution of the Federation, the 1960 United Nations (UN) Resolution 1514 (XV) was adopted whereby the UN recognized the yearning for independence on the part of dependent peoples and colonial powers were encouraged to end colonialism in all of its manifestations. ${ }^{585}$

\subsubsection{Decolonization in the British Caribbean}

The Caribbean era of decolonization commenced in 1962 when both Jamaica and Trinidad and Tobago attained their independence from the UK. ${ }^{586}$ Four years later in 1966, Guyana

\footnotetext{
582 In 1947 when the GATT was signed, the British Caribbean territories were considered part of the dependent territories of the UK and as such, some of their trade relations were governed by GATT Article I: 2(b).

583 "A colony is a non-metropolitan territory over which the parent State (colonial power) exercises control. The parent State can determine the extent (if any) to which the colony has control of its own affairs. But, even for the most advanced colonies, the parent State will usually retain responsibility for defence and foreign affairs. A colony cannot conclude treaties without the authority of the parent State. Nor can it enter into diplomatic relations, although consular posts may be established in a colony with the permission of the parent State." A. Aust, Handbook on International Law, Second Edition (Cambridge University Press, 2010), p. 30. ${ }^{584}$ The West Indies Federation Act was passed on $2^{\text {nd }}$ August 1956; however, the West Indies Federation was established on $3^{\text {rd }}$ January 1958.

${ }^{585}$ See United Nations Secretariat, Declaration on the Granting of Independence to Colonial Countries and Peoples, UNGA Resolution 1514 (XV) (New York, 14 ${ }^{\text {th }}$ December 1960) [A/RES/1514(XV). It is instructive to note that the UK was one of nine UN members to abstain in voting on this resolution.

${ }^{586}$ Jamaica gained its independence on $6^{\text {th }}$ August 1962 and Trinidad and Tobago gained its independence on $31^{\text {st }}$ August 1962 .
} 
and Barbados attained their independence. ${ }^{587}$ Therefore by 1966, four of the British Caribbean territories had attained independence and in the eyes of international law, they were sovereign states possessing the capacity to inter alia join the UN, establish diplomatic relations with other independent states and conclude their own treaties. ${ }^{588}$ Conversely, the other seven British Caribbean territories that were previously members of the Federation, but were yet to gain independence from the UK, reverted back to being full colonies. ${ }^{589}$ The powers and duties that were previously conferred upon the then federal government were transferred back to the UK and its colonial authorities. Moreover, the UK parliament passed the 1967 Associated Statehood Act, which changed the constitutional status of six of the seven colonies with Montserrat being the exception. ${ }^{590}$ Given the anti-colonial sentiment that had gained prominence in the aftermath of the UNGA Resolution 1514 $(\mathrm{XV})$, the UK was required to formulate a constitutional solution for these small territories, which were economically unfit to be granted independence at this particular juncture. ${ }^{591}$ The main aim of the 1967 Associated Statehood Act was to grant the six British Caribbean territories control over their constitutions as well as to provide them with internal selfgovernment whilst the UK retained responsibility for external affairs and defence. ${ }^{592}$

${ }^{587}$ Guyana gained its independence on $26^{\text {th }}$ May 1966 and it is important to note that Guyana was not a member of the West Indies Federation. Further, Barbados gained its independence on 30 ${ }^{\text {th }}$ November 1966.

${ }^{588}$ By the end of 1966, all four independent Caribbean countries had joined the UN: Jamaica (18 ${ }^{\text {th }}$ September $1962)$, Trinidad and Tobago (18 ${ }^{\text {th }}$ September 1962), Guyana $\left(20^{\text {th }}\right.$ September 1966$)$, Barbados $\left(9^{\text {th }}\right.$ December 1966). Additionally on $12^{\text {th }}$ December 1972, all four independent Caribbean countries established diplomatic relations with Cuba. See Part III, The International Level in (eds) A. Payne, P. Sutton, Dependency under Challenge: The Political Economy of the Commonwealth Caribbean (Manchester University Press, 1984), p. 176.

${ }^{589}$ Post-1962, Grenada, Dominica, St. Lucia, St. Vincent, Antigua and Barbuda, St. Kits-Nevis-Anguilla and Montserrat reverted to UK colonies. It is notable that Montserrat still remains an overseas territory (colony) of the UK.

590 The 1967 Associated Statehood Act marked the start of sub-regional unity for these six British Caribbean territories as they eventually formed the Eastern Caribbean Common Market (ECCM) in 1968 and the Organization of Eastern Caribbean States (OECS) in 1981. On a related note, Anguilla seceded from St. Kitts and Nevis in 1969 and then reverted from an Associated State to being a full colony under British rule. It remains as such today.

591 "Independence being thus ruled out by the Colonial Office, it reacted quickly to the resolutions in favor of internal self-government. The case against it was a simple and attractive one: whereas Associated Statehood would be specifically tailored to their specific and long term needs, the more orthodox status was a precursor to independence." T. Thorndike, "The Politics of Inadequacy: A Study of the Associated Statehood negotiation and constitutional arrangements for the Eastern Caribbean", Social and Economic Studies, 1979, Vol. 28(3), pp. 597-617, p. 600.

592 “[...] Her Majesty's Government in the United Kingdom shall have no responsibility for the government of any Associated State except in respect of - (a) any matter which in the opinion of Her Majesty's Government in the United Kingdom is a matter relating to defence [... or to external affairs." See Associated Statehood Act 1967 s. 2(1). 
Regarding the matter of external affairs, the UK government defined which matters qualified within this definition. For instance, negotiations with the independent Caribbean countries on regional matters were not considered external affairs. ${ }^{593}$ Participation in Caribbean regional agencies was also not considered external affairs and as such, the Associated States had full competence to undertake such matters. When the six Associated States eventually joined CARIFTA on $1^{\text {st }}$ July 1968 , the decision-making powers to enable their membership was taken at the local level and the UK was not required to assent to their decision to join the PTA. ${ }^{594}$ Therefore, six of the signatories to the first Caribbean PTA that was notified at the GATT Secretariat were not independent States. Despite the nomenclature used by the UK government, these British Caribbean territories were still viewed as possessing the constitutional status of colonies under international law.

It is important to differentiate between the nomenclature utilized (individually) by the UK and the constitutional status recognized by international law. Although the UK undertook efforts to demarcate a line between an Associated State and a colony, ${ }^{595}$ the fact remains that the former was not recognized as being substantively different from the latter under international law. ${ }^{596}$ Additionally in 1973 when the UK joined the EEC, all six Associated States, Montserrat and Belize were granted association under Part IV of the Treaty of Rome

\footnotetext{
593 "No restriction was placed upon direct negotiations with officials of the Caribbean Commonwealth countries since, in virtue of a tradition of co-operation and close consultation in the area, culminating in the various proposals for federation, the relations between them have been of a somewhat informal nature. It was stated in the House of Commons during the second reading of the West Indies Bill that it contained no bar to the joining and setting up of regional agencies." M. Broderick, "Associated Statehood - A new form of decolonization", International and Comparative Law Quarterly, 1968, Vol. 17 (2), pp. 368-403, p. 377.

594 "An example of this is the Caribbean Free Trade Agreement (CARIFTA), which establishes a free trade area between Guyana, Barbados and Antigua. A question was asked in the House of Lords as to whether there was any provision for a Customs Union in the West Indies Bill, and the Government replied to the effect that customs were matters exclusively for local bodies and as such were not within the ambit of the reserved external affairs power of the Government." Ibid, M. Broderick, 1968, p. 378.

595 "Notwithstanding anything in the interpretation Act of 1889, the expression "colony' in any Act of the Parliament of the United Kingdom passed on or after the appointed day shall not include an Associate State." See Associated Statehood Act 1967 s. 3(5).

596 "It was further explained that in this situation, international law dictated that the British Government would be held responsible for all aspects of that territory's affairs, whether internal, constitutional or external i.e. including many matters which they had no means of controlling." T. Thorndike, "The Politics of Inadequacy: A Study of the Associated Statehood negotiation and constitutional arrangements for the Eastern Caribbean”, Social and Economic Studies, 1979, Vol. 28(3), pp. 597-617, p. 601.
} 
establishing the EEC. ${ }^{597}$ Later in 1974, twelve years after the first British Caribbean territory was granted independence, the first of the Associated States was granted independence. ${ }^{598}$ Thereafter, the other five Associated States were granted their independence between 1978 and 1983. St. Kitts and Nevis was the last of the present day CARICOM Member States to be granted independence, which occurred on 19 September 1983.

The aforementioned summary of the road to independence has accounted for all of the British Caribbean territories that participated in the Federation. ${ }^{599}$ This also included Montserrat, which participated in the Federation and still remains an overseas territory of the UK. Also mentioned was the independence of Guyana, which was not a Member of the Federation, but is a present day CARICOM Member State. In a similar vein, Belize was not a Member of the Federation, but is a present day CARICOM Member State. Belize remained a British colony throughout the period of Associated statehood for the aforementioned six British Caribbean territories. Chapter 6 of this dissertation outlines how the path to independence for Belize was stymied by the Guatemalan territorial claim. Consequently, Belize acquired the status of a self-governing colony in 1964 and was one of the last British Caribbean territories to be granted independence in $1981 .{ }^{600}$

\footnotetext{
${ }^{597}$ Montserrat and Belize were still British colonies in 1973. The Treaty concerning the Accession of the Kingdom of Denmark, Ireland, the Kingdom of Norway and the United Kingdom to the EEC and the EAEC (1972) offered the UK overseas territories association with the EEC under Part IV of the Treaty of Rome (1957). See A. Oye Cukwurah, The Position of Overseas Associated States in the EEC in (ed.) B.A. Wortley, The Law of the Common Market (Manchester University Press, 1974), p. 224.

${ }_{598}^{598}$ Grenada attained its independence on $7^{\text {th }}$ February 1974.

${ }^{599}$ This summary does not include the present day CARICOM Member States of the Bahamas, Suriname and Haiti. All three of these CARICOM Member States do not participate in the CARICOM single market. Despite this, it is notable that the Bahamas was a former British colony and it attained its independence on $10^{\text {th }}$ July 1973.

${ }^{600}$ Like the Associated States, Belize also joined CARICOM when it had yet to achieve its independence. It is presumed that, similarly to the West Indies Associated States, the joining of a regional cooperation mechanism by Belize did not present the UK government with legal complications.
} 


\subsubsection{From Politics to Economics}

As previously noted, the origins of regional integration in the Caribbean were considered more political than economic. The global transformation of the international system brought about by decolonization aided in cultivating the Caribbean interpretation of regional integration, which placed independence as the ultimate end game or dominant goal. ${ }^{601}$ The Caribbean quest for independence was compounded by the fact that the UK applied for EEC membership on 10 August $1961 .^{602}$ This factor had important implications for regional integration in the Caribbean. It germinated the realization that trade preferences could be threatened if the UK acceded to the EEC and the other EEC partners deemed such trade preferences too generous. ${ }^{603}$

Another important issue of concern was the progressive developments in the General Agreement on Tariffs and Trade (GATT) rounds of multilateral trade negotiations, which led to increased Caribbean awareness about multilateral trade rules. By the early 1960s, Jamaica and Trinidad and Tobago were independent states and both had become GATT Contracting Parties. ${ }^{604}$ There was now an appreciation for the articulation of the Caribbean position on international trade issues that was reflected at the start of the 1964 Kennedy Round of multilateral trade negotiations when the independent Caribbean countries coordinated their policy positions. ${ }^{605}$

\footnotetext{
${ }^{601}$ Therefore, the foundational motivation was autonomy. This differs from the foundational motivation in regions such as Europe where the promotion of peace and the prevention of war constituted the main goals.

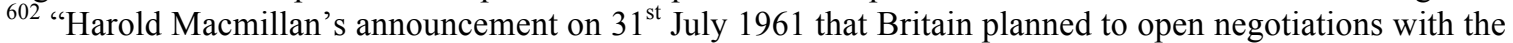
EEC with a view to full membership was widely hailed as a historic turning point." N. Piers Ludlow, Dealing with Britain: The Six and the First UK Application to the EEC (Cambridge University Press, 1997), p. 12.

603 "By the end of 1960, the British were involved in exploratory discussion with two of the larger Community Member States [...] Both the Germans and the Italians displayed great flexibility on the two most contentious issues - British domestic agriculture and Commonwealth trade...Both countries acknowledged the importance of Commonwealth trade. They could not go so far as to say that the tariff-free entry of Commonwealth goods into the UK should continue unchanged, but they appeared to accept that the Six would have to show understanding towards Britain's former colonies." Ibid, N. Piers Ludlow, 1997, p. 33. See also A. Payne, The Politics of the Caribbean Community: 1961 - 1979, Regional Integration amongst New States (Manchester University Press, 1980), p. 37.

${ }^{604}$ Trinidad and Tobago joined the GATT on $23^{\text {rd }}$ October 1962. Jamaica joined the GATT on $31^{\text {st }}$ December 1963. Later, Barbados joined the GATT on $15^{\text {th }}$ February 1967.

605 "It was agreed that there should be continuing close collaboration between Jamaica and Trinidad and Tobago in their approach to the Trade and Development Conference to be held in Geneva from March 23 to June 15,1964, as well as in the review of the General Agreement on Tariffs and Trade, and in the negotiations on the U.S. Trade Expansion Act (The Kennedy Round), as the interests of both these countries are largely identical in these matters. It was also agreed that the territories of the British Caribbean should submit their
} 
Many newly independent developing countries became GATT Contracting Parties in the 1960s and in February 1965, Part IV of the GATT on Trade and Development was adopted whereby further attention was given to developing country trade issues. ${ }^{606}$ Moreover, agricultural trade was already under the GATT spotlight as the 1958 Haberler Report $^{607}$ was issued and it examined inter alia the effect of protectionism in agriculture and fluctuating commodity prices. ${ }^{608}$ Since the existing British Caribbean territories and the newly independent Caribbean countries were beneficiaries of agricultural trade preferences, there was ample cause for concern. It is submitted that the cumulative geopolitical effect of these developments in the international trade arena led Caribbean leaders to accelerate the momentum on regional integration for the sake of participating in the global debate. ${ }^{609}$

This dissertation also maintains its assertion that UK trade preferences on bananas and sugar served as a prism through which many global developments were viewed. With respect to the establishment of the first Caribbean PTA, it is argued that the preservation of such trade preferences served as one of the dominant goals to be achieved. The possible UK accession to the EEC and advancements in the multilateral trade sphere were two

views to the Governments of Jamaica and of Trinidad and Tobago, and that a meeting of all the Commonwealth countries of the Caribbean would, if possible, be arranged in advance of the U.N. Conference, to give these countries the opportunity of an exchange of views." Communiqué issued at the $2^{\text {nd }}$ Conference of Heads of Government of the Commonwealth Caribbean Countries, $13^{\text {th }}-17^{\text {th }}$ January 1964 , Kingston, Jamaica.

${ }^{606}$ The GATT 1947 did not recognize the special needs of developing countries despite the fact that 11 of the 23 original contracting parties were developing countries and this resulted in developing countries participating in the MTS as equal partners adhering to uniform rules with developed countries from 1948 until the clamor for asymmetrical treatment yielded some results. See P. Conconi, C. Perroni, Special and Differential Treatment of Developing Countries in the WTO, World Trade Review, 2015, Vol. 14(1) pp. 67 - 86, p. 71; Report by the Consultative Board to the Director General Supachai Panitchpakdi, The Future of the WTO: Addressing Institutional Challenges in the New Millennium (The Sutherland Report) WTO 2004, p. 24, para. 90; R. Wilkinson, J. Scott, Developing Country participation in the GATT: A Reassessment, World Trade Review, 2008, Vol. 7(3) pp. 473-510, p. 479; R. Hudec, Developing Countries in the GATT Legal System (Cambridge University Press, 2011), p. 41.

${ }^{607}$ Trends in International Trade (The Haberler Report) Sales No GATT/1958-3, Geneva: GATT. The members of the panel included: Professor Gottfried Haberler (Chairman), Roberto da Oliveira Campos, James Meade, Jan Tinbergen

${ }^{608}$ See also P. Mavroidis, The Regulation of International Trade, Volume I, GATT (MIT Press, 2016), p. 243.

${ }^{609}$ Part IV of the GATT was negotiated in 1964 and signed in 1965. The Committee on Trade and Development (CTD) was also established in 1965 and tasked with inter alia reviewing the application of the provisions of Part IV of the GATT. 
global developments, which reinforced the need to safeguard these trade preferences. It is submitted that these events propelled a reassessment of the Caribbean international trade arrangements and led to serious contemplations about the establishment of the first Caribbean PTA. ${ }^{610}$

\subsection{Phase 2: The Caribbean Free Trade Association}

At the July 1965 Conference of the Heads of Government of the Caribbean, serious discussions were held regarding the establishment of a Caribbean free trade association. This would be limited to the non-sensitive issue of trade in goods and entail the elimination of trade barriers between the trade partners. Economic integration was not explored during the Federation era and the region retained the same primary product export-led economic strategy, which lacked emphasis on intra-regional trade. ${ }^{611}$ The Dickenson Bay Agreement created CARIFTA on 15 December 1965 and was aimed at utilizing regional integration to accelerate economic development by increasing intra-regional trade whilst diversifying and liberalizing trade. ${ }^{612}$ It also marked the first time that a trade arrangement was linked with the future development of regional integration in the Caribbean. Subsequently, a Caribbean Conference of Heads of Government resolution eliminated all import duties and quantitative restrictions on products traded among the British Caribbean territories and

\footnotetext{
610 "The growing sentiment among the Caribbean leaders at the time was that some form of collaboration was needed to stimulate economic development and to minimize the region's external dependence. They were particularly concerned about the relatively sparse volume of inter-island trade caused by tariff barriers, market prospects for their primary products, and continued preferential trading ties with Great Britain, in light of its application to join the European Economic Community (EEC) and its likely abandonment of the region's preference." E. Rose, Dependence and Socialism in the Modern Caribbean (Lexington Books Publishing, USA, 2002), p. 93.

611 "Britain provided local governments with expertise in order to draft the constitution of CARIFTA, and this is obvious in its ethos. CARIFTA was the exact counterpart of the European Free Trade Association (EFTA), which Britain had been keen to establish in the 1950s and early 1960s, as a counterweight to the European Common Market and, in Ted Heath's own words, in order to exert pressure on the Common Market. This was not the case of CARIFTA, whose intentions were not essentially negative, and which was solely intended to facilitate trade between member countries. Unlike the ill-fated EFTA, CARIFTA was a success. By 1971, it had 13 members." See J. Revauger, Regional Integration in the Commonwealth Caribbean and the Impact of the European Union, The Round Table, 2008, 97(399), pp. 857-869, p. 860.

${ }^{612}$ See Dickenson Bay Agreement establishing the Caribbean Free Trade Association (adopted $15^{\text {th }}$ December 1965, in force $1^{\text {st }}$ May 1968) 772 UNTS 3. The four initial signatories of the CARIFTA were Antigua and Barbuda, Barbados, Guyana and Trinidad and Tobago. The only independent country signatory was Trinidad and Tobago. Implementation of the agreement was initially delayed to give other Caribbean countries the opportunity to consider membership. See Ibid, J. Revauger, 2008, p. 860.
} 
independent Caribbean countries. ${ }^{613}$ A reserve list of certain products to be exempted from free trade for five years was established known as the agricultural marketing protocol (AMP) and non-discriminatory fiscal measures were allowed to offset customs revenue losses. ${ }^{614}$

Only four Caribbean territories were signatories to CARIFTA when it entered into force on 1 May $1968 .^{615}$ Dominica, Grenada, St. Kitts and Nevis-Anguilla, St. Lucia and St. Vincent signed CARIFTA on 1 July 1968 and Jamaica signed the Agreement on 1 August 1968. CARIFTA was the first Caribbean PTA to be notified at the GATT Secretariat and the PTA was able to liberalize over $90 \%$ of intra-regional trade, which increased in value from $\$ 48$ Million USD in 1967 to $\$ 83.6$ Million USD in $1970 .{ }^{616}$ This represented a $74 \%$ increase in intra-regional trade. Exports from the three more developed territories (Jamaica, Barbados and Trinidad and Tobago) of the grouping to the rest of the region also increased by $77 \%$, whereas there was a more modest increase of $35 \%$ for the exports of lesserdeveloped territories. ${ }^{617} \mathrm{~A}$ matter of some sensitivity was the fact that the lesser-developed territories of the grouping did not benefit as greatly as the more developed territories. This highlights that there have been challenges to cultivate intra-regional trade and increased growth for the lesser-developed territories from the first Caribbean PTA. ${ }^{618}$

\footnotetext{
${ }^{613}$ Appendix I and II of the Summary of Conclusions of the $4{ }^{\text {th }}$ Conference of the Heads of Government of the Commonwealth Caribbean Countries, 23-27 October 1967, Bridgetown, Barbados available at www.caricom.org.

${ }^{614}$ See Dickenson Bay Agreement Fifth Schedule, Article 5(d), Resolution adopted by the Fourth Heads of Government on Regional Integration, which states: Free Trade should be introduced with respect to all intraCommonwealth Caribbean trade by 1st May 1968, subject to a list of reserved commodities which would be freed within a five-year period for the more-developed countries and within a ten-year period for the lessdeveloped countries; subject to special provisions for appeal by a less-developed Territory to the governing body of the Free Trade Area for further extension in any case where serious injury may be done to a territorial industry. See AMP in Chapter 3, Section 3.4.1. 2 entitled CARIFTA Analysis in light of GATT Article XXIV:5.

${ }_{615}^{615}$ Trinidad and Tobago, Antigua, Barbados and Guyana.

${ }^{616}$ See CARIFTA in Chapter 3, Section 3.4.1 entitled CARIFTA. See also K. Hope, CARIFTA and Caribbean Trade, An Overview, Caribbean Studies, 1974, Vol. 14 (1) pp. 169-179, p. 173.

${ }^{617}$ Ibid, K. Hope, 1974, p. 173.

${ }^{618}$ This complexity in the distribution of benefits has proven itself to be a consistent feature, as the trend still exists in present day CARICOM. See D. O'Brien, CARICOM: Regional Integration in a Post-Colonial World, European Law Journal, 2011, Vol. 17(5), pp. 630-648, p. 637; A. Payne, The Rise and Fall of Caribbean Regionalism, Journal of Common Market Studies, 1981, Vol. 19(3), pp. 255-280, p. 264.
} 
Shortly after the establishment of CARIFTA, differences about the overall vision of regional integration and mutual distrust emerged ${ }^{619}$ This hampered the further progression of CARIFTA and in 1968, the lesser-developed territories formed their own sub-regional arrangement, the East Caribbean Common Market (ECCM) ${ }^{620}$ Such developments suggest that the design of CARIFTA as a free trade agreement was not fully agreed upon and that intra-regional trade creation as an economic strategy might not have been the foremost motivation for all of the Caribbean territories. It is again asserted that the main motivation in establishing CARIFTA was the maintenance of a strategic, geopolitical relationship with the UK, which was perceived to be at risk due to the 1961 UK application to accede to the EEC. ${ }^{621}$ The future of the UK colonial trade preferences was in doubt and consequently, there was an impetus to act in order to protect the main agricultural exports of the monoculture Caribbean economies.

\subsection{Phase 3: The Caribbean Community and Common Market}

It is submitted that developments regarding the UK accession to the EEC acted as a catalyst in the progression of regional integration in the Caribbean. The 1969 Hague Summit, however, changed the calculus regarding EEC enlargement policy. ${ }^{622}$ Renewed hope

\footnotetext{
${ }^{619}$ The lesser-developed territories were dissatisfied with the lack of distributive measures and initially declined to sign the agreement in 1968 over fears of marginalization. See also G. Atkinson, Economic Integration in the Caribbean Community: A Problem of Institutional Adjustment, Journal of Economic Issues, 1982, Vol. 16 (2), pp. 507-513, p. 508.

${ }^{620}$ See Agreement Establishing the Eastern Caribbean Common Market (adopted 11 June 1968, in force 1 July 1968) 1338 UNTS 55. The signatories were Antigua, Dominica, Grenada, St. Kitts and Nevis-Anguilla, St. Lucia and St. Vincent. The ECCM Agreement essentially amounted to a restricted common market zone with the larger CARIFTA area. It has been compared to the Benelux arrangement within the EEC. See H. Geiser, P. Alleyne, C. Garaj, Legal Problems of Caribbean Integration: A Study on the Legal Aspects of CARICOM (Institute of International Relations, St. Augustine, Trinidad and Tobago and A.W. Sijthoff International Publishing, Leiden, Netherlands, 1976), p. 56. See also ECCM in Chapter 5, Section 5.4 entitled Marginalization of LDCs? The ECCM subsequently evolved into the Organization of Eastern Caribbean States in 1981 with the signing of the Treaty of Basseterre. See also OECS in Chapter 5, Section 5.1 entitled Natural Trading Partners?

${ }^{621}$ D. O'Brien, CARICOM: Regional Integration in a Post-Colonial World, European Law Journal, 2011, Vol. 17(5), pp. 630-648, p. 636; A. Payne, The Rise and Fall of Caribbean Regionalism, Journal of Common Market Studies, 1981, Vol. 19(3), pp. 255-280, p. 256.

622 "The European Communities remain the original nucleus from which European unity has been developed and intensified. The entry of other countries of this continent to the Communities - in accordance with the provisions of the Treaties of Rome - would undoubtedly help the Communities to grow to dimensions more in conformity with the present state of world economy and technology." Final Communique of the Conference of Heads of State or Government of the European Economic Community held on $1^{\text {st }}$ and $2^{\text {nd }}$ December 1969

at

The 184
} 
emerged about the UK accession and behind the scenes negotiations commenced, which culminated in a third application for entry in June 1971. ${ }^{623}$ The UK colonial trade preferences on sugar, personified in the CSA, were a divisive issue during the accession negotiations. The UK wanted to retain its arrangement ${ }^{624}$ and expressed its concern regarding the impact of sudden changes on the economies of the small, developing Commonwealth territories and countries. ${ }^{625}$ The British position on the CSA was defended in their 1967 statement at the meeting of the Council of the Western European Union. ${ }^{626}$

\footnotetext{
http://www.cvce.eu/obj/final communique of the hague summit 2 december 1969-en-33078789-803049c8- b4e0-15d053834507.html [accessed on $1^{\text {st }}$ June 2016].

"The Hague Summit of December 1969, the first meeting of Heads of State since the tenth anniversary of the Treaty of Rome, laid much of the groundwork for future change. It [...] confirmed a decision to proceed with the enlargement of the community and specifically to admit Great Britain as a member." J. Gillingham, European Integration 1950 - 2003: Super State or New Market Economy? (Cambridge University Press, 2003), p. 82.

${ }^{623}$ The UK had submitted two unsuccessful applications for EEC membership on $10^{\text {th }}$ August 1961 and $27^{\text {th }}$ November 1967 respectively.

${ }^{624}$ See Section 4.3 entitled The Commonwealth Sugar Agreement (CSA). "Britain argued in favour of preferential treatment for its former colonies, and demanded that they be exempted from the common European external tariff, which applied to all imports from outside Europe. Ironically, the British case was strengthened by the position of France, which shared the same concern, not towards its Caribbean departements, which were part of the national French territory and had full access to the European market, but towards its former colonies in Africa. A long round of negotiations started, leading to a series of conventions and agreements between the Common Market and the African Caribbean and Pacific countries (ACP), much to the annoyance of other nations which produced the same goods at a much cheaper rate, reflecting the low cost of labour, but who were hit by the external tariff." See J. Revauger, Regional Integration in the Commonwealth Caribbean and the Impact of the European Union, The Round Table, 2008, 97(399), pp. 857-869, p. 861.

625 "The question of sugar in our [accession] negotiations meant primarily but by no means exclusively, the problem of continuing to provide a market after our entry into the community for quantities of sugar which we were obliged to buy at negotiated prices (which had regularly been far above the world price) from the producing members of the Commonwealth Sugar Agreement. It turned out to be both technically and politically one of the most complex, if not the most complex, of all the problems of the whole negotiations. There was a great variety of parties involved, whose interests were often diametrically opposed." C. O'Neil, Britain's Entry into the European Community (Whitehall History Publishing, London, 2000), p.100.

626 "For Sugar, as you know, we have an agreement with the Commonwealth sugar producers which runs until the end of 1974. Your own transitional arrangements are due to expire six months later. The commitment we have under the Commonwealth Sugar Agreement is a contract that we must fulfill. We believe that the sugar exported to Britain under the Commonwealth Sugar Agreement can be accommodated within a reasonable production quota under existing Community arrangements and without departure from the precedents, which you have set for yourselves. We have also to look to the longer-term interests of the developing countries and territories many of whose economies are overwhelmingly dependent on their exports of sugar and we believe that it is in the Community's longer-term interest that we should do so. In due course, we shall wish to discuss with you how these interests can be safeguarded in the longer term." See British Application to join the EEC. Statement by the Rt. Hon. George Brown M.P., Secretary of State for Foreign Affairs, at the Meeting of the Council of the Western European Union, The Hague, $4^{\text {th }}$ July 1967 , p. 6 , para. 33 .
} 
Given the deliberations on the CSA, there was much apprehension in the Caribbean regarding possible changes to the structure of UK colonial trade preferences. ${ }^{62}$ The Sixth Conference of Caribbean Heads of Government in 1970 adopted a Report of the Special Meeting of the CARIFTA Council of Ministers in relation to an expanded EEC $^{628}$ and in 1972, the decision to transform CARIFTA into a Common Market was agreed upon. ${ }^{629}$ Although CARIFTA had created a regionally integrated unit, the effects of the British colonial paradigm and colonial trade policy were still apparent. The Caribbean region was still characterized by net importing, undiversified economies that were incapable of producing basic consumer goods necessary for productive expansion.

Regional policy makers reiterated that the Caribbean territories had been inserted into the world economy as primary producers, which resulted in the structural dependence of their economies. ${ }^{630}$ There was a need for a policy framework on political cooperation, the free movement of labor and capital as well as measures to address the disparity in development levels among the various Member States. ${ }^{631}$ The recognized importance of the latter point was exemplified in several decisions taken by the Caribbean Heads of Government, which were specifically designed to assist the lesser-developed territories. ${ }^{632}$ In other words,

\footnotetext{
627 "The other action, with no less serious implications for the Caribbean colonies was Britain's decision to join the European Common Market. The West Indies' economy is still predominantly agricultural, and its sugar and bananas are not competitive without the imperial preference and quotas long accorded the islands. If special terms of entry for such colonial products cannot be arranged, the already poverty stricken British Caribbean may well face financial disaster." See E. Wallace, The West Indies Federation: Decline and Fall, International Journal, 1962, Vol. 17 (3) pp. 269 - 288, p. 283.

${ }^{628}$ CARICOM Press Release No. $15 / 1970$ dated $15^{\text {th }}$ April 1970 available at http://www.caricom.org.

${ }^{629}$ The CARIFTA structure was viewed as being incapable of stimulating viable economic development and a common market was now better suited to the needs of the Caribbean region. See A. Payne, The Rise and Fall of Caribbean Regionalism, Journal of Common Market Studies, 1981, Vol. 19(3), pp. 255-280, p. 268. A common market has been defined as " a group of trading nations that permits the free movement of goods and services among themselves as well as the initiation of common external trade restrictions against nonmembers and the free movement of the factors of production across national borders within their economic bloc." See R. Carbaugh, International Economics 12 ${ }^{\text {th }}$ Edition (SouthWestern, 2009) p. 534.

630 "The European colonial powers not only colonized and dominated the territories of the Caribbean, but also inserted their economies into the international economic system as sugar cane plantation societies, producers of raw materials, cheap and free labor and as outlets for their financial surpluses." E. Rose, Dependence and Socialism in the Modern Caribbean (Lexington Books Publishing, USA, 2002), p. 51.

${ }^{631}$ (eds.) K. Hall, M. Chuck-A-Sang, The Integrationist, CARICOM Single Market and Economy: Challenges, Benefits, Prospects (Ian Randal Publishers, Jamaica, 2007), p. 16.

${ }_{632}$ Communique issued at the 7th Conference of Heads of Government of the Commonwealth Caribbean Countries, $9^{\text {th }}-14^{\text {th }}$ October 1972, Chaguaramas, Trinidad and Tobago available at $\mathrm{http}: / / \mathrm{www}$. caricom.org
} 
various policy instruments were designed in order to operationalize the cooperation that would occur on the regional integration platform.

\subsubsection{The Original Treaty of Chaguaramas}

The OTC created the Caribbean Community and Common Market and was signed by Barbados, Jamaica, Guyana and Trinidad and Tobago on 4 July $1973 .{ }^{633}$ Subsequently, eight other Caribbean territories joined the common market. It is important to emphasize that at this stage, the regional integration arrangement possessed Members with three different constitutional statuses as of $1973 .{ }^{634}$ This persisted until 1983 when St. Kitts and Nevis attained its independence. Also notable is that the Caribbean Community and the Common Market were two separate legal instruments contained within one treaty. The Caribbean Community was endowed with juridical personality and addressed aspects of functional cooperation, treaty making as well as foreign policy coordination. The Common Market Annex addressed aspects of economic integration among the CARICOM Member States that had signed both instruments. ${ }^{635}$ This institutional arrangement was necessary to facilitate Community membership for the territories that opted against joining the Common Market. ${ }^{636}$ However, the CARICOM Member States wishing to join the Common Market were required to join the Caribbean Community. The Treaty itself was also considered a constituent instrument of an international organization and had the characteristics of a multilateral inter-state treaty governed by general international law. ${ }^{637}$

\footnotetext{
${ }^{633}$ See The Treaty of Chaguaramas (adopted $4^{\text {th }}$ July 1973 , in force $1^{\text {st }}$ August 1973) 946 UNTS 17 . The OTC created the second Caribbean PTA that was notified at the GATT Secretariat and expanded the foundation laid by CARIFTA. See GATT Secretariat, Treaty Establishing the Caribbean Community (Geneva, $14^{\text {th }}$ October 1974) [L/4083]. See also The Treaty of Chaguaramas in Chapter 3, Section 3.4.2 entitled The Original Treaty of Chaguaramas (OTC).

${ }^{634}$ Five members were sovereign states: Barbados, Grenada, Guyana, Jamaica and Trinidad and Tobago; six members had associated status with the UK: Antigua, Dominica, St. Kitts-Nevis-Anguilla, St. Lucia, St. Vincent and Montserrat and one member was a UK colony: Belize. See also Section 4.5 entitled The Issue of Constitutional Status.

635 "The double treaty arrangement created two distinct but potentially overlapping treaty regimes: a state could become a party to the Treaty and not the Annex, but not vice versa. This... represented a compromise between the different goals of regional integration. Rather than create two completely separate treaties, the Treaty Annex compromise preserved a strong, formal like to ensure coherence." D. Berry, Caribbean Integration Law (Oxford University Press, 2014), p. 22. See also The Treaty of Chaguaramas in Chapter 3, Section 3.4.2 entitled The Original Treaty of Chaguaramas (OTC).

${ }_{636}$ The Bahamas was able to join the Caribbean Community in 1983 without joining the Common Market.

${ }^{637}$ H. Geiser, P. Alleyne, C. Garaj, Legal Problems of Caribbean Integration: A Study on the Legal Aspects of CARICOM (Institute of International Relations, St. Augustine, Trinidad and Tobago and A.W. Sijthoff
} 
It is useful to explain that this progression of regional integration was not driven by a federalist ideology. The unfolding of regional integration in the Caribbean did not feature neofunctionalist elements such as a supranational institution within its administrative framework. ${ }^{638}$ This has been attributed to the preference of CARICOM Member States to retain their sovereignty. In light of the experience with British colonialism, CARICOM Member States are not inclined to forego their national autonomy and this issue is considered particularly sensitive within the context of regional integration. Consequently, the nation state has been the dominant actor in the various phases of regional integration in the Caribbean. ${ }^{639}$ As such, the OTC designated the Conference of Heads of Government as the principal organ of CARICOM. ${ }^{640}$ The framework of regional integration outlined in the OTC reflects some features of liberal intergovernmentalism, as the interstate decisionmaking is based on a common preference formation due largely to the constrained nature of CARICOM economies. ${ }^{641}$

Various CARICOM institutions focusing on 'low politics' policy issues have also been created to secure achieved outcomes in the face of future uncertainty. Again, it must be stated that the delineation of 'low politics' and 'high politics' policy issues has not been as straightforward as seen in regional integration in Europe. Although regional integration in the Caribbean has featured an intergovernmentalist approach, this has not resulted in the consideration of many 'high politics' policy issues. Many 'high politics' policy issues such

\footnotetext{
International Publishing, Leiden, Netherlands, 1976), p. 145. See also Chapter 7, Section 7.1.4 entitled Legal Competence under The RTC.

${ }^{638}$ See J. Caporaso, Regional Integration Theory: Understanding our past and anticipating our future, Journal of European Public Policy, 1999, Vol. 5(1), pp.1-16, p. 8; See J. Lewis, Coreper: National Interests and the Logic of Appropriateness in (eds) J. Peterson, D. Hodson, Institutions of the European Union, Fourth Edition (Oxford University Press, 2017), p. 339.

${ }^{639}$ See A. Payne, The Rise and Fall of Caribbean Regionalism, Journal of Common Market Studies, 1981, Vol. 19(3), pp. 255-280, p. 256; A. Stone Sweet, W. Sandholtz, European Integration and Supranational Governance, Journal of European Public Policy, 1997, Vol. 4(3), pp. 297-317, p. 298; K.Hall, B. Blake, The Caribbean Community: Administrative and Institutional Aspects, Journal of Common Market Studies, 1978, Vol. 16(3), pp. 211-228, p. 215.

${ }^{640}$ Article 6 of the OTC states "The principal organs of the Community shall be the Conference of Heads of Government and The Common Market Council established under the Annex."

${ }^{641}$ See A. Moravcsik, F. Schinmelfennig, Liberal Intergovernmentalism in (eds) T. Diez and A. Wiener, European Integration Theory (Oxford University Press, 2009) p. 69; A. Payne, The End of Green Gold? Comparative Development Options and Strategies in the Eastern Caribbean Banana-Producing Islands, Studies in Comparative International Development, 2006, Vol. 41 (3), pp. 25-46, p. 28.
} 
as political integration and most issues pertaining to the CARICOM single economy have not advanced on the regional integration agenda, as there is a lack of political will on such matters. Rather, it is submitted that the emphasis on intergovernmentalism is more a reflection of the Caribbean political class desiring greater control of the regional integration process than actually possessing the political will to expand upon 'high politics' policy issues.

The timing of this third phase of regional integration supports the argument advanced by this dissertation regarding the primacy with which UK colonial trade preferences were viewed. It is argued that this economic rationale was the main underlying force that shaped the way that regional integration in the Caribbean unfolded. The UK accession to the EEC occurred in 1972. Prior to this, the UK had been assured that its British Caribbean interests would be safeguarded in the period after 1974. ${ }^{642}$ Consequently, the British Caribbean territories signed the 1975 Georgetown Agreement and joined the African Caribbean and Pacific (ACP) Group of States, which is a grouping that included the colonial interests of all of the EEC Member States. ${ }^{643}$ Thereafter, the CARICOM Member States conducted their trade cooperation relations with the EEC as a member of the ACP grouping.

\subsubsection{The Growth of PTAs in the American Hemisphere}

By the late 1980s, some objectives of the OTC still remained unfulfilled and intra-regional trade had declined by almost 50\%. ${ }^{644}$ As seen with CARIFTA, the Caribbean PTA partners determined that the decline in trade creation required a change in their overall trade creation structure. ${ }^{645}$ It is submitted that, in addition to the slowdown in intra-regional trade, the

\footnotetext{
${ }^{642}$ See Lome Convention in Section 4.2 entitled The Caribbean Banana Trade. See also See J. Revauger, Regional Integration in the Commonwealth Caribbean and the Impact of the European Union, The Round Table, 2008, Vol. 97 (399) pp. 857-869, p. 860.

${ }^{643}$ The main stated objectives of the ACP included the sustainable development of its Member States and their gradual integration into the global economy whilst reducing poverty and establishing a more equitable world order.

${ }^{644}$ (eds.) K. Hall, M. Chuck-A-Sang, The Integrationist, CARICOM Single Market and Economy: Challenges, Benefits, Prospects (Ian Randal Publishers, Jamaica, 2007), p. 5.

${ }^{645}$ As of 1988, the Common External Tariff (CET) was still inoperable because most Member States had not harmonized their national tariff systems. Moreover, CARICOM had abandoned several schemes, which gave special benefits to primary products from the LDCs within the grouping. The AMP, which had been criticized by two GATT working parties as discriminatory, was discontinued as the market liberalization approach to international trade gained further currency.
} 
further consolidation of South American regional integration served as an externality that influenced the policy thinking regarding the advancement of the Caribbean PTA. In 1991, Argentina, Brazil, Paraguay and Uruguay established MERCOSUR with the signing of the Treaty of Asuncion and committed themselves to establishing a common market. ${ }^{646}$ Similar to Caribbean regional integration, the main goal of MERCOSUR was to promote economic development through the free movement of the four factors of production, the creation of a common external tariff and coordinated macroeconomic policies. ${ }^{647}$ In 1994, the Treaty of Ouro Preto transformed the common market into a customs union and furthered the advancement of regional integration among these four countries.

The Andean Community was another illustration of South American integration that was noteworthy to CARICOM Member States. The Andean Community was created by the 1969 Agreement on Andean Sub-regional Integration (Cartagena Agreement), which was signed by Bolivia, Chile, Colombia, Ecuador and Peru. ${ }^{648}$ At the time, the Cartagena Agreement was meant to aid in the creation of a common market and a customs union; however, disruption in the membership rendered this a challenging task. In 1987, the Quito Protocol was signed, which reaffirmed the commitment to closer economic relations and the eventual formation of a customs union. ${ }^{649}$ The impact of these developments was not

\footnotetext{
${ }^{646}$ See Treaty Establishing a Common Market between The Argentine Republic, The Federal Republic of Brazil, The Republic of Paraguay and the Eastern Republic of Uruguay (adopted $26^{\text {th }}$ March 1991, in force $29^{\text {th }}$ November 1991) 2140 UNTS 319. The Treaty was notified under the Enabling Clause at the GATT Secretariat on $17^{\text {th }}$ February 1991. See GATT Secretariat, Southern Common Market (MERCOSUR), (Geneva, $9^{\text {th }}$ July 1992) [L/7044]. Subsequent to this, the Protocol of Montevideo on Trade in Services in the MERCOSUR was signed on $15^{\text {th }}$ December 1997 and entered into force on $7^{\text {th }}$ December 2005. This Protocol was notified at the WTO Secretariat under GATS Article V. See WTO Secretariat, Notification Pursuant to Article V: 7 of the General Agreement on Trade in Services (Geneva, $18^{\text {th }}$ December 2006) [S/C/N/388].

${ }^{647}$ As previously noted in this dissertation, many PTAs have been motivated by non-trade related concerns and MERCOSUR is no exception to this trend. The need for political stability in a region with a history of military dictatorships was not overlooked when the plans for MERCOSUR were drafted. Consequently, one of its main goals was to assist in strengthening the new democracies of South America. See Chapter 1, Section 1.7 entitled PTA Motivation. See also G. Gardini, The Origins of MERCOSUR: Democracy and Regionalization in South America (Palgrave MacMillan, 2010), p. 155-156.

${ }^{648}$ Agreement on Andean Sub-regional Integration (Cartagena Agreement) (adopted 26 ${ }^{\text {th }}$ May 1969, in force $16^{\text {th }}$ October 1969) 8 ILM 910.

${ }^{649}$ See Quito Protocol to the Cartagena Agreement creating the Andean Common Market (adopted $12^{\text {th }}$ May 1987) 28 ILM 1165. The (revised) Cartagena Agreement, which resulted from the 1987 Quito Protocol, was notified under the Enabling Clause at the GATT Secretariat on $1^{\text {st }}$ October 1990. See GATT Secretariat, Andean Group - Report submitted by the Member States of the Andean Group (Geneva, 12 ${ }^{\text {th }}$ October 1990) [L/6737].
} 
overlooked especially since two CARICOM Member States are geographically located in South America (Suriname and Guyana) and a third Member State is located off the coast of the South American mainland (Trinidad and Tobago). Thus, it is likely that the growth of PTAs in South America was an additional underlying force that impacted Caribbean policy thinking regarding the effectiveness of their regional integration efforts and further bolstered the case for the further evolution of regional integration in the Caribbean.

Furthermore, the announcement of plans to negotiate the North American Free Trade Agreement (NAFTA) was another externality that impacted the thinking about Caribbean regional integration. ${ }^{650}$ This development was met with widespread concern in the Caribbean as NAFTA threatened to erode the preferences contained in the Caribbean Basin Initiative $(\mathrm{CBI})$ with the United States ${ }^{651}$ and the Caribbean-Canada Trade Agreement (CARIBCAN). ${ }^{652}$ One of the main concerns was that duty free Mexican exports to the North American market would render Mexico the preferred market for the textiles and apparel sector and potentially erode Caribbean market share. ${ }^{653}$ The CBI specifically excluded the textiles and apparel sector, whilst NAFTA eliminated the duty and quota treatment for Mexican exports in this sector. Consequently, Caribbean Basin exporters

\footnotetext{
${ }^{650}$ See North American Free Trade Agreement (adopted $17^{\text {th }}$ December 1992, in force on $1^{\text {st }}$ January 1994) 32 ILM 289. It was the first PTA between developed countries (USA and Canada) and a developing country (Mexico). The PTA was notified at the GATT Secretariat on $29^{\text {th }}$ January 1993. See GATT Secretariat, NAFTA - Communications from the Parties to the Agreement (Geneva, $1^{\text {st }}$ February 1993) [L/7176] and WTO Secretariat, NAFTA - Joint Communication from Canada, Mexico and the United States of America (Geneva, $1^{\text {st }}$ March 1995) [S/C/N/4].

${ }^{651}$ The United States Caribbean Basin Economic Recovery Act (US-Caribbean CBERA) entered into force on $1^{\text {st }}$ January 1984 and was provided with legal cover via a GATT Waiver under GATT Article I: 1.

${ }^{652}$ The Canadian tariff treatment for Commonwealth Caribbean countries (CARIBCAN) entered into force on $12^{\text {th }}$ May 1986 and was provided with legal cover via a GATT Waiver under GATT Article I: 1. "It was only in 2001, in the Revised Treaty of Chaguaramas... that member states were able to formally commit themselves to fundamentally transform the institutional and legal structures of CARICOM. They did so in a context where their two main trading partners were themselves involved in ever deepening integration processes, the US under NAFTA and Europe under the Treaty of the European Union (The Treaty of Maastricht) and where WTO pressures to remove trade preferences had increased." D. Berry, Caribbean Integration Law (Oxford University Press, 2014), p. 25.

653 "Mexico gains parity with the Caribbean countries for CBI- covered products, establishing a level playing field for those items on which Mexican and Caribbean exporters face no duty. But on the products excluded from the CBI, such as textile and apparel products, Mexico gains access to the US market, exceeding that granted to the Caribbean countries. This tilts the playing field in Mexico's favor, and gives Mexican exporters a distinct advantage over Caribbean exporters. When combined with Mexico's access to cheap energy, lower transport costs, greater economies of scale and low wage rates, this advantage becomes quite substantial." R. Bernal, The Case for NAFTA Parity for CBI Countries, Caribbean Dialogue Quarterly, 1996, Vol. 2(4), pp. $1-9$, p. 2.
} 
lobbied for CBI/NAFTA parity prior to the passage of NAFTA. ${ }^{654}$ However, it was not until the 2001 Caribbean Basin Trade Partnership Act (CBTPA) was passed that CARICOM Member States were granted the parity that had been sought since the early 1990s.

\subsection{Phase 4: The CARICOM Single Market and Economy}

The advent of the NAFTA era also coincided with the conclusion of the Uruguay Round of GATT multilateral trade negotiations, which was aimed at the further dismantling tariff and non-tariff barriers. ${ }^{655}$ The locking-in of reforms that were favorable to free market arrangements and new principles for the regulation of production and trade were becoming apparent for the MTS. Consequently, CARICOM Member States reached the realization that the protectionist policies that had shielded much of its trade might attract more scrutiny. ${ }^{656}$ The policy decision to transition from a common market to a customs union ${ }^{657}$ was undertaken at the $10^{\text {th }}$ Meeting of the Conference of Heads of Government in 1989 and this resulted in the Grand Anse Declaration. ${ }^{658}$

\footnotetext{
${ }^{654}$ The main intention behind this initiative was to extend NAFTA equivalent trade preferences to the CBI countries and in doing so, lessen the disadvantages brought about by Mexican duty free access to the North American markets. Caribbean Basin Struggles in NAFTA's Shadow, $10^{\text {th }}$ February 1997, Bridges, Vol. 1(1) available at www.ictsd.org/bridges-news/bridges/news/caribbean-basin-struglles-in-naftas-shadow-0 [accessed on 1st June 2016].

${ }^{655}$ The Uruguay Round of multilateral trade negotiations was finalized in 1993 whilst NAFTA entered into force in 1994.

656 "In agreeing to reconstitute itself as a Single Market and Economy, the [Caribbean] region, for the first time, sought to rest its own development and its relationship with the rest of the world on the embrace of the economic ideology of liberalisation." O. Arthur, Caribbean Regionalism in the Context of Economic Challenges, Caribbean Journal of International Relations, 2014, Vol. 2(4), pp. 147-164, p. 151. It should also be noted that by this time, the first legal challenge to the EC banana import regime had already occurred. See GATT Panel Report, EEC-Import Regime for Bananas, DS38/R, $11^{\text {th }}$ February 1994, unadopted.

${ }^{657}$ A customs union is defined as "a form of a trade agreement under which certain countries preferentially grant tariff free market access to each other's imports and agree to apply a common set of external tariffs to imports from the rest of the world. [...] A customs union can be thought of as a deeper form of integration than a Free Trade Area, generally requiring more coordination and a greater loss of autonomy." See S. Andriamananjara, Customs Unions in (eds.) J. Chauffor, J. Maur, Preferential Trade Agreement Policies for Development: A Handbook (World Bank, 2011), p. 111.

${ }^{658}$ The Gran Anse Declaration identified 13 main areas for action and was accompanied by an ambitious timeframe for completion that was reflected in the preamble to the work program, which stated "We are determined to work towards the establishment, in the shortest possible time, of a single market and economy for the Caribbean Community. To that end, we shall ensure that the following steps are taken not later than 4 July 1993, taking into account the need for the continuance of Special Measures for the LDCs."
} 


\subsubsection{The Grand Anse Declaration}

The Grand Anse Declaration emphasized the intention to fast track the delayed implementation of the CET for the LDCs, common rules of origin and a harmonized scheme of fiscal incentives. ${ }^{659}$ The ambitious deadline for the completion of these instruments was January 1991; however, actual implementation required a decade to complete. The creation of the CSME required a comprehensive legal framework that revised the OTC with nine protocols of amendment, which were drafted and negotiated among Member States from 1992 to 1998. This resulted in the creation of the Revised Treaty of Chaguaramas (RTC). ${ }^{660}$ Although many elements of the CARICOM legal and institutional structure are common to both the CARICOM single market and single economy as a whole, the two components are separate entities. The single market component was inaugurated in January 2006 when 6 Member States signed the CSM Declaration. ${ }^{661}$ Most of the LDCs signed the Declaration in June 2006 after seeking assurances that the arrangement would consider their special needs. ${ }^{662}$ To date, 13 Member States have signed the CSM Declaration and are parties to the RTC with the notable exceptions being the Bahamas and Montserrat.

\subsubsection{The CARICOM Single Market}

The CSM legal provisions provide coverage for its five core regimes and give effect to the unfettered freedom of movement of goods, services, capital and skilled persons throughout the CARICOM region thereby achieving a single economic space. Firstly, the free

\footnotetext{
${ }^{659}$ The Grand Anse Declaration also called for inter alia the strengthening of customs cooperation and customs administration in advance of the (then imminent) Customs Union; the removal of all remaining barriers to trade and coordination of policies at the macro-economic level and a greater collective effort for joint representation in international economic negotiations. See O. Arthur, Caribbean Regionalism in the Context of Economic Challenges, Caribbean Journal of International Relations, 2014, Vol. 2(4), pp. 147164, p. 152; See J. Revauger, Regional Integration in the Commonwealth Caribbean and the Impact of the European Union, The Round Table, 2008, Vol. 97 (399) pp. 857-869, p. 864.

${ }^{660}$ See Revised Treaty of Chaguaramas establishing The Caribbean Community including the CARICOM Single Market and Economy (adopted $5^{\text {th }}$ July 2001, in force $1^{\text {st }}$ January 2006) 2259 UNTS 293.

The RTC was additionally notified at the WTO Secretariat on $19^{\text {th }}$ February 2003 under GATS Article V as the updated treaty provided coverage for Trade in Services. See WTO Secretariat, Notification pursuant to Article V: 7(a) of the General Agreement on Trade in Services (Geneva, $19^{\text {th }}$ February 2003) [S/C/N/229]

${ }^{661}$ Barbados, Belize, Jamaica, Guyana, Suriname and Trinidad and Tobago.

${ }^{662}$ The initial six Member States were subsequently joined by Antigua and Barbuda, Dominica, Grenada, St. Kitts and Nevis, St. Lucia and St. Vincent and the Grenadines. A similar delay tactic was utilized with the signing of CARIFTA in 1965 and the OTC in 1973.
} 
movement of goods is the most mature of the single market arrangements as it dates back to the CARIFTA era and has been extensively implemented. ${ }^{663}$ Secondly, the free movement of skilled persons has been operationalized by the removal of the work permit requirements for the eligible categories of workers listed in the RTC. ${ }^{664}$ Thirdly, the free movement of services has seen several Member States liberalize individual service industries and service sectors. ${ }^{665}$

Fourthly, the right of establishment permits the establishment of CARICOM-owned businesses in any Member State without restrictions. ${ }^{666}$ Most Member States are in compliance with this treaty requirement as they have removed the discriminatory aspects from their company law provisions, which make mention of issues such as non-national participation in directorships and shareholding. Fifthly, where the movement of capital is concerned, most Member States have abolished exchange controls for current and capital transactions. ${ }^{667}$ In addition to the legal infrastructure that is required for the proper functioning of the single market, a substructure of government is required which should include the various institutions, competent parties, board regulations and administrative processes to enable and facilitate the ability of CARICOM nationals to effectively participate in the single market. Criticism has been levied at this particular apparatus and it is generally accepted that governmental capacity to operate the CSM requires some strengthening. ${ }^{668}$

\footnotetext{
${ }^{663}$ See Chapter 5 of the RTC entitled Trade Policy, Part 2 entitled Trade Liberalization.

${ }^{664}$ The RTC lists nine categories of skilled workers as being eligible for free movement: University Graduates, Artists, Musicians, Sportspersons, Media Workers, Nurses, Teachers, Artisans with a Caribbean Vocational Qualification and Holders of Associate degrees or comparable qualifications. See RTC Article 45 entitled Movement of Community Nationals and Article 46 entitled Movement of Skilled Community Nationals.

${ }^{665}$ See RTC Article 36 entitled Prohibition of New Restrictions on the Provision of Services, Article 37 entitled Removal of Restrictions on Provision of Services and Article 38 entitled Removal of Restrictions on Banking, Insurance and Other Financial Services.

${ }^{666}$ See RTC Article 32 entitled Prohibition of New Restrictions on the Right of Establishment, Article 33 entitled Removal of Restrictions on the Right of Establishment and Article 34 entitled Management of Removal of Restrictions on the Right of Establishment.

${ }^{667}$ See RTC Article 39 entitled Prohibition of New Restrictions on Movement of Capital and Current Transactions, Article 40 entitled Removal of Restrictions on Movement of Capital and Current Transactions, Article 41 entitled Authorisation to Facilitate Movement of Capital, Article 42 entitled Co-ordination of Foreign Exchange Policies and Exchange of Information, Article 43 entitled Restrictions to Safeguard Balance-of-Payments and Article 44 entitled Measures to Facilitate Establishment, Provision of Services and Movement of Capital.

${ }^{668}$ P. Lewis, Agony of the Fifteen: The Crisis of Implementation, Social and Economic Studies, 2005, Vol. 54(3), pp. 145-175, p. 153.
} 
4.8.3 Future Outlook on Regional Integration in the Caribbean

After various phases, the CSME is now the embodiment of regional integration in the Caribbean and the principal CARICOM mechanism aimed at responding to the challenge of a globalized economy. ${ }^{669}$ It is also the base upon which the CARICOM Member States have negotiated bilateral and preferential trade agreements in order to extend trade relations with third countries. ${ }^{670}$ The RTC was the third Caribbean PTA notified to the WTO Secretariat and much of its stated goals are consistent with those originally pursued by CARIFTA and CARICOM. The RTC also continues the tradition initiated by the OTC in that the structural framework driving CARICOM forward is characterized by elements of intergovernmentalism. However, the question remains whether the Caribbean region has truly adapted itself to the changes required by globalization. Much of the aforementioned integration efforts have been plagued by an implementation deficit regarding the decisions and declarations issued over the years. ${ }^{671}$ Many regional scholars have attributed the pace of implementation to the intergovernmental nature of cooperation whereby inaction on previously agreed decisions is allowed to pass. ${ }^{672}$ The CARICOM decision-making process has been characterized in some quarters as being inefficient and critics have noted that the Caribbean preference to the state centric approach to regional integration might not be the best option going forward. Nevertheless, the fact remains that great value is still attached to the nominal value of sovereignty and CARICOM is continuously described as a 'Community of Sovereign States'. ${ }^{673}$ Any suggestions regarding the deepening of political

\footnotetext{
669 “.... Regionalism is no longer a lofty ideal for CARICOM countries, but a necessity in order to adapt and prosper in today's world trading system. The CSME, if it functions correctly, will assist individual members in cushioning the shocks of the changes in the external trading system." R. Simms, E. Simms, The Building Blocks of Successful Regional Integration: Lessons for the CSME from other integration schemes, Social and Economic Studies, 2007, Vol. 56 (4), pp. 255-285, p. 257.

${ }^{670}$ See Chapter 7, Section 7.8 entitled External Trade Coordination

${ }^{671}$ N. Girvan, Existential Threats in the Caribbean: Democratizing Politics, Regionalizing Governance in (ed.) K. Hall, The Integrationist: The Pertinence of CARICOM in the $21^{\text {st }}$ Century: Some Perspectives (Trafford Publishing, 2012), p. 483.

672 "Presently, the CSME does not rely on the principle of "direct effect" and the process of adoption of community decisions into national law has not been happening at a fast enough pace.” R. Simms, E. Simms, The Building Blocks of Successful Regional Integration: Lessons for the CSME from other integration schemes, Social and Economic Studies, 2007, Vol. 56 (4), pp. 255-285, p. 276.

673 "Political will or the lack thereof, is one of the key issues confronting the CSME today. The lack of political will stems from the fear of loss of sovereignty. There are many reasons for this fear in the region. These include the fact that most members only gained their sovereignty a few decades ago..." Ibid, R. Simms, E. Simms, 2007, p. 278.
} 
cooperation or the adoption of supranational features within the regional arrangement have been effectively mooted. ${ }^{674}$

\subsection{Conclusion}

Chapter 4 asserts that regional integration in the Caribbean was pursued initially as a means of securing sovereignty in a federal context. This attempt was short-lived and subsequently when individual national sovereignty was attained, Caribbean countries resorted to regional integration as a defence mechanism in an increasingly globalized world characterized by the expansion of PTAs. The three Caribbean PTAs that have been notified at the GATT and WTO Secretariat have served to solidify the continued commitment to further development through the use of regional integration characterized by features of intergovernmentalism.

The lasting legacy of Caribbean colonial paradigm is noted for its role in entrenching agricultural commodities such as bananas and sugar as the main export of most of the former British Caribbean territories. The continued emphasis on this export-led model of agricultural production stifled most attempts to diversify the Caribbean economies and the systemic effects thereof are still evident today. Most of the trade policies of the current CARICOM Member States remain largely shaped around the aforementioned agricultural model and this is further explored in Chapter 5 of this dissertation.

\footnotetext{
${ }^{674}$ N. Girvan, The Caribbean in a Turbulent World in (eds.) G. Mace, A. Cooper, T. Shaw, InterAmerican Cooperation at a Crossroads (Palgrave Macmillan, 2010), p. 69.
} 


\section{Chapter 5 \\ CARICOM Intra-regional Trade}

\section{Introduction}

Chapter 5 is aimed at outlining the landscape of Caribbean Community (CARICOM) intraregional trade. In doing so, it inquires whether the CARICOM preferential trade agreement (PTA) has resulted in trade creation by undertaking a quantitative assessment of the pattern and volume of CARICOM intra-regional trade. It is subsequently illuminated through the use of CARICOM Statistics Unit documentation as well as policy documents from other international organizations that most of the CARICOM Member States have not experienced net economic welfare gains from their involvement in the CARICOM PTA. ${ }^{675}$ The CARICOM more developed countries (MDCs) have derived benefits from intraregional trade whilst the CARICOM less developed countries (LDCs) have remained on the periphery of the intra-regional trade market. ${ }^{676}$ In light of the foregoing, Chapter 5 also investigates why the CARICOM PTA has been unable to create significant intra-regional trade.

Although the Revised Treaty of Chaguaramas (RTC) provides special and differential treatment (SDT) to the LDCs, there has been a continued inability to cultivate intraregional trading relationships on their part. Most of the CARICOM Member States are

675 See CARICOM's Trade: A Quick Reference to Some Summary Data, 1996 - 2001, Fourth Edition (Georgetown, Guyana, December 2005); CARICOM Statistical Unit, CARICOM's Trade: A Quick Reference to Some Summary Data, 2005 - 2010 (Georgetown, Guyana, 2013). See also World Bank/Organization of American States, co-produced with the Governments of the CARIFORUM Countries, Poverty Reduction and Economic Management Sector Unit, Latin America and Caribbean Region, The Caribbean: Accelerating Trade Integration, Policy Options for Sustained Growth, Job Creation and Poverty Reduction (December 2008); European Union All ACP Commodities Programme Caribbean Region/International Trade Center, Grenada Nutmeg Sector Development Strategy 2010-2015 (St. George's, Grenada, July 2010); InterAmerican Institute for Cooperation and Agriculture (IICA), St. Kitts and Nevis 2005 Annual Report, The Contribution of IICA to the development of Agriculture and Rural Communities (St. Kitts and Nevis, 2005); Inter-American Development Bank (IDB), Dominica: Private Sector Assessment Report, 2013 (Roseau, Dominica, 2013).

${ }^{676}$ Although CARICOM consists of fifteen Member States, three Member States (The Bahamas, Haiti and Montserrat) do not participate in the CARICOM Single Market (CSM) for various policy reasons. Of the remaining twelve Member States, five are considered more developed countries (MDCs): Barbados, Guyana, Jamaica, Suriname as well as Trinidad and Tobago and seven are considered lesser developed countries (LDCs) namely: Antigua and Barbuda, Belize, Dominica, Grenada, St. Kitts and Nevis, St. Lucia and St. Vincent and the Grenadines. This distinction among CARICOM Member States is provided for in Article 4 of the Revised Treaty of Chaguaramas (RTC). 
considered net importing developing countries (NIDCs) and feature a limited manufacturing base, which has contributed to reliance on imports of manufactured goods particularly from the United States of America (USA). ${ }^{677}$ Despite the formation of the CARICOM Single Market (CSM), the USA remains the main trading partner of the twelve CARICOM Member States. In addition to this, the impact of the British Caribbean colonial paradigm remains visible as all CARICOM Member States maintain active trade relations with the European Union (EU) under the last vestiges of trade preferences for agricultural exports commodities. Consequently, CARICOM's extra-regional trade (as opposed to its intra-regional trade) accounts for the dominant share of its trade receipts. It is noteworthy that the CARICOM extra-regional trade sector is still anchored on preferential access to export markets in Europe, the USA and Canada. ${ }^{678}$

\subsection{Natural Trading Partners?}

The 1971 General Agreement on Tariffs and Trade (GATT) working party report on the Caribbean Free Trade Association (CARIFTA) noted that there was a "historic and geographic background, which provided a logical case for economic integration in the Caribbean region". ${ }^{679}$ Conversely, Chapter 5 argues that the geographically proximate CARICOM Member States are unnatural trading partners. This is mainly attributable to a confluence of dynamics that is rooted in British Caribbean colonial paradigm and its effects on CARICOM trade policy. The presence of pre-independence monoculture economies and the provision of trade preferences have contributed to an undiversified export basket of goods for most CARICOM Member States. It has also contributed to the stagnation of intra-regional trade within the CARICOM PTA, as there is only a minimal volume of trade-

\footnotetext{
677 See World Bank/Organization of American States, co-produced with the Governments of the CARIFORUM Countries, Poverty Reduction and Economic Management Sector Unit, Latin America and Caribbean Region, The Caribbean: Accelerating Trade Integration, Policy Options for Sustained Growth, Job Creation and Poverty Reduction (December 2008), Chapter 2, p. 34, para. 2.51.

678 See Ibid, World Bank/Organization of American States, co-produced with the Governments of the CARIFORUM Countries, Poverty Reduction and Economic Management Sector Unit, Latin America and Caribbean Region, 2008, Chapter 2, p. 33, para. 2.46.

${ }^{679}$ GATT Secretariat, Report of the Working Party on the Caribbean Free Trade Agreement $\left(\right.$ Geneva, $29^{\text {th }}$ September 1971) [L/3584], p. 1, para. 3.
} 
able goods. ${ }^{680}$ Furthermore, the spirit of regional integration has been fractured by the parallel process now underway with the six CARICOM Member States that constitute the Organization of Eastern Caribbean States (OECS) as they are seeking to deepen their own integration movement with the creation of a sub-regional economic union. ${ }^{681}$ The OECS was created by the Treaty of Basseterre (1981) and the main objective of the sub-regional grouping is to further the consolidation of regional integration by inter alia promoting cooperation at the regional and international levels as well as the promotion of economic integration. ${ }^{682}$

\subsection{Un-Natural Trading Partners}

The theory of natural trading partners presumes that certain country characteristics should ensure welfare gains within a PTA. It is centered on the premise that geographically proximate countries that participate in a PTA are likely to have higher volumes of trade with each other than those with a greater geographical distance between them. ${ }^{683}$ Therefore, geographically proximate countries are less likely to experience welfare reducing effects such as trade diversion. A review of the literature on this theory shows that the volume of trade and transport costs prior to the establishment of the PTA are criteria considered when assessing whether a potential PTA has the ability to generate a reasonable volume of trade. ${ }^{684}$ Furthermore, two additional criteria that have been noted regarding the "natural trading partner' theory are the relative levels of economic development and the

\footnotetext{
${ }^{680}$ M. Gasiorek, L. Winters, What Role for the EPA in the Caribbean? The World Economy, 2004, Vol. 27(9), pp. 1335-1362, p.1336; D. Mohammed, Size and Competiveness: An Examination of the CARICOM Single Market and Economy, The Roundtable, 2008, Vol. 97 (395), pp. 287-303, p. 294.

${ }^{681}$ See J. Revauger, Regional Integration in the Commonwealth Caribbean and the Impact of the European Union, The Round Table, 2008, Vol. 97 (399) pp. 857-869, p. 861.

${ }^{682}$ See Treaty establishing the Organization of Eastern Caribbean States (adopted 18 June 1981, in force 2 July 1981) 1338 UNTS 97. The sub-regional grouping consists of 10 members: 7 full members - Antigua and Barbuda, Dominica, Grenada, Montserrat, St. Kitts and Nevis, St. Lucia, St. Vincent and the Grenadines and 3 associate members - British Virgin Islands, Anguilla and Martinique. The OECS Secretariat is based in St. Lucia. See also Eastern Caribbean States in Section 5.4 entitled Marginalization of LDCs?

${ }^{683}$ J. Bhagwati, Regionalism and Multilateralism: An Overview in (eds.) J. Bhagwati, P. Krishna, A. Panagariya, Trading Blocs: Alternative Approaches to Analyzing Preferential Trade Agreements (MIT Press, 1999), p. 57.

${ }^{684}$ See A. Panagariya, Preferential Trading and the Myth of Natural Trading Partners, Japan and The World Economy, 1997, Vol. 9, pp. 471 - 489, p. 487; M. Schiff, L. Winters, Regional Integration and Development (World Bank/Oxford University Press, 2003), p. 66; P. Krishna, The Economics of PTAs in (eds.) S. Lester, B. Mercurio, L. Bartels, Bilateral and Regional Trade Agreements: Commentary and Analysis, Second Edition (Cambridge University Press, 2015), p. 18.
} 
complementarity versus competitiveness of the economies involved. ${ }^{65}$ This dissertation submits that when the prior volume of trade criterion and the prior transport cost criterion are applied to the CARICOM context, both criteria are invalidated due to how the British Caribbean colonial paradigm functioned. Thus, these factors fail to serve as a litmus test that could assist in determining whether CARICOM Member States are natural trading partners.

\subsubsection{Prior Volumes of Trade}

On the issue of prior volumes of trade among the British Caribbean territories that formed CARICOM, the pre-CARIFTA ${ }^{686}$ economic structure of most Member States was that of monoculture economies. The main focus of the British Caribbean colonial paradigm was on the maintenance of industries that specialized in the production of limited range of agricultural products that were exported to the United Kingdom(UK). ${ }^{687}$ These agricultural products were not marketed to the geographically proximate British Caribbean territories that eventually became PTA partners as most of these territories specialized in the same export goods: bananas, sugar and sugar by-products. ${ }^{688}$ Therefore, there was an inherent limitation to the then prospective PTA partners trading with each other. This is especially so when it is considered that the export of these agricultural goods yielded above world market prices in the UK. ${ }^{689}$ Still, this dissertation asserts that some pre-CARIFTA volume of trade existed. However, it is argued that this was de-minimis as most of the British

\footnotetext{
${ }^{685}$ These two factors were contributed in P. Wonnacott, M. Lutz, There a Case for FTAs? (1989), however, they have been labeled "difficult to evaluate" by economists and regional trade specialists. See also Ibid, J. Bhagwati in (eds.) J. Bhagwati, P. Krishna, A. Panagariya, 1999, p. 57.

${ }^{686}$ This term is used to denote the period before 1965 prior to the signature of CARIFTA. Although the West Indies Federation was the first Caribbean attempt at regional integration, it did not entail any adjustment to the tariff structure of its constituent territories.

687 "It was important to note that the [CARIFTA] member territories were predominantly agricultural, depending heavily on one or two primary products for their export income." See GATT Secretariat, Report of the Working Party on the Caribbean Free Trade Agreement (Geneva, 29 ${ }^{\text {th }}$ September 1971) [L/3584], p. 1, para. 3.

${ }^{688}$ For example, Belize, Barbados, Jamaica, St. Kitts and Guyana were some of the territories that specialized in sugar production. See Recipients of the CSA in Chapter 4, Section 4.3 entitled The Commonwealth Sugar Agreement (CSA) And, Jamaica, St. Lucia, St. Vincent, Belize, Dominica and Grenada specialized in banana production. See Windward Island Banana production in Chapter 4, Section 4.2.1 entitled The Early Caribbean Banana Trade. See also G. Atkinson, Economic Integration in the Caribbean Community: A Problem of Institutional Adjustment, Journal of Economic Issues, 1982, Vol. 16 (2), pp. 507-513, p. 507.

${ }^{689}$ This export production strategy can be attributed to the history of colonial trade preferences that has been a feature of Caribbean trade relations since 1944. See colonial trade preferences in Chapter 4, Section 4.2.1 on The Early Caribbean Banana Trade and Section 4.3 on The Commonwealth Sugar Agreement.
} 
Caribbean territories lacked a sufficient manufacturing base in the $1960 \mathrm{~s} .{ }^{690}$ In support of this point, it has been stated that between 1900 and 1960, twenty-one commodities accounted for over $90 \%$ of domestic exports for the Caribbean territories. ${ }^{691}$ Given the lack of a manufacturing base, it is argued that intra-regional trade more than likely consisted of some of the referenced agricultural products and this demonstrates that there was a high reliance on extra-regionally imported foodstuff.

\subsubsection{Prior Transport Costs}

Transport costs have been a cause for concern since the advent of regional integration in the Caribbean and still remain an issue affecting the facilitation of intra-regional trade within the CSM. ${ }^{692}$ Despite having a general geographic proximity, CARICOM Member States are island countries dispersed throughout the Caribbean Sea. This geographic layout has served as a hindrance to trade given the continued absence of an adequate transportation network to facilitate the free movement of goods. During the West Indies Federation era, the West Indies Federation Parliament enacted the 1961 West Indies Shipping Corporation Act, which outlined the operation of an intra-regional merchant shipping service between the participating Caribbean territories. This service was operated by two multipurpose ships, the Federal Palm and the Federal Maple, which were donated to the West Indies Federation by the Government of Canada. ${ }^{63}$ Although precise pre-CARIFTA transport

\footnotetext{
690 "Manufacturing accounted for about 15\% of gross domestic product in the most advanced member territory and about $2 \%$ in the least advanced. Approximately $50 \%$ of the area's food requirements were imported." See GATT Secretariat, Report of the Working Party on the Caribbean Free Trade Agreement (Geneva, 29 ${ }^{\text {th }}$ September 1971) [L/3584], p. 1, para. 3; G. Atkinson, Economic Integration in the Caribbean Community: A Problem of Institutional Adjustment, Journal of Economic Issues, 1982, Vol. 16 (2), pp. 507513, p. 508.

${ }^{691}$ It should be noted that the aforementioned statement refers to all (French, Spanish, Dutch) of the then existing Caribbean territories, which included the British Caribbean territories as a subset. These commodities referenced included: sugar, molasses, rum, tobacco leaf, cigars, cacao, coffee, cotton, logwood, mahogany, rubber, spices, bananas, rice, minerals and gold. See V. Bulmer-Thomas, The Economic History of the Caribbean since the Napoleonic Wars (Cambridge University Press, 2012), p. 229.

${ }^{692}$ H. Sandberg, J. Seale, T. Taylor, History, Regionalism and CARICOM Trade: A Gravity Model Analysis, Journal of Development Studies, 2006, Vol. 42 (5) pp. 795-811, p. 808.

${ }^{693}$ In 1993, it was noted that the strengthening of shipping links was a priority for CARICOM and it was stated that "It has not been for want of trying that progress in this respect has been disappointing. After [The] Federation collapsed, a Regional Shipping Council took over the operation of the 'Federal Palm' and the 'Federal Maple' [...] [but shipping arrangements were still] plagued by problems - management shortcomings, operating deficits, subscription shortfalls, contradictory policy directives and at the time of writing has ceased operations." See Report of the West Indian Commission, Time for Action Second Edition (University of West Indies Press, Kingston, Jamaica 1993), p. 39.
} 
costs are unknown, by 1971 transportation issues within the context of CARIFTA were described as "a more serious obstacle to trade than the customs tariffs". ${ }^{694}$ Consequently, it can be deduced that intra-regional transport costs were high.

Further to this, it can be surmised that the colonial trade policy utilized at that time, placed more emphasis on transportation links between the British Caribbean territories and the UK. ${ }^{695}$ The British Caribbean banana trade demonstrated that the UK trading interests were heavily invested in having the highly perishable banana fruit arrive in the UK in a timely and physically marketable fashion. Thus, the development of refrigerated shipping capacities was welcomed. ${ }^{696}$ It is also noted that one of the factors leading to the economic inefficiency of the British Caribbean banana trade related to the lengthy voyage involved in its transshipment due to the fact that ships were required to undertake individual stops at several ports throughout the Eastern Caribbean in order to collect bananas. ${ }^{697}$ This suggests that there was no intra-regional shipping arrangement present whereby all of the bananas produced in the Eastern Caribbean could be shipped to a central Caribbean location prior to further transshipment to the UK. The prohibitive nature of shipping costs could have been a probable cause for the aforementioned logistical arrangement.

5.2.3 Complementarity vs. Competitiveness and Relative levels of Economic Development This dissertation submits that concepts such as complementarity and competiveness have been elusive for the agricultural industries of the British Caribbean territories and this is mainly attributed to colonial trade policy and the use of UK/European Economic Community (EEC) trade preferences. The British Caribbean colonial paradigm was characterized by the continued concentration on export-oriented agricultural production, which was incompatible with the long-term comparative advantage of the British

\footnotetext{
${ }^{694}$ GATT Secretariat, Report of the Working Party on the Caribbean Free Trade Agreement (Geneva, $29^{\text {th }}$ September 1971) [L/3584], p. 1, para. 3.

${ }^{695} \mathrm{G}$. Atkinson, Economic Integration in the Caribbean Community: A Problem of Institutional Adjustment, Journal of Economic Issues, 1982, Vol. 16 (2), pp. 507-513, p. 507.

${ }^{696}$ See Expansion of the Caribbean Banana trade in Chapter 4, Section 4.2.1 entitled The Early Caribbean Banana Trade.

${ }^{697}$ See Expansion of the Caribbean Banana trade in Chapter 4, Section 4.2.1 entitled The Early Caribbean Banana Trade.
} 
Caribbean territories and featured inefficiently high production costs. ${ }^{698}$ It has been suggested that these trade preferences acted as a disincentive to much-needed reform that would have resulted in earlier product and market diversification efforts. ${ }^{699}$ This argument feeds into the issue of complementarity versus competitiveness of the economies involved in a given PTA and how it impacts whether such countries can be considered natural trading partners. It is argued that the pre-CARIFTA economies lacked complementarity due to a high concentration on export-oriented agricultural production focused on a few commodities. $^{700}$

In 1967, several University of West Indies (UWI) economists had proposed that Caribbean regional integration adopt a macroeconomic approach propelled by a production integration strategy that would allow for different territories to achieve sector-specific specialization. It was argued that this would result in regional complementarity in the overall production of certain industries. ${ }^{701}$ However, this approach was rejected in favor of the free trade model personified in CARIFTA, as it was considered an appropriate extension of the economic policies pursued by the regional governments at the time. ${ }^{702}$ Thus, a low level of complementarity existed among the territories prior to the formation of CARIFTA and where the level of competitiveness is concerned, most of the main economic sectors (agriculture) in these British Caribbean territories were anchored on UK trade preferences and struggled to achieve any semblance of competiveness relative to

\footnotetext{
${ }^{698}$ See Economic inefficiency of the Caribbean Banana trade in Chapter 4, Section 4.2.1 entitled The Early Caribbean Banana Trade.

699 "Empirical evidence has shown that trade preferences do not help overall trade performance. This has been seen in the Caribbean with apparel, sugar, bananas and other agro-based products...Preferences have diverted attention and energy away from sectors that could have been more competitive and negatively affected growth, volume and dynamism of overall exports." See World Bank/Organization of American States, co-produced with the Governments of the CARIFORUM Countries, Poverty Reduction and Economic Management Sector Unit, Latin America and Caribbean Region, The Caribbean: Accelerating Trade Integration, Policy Options for Sustained Growth, Job Creation and Poverty Reduction (December 2008), p. 76, para. 4.45; H. Sandberg, J. Seale, T. Taylor, History, Regionalism and CARICOM Trade: A Gravity Model Analysis, Journal of Development Studies, 2006, Vol. 42 (5) pp. 795-811, p. 808.

${ }^{700}$ P. Egoume-Bossogo, C. Mendis, Trade and Integration in the Caribbean, International Monetary Fund (IMF) Working Paper, 2002, [WP/02/148], p. 6.

${ }_{701}$ A. Payne, The Political History of CARICOM (Ian Randle Publishers, 2008), p. 55.

${ }^{702}$ Ibid, A. Payne, 2008, p. 60.
} 
other countries. ${ }^{703}$ This particular argument underlines the impact of the British Caribbean colonial paradigm.

Regarding relative levels of economic development, the British Caribbean territories had a low level of economic development, as the UK government was unable to address the economic ills that afflicted their colonies especially in the aftermath of the Second World War. ${ }^{704}$ Nevertheless, there was still a development divide between the larger, more economically prosperous territories such as Jamaica and Trinidad and Tobago and the smaller territories of the Eastern Caribbean. Both Jamaica and Trinidad and Tobago had the ability to contribute $85 \%$ of the cost for the initial budget for the West Indies Federation in $1956 .{ }^{705}$ Consequently, one reason cited for the demise of the West Indies Federation was the differences among the territories regarding the burden sharing required within a regional grouping, which consisted of a few more developed territories and several lesserdeveloped territories. ${ }^{706}$

\subsection{Statistical Overview of Trade}

The foregoing analysis on the 'natural trading partner' theory is meant to provide a background of the incompatibilities, which colored the early trade relationship among the British Caribbean territories that formed CARICOM. The cultivation of intra-PTA trade is seen as the ultimate ambition of any PTA and as outlined in GATT Article XXIV: 4, the purpose of a PTA "should be to facilitate trade between the constituent territories and not

\footnotetext{
${ }^{703}$ A 2008 analysis of the Caribbean sugar industry noted that the estimated cost of sugar production and export in Belize and Guyana, the lowest cost producers in the Caribbean, are still 50\% to $60 \%$ higher than one of the higher cost free market exporters. See World Bank/Organization of American States, co-produced with the Governments of the CARIFORUM Countries, Poverty Reduction and Economic Management Sector Unit, Latin America and Caribbean Region, The Caribbean: Accelerating Trade Integration, Policy Options for Sustained Growth, Job Creation and Poverty Reduction (December 2008), Introduction, page iii. 704 "In the early postwar years, Britain was unable to meet colonial demands for development expenditure and most West Indian colonies lacked economic resources necessary to satisfy mounting domestic demands for housing, education, health facilities and the like." A. Hinds, Sterling and Decolonization in the British Empire, 1945 - 1958, Social and Economic Studies, 1999, Vol. 48 (4), pp. 97-116, p. 103; D. O'Brien, CARICOM: Regional Integration in a Post-Colonial World, European Law Journal, 2011, Vol. 17(5), pp. 630-648, p. 633.

705 "Concerns were expressed about the level of contribution to the Federation by certain member states, with Jamaica and Trinidad and Tobago being dissatisfied with having to contribute together more than three quarters of the budget." D. Berry, Caribbean Integration Law (Oxford University Press, 2014), p. 20; See also Financing of The Federation in Chapter 4, Section 4.4 entitled Phase 1: The West Indies Federation.

${ }^{706}$ See Demise of West Indies Federation in Chapter 4, Section 4.4, Phase 1: The West Indies Federation.
} 
to raise barriers to the trade of other contracting parties with such territories" 707 Consequently, it is enquired whether the CARICOM PTA has facilitated trade among its constituents and the impact of the British Caribbean colonial paradigm on CARICOM trade policy is measured by reference to this benchmark. A review of statistical evidence suggests that intra-regional trade is limited and skewed towards a few Member States whilst others remain on the periphery of trading relations. ${ }^{708}$ Several trading patterns were noted for the period of 1996 to 2010 namely: (i) CARICOM intra-regional trade was dominated by the MDCs, (ii) the LDCs have been involved in a low volume of CARICOM intra-regional trade, (iii) the principal trading partner for most CARICOM Member States with respect to both extra-regional imports and exports was the USA and (iv) the second principal trading partner for CARICOM with respect to extra-regional exports was the EU. The main statistical analysis provided has been divided into two time periods: 1996 to 2001 and 2005 to 2010. These time periods reflect those used by the CARICOM Statistical Unit to track intra-regional trade developments in CARICOM. ${ }^{709}$ It also undertakes deeper analysis of select CARICOM economies with a view to understanding their individual trading patterns and why certain economic shifts have occurred. In furtherance of this, Gross Domestic Product (GDP) is utilized as an aggregate measure of overall country welfare. ${ }^{710}$

\footnotetext{
${ }^{707}$ This raison d'etre is reinforced in The Understanding on the Interpretation of Article XXIV of the GATT 1994, which states "Reaffirming that the purpose of such [preferential trade] agreements should be to facilitate trade between constituent territories and not to raise barriers to the trade of other Members with such territories; and that in their formation or enlargement the parties to them should to the greatest extent avoid creating adverse effects on the trade of other members".

${ }^{708}$ H. Sandberg, J. Seale, T. Taylor, History, Regionalism and CARICOM Trade: A Gravity Model Analysis, Journal of Development Studies, 2006, Vol. 42 (5) pp. 795-811, p. 807.

${ }^{709}$ Statistical analysis for some of the intervening and subsequent years are provided for with data extracted from inter alia the WTO Trade Policy Reviews of various CARICOM Member States as well as Caribbean Development Bank (CDB) Reports, Inter-American Development Bank (IDB) Reports.

${ }^{710} \mathrm{GDP}$ is defined as the market value of all final goods and services produced within a country in a given period of time. The percentage contribution to GDP provides an indication of the value and relative importance of given sectors of the economy to the overall annual production. See N. G. Mankiw, Principle of Economics, Third Edition (South-Western College Publishing, 2003), p. 502.
} 
Figure 2.2: Percentage Distribution of CARICOM's Intra-Regional Imports: 2005

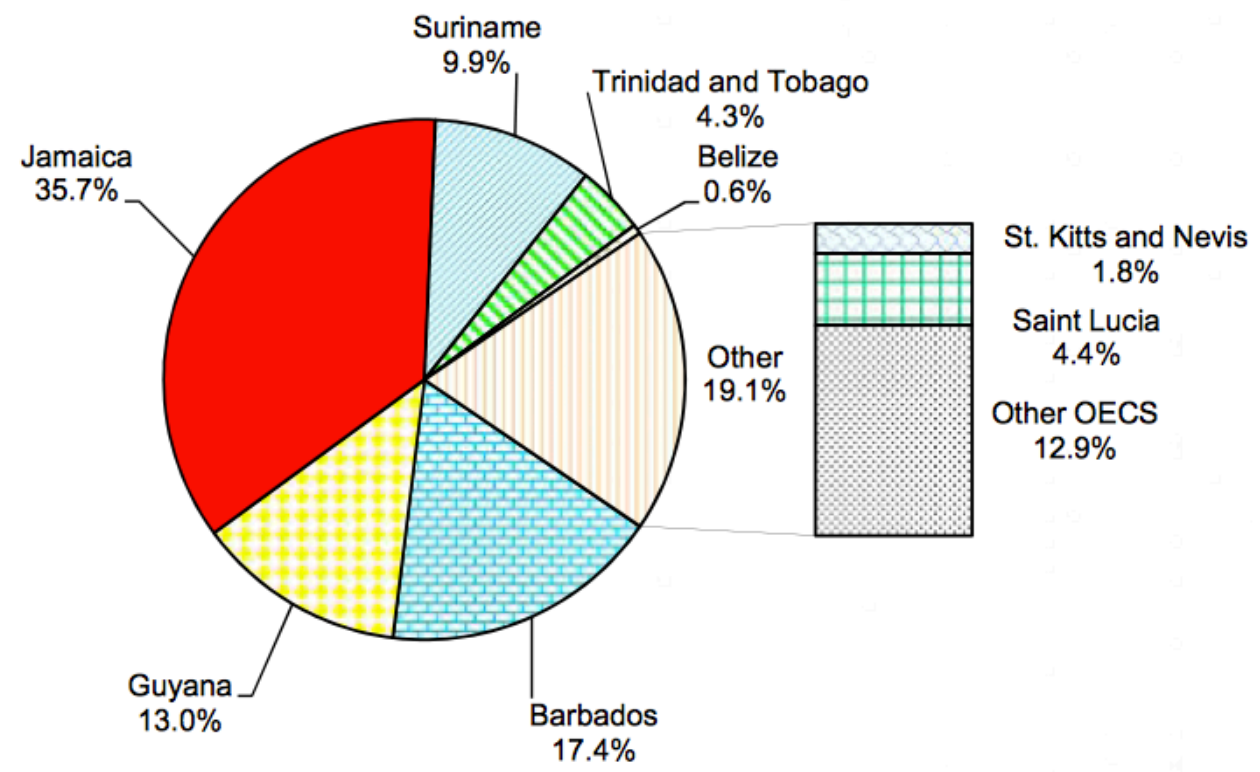

Chart 1 - Source: CARICOM Statistical Unit, CARICOM's Trade: A Quick Reference to Some Summary Data, 2005 - 2010 (Georgetown, Guyana, 2013), Figure 2.2, Percentage Distribution of Intra-regional Imports by CARICOM Countries in 2005, p. 32.

Figure 2.3: Percentage Distribution of CARICOM's Intra-Regional Imports: 2010

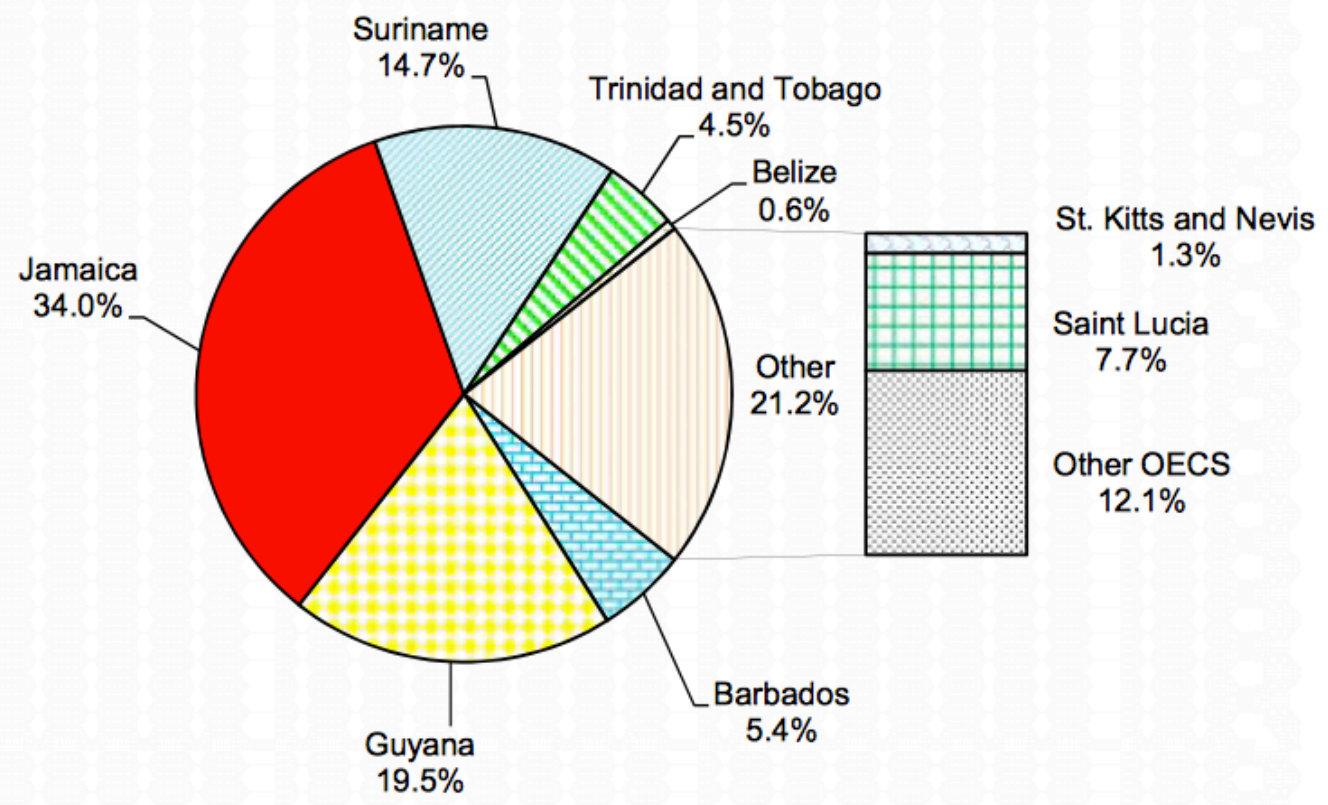

Chart 2 - Source: Ibid, CARICOM Statistical Unit, 2013, Figure 2.3, Percentage Distribution of Intra-regional Imports by CARICOM Countries in 2010, p. 32. 
Figure 2.4: Percentage Distribution of CARICOM's Intra-Regional Total Exports: 2005

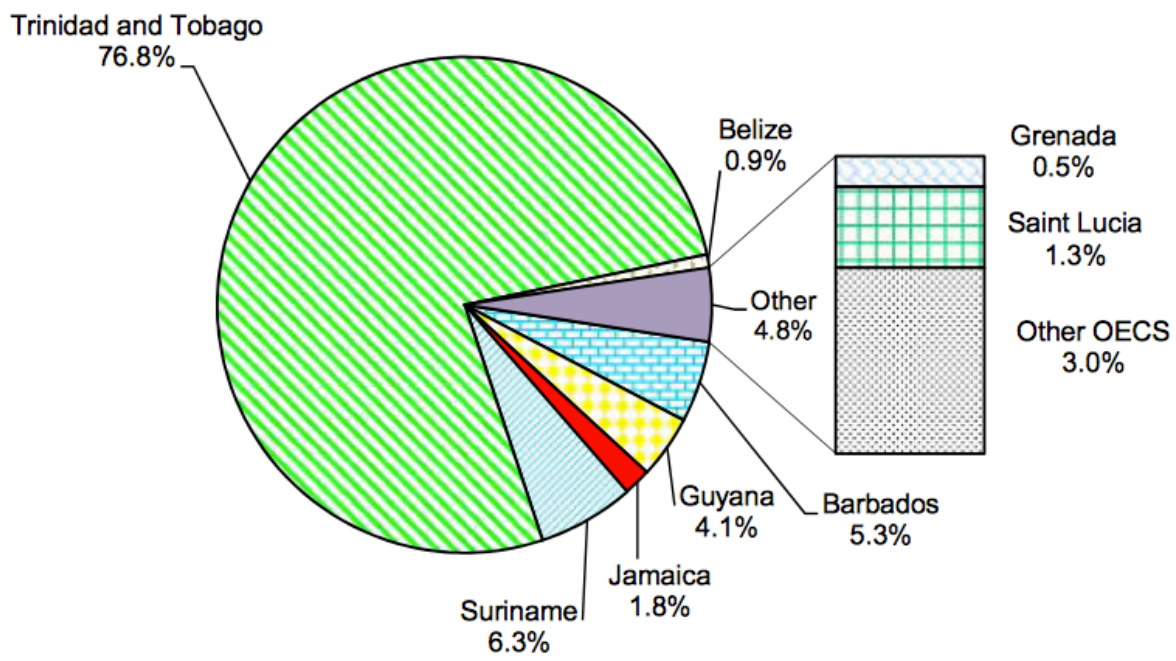

Chart 3 - Source: Ibid, CARICOM Statistical Unit, 2013, Figure 2.4, Percentage Distribution of Intra-regional Total Exports by CARICOM Countries in 2005, p. 35.

Figure 2.5: Percentage Distribution of CARICOM's Intra-Regional Total Exports: 2010

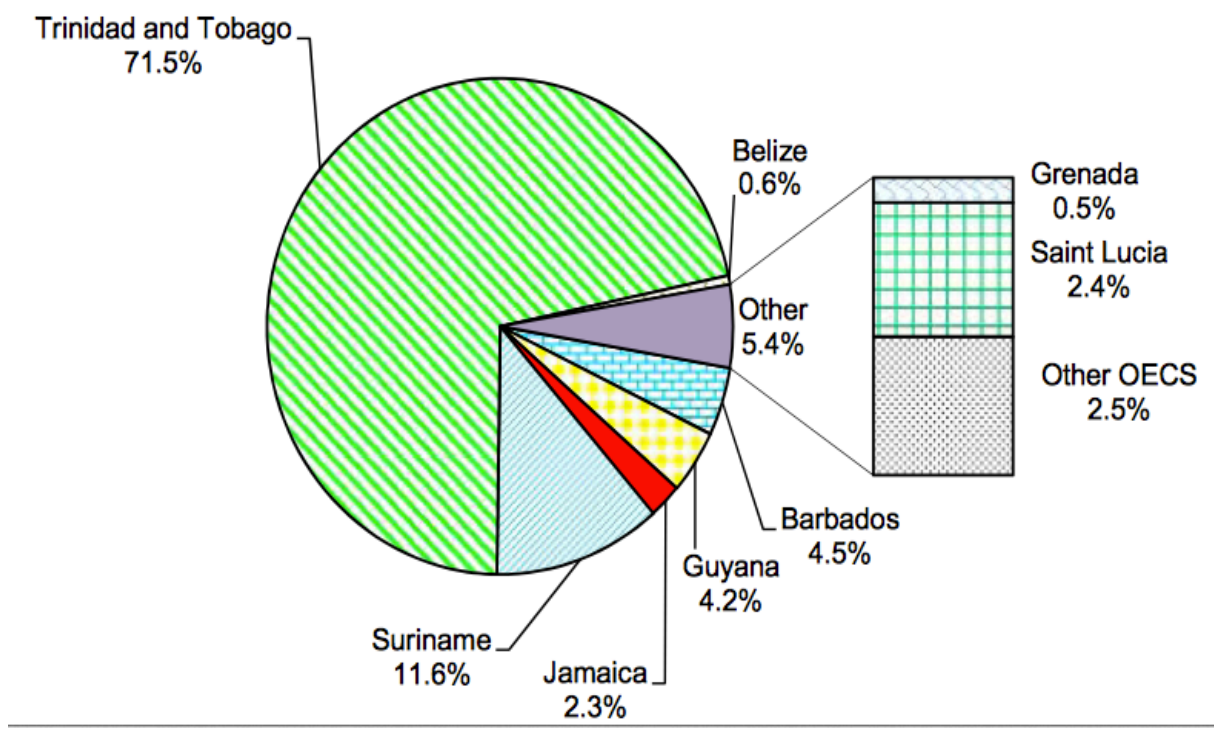

Chart 4 - Source: Ibid, CARICOM Statistical Unit, 2013, Figure 2.5, Percentage Distribution of Intra-regional Total Exports by CARICOM Countries in 2005, p. 35. 
5.3.1 CARICOM MDCs \& Intra-regional trade: $1996-2010$

CARICOM intra-regional trade has fluctuated between the second and fourth source of overall trade for the CARICOM market. For the period of 1996 to 2001, the CARICOM internal market was the fourth source of overall imports and accounted for $10.6 \%$ of imports. ${ }^{711}$ By contrast, the CARICOM internal market was the second principal destination for exports, as it accounted for $19.6 \%$ of exports. ${ }^{712}$ Between the period of 2005 and 2010, the CARICOM internal market was the third source of imports and accounted for $12.9 \%$ of overall imports. ${ }^{713}$ Moreover, the CARICOM internal market was the second principal export destination and accounted for $16.1 \%$ of overall domestic exports. ${ }^{714}$ These figures represent a relatively low volume of trade given that it is the only customs union agreement for all of the CARICOM Member States. ${ }^{715}$ It also indicates that other trading relationships are more vital in the larger scheme of international trade relations.

Several CARICOM MDCs such as Barbados, Jamaica and Trinidad and Tobago have dominated intra-regional trade at different intervals. Where intra-regional imports for the period of 1996 to 2001 are concerned, the five MDCs accounted for an estimated average of $73 \%$ of overall trade. A disaggregation of this figure shows that Jamaica accounted for an estimated average of $35 \%$ of imports, Barbados accounted for an estimated average of $17 \%$ of imports and Trinidad and Tobago accounted for an estimated average of $10 \%$ of imports. However, the main intra-regional imports for the 1996-2001 period were mineral fuel and related materials, which accounted for $38.9 \%$ of imports in 1996 and $45 \%$ of imports in $2001 .{ }^{716}$ Chemicals accounted for $11.7 \%$ of imports in 1996 and $8 \%$ of imports

\footnotetext{
${ }^{711}$ CARICOM Statistical Unit, CARICOM's Trade: A Quick Reference to Some Summary Data, 1996-2001, Fourth Edition (Georgetown, Guyana, December 2005), p. 4.

${ }_{712}^{712}$ Ibid, CARICOM Statistical Unit, 2005, p. 4.

${ }^{713}$ CARICOM Statistical Unit, CARICOM's Trade: A Quick Reference to Some Summary Data, 2005 - 2010 (Georgetown, Guyana, 2013), p. 9.

${ }^{714}$ Ibid, CARICOM Statistical Unit, 2013, p. 11.

${ }^{715}$ In this context, it should be noted that the Revised Treaty of Basseterre (2010), which established the OECS Economic Union contains provisions for the eventual establishment of common customs tariff. See Article 6 of the Protocol of the OECS Economic Union, which states: "The Common Customs Tariff will be set by or under the authority of an Act of the Organisation under Article 14.1(a) of this Treaty, provided that for any period when this tariff is not set the Common External Tariff under the Revised Treaty of Chaguaramas shall be the Common Customs Tariff. Protocol Member States may not impose higher tariffs than the Common Customs Tariff."

${ }^{716}$ CARICOM Statistical Unit, CARICOM's Trade: A Quick Reference to Some Summary Data, 1996-2001, Fourth Edition (Georgetown, Guyana, December 2005), p. 399.
} 
in 2001. ${ }^{717}$ Both are main export products of Trinidad and Tobago and explain that whilst Trinidad and Tobago may appear as a weak intra-regional importer, the trade data demonstrates that Trinidadian exports are dominant and are the main imports of other CARICOM Member States. ${ }^{718}$ Where intra-regional imports for the period of 2005 to 2010 are concerned, the MDCs dominated trade and accounted for $80.4 \%$ of trade. The main performers were Jamaica, Guyana and Barbados. Trinidad and Tobago ranked as the fourth importer; however, this trend reflected that other CARICOM Member States were importing exports of Trinidad and Tobago. Conversely, Trinidad and Tobago did not import much of the products being produced elsewhere in CARICOM.

${ }^{717}$ Ibid, CARICOM Statistical Unit, 2005, p. 399.

${ }^{718}$ Ibid, CARICOM Statistical Unit, 2005, p. 402. 
Table 1: CARICOM MDC Intra-regional Imports $1996-2001$ by percentages $^{719}$

\begin{tabular}{|l|l|l|l|l|l|l|}
\hline & $\mathbf{1 9 9 6}$ & $\mathbf{1 9 9 7}$ & $\mathbf{1 9 9 8}$ & $\mathbf{1 9 9 9}$ & $\mathbf{2 0 0 0}$ & $\mathbf{2 0 0 1}$ \\
\hline MDC \% & 71.7 & 75.7 & 75.4 & 72.8 & 75.2 & 73.0 \\
\hline Barbados & 16.3 & 12.9 & 18.2 & 14.7 & 20.3 & 21.2 \\
\hline Guyana & $\ldots$ & 11.1 & 10.8 & 7.2 & 8.6 & $\ldots$ \\
\hline Jamaica & 37.8 & 32.9 & 34.6 & 33.1 & 35.2 & 42.1 \\
\hline Suriname & 6.5 & 8.7 & $\ldots$ & 6.0 & $\ldots$ & $\ldots$ \\
\hline Trinidad and Tobago & 11.1 & 10.2 & 11.7 & 11.8 & 11.1 & 9.7 \\
\hline
\end{tabular}

${ }^{719}$ Author's own compilation of MDC trade data based on Ibid, CARICOM Statistical Unit, 2005, Table 2.12.2, Percentage Distribution of Intra-regional Imports by CARICOM Countries from 1996 to 2001, p. 370 . 
Table 2: CARICOM MDC Intra-regional Domestic Exports $1996-2001$ by percentages ${ }^{720}$

\begin{tabular}{|l|l|l|l|l|l|l|}
\hline & $\mathbf{1 9 9 6}$ & $\mathbf{1 9 9 7}$ & $\mathbf{1 9 9 8}$ & $\mathbf{1 9 9 9}$ & $\mathbf{2 0 0 0}$ & $\mathbf{2 0 0 1}$ \\
\hline MDC \% & 91.8 & 91.6 & 90.5 & 91.6 & 93.2 & 93.1 \\
\hline Barbados & 10.4 & 9.6 & 10.2 & 9.4 & 7.8 & 7.2 \\
\hline Guyana & $\ldots$ & 6.2 & 5.4 & 5.4 & 5.4 & $\ldots$ \\
\hline Jamaica & 6.2 & 4.8 & 4.5 & 3.8 & 3.3 & 3.8 \\
\hline Suriname & 1.9 & 2.8 & $\ldots$ & 4.8 & $\ldots$ & $\ldots$ \\
\hline Trinidad and Tobago & 73.3 & 68.1 & 70.4 & 68.2 & 76.7 & 82.0 \\
\hline
\end{tabular}

${ }^{720}$ Author's own compilation of MDC trade based on Ibid, CARICOM Statistical Unit, 2005, Table 2.12.3, Percentage Distribution of Intra-regional Domestic Exports by CARICOM Countries from 1996 to 2001, p. 371. 
Table 3: CARICOM MDC Intra-regional Total Exports 1996 - 2001 by percentages ${ }^{721}$

\begin{tabular}{|l|l|l|l|l|l|l|}
\hline & $\mathbf{1 9 9 6}$ & $\mathbf{1 9 9 7}$ & $\mathbf{1 9 9 8}$ & $\mathbf{1 9 9 9}$ & $\mathbf{2 0 0 0}$ & $\mathbf{2 0 0 1}$ \\
\hline MDC \% & 91.8 & 91.7 & 91.1 & 91.0 & 93.0 & 92.8 \\
\hline Barbados & 11.5 & 10.3 & 10.6 & 10.6 & 9.1 & 8.5 \\
\hline Guyana & $\ldots$ & 5.8 & 4.9 & 5.1 & 3.1 & $\ldots$ \\
\hline Jamaica & 6.1 & 4.7 & 4.2 & 3.8 & 3.7 & 4.0 \\
\hline Suriname & 2.7 & 3.8 & $\ldots$ & 4.9 & $\ldots$ & $\ldots$ \\
\hline Trinidad and Tobago & 71.5 & 67.2 & 71.4 & 66.5 & 75.1 & 80.4 \\
\hline
\end{tabular}

${ }^{721}$ Author's own compilation of MDC trade based on Ibid, CARICOM Statistical Unit, 2005, Table 2.12.4, Percentage Distribution of Intra-regional Domestic Exports by CARICOM Countries from 1996 to 2001, p. 372. 
Table 4: CARICOM MDC Intra-regional Imports $2005-2010$ by percentages ${ }^{722}$

\begin{tabular}{|c|c|c|c|c|c|c|c|}
\hline Year & 2005 & 2006 & 2007 & 2008 & 2009 & 2010 & Total Avg \\
\hline MDC \% & 80.4 & 77.1 & 76.8 & 82.7 & 76.1 & 78.2 & 80.4 \\
\hline Barbados & 17.4 & 18.9 & 5.9 & 12.7 & 16.2 & 5.4 & 12.8 \\
\hline Guyana & 13.0 & 13.6 & 11.3 & 11.0 & 14.1 & 19.5 & 13.8 \\
\hline Jamaica & 35.7 & 29.5 & 46.0 & 47.0 & 28.4 & 34.0 & 38.5 \\
\hline Suriname & 9.9 & 10.8 & 9.0 & 8.5 & 12.7 & 14.7 & 11.0 \\
\hline $\begin{array}{l}\text { Trinidad and } \\
\text { Tobago }\end{array}$ & 4.3 & 4.3 & 4.6 & 3.5 & 4.7 & 4.5 & 4.3 \\
\hline
\end{tabular}

${ }^{722}$ Author's own compilation of MDC trade data based on CARICOM Statistical Unit, CARICOM's Trade: A Quick Reference to Some Summary Data, 2005 - 2010 (Georgetown, Guyana, 2013), Table 2.3, Percentage Distribution of Intra-regional Imports by CARICOM Countries from 2005 to 2010, p. 31. 
Table 5: CARICOM MDC Intra-regional Domestic Exports $2005-2010$ by percentages ${ }^{723}$

\begin{tabular}{|l|l|l|l|l|l|l|l|}
\hline Year & $\mathbf{2 0 0 5}$ & $\mathbf{2 0 0 6}$ & $\mathbf{2 0 0 7}$ & $\mathbf{2 0 0 8}$ & $\mathbf{2 0 0 9}$ & $\mathbf{2 0 1 0}$ & Total Avg \\
\hline MDC \% & 96.0 & 96.3 & 95.1 & 97.0 & 94.1 & 95.7 & 95.9 \\
\hline Barbados & 4.7 & 4.2 & 7.6 & 3.4 & 5.8 & 3.8 & 4.7 \\
\hline Guyana & 4.2 & 4.2 & 5.3 & 3.0 & 5.7 & 4.3 & 4.2 \\
\hline Jamaica & 1.6 & 1.6 & 2.0 & 1.4 & 3.0 & 2.1 & 1.9 \\
\hline Suriname & 5.9 & 5.7 & 6.3 & 8.0 & 6.4 & 10.8 & 7.3 \\
\hline $\begin{array}{l}\text { Trinidad } \\
\text { Tobago }\end{array}$ & 79.6 & 80.6 & 73.8 & 81.2 & 73.2 & 74.7 & 77.8 \\
\hline
\end{tabular}

723 Author's own compilation of MDC trade based on Ibid, CARICOM Statistics Unit, 2013, Table 2.4, Percentage Distribution of Intra-regional Domestic Exports by CARICOM Countries from 2005 to 2010 , p. 33. 
Table 6: CARICOM MDC Intra-regional Total Exports $2005-2010$ by percentages ${ }^{724}$

\begin{tabular}{|l|l|l|l|l|l|l|l|}
\hline Year & $\mathbf{2 0 0 5}$ & $\mathbf{2 0 0 6}$ & $\mathbf{2 0 0 7}$ & $\mathbf{2 0 0 8}$ & $\mathbf{2 0 0 9}$ & $\mathbf{2 0 1 0}$ & Total Avg \\
\hline MDC \% & 94.3 & 95.5 & 90.8 & 95.7 & 88.4 & 94.0 & 94.4 \\
\hline Barbados & 5.3 & 4.8 & 7.2 & 3.8 & 6.4 & 4.5 & 5.2 \\
\hline Guyana & 4.1 & 4.0 & 5.2 & 2.9 & 5.2 & 4.2 & 4.1 \\
\hline Jamaica & 1.8 & 1.7 & 2.2 & 1.6 & 3.1 & 2.3 & 2.1 \\
\hline Suriname & 6.3 & 6.3 & 6.8 & 8.5 & 7.4 & 11.6 & 8.0 \\
\hline Trinidad & 76.8 & 78.6 & 69.5 & 79.0 & 66.2 & 71.5 & 75.1 \\
\hline
\end{tabular}

${ }^{724}$ Author's own compilation of MDC trade based on Ibid, CARICOM Statistics Unit, 2013, Table 2.5, Percentage Distribution of Intra-regional Total Exports by CARICOM Countries from 2005 to 2010, p. 34. 


\subsubsection{Profile: Jamaica}

Jamaica has estimated population of $2,990,561^{725}$ and ranked as one of the main intraregional importers during the period of 2005 to 2010. Its economy is heavily reliant on foreign imports as average annual imports totaled 43.8\% of GDP between 2003 and 2009. ${ }^{726}$ During this same period, $77 \%$ of these imports were sourced from the Americas whilst $10 \%$ were sourced from Europe and another $10 \%$ from Asia respectively. ${ }^{727}$ Of the $77 \%$ of imports sourced from the Americas, $37 \%$ came from the USA mainly in the form of foodstuff, machinery, motor vehicles, industrial inputs and materials for assembly and exports. $^{728}$ The remaining $40 \%$ of imports were sourced from Trinidad and Tobago, Venezuela and Mexico, which were mainly petroleum and petroleum products. ${ }^{729}$ The Jamaican export basket is heavily concentrated on a few products namely bauxite, alumina, sugar, bananas, coffee and cocoa. ${ }^{730}$ Jamaica is a leading producer of bauxite and alumina and as such, mining is the largest non-service export activity. ${ }^{731}$ In the years preceding 2009 , bauxite and alumina goods accounted for $60 \%$ of Jamaican exports. ${ }^{732}$ Thus, between 2004 and 2008, mining and quarrying alone contributed 4\% to the Jamaican GDP. ${ }^{733}$

Agriculture has declined in its importance to the Jamaican GDP, as it only contributed 5\% to GDP between 2003 and 2009. ${ }^{734}$ Nevertheless, agriculture is deemed a sensitive sector because of its importance in poverty reduction and the provision of employment. Agriculture remains the largest employer of labor in rural Jamaica. ${ }^{735}$ Within the Jamaican agriculture industry, sugar remains the most important crop, however, in recent years the industry has been affected by declining sugar prices, low productivity and high production costs. Jamaica also has an increased vulnerability to external climatic and economic

\footnotetext{
725 July 2017, CIA World Fact book.

${ }^{726}$ WTO Secretariat, Trade Policy Review of Jamaica 2010, Report by the Secretariat (Geneva, $7^{\text {th }}$ December 2010) [WT/TPR/G/242], p. 8, para. 18.

${ }^{727}$ WTO Secretariat, Trade Policy Review of Jamaica 2010, Report by the Secretariat (Geneva, $22^{\text {nd }}$ February 2011) [WT/TPR/G/242/Rev.1], p. 8, para. 27.

${ }_{728}$ Ibid, WTO Secretariat, 2011, p. 8, para. 27.

${ }^{729}$ Ibid, WTO Secretariat, 2011, p. 8, para. 27.

${ }^{730}$ Ibid, WTO Secretariat, 2011, p. 60, para. 6.

${ }^{731}$ Ibid, WTO Secretariat, 2011, p. ix, para. 17.

${ }^{732}$ Ibid, WTO Secretariat, 2011, p. 6, para. 24.

${ }^{733}$ Ibid, WTO Secretariat, 2011, p. 67, para. 32.

${ }_{734}^{734}$ Ibid, WTO Secretariat, 2011, p. 60, para. 6.

${ }^{735}$ Ibid, WTO Secretariat, 2011, p. 60, para. 7.
} 
shocks, as was illustrated in 2008 when there were no banana exports due to tropical storm damage to the yearly crop. ${ }^{736}$ Manufacturing is also a sector of importance to the Jamaican economy and accounted for $9.1 \%$ of GDP in 2005 and $8.3 \%$ of GDP in $2009 .{ }^{737}$ The main subsectors in manufacturing are food, beverages and tobacco. ${ }^{738}$

The USA, Canada and the EU are Jamaica's main export markets. In 2009, these three markets accounted for $90 \%$ of Jamaican exports, which represented an increase from 2003 when these export markets accounted for 77\% of Jamaican exports. Between 2003 and 2009 , an average of $30 \%$ of exports went to the EU market under preferential trade arrangements for bananas, sugar and other tropical products. ${ }^{739} 90 \%$ of Jamaican exports to the USA during this period were conducted under the preferential Caribbean Basin Initiative (CBI) scheme. ${ }^{740}$ Given this overview of Jamaica's main trade destinations, it is apparent that a comparatively low volume of trade is conducted on the CARICOM intraregional market.

\subsubsection{Profile: Barbados}

Barbados has an estimated population of $292,336^{741}$ and ranked as the second main importer between 2005 to 2010. Tourism services are a main contributor to GDP of Barbados and there have been many positive spillover effects to other industries such as construction, distribution services, electricity, agriculture and manufacturing. ${ }^{72}$ The manufacturing sector contributed 6\% to GDP from 2008 to $2012 .{ }^{743}$ This figure represented a higher contribution to GDP than agriculture, which contributed around $4 \%$ during the same period. ${ }^{744}$ Agriculture is considered a minor industry in Barbados with the exception

\footnotetext{
${ }^{736}$ Ibid, WTO Secretariat, 2011, p. 6, para. 24.

${ }^{737}$ WTO Secretariat, Trade Policy Review of Jamaica 2010, Report by the Secretariat (Geneva, 7 th December 2010) [WT/TPR/G/242], p. 8, para. 23.

${ }^{738}$ WTO Secretariat, Trade Policy Review of Jamaica 2010, Report by the Secretariat (Geneva, $22^{\text {nd }}$ February 2011) [WT/TPR/G/242/Rev.1], p. 69, para. 41.

${ }^{739}$ Ibid, WTO Secretariat, 2011, p. 8, para. 27.

${ }^{740}$ Ibid, WTO Secretariat, 2011, p. vii, para. 6.

${ }^{741}$ July 2017, CIA World Fact book.

${ }^{742}$ WTO Secretariat, Trade Policy Review of Barbados 2014, Report by the Secretariat (Geneva, $16^{\text {th }}$ December 2014) [WT/TPR/6/308], p. 9, para. 21.

743 Ibid, WTO Secretariat, 2014, p. 6, para. 4.3.

${ }^{744}$ Ibid, WTO Secretariat, 2014, p. 6, para. 4.6.
} 
of the sugar industry as raw sugar is utilized as an input for rum, which is a main export product. ${ }^{745}$ Between 2007 and 2013, the main export destinations for Barbados were the USA followed by Trinidad and Tobago and the EU. ${ }^{746}$ With respect to imports, an estimated 70\% of overall imports were sourced from the Americas between 2007 and 2013. The USA accounted for most imports followed by Trinidad and Tobago and Canada. Outside of the Americas, imports sourced from Europe accounted for an estimated average of $14 \%$ and Asia accounted for an estimated average 13\% between 2007 and $2013 .{ }^{747}$ As previously seen with Jamaica, Barbados also maintains a more robust trading relationship with extra-regional partners when compared to that with its CARICOM trading partners.

\subsubsection{Profile: Trinidad and Tobago}

Trinidad and Tobago is the largest CARICOM economy ${ }^{748}$ and the third most populous CARICOM Member State with an estimated population of 1,218,208. ${ }^{749}$ The crude oil and gas industry is the most important sector for the Trinidadian economy, as it accounts for an estimated average of $75 \%$ of exports and $50 \%$ of government revenue. ${ }^{750}$ In 2005 , crude oil and gas accounted for $71 \%$ of merchandise exports and in 2009 , this increased to $76 \%{ }^{751}$ As of 2012 , crude oil and gas accounted for $83 \%$ of merchandise exports. ${ }^{752}$ Nevertheless, the crude oil and gas industry provides a relatively low level of employment and in 2012 accounted for only 3\% of employment. ${ }^{753}$ Consequently, the Government of Trinidad and Tobago has undertaken to wean the economy from its overdependence on crude oil and gas as well as the inherent sensitivity to world oil prices that accompanies it.

\footnotetext{
${ }^{745}$ Ibid, WTO Secretariat, 2014, p. 9, para. 19.

${ }^{746}$ WTO Secretariat, Trade Policy Review of Barbados 2014, Report by the Secretariat (Geneva, 30 ${ }^{\text {th }}$ March 2015) [WT/TPR/6/308/Rev. 1], p. 19, para. 1.39.

${ }^{747}$ Ibid, WTO Secretariat, 2015, p. 20, para. 1.40.

${ }^{748}$ WTO Secretariat, Trade Policy Review of Trinidad and Tobago 2012, Report by the Secretariat (Geneva, $2^{\text {nd }}$ May 2012) [WT/TPR/S/260/Rev.1], p. 1, para.1.

749 July 2017, CIA World Fact book.

${ }^{750}$ WTO Secretariat, Trade Policy Review of Trinidad and Tobago 2012, Report by the Secretariat (Geneva, $2^{\text {nd }}$ May 2012) [WT/TPR/S/260/Rev.1], p.1, para. 1.

${ }^{751}$ Ibid, WTO Secretariat, 2012, p. 8, para. 20.

752 Regional Trade Policy Adviser assigned to the CARICOM Secretariat under the Commonwealth Secretariat "Hubs and Spokes" Project in collaboration with the Ministry of Trade, Industry and Investment, Trade Policy and Strategy, Trinidad and Tobago 2013 - 2017 (Georgetown, Guyana, 23 ${ }^{\text {rd }}$ August 2013), p. 10.

${ }^{753}$ Ibid, Regional Trade Policy Adviser assigned to the CARICOM Secretariat under the Commonwealth Secretariat "Hubs and Spokes" Project in collaboration with the Ministry of Trade, Industry and Investment, 2013, p. 10.
} 
Several avenues of diversification for the economy have been identified and the Government of Trinidad and Tobago has endeavored to further enhance these industries.

The agricultural sector provides a small contribution to GDP, which was estimated at $0.6 \%$ in $2012 .^{754}$ This industry features the lowest area of labor productivity ${ }^{755}$ and consequently, it has received high levels of government support to assist with the decline caused by preference erosion and decreased production of high value crops such as cocoa and coffee. ${ }^{756}$ Increased efforts at diversification have extended to the tourism industry, as it previously provided a low contribution to GDP and is not considered a major sector of the economy. ${ }^{757}$ Despite the prominence of the crude oil and gas industry, the services sector provides a larger contribution to GDP and accounted for $46 \%$ in 2010 and $50 \%$ in $2012 .^{758}$ Services accounted for $70 \%$ of employment between 2006 and 2012 as well as $12 \%$ of exports in $2012 .^{759}$ The services sector provides important inputs for the production of other goods and aids the manufacturing industry, which accounted for $6 \%$ of GDP in $2012^{760}$ Trinidad and Tobago is also considered a regional financial center and this is reflected in the main services sub-sectors such as finance, insurance and real estate. ${ }^{761}$ It is notable that there are positive spillovers to other service sectors such as distribution, construction, quarrying, transport, storage and communication.

\footnotetext{
${ }^{754}$ Ibid, Regional Trade Policy Adviser assigned to the CARICOM Secretariat under the Commonwealth Secretariat "Hubs and Spokes" Project in collaboration with the Ministry of Trade, Industry and Investment, 2013, p. 17.

${ }^{755}$ WTO Secretariat, Trade Policy Review of Trinidad and Tobago 2012, Report by the Secretariat (Geneva, $2^{\text {nd }}$ May 2012) [WT/TPR/S/260/Rev.1], p. 1, para. 3.

${ }^{756}$ Ibid, WTO Secretariat, 2012, p. viii, para. 8.

${ }^{757}$ Ibid, WTO Secretariat, 2012, p. ix, para. 13.

${ }^{758}$ Regional Trade Policy Adviser assigned to the CARICOM Secretariat under the Commonwealth Secretariat "Hubs and Spokes" Project in collaboration with the Ministry of Trade, Industry and Investment, Trade Policy and Strategy, Trinidad and Tobago 2013 - 2017 (Georgetown, Guyana, 23 ${ }^{\text {rd }}$ August 2013), p. 10.

${ }^{759}$ WTO Secretariat, Trade Policy Review of Trinidad and Tobago 2012, Report by the Secretariat (Geneva, $2^{\text {nd }}$ May 2012) [WT/TPR/S/260/Rev.1], p. viii, para. 10.

${ }^{760}$ Regional Trade Policy Adviser assigned to the CARICOM Secretariat under the Commonwealth Secretariat "Hubs and Spokes" Project in collaboration with the Ministry of Trade, Industry and Investment, Trade Policy and Strategy, Trinidad and Tobago 2013 - 2017 (Georgetown, Guyana, 23 ${ }^{\text {rd }}$ August 2013), p. 17.

${ }^{761}$ Ibid, Regional Trade Policy Adviser assigned to the CARICOM Secretariat under the Commonwealth Secretariat "Hubs and Spokes" Project in collaboration with the Ministry of Trade, Industry and Investment, 2013, p. 19.
} 
The principal export markets for Trinidad and Tobago between 2006 and 2012 were the USA, CARICOM and the EU. In 2012, exports to the USA accounted for $47.4 \%$ of total exports, exports to CARICOM accounted for $18.5 \%$ of total exports, exports to the EU accounted for $7.9 \%$ of total exports and exports to Central and South America accounted for $5.9 \%$ of total exports. With respect to the USA, Trinidad and Tobago was the leading exporter under the CBI since $2006^{762}$ and in 2010 , Trinidad and Tobago exported US\$2.2 Billion to the USA under CBI tariff preferences. ${ }^{763}$ Regarding CARICOM intra-regional trade, although Trinidad and Tobago accounts for the largest share of combined intraregional trade (imports and exports), this figure only computes to about 13\% of Trinidad's total trade. ${ }^{764}$ It is consequently argued that despite being considered a dominant player in terms of intra-regional trade, the CARICOM market is possibly viewed in a different light from the Trinidad and Tobago perspective.

Additionally, Trinidad and Tobago has a higher rate of utilization of CARICOM bilateral FTAs than most of the other CARICOM Member States. This is reflected in its trade receipts with Venezuela, Colombia, Dominican Republic, Costa Rica and Cuba. ${ }^{765} 90 \%$ of CARICOM's trade with Colombia under the CARICOM-Colombia Agreement is undertaken by Trinidad and Tobago. ${ }^{766}$ The other $10 \%$ of CARICOM trade is shared amongst the other MDCs. Although trade between Trinidad and Tobago and Colombia declined between 2004 and 2009, it still accounted for USD\$332 million in $2010 .^{767}$

\footnotetext{
${ }^{762}$ WTO Secretariat, Trade Policy Review of Trinidad and Tobago 2012, Report by the Secretariat (Geneva, $1^{\text {st }}$ February 2012) [WT/TPR/S/260], p. 10, para. 22.

${ }^{763}$ Ibid, WTO Secretariat, 2012, p. 12, para. 26.

${ }^{764}$ Regional Trade Policy Adviser assigned to the CARICOM Secretariat under the Commonwealth Secretariat "Hubs and Spokes" Project in collaboration with the Ministry of Trade, Industry and Investment, Trade Policy and Strategy, Trinidad and Tobago 2013 - 2017 (Georgetown, Guyana, 23 ${ }^{\text {rd }}$ August 2013), p. 12.

${ }^{765}$ Ibid, Regional Trade Policy Adviser assigned to the CARICOM Secretariat under the Commonwealth Secretariat "Hubs and Spokes" Project in collaboration with the Ministry of Trade, Industry and Investment, 2013, p. 24.

${ }^{766}$ The CARICOM-Colombia FTA entered into force on $1^{\text {st }}$ January 1995 and is a PTA that has not been notified at the WTO secretariat. As such, it is included in the list on non-notified PTAs. See WTO Secretariat, CRTA: List of RTAs, which have appeared in factual presentations (issued up to $27^{\text {th }}$ October 2017) and have not yet been notified to the WTO. (Geneva, $30^{\text {th }}$ October 2017) [WT/REG/W/122].

767 Regional Trade Policy Adviser assigned to the CARICOM Secretariat under the Commonwealth Secretariat "Hubs and Spokes" Project in collaboration with the Ministry of Trade, Industry and Investment, Trade Policy and Strategy, Trinidad and Tobago $2013-2017$ (Georgetown, Guyana, 23 ${ }^{\text {rd }}$ August 2013), p. 22.
} 
Trinidad and Tobago negotiated a partial scope agreement ${ }^{768}$ with Panama in October 2013 and has stated its intention to engage Guatemala, El Salvador and Honduras in its bid to penetrate additional export markets in Central America. ${ }^{769}$ Moreover, the principal source of imports for Trinidad and Tobago between 2006 and 2012 were the USA, EU and Colombia. It should be mentioned that a good proportion of Trinidad and Tobago's general imports were crude oil intended for refining particularly from the Russian Federation and Gabon. ${ }^{770}$

5.4 CARICOM LDCs \& Intra-regional trade: 1996 - 2010

A review of CARICOM intra-regional trade for the period of 1996 to 2010 illustrated that the CARICOM LDCs have not participated in a considerable amount of intra-regional trade. As noted before, the CARICOM PTA represents the main customs union agreement, which these countries have signed and yet only a minor volume of trade is conducted on the intra-regional market. ${ }^{771}$ In light of this, it can be argued that the intra-PTA trade is not the most important trading relationship for the LDCs, as they maintain more beneficial trading relationships with the USA and the EU. ${ }^{772}$ In the case of Belize, trade with neighboring Central America is also increasing to a considerable degree. ${ }^{773}$ To this end, it questioned whether regional integration is perceived as a development priority for all of the CARICOM Member States, as its potential for spurring growth through increased regional trade has been underutilized. ${ }^{774}$

\footnotetext{
768 This partial scope agreement has not yet entered into force.

${ }^{769}$ WTO Secretariat, Trade Policy Review of Trinidad and Tobago 2012, Report by the Secretariat (Geneva, $1^{\text {st }}$ February 2012) [WT/TPR/S/260], p. 11, para. 21.

${ }^{770}$ Ibid, WTO Secretariat, 2012, p. 10, para. 22.

${ }^{771}$ This is subject to change for the OECS given the eventual implementation of the OECS common customs tariff.

772 See World Bank/Organization of American States, co-produced with the Governments of the CARIFORUM Countries, Poverty Reduction and Economic Management Sector Unit, Latin America and Caribbean Region, The Caribbean: Accelerating Trade Integration, Policy Options for Sustained Growth, Job Creation and Poverty Reduction (December 2008), Chapter 2, p. 55, para. 2.5.2.

${ }^{773}$ WTO Secretariat, Belize Trade Policy Review, Report by the Secretariat (Geneva, $23^{\text {rd }}$ November 2010) [WT/TPR/G/238/Rev.1], p. 5, para. 2.

774 See World Bank/Organization of American States, co-produced with the Governments of the CARIFORUM Countries, Poverty Reduction and Economic Management Sector Unit, Latin America and Caribbean Region, The Caribbean: Accelerating Trade Integration, Policy Options for Sustained Growth, Job Creation and Poverty Reduction (December 2008), Chapter 2, p. 22, para. 2.8.
} 
During the period of 1996 to 2001, LDC intra-regional imports accounted for an estimated average of $26 \%$ of overall intra-regional trade (Table 7). ${ }^{775}$ The strongest LDC performers were St. Lucia and Grenada whilst the other LDCs averaged less than 5\% of their import trade from the intra-regional market. The overall picture of intra-regional export trade for the LDCs illustrated that these countries are on the periphery of CARICOM trade and only nominally involved in intra-regional trade (Table 8). ${ }^{776}$ Only two LDCs, Dominica and St. Vincent and the Grenadines, on average exported more than $2 \%$ of their exports to the CARICOM intra-regional market. It is therefore questioned whether the LDCs perceive the intra-regional market as a place to undertake trade, as most of them on average exported $1 \%$ or less of their exports to the intra-regional market during the period of 1996 to 2001.

\footnotetext{
${ }^{775}$ See Table 7 on CARICOM LDC intra-regional imports 1996 - 2001 by percentages.

${ }^{776}$ See Table 8 on CARICOM LDC intra-regional domestic exports 1996 - 2001 by percentages and Table 9 on CARICOM LDC intra-regional total exports $1996-2001$ by percentages.
} 
Table 7: CARICOM LDC Intra-regional Imports 1996 - 2001 by percentages ${ }^{777}$

\begin{tabular}{|l|l|l|l|l|l|l|}
\hline & $\mathbf{1 9 9 6}$ & $\mathbf{1 9 9 7}$ & $\mathbf{1 9 9 8}$ & $\mathbf{1 9 9 9}$ & $\mathbf{2 0 0 0}$ & $\mathbf{2 0 0 1}$ \\
\hline LDCs \% & 28.3 & 24.3 & 24.6 & 27.2 & 24.8 & 27.0 \\
\hline BELIZE & 1.4 & 1.1 & 1.2 & 1.2 & 1.2 & 2.1 \\
\hline OECS \% & 26.9 & 23.2 & 23.4 & 26.0 & 23.5 & 24.9 \\
\hline $\begin{array}{l}\text { Antigua \& } \\
\text { Barbuda }\end{array}$ & $\ldots$ & $\ldots$ & $\ldots$ & 4.0 & $\ldots$ & $\ldots$ \\
\hline Dominica & 4.2 & 3.6 & 1.4 & 3.0 & 3.5 & 3.5 \\
\hline Grenada & 5.3 & 4.9 & 6.2 & 5.0 & 5.1 & 5.2 \\
\hline Montserrat & $\ldots$ & $\ldots$ & $\ldots$ & 0.3 & 0.4 & 0.4 \\
\hline St. Kitts \& Nevis & 3.4 & 2.9 & 2.7 & 2.5 & 3.2 & 3.3 \\
\hline St. Lucia & 9.0 & 7.4 & 7.9 & 6.9 & 7.0 & 7.6 \\
\hline $\begin{array}{l}\text { St. Vincent and } \\
\text { the Grenadines }\end{array}$ & 5.0 & 4.4 & 5.3 & 4.2 & 4.3 & 4.9 \\
\hline
\end{tabular}

${ }^{777}$ Author's own compilation of LDC trade data based on CARICOM Statistical Unit, CARICOM's Trade: A Quick Reference to Some Summary Data, 1996 - 2001, Fourth Edition (Georgetown, Guyana, December 2005), Table 2.12.2, Percentage Distribution of Intra-regional Imports by CARICOM Countries from 1996 to 2001 , p. 370 .

${ }^{778}$ Trade data unavailable. 
Table 8: CARICOM LDC Intra-regional Domestic Exports $1996-2001$ by percentages ${ }^{779}$

\begin{tabular}{|l|l|l|l|l|l|l|}
\hline & $\mathbf{1 9 9 6}$ & $\mathbf{1 9 9 7}$ & $\mathbf{1 9 9 8}$ & $\mathbf{1 9 9 9}$ & $\mathbf{2 0 0 0}$ & $\mathbf{2 0 0 1}$ \\
\hline LDCs \% & 8.2 & 8.4 & 9.5 & 8.4 & 6.8 & 6.9 \\
\hline BELIZE & 0.6 & 0.8 & 1.2 & 0.9 & 0.7 & 0.9 \\
\hline OECS \% & 7.7 & 7.6 & 8.2 & 7.4 & 6.1 & 6.0 \\
\hline $\begin{array}{l}\text { Antigua } \\
\text { Barbuda }\end{array}$ & $\ldots$ & $\ldots$ & $\ldots$ & 0.3 & $\ldots$ & $\ldots$ \\
\hline Dominica & 2.9 & 2.9 & 3.5 & 2.9 & 2.4 & 2.1 \\
\hline Grenada & 0.6 & 0.8 & 0.9 & 0.9 & 0.8 & 0.8 \\
\hline Montserrat & 0.0 & $\ldots$ & $\ldots$ & 0.0 & 0.0 & 0.0 \\
\hline St. Kitts \& Nevis & 0.0 & 0.1 & 0.1 & 0.1 & 0.2 & 0.1 \\
\hline St. Lucia & 1.2 & 1.0 & 1.1 & 1.1 & 0.9 & 1.2 \\
\hline $\begin{array}{l}\text { St. Vincent and } \\
\text { the Grenadines }\end{array}$ & 2.9 & 2.8 & 2.5 & 2.2 & 1.7 & 1.9 \\
\hline
\end{tabular}

${ }^{779}$ Author's own compilation of LDC trade based on Ibid, CARICOM Statistical Unit, 2005, Table 2.12.3, Percentage Distribution of Intra-regional Domestic Exports by CARICOM Countries from 1996 to 2001, p. 371. 
Table 9: CARICOM LDC Intra-regional Total Exports $1996-2001$ by percentages ${ }^{780}$

\begin{tabular}{|l|l|l|l|l|l|l|}
\hline & $\mathbf{1 9 9 6}$ & $\mathbf{1 9 9 7}$ & $\mathbf{1 9 9 8}$ & $\mathbf{1 9 9 9}$ & $\mathbf{2 0 0 0}$ & $\mathbf{2 0 0 1}$ \\
\hline LDCs \% & 8.2 & 8.3 & 8.9 & 9.0 & 7.0 & 7.2 \\
\hline BELIZE & 0.5 & 0.8 & 1.1 & 0.9 & 0.7 & 0.9 \\
\hline OECS \% & 7.7 & 7.5 & 7.8 & 8.1 & 6.3 & 6.3 \\
\hline $\begin{array}{l}\text { Antigua } \\
\text { Barbuda }\end{array}$ & $\ldots$ & $\ldots$ & $\ldots$ & 0.7 & $\ldots$ & $\ldots$ \\
\hline Dominica & 2.7 & 2.7 & 3.3 & 2.8 & 2.4 & 2.1 \\
\hline Grenada & 0.7 & 0.9 & 1.0 & 0.9 & 0.9 & 1.0 \\
\hline Montserrat & 0.1 & $\ldots$ & $\ldots$ & 0.1 & 0.2 & 0.1 \\
\hline St. Kitts \& Nevis & 0.1 & 0.1 & 0.1 & 0.1 & 0.2 & 0.1 \\
\hline St. Lucia & 1.2 & 1.0 & 1.0 & 0.1 & 1.0 & 1.3 \\
\hline $\begin{array}{l}\text { St. Vincent and } \\
\text { the Grenadines }\end{array}$ & 2.9 & 2.7 & 2.4 & 2.3 & 1.8 & 1.9 \\
\hline
\end{tabular}

${ }^{780}$ Author's own compilation of LDC trade based on Ibid, CARICOM Statistical Unit, 2005, Table 2.12.4, Percentage Distribution of Intra-regional Total Exports by CARICOM Countries from 1996 to 2001, p. 372. 
This LDC pattern of trade continued during the period of 2005 to 2010 for intra-regional imports as overall LDC contribution amounted to $19.6 \%$, which represents a diminution of trade from the previous five-year period (Table 10) ${ }^{781}$ The majority of the LDCs sourced less than $5 \%$ of their imports from the intra-regional market. Furthermore, the export trade capacity of the LDCs showed itself to be particularly weak as its overall share of exports was at best 5\% during the period of 2005 to 2010 (Table 11). ${ }^{782}$ Most of the LDCs exported $1 \%$ or less of their total exports to the intra-regional market. Such figures substantiate the claim that the CARICOM LDCs, which tend to feature small economies with limited production capacity are unable to achieve economies of scale. ${ }^{783}$ Hence, their export trade remains unprofitable. It also reflects the commonality of the LDCs having a very narrow export base alongside high reliance on imports mainly from the USA. ${ }^{784}$

The weak export trade figures have underscored the point that the OECS countries are in an acute circumstance of being net importers of goods and net exporters of services. Various exogenous shocks have resulted in a shift in their economies whereby the contribution of trade in goods has declined in its importance to GDP and the contribution of trade in services to annual GDP has grown. ${ }^{785}$ For example in 2011, travel and tourism services alone posted the following contributions to GDP in the OECS: Antigua and Barbuda $-74.2 \%$, Dominica $-24.8 \%$, Grenada $-24.2 \%$, St. Lucia $-45.8 \%$ and St. Vincent and the Grenadines $-26.2 \%{ }^{786}$ The geographical location of the OECS countries exposes them to climatic vulnerabilities and this directly impacts on their export capacity. ${ }^{787}$ Nevertheless, it is submitted that all of the CARICOM LDCs should concentrate their

\footnotetext{
${ }^{781}$ See Table 10 on CARICOM LDC intra-regional imports $2005-2010$ by percentages.

${ }^{782}$ See Table 11 on CARICOM LDC intra-regional domestic exports $2005-2010$ by percentages and Table 12 on CARICOM LDC intra-regional total exports $2005-2010$ by percentages.

${ }^{783}$ M. Gasiorek, L. Winters, What Role for the EPA in the Caribbean? The World Economy, 2004, Vol. 27(9), pp. 1335-1362, p. 1336.

${ }_{784}$ Ibid, M. Gasiorek, L. Winters, 2004, p. 1335.

${ }^{785}$ Most CARICOM Member States traditionally considered themselves as producers of goods as opposed to providers of services. See Ibid, M. Gasiorek, L. Winters, 2004, p. 1339; WTO Secretariat, Trade Policy Review of the OECS- WTO Members, Report by the Secretariat (Geneva, 22 ${ }^{\text {nd }}$ September 2014) [WT/TPR/S/299/Rev.1] p. 116, para. 1.1.

${ }^{786}$ OECS Common Tourism Policy prepared with the assistance of the Commonwealth Secretariat (September 2011), p. 4.

${ }^{787}$ P. Egoume-Bossogo, C. Mendis, Trade and Integration in the Caribbean, International Monetary Fund (IMF) Working Paper, 2002, [WP/02/148], p. 11.
} 
efforts on strengthening their supply side constraints and enhancing their manufacturing base. This strategy could include an integrated approach to production, which was recommended to CARICOM Member States at the advent of regional integration in the Caribbean and is mindful of the small size of these economies. ${ }^{788}$ If such measures are undertaken, they might assist CARICOM LDCs in benefiting more from the CARICOM PTA in the future especially where the growth of intra-regional trade is concerned.

${ }^{788}$ A. Payne, The Political History of CARICOM (Ian Randle Publishers, 2008), p. 55. 
Table 10: CARICOM LDC Intra-regional Imports $2005-2010$ by percentages ${ }^{789}$

\begin{tabular}{|l|l|l|l|l|l|l|l|}
\hline & $\mathbf{2 0 0 5}$ & $\mathbf{2 0 0 6}$ & $\mathbf{2 0 0 7}$ & $\mathbf{2 0 0 8}$ & $\mathbf{2 0 0 9}$ & $\mathbf{2 0 1 0}$ & Total Avg. \\
\hline LDCs \% & 19.6 & 22.9 & 23.2 & 17.3 & 23.9 & 21.8 & 19.6 \\
\hline BELIZE & 0.6 & 0.6 & 0.5 & 0.4 & 0.6 & 0.6 & 0.5 \\
\hline OECS \% & 19.1 & 22.3 & 22.7 & 16.9 & 23.3 & 21.2 & 19.0 \\
\hline $\begin{array}{l}\text { Antigua } \\
\text { Barbuda }\end{array}$ & 3.4 & 3.7 & 1.9 & $\ldots$ & 2.3 & 1.6 & $\ldots$ \\
\hline Dominica & 2.2 & 2.4 & 2.4 & 2.0 & 2.2 & 2.2 & 2.2 \\
\hline Grenada & 3.8 & 3.2 & 4.6 & 3.2 & 3.8 & 4.2 & 3.9 \\
\hline Montserrat & 0.3 & 0.5 & 0.4 & 0.2 & 0.2 & 0.1 & 0.3 \\
\hline St. Kitts \& Nevis & 1.8 & 2.0 & 1.7 & 1.6 & 1.7 & 1.3 & 1.7 \\
\hline St. Lucia & 4.4 & 6.6 & 7.8 & 6.9 & 8.6 & 7.7 & 7.2 \\
\hline $\begin{array}{l}\text { St. Vincent and } \\
\text { the Grenadines }\end{array}$ & 3.2 & 3.9 & 3.8 & 2.9 & 4.6 & 4.1 & 3.8 \\
\hline
\end{tabular}

${ }^{789}$ Author's own compilation of LDC trade based on CARICOM Statistical Unit, CARICOM's Trade: A Quick Reference to Some Summary Data, 2005 - 2010 (Georgetown, Guyana, 2013), Table 2.3, Percentage Distribution of Intra-regional Imports by CARICOM Countries from 2005 to 2010, p. 31. 
Table 11: CARICOM LDC Intra-regional Domestic Exports $2005-2010$ by percentages ${ }^{790}$

\begin{tabular}{|l|l|l|l|l|l|l|l|}
\hline & $\mathbf{2 0 0 5}$ & $\mathbf{2 0 0 6}$ & $\mathbf{2 0 0 7}$ & $\mathbf{2 0 0 8}$ & $\mathbf{2 0 0 9}$ & $\mathbf{2 0 1 0}$ & Total Avg. \\
\hline LDCs \% & 4.0 & 3.7 & 4.9 & 3.0 & 5.9 & 4.3 & 4.1 \\
\hline BELIZE & 0.9 & 0.7 & 0.8 & 0.4 & 0.7 & 0.6 & 0.7 \\
\hline OECS \% & 3.1 & 2.9 & 4.1 & 2.7 & 5.2 & 3.7 & 3.4 \\
\hline $\begin{array}{l}\text { Antigua } \\
\text { Barbuda }\end{array}$ & 0.1 & $\ldots$ & 0.1 & $\ldots$ & 0.1 & 0.0 & $\ldots$ \\
\hline Dominica & 0.9 & 0.9 & 1.0 & 0.6 & 1.0 & 0.8 & 0.8 \\
\hline Grenada & 0.4 & 0.4 & 0.5 & 0.4 & 0.7 & 0.5 & 0.4 \\
\hline Montserrat & 0.0 & 0.0 & 0.0 & 0.0 & 0.0 & $\ldots$ & $\ldots$ \\
\hline St. Kitts \& Nevis & 0.0 & 0.1 & 0.1 & 0.1 & 0.2 & 0.1 & 0.1 \\
\hline St. Lucia & 0.8 & 0.8 & 1.4 & 0.8 & 1.4 & 1.2 & 1.0 \\
\hline $\begin{array}{l}\text { St. Vincent and } \\
\text { the Grenadines }\end{array}$ & 0.9 & 0.8 & 1.1 & 0.8 & 1.8 & 1.1 & 1.0 \\
\hline
\end{tabular}

${ }^{790}$ Author's own compilation of LDC trade based on Ibid, CARICOM Statistics Unit, 2013, Table 2.4, Percentage Distribution of Intra-regional Domestic Exports by CARICOM Countries from 2005 to 2010, p. 33. 
Table 12: CARICOM LDC Intra-regional Total Exports $2005-2010$ by percentages ${ }^{791}$

\begin{tabular}{|l|l|l|l|l|l|l|l|}
\hline & $\mathbf{2 0 0 5}$ & $\mathbf{2 0 0 6}$ & $\mathbf{2 0 0 7}$ & $\mathbf{2 0 0 8}$ & $\mathbf{2 0 0 9}$ & $\mathbf{2 0 1 0}$ & Total Avg. \\
\hline LDCs \% & 5.7 & 4.5 & 9.2 & 4.3 & 11.6 & 6.0 & 5.6 \\
\hline BELIZE & 0.9 & 0.7 & 0.8 & 0.4 & 0.6 & 0.6 & 0.6 \\
\hline OECS \% & 4.8 & 3.8 & 8.4 & 3.9 & 11.0 & 5.4 & 4.9 \\
\hline $\begin{array}{l}\text { Antigua } \\
\text { Barbuda }\end{array}$ & 1.0 & $\ldots$ & 0.9 & $\ldots$ & 4.5 & 0.2 & $\ldots$ \\
\hline Dominica & 0.9 & 0.8 & 0.9 & 0.6 & 0.9 & 0.9 & 0.8 \\
\hline Grenada & 0.5 & 0.5 & 0.5 & 0.4 & 0.7 & 0.5 & 0.5 \\
\hline Montserrat & 0.0 & 0.0 & 0.0 & 0.0 & 0.1 & $\ldots$ & $\ldots$ \\
\hline St. Kitts \& Nevis & 0.1 & 0.1 & 0.1 & 0.1 & 0.3 & 0.2 & 0.1 \\
\hline St. Lucia & 1.3 & 1.6 & 4.6 & 1.8 & 2.7 & 2.4 & 2.3 \\
\hline $\begin{array}{l}\text { St. Vincent and } \\
\text { the Grenadines }\end{array}$ & 0.9 & 0.8 & 1.4 & 1.1 & 1.9 & 1.1 & 1.2 \\
\hline
\end{tabular}

${ }^{791}$ Author's own compilation of LDC trade based on Ibid, CARICOM Statistics Unit, 2013, Table 2.5, Percentage Distribution of Intra-regional Total Exports by CARICOM Countries from 2005 to 2010, p. 34. 


\subsubsection{LDC Profile: The Grenada Nutmeg Industry}

A vivid illustration of the abovementioned economic shift was seen in Grenada in 2004 and 2005 with its nutmeg industry. Prior to 2004, Grenada was the second largest producer of nutmeg in the world, producing over $23 \%$ of world supply whilst Indonesia produced an estimated $73 \%{ }^{792}$ The nutmeg industry was an important source of employment and of the estimated 2004 population of 100,000 persons, about $30 \%$ relied on the industry as a source of income. ${ }^{793}$ In 2002, nutmegs constituted $22.5 \%$ of Grenada's total merchandise export and were principally exported to the EU where it was used in meat preservation and sausage making. ${ }^{794}$ However, Grenada was struck by hurricanes in both 2004 and 2005, which decimated $90 \%$ of its nutmeg trees and brought the nutmeg industry to an economic standstill. ${ }^{795}$ Many nutmeg farms were neglected and minimal production continued in the aftermath of the hurricanes. This had a palpable effect on the export trade in nutmegs as, 2,300 tonnes of nutmegs were exported in 2002 and only 200 tonnes were exported in $2009 .{ }^{796}$ This tonnage represented about $2 \%$ of world export at the time and although efforts are underway to revive the nutmeg industry, a short-term recovery is not anticipated. ${ }^{797}$ As of 2011, the production volumes for nutmeg were less than $15 \%$ of the 2004 levels. ${ }^{798}$ The main consequence of the decline of the nutmeg industry has been a shift in focus towards tourism and other services-oriented industries, which has been accompanied by its own vulnerabilities. ${ }^{799}$

\footnotetext{
${ }^{792}$ European Union All ACP Commodities Programme Caribbean Region/International Trade Center, Grenada Nutmeg Sector Development Strategy 2010-2015 (St. George's, Grenada, July 2010), p. 19.

${ }^{793}$ Ibid European Union All ACP Commodities Programme Caribbean Region/International Trade Center, 2010 , p. 24.

${ }^{794}$ Ibid European Union All ACP Commodities Programme Caribbean Region/International Trade Center, 2010, p. 19; WTO Secretariat, Trade Policy Review of the OECS- WTO Members, Report by the Secretariat (Geneva, 22 ${ }^{\text {nd }}$ September 2014) [WT/TPR/S/299/Rev.1], p. 166, para. 1.2.

${ }^{795}$ Ibid European Union All ACP Commodities Programme Caribbean Region/International Trade Center, 2010, p. 20; see also Inter-American Institute for Cooperation on Agriculture (IICA), Grenada 2005 Annual Report, The Contribution of IICA to the development of Agriculture and Rural Communities (Grenada, 2005), p. 9.

${ }^{796}$ Ibid European Union All ACP Commodities Programme Caribbean Region/International Trade Center, 2010 , p. 23.

${ }^{797}$ Ibid European Union All ACP Commodities Programme Caribbean Region/International Trade Center, 2010, p. 34; WTO Secretariat, Trade Policy Review of the OECS- WTO Members, Report by the Secretariat (Geneva, $22^{\text {nd }}$ September 2014) [WT/TPR/S/299/Rev.1], p. 166, para. 1.2.

${ }^{798}$ Ibid European Union All ACP Commodities Programme Caribbean Region/International Trade Center, 2010 , p. 35.

799 "The importance of the services sector in Grenada [has] increased [...] as the agriculture sector continued to shrink. This trend is more pronounced than in other OECS member states. [...] Services accounted for
} 


\subsubsection{LDC Profile: St. Kitts and Nevis}

Another example of this type of economic shift was seen with St. Kitts and Nevis, which previously relied upon its agriculture industry to provide $15.6 \%$ of annual GDP in the $1980 \mathrm{~s}$ but by 2004 only provided 5.2\% of annual GDP. During this time, the contribution of sugar exports to annual GDP fell from $9.2 \%$ in 1980 to $2.1 \%$ in $2004 .{ }^{800}$ The sugar industry represented a major source of rural employment, however, the decision was undertaken to end the export production of sugar due to high production costs and the unprofitable performance of the industry. ${ }^{801}$ Consequently, the 2005 sugar crop denoted not only the end of sugar export production, but also the end of a 350-year tradition: a tradition, which had blossomed under the British Caribbean colonial paradigm. ${ }^{802}$ A subsequent shift to trade in services has been increasingly noted as the sector grew in its contribution to annual GDP from $71.3 \%$ in 2007 to $78.4 \%$ in 2012. ${ }^{803}$ Between 2007 and 2012, agriculture contributed 1\% to GDP, which represented a decline from 3\% in 2005 when export production of sugar ceased. ${ }^{804}$ Such figures indicate that despite efforts to diversify the agricultural industry, there is still much stagnation, which can be contrasted with the visible growth in the services sector.

\subsubsection{LDC Profile: Dominica}

The case of Dominica also demonstrates the visible economic shift of its economy from a specialization in trade in goods to that of trade in services. ${ }^{805}$ Previously, Dominica's

slightly over 80\% of GDP in 2012 and 2013." WTO Secretariat, Trade Policy Review of the OECS- WTO Members, Report by the Secretariat (Geneva, $22^{\text {nd }}$ September 2014) [WT/TPR/S/299/Rev.1], p. 165, para. 1.1 .

${ }^{800}$ Inter-American Institute for Cooperation and Agriculture (IICA), St. Kitts and Nevis 2005 Annual Report, The Contribution of IICA to the development of Agriculture and Rural Communities (St. Kitts and Nevis, 2005), p. 12.

${ }^{801}$ Caribbean Development Bank (CDB), 2005 St. Kitts and Nevis Annual Economic Review (Bridgetown, Barbados, 2005), p. 92.

${ }^{802}$ Inter-American Institute for Cooperation and Agriculture (IICA), St. Kitts and Nevis 2005 Annual Report, The Contribution of IICA to the development of Agriculture and Rural Communities (St. Kitts and Nevis, 2005), p. 12.

${ }^{803}$ WTO Secretariat, Trade Policy Review of the OECS- WTO Members, Report by the Secretariat (Geneva, $18^{\text {th }}$ September 2014) [WT/TPR/G/299/Rev.1], p. 68, para. 1.2.

${ }^{804}$ Ibid, WTO Secretariat, 2014, p. 68, para. 2.1.

805 D. Mohammed, Size and Competiveness: An Examination of the CARICOM Single Market and Economy, The Roundtable, 2008, Vol. 97 (395), pp. 287-303, p. 294. 
comparative advantage was in the banana trade whereby its banana industry featured the typical model of export-oriented production for which the British Caribbean colonial paradigm was known. ${ }^{806}$ However, this has been severely affected by preference erosion, plant disease as well as reduced demand and significant adaptations have been undertaken. ${ }^{807}$ A concerted effort is now being made to diversify the agricultural portfolio of crops and focus has now been placed on non-banana crops such as plantains, citrus, root crops, herbs and spices in an attempt to maintain the agriculture industry, which still employs about an estimated $33 \%{ }^{808}$ of the labor force and in 2013 contributed $14.3 \%$ to GDP. ${ }^{809}$ The growth of trade in services has been a visible change in the Dominican economy, as in 1980 it accounted for less than 30\% of GDP and in 2013, it had grown to account for $68 \%$ of GDP. ${ }^{810}$

\subsection{Marginalization of LDCs?}

The previous analysis of intra-regional trade within the CARICOM PTA demonstrates that trade flows are skewed towards a few Member States ${ }^{811}$ and a few products. ${ }^{812}$ Coupled with relatively high transport costs, this has limited the potential for expanding regional trade to the extent where the CARICOM LDCs are able to extract meaningful benefits. ${ }^{813}$ Moreover, this is a possible response to the second subsidiary research question of this dissertation, which inquires why the CARICOM PTA has been unable to create greater intra-regional trade. As noted in Chapter 4 of this dissertation, the CARICOM LDCs (with the exception of Belize) have often viewed themselves as being marginalized in the grand scheme of regional integration in the Caribbean. Delay tactics were employed with regard

\footnotetext{
${ }^{806}$ A. Payne, The End of Green Gold? Comparative Development Options and Strategies in the Eastern Caribbean Banana-Producing Islands, Studies in Comparative International Development, 2006, Vol. 41 (3), pp. 25-46, p. 26.

${ }^{807}$ Inter-American Development Bank (IDB), Dominica: Private Sector Assessment Report, 2013 (Roseau, Dominica, 2013), p. 11; WTO Secretariat, Trade Policy Review of the OECS-WTO Members, Report by the Secretariat (Geneva, 22 ${ }^{\text {nd }}$ September 2014) [WT/TPR/S/299/Rev.1], p. 116, para. 1.2.

${ }^{808}$ WTO Secretariat, Trade Policy Review of the OECS-WTO Members, Report by the Secretariat (Geneva, $18^{\text {th }}$ September 2014) [WT/TPR/G/299/Rev.1], p. 45, para. 5.2.

${ }^{809}$ Inter-American Development Bank (IDB), Dominica: Private Sector Assessment Report, 2013 (Roseau, Dominica, 2013), p. 10.

${ }^{810}$ Ibid, IDB, 2013, p. 9.

${ }^{811}$ Trinidad \& Tobago, Jamaica, Barbados and to a lesser extent Guyana.

${ }_{812}^{812}$ Natural gas, petroleum, chemicals, construction equipment.

${ }^{813}$ Inter-American Development Bank (IDB)/Institute for Integration of Latin America and the Caribbean (INTAL), CARICOM Report Number 2, (Buenos Aires, Argentina, 2005), p. 21.
} 
to the signing of CARIFTA in 1965 and the CSM Agreement in 2006 until they were assured that special and differential treatment (SDT) would be accorded to them. ${ }^{814}$ Further to this, the Eastern Caribbean CARICOM LDCs have established several parallel entities alongside the main integration initiatives pursued by the wider CARICOM membership. In 1966, the West Indies Associated States (WIAS) was established to assist the LDC territories in safeguarding their interests and this eventually evolved into the Eastern Caribbean Common Market (ECCM) in $1968 .^{815}$ The ECCM was described as a negotiating and defence mechanism for the eastern Caribbean LDCs within CARIFTA and this was mainly intended to protect their interests given the vulnerabilities due to their small size and limited capacities. ${ }^{816}$

The ECCM endured despite the signing of the 1973 Original Treaty of Chaguaramas (OTC). The continued efforts of sub-regional integration has reflected the accepted need for the safeguarding of the Eastern Caribbean LDC interest and thus, the ECCM was eventually replaced by the OECS in 1981, which was established with the signing of the Treaty of Basseterre. ${ }^{817}$ The OECS has been successful in establishing several common institutions including the Eastern Caribbean Supreme Court (ECSC), the Eastern Caribbean Central Bank (ECCB) and the Eastern Caribbean Civil Aviation Authority

\footnotetext{
${ }^{814}$ See A. Payne, The Rise and Fall of Caribbean Regionalism, Journal of Common Market Studies, 1981, Vol. 19(3), pp. 255-280, p. 264. In this context, it should be noted that the special and differential provisions contained in the OTC were not entirely beneficial to the CARICOM LDCs. Article 56 of the OTC provided for the promotion of industrial development in the CARICOM LDCs and permitted the suspension of the common market tariff on imports for a temporary period of time. However, a majority decision including the affirmative vote of two MDCs was required to approve such suspensions and in many cases, the imports for which the suspensions were being sought were in fact imports from MDCs.

${ }^{815}$ See Agreement Establishing the Eastern Caribbean Common Market (adopted 11 June 1968, in force 1 July 1968) 1338 UNTS 55. See also West Indies Associated States in Chapter 4, Section 4.5 entitled The Issue of Constitutional Status.

${ }^{816}$ S. Nicolls, A. Birchwood, P. Colthrust, E. Boodoo, The State of and Prospects for the Deepening and Widening of Caribbean Integration, The World Economy, 2000, Vol. 23(9), pp. 1161-1194, p. 1162.

${ }^{817}$ The full members of the OECS are: Antigua and Barbuda, Grenada, St. Kitts and Nevis, St. Lucia, St. Vincent and the Grenadines and Montserrat. Anguilla and the British Virgin Islands are associate members of the OECS. "A strong impetus lay in the need for a harmonizing body to represent the interests of the smaller states in the [Caribbean] region, both with respect to the region and with respect to the outside world. Protectionism had started to emerge on the part of some of the larger Caribbean states and the OECS countries quickly realized that they needed a strong organization to protect their interest." D. Berry, Caribbean Integration Law (Oxford University Press, 2014), p. 25.
} 
(ECCAA). ${ }^{818}$ All of the full members of the OECS have used a common currency, the Eastern Caribbean Dollar (EC\$), since 1965. ${ }^{819}$ The OECS Secretariat is based in St. Lucia and there are OECS diplomatic missions accredited to the WTO in Geneva, Switzerland and to the European Union in Brussels, Belgium. Admittedly, much of these initiatives are of great practicality as the OECS countries are not only small in terms of land mass, but also in terms of population. ${ }^{820}$ As of July 2017, the CARICOM Member States of the OECS recorded the following population figures: Antigua and Barbuda - 94, 731, Dominica 73,897, Grenada - 111,724, St. Kitts and Nevis - 52,715, St. Lucia - 164,994, St. Vincent and the Grenadines - 102,089. ${ }^{821}$ Thus collectively speaking, the CARICOM Member States of the OECS account for slightly over 700,000 persons and in light of this, there is a strong rationale for pooled resources to be directed at the aforementioned joint institutions. ${ }^{822}$ In this vein, it has been submitted that one of the greatest benefits of the sub-regional approach to integration is pooling of limited resources for these microstates. $^{823}$

818 "Arguably, the OECS has [...] succeeded in several areas where CARICOM has either failed or is lagging behind. The lessons are that similarities of size and levels of development, a shared history of shared services, geographical and social proximity and a sense of community are powerful integrative forces that are absent or much weaker in the wider CARICOM grouping." N. Girvan, Caribbean Community: The Elusive Quest for Economic Integration in (eds.) K. Hall, M. Chuck-A-Sang, Regional Integration: Key to Caribbean Survival and Prosperity (Trafford Publishing, USA, 2012), p. 50.

${ }^{819}$ The Eastern Caribbean Economic and Currency Union is one of four currency unions in the world. The other three currency union are: the European Economic and Monetary Union, Central African Economic and Monetary Community and the West African Economic and Monetary Union. See A. Schipke, A. Cebotari, N. Thacker, The Eastern Caribbean Economic and Currency Union: Overview and Key Issues in (eds.) A. Schipke, A. Cebotari, N. Thacker, The Eastern Caribbean Economic and Currency Union: Macroeconomic and Financial Systems (International Monetary Fund, 2013), p. 3.

820 "The OECS's formation marked a qualitative stage in the regional integration movement, representing the formal differentiation of interests between the smaller Windward and Leeward islands within the broader Commonwealth Caribbean integration movement. The basis for this differentiation was their miniscule size, poor resource bases and relative poverty. It was the culmination of a long process that forced them to recognize a commonality of interests and served to develop what was considered to be an Eastern Caribbean identity." P. Lewis, Surviving Small Size: Regional Integration in Caribbean Mini-States (University of West Indies Press, Kingston Jamaica, 2002), p. 31.

${ }^{821}$ Sourced from the CIA World Fact book.

${ }^{822}$ This figure excludes the OECS associate members (British Virgin Islands, Anguilla and Martinique), which are not CARICOM Member States and are technically considered overseas departments/ territories of EU Member States. It also excludes Montserrat, which although it is a CARICOM Member State, but still an overseas territory of the UK and does not participate in the CSM.

${ }^{823}$ It has been asserted that the most beneficial element of the sub-regional integration process for the OECS is not increased intra-regional trade, but rather the achievement of economies of scale, risking sharing, the rationalization of the provision of public services, eliminating duplication of administrative structures and the better ability to represent the region in international forums. See A. Schipke, A. Cebotari, N. Thacker, The Eastern Caribbean Economic and Currency Union: Overview and Key Issues in (eds.) A. Schipke, A. 
The OECS countries signed the Revised Treaty of Basseterre (RTB) in 2010, which established the OECS Economic Union and is aimed at the further deepening of integration. ${ }^{824}$ This economic union is meant to facilitate a single financial and economic space with the freedom of movement of the four factors of production, the harmonization of monetary and fiscal policies and the adoption of a common approach to trade, health, education and environment. These initiatives are intended to complement efforts already undertaken at the CARICOM level. ${ }^{825}$ In 2011, the full free movement of persons commenced whereby OECS citizens are allowed to enter and remain in any OECS country for an indefinite period in order to live, work, establish businesses and provide services. ${ }^{826}$ Although comparisons have been made with the Benelux arrangement within the EU, these initiatives have invited commentary regarding whether the OECS countries view the prevailing CARICOM regimes as insufficient or ineffective. ${ }^{827}$

It also resurrects long held views about whether the CARICOM PTA has marginalized these particular LDCs to the point where they have sought an alternative arrangement whilst remaining within the CARICOM sphere. The existing status quo has resulted in parallel regional integration efforts, as the Revised Treaty of Basseterre provides for the establishment of a common customs tariff (CCT) to be levied on goods from outside of the Economic Union. ${ }^{828}$ Although the preamble of the Revised Treaty of Basseterre states that it is "mindful of obligations towards the wider grouping of the CSME", the CARICOM

Cebotari, N. Thacker, The Eastern Caribbean Economic and Currency Union: Macroeconomic and Financial Systems (International Monetary Fund, 2013), p. 5.

${ }^{824}$ It should be noted that the RTB consists of three regimes: the Revised Treaty of Basseterre establishing the Organization of Eastern Caribbean States, the Annex on the Settlement of Disputes and the Protocol of the Organization of Eastern Caribbean States Economic Union. See Article 24.1 of the RTB, which states: "The Dispute Settlement Annex and the Economic Union Protocol shall form an integral part of this Treaty." ${ }^{825}$ WTO Secretariat, Trade Policy Review of the OECS- WTO Members, Report by the Secretariat (Geneva, $18^{\text {th }}$ September 2014) [WT/TPR/G/299/Rev.1], p. 8, para. 12.

${ }^{826}$ Article 12.1 of the Protocol of the OECS Economic Union states: "Freedom of movement for citizens of Protocol Member States shall be secured within the Economic Union Area."

${ }^{827}$ Inter-American Development Bank (IDB)/Institute for Integration of Latin America and the Caribbean (INTAL), CARICOM Report Number 2, (Buenos Aires, Argentina, 2005), p. 11.

${ }^{828}$ Article 6 of the Protocol of the OECS Economic Union states: "The Common Customs Tariff will be set by or under the authority of an Act of the Organisation under Article 14.1(a) of this Treaty, provided that for any period when this tariff is not set the Common External Tariff under the Revised Treaty of Chaguaramas shall be the Common Customs Tariff. Protocol Member States may not impose higher tariffs than the Common Customs Tariff." 
Heads of Government agreed in 2013 to amend the RTC by way of a protocol, which would enable the CARICOM Member States of the OECS to pursue integration at a faster rate than the rest of CARICOM and underscored that this should not prejudice or remove any settled rights and obligations of other Member States pursuant to the RTC. ${ }^{829}$ It remains to be seen how this will affect the further unfolding of regional integration in the Caribbean and whether it will have any effects on intra-regional trade. ${ }^{830}$

\subsection{Principal Trading Partner}

The principal trading partner for all of the CARICOM Member States during the period of 1996 to 2001 was the USA. During this period, imports from the USA accounted for $43.6 \%$ of CARICOM's total imports and where exports are concerned, the USA was the principal export destination as it accounted for $36.9 \%$ of CARICOM exports. ${ }^{831}$ This trend was replicated during the period of 2005 to 2010 as imports from the USA accounted for $33 \%{ }^{832}$ of CARICOM's total imports and CARICOM exports to the USA accounted for $44.4 \%{ }^{833}$ The fluctuation in the aforementioned percentages for the two respective time periods was mainly attributable to changes in the petroleum and crude oil sector. ${ }^{834}$ Given this overview, it is argued that the CARICOM PTA does not facilitate the main trading relationship of all of the CARICOM Member States. This is partly attributed to the fact that most of the CARICOM Member States are NIDCs that are heavily reliant on imports for consumption purposes as it is inefficient to produce small quantities of products, which

\footnotetext{
${ }^{829}$ WTO Secretariat, Trade Policy Review of the OECS- WTO Members, Report by the Secretariat (Geneva, $18^{\text {th }}$ September 2014) [WT/TPR/G/299/Rev.1] p. 20, para. 4.14 .

${ }^{830}$ It is important to note that although the OECS arrangement has included a common market and the present plans to form an economic union, none of the OECS Treaties have been notified as PTAs at the WTO Secretariat.

${ }^{831}$ CARICOM Statistical Unit, CARICOM's Trade: A Quick Reference to Some Summary Data, 1996 - 2001, Fourth Edition (Georgetown, Guyana, December 2005), p. 4.

${ }^{832}$ CARICOM Statistical Unit, CARICOM's Trade: A Quick Reference to Some Summary Data, 2005 - 2010 (Georgetown, Guyana, 2013), p. 9.

${ }_{833}^{83}$ Ibid, CARICOM Statistical Unit, 2013, p. 12.

${ }^{834}$ It is important to note the dominance of Trinidad and Tobago in the oil and petroleum sector. A large percentage of CARICOM exports to the USA consist of petroleum, petroleum-related products and methanol. Conversely, a large percentage of CARICOM imports from the USA consist of oil and petroleum, which are sent to Trinidad and Tobago for refining purposes. During the period of 2005 to 2010, both imports and exports in this sector were affected by increased US production of crude petroleum and declining world oil prices. Additionally, where Jamaica is concerned, there was decrease in trade for fuel ethanol due to developments in the global sugar markets. See Office of the United States Trade Representative, $11^{\text {th }}$ Report to United States Congress on the Operation of the Caribbean Basin Economic Recovery Act (Washington D.C. USA, $30^{\text {th }}$ December 2015), p. 12.
} 
they demand. ${ }^{835}$ In addition to this, the CARICOM Member States have previously resisted calls to diversify their economies away from the monoculture export-oriented model that was introduced under the British Caribbean colonial paradigm. Again, this represents a possible response to the second subsidiary research question of this dissertation, which inquires why the CARICOM PTA has been unable to create significant intra-regional trade.

Furthermore, this statistical overview supports the prevailing view that the small domestic markets in CARICOM have inhibited the growth of economies of scale, which coupled with high production costs have resulted in limited diversification of goods produced. ${ }^{836}$ These high production costs have limited CARICOM's ability to compete on international markets. ${ }^{837}$ This has served to further entrench dependence on the export of a few primary commodities, which has been accompanied by increased exposure to terms of trade risk. ${ }^{838}$ All of the CARICOM Member States with the exception of Suriname are beneficiary countries under the Caribbean Basin Initiative (CBI), which includes two USA preferential trade programs: the Caribbean Basin Economic Recovery Act (CBERA) and the USCaribbean Basin Trade Partnership Act (CBTPA). Under CBERA preferences, CARICOM exports to the USA are granted unilateral, duty-free treatment provided that they meet the eligibility criteria outlined in the CBERA Act. ${ }^{839}$ Under the CBTPA preferences, recognition is given to apparel as a prominent component in the exports sent to the USA. Duty-free and quota-free treatment is applied to apparel made in the Caribbean Basin region provided that they are inter alia made from US fabrics formed from US yarns and

${ }^{835}$ See World Bank/Organization of American States, co-produced with the Governments of the CARIFORUM Countries, Poverty Reduction and Economic Management Sector Unit, Latin America and Caribbean Region, The Caribbean: Accelerating Trade Integration, Policy Options for Sustained Growth, Job Creation and Poverty Reduction (December 2008), Introduction, p. 64, para. 4.5.

${ }^{836}$ Ibid, World Bank/Organization of American States, co-produced with the Governments of the CARIFORUM Countries, Poverty Reduction and Economic Management Sector Unit, Latin America and Caribbean Region, 2008, Introduction, p. 11, para. 1.30.

${ }^{837}$ Ibid, World Bank/Organization of American States, co-produced with the Governments of the CARIFORUM Countries, Poverty Reduction and Economic Management Sector Unit, Latin America and Caribbean Region, 2008, Introduction, p. 11, para. 1.30.

${ }^{838}$ Ibid, World Bank/Organization of American States, co-produced with the Governments of the CARIFORUM Countries, Poverty Reduction and Economic Management Sector Unit, Latin America and Caribbean Region, 2008, Introduction, p. 19, para. 1.42.

${ }^{839}$ See GATT Secretariat, Caribbean Basin Economic Recovery Act (Geneva, 14 ${ }^{\text {th }}$ November 1983) [L/5577]. CBERA entered into force on $5^{\text {th }}$ August 1983 and 13 CARICOM Member States are CBERA beneficiary countries: Antigua and Barbuda, Barbados, Belize, Dominica, Grenada, Haiti, Jamaica, St. Kitts and Nevis, St. Lucia, St. Vincent and the Grenadines, Trinidad and Tobago, the Bahamas and Guyana. 
cut in the USA. ${ }^{840}$ As of 2013, the only seven CARICOM Member States were designated eligible beneficiaries of the CBTPA: Barbados, Belize, Guyana, Haiti, Jamaica, St. Lucia and Trinidad and Tobago. ${ }^{841}$

As previously noted, Trinidad and Tobago has been the lead exporter under the CBI since 2005 with export trade amounting to 1.2 Billion USD in 2014. Most of Trinidad and Tobago's exports to the USA were petroleum and related products as well as methanol. $55 \%$ of Trinidad and Tobago's exports of these products entered the USA under CBI preferences. ${ }^{842}$ Most of the CARICOM Member States have maintained a healthy trade relationship with the USA. Haiti has been the second leading source of exports to the USA under the $\mathrm{CBI}^{843}$ and Jamaica has been the third leading source of exports to the USA under the CBI ${ }^{844}$ Belize also featured as exporting $82.3 \%$ of its exports ${ }^{845}$ to the USA under CBI tariff preferences. ${ }^{846}$ Conversely, USA exports to the CBI beneficiary countries amount to 19 Billion USD in 2012. This monetary figure represented $1.4 \%$ of total US exports in 2012 and the CBI region ranked as the $19^{\text {th }}$ USA export destination in $2012 .{ }^{847}$ It is notable that the Bahamas, Trinidad and Tobago, Jamaica and Panama ${ }^{848}$ accounted for almost $80 \%$ of USA exports to the CBI region in 2012. Most of these USA exports consisted of petroleum products, aircraft, rice, wheat, chicken cuts, cellphones and corn. ${ }^{849}$

\footnotetext{
${ }^{840}$ Office of the United States Trade Representative, $10^{\text {th }}$ Report to United States Congress on the Operation of the Caribbean Basin Economic Recovery Act (Washington D.C. USA, $31^{\text {st }}$ December 2013), p. 3.

${ }^{841}$ The CBTPA entered into force on $1^{\text {st }}$ October 2000.

${ }^{842}$ Office of the United States Trade Representative, $10^{\text {th }}$ Report to United States Congress on the Operation of the Caribbean Basin Economic Recovery Act (Washington D.C. USA, $31^{\text {st }}$ December 2013), p. 13.

${ }^{843}$ Since 2009, Haiti has been the second leading source of US imports. $96 \%$ of these imports were listed as apparel. See Office of the United States Trade Representative, $11^{\text {th }}$ Report to United States Congress on the Operation of the Caribbean Basin Economic Recovery Act (Washington D.C. USA, 30 ${ }^{\text {th }}$ December 2015), p. 13.

${ }^{844}$ These exports consisted mainly of fuel ethanol.

${ }^{845}$ These exports consisted mainly of orange concentrate and papayas.

${ }^{846}$ Office of the United States Trade Representative, $10^{\text {th }}$ Report to United States Congress on the Operation of the Caribbean Basin Economic Recovery Act (Washington D.C. USA, $31^{\text {st }}$ December 2013), p. 13.

${ }^{847}$ Ibid, Office of the United States Trade Representative, 2013, p. 14.

${ }^{848}$ As of $31^{\text {st }}$ October 2012, Panama is no longer a CBI beneficiary country. This date also coincided with the entry into force of the United States - Panama Trade Promotion Agreement.

${ }^{849}$ Office of the United States Trade Representative, $10^{\text {th }}$ Report to United States Congress on the Operation of the Caribbean Basin Economic Recovery Act (Washington D.C. USA, $31^{\text {st }}$ December 2013), p. 14.
} 


\subsection{European Union Trade}

The EU was the second principal trading partner for CARICOM Member States during the period under review. Between 1996 and 2001, imports from the EU accounted for 13.1\% of total CARICOM imports and as the third principal export destination, exports to the EU accounted for $17.3 \%$ of exports. ${ }^{850}$ Most of the exports to the EU market were commodities exported under trade preferences and this demonstrates the continued impact of the remnants of colonial trade policy. For the period of 2005 to 2010, the imports from the EU market placed fourth and accounted for $10.7 \%$ of CARICOM's total imports. ${ }^{851}$ Exports to the EU market amounted to $13.7 \%$ of CARICOM's total exports and ranked as the third principal export destination. ${ }^{852}$ It is argued that the decrease in exports to the EU market reflects the preference erosion, which has affected CARICOM's relationship with the EU in recent times. Despite this, the main CARICOM exports to the EU market between 2005 and 2010 were as follows: mineral fuels, lubricants and related materials, food and live animals, agricultural commodities, chemicals and related products and crude materials. ${ }^{853}$ A more detailed analysis of the trade flows between CARICOM and the EU also demonstrated that the focus was on exports. The CARICOM MDCs such as Trinidad and Tobago, Jamaica and Barbados sourced more imports from the EU; however, the LDCs on average only imported $2 \%$ to $4 \%$ of their annual imports from the EU. This trend remained during the period of 2005 to 2010 .

\footnotetext{
${ }^{850}$ CARICOM Statistical Unit, CARICOM's Trade: A Quick Reference to Some Summary Data, 1996-2001, Fourth Edition (Georgetown, Guyana, December 2005), p. 4.

${ }^{851}$ CARICOM Statistical Unit, CARICOM's Trade: A Quick Reference to Some Summary Data, 2005 - 2010 (Georgetown, Guyana, 2013), p. 9.

${ }_{852}^{85}$ Ibid, CARICOM Statistical Unit, 2013, p. 12.

${ }^{853}$ Ibid, CARICOM Statistical Unit, 2013, p. 200
} 


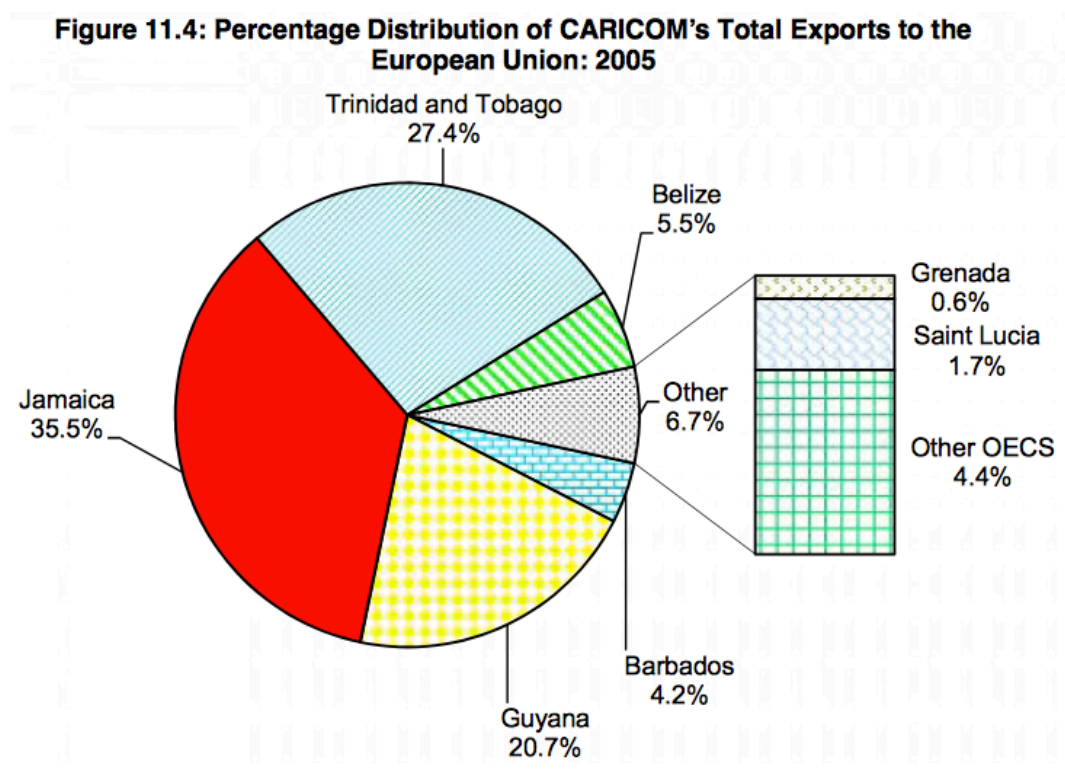

Chart 5 - Source: Ibid, CARICOM Statistical Unit, 2013, Figure 11.4, Percentage Distribution of CARICOM's Total Exports to the EU in 2005, p. 197.

Figure 11.5: Percentage Distribution of CARICOM's Total Exports to the European Union: 2010

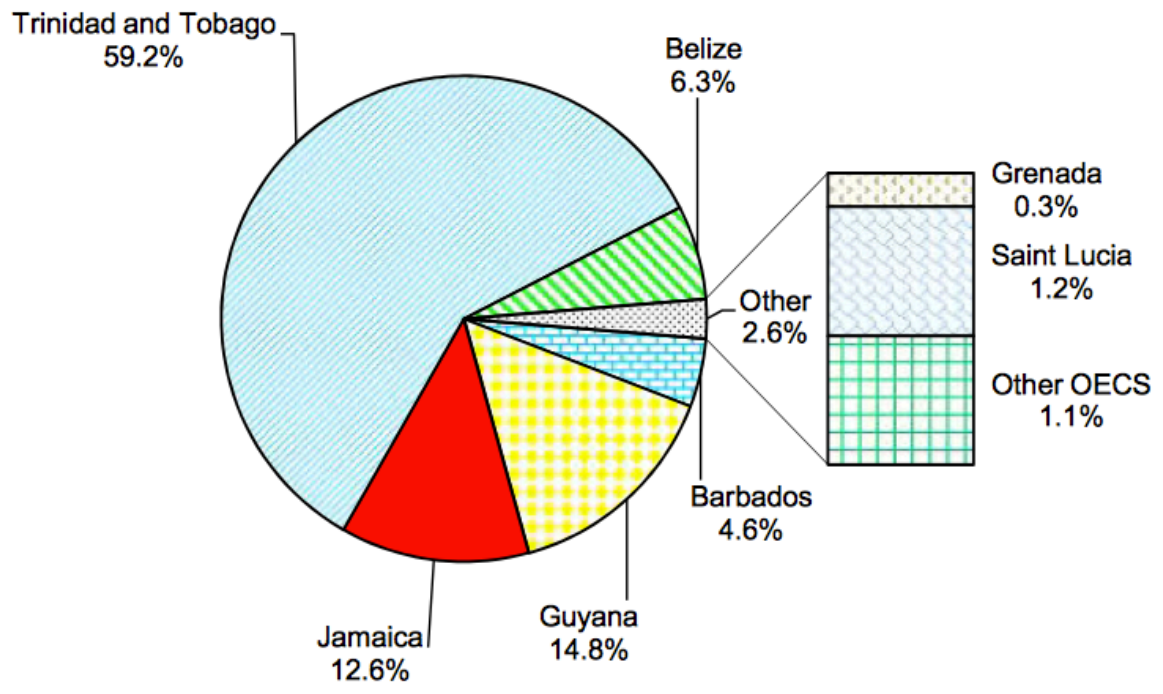

Chart 6 - Source: Ibid, CARICOM Statistical Unit, 2013, Figure 11.5, Percentage Distribution of CARICOM's Total Exports to the EU in 2010, p. 197. 


\subsection{Trade Diversion}

There are no indications that the CARICOM PTA has created trade diversion. The previously illustrated limited intra-regional trade in goods has not resulted in a notable shift from a more efficient non-PTA third country supplier to a less efficient intra-PTA supplier for any of the major trade segments recorded by the CARICOM Statistics Unit. Trinidad and Tobago is one CARICOM Member State that has achieved a measure of economic dominance in the crude oil and gas industry and this is evidenced by its trade receipts not only in the intra-PTA context, but also with third countries such as the USA, the Russian Federation and Gabon. Hence, it has experienced trade expansion as opposed to creating trade diversion. Most CARICOM economies are still primary product economies or services dominant economies and few have achieved economies of scale in any given industry. The overall trading pattern exhibited has been for CARICOM Member States to maintain substantial import and export trade with non-PTA third countries such as the USA, EU and to a minor extent other countries such as Canada due to their NIDC status.

\subsection{Conclusion}

Chapter 5 demonstrates that even though the CARICOM PTA has satisfied the legal requirements of GATT Article XXIV, its subsequent trade data illuminates that limited trade creation and limited furthering of welfare gains have been generated since. One of the main reasons for this is the continuance of policies enacted under the British Caribbean colonial paradigm. Although limited diversification away from export oriented agricultural trade is finally underway, the shift to an emphasis on services trade is accompanied by its own risks. It is clear that the dominant player in the CARICOM PTA is Trinidad and Tobago whose trade receipts serve to uplift most of the CARICOM intra-regional trade data. If Trinidad and Tobago were to be extracted from the data set, the intra-regional trade statistics of the CARICOM PTA would accentuate that the remaining CARICOM Member States have limited trade with each other. Various factors such as small size, inability to achieve economies of scale and the lack of trade-able goods have been noted as contributing to the continued inability of the CARICOM PTA to stimulate intra-regional trade. Nevertheless, this dissertation submits that GATT Article XXIV does not constitute a legal obligation to create trade and as such, the lack of significant trade creation by the 
CARICOM PTA has not violated any substantive WTO rule. Further chapters of this dissertation will demonstrate that where the overall purview of regional integration in the Caribbean is concerned, the CARICOM PTA might be challenged with intra-regional trade creation, however, it has provided significant non-trade related benefits for its PTA constituents, which will be explored in Chapters 6 and 7 of this dissertation. 


\section{CHAPTER 6}

Case Study on Belize

\section{Introduction}

Chapter 6 is the first chapter of Part III of this dissertation and it continues the regional focus on the Caribbean Community (CARICOM) preferential trade agreement (PTA) by observing some of its non-trade related benefits. Chapter 6 presents a case study that explores the issue of motivation for PTA membership and demonstrates how non-trade related benefits can motivate countries to enter a trade agreement. An examination is undertaken into the issues that motivated Belize, a country with strong colonial ties to the United Kingdom (UK), to seek membership in the CARICOM PTA. It also underlines how the British Caribbean colonial paradigm impacted Belize's policy thinking on CARICOM trade policy. By delving into the issue of motivation, Chapter 6 utilizes Belizean and Caribbean history books alongside journals as well as several interviews to demonstrate how non-trade related benefits can serve as pull factors influencing the policy decision to pursue PTA membership.

In pure economic and normative terms, a policy decision to join a PTA should be motivated primarily by the pursuit of trade creation and increased economic welfare. ${ }^{854}$ However, such considerations are rarely the motivations for participating in a PTA, as many are driven by non-trade related motivations. ${ }^{855}$ The European Economic Community (EEC), North American Free Trade Agreement (NAFTA) and the Southern Common Market (MERCOSUR) were driven by non-economic motivations such as the locking in of domestic policy reforms to make policy reversals difficult to undertake by subsequent governments, the prevention of the reoccurrence of war in Europe ${ }^{856}$ and the bolstering of political stability between fragile democracies. ${ }^{857}$ Although the aforementioned PTAs were

\footnotetext{
${ }^{854}$ WTO Secretariat, World Trade Report 2011, (Geneva, 2011), p. 9.

${ }^{855}$ See non-trade related goals in Chapter 1, Section 1.7 entitled PTA Motivation.

${ }^{856}$ The preamble to the 1951 Treaty of Paris, which established the ECSC, makes clear mention that it was aimed at "creating a deeper Community among peoples long divided by bloody conflict."

${ }^{857}$ Other stated PTA motivations include the promotion of democracy and human rights, regional cooperation and coordination and involvement as a defensive necessity against economic isolation. M. Schiff, L. Winters, Regional Integration and Development (World Bank/Oxford University Press, 2003), p. 9; N. Limao, Are Preferential Trade Agreements with Non-Trade Objectives a Stumbling Bloc for Multilateral Liberalization, The Review of Economic Studies, 2007, Vol. 74 (3), pp. 821-855.
} 
driven by non-trade related motivations, they nevertheless resulted in a significant volume of trade creation. Therefore, the motivations that drive a PTA can prove to be of minor import where actual PTA trade creation is concerned.

\subsection{Scope of Case Study}

This case study investigates the motivation that underpinned the policy decision of Belize to seek membership in the CARICOM PTA in 1974. Undertaken within the wider quest for independence, this policy decision is of relevance to the central research question of this dissertation because Belize's status as a British colony under the British Caribbean colonial paradigm influenced its policy approach to regional integration in the Caribbean. It is argued that political concerns exhibited greater importance than economic concerns. The actual cultivation of trade between Belize and the other CARICOM Member States was not a primary concern due to the fact that the direction of majority of Belize's global trade was already skewed towards export markets in the UK. Thus, Belize was able to contextualize its policy decision to seek membership in the CARICOM PTA for the political gains to be had versus the limited economic losses.

Also highlighted in this case study is the distinctiveness of Belize as a CARICOM Member State. Belize was one of the last CARICOM Member States to attain independence from the UK. ${ }^{858}$ Further to this, Belize and the Organization of Eastern Caribbean States (OECS) CARICOM Member States have been legally designated as the lesser-developed countries (LDCs) under Article 4 of the Revised Treaty of Chaguaramas (RTC). ${ }^{859}$ However, the OECS Member States have long enjoyed a sub-regional unity and the collective strength derived by their common history of being Associated States of the UK as well as Members of the Eastern Caribbean Common Market (ECCM). Thus, Belize holds the distinction of being the sole CARICOM LDC outside of the OECS and outside an intra-CARICOM

\footnotetext{
${ }^{858}$ Belize attained its independence in 1981 and St. Kitts and Nevis, the last CARICOM Member State to attain independence, did so in 1983.

${ }^{859}$ Article 4 of the RTC defines Belize and the 6 OECS Member States as LDCs. Chapter 7 of the RTC is entitled "Disadvantaged Countries, Regions and Sectors" and constitutes a chapter of special and differential treatment provisions that are available to the CARICOM LDCs to assist them in adjusting to the full implementation of the CARICOM single market and economy. The LDC classification is based on economic size, structure and vulnerability. See Associated States in Chapter 4, Section 4.5 entitled The Issue of Constitutional Status. See also The OECS in Chapter 5, Section 5.5 entitled Marginalization of LDCs?
} 
coalition, as the CARICOM more-developed countries (MDCs) tend have to shared interests that are pursued in the wider CARICOM intergovernmental negotiation and decision-making process.

As previously noted, the Belize policy decision to seek membership in the CARICOM PTA was driven by non-trade related motivations. These were born out of political expediency related to the quest for independence. It is still arguable whether Belize has benefited from CARICOM PTA membership in the long term, as its involvement has not yielded much traditional trade gains. Despite over forty years of membership, Belize has not adapted its trade policy to fully capitalize on CARICOM market access and trade flows between Belize and the rest of CARICOM remain minimal. ${ }^{860}$ The United States of America (USA) remains the primary trading partner of Belize where both imports and exports are concerned. $^{861}$ The UK also remains the second largest export market. Therefore, involvement in the CARICOM PTA has not altered the trading pattern of Belize. Given the normative aims of GATT Article XXIV, the legal provision under which the CARICOM PTA was notified to the WTO Secretariat, it is argued that membership in the CARICOM PTA should have positively affected the trade flow of Belize towards the CARICOM intra-regional trade market. In this regard, however, the provision of trade preferences, initially linked with the British Caribbean colonial paradigm, has been a determining influence on the direction of trade flows. ${ }^{862}$ It, therefore, contributed to Belize viewing the CARICOM intra-regional trade market as a secondary concern when compared with the primary export markets of the UK and also contributed to a lack of urgency in attempts to cultivate CARICOM intra-regional trade.

\footnotetext{
${ }^{860}$ WTO Secretariat, Belize Trade Policy Review, Report by the Secretariat (Geneva, 17 ${ }^{\text {th }}$ March 2017) [WT/TPR/S/353], p. 21, chart 1.2.

${ }^{861}$ Ibid, WTO Secretariat, 2017, p. 21, para. 1.3.2.

${ }^{862}$ Commencing in 1951, Belize became a recipient of UK trade preferences under the Commonwealth Sugar Agreement (CSA) and post-1975, Belize received trade preferences under the Lome Convention. V. BulmerThomas, The Economic History of the Caribbean since the Napoleonic Wars (Cambridge University Press, 2012), p. 311, 313. See also Recipients of the CSA in Chapter 4, Section 4.3.2 entitled A Formalized Cycle of Economic Dependence. Further to this, Belize is a recipient of trade preferences under the United States Caribbean Basin Economic Recovery Act (CBERA), which commenced in 1984.
} 
Since Belize joined the CARICOM PTA, the regional integration initiative has evolved from a common market and now exists as a customs union that features a single market with plans to establish a single economy. ${ }^{863}$ The RTC established the CARICOM Single Market (CSM) as well as 'The Community', which has been endowed with juridical personality. As a result of its juridical personality, 'The Community' has pursued several bilateral trade agreements on behalf of the CARICOM Member States. ${ }^{864}$ Many of the bilateral trade agreements have not been favorable to the CARICOM LDCs, which possess smaller economies and limited production bases. The CARICOM LDC rate of utilization of these PTAs has been negligible. ${ }^{865}$ It, therefore, begs the question whether the Government of Belize (GoB) should reframe its relationship with CARICOM with a view to capitalizing on the opportunities provided therein. This case study argues that new policy options that holistically consider the CSM should be undertaken in an attempt to garner more economic welfare gains from the CARICOM PTA.

\subsection{Case Study Research Question}

The primary enquiry of this case study is what motivated Belize to join the CARICOM PTA and in investigating this, the case study will demonstrate that political considerations were paramount when the policy decision was undertaken. It is also argued that such policy decisions are more complex in developing countries with colonial ties. Belize, which was still a British colony at the time, had to contend with the various ways in which the British Caribbean colonial paradigm affected various areas of its policymaking. As noted in Chapter 4 of this dissertation, the colonial origins of the Caribbean impacted various facets

\footnotetext{
${ }^{863}$ By 1974, CARIFTA had already evolved into the Caribbean Community and Common Market. Furthermore, several independent CARICOM Member States had already joined the GATT: Trinidad and Tobago joined the GATT on $23^{\text {rd }}$ October 1962. Jamaica joined the GATT on $31^{\text {st }}$ December 1963. Later, Barbados joined the GATT on $15^{\text {th }}$ February 1967. Therefore, it is submitted that there was an increased awareness in the Caribbean of the rules-based approach to multilateral trade and this is evidenced by efforts to coordinate the policy positions of the then independent CARICOM Member States for the Kennedy Round of GATT multilateral trade negotiations, which commenced in 1964. See Communique issued at the $2^{\text {nd }}$ Conference of Heads of Government of the Commonwealth Caribbean Countries, $13^{\text {th }}-17^{\text {th }}$ January 1964, Kingston, Jamaica.

${ }^{864}$ CARICOM has negotiated bilateral trade agreements with Columbia, Cuba, Costa Rica, Venezuela and the Dominican Republic.

${ }^{865}$ In this regard, it is noted that Belize has only ratified the bilateral agreements with Costa Rica and Cuba. The others have yet to be ratified. See WTO Secretariat, Belize Trade Policy Review, Report by the Secretariat (Geneva, $17^{\text {th }}$ March 2017) [WT/TPR/S/353], p. 7, para. 6. See also CARICOM LDC trade flows in Chapter 5, Section 5.4 entitled CARICOM LDCs and Intra-regional trade: 1996-2010.
} 
of life including the very governance of the British Caribbean territories. The issue of sovereignty was intertwined with the decision of Belize to join the CARICOM PTA, as CARICOM membership was viewed as part and parcel of the thrust towards independence from the UK. Although geographically located in Central America, Belize shares more commonalities with the former British Caribbean island territories that constitute CARICOM than with its mainland Central American neighbors. ${ }^{866}$ This case study will demonstrate how Belize was able to capitalize on these commonalities in order to advance its quest for independence.

\subsection{Limitations}

The case study is divided into two time periods. The first time period examines the historical context of the pre-independence decision of Belize to join the CARICOM PTA and references events that occurred in the 1930s spanning to the attainment of independence in 1981. The events discussed in this section are contextualized solely as they relate to the escalation of the Guatemalan claim to Belize and their ensuing effects on the formulation of a Belizean policy response, which ultimately included a pivot to membership in the CARICOM PTA. The second time period examines the postindependence era since 1981 to the present day. In this context, the evolution of the CARICOM PTA is referenced and the level of participation in the CARICOM PTA is addressed. The examination of the level of participation is limited to the approach taken towards (i) attempts to cultivate a sense of CARICOM identity in Belize, (ii) attendance at regional meetings, (iii) key policy issues and (iv) implementation of regional decisions. In addition to this, a statistical picture of trade in goods between Belize and the CARICOM intra-regional market is outlined for the time period of $2003-2014$. This reflects the time period utilized by the Statistical Institute of Belize (SIB), however, data from the CARICOM Statistics Unit is also utilized. ${ }^{867}$

\footnotetext{
${ }^{866}$ These commonalities include inter alia the English language; the Westminster system of parliamentary government and the (English) Common Law based legal system.

${ }^{867}$ The statistical review will be limited to trade in goods, which is the most mature aspect of Belizean trade relations with CARICOM and data is more readily available. The documenting of trade in services is a recent development in Belize and reliable data is challenging to obtain.
} 


\subsection{Theoretical Framework}

This case study utilizes a realist theoretical framework, which argues that the Belizean policy decision to participate in the CARICOM PTA was mainly informed by selfpreservation. ${ }^{868}$ Therefore, Belize should continue to act in order to maximize its best interests within the CARICOM PTA and such actions extend to the maximization of economic welfare. As previously noted, PTAs can be driven by varying motivations including inter alia traditional trade gains, the strengthening of domestic policy reform, increased multilateral bargaining power and strategic linkages. ${ }^{869}$ This case study argues that several of these motivations are first best policy options available to large developing and developed countries with diversified economies that can afford such considerations prior to the formulation of a policy decision to participate in a PTA. Many of these motivations were not considerations for Belize in its policy decision to participate in the CARICOM PTA due to the complexities brought about by strong colonial ties with the UK and the Guatemalan territorial claim.

The policy decision of Belize to join the CARICOM PTA fits the realist mold, as it was based on the very survival of the then UK colony in the face of a pressing threat by a militarily superior neighboring country, Guatemala. ${ }^{870}$ The policy thinking of Belize gave recognition to a core concept of the realist philosophy of statism, which asserts that the state is the primary actor in international affairs. ${ }^{871}$ As a UK colony, Belize was not endowed with state authority or sovereignty and thus, the pivot to the CARICOM PTA

\footnotetext{
${ }^{868}$ Hans Morgenthau is considered one of the fathers of modern realism and his publication of Politics Among Nations espoused much of the $19^{\text {th }}$ Century understandings the theory. One of the main realist assumptions revolves around the idea that the most basic motive driving the behavior of states is their survival. It is imperative to note that realism has been associated with classical thinkers including inter alia Thomas Hobbes, Niccolo Machiavelli and Thucydides. See J.J. Mearsheimer, The False Promise of International Institutions, International Security, 1994, Vol. 19 (3), pp. 5-49, p.10; See also K. Waltz, Theory of International Politics (Waveland Press, 2010), p. 91.

${ }^{869}$ See PTA motivations in Chapter 1, Section 1.7 entitled PTA Motivation.

870 "Guatemala's claim to the entire territory of Belize led to serious national security threats as Belize advanced towards independence. Guatemala's invasion threats led to Belize arranging a British security guarantee at the time of its independence in 1981." I. Griffith, The Quest for Security in the Caribbean: Problems and Promises in Subordinate States (Routledge, 2015), p. 69.

871 "According to realists, the state is the main actor and sovereignty is its distinguishing trait. By identifying the state as the central actor in international politics, the survival of the state is the overriding object of national security." B. Schmidt, The Primacy of National Security in (eds.) S. Smith, A. Hadfield, T. Dunne, Foreign Policy: Theories, Actors, Cases, Third Edition (Oxford University Press, 2016), p. 209.
} 
allowed Belize to rely on the voice of the independent CARICOM Member States to amplify its concerns on the international plane regarding its quest for independence and the Guatemalan claim to its territory. ${ }^{872}$

In light of the aforementioned, it is submitted that the policy decision to seek membership in the CARICOM PTA also represented a way for Belize to advance its interest of achieving greater support for its independence in order to manifest its own understandings of self-determination. ${ }^{873}$ This was seen as the most optimal way to ensure that Belize would continue to exist with its territory intact. ${ }^{874}$ The policy thinking of Belize recognized the complexities involved in this situation. Firstly, the Belize internationalization campaign that commenced in 1975 was fully cognizant that Guatemala possessed superior military capacity, which it had threatened to use on several occasions. As such, Belize pressed for a defense guarantee from the UK. Secondly, in pressing for a defense guarantee, Belize firmly recognized that the UK was a great world power with economic and military might to defend its (soon to be former) colony. Thus, there was recognition that the UK possessed the ability to act decisively in the event of any conflict. ${ }^{875}$

The Belize policy decision also demonstrated a shift to institutionalism under the belief that cooperation could represent a rational, self-interested strategy to pursue given the conditions engendered by the Guatemalan claim. ${ }^{876}$ In light of the history of CARIFTA and the subsequent ideals formulated prior to the signature of the Original Treaty of Chaguaramas (OTC), the CARICOM PTA was defined by a set of rules, norms, practices

\footnotetext{
${ }^{872}$ See Section 7.6.3 entitled Political Pivot to CARICOM.

${ }^{873}$ In 1960, the United Nations recognized the yearning for independence on the part of dependent peoples and colonial powers were encouraged to end colonialism in all of its manifestations. See United Nations Secretariat, Declaration on the Granting of Independence to Colonial Countries and Peoples, UNGA Resolution 1514 (XV) (New York, 14 ${ }^{\text {th }}$ December 1960) [A/RES/1514(XV).

${ }^{874}$ See J.J. Mearsheimer, The False Promise of International Institutions, International Security, 1994 , Vol. 19 (3), pp. 5-49, p. 10.

875 "The British presence is intended to defend Belize against Guatemalan aggression, assist in training the Belize Army, gather intelligence on Central American development and help with disaster relief. [...] Belize does have a military establishment, but it is too small to be effective against the much better armed and trained Guatemalans. I. Griffith, The Quest for Security in the Caribbean: Problems and Promises in Subordinate States (Routledge, 2015), p. 69; See J. Baylis, S. Smith, P. Owens, The Globalization of World Politics, Seventh Edition (Oxford University Press, 2016), p. 106.

${ }^{876}$ See R. Keohane, After Hegemony: Cooperation and Discord in the World Political Economy (Princeton University Press, 1984), p. 54.
} 
and decision-making procedures that shaped some of the expectations of regional integration in the Caribbean and aided in overcoming some of the uncertainty that can undermine intergovernmental cooperation. ${ }^{877}$ It is argued that since Belize achieved its end goal of independence in 1981, it should act in accordance with the core institutionalist principle, which asserts that countries belonging to common institutions like PTAs must interact with the same partners repeatedly and this provides an incentive to comply with agreements in the short term so as to extract benefits in the long term. ${ }^{878}$

\subsection{Methodology}

This case study recognizes that the Belize policy decision to seek membership in the CARICOM PTA was undertaken in a political atmosphere characterized by the weakening of the British Caribbean colonial paradigm, as decolonization in the wider British Caribbean had already commenced. Alongside this, there was the individual Belizean quest for independence and a territorial claim to Belize by Guatemala. Consequently, a historical assessment of several events related to the Guatemalan claim to Belize is undertaken in order to establish a causal link between them and Belizean policy thinking. Belizean and Caribbean history books are used to contextualize this policy decision in the historical context of the latter years of decolonization in the British Caribbean region and emphasis is placed on the internationalization campaign of Belize. ${ }^{879}$ The case study also employs the use of other secondary sources such as CARICOM Secretariat documents, GATT Secretariat documents, United Nations Secretariat documents, Central Bank of Belize policy papers and international law journals. ${ }^{800}$ These secondary sources assist in

\footnotetext{
${ }^{877}$ The practice of countries pooling their decision-making by creating community institutions to secure their achieved outcomes in the face of future uncertainty has been noted as one of the assumptions of liberal intergovernmentalism. See W. Mattli, The Logic of Regional Integration: Europe and Beyond (Cambridge University Press, 1999), p. 6; A. Moravcsik, Preferences and Power in the European Community: A Liberal Intergovernmentalist Approach, Journal of Common Market Studies, 1993, Vol. 31(4) pp. 473-524, p. 501.

${ }^{878}$ See R. Keohane, After Hegemony: Cooperation and Discord in the World Political Economy (Princeton University Press, 1984), 97.

${ }^{879}$ E. Lauterpacht, S. Schwebel, S. Rosenne, F. Orrego Vicuna, Government of Belize Legal Opinion on Guatemala's Territorial Claim to Belize (November 2001); A. Shoman, Belize's Independence and Decolonization in Latin America: Guatemala, Britain and the UN (Palgrave MacMillan, 2010); A. Shoman, A History of Belize in 13 Chapters, $2^{\text {nd }}$ Edition (Angelus Press, Belize, 2011); A. Payne, A Political History of CARICOM (Ian Randle Publishers, 2008); P. Thomson, Belize: A Concise History (Macmillan Publishers Limited, 2004).

${ }^{880}$ R. Willard, "How to get less than you bargain for: Adjudicating the Guatemala - Belize territorial dispute at the ICJ" Emory International Law Review, 2009, Vol. 23, pp. 739 - 782; K. Wiegand, "Nationalist
} 
establishing the aforementioned causal link between the circumstances surrounding the Guatemalan claim to Belize and the Belize decision to seek diplomatic support from the Caribbean countries as a non-trade related benefit of joining the CARICOM PTA.

Primary data collected through six semi-structured interviews with state and non-state actors as well as former state actors also assisted the analysis provided in this case study. These interviews were conducted between December 2013 and January 2014. The persons interviewed were selected to reflect the perspectives of the public, private and political sectors as they dealt with matters relating to the broad involvement of Belize in the CARICOM PTA from both a foreign policy perspective and an international trade perspective. The primary data collected served to support much of the insights received from the use of the aforementioned secondary data and affirmed that political considerations underpinned the decision to seek membership in the CARICOM PTA. Much of the primary data also reinforced the notion that Belize is not proactively engaging in the CARICOM PTA and that improvements are required in this regard. Additionally, the issue of public education on the overall aims of regional integration in the Caribbean was identified as a necessary component in the efficient use of Belize's membership in the CARICOM PTA. All of the interviews were held on a face-to-face basis and were held on an attributable basis. Notes were written for these interviews and are included in the annex of the case study along with the case study interview guide. Statistical data from the SIB and the CARICOM Statistics Unit is also used to support the arguments relating to volumes of trade and the main import and export destinations of Belizean trade.

\subsection{Country Profile of Belize}

Belize is a former British colony located on the eastern coast of the Central American mainland. It is bordered on the north by Mexico, on the south and west by Guatemala and on the east by the Caribbean Sea. It is the only English-speaking country on the Central American mainland. As of July 2017, the estimated population is $360,346 .{ }^{881}$ The Belizean

Discourse and Domestic Incentives to prevent settlement of the Territorial Dispute between Guatemala and Belize" Nationalism and Ethnic Politics, 2005 Vol. 11(3) pp. 349-383.

${ }^{881}$ CIA World Fact book, July 2017 
economy has evolved from a monoculture economy based on agriculture to a diversified economy based on tourism services, agriculture and crude oil. In the 1980s, the Belizean economy was dominated by exports of sugar, citrus and bananas, which were the main source of annual GDP growth. ${ }^{882}$ Much of the growth from agricultural trade can be attributed to the British and eventually European trade preferences granted to sugar and banana exports. ${ }^{883}$ The latter underscores the previously noted point that direction of Belize's main trade flow was skewed towards the UK export market mainly due to the previous structures, which were in place due to the policies of the British Caribbean colonial paradigm. Agriculture accounted for $22 \%$ of exports in the $1980 \mathrm{~s}$, however, agricultural exports eventually declined as a result of a combination of natural disasters and the advent of preference erosion. ${ }^{884}$

In recent years, tourism has emerged as a key economic contributor to the Belizean economy and the sector accounted for $20 \%$ of GDP in 2010, which can be contrasted with its $6 \%$ contribution in $1985 .^{885}$ The Belizean economy features a limited production base that has led to reliance on imported manufactured goods and there is still economic reliance on the export of agricultural products such as sugar, citrus, bananas and marine products. ${ }^{886}$ Efforts are underway to further diversify the Belizean export basket of goods with the development of several non-traditional products including papayas, honey and pepper products, however, these currently account for a minimal contribution to overall exports. ${ }^{887}$

\footnotetext{
${ }^{882}$ Y. Metzgen, Belize: 30 Year Retrospect and the Challenges Ahead (Central Bank of Belize, September 2012), p. 5.

883 "British entry into the European Economic Community (EEC) in 1973 meant that Belize's preferences were now determined under the EEC's Lome Convention, applicable to all former and current European colonies rather than determined bilaterally between Belize and the UK." V. Bulmer-Thomas, The Economic History of the Caribbean since the Napoleonic Wars (Cambridge University Press, 2012), p. 313.

${ }^{884}$ Y. Metzgen, Belize: 30 Year Retrospect and the Challenges Ahead (Central Bank of Belize, September 2012), p. 5.

${ }^{885}$ Ibid, Y. Metzgen, 2012, p. 6; WTO Secretariat, Belize Trade Policy Review, Report by the Secretariat (Geneva, 17 $7^{\text {th }}$ March 2017) [WT/TPR/S/353], p. 8, para. 14.

${ }^{886}$ WTO Secretariat, Belize Trade Policy Review, Report by the Secretariat (Geneva, $17^{\text {th }}$ March 2017) [WT/TPR/S/353], p. 8, para. 11.

${ }^{887}$ WTO Secretariat, Belize Trade Policy Review, Report by the Secretariat (Geneva, $23^{\text {rd }}$ November 2010) [WT/TPR/G/238/Rev.1], p. 8, para. 19.
} 


\subsubsection{The Guatemalan Territorial Claim}

This case study argues that the Belizean policy decision to join CARICOM in 1974 was motivated by political concerns that were linked to the Guatemalan territorial claim to Belize. ${ }^{88}$ The historical background to the territorial claim revolves around the Guatemalan contention that the 1859 Anglo-Guatemalan Convention ${ }^{889}$ (1859 Convention) was a treaty of cession ${ }^{890}$ whereby the UK was given territory that was previously held by Guatemala. It has been argued that the UK and Guatemala had different views regarding the 1859 Convention from the very beginning. ${ }^{891}$ Nevertheless, it remains undisputed that by early 1859 , the UK had not proclaimed explicit sovereignty over Belize and the boundaries of Belize have not been re-defined by any treaty since the Anglo-Spanish treaties of 1783 and $1786 .{ }^{892}$ It is the view of Guatemala that the UK failed to fulfill its obligations under the Convention and this breach entitled Guatemala to treat the Convention as terminated. As such, the territory now known as Belize should revert in ownership to Guatemala. ${ }^{893}$ Belize has always maintained that it considers the 1859 Convention to be a boundary treaty and has argued that the International Court of Justice (ICJ) principle expounded in the Case concerning the Territorial Dispute between Libyan Arab Jamahiriya/Chad (Libya/Chad case) ${ }^{894}$ that "a boundary once established by treaty,

\footnotetext{
${ }^{888}$ To date, the Guatemalan territorial claim to Belize remains unresolved. This case study attempts to present the facts regarding the territorial claim in a contextualized way as it relates to CARICOM's support of Belize in internationalizing the issue of the territorial claim. The effect of the territorial claim in delaying the independence of Belize is also examined.

${ }^{889}$ The Convention between Her Majesty and the Republic of Guatemala, relative to the Boundary of British Honduras.

${ }^{890}$ The definition of cession in the Concise Oxford Dictionary reads as follows: "The formal giving up of rights, property or territory by a state."

891 "As far as the British were concerned, the [1859] boundary treaty simply gave de jure recognition to a de facto situation. But Guatemala saw its acceptance of the Convention as a cession of territory that had to be disguised as Britain was precluded from acquiring territory in the area by the Clayton Bulwer Treaty of 1850 and for which the construction of the road by Britain was compensatory." C. H. Grant, The Making of Modern Belize: Politics, Society and British Colonialism in Central America (Cambridge University Press, 1976), p. 32.

${ }^{892}$ R. A. Humphreys, The Diplomatic History of British Honduras 1638 - 1901 (Oxford University Press, 1961), p. 59.

${ }^{893}$ See E.R. Willard, "How to get less than you bargain for: Adjudicating the Guatemala - Belize territorial dispute at the ICJ" Emory International Law Review, 2009, Vol. 23, pp. 739 - 782, p. 740.

${ }^{894}$ Case concerning the Territorial Dispute between Libyan Arab Jamahiriya/Chad, Judgment of $3{ }^{\text {rd }}$ February 1994, ICJ Reports 1994.
} 
possesses a legal life of its own, independent of the fate of the treaty" is applicable to this case. $^{895}$

Furthermore, the 1859 Convention makes mention of a boundary between Guatemala and British Honduras ${ }^{896}$ (present day Belize) in its Article I. ${ }^{897}$ The Convention provided for the demarcation of the boundary and free navigation in the channels forming the water line of the boundary as per Articles II - V. Both parties agreed to establish the easiest communication between the Capital of Guatemala and the fittest place on the Atlantic Coast near the settlement of Belize as per Article VII. ${ }^{898}$ It is the view of Guatemala that Article VII of the 1859 Convention provided for the construction of a cart road from Guatemala City to the nearest point on the Guatemalan coast, which was to be partly funded by the UK. Guatemala has alleged that the non-performance of the UK in this regard entitled it to unilaterally terminate the 1859 Convention. ${ }^{899}$ Thus, Guatemala considers the

\footnotetext{
${ }^{895}$ E. Lauterpacht, S. Schwebel, S. Rosenne, F. Orrego Vicuna, Government of Belize Legal Opinion on Guatemala's Territorial Claim to Belize (November 2001), p. 11, para. 15.

${ }^{896}$ For the sake of clarity and consistency, this case study employs the use of the name Belize. However, it should be noted that from 1862 to 1973, the territory of Belize was known as British Honduras. The official name change occurred in 1973. A. Shoman, Belize's Independence and Decolonization in Latin America: Guatemala, Britain and the UN (Palgrave MacMillan, 2010), p. 1.

897 "It is agreed between Her Britannic Majesty and the Republic of Guatemala that the boundary between the Republic and the British settlement and Possessions in the Bay of Honduras, as they existed previous to and on the 1st day of January, 1850, and have continued to exist up to the present time, was and is as follows $[\ldots]$ It is agreed and declared [...] that all the territory to the north and east of the line of boundary above described, belongs to her Britannic Majesty; and that all the territory to the south and west of the same belongs to the Republic of Guatemala"

898 "With the object of practically carrying out the views set forth in the preamble of the present Convention, for improving and perpetuating the friendly relations which at present so happily exist between the two High Contracting Parties, they mutually agree conjointly to use their best efforts, by taking adequate means for establishing the easiest communication (either by means of a cart-road, or employing the rivers, or both united, according to the opinion of the surveying engineers), between the fittest place on the Atlantic Coast, near the settlement of Belize, and the capital of Guatemala; whereby the commerce of England on the one hand, and the material prosperity of the Republic on the other, cannot fail to be sensibly increased, at the same time that the limits of the two countries being now clearly defined, all further encroachments by either party on the territory of the other will be effectually checked and prevented for the future."

899 "In [the 1859] treaty, both parties agreed to Article VII, in which the two states would develop a road from Guatemala City to the Caribbean Sea as a means to improve trade and general relations between the two countries. In 1933, joint commissioners placed concrete markers on the boundary, as established in the 1859 treaty, but in 1940, Guatemala officially revived its claim for British Honduras by declaring the 1859 treaty null and void, alleging that the British never implemented Article VII by failing to build the interstate road to the sea." K. Wiegand, "Nationalist Discourse and Domestic Incentives to prevent settlement of the Territorial Dispute between Guatemala and Belize", Nationalism and Ethnic Politics, 2005 Vol. 11(3) pp. 349-383, p. 353.
} 
treaty invalid and the cession of territory (Belize) also invalid. Therefore, Belize should now revert to Guatemala. ${ }^{900}$

\subsubsection{Guatemalan Efforts regarding the Territorial Claim}

This case study argues that intransigence on the part of Guatemala played a key role in the political pivot of Belize towards regional integration in the Caribbean. Belize was compelled to engage in a delicate balancing act, as it was still economically dependent on the UK whilst pressing for its political independence at a time when its geographical neighbors were opposed to its full autonomy. Beyond simply voicing its claim over Belize, Guatemala published a White Book in 1939 that outlined its territorial claim to Belize. Thereafter, Guatemala sought and received Latin American support for its cause. ${ }^{901}$ In 1945, Guatemala instituted a constitutional amendment that declared Belize as a part of its territory and espoused the view that it was in the national interest to reincorporate Belize back into the Guatemalan Republic. ${ }^{902}$ At the time, the UK insisted that the Guatemalan claim was unfounded and refused to be drawn into negotiations on the matter. ${ }^{903}$

In 1955, the first meeting of Central American Foreign Ministers issued a unanimous decision that supported the Guatemalan territorial claim to Belize. ${ }^{904}$ The 1960s saw many CARICOM Member States achieve their independence, however, Belize remained a UK colony. The Belizean political class noted the decolonization process that unfolded

\footnotetext{
${ }^{900}$ E. Lauterpacht, S. Schwebel, S. Rosenne, F. Orrego Vicuna, Government of Belize Legal Opinion on Guatemala's Territorial Claim to Belize (November 2001), p. 9, para. 7; P. Thomson, Belize: A Concise History (Macmillan Publishers Limited, 2004), p. 166.

${ }^{901}$ Ministry of Foreign Affairs of Guatemala, The White Book: Controversy between Guatemala and Great Britain Relative to the Convention of 1859 on Territorial Matters: Belize Question (1938).

${ }^{902}$ Constitution of the Republic of Guatemala, "Disposiciones Transitorias", Articulo 1, "Guatemala declara que Belize es parte de su territorio, y considera de interes nacional las gestiones encaminadas a lograr su effectiva reincorporacion a la Republica" (1 $1^{\text {th }}$ March 1945); P. Thomson, Belize: A Concise History (Macmillan Publishers Limited, 2004), p. 166.

${ }_{903}$ Given the timing of the Guatemalan constitutional amendment in 1945, much of the attention of the international community was focused on the Second World War. It was not until the 1960s long after imperial nations were encouraged to grant independence to their colonies that the UK agreed to engage in diplomatic negotiations with Guatemala as well as with the US, as regional hegemon, in an attempt to resolve the territorial claim and eventually grant Belize its independence. A. Shoman, Belize's Independence and Decolonization in Latin America: Guatemala, Britain and the UN (Palgrave MacMillan, 2010), p. 6.

${ }^{904}$ The first meeting of Ministers of Foreign Affairs of Central America was held on $18^{\text {th }}$ August 1955 and issued the 1955 Declaration of Antigua whereby Guatemala garnered Central American support for its territorial claim to Belize.
} 
throughout the British Empire and clamored for the same. ${ }^{905}$ In 1964, Belize was granted internal self-government and consequently, Guatemala issued a diplomatic protest by downsizing its diplomatic representation in London from an embassy to a consulate in order to emphasize its displeasure. ${ }^{906}$ In 1964, Guatemala succeeded in its efforts at the Organization of American States (OAS) to have its view reflected in the Act of Washington, which amended the OAS Charter. ${ }^{907}$ This rule of admission meant that Belize and Guyana were not permitted to join the OAS until their respective territorial disputes were resolved. ${ }^{908}$ In this regard, it should be noted that the regional Latin American bloc had its reservations to all of the CARICOM Member States joining the OAS. The main issue of contention that was expressed at the time was the perceived incompatibility of CARICOM's (preference-based) trade systems and political affiliations. ${ }^{909}$ Nevertheless, CARICOM Member States recognized the geopolitical import of OAS membership and still pursued its membership ambitions.

\subsubsection{Political Pivot to CARICOM}

As a consequence of the Guatemalan territorial claim to Belize and the Latin American support for Guatemala, it is submitted that Belize leaned towards the CARICOM Member States for political support in its quest for independence and for assistance in internationalizing its view on the Guatemalan territorial claim. ${ }^{910}$ As noted earlier, Belize shares several commonalities with the CARICOM Member States, as most were former British colonies, which were governed under the British Caribbean colonial paradigm.

\footnotetext{
905 Jamaica was granted independence on 6th August 1962 and Trinidad and Tobago was granted independence on 31st August 1962.

${ }^{906}$ R.P. Barston, Modern Diplomacy, $4^{\text {th }}$ Edition (Routledge, 2014), p. 286.

${ }^{907}$ Paragraph 3 of the Act of Washington stated that "no political entity can be admitted to the OAS whose territory in whole or in part, is subject, prior to the date of this resolution, to litigation or claim between an extra-continental country and one or more member state of the OAS, until the dispute has been ended by some peaceful procedure."

${ }^{908}$ In another longstanding territorial dispute in the American hemisphere, Venezuela claims ownership over two-thirds of Guyanese territory.

${ }^{909}$ Latin American countries viewed CARICOM membership in the OAS with a certain level of suspicion given their historical ties with the UK, their eventual signature of the Lome Convention with the EEC in 1975 and the possible extra-territorial influence that it could result from it. See C. Thomas, J. Magloire, Regionalism versus Multilateralism: The OAS in a Global Changing Environment (Springer Science and Business Media, 2000), p. 46.

${ }^{910}$ A. Shoman, Belize's Independence and Decolonization in Latin America: Guatemala, Britain and the UN (Palgrave MacMillan, 2010), p. 79.
} 
Consequently, they are English speaking countries, which feature the Westminster system of parliamentary government and the (English) common law based legal system. The initial idea regarding the pursuit of independence for Belize was to firstly, resolve the territorial claim and secondly, pursue independence from the UK with Belizean territory fully intact. However in 1969, there was a shift in strategy due to Guatemalan inflexibility and it was decided that Belizean independence would be sought without a resolution of the territorial claim. $^{911}$

The Belizean authorities sought a defense arrangement with the UK or other countries as a security measure in the event of Guatemalan aggression. ${ }^{912}$ It is important to note that the Guatemalan position at this time was that the territorial claim should be resolved before any change in the constitutional status of Belize. The diplomatic support of CARICOM was crucial to the aforementioned Belizean strategy change. Moreover, Belize did not actively pursue its internationalization initiative until 1975 and commenced it with the aim of pressuring the UK into providing a defense guarantee. ${ }^{913}$ It should be mentioned that the UK was not opposed to granting Belize its independence, but it was heavily opposed to providing the much coveted defense guarantee. ${ }^{914}$ Successive UK governments from 1966 to 1979 echoed this policy. ${ }^{915}$

\footnotetext{
${ }^{911}$ A. Shoman, A History of Belize in 13 Chapters, $2^{\text {nd }}$ Edition (Angelus Press, Belize, 2011), p. 70.

912 The defense arrangement was seen as a necessity given that Guatemala had previously issued threats to use force in order to preserve its so-called rights. Ibid, Shoman, 2011, p. 70.

${ }^{913}$ Ibid, Shoman, 2011, p. 231.

914 "By 1960, Britain's determination to shed its colonies ... became inexorable. That is when Britain signaled to Belize its readiness, indeed its desire, to discard its imperial mantle there, changing the decolonization movement in that colony from standard anti-colonial struggle against the metropole to one focused on removing the remaining obstacle to independence, the Guatemalan claim and requiring Belizean leaders to concentrate on the international environment, which was then heavily affected by Cold War politics." A. Shoman, Belize's Independence and Decolonization in Latin America: Guatemala, Britain and the UN (Palgrave MacMillan, 2010), p. 6.

915 “[Prime Minister Harold] Wilson's second government (1966 - 1970) enunciated to Belize its policy of no defense guarantee after independence. [Prime Minister Edward] Heath's Conservative government (1970 - 1974) maintained this policy." Ibid, Shoman, 2010, p. 10.
} 


\subsubsection{CARICOM and the International Community}

The then independent CARICOM Member States undertook efforts to shine the international spotlight on the Guatemalan territorial claim to Belize. ${ }^{916}$ In March 1973 at a special meeting of the United Nations Security Council (UNSC) held in Panama, Guyana spoke in defense of Belize and invited the UNSC to note the Guatemalan territorial claim. ${ }^{917}$ On $1^{\text {st }}$ May 1974, Belize formally joined CARICOM and consequently Guatemala issued a formal protest against this decision. ${ }^{918}$ In July 1974 at the first meeting of the Heads of Government of CARICOM, there was a denunciation of all policies that would impede Belizean independence and a pledge of support to assist Belize in achieving independence whilst securing and preserving its sovereignty. ${ }^{919}$ In this regard, it is clearly demonstrated that Belize derived the non-trade benefit of political solidarity and increased bargaining power on the international plane. The economic benefits of Belize's membership in the CARICOM PTA were less clear-cut and this will be examined further in Section 6.8.2 of this chapter. ${ }^{920}$

\subsubsection{The Question of Belize at the United Nations}

The issue of Belize's independence guaranteed by a Commonwealth commitment was tabled at the May 1975 Commonwealth Heads of Government Meeting (CHOGM) that was held in Jamaica. ${ }^{921}$ In a show of diplomatic support, the CARICOM Member States pressed for the UK to provide a defense to assure the territorial integrity of Belize. ${ }^{922}$ At

\footnotetext{
916 The independent CARICOM Member States championed the cause of Belize and consistently publicized the territorial dispute at international gatherings where Belize lacked diplomatic voice and status since it was still a self-governing colony of the UK.

${ }^{917}$ A. Shoman, A History of Belize in 13 Chapters, $2^{\text {nd }}$ Edition (Angelus Press, Belize, 2011), p. 233.

${ }^{918}$ Ibid, Shoman, 2011, p. 233.

${ }^{919}$ Ibid, Shoman, 2011, p. 233.

920 "Belize joined the newly formed Caribbean Community (CARICOM) in 1974, but this had very little [economic] impact because such a small part of the country's exports went to the other member states (trade links with Central America were even less important)." V. Bulmer-Thomas, The Economic History of the Caribbean since the Napoleonic Wars (Cambridge University Press, 2012), p. 313; See also Section 6.8.2 entitled Statistical Picture of Intra-regional Trade.

921 A. Shoman, A History of Belize in 13 Chapters, $2^{\text {nd }}$ Edition (Angelus Press, Belize, 2011), p. 231.

922 The 1975 CHOGM Communiqué stated "The Heads of Government offered their full support for the aspirations of the people of Belize for early independence. Noting that talks had recently been resumed with Guatemala, and bearing in mind the special responsibilities of Britain as the administering power, the Heads of Government urged the parties to take all necessary action for a speedy solution to the problem, which could be endorsed by the international community through the United Nations, in accordance with the principle of the self-determination of peoples as enshrined in the Charter of the United Nations".
} 
the Thirtieth Session of the United Nations General Assembly (UNGA) in 1975, the CARICOM Member States also supported the passage of UNGA resolution 3432 on the Question of Belize, which reaffirmed Belize's inalienable right to self-determination and independence with all its territorial integrity preserved. ${ }^{923}$ UNGA resolution 3432 also ventilated the fact that the UK was prepared to grant Belize its independence, however, the main stumbling block was the Guatemalan territorial claim. ${ }^{924}$

From the period of 1975 to 1980, the UNGA resolution on the Question of Belize was passed and with each passing year the resolution gained more supporting votes including votes from Latin American countries. CARICOM Member States provided an immeasurable source of diplomatic assistance and Guatemala was eventually marginalized in its insistence on the territorial claim to Belize. ${ }^{925}$ In November 1980, the UNGA resolution on the Question of Belize called for the independence of Belize within a year and subsequent political maneuvering meant that Belize would proceed to independence. ${ }^{926}$ Belize was eventually granted independence on $21^{\text {st }}$ September $1981 .^{927}$

Commonwealth Secretariat, Communique issued at the conclusion of the Commonwealth Heads of Government Meeting, Kingston, Jamaica, $29^{\text {th }}$ April $-6^{\text {th }}$ May 1975, p. 4, para. 16.

${ }^{923}$ UNGA Resolution 3432 on the Question of Belize was passed on $8^{\text {th }}$ December 1975 during the $2431^{\text {st }}$ Plenary Meeting of the UNGA. The voting breakdown was as follows: 110 votes in favor, 9 against, 16 abstentions. It is notable that Cuba was the only Latin American country to support the resolution as all the others voted against it.

${ }_{924}$ UNGA Resolution 3432 stated "Bearing in mind the repeated assurances by the Government of the UK, as the administering Power, that it standing ready, in accordance with resolution 1514 to take the formal steps necessary for Belize to exercise its rights to self-determination and independence."

925 "Belize was [eventually] admitted to the UN four days after its independence with a near unanimous General Assembly vote. Only Guatemala voted not to admit Belize. At this time, Guatemala also broke off consular relations with the UK and closed its border with Belize." E.R. Willard, "How to get less than you bargain for: Adjudicating the Guatemala - Belize territorial dispute at the ICJ" Emory International Law Review, 2009, Vol. 23, pp. $739-782$, p. 744.

926 "2. Declares that Belize should become an independent State before the conclusion of the thirty-sixth session of the General Assembly." UN Secretariat, Resolution 35/20, 57 ${ }^{\text {th }}$ Plenary Meeting (New York, $11^{\text {th }}$ November 1980) [A/RES/35/20].

927 "When Belize gained independence on $21^{\text {st }}$ September 1981, Guatemala announced that it would not recognize its sovereignty and that the territory belonged to Guatemala, which was being held illegally by Belize." K. Wiegand, "Nationalist Discourse and Domestic Incentives to prevent settlement of the Territorial Dispute between Guatemala and Belize" Nationalism and Ethnic Politics, 2005 Vol. 11(3) pp. 349-383, p. 353. 


\subsection{Post-Independence: Level of Involvement in CARICOM}

As noted in Chapter 4 of this dissertation, the original vision of regional integration in the Caribbean was political in nature, however, certain global events heralded a policy shift and regional integration efforts adopted an economic perspective with the signing of CARIFTA in $1965 .{ }^{928}$ By 1974 when Belize joined the CARICOM PTA, it was a common market. ${ }^{929}$ Despite the economic focus of the CARICOM PTA, Belize still endeavored to join for the geopolitical reasons outlined in the previous section. ${ }^{930}$ It is argued that Belize was able to focus on the geopolitical advantages to be gained from the CARICOM PTA because much of its trade flows were already skewed towards the UK export market due to policies implemented under the British Caribbean colonial paradigm. Therefore, the effects of the British Caribbean colonial paradigm impacted Belize's approach to CARICOM trade policy and Belize's view on the importance of attempting to cultivate trade within the CARICOM arrangement. The next sections of this case study demonstrate that the post-independence level of participation in the CARICOM PTA exhibited by Belize has been less than stellar. This disconnect is glaring when it is considered that this is the only custom union agreement that Belize has signed. Given the tariff coordination requirements as well as the harmonization of other policies, it is submitted that Belize should place more emphasis on its involvement in the CARICOM PTA. The evolution of the CARICOM PTA into a customs union in the form of a single market and an impending single economy has rendered it costly for Belize to ignore it.

\subsubsection{Long Term Economic View}

A customs union is regarded as one of the deepest forms of economic integration as it features inter alia a common trade policy and a common external tariff. ${ }^{931}$ The most vivid

\footnotetext{
${ }^{928}$ See GATT Secretariat, Caribbean Free Trade Agreement, Notification Pursuant to Article XXIV: 7(a) (Geneva, 22 ${ }^{\text {nd }}$ October 1968) [L/3074].

929 See GATT Secretariat, Treaty Establishing the Caribbean Community (Geneva, 14 ${ }^{\text {th }}$ October 1974) [L/4083].

${ }^{930}$ This case study submits that the underlying motivation of the Belizean pivot to CARICOM was the garnering of support to secure independence from the UK. The Belize internationalization campaign highlighted that the CARICOM foreign policy coordination machinery proved effective in advancing the Belize position on the Guatemalan territorial claim.

931 "A customs union is defined as an agreement between members of a group of countries to remove tariffs levied by each other on imports from the others, while establishing a tariff at common rates on imports into the member countries from non-member countries. It is to be distinguished from a free trade area, which
} 
illustration of a customs union is the European Union (EU), which operates a single market among its 28 Member States and shares a common currency among the 19 Members of the Eurozone. Many elements of the neofunctionalist approach to regional integration have been visible with the manner in which European regional integration has unfolded. ${ }^{932}$ Since the EU operates under the tenets of supranationality, the operation of its customs union requires that EU Member States cede a greater amount of state autonomy than is required with a free trade area (FTA). Perhaps as a result of this, countries have been less inclined to participate in customs unions and this is substantiated by the fact that the majority of the PTAs notified at the WTO are FTAs as opposed to customs unions. ${ }^{933}$

The concept of 'spillover' has been noted in various frameworks on regional integration and is associated with the unintended expansion of policy issues covered by the process of regional integration. ${ }^{934}$ For the CARICOM Member States, a significant portion of the deeper economic policies associated with regional integration are still forthcoming as the CARICOM single economy has not yet been implemented. With respect to the implementation of the CSM, the legal and administrative arrangements to facilitate the movement of the four factors of production and the harmonization of tariffs constitute the main framework of policies that are currently being pursued. Belize has complied with these requirements and was able to implement the CSM in 2006. However, it is noted a

allows members to fix their own separate tariff rates on imports from non-members, though they remove tariffs on trade among themselves." H. G. Johnson, The Economic Theory of Customs Union in (eds.) J. Bhagwati, P. Krishna, A. Panagariya, Trading Blocs: Alternative Approaches to Analyzing Preferential Trade Agreements (MIT Press, 1999), p. 142.

932 See J. Caporaso, Regional Integration Theory: Understanding our past and anticipating our future, Journal of European Public Policy, 1999, Vol. 5(1), pp. 1-16, p. 8; P. Schmitter, Ernst B. Haas and the Legacy of Neofunctionalism, Journal for European Public Policy, 2005, Vol. 12(2), pp. 255-272, p. 257.

${ }^{933}$ Of the numerous PTAs notified at the WTO Secretariat, only 17 are customs unions: the European Union, the Central American Common Market, the Caribbean Community, the Andean Community, the EU-Andorra Customs Union, the Southern Common Market, the Economic Community of West African States, the Common Market for Eastern and Southern Africa, the EU-Turkey Customs Union, the Eurasian Economic Community, the Russian Federation-Belarus-Kazakhstan Customs Union, the Economic and Monetary Community of Central Africa, the West African Economic and Monetary Union, the East African Community, the EU-San Marino Customs Union, the Gulf Cooperation Council and the Southern Africa Customs Union.

934 J. Wunderlich, Regionalism, Globalization and the International Order: Europe and Southeast Asia (Ashgate, 2007), p. 7; See L. Lindberg, The Political Dynamics of European Economic Integration (Standford University Press, 1963); See J. Caporaso, Regional Integration Theory: Understanding our past and anticipating our future, Journal of European Public Policy, 1999, Vol. 5(1), pp. 1-16, p. 9. 
'spillover' has not occurred regarding the long term economic planning of the GoB and the commitments undertaken in the context of regional integration.

In 2010, the GoB released its long-term development plan entitled Horizon 2030: National Development Framework for Belize 2010-2030 (Horizon 2030), which is aimed at establishing development targets and indicators to guide both public and private stakeholders in the development, implementation and monitoring of wide-ranging policies. ${ }^{935}$ Under the section entitled 'Economic Resilience', Horizon 2030 makes no mention of further economic integration into the CSM or the impending CARICOM single economy. Under 'Strategies to achieve the Goals for Economic Resilience', Horizon 2030 states that one of its aims is "to develop the domestic market as a springboard for exports, produce quality goods and services and expand export". ${ }^{936}$ However, there is no specific mention of capitalizing on increased CARICOM market access. Since the CARICOM PTA remains the deepest expression of economic integration that Belize has pursued in its postindependence era, it is submitted that there should be an alignment of economic policies that reflects these PTA commitments. Again, it would appear that the further development of CARICOM trade policy and the cultivation of CARICOM intra-regional trade creation does not feature as a priority issue for the GoB. In light of the above, it would appear that CARICOM economic commitments are viewed in isolation from the general policy thinking on economic issues.

\subsubsection{Social Attitudes towards CARICOM}

This case study argues that there have been limited efforts to shape Belizean social attitudes to regional integration in the Caribbean during the post-independence era. Both the functionalist framework on international integration and the neofunctionalist framework on regional integration refer to the concept of 'loyalty shifts' whereby it is assumed that the integration process will eventually result in a transfer of loyalties (by different facets

\footnotetext{
${ }^{935}$ Horizon 2030 features two main pillars: democratic governance as a foundation for development and education for development. The long-term development plan outlines an implementation framework and includes the creation of specific committees at the local and national level.

${ }^{936}$ Government of Belize, Horizon 2030: National Development Framework for Belize 2010-2030, Economic Resilience (Belmopan City, Belize, 2010), p. 28.
} 
of society) from the national level to the transnational level. ${ }^{937}$ In this regard, the formation of a common Caribbean identity is seen as one of the unifying aspects of CARICOM and is exemplified in the common CARICOM passport that is now used by most CARICOM Member States.

It is argued that the geographic location of Belize in Central America lends both a physical and psychological isolation from the other CARICOM Member States. In light of the broader regional integration process envisioned by the creation of the CSM, it is submitted that Belize cannot afford to have its citizens remain uninformed about the intricacies of the regional integration process. ${ }^{938}$ Many Belizeans are either unaware or not sufficiently informed of the constituent CSM regimes. ${ }^{939}$ Furthermore in 2010, the CARICOM Secretariat released an impact assessment report entitled Development of CSME Public Educational Products and Assessment of the Impact of Previous Products (CSME Report), which was aimed at providing quantitative evidence about the CSME awareness level of CARICOM nationals. ${ }^{940}$ Belize was one of the select Member States included in the surveys undertaken to formulate the CSME Report and the general results revealed that although there is a general knowledge in most Member States that the CSME exists, there is a very low level of understanding about the CSME and what it is meant to achieve. ${ }^{941}$

On the issue of the social impact of the CSME, the CSME Report explained that "there is an opportunity to improve social relations between the citizens of CARICOM Member States", but also noted that "cultural differences exist and can prevent closer regional

\footnotetext{
937 J. Wunderlich, Regionalism, Globalization and the International Order: Europe and Southeast Asia (Ashgate, 2007), p. 14.

${ }^{938}$ The 2016 decision by the United Kingdom to exit the EU has demonstrated that public opinion of the regional integration process is an important factor in the overall functioning of a regional integration project. See A. Malamud, L. de Sousa, Regional Parliaments in Europe and Latin America: Between Empowerment and Irrelevance in (eds.) A. Ribeiro Hoffman, A. Van der Vleuten, Closing or Widening the Gap? Legitimacy and Democracy in Regional Integration Organizations, (Routledge, 2016), p. 89; W. Grenade, Paradoxes of Regionalism and Democracy: Brexit's Lessons for the Commonwealth, The Round Table, 2016, Vol. 105 (5), pp. 509-518, p. 510.

${ }_{939}$ All of the state and non-state actors interviewed for this case study agreed with this notion.

$9409^{\text {th }}$ European Development Fund (EDF), Caribbean Integration Support Program, Development of CSME Public Educational Products and Assessment of the Impact of Previous Products, Impact Assessment Report (October 2010) [EuropeAid/127586/C/SER/GY], p. 4.

${ }^{941}$ Ibid, $9^{\text {th }}$ EDF, Caribbean Integration Support Program, 2010, p. 4.
} 
integration". ${ }^{942}$ One of the main recommendations emanating from this report is for a sustained media campaign along with the greater use of media resources. ${ }^{943}$ The CSME Unit of the CARICOM Secretariat is tasked with the mandate of building CSME awareness and the CSME Report notes that between 2006 and 2010, the CSME Unit did not realize their anticipated goals in this regard. ${ }^{944}$ Admittedly, this is a reference to the public education efforts undertaken by the CARICOM Secretariat, however, it is asserted that a portion of this responsibility to increase awareness falls within the remit of the respective national governments. In this regard, the efforts of GoB have been lacking. A key finding that was noted in the CSME Report is the inconsistent messages from political leaders and policymakers regarding the CSME, which has led to misunderstandings and a lack of awareness about Caribbean regional integration. ${ }^{945}$ The CSME report also confirmed that previous efforts on CSME public education were ad hoc and lacked a defined communications strategy for the medium to long term. ${ }^{946}$

Many of the CSME Report findings are applicable to Belize, as there has been a limited attempt to cultivate a sense of CARICOM identity. Some of the questions and discussion points listed in the Case Study interview guide (See Annex 1) were centered on awareness of CARICOM membership and the question of identity in Belize. In this vein, the formation of 'transnational loyalty' is noted and it is asserted that regional integration has not yet resulted in Belizean social and political groups transferring their loyalty from the national realm to the transnational realm. ${ }^{947}$ In the context of this case study, it is submitted that insufficient information is known about the transnational realm.

All of the case study interviewees agreed that there was a low level of awareness on regional integration in the Caribbean and public education on the overall aims, core

\footnotetext{
${ }^{942}$ Ibid, $9^{\text {th }}$ EDF, Caribbean Integration Support Program, 2010, p. 26.

${ }^{943}$ Ibid, $9^{\text {th }}$ EDF, Caribbean Integration Support Program, 2010, p. 28.

${ }_{944}^{94}$ Ibid, $9^{\text {th }}$ EDF, Caribbean Integration Support Program, 2010, p. 5.

${ }^{945}$ Ibid, $9^{\text {th }}$ EDF, Caribbean Integration Support Program, 2010, p. 13.

${ }_{946}$ Ibid, $9^{\text {th }}$ EDF, Caribbean Integration Support Program, 2010, p. 13.

947 J. Wunderlich, Regionalism, Globalization and the International Order: Europe and Southeast Asia (Ashgate, 2007), p. 11; C. Bickerton, D. Hodson, U. Puetter, The New Intergovernmentalism and the Study of European Integration in (eds.) C. Bickerton, D. Hodson, U. Puetter, The New Intergovernmentalism: States and Supranatioanal Actors in the Post-Maastricht Era (Oxford University Press, 2015), p. 13.
} 
regimes and core institutions is required. Furthermore, all case study interviewees agreed that more should be done to cultivate a sense of CARICOM identity in Belize. Interviewee 3, Mr. Eamon Courtenay, a former Minister of Foreign Affairs of Belize, stated "there is no connection between the Belizean citizenry and the Caribbean as Belizeans do not regard themselves as a Caribbean people." He added that successive governments in Belize have been "unable to inculcate in Belizeans the role that CARICOM can play in the long term development of Belize." He attributed this to "the lack of vision of Belize's political leaders", which has resulted in Belizeans failing to understand the importance of CARICOM membership including the concept of national treatment within the CSM.

Interviewee 4, Ms. Lisa Shoman, a former Minister of Foreign Affairs of Belize, echoed the same sentiments as she explained that "Belize does not possess a CARICOM identity and the idea of it is irrelevant to the daily lives of most Belizeans." She explained that the "Belizean national identity was all that Belize has" and for those with a knowledge of history, CARICOM represented the "symbolism of Caribbean togetherness especially in a political sense." Interviewee 1, Mr. Yashin Dujon, the then Director of Foreign Trade at the Ministry of Foreign Trade, shared that much more is required to improve awareness particularly about the rules of the CSM and was of the opinion that the Myrie v. The State of Barbados Caribbean Court of Justice (CCJ) (original jurisdiction) case assisted in this regard. ${ }^{948}$ He voiced a note of caution by saying that sufficient effort has not been placed into analyzing how the CSM could be detrimental to the Belizean economy. Interviewee 2, Mr. Richard Reid, the Deputy Director of Foreign Trade at the Ministry of Foreign Trade, noted that more cultivation of the CARICOM identity is needed and can be built upon the fact that Belize already shares "the same educational, legal and social system as the other CARICOM Member States.” Interviewee 6, Ms. Kay Menzies, then President of the Belize Chamber of Commerce and Industry, attested that the social attitude of the Belizean private sector is characterized by a lack of awareness about the benefits and regimes associated with the CSME. The little that is known has resulted in a more protectionist stance to

\footnotetext{
${ }^{948}$ See CCJ Application No. OA 002 of 2012, Shanique Myrie v The State of Barbados, 4 October 2013. The Government of Barbados was found liable for violating the right of free movement of a Jamaican national and required to pay damages. The case illuminated the rules of the free movement of persons within the CARICOM single market.
} 
CSME-related issues. She described the private sector as being less trade-oriented in their approach to the CARICOM PTA and that the main mode was a defensive one, whilst failing to recognize the potential benefits.

The lack of direct travel connections between Belize and the rest of the Caribbean is also a factor to be considered as travel is prohibitively expensive and entails transiting the US, which can be a restrictive element given the separate US entry requirements. In the absence of direct travel connections to any other CARICOM Member State, Belize does not directly benefit from regional integration initiatives such as the hassle-free travel regime. This limits both the ability and willingness of Belizean nationals to travel to other CARICOM Member States, which could serve to increase exposure to fellow CARICOM nationals and other CARICOM cultures. With respect to Belizean exposure to CARICOM, Interviewee 3, Mr. Eamon Courtenay, asserted "Belizeans tend to be myopic and insular in their thinking mainly because they have not been educated about CARICOM." He advocated "an intensive public education campaign would be a start in the right direction to sensitize Belizeans about the importance of CARICOM." Interviewee 6, Ms. Kay Menzies, noted "Belizeans have a lack of awareness and a low level of interest where CARICOM is concerned."

It is instructive to note that the CSME Report mentions as one of its main findings the expense associated with regional travel. It affirms that this factor acts as a deterrent for deeper integration and leisure travel within CARICOM as many people can travel to destinations in North America at a lesser cost. ${ }^{949}$ Perhaps as a result of the foregoing, Belize was selected as one of six CARICOM Member States in 2014 to participate in intensive public education sessions to widen the scope of participation by stakeholders of the CSM. Several awareness sessions were held in Belize with an aim to formulate an appropriate national communication strategy geared at explaining the CSM rules regarding the movement of the factors of production. ${ }^{950}$ It is hoped that increased sensitization efforts

\footnotetext{
${ }^{949} 9^{\text {th }}$ European Development Fund (EDF), Caribbean Integration Support Program, Development of CSME Public Educational Products and Assessment of the Impact of Previous Products, Impact Assessment Report (October 2010) [EuropeAid/127586/C/SER/GY], p. 22.

${ }^{950}$ CARICOM Secretariat, Press Release 277/2014 (Georgetown, Guyana, $12^{\text {th }}$ December 2014).
} 
should assist in cultivating awareness about regional integration in the Caribbean. There is also the intention to infuse information about the various CSM regimes into school curricula in order to stimulate greater interest in regional integration among the younger generation.

\subsubsection{Political Summit Attendance}

Article 12 of the RTC outlines that the Conference of Heads of Government (CHOG) is the supreme organ of CARICOM and its main task includes inter alia to determine and to provide policy direction for the Community. The CHOG is composed of the Heads of Government of the CARICOM Member States and is equivalent to the European Union Council meetings. ${ }^{951}$ The CHOG meets on a biannual basis with its 'Inter-sessional' meeting customarily held in spring (usually February) and its 'Regular' meeting customarily held in summer (July) of every year. ${ }^{952}$ As the supreme organ that decides on the customs union policy issues as well as the manner in which CARICOM interacts with the rest of the world, it is irrefutable that a high level of importance should be given to the aforementioned biannual sessions.

Furthermore, it is asserted that greater importance should be placed on the workings of the CHOG due to the fact that regional integration in the Caribbean operates under the tenets of intergovernmentalism. ${ }^{953}$ Consequently, the CARICOM Member States are the central actors that shape regional integration according to their own goals and this is operationalized through interstate bargaining. ${ }^{954}$ There is no CARICOM supranational organization that has been endowed with specific legal competences to direct the unfolding of the regional integration process. The $\mathrm{CHOG}$ and other issue-specific organs undertake all such decisions. ${ }^{955}$ Given the far-reaching effects of the CSM regulations, it is

\footnotetext{
951 See Article 11 of the RTC.

952 On several occasions, the inter-sessional meeting has been held in March.

${ }^{953}$ The intergovernmental approach to regional integration places primacy on state sovereignty and the State is the primary actor in the regional integration process. See A. Stone Sweet, W. Sandholtz, European Integration and Supranational Governance, Journal of European Public Policy, 1997, Vol. 4(3), pp. 297-317, p. 298; M. Cini, Intergovernmentalism in (ed.) M. Cini, European Union Politics, Second Edition (Oxford University Press, 2007), p. 101; (ed.) M. O'Neill, The Politics of European Integration, A Reader (Routledge, 2005), p. 56.

${ }_{954}$ See Ibid, A. Stone Sweet, W. Sandholtz, 1997, p. 298.

955 See Chapter 7, Section 7.2.2 entitled Institutional and Procedural Arrangements under the RTC.
} 
underscored that these decisions should be undertaken in proper consultation. Attendance at CHOG meetings also sends a symbolic message of commitment to the goal of realizing regional integration in the Caribbean. Yet despite this, the record of attendance for Belize during the period from 2002 to 2017 is in itself telling. Whereas most CARICOM Member States have been consistently represented by their Heads of Government, Belize was oftentimes represented at the ministerial or ambassadorial levels. ${ }^{956}$ In addition to the lack of diplomatic parity in the representation sent by Belize to these meetings, it is asserted that such a consistent practice sends a message of its own.

\footnotetext{
${ }^{956}$ See Table 1: Attendance Record of Belize at the Conference of Heads of Government of the Caribbean Community.
} 
Table 1: Attendance Record of Belize at the Conference of Heads of Government of the Caribbean Community ${ }^{957}$

\begin{tabular}{|c|c|c|}
\hline YEAR & $\begin{array}{l}\text { SPRING INTER-SESSIONAL } \\
\text { MEETING }\end{array}$ & REGULAR JULY MEETING \\
\hline 2002 & $\begin{array}{l}\text { - } 13^{\text {th }} \text { Inter-sessional Meeting } \\
\text { held on 3-5 February } 2002 \\
\text { *Meeting held in Belize } \\
\text { - Prime Minister in attendance }\end{array}$ & $\begin{array}{l}\text { - } 23^{\text {rd }} \text { Regular Meeting held on } \\
3-5 \text { July } 2002 \\
\text { - } \quad \text { Prime Minister in attendance }\end{array}$ \\
\hline 2003 & $\begin{array}{l}14^{\text {th }} \text { Inter-sessional Meeting } \\
\text { held on } 14-15 \text { February } 2003 \\
\text { - Ambassador in attendance }\end{array}$ & $\begin{array}{l}\text { - } 24^{\text {th }} \text { Regular Meeting held on } \\
2-3 \text { July } 2003 \\
\text { - } \quad \text { Prime Minister in attendance }\end{array}$ \\
\hline 2004 & $\begin{array}{l}15^{\text {th }} \text { Inter-sessional Meeting } \\
\text { held on 25-26 March } 2004 \\
\text { - Minister of Foreign Trade in } \\
\text { attendance }\end{array}$ & $\begin{array}{l}\text { - } 25^{\text {th }} \text { Regular Meeting held on } \\
\text { 4-7 July } 2004 \\
\text { - Prime Minister in attendance }\end{array}$ \\
\hline 2005 & $\begin{array}{l}16^{\text {th }} \text { Inter-sessional Meeting } \\
\text { held on } 16-17 \text { February } 2005 \\
\text { - Prime Minister in attendance }\end{array}$ & $\begin{array}{l}\text { - } 26^{\text {th }} \text { Regular Meeting held on } \\
\text { 3-6 July } 2005 \\
\text { - } \begin{array}{l}\text { Deputy Prime Minister in } \\
\text { attendance }\end{array}\end{array}$ \\
\hline 2006 & $\begin{array}{l}\text { - } 17^{\text {th }} \text { Inter-sessional Meeting } \\
\text { held on 9-10 February } 2006 \\
\text { - Ambassador in attendance }\end{array}$ & $\begin{array}{l}\text { - } 27^{\text {th }} \text { Regular Meeting held on } \\
\text { 3-6 July } 2006 \\
\text { - } \quad \text { Prime Minister in attendance }\end{array}$ \\
\hline 2007 & $\begin{array}{l}18^{\text {th }} \text { Inter-sessional Meeting } \\
\text { held on } 12-14 \text { February } 2007\end{array}$ & $\begin{array}{l}28^{\text {th }} \text { Regular Meeting held on } \\
1-4 \text { July } 2007\end{array}$ \\
\hline
\end{tabular}

957 Author's compilation based on information regarding CARICOM Member State representation from CARICOM press releases and Conference of Heads of Government Meeting Communiqués 


\begin{tabular}{|c|c|c|}
\hline & $\begin{array}{l}\text { - Minister of Foreign Affairs } \\
\text { in attendance }\end{array}$ & $\begin{array}{l}\text { - Minister of Foreign Affairs in } \\
\text { attendance }\end{array}$ \\
\hline 2008 & $\begin{array}{l}\text { - Information Unavailable } \\
\text { - attendance unknown }\end{array}$ & $\begin{array}{l}\text { - } 29^{\text {th }} \text { Regular Meeting held on } \\
\text { 1-4 July } 2008 \\
\text { - Minister of Foreign Affairs in } \\
\text { attendance }\end{array}$ \\
\hline 2009 & $\begin{array}{l}20^{\text {th }} \text { Inter-sessional Meeting } \\
\text { held on 12-13 March } 2009 \\
\text { *Meeting held in Belize } \\
\text { - } \quad \text { Prime Minister in attendance }\end{array}$ & $\begin{array}{l}\text { - } 30^{\text {th }} \text { Regular Meeting held on } \\
2-5 \text { July } 2009 \\
\text { - } \quad \text { Prime Minister in attendance }\end{array}$ \\
\hline 2010 & $\begin{array}{l}\text { - } 21^{\text {st }} \text { Inter-sessional Meeting } \\
\text { held on 11-12 March } 2010 \\
\text { - Minister of Foreign Affairs } \\
\text { in attendance }\end{array}$ & $\begin{array}{l}\text { - } 31^{\text {st }} \text { Regular Meeting held on } \\
\text { 4-7 July } 2010 \\
\text { - Minister of Foreign Affairs in } \\
\text { attendance }\end{array}$ \\
\hline 2011 & $\begin{array}{l}\text { - } 22^{\text {nd }} \text { Inter-sessional Meeting } \\
\text { held on 25-26 February } 2011 \\
\text { - Prime Minister in attendance }\end{array}$ & $\begin{array}{l}\text { - } 32^{\text {nd }} \text { Regular Meeting held on } \\
30 \text { June-4 July } 2011 \\
\text { - Minister of Foreign Affairs in } \\
\text { attendance }\end{array}$ \\
\hline 2012 & $\begin{array}{l}\text { - } 23^{\text {rd }} \text { Inter-sessional Meeting } \\
\text { held on 8-9 March } 2012 \\
\text { - attendance unknown }\end{array}$ & $\begin{array}{l}\text { - } 33^{\text {rd }} \text { Regular Meeting held on } \\
\text { 4-6 July } 2012 \\
\text { - } \begin{array}{l}\text { Minister of Foreign Affairs in } \\
\text { attendance }\end{array}\end{array}$ \\
\hline 2013 & $\begin{array}{l}\text { - } 24^{\text {th }} \text { Inter-sessional Meeting } \\
\text { held on 18-19 February } 2013 \\
\text { - Chief Executive Officer, } \\
\text { Ministry of Foreign Affairs } \\
\text { of Belize in attendance }\end{array}$ & $\begin{array}{l}\text { - } 34^{\text {th }} \text { Regular Meeting held on } \\
\text { 3-6 July } 2013 \\
\text { - Minister of Foreign Affairs in } \\
\text { attendance }\end{array}$ \\
\hline
\end{tabular}




\begin{tabular}{|c|c|c|}
\hline 2014 & $\begin{array}{l}25^{\text {th }} \text { Inter-sessional Meeting } \\
\text { held on } 10-11 \text { February } 2014 \\
\text { - Prime Minister in attendance }\end{array}$ & $\begin{array}{l}\text { - } 35^{\text {th }} \text { Regular Meeting held on } \\
1-4 \text { July } 2014 \\
\text { - Minister of Foreign Affairs in } \\
\text { attendance }\end{array}$ \\
\hline 2015 & $\begin{array}{l}\text { - } 26^{\text {th }} \text { Inter-sessional Meeting } \\
\text { held on 26-27 February } 2015 \\
\text { - Prime Minister in attendance }\end{array}$ & $\begin{array}{l}\text { - } 36^{\text {th }} \text { Regular Meeting held on } \\
\text { 2-4 July } 2015 \\
\text { - Minister of Foreign Affairs in } \\
\text { attendance }\end{array}$ \\
\hline 2016 & $\begin{array}{l}\text { - } 27^{\text {th }} \text { Inter-sessional Meeting } \\
\text { held on 16-17 February } 2016 \\
\text { *Meeting held in Belize } \\
\text { - } \quad \text { Prime Minister in attendance }\end{array}$ & $\begin{array}{l}\text { - } 37^{\text {th }} \text { Regular Meeting held on } \\
4-6 \text { July } 2016 \\
\text { - Minister of Foreign Affairs in } \\
\text { attendance }\end{array}$ \\
\hline 2017 & $\begin{array}{l}\text { - } 28^{\text {st }} \text { Inter-sessional Meeting } \\
\text { held on 16-17 February } 2017 \\
\text { - Minister of Foreign Affairs } \\
\text { in attendance }\end{array}$ & $\begin{array}{l}\text { - } 38^{\text {th }} \text { Regular Meeting held on } \\
\text { 4-6 July } 2017 \\
\text { - Minister of Foreign Affairs in } \\
\text { attendance }\end{array}$ \\
\hline
\end{tabular}


6.8 Importance Given to Foreign and International Trade Policy

One common area of agreement for all of the case study interviewees has been the understanding that membership in the CARICOM PTA is important for the foreign and international trade policy of Belize. Interviewee 2, Mr. Richard Reid, elucidated that, as a CARICOM Member State participating in the CSM, the foreign and international trade policy of Belize must always be contextualized in light of the RTC and the coordinated regional trade policy. He noted the importance of regional integration in the multilateral trading system (MTS) and explained that due to certain aspects of the coordinated trade policy, "Belize interacts with the rest of the world as a member of CARICOM, not as an individual state." In light of this assertion, the question remains why this approach is not properly filtered into public policy.

Interviewee 3, Mr. Eamon Courtenay, commented that "Belize has yet to leverage its membership to the greatest extent possible", but was firm that "there are benefits to be accrued" from participating in the regional arrangement. Interviewee 4, Ms. Lisa Shoman, added that the importance was "incalculable". Interviewee 5, Mr. Godfrey Smith, a former Minister of Foreign Affairs, stated CARICOM was indeed important to external relations and shared that "the views and interests of small developing countries are likely to be ignored if they are addressed in isolation whereas the CARICOM platform provides more visibility because of the group dynamic." Interviewee 6, Ms. Kay Menzies, explained that there was "tremendous potential to be derived from CARICOM trading opportunities, but poor public relations has been employed to promote the positives of regional integration."

Moreover, when referring to the importance of CARICOM to the foreign policy of Belize, many of the case study interviewees made reference to the historical role that CARICOM played in aiding the Belize quest for independence from the UK. In this context, Interviewee 4, Ms. Lisa Shoman, mentioned the importance of the former Minister of Foreign Affairs of Guyana, Sir Shridath Ramphal, who greatly assisted in the drafting of the historic UNGA Resolution 3432 on the Question of Belize, which was passed in December 1975 and is widely seen as an important building block in the Belize 
internationalization campaign. Interviewee 3, Mr. Eamon Courtenay, also described CARICOM as the "ultimate guardian and champion of Belize's political independence."

\subsubsection{Political Importance of CARICOM}

It is submitted that the political coordination of the CARICOM Member States has been the main dimension of the CARICOM PTA that has been utilized by Belize. The comments of many case study interviewees appear to reinforce this view. Interviewee 5, Mr. Godfrey Smith, commented that CARICOM has had "greater success with political issues when compared to international trade issues." Case study interviewees 3 and 4, Mr. Eamon Courtenay and Ms. Lisa Shoman, echoed this sentiment by saying that politically speaking, CARICOM continues to aid Belize with the yet unresolved Guatemalan territorial claim and mainly because of this, membership is politically important to Belize. Interviewee 1, Mr. Yashin Dujon, voiced that he considered CARICOM "a political tool, not an economic tool" and further explained that there is the perception in Belize that CARICOM is "only a political support group and thus, keen attention is not given to the details or various stages of evolution, which the regional integration movement has undergone."

Interviewee 2, Mr. Richard Reid, stated "Belize's participation in CARICOM is driven by the political dimension mainly because Belize's share of intra-regional trade has remained at $5 \%$ to $10 \%$ for the past 20 years." Where the level of participation of Belize in CARICOM is concerned, the case study interviewees had varying views on the matter, but the common thread noted was that each view was intermixed with critiques about how the regional integration project was being administrated. Most case study interviewees admitted that Belize was not fully participating in CARICOM, but the sub-optimal level of participation had to be contextualized with the administrative shortcomings within the CARICOM Secretariat. ${ }^{958}$

\footnotetext{
${ }^{958}$ Although issues relating to the administration of the CARICOM Secretariat have not been addressed by this case study, it should be noted that institutional reform of the CARICOM Secretariat has been a key issue of concern for several years. Much of these concerns pertain to implementation of decisions, the institutional structure and member state representation in the CARICOM Secretariat. See CARICOM Secretariat, Turning Around CARICOM: Proposals to Restructure the Secretariat, Final Report (January 2012).
} 
Interviewee 4, Ms. Lisa Shoman, opined that the CARICOM Secretariat became passive after the election of a (new) Secretary General in 2013. She explained that although the Secretariat has a new leader from within, CARICOM would have required an innovator who is willing to challenge the Heads of Government regarding the direction of the regional integration movement and the implementation of its decisions. She noted that although the RTC was still the architectural framework of the Caribbean regional integration project, the CSME had taken an inordinately long time to materialize. She further intimated that the MDCs are the key players in the arrangement and there have been instances where they have been able to obtain exceptions for themselves in an arrangement, which is meant to be rules-based. Interviewee 1, Mr. Yashin Dujon, also echoed the same sentiments as he explained that there was a low level of satisfaction with the manner in which the CARICOM Secretariat functions as some Member States are allowed to flout the rules.

Interviewee 3, Mr. Eamon Courtenay, explained that Belize has yet to define its role in CARICOM and that the internal policies of Belize have not enunciated what it wants from CARICOM membership. He stated that it was his view that the GoB had no position on whether CARICOM was a political, economic or social tool. Further, membership in CARICOM has not been proactively used to solve political problems apart from publicizing the Guatemalan territorial claim to Belize. Regarding CARICOM itself, Interviewee 3, Mr. Eamon Courtenay, stated that the CARICOM Secretariat has not taken policy positions on key international issues that affect the Caribbean. ${ }^{959}$ He cited several suggestions including that CARICOM is in need of resident representation in Belize and that this could be used as a new tool to bring the concept of CARICOM closer to CARICOM nationals. ${ }^{960} \mathrm{He}$ explained that such an initiative is essential to the future of Caribbean regional integration in the $21^{\text {st }}$ Century, as there needs to be a shift from (current) the email-based dissemination of information. He added that CARICOM must start its crusade to assert its relevance as it has the ability to do so. He also suggested that GoB

\footnotetext{
${ }^{959}$ The main example cited in this regard was growing threat to the Caribbean offshore financial services industry and it was noted that CARICOM had not spoken in defence of an industry that was a major employer in various CARICOM Member States.

${ }^{960}$ In this regard, it should be noted that the CARICOM Secretariat maintains an office in Barbados and in Jamaica.
} 
invest more resources into representing Belize at the CARICOM level including attendance at CARICOM meetings and the implementation of CARICOM agreements.

\subsubsection{Statistical Picture of Intra-regional Trade}

A closer look at the pattern of trade between Belize and the CARICOM intra-regional market indicates that the CARICOM PTA has facilitated a small volume of trade. Chapter 5 of this dissertation probed the issue of why the CARICOM PTA has not resulted in greater intra-regional trade among its constituents. Several of the issues raised in this regard pertained to an entrenched agricultural production sector that is hinged on the last remnants of trade preferences, a lack of tradable goods and the absence of adequate manufacturing capabilities. ${ }^{961}$ It can be reasserted that the British Caribbean colonial paradigm has contributed to some of the aforementioned underlying reasons why the CARICOM PTA has been challenged in cultivating trade creation. This case study submits that the GoB, in coordination with the Belizean private sector, should formulate specific policies that are targeted at penetrating the CARICOM intra-regional market. As asserted by interviewee 2, Mr. Richard Reid, "the Belizean export stream into CARICOM is under-developed and thus, there is much room for trade expansion."

\subsubsection{Belizean Export Trade}

A review of the main Belizean exports for the period of 2003 to 2014 demonstrated that the United States of America (USA) was the primary export destination. ${ }^{962}$ As of 2015, the USA retained this position with $40.2 \%$ of Belizean exports directed to this market. ${ }^{963}$ Most of these exports are traded under the unilateral, duty free market access afforded by the Caribbean Basin Initiative (CBI). The main products exported to the USA include sugar, orange concentrate, grapefruit concentrate, papayas, crude petroleum and shrimps. ${ }^{964}$ For the period of 2003 to 2014, the UK market was cited as the second primary export destination with exports of sugar, grapefruit concentrate, bananas and shrimps directed to

\footnotetext{
${ }^{961}$ See Chapter 5, Section 5.3 entitled Statistical Overview of Trade.

${ }^{962}$ Trade data from the Statistical Institute of Belize (SIB) was used for this analysis. The main period under review for the data sourced from the SIB was 2003 to 2014. See Annex 8.

963 WTO Secretariat, Belize Trade Policy Review, Report by the Secretariat (Geneva, 17 ${ }^{\text {th }}$ March 2017) [WT/TPR/S/353], p. 20, para. 1.3.2.

${ }^{964}$ See Statistical Institute of Belize, Annual Exports 2003 - 2015, Selected Exports by Destination.
} 
this market. ${ }^{965}$ Although the EU is the most important market regarding the trade in Belizean bananas and sugar, it should be noted that the UK is the EU Member State that imports the most Belizean sugar exports. Between 2004 and 2008, the UK imported more than $50 \%$ of the total sugar exports of Belize. ${ }^{966}$ As of 2015 , the EU was cited as the second primary export destination with $35.3 \%$ of Belizean exports directed to this market. ${ }^{967}$

CARICOM and the other EU Member States were interchangeably ranked as the third and fourth export destinations during the period of 2003 to 2014. Where the other EU Member States were concerned, grapefruit and orange concentrates were exported to the Netherlands and bananas as well as shrimps were exported to Spain. ${ }^{968}$ Some banana exports were also sold to Ireland. Regarding the CARICOM intra-regional market, orange and grapefruit concentrate, sugar and shrimps were exported to Trinidad and Tobago. Exports of grapefruit and orange concentrate as well as shrimps were sent to Jamaica. ${ }^{969}$ In 2008 , only $5 \%$ of Belizean exports were traded on the CARICOM intra-regional market. ${ }^{970}$ $80 \%$ of these exports were traded with Jamaica and Trinidad and Tobago. ${ }^{971}$ As of 2015 , Jamaica and Trinidad and Tobago remain the CARICOM export destinations for Belizean products as $3.6 \%$ of Belizean exports were directed to Jamaica and $4.1 \%$ of Belizean exports were directed to Trinidad and Tobago. ${ }^{972}$ This represents an increase in intraregional exports from 2008.

Consequently, trade data demonstrates that only a few CARICOM Member States appear to be export destinations for Belizean goods. ${ }^{973}$ The CARICOM MDCs tend to feature a

\footnotetext{
${ }^{965}$ See Statistical Institute of Belize, Annual Exports 2003 - 2015, Selected Exports by Destination.

${ }^{966}$ Inter-American Development Bank (IDB), (eds.) E. Martin, O. Manzano, Towards a Sustainable and Efficient State: The Development Agenda of Belize, Trade Sector: Exporting for Growth (Washington D.C. USA, September 2010), p. 64.

${ }^{967}$ WTO Secretariat, Belize Trade Policy Review, Report by the Secretariat (Geneva, $17^{\text {th }}$ March 2017) [WT/TPR/S/353], p. 20, para. 1.3.2.

${ }_{968}$ See Statistical Institute of Belize, Annual Exports 2003 - 2015, Selected Exports by Destination.

${ }^{969}$ See Statistical Institute of Belize, Annual Exports 2003 - 2015, Selected Exports by Destination.

${ }^{970}$ Inter-American Development Bank (IDB), (eds.) E. Martin, O. Manzano, Towards a Sustainable and Efficient State: The Development Agenda of Belize, Trade Sector: Exporting for Growth (Washington D.C. USA, September 2010), p. 62.

${ }^{971}$ Ibid, IDB, (eds.) E. Martin, O. Manzano, September 2010, p. 63.

972 WTO Secretariat, Belize Trade Policy Review, Report by the Secretariat (Geneva, 17 ${ }^{\text {th }}$ March 2017) [WT/TPR/S/353], p. 21, chart 1.2.

${ }^{973}$ See Annex 9.
} 
more developed manufacturing base and as such, they were the primary export destinations for some Belizean exports. ${ }^{974}$ Most of the exports from Belize aided in producing valueadded products such as finished fruit juices and seafood products. The total value of Belizean exports to the CARICOM market at its peak during the period under review amounted to an estimated $\$ 96,000.00$ BZE (estimated $\$ 48,000.00$ USD or $€ 43,000.00$ EURO). ${ }^{975}$ It should also be mentioned that Belizean exports to Latin America have grown as this trade stream previously accounted for $1 \%$ of exports in 1995, which can be contrasted with $21 \%$ in $2008 .{ }^{976}$ Similarly, Belizean exports to Central America grew faster than exports to any other region between 2000 and $2008 .{ }^{977}$ During this period, it is estimated that trade increased by $300 \%$ and consisted mainly of petroleum exports. ${ }^{978}$ As of 2015, Belizean exports to Central America experienced a decrease due mainly to low crude oil prices and decreased production. ${ }^{979}$

\footnotetext{
${ }^{974}$ Barbados, Jamaica, Suriname, Guyana and Trinidad and Tobago are considered more developed countries under Article 4 of the RTC.

${ }_{975}$ See Annex 9.

${ }^{976}$ Inter-American Development Bank (IDB), (eds.) E. Martin, O. Manzano, Towards a Sustainable and Efficient State: The Development Agenda of Belize, Trade Sector: Exporting for Growth (Washington D.C. USA, September 2010), p. 63.

${ }_{977}^{97}$ Ibid, IDB, (eds.) E. Martin, O. Manzano, September 2010, p. 63.

${ }^{978}$ WTO Secretariat, Belize Trade Policy Review, Report by the Secretariat (Geneva, $23^{\text {rd }}$ November 2010) [WT/TPR/G/238/Rev.1], p. 5, para. 2.

979 WTO Secretariat, Belize Trade Policy Review, Report by the Secretariat (Geneva, 17 ${ }^{\text {th }}$ March 2017) [WT/TPR/S/353], p. 21, chart 1.2.
} 
Figure 2.4: Percentage Distribution of CARICOM's Intra-Regional Total Exports:

Trinidad and Tobago

$76.8 \%$

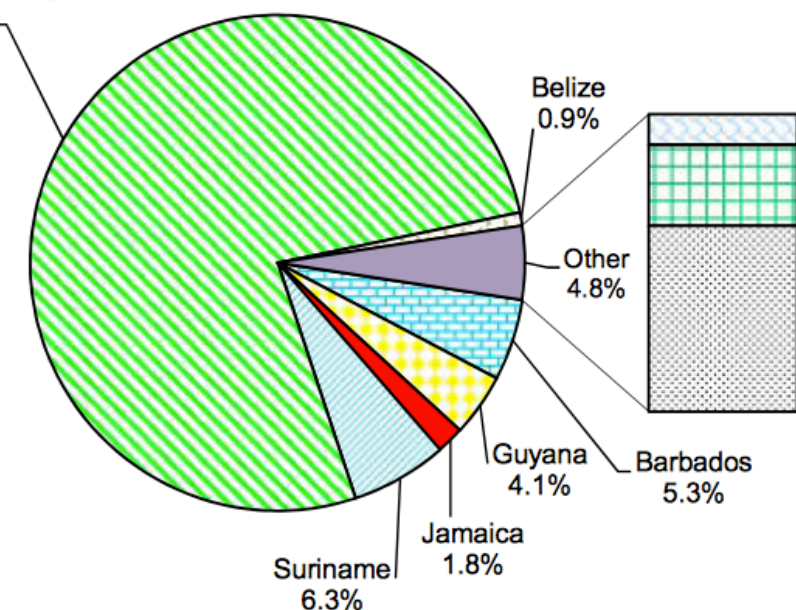

Grenada

$0.5 \%$

Saint Lucia

$1.3 \%$

Other OECS

$3.0 \%$

Source: CARICOM Statistical Unit, CARICOM's Trade: A Quick Reference to Some Summary Data, 2005 2010 (Georgetown, Guyana, 2013), Figure 2.4, Percentage Distribution of Intra-regional Total Exports by CARICOM Countries in 2005, p. 35.

Figure 2.5: Percentage Distribution of CARICOM's Intra-Regional Total Exports: 2010

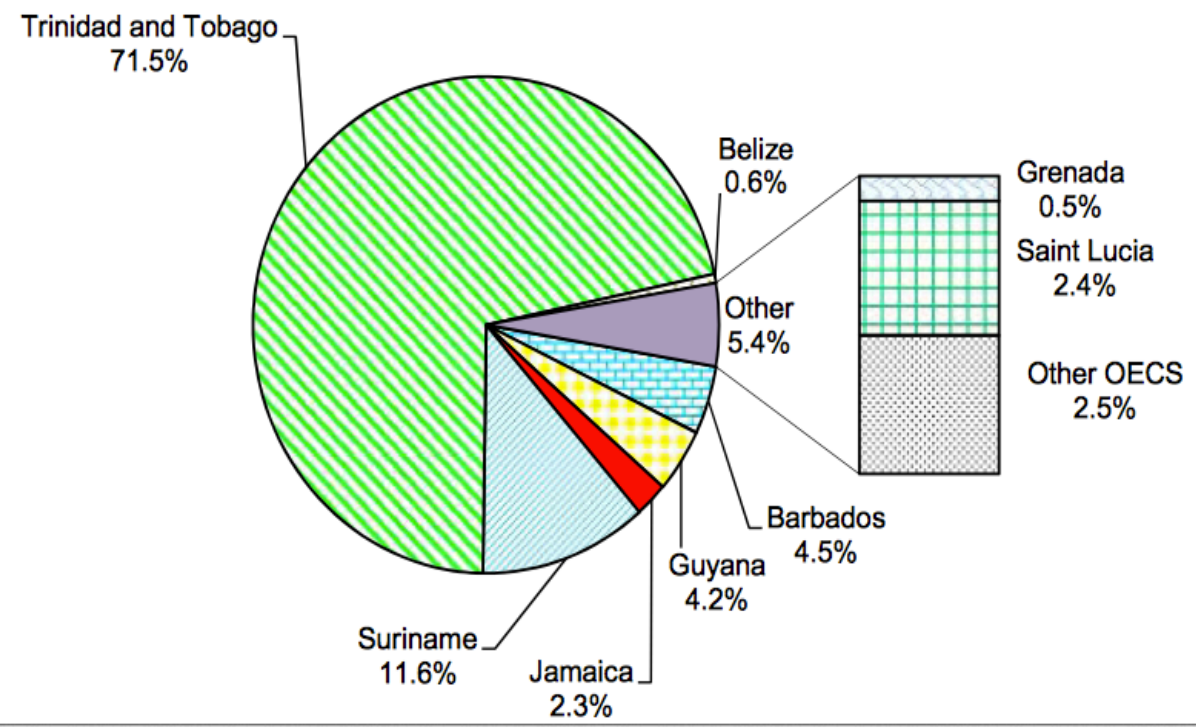

Source: Ibid, CARICOM Statistical Unit, 2013, Figure 2.5, Percentage Distribution of Intra-regional Total Exports by CARICOM Countries in 2005, p. 35. 
Figure 2.2: Percentage Distribution of CARICOM's Intra-Regional Imports: 2005

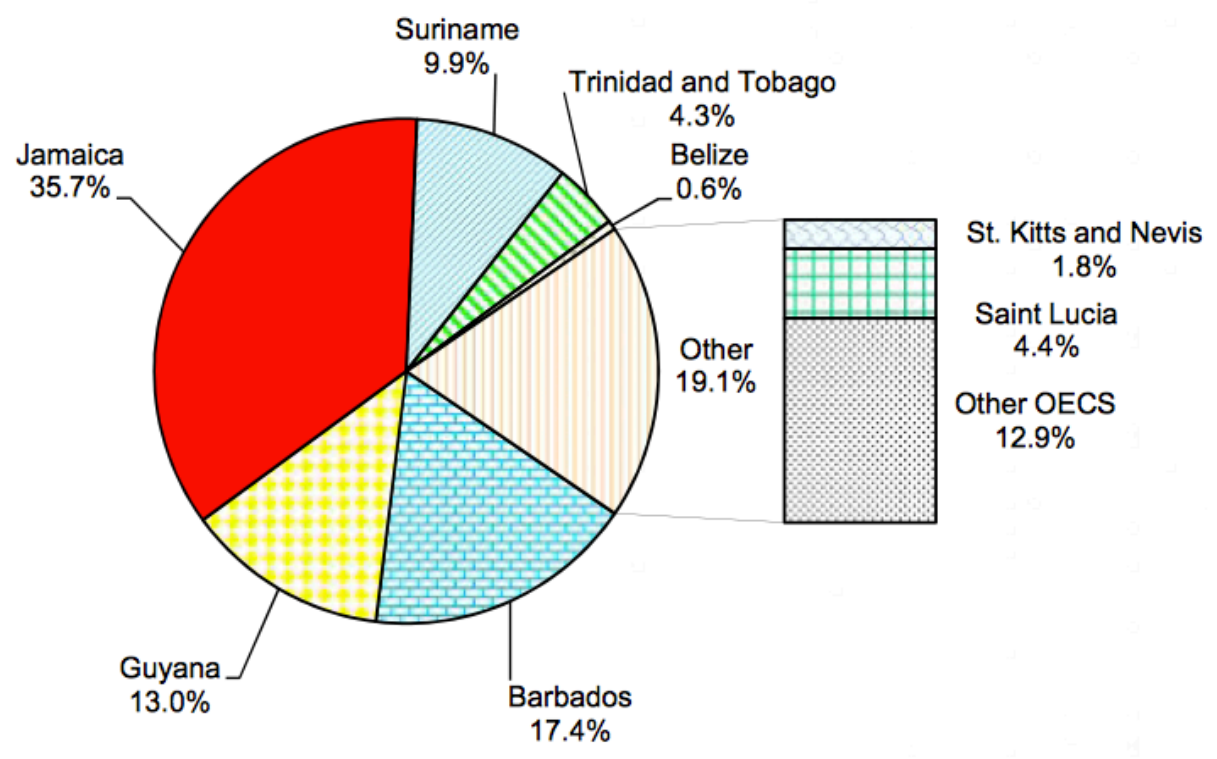

Source: Ibid, CARICOM Statistical Unit, 2013, Figure 2.2, Percentage Distribution of Intra-regional Total Imports by CARICOM Countries in 2005, p. 32.

Figure 2.3: Percentage Distribution of CARICOM's Intra-Regional Imports: 2010

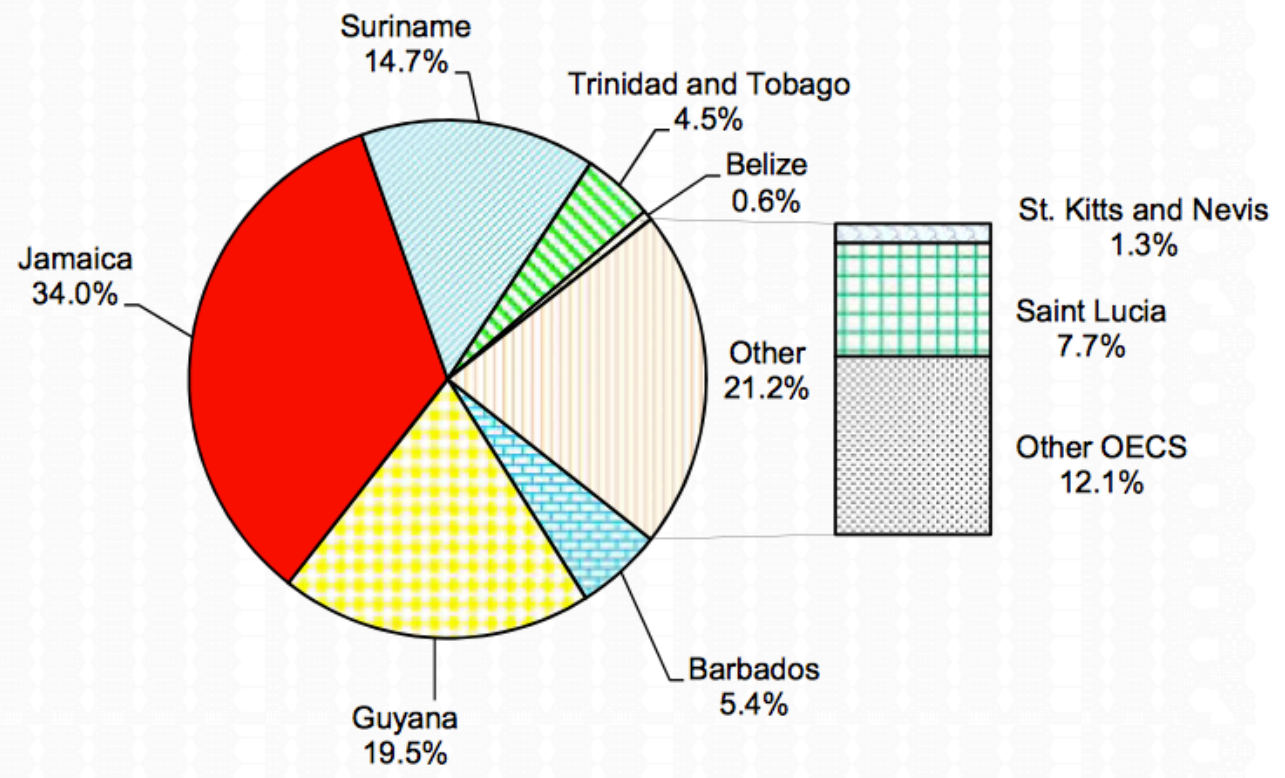

Source: Ibid, CARICOM Statistical Unit, 2013, Figure 2.3, Percentage Distribution of Intra-regional Total Imports by CARICOM Countries in 2005, p. 32. 
The comments of many of the case study interviewees appear to be in unison with the abovementioned statistical picture of trade. Interviewee 6, Ms. Kay Menzies, stated that the attempted penetration of the CARICOM intra-regional market has been a mixed success. She indicated that some non-traditional products such as fruits, fruit juices and beans are now being exported and that there was a slight increase in CARICOM imports to Belize in 2013. However, she explained that Belize has not been strategic about its involvement in CARICOM, as it tends to act in a reactive mode. Interviewee 6, Ms. Kay Menzies, also highlighted that one of the key challenges for Belizean trade was the lack of communication between the Ministry of Foreign Affairs and the Ministry of Foreign Trade. She intimated that the Belizean private sector has been more involved in the trade dialogue as they participated in consultations regarding the proposed Belize partial scope agreement with El Salvador and Mexico in 2013. However, she noted that the National Trade Negotiating Commission (NTNC) was not functioning and had yet to be properly reconstructed. ${ }^{980}$ As such, the current state of play is not consultative and the Belize Chamber of Commerce is asked to comment on plans that are essentially a fait accompli. ${ }^{981}$

Interviewee 2, Mr. Richard Reid, commented that the CARICOM MDCs tend to place greater focus on the CSM and are able to reap considerable benefits because of their developed manufacturing base. He highlighted that CARICOM intra-regional trade remains problematic, as the main trading partner for most CARICOM Member States is a country outside of the PTA. He cited that the only exception to this trade pattern is Trinidad and Tobago, which maintains about $75 \%$ of its trade with the CARICOM PTA partners. Moreover, Interviewee 6, Ms. Kay Menzies, opined that supply side constraints tend to be the main culprit that has contributed to the stagnant state of CARICOM intra-regional trade. Interviewee 2, Mr. Richard Reid, stated that from the first Lome Convention to the

\footnotetext{
${ }^{980}$ The NTNC is a consultative body, which consists of both private and public sector stakeholders that assist the Ministry of Foreign Trade of Belize in the formulation of trade policy. In the past, inputs received from this body aided with issues such as the preparation of policy positions for CARICOM Trade Ministerial Meetings, Belize's WTO Trade Policy Reviews and the Partial Scope Agreement between Belize and Guatemala.

${ }^{981}$ For instance, Interviewee 6 was unaware of the formal trade policy document, which the Ministry of Foreign Trade had finalized in 2013. The author of this dissertation asked whether the Chamber of Commerce had contributed to the policy document during the course of the interview as a result of information received in a previous interview with a state actor from the Ministry of Foreign Trade.
} 
EC-CARIFORUM EPA, CARICOM Member States have prioritized their trade relations to focus on European market access for their commodities much to the detriment of improving their export production capability and supply-side constraints. Far from criticizing this approach, he explained that as a developing country Belize has to adopt a realistic approach to trade relations. In the context of the ACP-EU relationship, the trade agreement with Europe is the singular trade agreement that provides a guaranteed financial aid package through the European Development Fund (EDF), which is used by the Ministry of Economic Development of Belize to fund various projects. ${ }^{982}$

\subsubsection{Belizean Import Trade}

A review of Belizean gross imports by destination showed that the primary source of imports was the USA followed secondly by Mexico and thirdly by Panama during the period from 2003 to $2014 .{ }^{983}$ As of 2015 , the USA retained its position as $33.8 \%$ of Belizean imports are sourced from this market. Likewise, Mexico retained its position as $10.6 \%$ of Belizean imports are sourced from this market. ${ }^{984}$ The third main source of Belizean imports in 2015 was The Netherland Antilles as 8.8\% of imports were sourced therefrom. ${ }^{985}$ During the period of 2003 to 2014 , CARICOM imports were ranked after imports from the rest of Central America, The Netherlands Antilles and "Other" countries and were conservatively estimated between $2 \%$ and $5 \%$ of total imports. ${ }^{986}$ With respect to imports from the CARICOM market, the main source of imports was Trinidad and Tobago, Jamaica and Barbados. ${ }^{987}$ As of 2015, imports sourced from the CARICOM intra-regional market amounted to less than $1 \%$ of gross imports. ${ }^{988}$ Although imports from the CARICOM market have fluctuated during the period under review, the peak of such trade amounted to an estimated $\$ 72,000.00$ BZE (an estimated $\$ 36,000.00$ USD or $€ 32,000.00$

\footnotetext{
${ }^{982}$ For the most recent EU development aid program, see $11^{\text {th }}$ EDF, Multi-annual Indicative Programme for Cooperation between Belize and the European Union: 2014-2020.

${ }_{983}$ See Annex 10.

${ }^{984}$ WTO Secretariat, Belize Trade Policy Review, Report by the Secretariat (Geneva, 17 ${ }^{\text {th }}$ March 2017) [WT/TPR/S/353], p. 21, para. 1.3.2.

${ }^{985}$ Ibid, WTO Secretariat, 2017, p. 21, chart 1.2.

${ }^{986}$ See Annex 10.

987 See Statistical Institute of Belize, Annual Imports 2003 - 2015, Gross Imports from CARICOM by Country.

${ }_{988}$ WTO Secretariat, Belize Trade Policy Review, Report by the Secretariat (Geneva, $17^{\text {th }}$ March 2017) [WT/TPR/S/353], p. 21, chart 1.2.
} 
EURO). ${ }^{989}$ This is still a low volume of trade and underlines the point that the other CARICOM Member States are equally challenged in producing export products for the Belizean market.

\subsection{Conclusion}

This case study demonstrates that non-trade related benefits can serve as pull factors that motivate countries to pursue PTA membership. Belize was primarily motivated by political concerns when the decision to seek membership in the CARICOM PTA was undertaken. Most of these political concerns pertained to the quest for independence from the UK as well as the Guatemalan territorial claim to Belize. Subsequent to its membership in the CARICOM PTA, Belize was able to derive various non-trade related benefits such as increased bargaining power through diplomatic support with its internationalization campaign regarding the Guatemalan assertion of its territorial claim. Belize was eventually granted its independence in 1981 with all of its territory in tact.

In the post-independence period, Belize's participation in the CARICOM PTA has yet to result in increased welfare gains, as trade flows have remained at a minimal level. The British Caribbean colonial paradigm has impacted Belize's view of CARICOM trade policy as it is viewed as a secondary concern. Significant efforts have not been undertaken to cultivate trade creation in the context of the CARICOM PTA and this is mainly attributable to Belize's trade flows being fixed on the UK and EU export markets. Although Belize has fulfilled many of its CSM obligations, it is submitted that Belize has yet to capitalize on the opportunities afforded by its membership in the CARICOM PTA. As previously noted, a certain degree of isolation has resulted from the fact that Belize is geographically located in Central America. Thus, more efforts are required to increase Belizean awareness on regional integration in the Caribbean as well as its associated aims, core rights and obligations and core institutions. Despite the aforementioned, it remains unquestionable that Belize has benefitted from the non-trade related benefits of the

\footnotetext{
989 See Statistical Institute of Belize, Annual Imports 2003 - 2015, Gross Imports from CARICOM by Country.
} 
CARICOM PTA and continues to do so with sustained diplomatic support from its fellow CARICOM Member States in light of the still unresolved Guatemalan territorial claim. 
$\underline{\text { Annex } 1}$

Interview No. 1

Mr. Yashin Dujon

Director of Foreign Trade, Ministry of Foreign Trade of Belize

Date of Interview: $20^{\text {th }}$ December 2013

Location of Interview: Ministry of Foreign Trade of Belize, Belmopan City, Belize

1. Do you think that CARICOM membership is important for Belize's foreign and international trade policy? If yes, why?

It is important politically, but it is not an economic tool. Withdrawing from the regional arrangement is not an option; however, Belize does the absolute minimum regarding its level of participation. Belize is not the only member state to adopt this position as some of the other LDCs have a similar approach.

2. What do you believe was Belize's main motivation in applying for CARICOM membership in 1974? How would you summarize Belize's level of participation since that time?

Belize's motivation regarding membership in the CARICOM PTA was a purely political one. Subsequently, there has been a low level of involvement in the regional arrangement. Membership serves a purpose in the sense that the CARICOM market can be used as a negotiating tool especially in Belize's negotiations with Central America.

3. In 2012, there has been a great deal of discussion about reforming the way in which the CARICOM Secretariat functions. What is your view with respect to the current functioning of the CARICOM Secretariat in relation to Belize and do you believe that change needs to be effected in any particular area?

Generally speaking, Belize is not satisfied with the way that the CARICOM Secretariat functions.

4. Do you believe that the Belizean populace is sufficiently aware of Belize's membership in CARICOM, the community's main institutions, the manner in which the organization functions and the advantages and/or disadvantages of Belize's membership? Belizeans are not sufficiently aware or interested in regional integration in the Caribbean. The recent CCJ Case (Myrie v. The State of Barbados) has awakened a certain level of awareness. A national as opposed to regional mentality is still prevalent in Belize for the most part.

5. When Belize joined the Caribbean Regional Integration movement, it was a free trade area known as CARIFTA. This has subsequently evolved into a Customs Union and now a Single Market; there is even the eventuality of the much postponed Single Economy. Do you believe that successive government administrations have appreciated the nuanced approach required to continue with this regional integration project. 
No, there is no appreciation for regional integration in the Caribbean. It is seen more so as a task to comply with certain requirements associated with the CARICOM work program and minimal proactive effort is undertaken.

6. The CARICOM Single Market and Economy is meant to be the main engine for regional development. What is your view on Belize's level of implementation thus far? Do you think that there is anything that can be done to accelerate Belize's pace of implementation?

No. Belize is doing the best that it can given its limitations as an LDC within the CARICOM PTA. It would be difficult to justify a more robust approach in light of the minimal volume of trade that is facilitated by the CARICOM PTA.

7. Belize was one of the CARICOM Member States that "readily" signed on to the 2008 Economic Partnership Agreement; do you believe that this agreement will benefit Belize in the long term?

No, the EPA will not benefit Belize in the long term, as generally speaking the terms of the agreement is not in Belize's favor.

8. What is your general view of Belize (as a member of CARICOM) being involved in WTO-plus North South Trade Agreements with trading giants such as the EU, Canada and the USA?

Belize is doing the best that it can in light of its circumstances. These asymmetrical agreements have far reaching implications for small, developing countries. Belize's participation in the WTO is important where such rules are concerned. Nevertheless, there are no plans to open a resident diplomatic representation that is accredited to the WTO. The Embassy of Belize in Brussels, Belgium has to continue with the workload for the time being. Belize objected to further negotiations on the (then proposed) CARICOM-Canada agreement as it maintains minimal annual trade with Canada and considered such trade flows as insufficient upon which to pursue a trade agreement.

9. Do you believe that Belize has derived any real benefits from the other existing trade agreements that it has signed as a member of CARICOM? No.

10. Rt. Hon. Said Musa's book is entitled "Belize: A Caribbean Country in Central America", which geographic region holds more importance for Belize: Central America or the Caribbean? And Why?

Belize has the ability to be the nexus between the two regions. 
$\underline{\text { Annex } 2}$

Interview No. 2

Mr. Richard Reid

Deputy Director of Foreign Trade, Ministry of Foreign Trade of Belize

Date of Interview: $23^{\text {rd }}$ December 2013

Location of Interview: Ministry of Foreign Trade of Belize, Belmopan City, Belize

1. Do you think that CARICOM membership is important for Belize's foreign and international trade policy? If yes, why?

Yes, it is important. Whether it is fully realized or not, Belize interacts with the world as a part of CARICOM due to the coordinated foreign and trade policy. In light of the Revised Treaty of Chaguaramas (RTC) and all its provisions, it is not possible to remove ourselves from certain aspects of the CARICOM regime.

2. What do you believe was Belize's main motivation in applying for CARICOM membership in 1974? How would you summarize Belize's level of participation since that time?

More than likely, it was a political motivation. Subsequently, Belize's level of participation has not been what it could be, but the reality is that only Trinidad and Tobago and Jamaica truly focus on the CARICOM Single Market (CSM). Belize has a great deal more that it can do in this regard. Belize's participation in CARICOM is driven by the political dimension mainly because Belize's share of intra-regional trade has remained at 5\% to $10 \%$ for the past 20 years

3. In 2012, there has been a great deal of discussion about reforming the way in which the CARICOM Secretariat functions. What is your view with respect to the current functioning of the CARICOM Secretariat in relation to Belize and do you believe that change needs to be effected in any particular area?

Irrespective of how the CARICOM Secretariat works, CARICOM member states need to focus on their supply side constraints in order to truly capitalize on trading opportunities whether it be with fellow PTA partners or the European Union.

4. Do you believe that the Belizean populace is sufficiently aware of Belize's membership in CARICOM, the community's main institutions, the manner in which the organization functions and the advantages and/or disadvantages of Belize's membership? No, they are not and appropriate public education is needed.

5. When Belize joined the Caribbean Regional Integration movement, it was a free trade area known as CARIFTA. This has subsequently evolved into a Customs Union and now a Single Market; there is even the eventuality of the much postponed Single Economy. Do you believe that successive government administrations have appreciated the nuanced approach required to continue with this regional integration project?

No. It also depends on how CARICOM membership is viewed. There is a matter of knowing what you need to do (in keeping with treaty obligations) and doing it; however, there is 
also the preset view of somehow managing with the obligations as Belize goes along into the future and hoping that everything falls from above. Belize needs to actively engage and adapt a strategy.

6. The CARICOM Single Market and Economy is meant to be the main engine for regional development. What is your view on Belize's level of implementation thus far? Do you think that there is anything that can be done to accelerate Belize's pace of implementation?

Belize's level of implementation has been satisfactory thus far especially when compared with other CARICOM member states. Regardless of the level of implementation, all of the CARICOM member states need to improve their capacity constraints if they are to truly capitalize on the trading opportunities brought about by the CSM. Intra-regional trade remains a problem and only Trinidad and Tobago is a winner in this regard. For all of the other CARICOM member states, the main trading partner is a country outside of CARICOM. This does not auger well for the future of the CSM. Particularly for Belize, the export stream with CARICOM is underdeveloped and there is adequate room for expansion for trade.

7. Belize was one of the CARICOM Member States that "readily" signed on to the 2008 Economic Partnership Agreement; do you believe that this agreement will benefit Belize in the long term?

The EPA is beneficial where trade in sugar and bananas are concerned. However, the fisheries industry is now an issue of concern since Belize was blacklisted by the EU in 2013. Again, the EPA highlights CARICOM's fixation with market access provisions for its commodities trade with Europe. Conversely, there has been little production for regional export where most products are concerned. CARICOM needs a mature trading relationship with Europe, however, the supply side is unprepared for such a long term arrangement. There is no overarching plan about the policy direction in this regard. There is a lack of tradable goods and a dire need for the industrial and agricultural sectors to produce more.

8. What is your general view of Belize (as a member of CARICOM) being involved in WTO-plus North South Trade Agreements with trading giants such as the EU, Canada and the USA?

Future possibilities exist in the area of trade in services. Where trade in goods is concerned, Belize needs to produce new products to trade with these markets. Belize must expand beyond sugar, bananas and fisheries. In this regard, investment financing is important to build a supply side capacity.

With respect to the EU, it must be borne in mind that the trade agreement with Europe is the singular trade agreement that provides a guaranteed financial aid package through the European Development Fund (EDF), which is used by the Ministry of Economic Development of Belize to fund various projects.

9. Do you believe that Belize has derived any real benefits from the other existing trade agreements that it has signed as a member of CARICOM? 
No. This is mainly due to supply side constraints and the under-development of the Belizean export stream.

10. Rt. Hon. Said Musa's book is entitled "Belize: A Caribbean Country in Central America", which geographic region holds more importance for Belize: Central America or the Caribbean? And Why?

Both regions are important to Belize, but Belizean trade policy must adapt in order to capitalize on the opportunities afforded by both regions. At the moment, Belize has a tendency to adopt a reactive approach when a proactive, exploratory approach is required. 
$\underline{\text { Annex } 3}$

Interview No. 3

Mr. Eamon Courtenay, Senior Counsel

Attorney at Law, Former Minister of Foreign Affairs and Foreign Trade of Belize

Date of Interview: $30^{\text {th }}$ December 2013

Location of Interview: Law Offices of Courtenay Coye LLP, Belize City, Belize

1. Do you think that CARICOM membership is important for Belize's foreign and international trade policy? If yes, why?

Yes, but Belize has not leveraged its membership to the greatest extent possible. There are benefits to be accrued, however, Belize has not defined its role in CARICOM or defined what it wants from CARICOM. Belize has not stated whether it will be a regional player or an international player. CARICOM was the ultimate guardian and champion of Belize's political independence.

2. What do you believe was Belize's main motivation in applying for CARICOM membership in 1974? How would you summarize Belize's level of participation since that time?

The main motivation was political and closely related to Belize's quest for independence. Since that time, Belize has had a low level of participation in CARICOM and there is a limited sense of the CARICOM identity in Belize. There is no connection between Belize and the rest of CARICOM; Belizeans do not regard themselves as a Caribbean people.

3. In 2012, there has been a great deal of discussion about reforming the way in which the CARICOM Secretariat functions. What is your view with respect to the current functioning of the CARICOM Secretariat in relation to Belize and do you believe that change needs to be effected in any particular area?

CARICOM should have a resident Ambassador in Belize and such a presence can be used as a tool to bring the concept of CARICOM closer to CARICOM nationals. This is essential to the future of the integration movement in the $21^{\text {st }}$ Century. Having someone on the ground in Belize is a more effective way of achieving CARICOM diplomacy as opposed to the email-based approach/dissemination of information, which is currently being used. Additionally, more of Government of Belize's national budget should be used for attending CARICOM meetings and implementing CARICOM Agreements.

4. Do you believe that the Belizean populace is sufficiently aware of Belize's membership in CARICOM, the community's main institutions, the manner in which the organization functions and the advantages and/or disadvantages of Belize's membership? No, they are not sufficiently aware. Belizeans tend to be myopic and insular in their thinking and they have not been sufficiently educated about CARICOM. In this regard, public education is a starting point. CARICOM, as an organization. has not been a sufficient voice to address the relevant issues affecting its member states. This has not aided the visibility of the organization. CARICOM has yet to effectively address the plight of highly indebted poor countries or reparations for slavery. 
5. When Belize joined the Caribbean Regional Integration movement, it was a free trade area known as CARIFTA. This has subsequently evolved into a Customs Union and now a Single Market; there is even the eventuality of the much postponed Single Economy. Do you believe that successive government administrations have appreciated the nuanced approach required to continue with this regional integration project?

Successive governments have been unable to inculcate in the Belizean people the role that CARICOM can play in the development of the country. This is largely due to the lack of vision of Belizean political leaders. CARICOM should be viewed beyond just a grouping that can provide political assistance and one that could take the lead on regional issues. $A$ classic example is that of the Caribbean Financial Services Task Force and the lack of a regional response on the matter.

6. The CARICOM Single Market and Economy is meant to be the main engine for regional development. What is your view on Belize's level of implementation thus far? Do you think that there is anything that can be done to accelerate Belize's pace of implementation?

Belize's level of implementation has been satisfactory in comparison to other CARICOM member states. However, Belize has not made proactive use of CARICOM and does not use CARICOM to solve its political problems. Belize has not had any view about which type of policy tool CARICOM can be for its benefit: political, economic or social. CARICOM has the ability to address many key issues confronting the Caribbean region.

7. Belize was one of the CARICOM Member States that "readily" signed on to the 2008 Economic Partnership Agreement; do you believe that this agreement will benefit Belize in the long term?

No. The agreement is not beneficial for Belize.

8. What is your general view of Belize (as a member of CARICOM) being involved in WTO-plus North South Trade Agreements with trading giants such as the EU, Canada and the USA?

It is not in Belize's interest to pursue such agreements because it is barely coping with its regional commitments.

9. Do you believe that Belize has derived any real benefits from the other existing trade agreements that it has signed as a member of CARICOM?

No, because these agreements are not being utilized.

10. Rt. Hon. Said Musa's book is entitled "Belize: A Caribbean Country in Central America", which geographic region holds more importance for Belize: Central America or the Caribbean? And Why?

Neither region holds a great deal of importance to Belize. There is an insufficient level of regional commitment to a development agenda in Central America and where CARICOM is concerned, there is also a lesser commitment to regionalism. 
$\underline{\text { Annex } 4}$

Interview No. 4

Ms. Ms. Lisa Shoman, Senior Counsel

Attorney at Law, Former Minister of Foreign Affairs and Foreign Trade of Belize

Date of Interview: $6^{\text {th }}$ January 2014

Location of Interview: Law Offices of Lisa Shoman, Belize City, Belize

1. Do you think that CARICOM membership is important for Belize's foreign and international trade policy? If yes, why?

Yes, CARICOM membership is incalculably important to Belize. Although Belize was not involved in the West Indies Federation, the Caribbean camaraderie and support was targeted in connection with the quest for independence.

2. What do you believe was Belize's main motivation in applying for CARICOM membership in 1974? How would you summarize Belize's level of participation since that time?

The main motivation in applying for CARICOM membership was that CARICOM would support Belize's bid for independence as the then Foreign Minister of Guyana, who eventually became the Secretary General of the Commonwealth helped to draft the key UN resolution on the Question of Belize. Belize has had a moderate level of participation thus far. But CARICOM itself has difficulties, which it needs to overcome. Although the RTC remains the architectural framework for regional integration, the CSME has taken and inordinate amount of time to be finalized. Some member states have yet to operationalize the free movement of persons as of 2013.

3. In 2012, there has been a great deal of discussion about reforming the way in which the CARICOM Secretariat functions. What is your view with respect to the current functioning of the CARICOM Secretariat in relation to Belize and do you believe that change needs to be effected in any particular area?

CARICOM as an organization has changed since the departure of the last Secretary General in 2013. The organization now has a new leader who previously worked within the organization. The Conference of Heads of Government wanted someone who is an employee and administrator so this option was chosen.

4. Do you believe that the Belizean populace is sufficiently aware of Belize's membership in CARICOM, the community's main institutions, the manner in which the organization functions and the advantages and/or disadvantages of Belize's membership? Belizeans are not aware of the inner workings of CARICOM and there is no CARICOM identity in Belize. The concept is irrelevant to most lives. The Caribbean is geographically located far away from mainland Belize and it is too hassling to travel there. The Belizean national identity is the only identity that Belizeans have. Notwithstanding this, there is a symbolism associated CARICOM membership but only in a political sense. It is only 
meaningful where the protection of a political grouping is concerned because for a long time there was a distrust of Central America.

5. When Belize joined the Caribbean Regional Integration movement, it was a free trade area known as CARIFTA. This has subsequently evolved into a Customs Union and now a Single Market; there is even the eventuality of the much postponed Single Economy. Do you believe that successive government administrations have appreciated the nuanced approach required to continue with this regional integration project?

No, successive governments have only been engaged in a limited way with CARICOM. The most important aspect has been support for the Belize-Guatemala territorial dispute. However, CARICOM itself is not without its flaws as there is a pretense about being a rules-based organization, but then exceptions are made for the MDCs of the grouping. The actual funding of the Caribbean integration project has always been an issue and on the technocrat-level there is also insufficient engagement.

6. The CARICOM Single Market and Economy is meant to be the main engine for regional development. What is your view on Belize's level of implementation thus far? Do you think that there is anything that can be done to accelerate Belize's pace of implementation?

There has been insufficient public education on the CSME. In many instances, the situation in CARICOM has been one where member states insist on their rights but walk away from their obligations. Belize needs to adapt an approach based on its own self-interest whilst at the same time maintaining a limited or token commitment to CARICOM.

7. Belize was one of the CARICOM Member States that "readily" signed on to the 2008 Economic Partnership Agreement; do you believe that this agreement will benefit Belize in the long term?

No, there are limited benefits for Belize in this arrangement. The Western district of Cayo in Belize has a very high unemployment rate whereby many adults lack suitable jobs. This should be an area of focus, not the signing of such agreements.

8. What is your general view of Belize (as a member of CARICOM) being involved in WTO-plus North South Trade Agreements with trading giants such as the EU, Canada and the USA?

Such agreements are not in Belize's best interest.

9. Do you believe that Belize has derived any real benefits from the other existing trade agreements that it has signed as a member of CARICOM?

No, because Belize has not even attempted to use these agreements.

10. Rt. Hon. Said Musa's book is entitled "Belize: A Caribbean Country in Central America", which geographic region holds more importance for Belize: Central America or the Caribbean? And Why?

The best approach for Belize is to be a bridge between Central America and CARICOM. Where trade is concerned, Belize should aim at importing incomplete exports from one region and re-export to the other region. The is a volume of trade to be exploited with 
Central America, however, the Belizean private sector tends to have a complacent approach about the matter. 
Annex 5

Interview No. 5

Mr. Godfrey Smith, Senior Counsel

Attorney at Law, Former Minister of Foreign Affairs of Belize

Date of Interview: $6^{\text {th }}$ January 2014

Location of Interview: Marine Parade Chambers, Belize City, Belize

1. Do you think that CARICOM membership is important for Belize's foreign and international trade policy? If yes, why?

Resoundingly, yes. The coordinated foreign policy is vital to small states because individual national views and interests are likely to be ignored in isolation versus when it is presented from the coordinated CARICOM platform. CARICOM membership has been vital with support for the Belize in its attempt to solve the Guatemalan claim and the membership has assisted with candidatures for international organizations. However, there has been a gap in how effective CARICOM has been with trade issues. CARICOM membership has had greater success with political issues.

2. What do you believe was Belize's main motivation in applying for CARICOM membership in 1974? How would you summarize Belize's level of participation since that time?

The main motivation was CARICOM support for Belize's quest for independence. Since that time, Belize has not participated as much as it could have in CARICOM affairs, but overall CARICOM as an organization has had an implementation deficit issue and the secretariat has been ineffective.

3. In 2012, there has been a great deal of discussion about reforming the way in which the CARICOM Secretariat functions. What is your view with respect to the current functioning of the CARICOM Secretariat in relation to Belize and do you believe that change needs to be effected in any particular area?

A new mechanism is required to do the business of CARICOM. Attendance at the annual CARICOM circuit of meetings is costly and videoconferencing would assist in minimizing costs.

4. Do you believe that the Belizean populace is sufficiently aware of Belize's membership in CARICOM, the community's main institutions, the manner in which the organization functions and the advantages and/or disadvantages of Belize's membership? No, most people are unaware of CARICOM membership and all that it entails

5. When Belize joined the Caribbean Regional Integration movement, it was a free trade area known as CARIFTA. This has subsequently evolved into a Customs Union and now a Single Market; there is even the eventuality of the much postponed Single Economy. Do you believe that successive government administrations have appreciated the nuanced approach required to continue with this regional integration project? 
No, they have not. Governments have grasped the broad idea regarding CARICOM, but not the specific issues. There is still a fundamental lack of understanding regarding national treatment issues in a CARICOM context. There is still a level of xenophobia whereby there is the expectation that Government should protect locals despite the existence of the CSM. Politically speaking, there is not much commitment to the idea of regional integration and its related policies.

6. The CARICOM Single Market and Economy is meant to be the main engine for regional development. What is your view on Belize's level of implementation thus far? Do you think that there is anything that can be done to accelerate Belize's pace of implementation?

Interviewee was not sufficiently aware of these issues to respond.

7. Belize was one of the CARICOM Member States that "readily" signed on to the 2008 Economic Partnership Agreement; do you believe that this agreement will benefit Belize in the long term?

Interviewee was not sufficiently aware of these issues to respond.

8. What is your general view of Belize (as a member of CARICOM) being involved in WTO-plus North South Trade Agreements with trading giants such as the EU, Canada and the USA?

Interviewee was not sufficiently aware of these issues to respond.

9. Do you believe that Belize has derived any real benefits from the other existing trade agreements that it has signed as a member of CARICOM?

Interviewee was not sufficiently aware of these issues to respond.

10. Rt. Hon. Said Musa's book is entitled "Belize: A Caribbean Country in Central America", which geographic region holds more importance for Belize: Central America or the Caribbean? And Why?

Central America is more important to Belize because of the geographical location as well as the lower transport costs involved with trade. In the future, Belize might have a difficult decision to make regarding which policy direction it truly wants to pursue. Currently, there is a great deal of commerce-related activities, which occur at the borders with Mexico and Guatemala. Much of these transactions are in contravention to the CARICOM treaty, but essentially impossible to stop. 
Annex 6

Interview No. 6

Ms. Kay Menzies

President, Belize Chamber of Commerce and Industry

Date of Interview: $6^{\text {th }}$ January 2014

Location of Interview: Offices of the Belize Chamber of Commerce and Industry, Withfield Tower, Belize City, Belize

1. Do you think that CARICOM membership is important for Belize's foreign and international trade policy? If yes, why?

Yes and No. There has been some export trade in commodities such as beans, corn, fruit and fruit juices; however, the import trade has been limited. Belize has not been strategic about its involvement in the CARICOM PTA. Over the decades, the behavior has been reactive as opposed to proactive. Where external trade negotiations for the Economic Partnership Agreement and the proposed CARICOM-Canada Agreement are concerned, CARICOM has not negotiated as a group due to the fact that the interests of certain member states are given greater priority.

2. What do you believe was Belize's main motivation in applying for CARICOM membership in 1974? How would you summarize Belize's level of participation since that time?

CARICOM membership was driven by political motivations. Since that time, the level of participation has been limited. Belize has not taken the lead on any major issue affecting the CARICOM member states.

3. In 2012, there has been a great deal of discussion about reforming the way in which the CARICOM Secretariat functions. What is your view with respect to the current functioning of the CARICOM Secretariat in relation to Belize and do you believe that change needs to be effected in any particular area?

Interviewee was not sufficiently aware of these issues to respond.

4. Do you believe that the Belizean populace is sufficiently aware of Belize's membership in CARICOM, the community's main institutions, the manner in which the organization functions and the advantages and/or disadvantages of Belize's membership? There is a general lack of awareness about the CARICOM PTA in Belize. Furthermore, there is a low level of interest in its inner workings.

5. When Belize joined the Caribbean Regional Integration movement, it was a free trade area known as CARIFTA. This has subsequently evolved into a Customs Union and now a Single Market; there is even the eventuality of the much postponed Single Economy. Do you believe that successive government administrations have appreciated the nuanced approach required to continue with this regional integration project. 
No. There is tremendous potential to be derived from the CARICOM PTA, however, a poor public relations strategy has been employed. The potential trade benefits have not been recognized as the approach taken in Belize tends to be more protectionist and less trade oriented. It is usually characterized by a defensive mode.

6. The CARICOM Single Market and Economy is meant to be the main engine for regional development. What is your view on Belize's level of implementation thus far? Do you think that there is anything that can be done to accelerate Belize's pace of implementation?

Interviewee was not sufficiently aware of these issues to respond.

7. Belize was one of the CARICOM Member States that "readily" signed on to the 2008 Economic Partnership Agreement; do you believe that this agreement will benefit Belize in the long term?

Efforts were made to educate the Belizean private sector on the EPA. However, many members did not utilize these opportunities. The implementation of the EPA will be accompanied by opportunities and threats. The Belizean private sector must change its mindset in order to adjust to the new realities. Many Belizean service providers have taken advantage of trainings and public education activities that were coordinated by the EPA unit in the Ministry of Foreign Trade.

8. What is your general view of Belize (as a member of CARICOM) being involved in WTO-plus North South Trade Agreements with trading giants such as the EU, Canada and the USA?

The administrative framework that enables Belize's participation in the negotiation of these types of agreements is lacking. As a private sector interest group, the Chamber of Commerce is not properly communicating with the Ministry of Foreign Trade or the Embassies of Belize that are on the front line of such negotiations. Belize needs to employ a more analytical approach to trade agreements. With respect to the EPA in particular, there was no sense of ownership of that agreement.

9. Do you believe that Belize has derived any real benefits from the other existing trade agreements that it has signed as a member of CARICOM?

No, Belize has not capitalized on any of the bilateral trade agreements that were signed by CARICOM.

10. Rt. Hon. Said Musa's book is entitled "Belize: A Caribbean Country in Central America", which geographic region holds more importance for Belize: Central America or the Caribbean? And Why?

Both regions are important to Belize. However, Belize has not capitalized on being the 'bridge' between CARICOM and Central America. 
Annex 7:

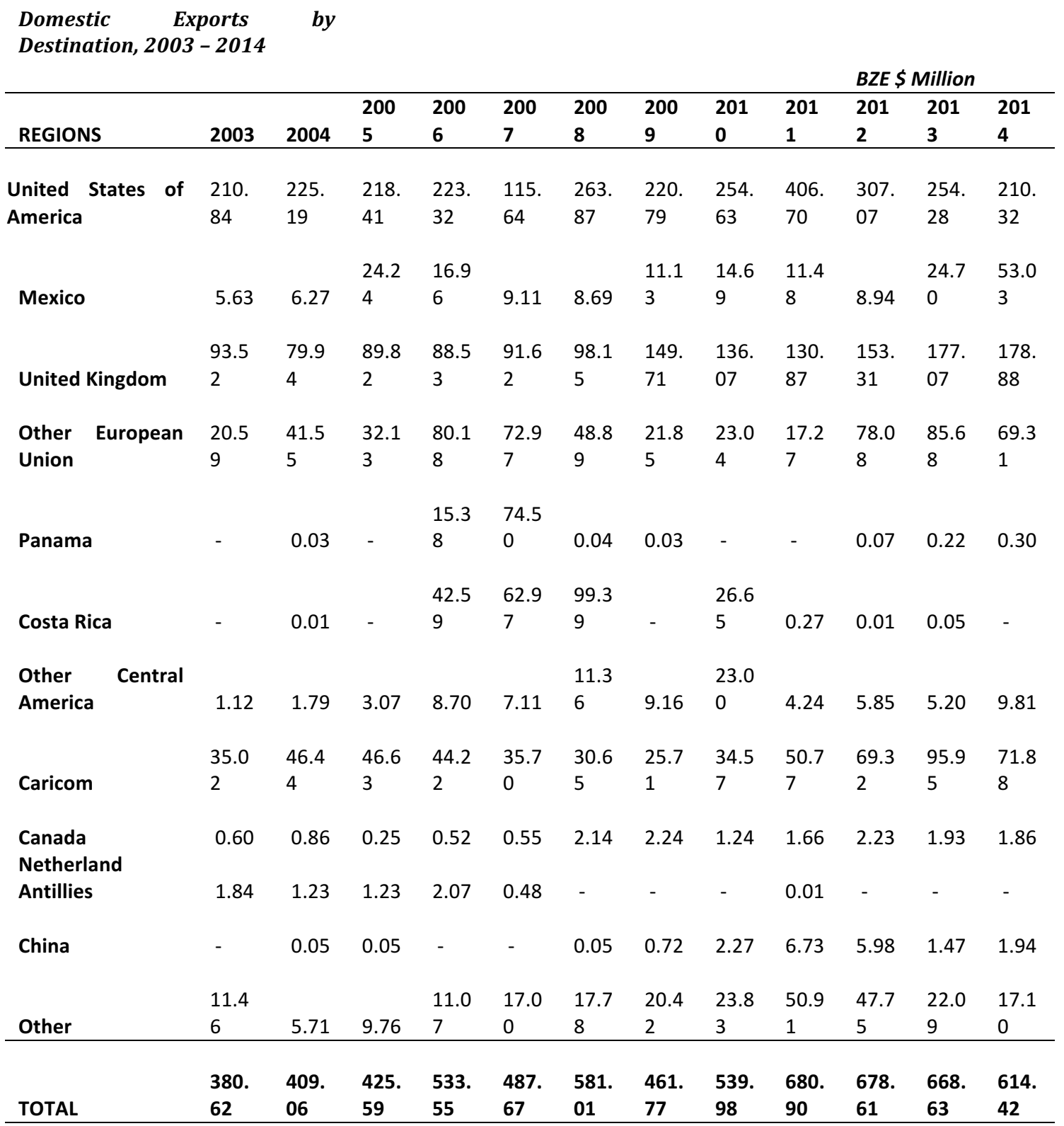

Source: Statistical Institute of Belize 


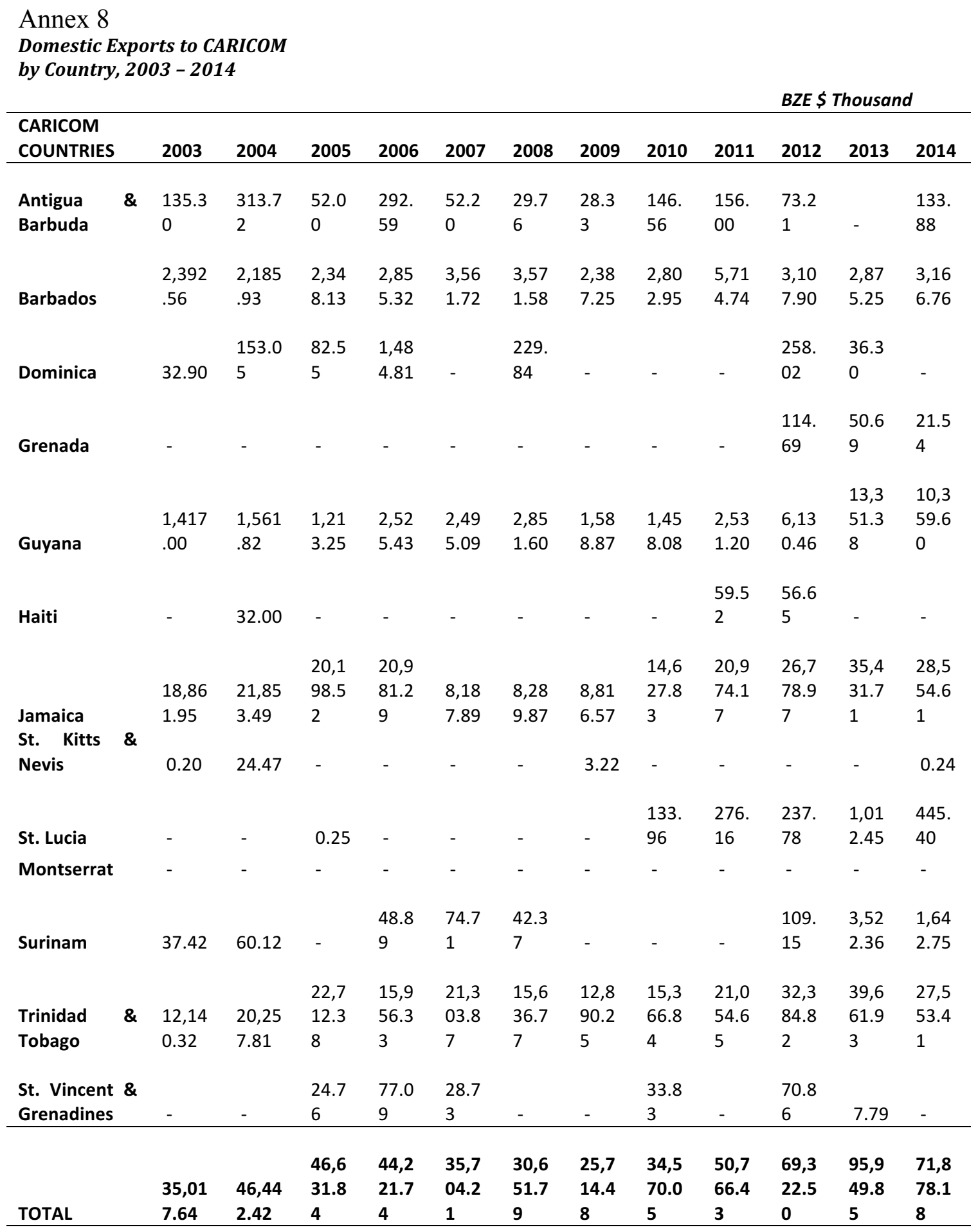

Source: Statistical Institute of Belize 
Annex 9

Gross Imports by Origin

BZE \$ Million

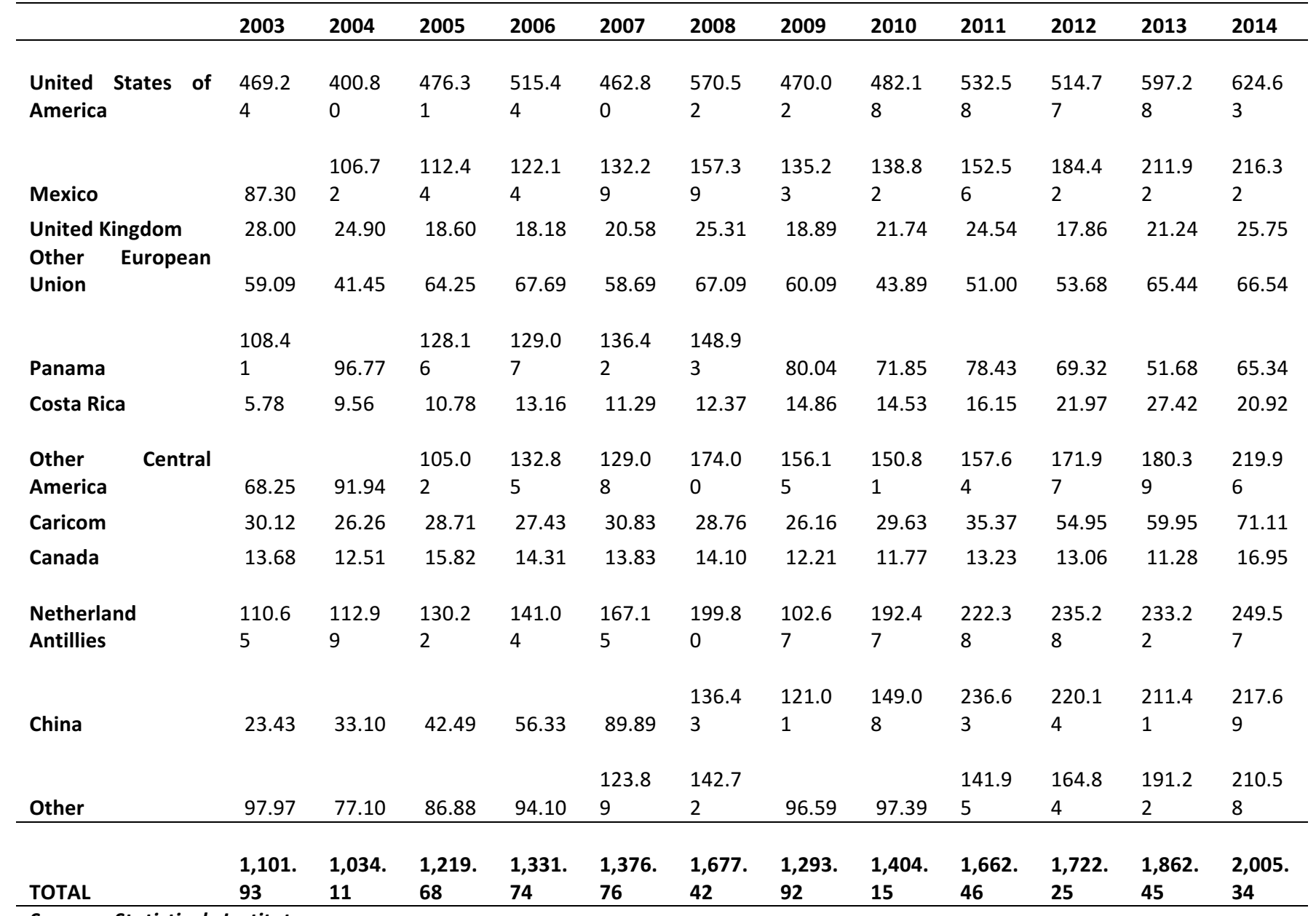

Source: Statistical Institute

of Belize 


\section{Chapter 7}

CARICOM: The External Dimension

\section{Introduction}

Chapter 7 is aimed at outlining the external dimension of the Caribbean Community (CARICOM) preferential trade agreement (PTA) and demonstrating the non-trade related benefits that are derived from the regional platform. The external dimension refers to the collective interaction of the CARICOM Member States on the international plane with third countries and international institutions in a bilateral, regional and multilateral context. ${ }^{990}$ Consequently, Chapter 7 probes the third subsidiary research question of this dissertation and illustrates how the CARICOM PTA has allowed small, developing countries to obtain advantages beyond the traditional trade gains associated with PTAs. Therefore, the CARICOM Member States have been able to efficiently utilize their limited resources whilst amplifying their voice and multiplying their influence on the international plane.

Chapter 5 of this dissertation highlighted that the internal dimension of the CARICOM PTA has generated limited traditional trade gains thus far. By comparison, the external dimension of the CARICOM PTA has been more useful. In order to assert the usefulness of the external dimension, its legal competences, institutional and procedural arrangements, as well as the substantive examples of coordination are examined with the use of CARICOM Secretariat documentation, Caribbean history books and Journals. ${ }^{991}$ The cooperation that has resulted from this process is benchmarked according to the volume and depth of the initiatives undertaken within the two most recent phases of regional integration in the Caribbean. ${ }^{992}$

\footnotetext{
${ }^{990}$ This also includes the treaty-making activities that have been undertaken by the respective CARICOM entities that have been endowed with juridical personality.

991 See Commonwealth Caribbean/CARICOM Secretariat Communiques issued at the conclusion of the Conference of Heads of Government of the Commonwealth Caribbean/CARICOM for the years spanning 1963 to 2016. See also H. Geiser, P. Alleyne, C. Garaj, Legal Problems of Caribbean Integration: A Study on the Legal Aspects of CARICOM (Institute of International Relations, St. Augustine, Trinidad and Tobago and A.W. Sijthoff International Publishing, Leiden, Netherlands, 1976); A. Payne, A Political History of CARICOM (Ian Randle Publishers, Kingston, Jamaica, 2008).

992 See K.O. Hall, B. Blake, "The Emergence of the African, Caribbean and Pacific Group of States: An Aspect of African and Caribbean International Cooperation" African Studies Review, 1979, Vol. 22(2) p. 111-125; E. Laurent, The Integrationist: Understanding International Trade - A CARICOM Perspective (Ian
} 
The first two phases of regional integration in the Caribbean, The West Indies Federation (The Federation) and the Caribbean Free Trade Association (CARIFTA), did not possess any legal competence for an external dimension. Most of the interstate cooperation and coordination on policy issues was subsumed under the intergovernmental workings of the Conference of Heads of Government (CHOG) ${ }^{993}$ Conversely, the Treaty of Chaguaramas (OTC) and the Revised Treaty of Chaguaramas (RTC), which represent the third and fourth phases of regional integration in the Caribbean, possess a legal competence for an external dimension. Both treaties contain legal provisions that underpin the concept of a coordinated foreign policy. And, both treaties created entities that have been endowed with juridical personality thereby legally enabling treaty-making activities and interaction with third states and international institutions.

The RTC introduced further legal competence for a coordinated external trade policy. In this context, it should be noted that CARICOM lacks a common foreign policy and a common external trade policy formulated by common institutions. Regional integration in the Caribbean operates under the tenets of intergovernmentalism and consequently, the CARICOM Member States retain a central role in the process including the formulation of core polices for areas such as foreign policy and external trade. Thus, the terms 'coordinated foreign policy' and 'coordinated external trade policy' are used to reflect the intergovernmental framework utilized to coordinate these policy realms. Both the OTC and the RTC confer authority on (ministerial) standing committees, councils and organs with the aim of attaining objectives related to these policy areas. ${ }^{994}$ Therefore, Chapter 7 charts the evolution of cooperation efforts that has served to advance CARICOM interests on the international plane.

Randle Publishers, Kingston, Jamaica, 2007); J. Braveboy-Wagner, Small States in Global Affairs: The Foreign Policies of the Caribbean Community (CARICOM) (Palgrave MacMillan, 2008).

${ }^{993}$ It is instructive to note that although Chapter 8 utilizes the term 'legal competence', it is meant to underscore the authority conferred by the respective treaties to attain certain objectives. As there are no supranational institutions within CARICOM, the concept of exclusive, shared and supporting legal competences, as seen in European Union law, do not apply to the legal and institutional arrangement of regional integration in the Caribbean. See K. Hall, CARICOM: Unity in Adversity in (ed.) K. Hall, The Integrationist: The Pertinence of CARICOM in the $21^{\text {st }}$ Century - Some Perspectives (Trafford Publishing, 2012), p. 16.

${ }_{994}$ The CARICOM regional integration arrangement does not possess any institutions, which feature the ability to legislate and adopt binding acts as seen with the European Commission or the European Parliament. 


\subsection{Non-Trade related Benefits}

Non-trade related benefits are advantages derived from PTA membership that are those other than traditional trade gains. Such benefits include inter alia regional cooperation and coordination on policy issues, greater social and political cohesion, conflict prevention, the gaining of increased multilateral bargaining power, the locking in of domestic policy reforms and the consolidation of democracy. ${ }^{995}$ An analysis of PTA use has demonstrated that such benefits can serve as motivation for countries to pursue membership in a PTA. In this regard, Chapter 6 illustrated that non-trade related benefits influenced the Belize policy decision to join the CARICOM PTA. However, analysis of PTA use has also shown that some PTAs generate more non-trade related benefits than traditional trade gains. ${ }^{996}$ Chapter 5 has illustrated that the CARICOM PTA is one such PTA. Most of the non-trade related benefits derived from the CARICOM PTA relate to the external dimension and assist in positioning the CARICOM Member States on the international plane. Given the increased interdependence and power politics involved with the international system, it is submitted that this aspect of the CARICOM PTA has provided the CARICOM Member States with a beneficial asset, which will be further explored in this chapter.

\subsubsection{The Concept of Legal Competence}

The next sections of this dissertation explain and expand upon the concept of legal competence within the context of regional integration in the Caribbean. The legal competences, which pertain to the external dimension of the CARICOM PTA, are the legally enshrined provisions that underpin the basis for CARICOM interaction on the international plane. These legal provisions outline the institutional and procedural manner of how such relations are governed and conducted. Designated standing committees,

\footnotetext{
995 M. Schiff, L. Winters, Regional Integration and Development (World Bank/Oxford University Press, 2003), p. 9; K. Chase, Trading Blocs: States, Firms and Regions in the World Economy (University of Michigan Press, 2005), p.18; T. Carpenter, A Historical Perspective on Regionalism in (eds) R. Baldwin, P. Low, Multilateralizing Regionalism: Challenges for the Global Trading System (Cambridge University Press, 2008), p. 13; J. Chauffour, J. Maur, Beyond Market Access in (eds.) J. Chauffour, J. Maur, Preferential Trade Agreement Policies for Development: A Handbook (World Bank, 2011), p. 25; R. Fernandez, J. Portes, Returns to Regionalism: An Analysis of Non-Traditional Gains from Regional Trade Agreements, World Bank Economic Review, 1998, Vol. 12(2), pp. 197-220.

${ }^{996}$ See N. Limao, Are Preferential Trade Agreements with Non-Trade Objectives a Stumbling Bloc for Multilateral Liberalization, The Review of Economic Studies, 2007, Vol. 74 (3), pp. 821-855.
} 
councils and organs may only act within the limits of the competences conferred. ${ }^{997}$ Since this dissertation is focused on the post-colonial Caribbean region, it is imperative to note that sovereignty is inherent to the legal competence required for acting on the international plane. The process of decolonization in the Caribbean has impacted this aspect of the external dimension, as sovereign (independent) states are the sole actors on the international plane and many CARICOM Member States were required to wait for the formal grant of independence before reaping the full benefits of the external dimension. ${ }^{998}$

7.1.2 Legal Competence under the West Indies Federation and the Caribbean Free Trade Association

Both the Federation and CARIFTA did not possess legal competence for an external dimension. In the case of the Federation, it must be recalled that all 10 British Caribbean territories retained the constitutional status of United Kingdom (UK) colonies and although several competences pertaining to self-government were transferred to the federal government after the establishment of the Federation, the Queen of the UK remained the sovereign Head of State and executive affairs remained vested in the British crown. Consequently, legal competence for issues pertaining to formal external relations with third countries remained with the UK government. ${ }^{999}$

In this context, the 10 members of the Federation, which were all UK colonies, were not recognized as actors on the international plane under international law. Nevertheless, intergovernmental cooperation and coordination of 'British Caribbean' policy issues among these UK colonies still existed informally. The very formation of the Federation was a result of intergovernmental cooperation due to the fact that they sought greater

\footnotetext{
${ }^{997}$ D. Pollard, Institutional and Legal Aspects of the Caribbean Community, Caribbean Studies, 1974 , Vol. 14 (1), pp. 39-74, p. 52.

998 Ibid, D. Pollard, 1974, Vol. 14 (1), pp. 39-74, p. 54.

999 “CARIFTA, by its very objectives, was mainly concerned with trade liberalization as among its member territories, [some] being fully entitled to continue trade and commerce, on an individual basis, with third parties. Consequently, the Association as such did not properly speaking, conduct any external relations." See H. Geiser, P. Alleyne, C. Garaj, Legal Problems of Caribbean Integration: A Study on the Legal Aspects of CARICOM (Institute of International Relations, St. Augustine, Trinidad and Tobago and A.W. Sijthoff International Publishing, Leiden, Netherlands, 1976), p.135. See also Chapter 4, Section 4.4 entitled Phase 1: The West Indies Federation.
} 
autonomy over their domestic affairs. ${ }^{1000}$ It must be recalled that these territories were separate colonies with separate identities geographically dispersed in the Caribbean Sea. Despite this, their political leaders were able to galvanize themselves for the purpose of a common pursuit. ${ }^{1001}$

In the case of CARIFTA, the PTA was mainly focused on the liberalization of tariffs and the generation of intraregional trade. This is noted in the exclusively trade related objectives of the 1965 Dickenson Bay Agreement that established CARIFTA. ${ }^{1002}$ It is important to recall that most of the signatories of CARIFTA were not independent states and as such, they lacked the sovereignty required to act on the international plane. ${ }^{1003}$ As a consequence of this, CARIFTA lacked legal provisions underpinning any formal aspect of foreign policy coordination among its signatories or other legal provisions outlining legal competences for an external dimension. ${ }^{1004}$ Nevertheless, intergovernmental coordination still continued and was able to thrive among these UK colonies with the tradition of convening the Conference of Heads of Government of the Commonwealth Caribbean,

\footnotetext{
1000 "The disturbances of the 1930s also brought about serious change in the political power structure of the colonies which... had serious implications for the formation of the federation. Out of the labor disturbances emerged staunch Caribbean nationalists such as Grantley Adams of Barbados, Norman Manley of Jamaica, Albertine Gomes of Trinidad, Hubert Critchlow of Guyana among others, committed to the achievement of self-government. For them federation represented a means to self-government. By 1938, the political leaders of the Eastern Caribbean territories were unequivocally committed to the federation. I. Boxhill, Ideology and Caribbean Integration (Canoe Press, University of the West Indies, 1997), p. 34.

1001 "The 1933 Agreement for the commencement of the federation was secured at a conference held in London between Colonial Office officials and Caribbean leaders. This was followed by another London conference in 1956 at which a decision was made to start the federation on $23^{\text {rd }}$ February of that year. Ibid, I. Boxhill, 1997, p. 35.

${ }_{1002}$ See Dickenson Bay Agreement establishing the Caribbean Free Trade Association (adopted $15^{\text {th }}$ December 1965, in force $1^{\text {st }}$ May 1968) 772 UNTS 3. Article 2 of the Dickinson Bay Agreement establishing CARIFTA states "The objectives of the Association shall be (a) to promote the expansion and diversification of trade in the area of the Association; (b) to secure that trade between member territories takes place in conditions of fair competition; (c) to encourage the progressive development of the economies of the Area; (d) to foster the harmonious development of Caribbean trade and its liberalization by the removal of barriers to it."

${ }^{1003}$ See Chapter 4, Section 4.5 entitled The Issue of Constitutional Status. See also D. Pollard, Institutional and Legal Aspects of the Caribbean Community, Caribbean Studies, 1974, Vol. 14 (1), pp. 39-74, p. 54.

${ }^{1004}$ The first formal mention of a coordinated foreign policy for CARICOM Member States was noted in Article 17 of the 1973 OTC, which was entitled Coordination of Foreign Policies and stated: "To the end that Member States aim at the fullest possible coordination of their foreign policies within their respective competences and seek to adopt as far as possible common positions in major international issues, there is hereby established a Standing Committee of Ministers responsible for Foreign Affairs."
} 
which commenced in $1963 .{ }^{1005}$ This resulted in the adoption of a common approach on key external issues of the day and particularly issues that pertained to Commonwealth trade preferences, which were seen as a benefit to the region as a whole versus that of individual UK colonies. ${ }^{1006}$

\subsubsection{Legal Competence under the Original Treaty of Chaguaramas}

The 1973 OTC was the first Caribbean PTA that included specific legal provisions outlining legal competences for an external dimension of the CARICOM PTA. ${ }^{1007}$ Firstly, the OTC contained legal provisions for foreign policy coordination. ${ }^{1008}$ Secondly, the OTC formalized the meeting of CHOG that had commenced in 1963 by formally designating it as one of the principal organs of the Community. ${ }^{1009}$ Thirdly, the OTC endowed the two entities that it created, 'The Caribbean Community' and 'The Caribbean Common Market', with juridical personality thereby making them subjects of international law and providing CARICOM with a legal basis upon which it could establish external relations. ${ }^{1010}$ As such,

\footnotetext{
${ }^{1005}$ The first Commonwealth Caribbean Conference of Heads of Government was convened in Port of Spain, Trinidad and Tobago from $22^{\text {nd }}-25^{\text {th }}$ July 1963 under the Chairmanship of the then Prime Minister of Trinidad and Tobago, Dr. Eric Williams. See D. Pollard, Institutional and Legal Aspects of the Caribbean Community, Caribbean Studies, 1974, Vol. 14 (1), pp. 39-74, p. 40.

"Agreed: The necessity for the closest possible collaboration among the Commonwealth Caribbean Countries on matters of common interests particularly in gaining recognition for the separate identity of the region, its unique history and background and its potential contribution to world peace and stability." Communiqué issued at the conclusion of the second conference of the Heads of Government of Commonwealth Caribbean Countries, 13-17 January 1964, Kingston Jamaica.

${ }^{1006}$ In this regard, the Communique issued at the conclusion of the third conference of the Heads of Government of Commonwealth Caribbean Countries, 8-10 March 1965, Georgetown, Guyana noted that the conference passed a resolution pertaining to the sale of sugar under the Commonwealth Sugar Agreement (CSA). Furthermore, the Summary of Conclusions of the fourth conference of the Heads of Government of Commonwealth Caribbean Countries, 23-27 October 1967, Bridgetown, Barbados noted that one of the agenda items discussed under International Questions of Common Interest was the Desirability of Commonwealth Caribbean Countries seeking Associate Overseas Territories Status with the EEC. It is important to note that the aforementioned external policy coordination occurred at a time when a formal foreign policy coordination mechanism did not exist, however, these illustrations demonstrate that there was a clear need for the British Caribbean territories to interact with the UK on an external political level.

${ }^{1007}$ See The Treaty of Chaguaramas (adopted $4^{\text {th }}$ July 1973, in force $1^{\text {st }}$ August 1973) 946 UNTS 17; See GATT Secretariat, Treaty Establishing the Caribbean Community (Geneva, 14 ${ }^{\text {th }}$ October 1974) [L/4083].

${ }^{1008}$ Article 4 (b) of the OTC states "The Community shall have as its objectives the coordination of the foreign polices of member states".

${ }^{1009}$ Article 6 of the OTC states "The principal organs of the Community shall be the Conference of Heads of Government and The Common Market Council established under the Annex."

${ }^{1010}$ Article 20 of the OTC states "The Community shall have full juridical personality." and Article 63(1) of the Caribbean Common Market Annex states "The Common Market shall have international juridical personality." See also C. Garaj, Legal Problems of Caribbean Integration: A Study on the Legal Aspects of 
'The Caribbean Community' was empowered with the legal capacity to enter into international agreements with third countries and international organizations. ${ }^{1011}$ And, 'The Caribbean Community' also possessed treaty-making functions as a result of its juridical personality. $^{1012}$

Another objective of the OTC was the coordination of economic and trade relations among the CARICOM Member States. ${ }^{1013}$ Chapter four of the Common Market Annex of the OTC outlined the requirements for CARICOM Member States desiring trade relations with third countries. ${ }^{1014}$ Article 34(2) of the Common Market Annex outlined the requirements for CARICOM Member States entering bilateral trade agreement with third countries. ${ }^{1015}$ The inclusion of this legal provision highlights that CARICOM Member States retained the legal competence to pursue their own (individual) trade policy objectives outside of those coordinated within the regional context. Thus, they were not legally obligated to conduct their trade policy exclusively on the regional platform. Article 34 of the Common Market Annex was infrequently used and only a few Member States initiated bilateral negotiations for PTAs. ${ }^{1016}$ It is argued that the minimal use of bilateral trade agreements by CARICOM Member States was attributable to the fact that the majority of CARICOM trade relations

CARICOM (Institute of International Relations, St. Augustine, Trinidad and Tobago and A.W. Sijthoff International Publishing, Leiden, Netherlands, 1976), p. 136.

${ }^{1011}$ Article 20(3) of the OTC states "The Community may enter into agreement with Member States, nonMember States and international organizations."

${ }^{1012}$ Article 8(4) of the OTC states "Subject to the relevant provisions of this Treaty, the Conference [of Heads of Government] shall be the final authority for the conclusion of treaties on behalf of the Community and for entering into relationships between the Community and International Organizations and States." and Article 70(1) of the Caribbean Common Market Annex states "The Council may, on behalf of the Common Market, negotiate agreements with Member States, non-Member States and other international organizations in order to promote the objectives of the Common Market."

${ }^{1013}$ Article 4(a) (i) of the OTC states "The Community shall have as its objectives...the strengthening, coordination and regulation of the economic and trade relations among Member States in order to promote their accelerated harmonious and balanced development;"

${ }^{1014}$ Article 34(1) of the Common Market Annex of the OTC states "Member States shall seek a progressive co-ordination of their trade relations with third countries or groups of third countries."

${ }^{1015}$ This legal provision stated "Member States undertake to transmit to the Secretariat particulars of any trade or aid agreements entered into after the entry into force of this Annex".

It is instructive to note that Article 34 of the Common Market Annex did not specify whether the notification requested regarding the details of trade or aid agreements was required prior to or after the entry into force of such agreements.

${ }^{1016}$ Guyana and Trinidad and Tobago utilized this provision to pursue respective partial scope agreements with Venezuela prior to the 1992 CARICOM-Venezuela FTA. The Guyana-Venezuela PSA was signed on $27^{\text {th }}$ October 1989 and has been superseded by the 1992 CARICOM-Venezuela FTA. The same principle applied to the Trinidad and Tobago-Venezuela FTA, which was signed on $4^{\text {th }}$ August 1989. 
were conducted under three preferential trading arrangements with Europe, Canada and the US that were accorded to the CARICOM regional bloc.

\subsubsection{Legal Competence under the Revised Treaty of Chaguaramas}

Although signed in 2001, the road leading to the RTC was paved in 1989 with the issuance of the Grand Anse Declaration and work program. ${ }^{1017}$ It is argued that an important catalyst that led to the rethink of the legal and institutional framework of Caribbean regional integration was the changing nature of international economic relations among sovereign states. ${ }^{1018}$ Eventually, nine protocols to revise the OTC were produced. ${ }^{1019}$ These protocols were aimed at establishing a framework that would direct the operations of the CARICOM single market and economy (CSME). The protocols were signed individually between 1993 and 2000. During this time, it was also acknowledged that the external dimension of CARICOM required improved institutional arrangements and consequently, the first protocol to the OTC restructured the organs and institutions of CARICOM. By 2001, various protocols were in effect and being provisionally applied. ${ }^{1020}$ In July 2001, all nine protocols were subsequently integrated into the RTC, which was notified to the WTO Secretariat. $^{1021}$

\footnotetext{
${ }^{1017}$ Post-1989, a program of action to create the CARICOM single market and economy was pursued and an intergovernmental task force was established in 1992. D. Mohammed, Size and Competiveness: An Examination of the CARICOM Single Market and Economy, The Roundtable, 2008, Vol. 97 (395), pp. 287303, p. 295.

1018 " [....] The Heads of Government of the Caribbean Community inspired by the spirit of cooperation and solidarity among us are moved by the need to work expeditiously together to deepen the integration process and strengthen the Caribbean Community in all of its dimensions to respond to the challenges and opportunities presented by the changes in the global economy." See Introduction to the 1989 Grand Anse Declaration and Work Programme for the advancement of the integration movement.

1019 The nine protocols were as follows: Protocol I: Restructuring the Organs and Institutions of the Community; Protocol II: Rights of Establishment, Provision of Services and Movement of Captial; Protocol III: Industrial Policy; Protocol IV: Trade Policy; Protocol V: Agricultural Policy; Protocol VI: Transportation Policy; Protocol VII: Disadvantaged Countries, Regions and Sectors; Protocol VIII: Competition Policy and Consumer Protection and Dumping and Subsidies; Protocol IX: Dispute Settlement Protocol

${ }^{1020}$ See CARICOM Secretariat, Communique issued at the Twentieth Meeting of the Conference of Heads of Government of the Caribbean Community, Port of Spain, Trinidad and Tobago, $4^{\text {th }}-7^{\text {th }}$ July 1999.

${ }^{1021}$ See Revised Treaty of Chaguaramas Establishing The Caribbean Community Including The CARICOM Single Market and Economy (adopted 5 July 2001, in force 1 January 2006) 2259 UNTS 293; WTO Secretariat, Caribbean Community and Common Market, Text of the Revised Treaty (Geneva, $8^{\text {th }}$ July 2003) [WT/REG155/1]; WTO Secretariat, Notification pursuant to Article V: 7(a) of the General Agreement on Trade in Services (Geneva, $19^{\text {th }}$ February 2003) [S/C/N/229].
} 
The RTC improved upon the legal competences for the external dimension of the CARICOM PTA as it established 'The Community', which is recognized as the successor of 'The Caribbean Community' and 'The Common Market'. ${ }^{1022}$ Therefore, 'The Community' is now the entity endowed with juridical personality and possesses the legal basis from which CARICOM external relations with third states and international institutions are pursued. Furthermore, the stated objectives of 'The Community' as it pertains to the external dimension include the expansion of trade and economic relations with third states and the enhanced coordination of the foreign and foreign economic policies of the CARICOM Member States. ${ }^{1023}$ Where legal provisions related to external trade policy are concerned, Article 80 (2) of the RTC affirms that CARICOM Member States should engage in external trade negotiations on a joint basis. ${ }^{1024}$ And, the RTC mandates that bilateral trade agreements between individual CARICOM Member States and third states be certified by the CARICOM Secretariat prior to their conclusion. ${ }^{1025}$ This represents a variance from Article 34 of the Common Market Annex of the OTC, which only required CARICOM Member States to transmit such agreements to the CARICOM Secretariat.

7.2 Institutional and Procedural Arrangements under the Federation and the Caribbean Free Trade Association

As was previously noted, the Federation and CARIFTA did not possess any legal competence for an external dimension. As such, most of their institutional and procedural arrangements pertained to the internal functioning of the regional initiative and this is outside the remit of this chapter, which focuses on the external dimension of the

\footnotetext{
${ }^{1022}$ Article 2 of the RTC states "The Community is hereby established and recognized in the Protocol hereto as successor to the Caribbean Community and Common Market."

${ }^{1023}$ Article 6 (d) of the RTC states "The Community shall have the following objectives: the expansion of trade and economic relations with third States;" and Article 6 (h) of the RTC states "The Community shall have the following objectives: the enhanced coordination of Member States' foreign and [foreign] economic policies;"

${ }^{1024}$ Article 80 (2) of the RTC states "The Community shall pursue the negotiation of external trade and economic agreements on a joint basis in accordance with principles and mechanisms established by the conference."

${ }^{1025}$ Article 80 (3) of the RTC states "Bilateral agreements to be negotiated by Member States in pursuance of their national strategic interests shall: (a) be without prejudice to their obligation under the Treaty; and (b) prior to their conclusion, be subject to certification by the CARICOM Secretariat that the agreements do not prejudice or place at a disadvantage the position of other CARICOM states vis-à-vis the Treaty."
} 
CARICOM PTA. With respect to CARIFTA, it is notable that a Commonwealth Caribbean regional secretariat (CCRS) was established in $1968 .{ }^{1026}$ The CCRS, which was based in Georgetown, Guyana, was created with the administrative mandate to give effect to the provisions of the Dickenson Bay Agreement that established CARIFTA.

7.2.1 Institutional and Procedural Arrangements under the Original Treaty of Chaguaramas The main bodies that facilitated the legal competence for the external dimension of the CARICOM PTA under the OTC referenced in section 7.1.3 of this chapter were the Standing Committee of Ministers responsible for Foreign Affairs (SCMFA) and the Conference of Heads of Government (CHOG). The CCRS, which was eventually renamed the CARICOM Secretariat, assisted with the administrative tasks associated with the unfolding of regional integration in the Caribbean Again, it is noted that regional integration in the Caribbean is a member-driven, state centric process whereby the CARICOM Member States assume a central role in directing how the regional integration process is managed. This reflects the strong intergovernmental emphasis that has been placed on the regional initiative. ${ }^{1027}$ Unlike regional integration in Europe, there is no supranational institution, which shares certain legal competences and is able to formulate and direct policy issues.

\subsubsection{The Standing Committee of Ministers of Foreign Affairs (SCMFA)}

The SCMFA was created by the OTC and designated as one of the institutions of the Community. ${ }^{1028}$ This body was composed of the Ministers of Foreign Affairs from the independent CARICOM Member States ${ }^{1029}$ and participation in the body was qualified by

\footnotetext{
${ }^{1026}$ See D. Pollard, Institutional and Legal Aspects of the Caribbean Community, Caribbean Studies, 1974, Vol. 14 (1), pp. 39-74, p. 57.

${ }^{1027}$ Intergovernmentalism, first advanced by Stanley Hoffmann in the mid-1960s, reflects the realist notion that nation states are rational, self-interested actors focused on their survival and economic growth. See M. Cini, Intergovernmentalism in (ed.) M. Cini, European Union Politics, Second Edition (Oxford University Press, 2007), p. 101; (ed.) M. O'Neill, The Politics of European Integration, A Reader (Routledge, 2005), p. 56.

${ }^{1028}$ Article 10 of the OTC states "Institutions of the Community shall be the Standing Committee of Ministers responsible for Foreign Affairs."

${ }^{1029}$ Article 11 of the OTC was entitled 'Composition of Institutions of the Community' and Article 11(1) stated "Each Institution of the Community as set out in paragraphs (a) to (h) of Article 10 of this Treaty shall consist of representatives of Member States. Each Member State shall designate a Minister of Government as its representative on each such institution".
} 
Article 17 (3) of the OTC, which outlined that only CARICOM Member States with the necessary competence for foreign affairs could partake in deliberations of the SCMFA. ${ }^{1030}$ Consequently, the principle of the sovereign equality of states was not observed in the SCMFA and the non-independent CARICOM Member States were not involved in certain aspects of foreign policy coordination. ${ }^{1031}$ The SCMFA exemplified the intergovernmental approach to interstate bargaining on key policy issues, as it was the representatives of the independent CARICOM Member States that were involved in the decision making process. ${ }^{1032}$ With respect to treaty-making powers, the non-independent CARICOM Member States were required to obtain permission from the UK prior to participation in such matters. ${ }^{1033}$ As a further reflection of the varying constitutional status of the CARICOM Member States, Article 17 (4) of the OTC explained that upon the achievement of independence after the entry into force of the OTC, the newly independent CARICOM Member States must elect whether they wish to be bound by the provisions of Article 17 of the OTC. ${ }^{1034}$

The SCMFA was responsible for formulating policies and performing functions necessary for the achievement of the objectives of the Community within the sphere of competence

\footnotetext{
${ }^{1030}$ When the OTC was signed on $4^{\text {th }}$ July 1973 , the four signatories were the independent Caribbean countries: Jamaica, Barbados, Guyana and Trinidad and Tobago. By the end of 1974, CARICOM had twelve Member States, however, only five were independent states. Belize and Montserrat were still UK colonies and the other five CARICOM Member States were Associated States with the UK. Thus, the UK Government held competence for the external affairs of these CARICOM Member States and this limited their involvement in CARICOM treaty-making and foreign policy coordination activities. See Chapter 4, Section 4.5 entitled The Issue of Constitutional Status. See D. Pollard, Institutional and Legal Aspects of the Caribbean Community, Caribbean Studies, 1974, Vol. 14 (1), pp. 39-74, p. 51.

${ }^{1031}$ See Ibid, D. Pollard, 1974, Vol. 14 (1), pp. 39-74, p. 54.

1032 See A. Stone Sweet, W. Sandholtz, European Integration and Supranational Governance, Journal of European Public Policy, 1997, Vol. 4(3), pp. 297-317, p. 298.

${ }^{1033}$ H. Geiser, P. Alleyne, C. Garaj, Legal Problems of Caribbean Integration: A Study on the Legal Aspects of CARICOM (Institute of International Relations, St. Augustine, Trinidad and Tobago and A.W. Sijthoff International Publishing, Leiden, Netherlands, 1976), p.128.

${ }^{1034}$ Despite the specific rules of procedure pertaining to non-independent CARICOM Member States, it is submitted that most negotiations were addressed in a general manner that emphasized the benefit received by the region as a whole. One beneficial aspect of this approach is that it allowed the smaller LDC CARICOM Member States the ability to reap the non-trade related benefits of international cooperation despite lacking the requisite negotiating expertise in addressing some of these matters. In this regard, the regional platform also provided a sense of security, as the less able Member States were aware that their best interests were still being safeguarded despite their limited participation in external negotiations.
} 
related to foreign affairs. ${ }^{1035}$ The powers and function of the SCMFA were subject to the direction of the CHOG and were restricted to the extent necessary to achieve community objectives. ${ }^{1036}$ Further to this, Article 17 of the OTC outlined that the main aim of CARICOM foreign policy coordination as "the fullest possible coordination of foreign policies within the respective competences and the adoption as far as possible common positions in major international issues". ${ }^{1037}$ Article 17 (2) of the OTC explained that the SCMFA had the power to make recommendations to the Governments of the CARICOM Member States represented on the Committee. Article 17(5) of the OTC outlined that the recommendations of the SCMFA shall be made by an affirmative (unanimous) vote of all the CARICOM Member States competent to participate in the deliberations. ${ }^{1038}$ Most of the key issues pertaining to foreign policy coordination among the CARICOM Member States were debated at the level of the SCMFA before being tabled at the CHOG level. As one of the principal organs of the Community, the CHOG was able to provide a final pronouncement on various foreign policy issues.

\subsubsection{The Conference of Heads of Government (CHOG)}

As previously noted, the meetings of the CHOG commenced informally in 1963. However, this body was formalized in Article 7 of the OTC, which outlined that the CHOG shall consist of the Heads of Government of the respective CARICOM Member States. Furthermore, Article 8 (1) of the OTC outlined the primary responsibility of the body as being "to determine the policy of the Community". In the context of facilitating the external dimension of the CARICOM PTA, the CHOG was described as "the final authority for the conclusion of treaties on behalf of the Community and for entering into relationships

\footnotetext{
1035 See Article 12 (1) of the OTC. It is argued that there was some degree of convergence between issues labeled as 'foreign policy' and those now labeled as 'external trade issues'. In 1973 when the OTC was signed, such issues were not precisely delineated and this was apparent in the manner that external trade issues were institutionally addressed within CARICOM. All issues pertaining to trade preferences were addressed within the SCMFA although such issues would now be considered as 'external trade issues'.

${ }^{1036}$ See D. Pollard, Institutional and Legal Aspects of the Caribbean Community, Caribbean Studies, 1974, Vol. 14 (1), pp. 39-74, p. 52.

${ }^{1037}$ See Article 17 (1) of the OTC.

${ }^{1038}$ It is noted that these recommendations were not binding on the CARICOM Member States and solely possessed persuasive force. See D. Pollard, Institutional and Legal Aspects of the Caribbean Community, Caribbean Studies, 1974, Vol. 14 (1), pp. 39-74, p. 53.
} 
between the Community and International Organizations and States". ${ }^{1039}$ The CHOG also retained the ability to "regulate its own procedure and decide to admit at its deliberations observers, representatives of non-Member States or other entities"1040 and could "consult with entities and other organizations within the region and for this purpose may establish such machinery as it deems necessary". 1041

Article 9 of the OTC outlined the voting procedure by explaining that each CARICOM Member State within the CHOG had one vote ${ }^{1042}$ and decisions and recommendations of the CHOG were undertaken by affirmative (unanimous) vote. ${ }^{1043}$ Article 9(3) of the OTC also clarified that decisions of the CHOG were binding upon each CARICOM Member State to which it was directed and that recommendations of the CHOG were persuasive with no binding force. With respect to treaty making, the $\mathrm{CHOG}$ acted to conclude treaties by undertaking a decision by an affirmative vote of its entire membership. This procedure was first utilized with the signing of the CARICOM-Mexico cooperation agreement. ${ }^{1044}$

7.2.1.3 The Prime Ministerial Sub-Committee on External Relations (PMSCER) and the Caribbean Regional Negotiating Machinery (CRNM)

In the early 1990s, the CHOG recognized the common need for all CARICOM Member States to strategize international economic relations given the advent of the North American Free Trade Agreement (NAFTA), which would enter into force in 1994 and the Summit of the Americas process, which envisioned the establishment of the Free Trade Areas of the Americas (FTAA). ${ }^{1045}$ Additionally, the Uruguay Round of GATT

\footnotetext{
${ }^{1039}$ See Article 8 (4) of the OTC.

${ }^{1040}$ See Article 8 (6) of the OTC.

${ }^{1041}$ See Article 8 (7) of the OTC.

${ }^{1042}$ See Article 9 (1) of the OTC.

${ }^{1043}$ See Article 9 (2) of the OTC. See also K. Hall, CARICOM: Unity in Adversity in (ed.) K. Hall, The Integrationist: The Pertinence of CARICOM in the $21^{\text {st }}$ Century - Some Perspectives (Trafford Publishing, 2012), p. 17.

${ }^{1044}$ C. Garaj, Legal Problems of Caribbean Integration: A Study on the Legal Aspects of CARICOM (Institute of International Relations, St. Augustine, Trinidad and Tobago and A.W. Sijthoff International Publishing, Leiden, Netherlands, 1976), p. 140. See also Section 8.4.1 entitled Cooperation Agreement with Mexico.

1045 "The Meeting took note of the major developments on the international scene. Of particular significance to the Heads of Government was the fact that since their Meeting in July 1992, Canada, Mexico and the United States had signed the North American Free Trade Agreement, (NAFTA) and the European Single Market had been established. They noted with concern the thrust on the part of industrialised countries towards the creation of large trading blocs and that the insistence of some of these countries on accelerated
} 
negotiations were headed towards a successful conclusion at the end of 1993, which eventually resulted in the creation of the World Trade Organization (WTO) in $1995 .{ }^{1046}$ Consequently, the CHOG established a PMSCER in 1993 to assist with the coordination of external economic matters at the political level. ${ }^{1047}$ There is no legal treaty provision underpinning the establishment of the PMSCER, as the body was created by an administrative decision of the CHOG. The PMSCER has been chaired by Jamaica since its creation and consists of four other CARICOM Member States. Its main task is to address external economic matters at a high political level and to mobilize the CARICOM Heads of Government when necessary. The PMSCER reports to the CHOG.

Furthermore, the CHOG established the CRNM in 1997 with the aim of addressing the external economic concerns of the CARICOM region at the technical level. The main task of the CRNM was to develop, coordinate and execute negotiating strategies for the various external trade negotiations that beckoned for the CARICOM region. Institutionally speaking, the CRNM reported to the PMSCER and the CHOG. After the RTC was signed in 2001, the CRNM also reported to the Council for Trade and Economic Development (COTED). ${ }^{1048}$ The creation of the CRNM illustrated the non-trade benefit derived from the pooling of resources and the joint effort of CARICOM Member States to confront the various negotiating challenges that were facing the CARICOM region in the 1990s. The

trade liberalisation in respect of all developing countries has presented a number of developing countries, including those of CARICOM, with major economic challenges." Communique issued at the Fourth InterSessional Meeting of the Conference of Heads of Government of the Caribbean Community, Roseau, Dominica, 22-23 March 1993.

${ }^{1046}$ By early 1996, all of the independent CARICOM Member States had acceded to the WTO and there was a regional realization that CARICOM would be required to participate in the multilateral liberalization of tariff and non-tariff barriers as well as the implementation of the other WTO Agreements.

1047 "Heads of Government, mindful of the rapidly changing global environment, the strengthening of regional trade blocs and the extremely high degree of uncertainty and volatility in the international trade... agreed that it was imperative for the region to act in concert to meet the challenges inherent in the new situation... They therefore approved a broad strategy and guidelines for the conduct of international economic and trade negotiations for CARICOM countries. In addition, they identified a team of Heads of Government, including the Heads of Government with specific responsibilities for external negotiations.... and high level officials from the Regional organisations to assume responsibility for coordinating and implementing the Region's External Programme." Communique issued at the Fourteenth Meeting of the Conference of Heads of Government of the Caribbean Community, Nassau, The Bahamas, 5-8 July 1993.

${ }_{1048}$ In 2009, the CRNM was renamed the Office of Trade Negotiations (OTN) and was integrated into the CARICOM Secretariat as a specialized department. 
rationalized mobilization of resources further demonstrated the ability of the CARICOM Member States to collaborate on external issues.

The CRNM played a crucial role in bolstering the limited negotiating capacity of the CARICOM Member States. ${ }^{1049}$ The agency was involved in CARICOM negotiations at the multilateral level with WTO negotiations, the EU (bilateral) level with negotiations regarding the successor agreement to the Cotonou agreement (the Economic Partnership Agreement), the hemispheric level with the FTAA negotiations and at the bilateral level with the negotiation bilateral FTAs. ${ }^{1050}$ The CRNM maintained offices in Brussels, Belgium and Geneva, Switzerland in order to assist with this mandate, which also included the formulation of common regional negotiating positions. Between 1973 and 2001 when the RTC was signed, it is submitted that the foreign policy coordination limb of the CARICOM PTA provided its constituents with the non-trade related benefit of pursuing common negotiating strategies aimed at adjusting to a changing international system. The additional institutional arrangements that were implemented with the establishment of the PMSCER and the CRNM were intended to arrest the institutional deficit that existed where the governance of international economic relations was concerned.

7.2.2 Institutional and Procedural Arrangements under the Revised Treaty of Chaguaramas The institutional arrangements regarding the CHOG remained unchanged under the RTC. Moreover, the RTC mandated that the CHOG be the supreme Organ of 'The Community', which is responsible for inter alia determining and providing policy direction. Additionally, the RTC mandated that the CHOG be the final authority for the conclusion of treaties and the entering into relationships between 'The Community' and international organizations and States. ${ }^{1051}$ The RTC also enhanced the facilitation of the external dimension of the

1049 See J. Byron, "Singing From the Same Hymn Sheet": Caribbean Diplomacy and The Cotonou Agreement, European Review of Latin America and Caribbean Studies, 2005, Vol. (79), pp. 3-23, p. 8.

${ }^{1050}$ The CARICOM-Venezuela FTA was signed on $13^{\text {th }}$ October 1992 and entered into force on $1^{\text {st }}$ January 1993. The CARICOM-Colombia FTA was signed on $24^{\text {th }}$ July 1994 . The CARICOM-Dominican Republic FTA was signed on $22^{\text {nd }}$ August 1998. The CARICOM-Cuba FTA was signed on $5^{\text {th }}$ July 2000 . These FTAs were imbued with the spirit of special and differential treatment, as the CARICOM LDCs were all granted non-reciprocal duty free market access, however, the CARICOM MDCs are required to provide reciprocal market access.

${ }^{1051}$ See Article 12 (1) - (3) of the RTC. 
CARICOM PTA by expanding the institutional treatment pertaining to foreign policy and external trade issues. Article 10(2) of the RTC provides for the establishment of various community organs including the Council for Trade and Economic Development (COTED) and the Council for Foreign and Community Relations (COFCOR) and in doing so, the RTC provides greater institutional coverage for external trade issues than was previously available under the OTC.

\subsubsection{The Council for Trade and Economic Development (COTED)}

The main responsibility of the COTED is the promotion of trade and economic development of the CARICOM Member States. The council consists of ministers designated by the respective CARICOM Member States and meets on a triannual basis. ${ }^{1052}$ In view of the external dimension of the CARICOM PTA, the main task of the COTED is to promote and develop, in collaboration with the COFCOR, coordinated policies for the enhancement of external economic and trade relations of the Community. ${ }^{1053}$ The COTED also serves to centralize the management of external economic relations as the PMSCER and the CRNM/ OTN report to this council. In 2002, CARICOM also appointed a Ministerial spokesperson on WTO matters whose main task is to ventilate, as necessary, the policy positions of the CARICOM Member States on matters pertaining to the Doha Round of WTO negotiations and other issues on the WTO agenda. ${ }^{1054}$

\subsubsection{The Council for Foreign and Community Relations (COFCOR)}

Most aspects of foreign policy coordination under the RTC have built upon that which was previously established by the SCMFA. The COFCOR is responsible for determining the relations between 'The Community' and international organizations as well as third states. ${ }^{1055}$ The council consists of ministers responsible for the Foreign Affairs of the

\footnotetext{
1052 See Article 15 (1) of the RTC. In practice, the respective Ministers of Foreign Trade or Ministers of Foreign Affairs and Foreign Trade of the CARICOM Member States have attended the COTED meetings. ${ }^{1053}$ Article 15 (2) (i) of the RTC states "Subject to the provisions of Article 12, COTED shall be responsible for the promotion of trade and economic development of the Community. In particular, COTED shall: promote and develop, in collaboration with the Council for Foreign and Community Relations, coordinated policies for the enhancement of external economic and trade relations of the Community;"

${ }_{1054}$ In 2002, the Foreign Minister of Guyana held this position.

${ }^{1055}$ Article 16 (2) of the RTC.
} 
respective CARICOM Member States and meets on an annual basis. ${ }^{1056}$ It should be noted that the COFCOR has the ability to meet in extraordinary sessions and has an annual informal consultation that is held during the margins of the United Nations General Assembly (UNGA) in New York. ${ }^{1057}$ The other duties of the COFCOR are outlined in Article 16 (3) of the RTC and include inter alia to establish measures to coordinate the foreign policies of the CARICOM Member States, to coordinate CARICOM positions for intergovernmental organizations and to collaborate with the COTED in promoting and developing coordinated polices for the enhancement of external economic and trade relations of 'The Community'. In light of the fact that Montserrat is still a non-independent CARICOM Member State, the RTC qualifies participation in the COFCOR by providing that only CARICOM Member States with the necessary competence can partake in the deliberations of COFCOR. ${ }^{1058}$

7.2.2.3 Council for Trade and Economic Development and Council for Foreign and Community Relations Procedure

It is noteworthy that both the COFCOR and the COTED are constituted of direct ministerial representatives of the CARICOM Member States, as it emphasizes the intergovernmental nature of both councils. Again, interstate bargaining is utilized to arrive at a consensus on decision-making in both councils where each CARICOM Member State has one vote. ${ }^{1059}$ A committee of officials representing all of the CARICOM Member States assists both the COFCOR and COTED by participating in a preparatory committee, which meets prior to the ordinary meetings of both councils. In both instances, the preparatory committee examines the provisional agenda and prepares a draft agenda for the consideration of the ministerial sessions of the COFCOR and the COTED. Key policy issues emanating from both the COTED and COFCOR levels are then tabled at the CHOG for final determination.

\footnotetext{
${ }^{1056}$ Article 16 (1) of the RTC.

1057 See CARICOM Secretariat, Rules of Procedure for COFCOR (Georgetown, Guyana), Rules 6 and 7.

${ }^{1058}$ Article 16 (4) of the RTC states "Only Member States possessing the necessary competence with respect to the matters under consideration from time to time may take part in the deliberations of COFCOR."

${ }^{1059}$ CARICOM Member States can request that decision be put to a vote. Recommendations require a $2 / 3 \mathrm{rds}$ majority vote. Decisions on substantive matters require a simple majority vote. Decisions on substantive matters require a qualified majority vote. Decisions of critical importance to the well being of a CARICOM Member State require a 2/3rds majority vote of all CARICOM Member States. See CARICOM Secretariat, Rules of Procedure for COFCOR (Georgetown, Guyana), Rule 21.
} 


\subsection{Substantive Areas of Coordination}

Most of the substantive areas of cooperation and coordination for the CARICOM Member States commenced in the early 1970s. This time period also coincided with the UK entry to the then EEC. By 1973 when the OTC was signed, the most crucial issue on the CARICOM agenda was securing an extension to the preferential terms under which Caribbean agricultural commodities including sugar was exported to the UK. ${ }^{1060}$ The Commonwealth Sugar Agreement (CSA) was due to expire in 1974 and even though the UK had been assured by the EEC (prior to its accession) that its overseas dependencies would be favorably integrated into the EEC scheme with other 'overseas territories', the contours of this proposed integration were yet unknown. ${ }^{1061}$ Therefore, one of the first policy endeavors that the CARICOM Member States undertook was a joint effort to secure a negotiated agreement that would safeguard their commodities trade with the UK, which was by then an EEC member. ${ }^{1062}$

Subsequent to these negotiations, the foreign policy coordination limb of the CARICOM PTA gradually developed to provide its constituents with the ability (i) to pursue common cooperation endeavors; (ii) provided a group dynamic platform that was utilized for further interaction with other regional groupings and (iii) allowed the CARICOM Member States to coordinate common policy positions on multilateral issues. These aspects of CARICOM foreign policy coordination are explored in the following sections of the dissertation.

\footnotetext{
${ }^{1060}$ At the time of UK accession to the EEC in 1972, the CSA was still valid for another two years until 1974. As part of the UK accession negotiations, it was agreed that the CSA would run its course until 1974.

1061 "The commission invited the commonwealth countries to indicate the form of relationship which they wished as well as to join in the discussions for the re- negotiation of the Yaounde Convention. The initiative by the EEC provided the stimulus for the 18 "associates" as well as the "associables" examine their approach to their future relationship with the EEC." K.O. Hall, B. Blake, "The Emergence of the African, Caribbean and Pacific Group of States: An Aspect of African and Caribbean International Cooperation" African Studies Review, 1979, Vol. 22(2) pp. 111-125, p.113.

${ }^{1062}$ The export of Caribbean sugar to the UK and eventually the EEC was a consistent agenda item on the Commonwealth Caribbean (and post-1973 CARICOM) Conference of Heads of Government since the tradition commenced in 1963.
} 


\subsubsection{Coordinated negotiation of the 1975 Lome Convention}

Significant intergovernmental cooperation efforts occurred among the independent CARICOM Member States as well as with the Commonwealth African countries and the Pacific countries in order to secure a framework agreement between themselves and the EEC. ${ }^{1063}$ The 1975 Lome Convention resulted from these protracted negotiations and this represented the advent of a CARICOM-EEC trade, development and economic framework that would endure for twenty-five years. ${ }^{1064}$ As a consequence of this framework, CARICOM-EEC trade relations operated under a negotiated, non-reciprocal preferential scheme that enabled the export of Caribbean agricultural commodities to the EEC Market. In addition to the first Lome Convention, the 1975 Georgetown Agreement was signed, which formalized the African, Caribbean and Pacific (ACP) group of states. ${ }^{1065}$ The role of a unified approach to negotiations was greatly lauded after the finalization of both the Lome Convention and the Georgetown Agreement. ${ }^{1066}$

These negotiations underscored the crucial role of CARICOM foreign policy coordination in unifying its constituents on the international plane due to a singularity of purpose. ${ }^{1067}$

1063 “ [...] there was sustained [diplomatic] activity between the African and Caribbean countries. The first step in this direction was taken at the informal meeting of foreign ministers, which met in Georgetown during the non-aligned meeting in August 1972. That meeting was attended by ministers and representatives from Guyana, Nigeria, Zambia, Tanzania, Kenya, Uganda, Trinidad and Tobago, and Jamaica. It was agreed that the countries present would press for the negotiations with the EEC to be open-ended to facilitate discussions of areas of common interest between the Yaounde states and the commonwealth countries. It was felt that the African and Caribbean states should work together in identifying the common areas of interest so that a united front could be presented to the EEC." K.O. Hall, B. Blake, "The Emergence of the African, Caribbean and Pacific Group of States: An Aspect of African and Caribbean International Cooperation" African Studies Review, 1979, Vol. 22(2) pp. 111-125, p.115.

${ }^{1064}$ In the aftermath of the WTO legal challenge to the EU import regime on sugar and bananas, advanced notification was given in the Cotonou Agreement of 2000, which informed that future trade relations between CARICOM (as a part of the ACP) and the EU would have be conducted under WTO compatible terms.

${ }^{1065}$ The Georgetown Agreement was signed on $6^{\text {th }}$ June 1975 and entered into force on $12^{\text {th }}$ February 1976. Only the five independent CARICOM Member States were initial signatories to the agreement. In addition to establishing the ACP Group of States, one of the stated objectives of the Georgetown Agreement was to ensure the realization of the Lome Convention.

1066 "ACP unity was demonstrated in the capacity of the group to influence the negotiations. First, they were able to postpone the negotiations until they were ready. Second, they were able to dictate the location of certain key negotiating sessions such as the ministerial meeting in Kingston. Third, they were able to avoid being locked into a predetermined form of agreement." K.O. Hall, B. Blake, "The Emergence of the African, Caribbean and Pacific Group of States: An Aspect of African and Caribbean International Cooperation" African Studies Review, 1979, Vol. 22(2) pp. 111-125, p.121.

1067 “....the final convention of association, signed at Lome in Togo in February 1975, constituted a relatively successful conclusion to the negotiations...In respect of the record of the CARICOM countries in coordinating their foreign policies, we can mark down the question of association with the EEC as a 
Furthermore, these negotiations exemplified how the non-trade related benefit of increased bargaining power assists countries that negotiate as a group. In the aforementioned context, this is especially pertinent given that some of the (ACP) African countries had prior experience in negotiating accords with the EEC. ${ }^{1068}$ One key issue of complexity that arose during the negotiations with the EEC was that of the position of the non-independent CARICOM Member States. As overseas dependencies of the UK, all eight of the nonindependent CARICOM Member States were listed under Part IV of the Treaty of Rome. ${ }^{1069}$ Nevertheless, the CARICOM Member States insisted that they be allowed to negotiate with the EEC as a regional bloc. ${ }^{1070}$ CARICOM devised a strategy whereby the independent CARICOM Member States were formally involved in the negotiations and the non-independent CARICOM Member States were kept informed of key developments and discussions. $^{1071}$

\subsection{CARICOM: The Common Cooperation Platform}

This dissertation submits that a visible area of benefit for the CARICOM Member States has been the ability to use the regional grouping of the CARICOM PTA as a common cooperation platform. Since the advent of regional integration in the Caribbean, this feature has been relied upon in the common interaction of the British Caribbean territories with the UK and subsequently with the EEC. As previously noted, the reset of economic

successful demonstration of the value to small states in pooling their bargaining power." A. Payne, A Political History of CARICOM (Ian Randle Publishers, Kingston, Jamaica, 2008), p. 178.

${ }^{1068}$ These include the Arusha Agreement of 1969 and the Yaounde Conventions of 1964 and 1971.

1069 Article 24 (1) of the 1972 Accession Treaty states "[...] the UK shall be added to the member states specified in the first sentence of Article 131 of the EEC Treaty." And Article 24(2) states "The following countries and territories shall be added to the list in Annex IV to the EEC Treaty: [...] British Honduras (modern day Belize) [...] Montserrat [...] Associated States in the Caribbean: Antigua and Barbuda, Dominica, Grenada, St. Lucia, St. Vincent and St. Kitts-Nevis-Anguilla.

1070 "Throughout the negotiations [on the issue of association with the EEC] [...] CARICOM territories adhered resolutely to the original decision of the CARIFTA council that the region should negotiate with the enlarged EEC as a group. At the opening conference in Brussels in July 1973[...] Guyana's foreign minister informed the EEC that all the territories of the region had chosen to sit together at this table under the single label of the 'Caribbean Countries' and even though the Caribbean grouping was subsequently incorporated within an ACP negotiating front, it continued to behave as a united bloc amongst ACP countries." A. Payne, A Political History of CARICOM (Ian Randle Publishers, Kingston, Jamaica, 2008) p. 176.

1071 "Barbados, Guyana, Jamaica and Trinidad and Tobago signed the [Lome] Convention and some of their negotiators are credited for much of the success secured by the ACP Group. The period of these negotiations is still widely regarded as the 'finest hour' for the Caribbean in ACP-European relations." E. Laurent, The Integrationist: Understanding International Trade - A CARICOM Perspective (Ian Randle Publishers, Kingston, Jamaica, 2007) p.13. 
relations with the UK in light of its then accession to the EEC was a priority issue for the CARICOM Member States in 1972. In this particular instance, CARICOM was able to benefit from the increased collective strength and bargaining power brought about by negotiating as a group as opposed to individual countries. ${ }^{1072}$ This approach also aided in solidifying the perception of the Caribbean countries as a regional bloc with uniform negotiating positions and policy concerns. ${ }^{1073}$

\subsubsection{Cooperation Agreement with Mexico}

The CARICOM platform was utilized to conclude the first CARICOM bilateral agreement. On $30^{\text {th }}$ July 1975, the Agreement establishing the CARICOM-Mexico Joint Commission (CARICOM-Mexico Agreement) was signed. ${ }^{1074}$ The main aim of the CARICOM-Mexico Agreement was to promote closer relations in the economic, cultural and technological fields; however, the agreement also provided the background for the CARICOM-Mexico joint commission, which initiated a work program aimed at fomenting closer ties between the two parties. ${ }^{1075}$ It was agreed that the agreement would enter into force upon the exchange of letters of approval of the agreement by the parties. ${ }^{1076}$ Presumably, this technique was employed due to the non-independent CARICOM Member States lacking treaty-making powers, as the UK government still held competence for their external affairs. It is notable that when the CARICOM-Mexico Agreement entered into force on $18^{\text {th }}$ September 1975, it was only the independent CARICOM Member States that had exchanged their letter of approval as per Article 5 of the agreement. Most of the nonindependent CARICOM Member States subsequently exchanged their letters of approval in 1976 whereupon the agreement was applicable to them.

\footnotetext{
1072 T. Carpenter, A Historical Perspective on Regionalism in (eds) R. Baldwin, P. Low, Multilateralizing Regionalism: Challenges for the Global Trading System (Cambridge University Press, 2008), p. 13.

${ }^{1073}$ M. Herz, The Organization of American States: Global Governance away from the Media (Routledge, 2011), p. 79.

1074 See (eds.) K. Hall, M. Chuck-A-Sang, The Integrationist: Confronting Challenges, Maximizing Opportunities - A New Diplomacy for Market Access (Ian Randle Publishers, 2007), p. 118.

${ }^{1075}$ See Ibid, (eds.) K. Hall, M. Chuck-A-Sang, 2007, p. 118.

1076 Article 5 of the 1974 CARICOM-Mexico Agreement states "This Agreement shall enter into force immediately upon the exchange of Letters of Approval of the Agreement by the Parties."
} 


\subsubsection{Cooperation Agreement with Canada}

On $20^{\text {th }}$ January 1979, the Trade and Economic Agreement between the Government of Canada and the Governments of the Member States of the Caribbean Common Market (CARICOM-Canada Agreement) was signed. This agreement was aimed at securing a mutually beneficial trade and economic relationship between its parties. ${ }^{1077}$ Unlike the CARICOM-Mexico Agreement, the CARICOM-Canada Agreement entered into force upon the signature of all parties. ${ }^{1078}$ It is also noteworthy that this agreement marked the beginning of a bilateral relationship with a country that is seen as having the "highest degree of understanding" for the CARICOM region and its interests. ${ }^{1079}$ Another note of importance is that Dominica attained its independence from the UK in 1978 and therefore, only 6 non-independent states signed the CARICOM-Canada Agreement in 1979. It is presumed that these CARICOM Member States were able to ascertain a previous specific delegation of power from the UK in order to facilitate their signing of this agreement on the same date as the independent CARICOM Member States.

\subsubsection{Other Common Cooperation Initiatives}

It is important to emphasize that during the 1980s, there was much focus on establishing the internal dimension of the CARICOM PTA. The inward oriented strategy of finalizing the common market experienced a shift by the late 1980s and CARICOM initiated a strategy where more emphasis was placed on relations with third states. As such, the volume and depth of cooperation initiatives were limited when compared with those initiated after the signing of the RTC. Most of the external policy pivot occurred in the aftermath of the 1989 Gran Anse declaration. ${ }^{1080}$ Consequently, more outreach with third states was undertaken and in 1993, CARICOM and Japan initiated the CARICOM-Japan consultations. This initiative has persevered in bringing the two parties closer through various Ministerial-level conferences and consultations in technical and economic fields.

\footnotetext{
1077 See (eds.) K. Hall, M. Chuck-A-Sang, The Integrationist: Confronting Challenges, Maximizing Opportunities - A New Diplomacy for Market Access (Ian Randle Publishers, 2007), p. 115.

${ }^{1078}$ Article 18 of the 1979 CARICOM-Canada Agreement states "This Agreement shall enter into force on signature of all by the Contracting Parties."

${ }_{1079}$ See (eds.) K. Hall, M. Chuck-A-Sang, The Integrationist: Confronting Challenges, Maximizing Opportunities - A New Diplomacy for Market Access (Ian Randle Publishers, 2007), p. 116.

${ }^{1080}$ See Grand Anse Declaration in Section 7.1.4 entitled Legal Competence under The RTC.
} 
Where international dialogue is concerned, the CARICOM platform has proven itself particularly useful in alliance-building with like-minded countries as many world leaders and senior officials of international institutions have been able to exchange their views on pertinent issues of the day by attending the annual meetings of the Conference of CHOG as special guests.

Commencing in the 1990s, this practice gained more prominence and the regional platform was able to garner the attention of various world leaders. ${ }^{1081}$ It is submitted that by the 1990s, the singularity of purpose that was displayed by CARICOM was successful in reaping rewards such as these audiences with world leaders and other senior officials. Undoubtedly, such audiences would have been more challenging to facilitate on a bilateral basis for a small developing country.

\subsection{CARICOM: Interaction with other Regional Groupings}

In another illustration of alliance building with like-minded states, CARICOM Member States have utilized the regional platform to pursue further interaction with other regional groups such as the Central American Integration System (SICA), the Association of Caribbean States (ACS) and the Rio Group.

\subsubsection{Regional Outreach to Central American Integration System (SICA)}

SICA was established in 1991 with the main objective of pursuing regional integration among the Central American countries of Costa Rica, El Salvador, Guatemala, Honduras, Nicaragua and Panama. Belize, which is a CARICOM Member State that is geographically

\footnotetext{
${ }^{1081}$ In 1990, the then President of Mexico attended and in 1994, the Managing Director of the International Monetary Fund (IMF) attended. In 1999 alone, the then Prime Minister of Spain, the then President of Venezuela, the then Secretary General of the Commonwealth and the Director General of the Food and Agriculture Organization (FAO) attended. 2001 was also an important year where special guests were concerned as CARICOM Heads of Government were able to convene special sessions with the then Director General of the WTO, the then President of Mexico, the Secretaries General of the Association of Caribbean States (ACS), the Commonwealth and the Organization of American States (OAS) as well as the Director General of the FAO. See CARICOM Secretariat, Communiques issued at the Conclusion of the Conference of Heads of Government of CARICOM in 1990, 1994, 1999 and 2001.
} 
located in Central America, joined SICA in 2000. ${ }^{1082}$ Cooperation efforts between CARICOM and SICA developed as a result of shared concerns and common goals including sustainable development and the mitigation of natural disasters. It was further recognized that there were strategic advantages to cultivating a relationship between the two sub-regions and it is imperative to note that this recognition represented an evolution in relations between the two sub-regions given the respective views previously held on the Belize-Guatemala territorial dispute. ${ }^{1083}$

In 2002 and 2007, CARICOM-SICA Summits were held in Belize whereby Heads of Government of both regions discussed issues of common concern such as tourism, trade and investment within the respective sub-regions. ${ }^{1084}$ In 2007, the CARICOM-SICA Plan of Action was agreed, which provided a framework for cooperation in various areas including inter alia human resource development, trade and investment and poverty eradication. ${ }^{1085}$ One of the key issues on the CARICOM-SICA agenda is the negotiation of an FTA between the two sub-regions; however, this has yet to be finalized. ${ }^{1086}$

\subsubsection{Regional Outreach to the Rio Group}

CARICOM also furthered its external collaboration when it commenced relations with the Rio Group in 1991. This was initiated upon an invitation that was extended to CARICOM in order for the two groupings to forge closer ties. It should be noted that the Rio Group was established in 1986 and at the time the process involved 11 Latin American

\footnotetext{
1082 Although Belize is a member of SICA, it does not participate in the Central American Economic Integration System (SIECA) and thus, it does not participate in the Council of Ministers of the Economy (COMIECO). It should also be noted that the Dominican Republic also became a member of SICA.

${ }^{1083}$ Most of the Central American countries had previously supported Guatemala in its territorial claim to Belize, whilst the CARICOM Member States have consistently supported the territorial integrity of Belize. Additionally, many of the Central American countries had opposed the membership of CARICOM countries in the OAS due to their linkages with the UK and preferential trade arrangements.

${ }^{1084}$ See CARICOM Secretariat, Joint Declaration issued on the occasion of the 2nd CARICOM-SICA Summit of Heads of State and Government (Belize, City, Belize, 12 ${ }^{\text {th }}$ May 2007) [Press Release No.107/2007].

${ }^{1085}$ See CARICOM Secretariat, Climate Change on Agenda for CARICOM-SICA Summit (Georgetown, Guyana, $11^{\text {th }}$ May 2007) [Press Release No.105/2007].

${ }^{1086}$ See O. Dabene, K. Parthenay, Regionalism in Central America: An "All-In" Strategy in (eds.) J. BricenoRuiz, I. Morales, Post-Hegemonic Regionalism in The Americas: Towards A Pacific-Atlantic Divide? (Routledge, 2017), p. 168.
} 
countries. ${ }^{1087}$ The main aim of the Rio Group was to strengthen political and economic relations within Latin America and eventually this was extended to the Caribbean. As a consequence of the 1991 Rio Group invitation, the CARICOM Heads of Government appointed a CARICOM Member State (then Jamaica) to serve as the CARICOM representative to the Rio Group. The main task involved is to monitor the activities of the Rio Group and keep all other CARICOM Member States abreast of developments within the grouping. ${ }^{1088}$

\subsubsection{Regional Outreach to the Association of Caribbean States}

CARICOM also participates in the ACS, which was formed in 1994 with the aim of promoting cooperation and concerted action among all Caribbean countries. ${ }^{1089}$ Consequently, the membership of the ACS includes countries and territories with French, Dutch and Spanish colonial heritages in addition to the CARICOM Member States, which are mainly former British Caribbean territories. ${ }^{1090}$ In 1997, CARICOM and the ACS signed a cooperation agreement that outlined a framework of issues such as the issuance of reciprocal invitations to meetings and conferences, the participation in meetings and the exchange of information and documentation. ${ }^{1091}$ Additionally, the CARICOM Secretariat is a founding observer of the ACS and participates in the ministerial councils and special committees of the ACS. Through CARICOM membership in the ACS, CARICOM Member States are able to cooperate with its wider Caribbean constituents on matters

\footnotetext{
${ }^{1087}$ The Rio Group has been described as a process due to the fact that during its early years, it did not have a secretariat and much of its work was conducted in the format of yearly summits.

${ }^{1088}$ See CARICOM Secretariat, Communique issued at the conclusion of the Second Inter-sessional Meeting of the Conference of Heads of Government of CARICOM, $26^{\text {th }}$ February 1991 (Port of Spain, Trinidad and Tobago).

1089 See (eds.) K. Hall, M. Chuck-A-Sang, The Integrationist: Confronting Challenges, Maximizing Opportunities - A New Diplomacy for Market Access (Ian Randle Publishers, 2007), p. 119.

${ }^{1090}$ The ACS consists of 25 Member States and 11 associate Member States. The ACS Secretariat is based in Port of Spain, Trinidad and Tobago. The ACS consists of the following members and associate members: Antigua and Barbuda, Bahamas, Barbados, Belize, Colombia, Costa Rica, Cuba, Dominica, Dominican Republic, El Salvador, Grenada, Guatemala, Guyana, Haiti, Honduras, Jamaica, Mexico, Nicaragua, Panama, St Kitts and Nevis, St Lucia, St Vincent and the Grenadines, Suriname, Trinidad and Tobago and Venezuela. Associate Members: Aruba, Bonaire, Curacao, Saba, Sint Maarten, Sint Eustatius, French Guiana, Guadeloupe, Martinique, Saint Barthelemy and St. Martin.

${ }^{1091}$ See CARICOM Secretariat, Special Agreement between the ACS and CARICOM (Georgetown, Guyana, $13^{\text {th }}$ November 1997) [Press Release No. 93/1997].
} 
pertaining to inter alia the preservation and conservation of the Caribbean Sea, sustainable tourism and natural disasters. ${ }^{1092}$

\subsection{CARICOM: The Coordination of Common Policy Positions}

One of the main thrusts of the CARICOM foreign policy machinery has focused on the coordination of common policy positions in international negotiations and on international policy issues. In the aftermath of the signing of the OTC in 1973, the CHOG advocated issues such as the granting of independence to the remaining non-independent CARICOM Member States and the coordination of the CARICOM position for international meetings. Furthermore, diplomatic support was provided for Belize and Guyana, as these CARICOM Member States were the subject of territorial claims by their respective neighboring states of Guatemala and Venezuela. ${ }^{1093}$

\subsubsection{Diplomatic Support for Belize}

CARICOM has displayed a unified foreign policy approach regarding the Guatemalan territorial claim to Belize. Chapter 6 of this dissertation examines the Belizean motivation to join CARICOM and underscores how the independent CARICOM Member States were able to draw the international spotlight on the issue of the Guatemalan territorial claim to Belize at the United Nations and within the Commonwealth of group of nations during the 1970s. Consequently, the then independent CARICOM Member States spoke with one authoritative voice in their interaction with the third states and international institutions on the issue of Belize. And thus, they were able to collaborate externally to provide diplomatic assistance for the Belizean quest for independence from the UK. ${ }^{1094}$ Throughout the $1980 \mathrm{~s}$, CARICOM continued with its diplomatic support for Belize despite its attainment of

1092 See (eds.) K. Hall, M. Chuck-A-Sang, The Integrationist: Confronting Challenges, Maximizing Opportunities - A New Diplomacy for Market Access (Ian Randle Publishers, 2007), p. 119.

1093 See CARICOM Secretariat, Communiques issued at the conclusion of the Conference of Heads of Government of the Commonwealth Caribbean in 1973, 1974 and 1975.

1094 "The Caribbean region stood solidly by the side of Belize in its longstanding dispute with Guatemala... The independent territories also consistently publicized the problem at international gatherings and were instrumental in engineering the overwhelming support given to the Belizean cause at the $30^{\text {th }}$ Session of the UNGA in autumn of 1975. They also came out in full support of the Belizean government in January 1978 when it vigorously opposed a British plan to cede some Belizean territory to Guatemala in exchange for an undertaking that Guatemala would give up the full extent of its claim.” A. Payne, A Political History of CARICOM (Ian Randle Publishers, Kingston, Jamaica, 2008) p. 179. 
independence in 1981. This was mainly due to the fact that Guatemala failed to recognize the sovereignty of Belize until $1991 .{ }^{1095}$ In the interim, the CARICOM platform provided Belize with the immeasurable support of knowing that eleven sovereign states unreservedly supported its sovereignty. ${ }^{1096}$

\subsubsection{Coordinated Voting at the United Nations}

One key illustration of the coordinated approach to voting at the UN was seen with CARICOM support for the UN resolution 3432 on the Question of Belize, which commenced in the mid-1970s and continued until Belize achieved its independence in $1981{ }^{1097}$ Further to this, the coordination of common policy positions was enhanced in 1983, as the last of the present day CARICOM Member States achieved independence from the UK. ${ }^{1098}$ This occurrence eased much of the complex arrangements regarding CARICOM foreign policy coordination, as the majority of the CARICOM Member States were now independent with no reliance on the UK for responsibility regarding their external affairs. The obvious exception to this is Montserrat, which has chosen to remain a UK colony.

By the end of 1983, all of the independent CARICOM Member States were members of the United Nations. Subsequently, the CARICOM Member States coordinated their policy positions on the issue of UN candidatures and by doing so they highlighted the benefit of their group dynamic solidarity and increased bargaining power. As a consequence of this, the CARICOM Member States also solidified the perception of the region as a regional bloc. It became clear to third states that garnering the support of CARICOM would entitle a candidature to the votes of 12 independent countries. ${ }^{1099}$ With respect to UN agenda items, most of the CARICOM Member States voted in support of the various anti-apartheid resolutions passed at the UN and CARICOM was vocal in its continuous support for an

\footnotetext{
${ }^{1095}$ The recognition of sovereignty by Guatemala also removed the final stumbling bloc thus allowing Belize to join the OAS in 1991.

1096 Prior to 1991, Suriname and Haiti were not CARICOM Member States and Montserrat was, and still remains, an overseas British territory. Therefore, there were only eleven independent CARICOM Member States in addition to Belize in 1991.

${ }^{1097}$ See Chapter 6, Section 6.6.5 entitled The Question of Belize at the United Nations.

${ }^{1098}$ St. Kitts and Nevis was granted independence in 1983.

1099 This was the case between 1983 and 1995.
} 
end to the apartheid regime in South Africa throughout the 1980s. ${ }^{1100}$ As a sign of appreciation for the support provided by CARICOM during these years, the then President of South Africa attended the CARICOM Conference of Heads of Government in 1998 and engaged in an exchange of views on key issues regarding the development of postapartheid South Africa. ${ }^{1101}$

\subsection{Foreign Policy Coordination: 2002 to Present}

As previously noted, one of the main points of emphasis of the RTC regarding foreign policy coordination has been the expansion of relations with third states and international institutions. As this policy track developed, it has reinforced the concept of an outward oriented integration strategy and reflects an admission on the part of CARICOM that "The Community' must pursue greater external outreach through alliance building due to the globalized nature of the international system. In this regard, it is argued that the CARICOM Member States have the potential to benefit from the CARICOM PTA even further in the future. CARICOM has welcomed the expansion of diplomatic relations with several third states that have accredited Ambassadorial representation to 'The Community'. ${ }^{1102}$ The extension of diplomatic relations is one of the more recent features in CARICOM foreign policy efforts post 2001. ${ }^{1103}$ In other areas, CARICOM Member States have deepened and matured their foreign policy coordination practices beyond that which had previously existed under the OTC.

\footnotetext{
${ }^{1100}$ See Communiques issued at the conclusion of the Conference of Heads of Government of the Caribbean Community from the years of 1982 to 1989. For detailed information regarding CARICOM voting patterns on the anti-apartheid resolutions at the United Nations, see J. Braveboy-Wagner, Small States in Global Affairs: The Foreign Policies of the Caribbean Community (CARICOM) (Palgrave MacMillian, 2008), p. 153.

${ }^{1101}$ See CARICOM Secretariat, Communique issued at the Nineteenth Meeting of the Conference of Heads of Government of the Caribbean Community, $30^{\text {th }}$ June $-4^{\text {th }}$ July 1998 (Castries, St. Lucia).

1102 The following countries have accredited Ambassadors to the Caribbean Community: Argentina, Australia, Austria, Belgium, Botswana, Brazil, Canada, Chile, Cuba, Delegation of the EU, Finland, France, Germany, India, Israel, Italy, Japan, Lithuania, Mexico, New Zealand, Portugal, Serbia, Singapore, Slovenia, South Africa, Spain, Sweden, The Netherlands, Turkey, United Kingdom, United States and Venezuela.

${ }^{1103}$ Most of the accreditation of diplomatic representatives from third states to CARICOM has occurred in the aftermath of the signing of the 2001 RTC.
} 


\subsubsection{Coordinated Support for Candidatures}

CARICOM has continued the practice of providing common support for international candidatures, and in several instances, CARICOM has forwarded its own CARICOM candidate for election to positions in international institutions. Both the Presidents of the $57^{\text {th }}$ and $68^{\text {th }}$ Sessions of the UNGA were CARICOM nationals who garnered the diplomatic support of all CARICOM Member States. ${ }^{1104}$ Given that CARICOM is a member of the Group of Latin America and the Caribbean countries (GRULAC) within the wider UN membership, these candidates were eventually presented to the UN membership as GRULAC candidates. However, it should be borne in mind that first and foremost, these candidates were commonly agreed upon by the CARICOM Member States to be the CARICOM candidates for the respective elections. This illustration of intergovernmental cooperation demonstrates the successful ability of the CARICOM Member States to select candidates who are able to represent the region on the international plane. ${ }^{1105}$ This nontrade related benefit of the regional platform provides CARICOM with the ability to participate to a greater extent in the international arena despite its limited resources.

\subsubsection{Coordination of Common Policy Positions}

CARICOM has continued with its coordination of common positions on international policy issues as well as its practice of agreed policy positions in advance of international conferences. Additionally, CARICOM has issued statements on issues affecting the Caribbean in an attempt to have its voice heard in the international dialogue pertaining to key international issues. Much of the aforementioned actions pertained to CARICOM involvement in the UN system as the regional grouping issued a common position on UN reform $^{1106}$ and encouraged greater participation from CARICOM Member States in UN events most pertinent to the Caribbean region such as the 2006 UNGA Special Session on

\footnotetext{
${ }^{1104}$ A CARICOM National from St. Lucia served as the President of the $57^{\text {th }}$ Session of the UNGA, 20032004. A CARICOM National from Antigua and Barbuda served as President of the $68^{\text {th }}$ Session of the UNGA, 2013-2014.

1105 CARICOM also supported the candidatures of CARICOM Nationals from Guyana and Trinidad and Tobago, which resulted in their successful election as judges to the International Criminal Court (ICC) and the International Criminal Tribunal for the former Yugoslavia (ICTY). A CARICOM National from Guyana served on the ICC panel of judges from 1997 to 2009 and a CARICOM National from Trinidad and Tobago served on the ICTY panel of judges from 2003 to 2007.

${ }^{1106}$ See CARICOM Secretariat, Communiqué issued at the Twenty-Sixth meeting of the Conference of Heads of Government of CARICOM, 3-6 July 2005 (Gros Islet, St. Lucia).
} 
Migration and Development, the 2009 and 2011 United Nations Climate Change Conferences, COP 15 and COP $17 .{ }^{1107}$

Since the majority of CARICOM Member States are small island states dispersed throughout the Caribbean Sea, there is a critical awareness of the inherent threats caused by climatic changes such as rising sea levels and the increased intensity of hurricanes. ${ }^{1108}$ The aforementioned illustrations demonstrate the ability of CARICOM Member States to insist upon the complementarity of action among themselves. Such coordinated efforts are increasingly important for small developing countries given the limited effectiveness of an individual country approach.

\subsubsection{Dialogues with Special Guests}

CARICOM efforts to dialogue with world leaders and senior officials from international organizations have expanded as the tradition of exchange of views with special guests has continued. In 2010, the then Managing Director of the IMF, the then President of the World Bank and the then President of the Inter-American Development (IDB) attended the spring (inter-sessional) meeting of the Conference of Heads of Government of CARICOM. In 2010 and 2015, the then UN Secretary General attended the July meeting of the Conference of Heads of Government of CARICOM. In 2013, the then Attorney General of the United States of America attending the July meeting to dialogue with CARICOM Heads of Government regarding crime and security in the Caribbean region. ${ }^{1109}$ Again, the aforementioned illustrations highlight the ability of the regional platform to assist CARICOM with its alliance building efforts and to attract the attention of senior policymakers and actors within the international system. It, therefore, provides CARICOM Member States with the opportunity to ventilate the view of small developing Caribbean

\footnotetext{
${ }^{1107}$ See CARICOM Secretariat, Communique issued at the Thirtieth Conference of Heads of Government of CARICOM, 2-5 July 2009, Georgetown, Guyana and Communique issued at the Thirty-Second Conference of Heads of Government of CARICOM, 30 $0^{\text {th }}$ June $-4^{\text {th }}$ July 2011 (Basseterre, St. Kitts and Nevis).

${ }_{1108}$ See (eds.) K. Hall, M. Chuck-A-Sang, The Integrationist: Confronting Challenges, Maximizing Opportunities - A New Diplomacy for Market Access (Ian Randle Publishers, 2007), p. 119.

${ }^{1109}$ See CARICOM Secretariat, Communiques issued at the conclusion of the Conference of Heads of Government of CARICOM in 2010, 2013 and 2015.
} 
countries where international policy issues are concerned. Such dialogue is particularly vital given the risk of marginalization that small developing countries often face.

Most importantly, this practice illustrates that the CARICOM regional platform is still a forum where CARICOM Heads of Government are able to articulate issues of mutual interest and formulate further plans of action. ${ }^{1110}$ It is instructive to note that although this chapter focuses on action taken at the level of the $\mathrm{CHOG}$, it does so due to the fact that the latter is the supreme organ of 'The Community'. It is, however, recognized that many of these international policy issues are dealt with at the technical level of the COFOR, COTED and other community organs prior to being tabled at the CHOG. Additionally, the efforts of the CARICOM caucus of Ambassadors resident in capitals around the world is of great pertinence, as they play a crucial role as interlocutors where the execution of CARICOM policy decisions are concerned. Much of the aforementioned practices continue to the present day with recent discussions focusing on the possible effects of the British exit from the EU (Brexit) on CARICOM in particular and the ACP in general. ${ }^{1111}$

\subsection{External Trade Coordination: 2002 to Present}

As noted earlier, by 1983 the majority of the CARICOM Member States had attained independence. At this time, most of CARICOM's external trade relations were hinged on preferential trade agreements guaranteeing access to three export markets: Europe, the USA and Canada. However, the various General Agreement on Tariffs and Trade (GATT)

\footnotetext{
${ }^{1110}$ Concrete illustrations of how CARICOM has been able to capitalize on its increased collective strength include the 2007 Conference on the Caribbean that was organized to strengthen relations between CARICOM and the US. CARICOM leaders were able to secure a summit with the US President and US Secretary of State to address key issues of concern regarding growth and development in CARICOM especially as it related to competiveness, trade and investment. See CARICOM Secretariat, Conference on the Caribbean 2007 Comprehensive Agenda to be finalized (Georgetown, Guyana, $8^{\text {th }}$ May 2007) [Press Release No.100/2007].

Additionally, since 1999 CARICOM has been able to engage with the EU in the context of the EU-LAC (Latin America and the Caribbean) strategic partnership, which focuses on the strengthening of democracy, rule of law, international peace and political stability. The grouping convenes biennial summits that rotate between the LAC region and the EU region. As of 2015, the grouping has been renamed EU-CELAC (Community of Latin America and Caribbean States) and now features a foundation based in Hamburg, Germany in an attempt to advance its goals.

Further to this, CARICOM also maintains joint commissions with Mexico, Chile, India and Spain.

${ }^{1111}$ See CARICOM Secretariat, Communique issued at the Thirty-Seventh Meeting of the Conference of Heads of Government of CARICOM, 4-6 July 2016 (Georgetown, Guyana).
} 
legal challenges to the European import regime on bananas ${ }^{1112}$ and the advent of the WTO in 1995 signaled the need for a change in the way that CARICOM conducted its coordination and cooperation on external (trade) issues. ${ }^{113}$ In the early 1990s, CARICOM instituted certain ad hoc measures to assist with the management of external trade relations. These institutional measures included the establishment of the PMSCER and the CRNM and are outlined in section 7.2.1.3 of this chapter. When the RTC was signed in 2001, it updated the CARICOM institutional structure by introducing legal competence for external trade relations alongside the provision of a specific institutional organ, which addressed external trade relations.

\subsubsection{Coordinated Trade Relations with the United States and Canada}

CARICOM trade relations with the US during the period of 1973 to 2001 were governed to a minor extent by the Generalized Systems of Preferences (GSP), which was adopted by the US in 1974. ${ }^{1114}$ Later in 1983, the Caribbean Basin Recovery Act (CBERA) was signed and it introduced a non-reciprocal, preferential trading arrangement between the US and most CARICOM countries. ${ }^{1115}$ CBERA was aimed at encouraging economic growth and development in the Caribbean by promoting increased production and exports of nontraditional products. ${ }^{1116}$ Under this arrangement, select CARICOM products were granted duty free entry into the US provided that they satisfied stated rule of origin criteria. ${ }^{117}$ Although the CBERA arrangement commenced as a temporary program, it was renewed

\footnotetext{
1112 See GATT Panel Report, EEC-Member States' Import Regimes for Bananas, DS32/R, $3^{\text {rd }}$ June 1993, unadopted and GATT Panel Report, EEC-Import Regime for Bananas, DS38/R, $11^{\text {th }}$ February 1994, unadopted.

${ }^{1113}$ D. Berry, Caribbean Integration Law (Oxford University Press, 2014), p. 27; N. Girvan, "Learning to Integrate": The Experience of Monitoring the CARICOM Single Market and Economy in (eds.) P. De Lombaerde, A. Estevadeordal, K. Souminen, Governing Regional Integration for Development: Monitoring Experiences, Methods and Prospects (Routledge, 2016), p. 39.

1114 “ [...] The US administration had adopted the Generalized System of Preferences (GSP) in 1974, but this was global in scope, with very limited regional impact because the non-US territories in the Caribbean had such little manufacturing capacity." V. Bulmer-Thomas, The Economic History of the Caribbean since the Napoleonic Wars (Cambridge University Press, 2012), p. 333.

${ }^{1115}$ See GATT Secretariat, Caribbean Basin Economic Recovery Act (Geneva, 14 ${ }^{\text {th }}$ November 1983) [L/5577].

${ }_{1116}$ Most of the CARICOM Member States were CBERA beneficiary countries with the exception of Montserrat and Grenada. Haiti, Suriname and the Bahamas were not CBERA beneficiary countries, however, these CARICOM Member States are not included in the scope of this dissertation since they were not involved in the regional integration process until its latter stages.

${ }^{1117}$ For further information on CARICOM exports to the US, see Chapter 5, Section 5.6 entitled Principal Trading Partner.
} 
in 1990 and transformed into a permanent program. In 2000, the Caribbean Basin Trade Partnership Act (CBTPA) was passed and one of the key developments emanating from this program was the granting of NAFTA parity to CARICOM Member States for their exports bound for the US market. ${ }^{1118}$

Regarding trade relations with Canada, the 1979 Caribbean-Canada Agreement initially governed trade flows between the two parties. In 1986, the Caribbean-Canada Trade Agreement (CARIBCAN) expanded upon these trade relations with an economic development program, which provided a non-reciprocal preferential trading arrangement for CARICOM exports to Canada provided that certain rules of origin criteria were satisfied. ${ }^{1119}$ Prior to the expiration of CARIBCAN in 2011, Canada indicated that it would not pursue another waiver for the extension of this trade agreement due to the fact that preferential, non-reciprocal trade agreements were deemed to be incompatible with WTO rules. ${ }^{1120}$ Subsequent to this, the CARICOM Member States and Canada attempted to negotiate a CARICOM-CANADA FTA; however, both sides failed to reach significant common ground and the negotiations stalled. ${ }^{1121}$ In 2015, Canada successfully requested a WTO waiver pursuant to Article IX: 4 of the WTO Agreement. This has enabled the CARIBCAN preferential trade framework to continue until $31^{\text {st }}$ December $2023 .{ }^{1122}$

\subsubsection{The World Trade Organization Agenda}

CARICOM has displayed a unity of purpose on the matter of its interactions with the WTO agenda due largely to the fact that most of its Member States were impacted by the WTO rulings in the various cases that legally challenged the EU sugar and banana import

\footnotetext{
${ }^{1118}$ Office of the United States Trade Representative, $10^{\text {th }}$ Report to United States Congress on the Operation of the Caribbean Basin Economic Recovery Act (Washington D.C. USA, $31^{\text {st }}$ December 2013), p. 3; J. Byron, "Singing From the Same Hymn Sheet": Caribbean Diplomacy and The Cotonou Agreement, European Review of Latin America and Caribbean Studies, 2005, Vol. (79), pp. 3-23, p. 8.

1119 Inter-American Development Bank (IADB), A. Deonarine, R. Hosein, J. Khadan, CARICOM and Canada: Good Trading Partners? (Washington D.C., October 2016) [Policy Brief No. IDB-PB-255], p. 2.

${ }^{1120}$ Ibid, Inter-American Development Bank (IADB), A. Deonarine, R. Hosein, J. Khadan, 2016, p. 2.

${ }^{1121}$ Ibid, Inter-American Development Bank (IADB), A. Deonarine, R. Hosein, J. Khadan, 2016, p. 1.

1122 See WTO Secretariat, CARIBCAN - Decision of $28^{\text {th }}$ July 2015 (Geneva, 30 $0^{\text {th }}$ July 2015) [WT/L/958]; WTO Secretariat, Canadian Tariff Treatment for Commonwealth Caribbean Countries - 2016 Report of the Government of Canada on the Trade-related provisions of CARIBCAN (Geneva, 14 $\left.{ }^{\text {th }} \mathrm{July} 2016\right)$ [WT/L/987].
} 
regime. ${ }^{1123}$ It is argued that developments in the MTS acted as a catalyst in increasing solidarity among CARICOM Member States particularly where the coordination of negotiating policy positions on WTO issues and implementation of WTO Agreements are concerned. ${ }^{1124}$ The common position of all of the CARICOM Member States has recognized the importance of the CRNM/OTN as the machinery that would be in the front line of WTO negotiations. It was also highlighted that the external trade negotiations agenda was increasingly demanding for the CARICOM region, which consists of small developing countries with limited financial and specialized human resources. ${ }^{1125}$

Another matter of concern for CARICOM Member States at this time was the growing trend of PTAs in the American hemisphere and this underpinned the recognized importance of participation in the WTO given that it is the multilateral forum where PTA rules are formulated. ${ }^{1126}$ Although there is no formal coordination structure for CARICOM Member States where the daily WTO Secretariat meetings are concerned, some informal coordination does occur regarding specific issues. Most of the CARICOM coordination on WTO policy issues tends to occur in advance of key meeting and ministerial conferences. In 2005, with the assistance of the CRNM, CARICOM Member States were able to collectively consolidate their understanding on the key negotiating issues and address the

\footnotetext{
${ }^{1123}$ Most of the CARICOM Member States were third parties in these respective cases. See Appellate Body Report, European Communities - Regime for the Importation, Sale and Distribution of Bananas, WT/DS27/AB/R, adopted 25 September 1997, DSR 1997:II, 591; Appellate Body Report, European Communities - Export Subsidies on Sugar, WT/DS265/AB/R, WT/DS266/AB/R, WT/DS283/AB/R, adopted 19 May 2005, DSR 2005:XIII, 6365. See also D. Mohammed, Size and Competiveness: An Examination of the CARICOM Single Market and Economy, The Roundtable, 2008, Vol. 97 (395), pp. 287-303, p. 295; J. Byron, "Singing From the Same Hymn Sheet": Caribbean Diplomacy and The Cotonou Agreement, European Review of Latin America and Caribbean Studies, 2005, Vol. (79), pp. 3-23, p. 8.

1124 "Heads of Government stressed the importance of the WTO negotiations which will serve as the basis for all trade agreements. They reiterated the need for active participation by [CARICOM] Member States in the revision of WTO rules particularly as they relate to regional trade agreements, to the development of provisions on special and differential treatment for developing countries and to the Work Programme on Small Economies. They also underlined the necessity for the multilateral trading system to ensure an equitable distribution of the gains from multilateral trade liberalisation to enable small developing countries to reap development benefits." See CARICOM Secretariat, Communique issued at the Twenty-Third Meeting of the Conference of Heads of Government of CARICOM, 3-5 July 2002 (Georgetown, Guyana).

${ }^{1125}$ See CARICOM Secretariat, Communique issued at the Twenty-Fifth Meeting of the Conference of Heads of Government of CARICOM, 4-7 July 2004, (St. George's, Grenada).

${ }^{1126} \mathrm{~K}$. Hall, CARICOM: Unity in Adversity in (ed.) K. Hall, The Integrationist: The Pertinence of CARICOM in the $21^{\text {st }}$ Century - Some Perspectives (Trafford Publishing, 2012), p. 29.
} 
possible implications on the CARICOM region. ${ }^{1127}$ This form of coordination has also occurred with subsequent WTO Ministerial Conferences and showcases the ability of CARICOM to pool its limited resources much to its benefit where participation in international trade negotiations are concerned.

Additionally, certain aspects of the implementation of WTO agreements are undertaken through regional coordination particularly with respect to legislative and institutional reforms. ${ }^{128}$ Since it is imperative that CSME legal arrangements are consistent with the various WTO Agreements, the CARICOM Secretariat has provided assistance through the development of model legislation and related trainings. The CRNM (post-2009 OTN) has convened technical working group meetings on WTO matters in an effort to further assist CARICOM Member States with participating in the WTO agenda. ${ }^{1129}$ The issue of participation in the WTO has been a matter of particular challenge for several CARICOM Member States, which do not maintain resident diplomatic representation accredited to the WTO Secretariat in Geneva, Switzerland. In light of the aforementioned, the role of the CRNM/OTN has been of great import as this agency has assisted in the dissemination of information as well as the coordination of policy positions on key issues whilst bearing in mind the limitations of various CARICOM Member States.

\subsubsection{The African, Caribbean and Pacific Group of States}

Post-2001, the most crucial issue on the external trade agenda of the ACP-EU was the negotiation of a successor agreement to the Cotonou Agreement. The Economic Partnership Agreement (EPA) negotiations commenced in 2002 at an all ACP level and

\footnotetext{
${ }^{1127}$ A Caribbean declaration on the $5^{\text {th }}$ WTO Ministerial Conference was formulated, which was used as a basis for forging a common position with the ACP. The common CARICOM position on issues pertinent to small developing countries was vital in the stance taken by all developing countries at the $5^{\text {th }}$ WTO Ministerial Conference. This resulted in the conclusion of the Ministerial Conference without substantial progress. See CRNM, Special Issue: Fifth WTO Ministerial Conference ( $8^{\text {th }}$ September 2003, Bridgetown, Barbados) [CRNM Update 0316]; CARICOM Secretariat, Caribbean Well Prepared for Cancun (Georgetown, Guyana, $8^{\text {th }}$ September 2003) [Press Release No. 20/03].

${ }^{1128}$ A recent illustration of this type of coordination was seen with the regional approach to implementing of the WTO Trade Facilitation Agreement. See CARICOM Secretariat, Capacity Building and Consultation: CARICOM Strategy for Regional Implementation of the WTO Agreement on Trade Facilitation (Georgetown, Guyana, 20 ${ }^{\text {th }}$ April 2017) [Press Release No. 68/2017].

${ }^{1129}$ The CRNM also assisted CARICOM Member States by providing technical missions regarding specific WTO issues.
} 
were then launched individually with the CARICOM countries in $2004 .^{1130}$ The EPA signaled a shift in ACP-EU relations for various reasons including inter alia the fact that the agreement would be individually negotiated with the respective regions of the ACP and that the agreement was required to be WTO-compatible. ${ }^{1131}$ Hence, CARICOM negotiated its own EPA independent of the African and Pacific states. ${ }^{1132}$ The EPA also signaled the introduction of a reciprocal trade relationship between CARICOM and the EU. ${ }^{1133}$

The CRNM played a vital role in securing an outcome that was deemed partially acceptable by most CARICOM Member States. ${ }^{1134}$ The EPA negotiations were concluded in 2008 and the agreement was signed by most CARICOM Member States at that time. ${ }^{1135}$ The EPA covers trade in goods, services, investment, competition, innovation and intellectual property, personal data protection and public procurement. ${ }^{1136}$ Although the agreement features a development component to assist CARICOM Member States with their individual development strategies, it must be highlighted that the coverage of the EPA exceeds that of the WTO and CSME agenda. In order to adjust to the changes occasioned

${ }^{1130}$ The Caribbean EPA negotiations were launched in Kingston, Jamaica on $16^{\text {th }}$ April 2004.

${ }^{1131}$ S. Silva, "Mix Up Matrimony": Crafting a Common Caribbean Market Access Offer in (eds.) A. Beviglia Zampetti, J. Lodge, The CARIFORUM-EU Economic Partnership Agreement: A Practioner's Analysis (Kluwer Law International, 2011), p. 56.

${ }^{1132}$ In the context of the ACP, CARICOM participates and negotiates as 'CARIFORUM', a grouping that includes the CARICOM Member States and the Dominican Republic.

${ }^{1133}$ R. Vahl, From Cotonou to Bridgetown: The Birth of the Caribbean EPA in Ibid, (eds.) A. Beviglia Zampetti, J. Lodge, 2011, p. 2; M. Gasiorek, L. Winters, What Role for the EPA in the Caribbean? The World Economy, 2004, Vol. 27(9), pp. 1335-1362, p.1335; D. Mohammed, Size and Competiveness: An Examination of the CARICOM Single Market and Economy, The Roundtable, 2008, Vol. 97 (395), pp. 287303, p. 293.

${ }^{1134}$ The EPA was initialed on $16^{\text {th }}$ December 2007 and signed on $15^{\text {th }}$ October 2008. It was provisionally applied since $29^{\text {th }}$ December 2008. "What has clearly emerged is the existence of two diametrically opposed view on the impact and usefulness of the [EPA] agreement. One view has it that the EPA is a major breakthrough in trade relations that will greatly benefit the region. On the other hand, some see it as being detrimental to the region and perhaps a total capitulation to the EU on the part of the CARIFORUM." See Economic Commission for Latin America and the Caribbean (ECLAC), The CARIFORUM-EPA: An Assessment of Issues relating to Market Access, Safeguards and Implications for Regional Integration (Port of Spain, Trinidad and Tobago, 26 ${ }^{\text {th }}$ November 2008) [LC/CAR/L.181], p.1; R. Bernal, The Challenge of Sustainable Implementation in Ibid, (eds.) A. Beviglia Zampetti, J. Lodge, 2011, p. 240; Ibid, M. Gasiorek, L. Winters, 2004, p.1360.

${ }^{1135}$ Guyana eventually signed the EPA on $20^{\text {th }}$ October 2009 and Haiti eventually signed the EPA on $11^{\text {th }}$ December 2009.

${ }_{1136}$ M. Gasiorek, L. Winters, What Role for the EPA in the Caribbean? The World Economy, 2004, Vol. 27(9), pp. 1335-1362, p.1346. 
by the entry into force of the EPA, a regional EPA implementation unit was established in the CARICOM Secretariat.

Much of the mandate of the EPA implementation unit involves structural cooperation and a regional approach to implementing the EPA. ${ }^{1137}$ A regional EPA implementation roadmap has been formulated to assist in executing the necessary obligations of the agreement and this initiative demonstrates how the regional platform aids CARICOM Member States in meeting their external trade commitments. In addition to EPA-related activities, CARICOM continues to coordinate its policy positions prior to its involvement in the wider ACP grouping on general ACP matters. In this regard, the role of the CARICOM caucus of Ambassadors accredited to the European Commission and the ACP Secretariat is noteworthy.

\subsection{Conclusion}

Both the 1973 OTC and the 2001 RTC represented watersheds in the evolution of regional integration in the Caribbean. Both treaties created respective CARICOM PTAs as well as entities that were endowed with juridical personality. Consequently, a new era commenced whereby the CARICOM Member States continuously expanded their external outreach activities through treaty-making activities and further engagement with third states and international organizations, which resulted in greater participation in the international system. Given the emphasis on interdependence that now grounds most interactions within the international system, the CARICOM shift to an outward oriented integration strategy in the late 1980 s was timely.

It is clear that the external dimension of the CARICOM PTA is a tremendous attribute to the CARICOM Member States, as it enables small developing countries to effectively participate in the international system through the use of various non-trade related benefits. General diplomacy and international trade relations have become increasingly expansive and it is submitted that the individual country approach to engagement has demonstrated

\footnotetext{
${ }^{1137}$ The regional EPA implementation Unit was established on $16^{\text {th }}$ February 2009. The Unit engages in the organization of seminars, workshops and other outreach activities.
} 
both its high costs and limitations. The group dynamic of the CARICOM platform remains the most optimal manner for the CARICOM Member States to engage with its external partners and this mechanism should be further nurtured.

The eventual British exit from the EU will further test the abilities of the CARICOM regional platform. It is submitted that the aforementioned non-trade related benefits including inter alia increased bargaining power and the common cooperation platform will be a sine qua non in assisting the CARICOM Member States in adjusting to the changes occasioned by British plans to extricate themselves from the European integration project. It is foreseeable that the CARICOM Member States will be required to craft a new relationship framework with the UK as well as the EU. 


\section{Chapter 8}

Conclusions and Recommendations

\section{The Importance of the Multilateral Setting}

It is widely accepted that the General Agreement on Tariffs and Trade (GATT) 1947 represented the missing limb of the Bretton Woods system, which marked a reset in the international economic system. Much of the policy thinking surrounding the initial idea of an International Trade Organization (ITO) and the eventual acceptance of the GATT 1947, as a second best option, was based on the understanding that the regulation of global trade was an important imperative. ${ }^{1138}$ In the minds of many policy thinkers, global trade was seen as a tool to cultivate economic prosperity. Increased global trade could lead to increased economic prosperity and its all-important byproducts of peace and conflict prevention. ${ }^{139}$ The inclusion of GATT Article XXIV, which allows for the formation of preferential trade agreements (PTAs), in the GATT 1947 was intended to reflect the contribution that this mechanism could provide to the growth of global trade. ${ }^{1140}$ PTAs were also intended to assist with the regional reconstruction of postwar Europe under preferential terms and to placate the imperial European nations that desired a continuation of trade ties with their colonial dominions. ${ }^{1141}$ The establishment of the World Trade Organization (WTO) in 1995 has strengthened the hand of the multilateral trading system

\footnotetext{
${ }^{1138}$ M. Matsushita, T. Schoenbaum, P. Mavroidis, M. Hahn, The WTO: Law, Practice and Policy, Third Edition (Oxford University Press, 2015), p. 27; L. Winters, What Can European Experience Teach Developing Countries About Integration?, The World Economy, 1997, Vol. 20 (7), p. 889-912, p. 890.

1139 See K. Kennedy, GATT 1994 in (eds) P. Macrory, A. Appleton, M. Plummer The World Trade Organization: Legal, Economic and Political Analysis, Volume II, (Springer Science and Business Media Inc, 2007), p. 91; T. Oppermann, On the Present International Economic Order: Basic Values and Shortcomings in (eds.) T. Oppermann, E. Petersmann, Reforming the International Economic Order (Dunker and Humblot, 1987), p.187.

${ }_{1140}$ See K. Dam, Regional Economic Arrangements and The GATT: The Legacy of A Misconception, University of Chicago Law Review, 1963, Vol. 30 (4), pp. 615-665, p. 622; J. Crawford, C. Lim, Cast Light and Evil Will Go Away: The Transparency Mechanism for Regulating Regional Trade Agreements, Three Years After, Journal of World Trade, 2011, Vol. 45(2), pp. 375-400, p. 377; O. Cattaneo, The Political Economy of PTAs in (eds.) S. Lester, B. Mercurio, L. Bartels, Bilateral and Regional Trade Agreements: Commentary and Analysis, Volume 1, Second Edition (Cambridge University Press, 2015), p. 31.

1141 J. Allen, The European Common Market and the GATT: A Study in Compatibility, Law and Contemporary Problems, 1961, Vol. 26 (3), pp. 559 - 571, p. 571; Y. Devuyst, GATT Customs Union Provisions and the Uruguay Round: The European Community Experience, Journal of World Trade, 1992, Vol. 26(1), pp. 15-34, p. 22.
} 
(MTS) in pursuing the aforementioned goal of regulating global trade. It is irrefutable that the growth of global trade remains an issue of continued importance. ${ }^{1142}$

Despite the importance of multilateral trade, the volume and intensity of PTAs has grown to a level beyond that originally conceived by the GATT drafters. It is reasserted that the MTS is (still) intended to function with global trade being conducted under most favored nation (MFN) terms. ${ }^{1143}$ Nevertheless, it is submitted that change has been a constant in the wider international system and some of these changes including inter alia the advance of decolonization and the fall of communism have contributed to the increased use of PTAs. ${ }^{1144}$ Decolonization in particular marked a major watershed in the evolution of the GATT legal architecture and its treatment of developing countries. As noted in this dissertation, the drafters of the GATT failed to consider the additional needs of developing countries despite the fact that 13 such countries were involved in the GATT drafting process. ${ }^{1145}$ Uniform trade rules were employed until a growing clamor against this approach resulted in several initiatives granting special and differential treatment (SDT) to developing countries. One such initiative was the 1979 Decision on Differential and More Favorable Treatment, Reciprocity and Fuller Participation of Developing Countries (the Enabling Clause), which also allows developing countries to form "global and regional

\footnotetext{
1142 "Trade may not be a silver bullet that will by itself deliver growth, but it is a fundamental and necessary ingredient for any strategy aiming at sustainable social and economic development. In this context, cooperative engagement at the international level is more important than ever. The structures of the multilateral trading system were built in direct response to the lessons of history. They represent the world's best effort to ensure that the mistakes of the past are not repeated. They provide the tools to deal with many problems that are at the forefront of the debate today." WTO Secretariat, WTO Annual Report 2017 (Geneva, 2017), p. 3.

${ }^{1143}$ R. Herzstein, J. Whitlock, Regulating Regional Trade Agreements - A Legal Analysis in (eds) P. Macrory, A. Appleton, M. Plummer The World Trade Organization: Legal, Economic and Political Analysis, Volume II, (Springer Science and Business Media Inc, 2007), p. 221; M. Trebilcock, R. Howse, A. Elliason, The Regulation of International Trade, Fourth Edition, (Routeledge, 2013), p. 56.

${ }_{1144}$ WTO Secretariat, World Trade Report 2011 (Geneva, 2011) p. 96; E. Mansfield, H. Milner, The New Wave of Regionalism, International Organization, 1999, Vol. 53 (3), pp.589-627, p. 600.

${ }^{1145}$ See P. Conconi, C. Perroni, Special and Differential Treatment of Developing Countries in the WTO, World Trade Review, 2015, Vol. 14(1) pp. 67 - 86, p. 71; Report by the Consultative Board to the Director General Supachai Panitchpakdi, The Future of the WTO: Addressing Institutional Challenges in the New Millennium (The Sutherland Report) WTO 2004, p. 24, para. 90; R. Wilkinson, J. Scott, Developing Country participation in the GATT: A Reassessment, World Trade Review, 2008, Vol. 7(3) pp. 473-510, p. 479; R. Hudec, Developing Countries in the GATT Legal System (Cambridge University Press, 2011), p. 41.
} 
trading arrangements" among themselves as per its paragraph 2 (c). ${ }^{1146}$ This wording has been interpreted to allow for the formation of developing country exclusive PTAs.

\subsection{Multilateral Rules for Preferential Trade Agreements}

Both GATT Article XXIV and paragraph 2 (c) of the Enabling Clause legally underpin the establishment of PTAs within the WTO legal architecture. As noted in this dissertation, these legal provisions outline the formation requirements for creating PTAs. Although both legal provisions are associated with the formation of PTAs, both legal provisions have also been afflicted by imprecise wording. This resulted in an interpretational divide among the WTO membership and contributed to regulatory stagnation, as most issues pertaining to PTAs were mired in controversy and disagreement. In the ten years since the Regional Trade Agreements Transparency Mechanism has been implemented, it appears that some of these concerns have been temporarily laid to rest. Despite this, the improved regulation of PTAs must be a priority issue for the WTO membership.

It still remains unknown whether PTAs contribute to the movement towards free trade or whether they serve to hinder certain goals of the MTS. Although this matter is yet to be reconciled, it is not a sign of encouragement when MFN tariffs are assumed to be the worstcase scenario available to UK trading interests in the aftermath of the decision on the British exit from the European Union (Brexit). ${ }^{1147}$ Nevertheless, this dissertation asserts that both GATT Article XXIV and paragraph 2 (c) of the Enabling Clause remain useful for outlining the formation requirements to create PTAs and for their contribution to the transparent monitoring of PTAs; however, these provisions do not constitute a legal obligation to create trade. The obligation assumed under both of these legal provisions extend solely to compliance with the formation requirements that should result in trade creation. Hence, the GATT and WTO Secretariats previously opted to legally examine PTAs with the aim of determining their compliance with GATT Article XXIV. ${ }^{1148}$ The

\footnotetext{
${ }^{1146}$ See GATT Secretariat, Differential and More Favorable Treatment, Reciprocity and Fuller Participation of Developing Countries, Decision of 28 November 1979 (Geneva, 3 December 1979) [L4903].

${ }^{1147}$ See The Economist, Why The "WTO Option" for Brexit will prove tricky, $9^{\text {th }}$ January 2017.

${ }^{1148}$ See R. Herzstein, J. Whitlock, Regulating Regional Trade Agreements - A Legal Analysis in (eds.) P. Macrory, A. Appleton, M. Plummer, The World Trade Organization: Legal, Economic and Political 
failure to create trade would not form a basis for a request for consultations under the WTO dispute settlement system or the subsequent establishment of a WTO Panel, as there is no benefit accruing from the covered agreements that has been impaired by the measures of another WTO Member or the existence of a situation that nullifies or impairs a benefit.

\subsection{The CARICOM Preferential Trade Agreement and GATT Article XXIV}

As argued in this dissertation, GATT Article XXIV and paragraph 2 (c) of the Enabling Clause do not create a legal obligation for trade creation. The legal provisions serve to outline a framework of formation requirements that, if implemented, should result in increased trade creation. The Caribbean Community (CARICOM) PTA, which is the main focus of this dissertation, was notified at the GATT Secretariat under GATT Article XXIV. The 1973 Original Treaty of Chaguaramas (OTC), which established the Caribbean Community and Common Market, remains one of the few PTAs that was deemed consistent with GATT Article XXIV during its working party assessment. ${ }^{1149}$ Nevertheless, this dissertation has demonstrated that the CARICOM PTA has been challenged in its ability to create trade. It is submitted that although the CARICOM Member States were able to meet the criteria outlined in GATT Article XXIV in order to establish the normative framework of a PTA, the legacy of the British Caribbean colonial paradigm has prevented these countries from achieving significant trade creation. Despite over forty years of integration efforts and the free movement of goods, intra-regional trade among the CARICOM Member States remains limited. Present day CARICOM trade policy remains heavily influenced by the colonial trade policy, which was previously employed to administrate the production function of the Caribbean economies at various stages of their historical evolution. The end result of this has manifested itself in most CARICOM Member States retaining a 'relative' comparative advantage in the production of a similar range of agricultural commodities. This has placed inherent limitations on the growth of intra-regional trade.

Analysis, Volume II (Springer, 2005), p. 228. See also Chapter 3, Section 3.1 GATT Institutional Assessment: The Early Years and Section 3.2 The CRTA

1149 "It was generally agreed that the Caribbean Common Market constituted an interim agreement leading to the establishment of a customs union and as such, was consistent with the provisions of Article XXIV of the General Agreement." See GATT Secretariat, Report of the Working Party on the Caribbean Community and Common Market (Geneva, $2^{\text {nd }}$ February 1977) [L/4470], p. 5, para. 13. 


\subsection{The Imprint of the British Caribbean Colonial Paradigm}

The CARICOM PTA reflects the efforts by a small, developing country region to further its economic development through an intergovernmental approach to regional integration. Since the advent of regional integration in the Caribbean, the CARICOM Member States have played a central role in the institutional and procedural execution of the various regional policy initiatives. ${ }^{1150}$ Although regional integration in the Caribbean has been continuous since 1965, its successes have not been apparent in the realm of traditional trade gains. The CARICOM PTA has been challenged in generating significant intra-regional trade. There is a clear divide between the MDC CARICOM Member States that have benefitted from intra-regional trade and witnessed an increase in their welfare gains versus that of the LDC CARICOM Member States, which maintain limited contact with the intraregional trading market. ${ }^{1151}$ Much of this dichotomy as well as the general inability to generate traditional trade gains are attributable to the British Caribbean colonial paradigm and the impact that it has had on the internal and external trade policy of the CARICOM region.

\subsubsection{Preference Dependence}

Generally speaking, the CARICOM region still remains dependent on trade preferences. ${ }^{1152}$ The evolution of the region from British Caribbean slave colonies specialized in sugar production under the plantation economy model (the British Atlantic economy) to post-slavery British Caribbean colonies specialized in export-oriented agricultural production has left its imprint on modern day CARICOM trade policy. Despite

\footnotetext{
${ }^{1150}$ See K. Hall, CARICOM: Unity in Adversity in (ed.) K. Hall, The Integrationist: The Pertinence of CARICOM in the $21^{\text {st }}$ Century - Some Perspectives (Trafford Publishing, 2012), p. 16; D. Pollard, Institutional and Legal Aspects of the Caribbean Community, Caribbean Studies, 1974, Vol. 14 (1), pp. 3974, p. 51; A. Stone Sweet, W. Sandholtz, European Integration and Supranational Governance, Journal of European Public Policy, 1997, Vol. 4(3), pp. 297-317, p. 298.

1151 See World Bank/Organization of American States, co-produced with the Governments of the CARIFORUM Countries, Poverty Reduction and Economic Management Sector Unit, Latin America and Caribbean Region, The Caribbean: Accelerating Trade Integration, Policy Options for Sustained Growth, Job Creation and Poverty Reduction (December 2008), Chapter 2, p. 55, para. 2.5.2; Inter-American Development Bank (IDB)/Institute for Integration of Latin America and the Caribbean (INTAL), CARICOM Report Number 2, (Buenos Aires, Argentina, 2005), p. 21.

${ }^{1152}$ See Ibid, World Bank/Organization of American States, co-produced with the Governments of the CARIFORUM Countries, Poverty Reduction and Economic Management Sector Unit, Latin America and Caribbean Region, 2008, p. 33, para. 2.46.
} 
the fact that most CARICOM Member States attained their independence during the Caribbean period of decolonization (1962-1983), the export basket of tradable goods has remained largely the same since the end of the $20^{\text {th }}$ century. As noted in this dissertation, most CARICOM Member States tend to produce a similar basket of goods, which inherently limits their ability to trade with each other. ${ }^{1153}$ Admittedly, there have been some attempts at product diversification. Nevertheless, sugar and bananas have remained core exports and CARICOM external trade policy towards Europe has been underpinned by a policy of safeguarding existing market access for these commodities.

Much of the rationale for this policy approach is attributable to the fact that the external trade policy of the CARICOM Member States has been hinged on trade preferences initially provided from the United Kingdom (UK) through the imperial preference system as well as the Commonwealth Sugar Agreement (CSA). These preference initiatives were mainly targeted at bananas as well as sugar. For bananas, these preferences commenced prior to the First World War and for sugar, these preferences commenced after the Second World War. ${ }^{1154}$ Therefore, the colonial history of trade preferences in the British Caribbean predates the grant of independence by decades. In the aftermath of the UK entry to the European Economic Community (EEC) in 1972, the provision of trade preferences continued. Again, it is notable that from Lome I in 1975 to the EC-CARIFORUM EPA in 2008, CARICOM trade policy towards Europe has been guided by the art of safeguarding existing market access for its commodities. ${ }^{1155}$ Since the 2008 EC-CARIFORUM EPA was the first reciprocal PTA between the two regions, it is argued that CARICOM was willing to sacrifice a great deal to ensure continued market access for its dwindling commodities trade. This negotiating stance drew the ire of many critics in the CARICOM region. ${ }^{1156}$

\footnotetext{
${ }^{1153}$ M. Gasiorek, L. Winters, What Role for the EPA in the Caribbean? The World Economy, 2004, Vol. 27(9), pp. 1335-1362, p.1336; D. Mohammed, Size and Competiveness: An Examination of the CARICOM Single Market and Economy, The Roundtable, 2008, Vol. 97 (395), pp. 287-303, p. 294; G. Atkinson, Economic Integration in the Caribbean Community: A Problem of Institutional Adjustment, Journal of Economic Issues, 1982, Vol. 16 (2), pp. 507-513, p. 507.

${ }^{1154}$ See Chapter 4, Section 4.2.1. entitled The Early Banana Trade, Section 4.3 entitled The Commonwealth Sugar Agreement and Section 4.3.1 entitled The Effect of The Imperial Preference System on the Caribbean Sugar Industry.

${ }^{1155}$ See V. Bulmer-Thomas, The Economic History of the Caribbean since the Napoleonic Wars (Cambridge University Press, 2012), p. 229.

${ }^{1156}$ See Chapter 7, Section 7.8.3 entitled The ACP.
} 


\subsubsection{Lack of Product Diversification}

As noted in this dissertation, the provision of trade preferences served to deter product diversification and most of the CARICOM Member States retained trade policies centered on agricultural production. ${ }^{1157}$ This resulted in a policy emphasis on external trade whereby the needs of the domestic (and intra-regional) market were largely overlooked. As a result of this, the CARICOM PTA has been unable to create a significant level of intra-regional trade. A low level of priority has been placed on strengthening of manufacturing capabilities and as such, most of the CARICOM Member States remain net importing developing countries (NDICs). ${ }^{1158}$ This fact also serves to explain why the United States of America (USA) remains the principal trading partner for all of the CARICOM Member States. Most of the basic consumer goods continue to be sourced from the US, as there is minimal exploration of correcting supply side constraints. ${ }^{1159}$ Coupled with preferential, non-reciprocal trade arrangements with the USA and Canada, it is submitted that CARICOM must find a way to overcome the hold of trade preferences and establish economic structures that can kick start greater domestic production. ${ }^{1160}$ This will assist with the growth of intra-regional trade in addition to the obvious advantages entailed with the stimulation of the CARICOM private sector such as greater employment and its various byproducts.

The issue of tourism services must be mentioned in the context of product diversification. As outlined in this dissertation, many CARICOM Member States have transitioned to

\footnotetext{
1157 See World Bank/Organization of American States, co-produced with the Governments of the CARIFORUM Countries, Poverty Reduction and Economic Management Sector Unit, Latin America and Caribbean Region, The Caribbean: Accelerating Trade Integration, Policy Options for Sustained Growth, Job Creation and Poverty Reduction (December 2008), p. 76, para. 4.45; H. Sandberg, J. Seale, T. Taylor, History, Regionalism and CARICOM Trade: A Gravity Model Analysis, Journal of Development Studies, 2006, Vol. 42 (5) pp. 795-811, p. 808.

${ }^{1158}$ M. Gasiorek, L. Winters, What Role for the EPA in the Caribbean? The World Economy, 2004, Vol. 27(9), pp. 1335-1362, p. 1336.

${ }_{1159}$ CARICOM Statistical Unit, CARICOM's Trade: A Quick Reference to Some Summary Data, 2005 2010 (Georgetown, Guyana, 2013), p. 9; World Bank/Organization of American States, co-produced with the Governments of the CARIFORUM Countries, Poverty Reduction and Economic Management Sector Unit, Latin America and Caribbean Region, The Caribbean: Accelerating Trade Integration, Policy Options for Sustained Growth, Job Creation and Poverty Reduction (December 2008), Introduction, p. 64, para. 4.5. ${ }_{1160}$ Ibid, World Bank/Organization of American States, co-produced with the Governments of the CARIFORUM Countries, Poverty Reduction and Economic Management Sector Unit, Latin America and Caribbean Region, 2008, p. 11, para. 1.30.
} 
services dominant economies. ${ }^{161}$ For most of these CARICOM Member States, particularly the OECS countries, this has also resulted in an over-reliance on tourism services. Whilst it is submitted that any additional stream of GDP contribution is appreciated in small developing countries, it is argued that economic dependency on tourism services carries significant risks due to the inherent exposure to climatic shocks. ${ }^{1162}$ For many of the OECS countries, tourism services represent a contribution of between $24 \%$ and $74 \%$ to annual GDP. ${ }^{1163}$ In this regard, tourism services can constitute a part of the solution of stimulating the domestic economies of CARICOM; however, it cannot be the entire solution of dwindling primary product agricultural trade.

\subsection{Non-Trade related benefits}

Despite the growing pains that the CARICOM PTA has experienced with traditional trade gains, it is submitted that the regional construct is still a valuable tool. Its external dimension has provided the CARICOM Member States with incalculable non-trade related benefits, which have been utilized for further interaction on the international plane. ${ }^{1164}$ Irrespective of whether the CARICOM PTA cultivates intra-regional trade, the fact remains that the CARICOM region consists of small developing countries with strong colonial ties. Most of the CARICOM Member States have been independent for less than 50 years. Nation building in the era of the rules-based MTS, globalization and increased interdependence has been a challenging endeavor for these countries. The 1989 Grand Anse Declaration represented an admission of these challenges and formalized the

\footnotetext{
${ }^{1161}$ See M. Gasiorek, L. Winters, What Role for the EPA in the Caribbean? The World Economy, 2004, Vol. 27(9), pp. 1335-1362, p. 1339; WTO Secretariat, Trade Policy Review of the OECS- WTO Members, Report by the Secretariat (Geneva, $22^{\text {nd }}$ September 2014) [WT/TPR/S/299/Rev.1], p. 116, para. 1.1; D. Mohammed, Size and Competiveness: An Examination of the CARICOM Single Market and Economy, The Roundtable, 2008, Vol. 97 (395), pp. 287-303, p. 294.

${ }^{1162}$ See P. Egoume-Bossogo, C. Mendis, Trade and Integration in the Caribbean, International Monetary Fund (IMF) Working Paper, 2002, [WP/02/148], p. 11; European Union All ACP Commodities Programme Caribbean Region/International Trade Center, Grenada Nutmeg Sector Development Strategy 2010-2015 (St. George's, Grenada, July 2010) p. 20; Inter-American Institute for Cooperation on Agriculture (IICA), Grenada 2005 Annual Report, The Contribution of IICA to the development of Agriculture and Rural Communities (Grenada, 2005), p. 9.

${ }^{1163}$ See OECS Common Tourism Policy prepared with the assistance of the Commonwealth Secretariat (September 2011), p. 4.

${ }^{1164}$ See O. Arthur, Caribbean Regionalism in the Context of Economic Challenges, Caribbean Journal of International Relations, 2014, Vol. 2(4), pp. 147-164, p. 152; See J. Revauger, Regional Integration in the Commonwealth Caribbean and the Impact of the European Union, The Round Table, 2008, Vol. 97 (399) pp. 857-869, p. 864. See also Chapter 4, Section 4.8.1 entitled The Grand Anse Declaration.
} 
CARICOM shift from an internal oriented approach to regional integration to that of an external, expansive outreach approach. ${ }^{165}$

The regional platform provided by the CARICOM PTA has evolved into a defense mechanism that has assisted the CARICOM Member States with adjusting to the constant changes in an international system that has a tendency to rely on power politics dictated by larger players. When this dynamic is considered, it is clear that the individual country approach has its limitations especially for small developing countries. Consequently, the CARICOM regional platform should be nurtured, as it remains the most optimal tool for the CARICOM Member States to interact with international partners. As stated in this dissertation, it is likely that the CARICOM Member States will continue to benefit from the CARICOM PTA. However, the CARICOM institutional apparatus cannot be allowed to descend into complacency. An injection of new talent into the CARICOM Secretariat can assist in this regard, as new 'spillovers' will require technicians with new insights.

\subsection{Future Options}

Going forward, it is submitted that the CARICOM Member States must endeavor to resolve their intra-regional transportation deficiencies. The establishment of affordable and reliable transportation links among all of the CARICOM Member States is required. Unquestionably, the lack of reliable transportation links among the CARICOM Member States has been an issue of concern for over half a century. ${ }^{1166}$ This matter was cited as one of the factors that increased the cost of Caribbean banana production: banana ships were required to make several stops at the various ports in the Eastern Caribbean before journeying back to the UK. This resulted in increased transportation costs and a longer shipping time for the Caribbean banana trade. ${ }^{1167}$ In 1971, the GATT working party report for CARIFTA also cited transportation issues as a serious obstacle to trade. ${ }^{1168}$ The

\footnotetext{
${ }^{1165}$ See Chapter 7, Section 7.2.2 entitled Institutional and Procedural Arrangements under The RTC.

${ }^{1166}$ See H. Sandberg, J. Seale, T. Taylor, History, Regionalism and CARICOM Trade: A Gravity Model Analysis, Journal of Development Studies, 2006, Vol. 42 (5) pp. 795-811, p. 808.

1167 See G. Atkinson, Economic Integration in the Caribbean Community: A Problem of Institutional Adjustment, Journal of Economic Issues, 1982, Vol. 16 (2), pp. 507-513, p. 507.

${ }_{1168}$ See GATT Secretariat, Report of the Working Party on the Caribbean Free Trade Agreement (Geneva, $29^{\text {th }}$ September 1971) [L/3584], p. 1, para. 3.
} 
representatives of the Chamber of Commerce of Belize have also opined that transportation links into the CARICOM intra-regional market are not optimal. It is submitted that for CARICOM Member States like Belize, which is geographically located in Central America, direct transportation links could positively impact efforts to capitalize on access to the intra-regional trade market.

Another option that is worthy of consideration is the implementation of a regional strategy aimed at integrated production. It has been argued that the small size of CARICOM Member States has inhibited further growth due to the inherent challenges in achieving economies of scale. ${ }^{1169}$ However, the adoption and implementation of a regional strategy aimed at establishing regional value chains and the integration of production in a given industry can assist in gradually developing economies of scale. ${ }^{1170}$ Similar strategies including transnational production networks and inter-industry production linkages have been adopted in the Association of Southeast Asian Nations (ASEAN) region and have resulted in expanded regional input. ${ }^{1171}$ As noted in this dissertation, a 1967 proposal by several University of West Indies (UWI) economists had advocated that a macroeconomic approach propelled by a production integration strategy be adopted. This approach would allow for different territories to achieve sector-specific specialization and result in regional complementarity in the overall production of certain industries. ${ }^{1172}$ This approach was rejected in favor of the free trade model that was pursued with the establishment of CARIFTA. ${ }^{1173}$ Nevertheless, it is noteworthy that calls have been resurrected for

\footnotetext{
${ }^{1169}$ M. Gasiorek, L. Winters, What Role for the EPA in the Caribbean? The World Economy, 2004, Vol. 27(9), pp. 1335-1362, p. 1335; S. Nicolls, A. Birchwood, P. Colthrust, E. Boodoo, The State of and Prospects for the Deepening and Widening of Caribbean Integration, The World Economy, 2000, Vol. 23(9), pp. 11611194, p. 1162; World Bank/Organization of American States, co-produced with the Governments of the CARIFORUM Countries, Poverty Reduction and Economic Management Sector Unit, Latin America and Caribbean Region, The Caribbean: Accelerating Trade Integration, Policy Options for Sustained Growth, Job Creation and Poverty Reduction (December 2008), p. 11, para. 1.30.

${ }^{1170}$ P. Draper, M. Qobo, Rabbits caught in the headlights? Africa and the 'multilateralizing regionalism' paradigm in (ed.) U. Volz, Regional Integration, Economic Development and Global Governance (Edward Elgar Publishing, 2011), p. 137.

${ }^{1171}$ D. de Mel, S. Jayaratne, Vertical Integration of Industries in South Asia in (eds.) S. Hafeez Rahman, S. Khatri, H. Brunner, Regional Integration and Economic Development in South Asia (Edward Elgar Publishing, 2012), p. 46.

${ }_{1172}$ A. Payne, The Political History of CARICOM (Ian Randle Publishers, 2008), p. 55.

${ }^{1173}$ Ibid, A. Payne, 2008, p. 60.
} 
CARICOM to pursue a regional integrated production strategy, as it is argued that this can lead to a regional expansion of output and employment. ${ }^{1174}$

Issues of greater complexity stand in wait for the CARICOM Member States. The future impact of the Brexit on former British colonies is one such issue. The inclusion of the CARICOM Member States in the Lome I - IV Agreements, the Contonou Agreement and the EC-CARIFORUM EPA has been predicated on their status as former dependencies of the UK. At the moment, it is unknown whether the Brexit will impact the ECCARIFORUM EPA. It is also unknown how, if and when the UK will be able to extricate itself from the PTAs that it previously signed as an EU Member. What is abundantly clear is that the CARICOM Member States will have to consider the market access and development cooperation implications of these issues. In addition to this, the future impact of climate change is another issue of grave concern for CARICOM Member States. As island states dispersed throughout the Caribbean Sea, many CARICOM Member States are geographically located in a direct line of impact for rising sea levels and increased intensity of hurricanes, as was seen in 2017. It is submitted that the external dimension of the CARICOM PTA is a sine qua non for articulating the CARICOM position on these and future issues, which will confront the CARICOM Member States.

\footnotetext{
${ }^{1174}$ P. J. Patterson, CARICOM Beyond Thirty: Charting New Directions in (eds.) K. Hall, M. Chuck-A-Sang, The Integrationist: Regional Integration - Key to Caribbean Survival and Prosperity (Trafford Publishing, 2012), p. 168.
} 


\section{Valorisation Addendum}

1. Relevance. What is the social and/or economic relevance of your research results (i.e. in addition to the scientific relevance)?

The relevance of the research results contained in this dissertation lay in the fact that it provides a valuable record of the legal, political and economic history of regional integration in the Caribbean. Uniquely, regional integration in the Caribbean was bookmarked by the forces of decolonization and globalization. The other former colonial regions in Africa and Asia both attempted regional integration well after gaining independence from the various imperial powers. Thus, it must be recalled that the initial pivot to regional integration by the then British Caribbean territories, which eventually became Caribbean Community (CARICOM) Member States, was as a result of their quest for sovereignty and the right to determine their own post-colonial development path. In this vein, the research results map the twin forces of decolonization and globalization and their legal, political and economic effect on the small, developing countries of the CARICOM region as they continue their regional integration process. Despite the lasting imprint of colonial trade policy and the modern-day policy confines of the rules-based multilateral trading system (MTS), regional integration in the Caribbean is still largely aimed at the improvement of the Caribbean economic condition and the determination of the Caribbean development path. The research results capture how the use of regional integration, as an instrument, is still assisting the CARICOM Member States with this ambition in a changing international system.

Furthermore, the research results contained in this dissertation provide an assessment of the CARICOM preferential trade agreement (PTA). It is noted that the economic history of the CARICOM region, which contributed to an export-oriented model for trade in agricultural goods, requires an urgent rethink given the limited availability of preferential export markets. In addition to this, the highlighted shortcomings of CARICOM intraregional trade policy, which have resulted in the volume of trade flows remaining at a de- 
minimis level after fifty years of trade liberalization efforts, can assist in contextualizing present and future trade policy considerations. The research results also demonstrate that despite the dismal record on the generation of intra-regional trade, the CARICOM PTA is a beneficial platform for its constituents especially given the interdependent nature of the wider international system. Nevertheless, the main economic policy recommendation emanating from this dissertation remains clear: a general policy shift is required if the CARICOM Member States intend to produce and market tradable goods within the CARICOM intra-regional market.

2. Target Groups. To Whom, in addition to the academic community, are your research results of interest and why?

The research results contained in this dissertation are of interest to multiple target groups: Caribbean regional policymakers, political actors at the national level in the various CARICOM Member States, Caribbean legal professionals and Caribbean private sector actors. Although existing literature has addressed the chronological development of regional integration in the Caribbean, few have addressed the subject through the analytical lens of wider developments in the MTS. Even fewer have focused on the legal requirements of the CARICOM PTA and how its evolved legal competences have contributed to the continuous development of regional integration in the Caribbean. Generally speaking, the findings of this research present an opportunity for the aforementioned target groups to become further informed on legal and policy aspects of PTAs (as a feature of the MTS) as well as the history of regional integration in the Caribbean and the underlying reasons why its policy structures have not resulted in the creation of meaningful trade flows among the participating CARICOM Member States.

For the Caribbean regional policymakers, the research results contained in Chapter 7 (CARICOM: The External Dimension) and Chapter 8 (Conclusions and Recommendations), offer perspectives on the non-trade related benefits derived from the CARICOM PTA and how the trade can be improved upon within the existing policy structures of the CARICOM PTA. Such perspectives are timely given that at present in 
2018, there is an ongoing debate within the CARICOM region on whether the regional integration process is achieving its stated purpose and possible options going forward. For the political actors at the national level in the various CARICOM Member States, a fuller understanding of regional integration in the Caribbean can be had from the research results contained in Chapter 4 (The Evolution of Regional Integration in the Caribbean) and Chapter 5 (CARICOM intra-regional Trade). This is particularly noteworthy given that political actors tend to possess diverse backgrounds and might not be particularly au fait with the overall aims and instruments of regional integration in the Caribbean.

With respect to Caribbean legal professionals, it is submitted that engaging with the research results contained in Chapter 2 (Legal Design of Preferential Trade Agreements: GATT Article XXIV and the Enabling Clause) and Chapter 3 (Management: The Institutional Regulation of Preferential Trade Agreements) will provide a background on the multilateral trade rules underpinning the establishment of PTAs and how the CARICOM regional trade arrangement fits into the wider legal architecture of the MTS. This is especially useful for Caribbean legal professionals given that the original jurisdiction of the Caribbean Court of Justice (CCJ) functions as an international trade tribunal, which utilizes WTO law when adjudicating on legal matters pertaining to the intra-regional (internal) market created by the CARICOM PTA. The research results contained in Chapter 5 (CARICOM intra-regional Trade) and Chapter 6 (Case Study on Belize) are relevant to Caribbean private sector actors as it provides further information on the trade flow dynamic present in the CARICOM intra-regional market. The select trading profiles of various CARICOM Member States can provide a primer outlining possible export markets within the CARICOM intra-regional market. As noted in the dissertation, many private sector actors (particularly in Belize) have not considered trading on the intraregional market due to an insular approach to business driven solely by the needs of the immediate domestic market. 
3. Activities/Products. Into which concrete products, services, processes, activities or commercial activities will your results be translated and shaped?

Several chapters of the research results contained in this dissertation have been utilized to create a semester syllabus for a specialized, English-language, post-graduate course focusing on certain aspects of international trade law. This post-graduate course is currently being offered by the Slovak Diplomatic Academy at the Comenius University in Bratislava (Faculty of Law) in Bratislava, Slovakia. The post graduate course is one of several legal courses offered and is intended to provide a backgrounder to students of the Slovak Diplomatic Academy, who aspire to join the Slovak Foreign Service. The post-graduate course lectures are being delivered by the author of this $\mathrm{PhD}$ dissertation.

In this regard, certain aspects of Chapter 1 of the dissertation have been used to assist with a general introduction to the MTS and to assert the centrality of the multilateralism. Certain aspects of Chapters 2, 3 and 4 have also been used to introduce the legal exceptions (GATT Article XXIV and The Enabling Clause) which underpin the establishment of PTAs. In addition to this, the legal requirements and institutional regulation of PTAs is also addressed. The aforementioned information has aided in contextualizing the tension between multilateral trade and preferential trade and how both are legally situated in light of the objectives of the World Trade Organization (WTO) Agreement.

Furthermore, certain aspects of Chapter 1 of the dissertation have been used to provide background information on the Treaty of Rome and the historical circumstances that led to the creation of the then European Economic Community (EEC). Also addressed is the continued unfolding of regional integration in Europe and the existing legal arrangements from which the UK will have to extricate itself. Lastly, certain aspects of Chapters 4 and 5 have been utilized to provide an illustration of the unfolding of regional integration outside of the European context. Many of the legal arrangements pertaining to the CARICOM PTA and peculiarities of a small, developing country region is discussed. 
In addition to this, several parts of the research results contained in this dissertation are intended to be published as newspaper and journal articles.

4. Innovation. To what degree can your results be called innovative in respect to the existing range of products, services, processes, activities and commercial activities?

The research results contained in this dissertation can be considered innovative as they provide a detailed record of the history of PTAs and their evolution within the rules-based MTS. This is noteworthy given the existential crossroads at which the MTS now finds itself. This existential crossroads has been characterized by the continued growth of PTAs, the inability of WTO Members to successfully advance key issues during multilateral negotiating rounds and the open questioning of the usefulness of the WTO as an institution. Is the MTS at a tipping point beyond which the majority of global trade will be conducted mainly under preferential terms among select groups of WTO Members? Will multilateral trade liberalization become the exception as opposed to the rule? For the time being, this remains unknown. It is clear, however, that a more discriminatory and preferential approach to trade continues to gain traction among WTO Members. Given this, it is worthwhile to know and understand the path that PTAs have travelled since the drafting of the General Agreement on Tariffs and Trade (GATT) 1947. 


\section{Curriculum Vitae}

Ms. Gianni Avila was born in Belize City, Belize, Central America on $23^{\text {rd }}$ March 1981. Gianni graduated from the University of South Florida in Tampa, Florida, USA with a Bachelors degree in International Studies (Honours) in 2001. Following this, Gianni worked at the Ministry of Foreign Affairs of Belize for over five years where she focused on general diplomacy matters as well as international trade policy issues. In addition to this, Gianni served on a diplomatic posting at the Permanent Mission of Belize to the United Nations in New York. In 2008, Gianni graduated from the World Trade Institute in Bern, Switzerland with a Masters in International Law and Economics summa cum laude. Gianni then furthered her law studies at BPP Law School in London, England, United Kingdom and graduated with an LLB (Honours) in 2011. In 2012, Gianni was accepted as a $\mathrm{PhD}$ fellow at Maastricht University and commenced her research on the Caribbean Community and its involvement with preferential trade agreements under the supervision

of Prof. dr. Peter Van den Bossche. Since this time, Gianni has worked as a legal advisor to a Belize-based law firm advising on legal rules relating to Belize's membership in the Caribbean Community preferential trade agreement and at present, Gianni lectures on International Trade Law at the Comenius University in Bratislava, Slovakia. 